\title{
Buddhism and Medicine in Tibet: Origins, Ethics, and Tradition
}

\author{
William A. McGrath \\ Herndon, Virginia
}

B.Sc., University of Virginia, 2007

M.A., University of Virginia, 2015

A Dissertation presented to the Graduate Faculty of the

University of Virginia in Candidacy for the Degree of Doctor of Philosophy

Department of Religious Studies

University of Virginia

May, 2017 


\begin{abstract}
This dissertation claims that the turn of the fourteenth century marks a previously unrecognized period of intellectual unification and standardization in the Tibetan medical tradition. Prior to this time, approaches to healing in Tibet were fragmented, variegated, and incommensurable - an intellectual environment in which lineages of tantric diviners and scholarly literati came to both influence and compete with the schools of clinical physicians. Careful engagement with recently published manuscripts reveals that centuries of translation, assimilation, and intellectual development culminated in the unification of these lineages in the seminal work of the Tibetan tradition, the Four Tantras, by the end of the thirteenth century. The Drangti family of physicians - having adopted the Four Tantras and its corpus of supplementary literature from the Yutok school-established a curriculum for their dissemination at Sakya monastery, redacting the Four Tantras as a scripture distinct from the Eighteen Partial Branches addenda. Primarily focusing on the literary contributions made by the Drangti family at the Sakya Medical House, the present dissertation demonstrates the process in which the Tibetan medical tradition transitioned from controversy, competition, and change, to a narratively unified set of theories and practices that came to be taught at Buddhist institutions throughout the Tibetan plateau. From the fourteenth century onward, sharing an established Buddhist origin, bodhisattva code of ethics, and monastic institutional center, the theories and practical instructions of the Tibetan medical tradition continued to be transmitted and diffused throughout the Buddhist networks of Asia, from the center of the Tibetan plateau to the periphery of the Mongolian steppe and beyond.
\end{abstract}

Keywords: Buddhism, medicine, Tibet, narrative, history, transmission, practice, tradition 


\section{Table of Contents}

INTRODUCTION: ON THE VERY IDEA OF BUDDHIST MEDICINE IN TIBET .................... I

CHAPTER ONE: DIVINATION AND DIAGNOSIS IN THE EARLY TIBETAN MEDICAL TRADITION

The Social Context of the Medical Tradition in Twelfth-century Tibet .....................................II

Mirror Divination, Child Mediums, and Oracular Revelation: The Tibetan Assimilation of

Prasenā Divination....................................................................................................................................................... I4

On the Meaning of the Word Prasenā ..................................................................................................

Child Mediums, Prasenā Revelation, and Possession ........................................................................... I8

Prasenā Divination in Tibetan Literature ...................................................................................................23

Channel Examination and Prasenā Divination ....................................................................25

Channel Examination as Prasenā Divination .......................................................................................... 29

Prasenā Divination as Channel Examination .................................................................................32

The Indispensable Channel Prasenā Rituals .........................................................................................32

The Wonder Channels and the Subsequent Tantra.................................................................4I

Conclusion: Observation and Revelation in the Tibetan Medical Tradition.......................... 48

CHAPTER TWO: ADAPTATION AND INNOVATION IN TIBETAN MEDICAL

SCHOLASTICISM .....................................................................................................................................5 50

Medicine as a Scholastic Field of Knowledge .......................................................................................... 54

Practical Scholasticism in the Tibetan Medical Tradition ..............................................................63

The Small Practical Manual.........................................................................................................67

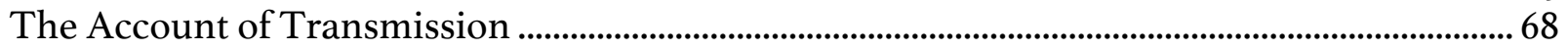

Diagnostics in the Small Practical Manual ...........................................................................................74

The Five Classifications of Medicine..........................................................................................................79

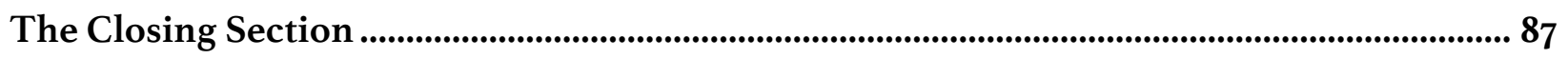

CHAPTER THREE: ORIGIN MYTHS AND THE BUDDHIST NARRATION OF

MEDICINE .................................................................................................................................................................... 94

Narrative and Polemics in the Tibetan Medical Tradition...............................................................97

The Collection of Medicine ...................................................................................................................... I05

Precedents for the Mythology of the Four Tantras .............................................................................II2 
Narrative Echoes from Mt. Wutai

The Great Tantra, the Lesser Tantra, the King of Tantras, and the Four Tantras................. I24

The Expanded Elucidation of Knowledge and the Reconciling of Narratives........................ I3I

CHAPTER FOUR: THE YUTOK STUDENT AND FAMILIAL LINEAGES AT THE SAKYA MEDICAL HOUSE

The Mongols, the Drangti Clan, and the Sakya Medical House .................................................. I42

The Drangti and the Yutok Familial Lineage ......................................................................................... I46

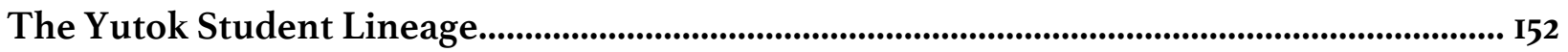

The Later Layers of the Indispensable Account ...................................................................................... I63

Canonization and Curriculum in the Tibetan Medical Tradition ............................................ I70

Conclusions: Education, Standardization, and Unification ............................................... I78

CHAPTER FIVE: IMPERIAL LEGENDS AND THE ESTABLISHMENT OF

PROFESSIONAL ETHICS IN THE TIBETAN MEDICAL TRADITION ...................................I80

The Expanded Elucidation of Knowledge in the Tibetan Tradition of Buddhist

Historiography ......................................................................................................................................... 82

The Escape of Minister Gar ....................................................................................................................... I86

Foreign Physicians and the Tibetan Assimilation of Medicine ................................................ I92

The Early Propagation: The Inception of Medical Lineages ............................................................ I93

The Middle Propagation: The Translation of Medical Texts............................................................ I94

Geographical Precedents in Tibetan Medical Literature.......................................................... 199

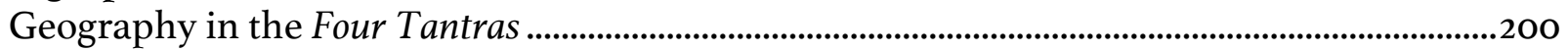

Geography in the Gold Measure Collection ........................................................................................... 203

Geography in Khokbuk Literature .................................................................................................... 205

The Establishment of Professional Ethics in the Tibetan Medical Tradition.........................2II

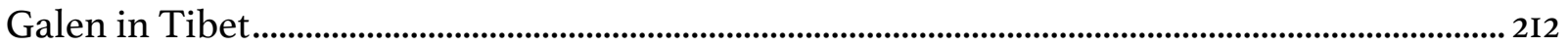

Professional Ethics in the Tibetan Medical Tradition ....................................................................... 213

Precedents and Interpretations of Professional Ethics in the Tibetan Medical Tradition... 220

Summary and Conclusions: A Tradition of Historiographical Creativity at the Sakya

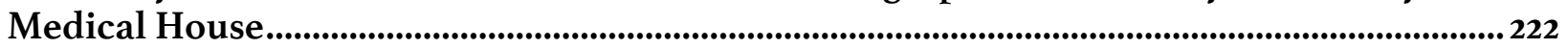

CONCLUSIONS: DIAGNOSIS AND PRESCRIPTION, HISTORY AND PROPHESY ..........225

BIBLIOGRAPHY ...........................................................................................................................................228 


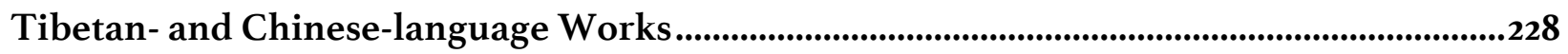

European-language Works............................................................................................................................2232

APPENDIX: APPROXIMATE CHRONOLOGY AND ANNOTATED BIBLIOGRAPHY OF EARLY LITERATURE IN THE TIBETAN MEDICAL TRADITION .......................................244

Pre-eleventh Century ......................................................................................................................................245

The Eleventh and Twelfth Centuries...............................................................................................252

The Thirteenth Century .....................................................................................................................258

The Fourteenth Century .....................................................................................................................262 


\section{Acknowledgements}

As I reflect upon the many long years leading up to the completion of this dissertation project, I am overwhelmed by the many friends, teachers, and colleagues that I have had the pleasure of encountering along the way. Not unlike my very life, my very breath, my very being, the story of my engagement with Buddhism and Tibet begins with my dear family. Growing up in a home where images of Mañjuśrī would adorn the walls and Robert Thurman's translation of the Vimalakìrti Sūtra would grace the bookshelves, Buddhist teachings have long provided me with tools for navigating existence. During my first year as an undergraduate at the University of Virginia, where I was studying Biochemistry and planning to go on to medical school, I was afforded my first glimpse into the academic study of Buddhism when I took a course on Buddhist Meditation with Jeffrey Hopkins. That semester would turn out to be his final semester teaching at UVa, ending thirty years of instruction on and the academic institutionalization of Buddhist Studies in Virginia. Inspired by Professor Hopkins and his other accomplished colleagues, I went on to begin studying the Tibetan language at the University of Virginia in the summer of 2004. Under the tutelage of Tsering Wangchuk, Sonam Yangkyi, Douglas Duckworth, and the incomparable Nicolas Tournadre, I was able to grasp the foundations of Tibetan grammar and vocabulary, allowing me to continue studying alongside Robert Barnett at Tibet University in the summer of 2005. It was this summer that marked a watershed in my intellectual trajectory, prompting a hunger for experience and understanding that would not soon be satiated.

Upon my return to Virginia, I completed my undergraduate degree in Biochemistry, but I also continued to study the anthropology, history, and Buddhist Studies with Nicolas Sihlé, Paul Groner, Kurtis Schaeffer, and David Germano. As I was preparing to graduate, my life took another major turn when David offered me a job working for the digital projects of the Tibetan Himalayan Library and the Journal of the International Association of Tibetan Studies along with Steven Weinberger and other talented specialists. It was during this time that I also had the good fortune to connect with Lobsang and Tashi Rabgey, co-founders and directors of Machik, who connected me with a network of bright and talented academics, professionals, and social entrepreneurs engaging Tibetan issues, both on and off the plateau. When David gave me the opportunity to spend several years working for THL and living in the People's Republic of China, it was this community that helped me at every turn, with their kindness, hospitality, and friendship. From Rabsal to Winrock, from Kangding to Beijing, you know who you are.

In the fall of 2010 I returned to Charlottesville once again, this time to study Tibetan and Chinese histories, languages, and religious and medical traditions at the University of Virginia. Under the tutelage of Shu-chen Chen, Hsin-hsin Liang, Anne Kinney, and Paul Groner, and with the generous support of the Foreign Language and Area Studies grant from the American federal government, I was able to study both Mandarin and Classical Chinese in 
a formal context at the University of Virginia, providing a depth of ability and understanding that proved to be invaluable in my continued engagement with the Sinosphere. My understanding of Chinese history and religions was also deepened greatly under the tutelage of Dorothy Wong, Clarke Hudson, Paul Groner, and Ellen Zhang, to whom I shall long be grateful. With the generous support of the Blakemore Foundation, I was also able to continue my Chinese language studies at Tsinghua University in Beijing during the 2012-2013 academic year, benefitting from the unparalleled pedagogy and educational environment of the InterUniversity Program. In the summer of 2013, following my time at IUP, the Arts, Humanities and Social Sciences Summer Research Award from the University of Virginia allowed me to begin transitioning from the classroom to the field-from the textbook to the manuscript-a process that has ultimately culminated in the present dissertation.

During my graduate studies at the University of Virginia, I also continued to study Tibetan language, history, and religion, of course, in the classroom with Tsetan Chonjore, Kurtis Schaeffer, and David Germano, but also outside of the classroom with Khenpo Ngawang Dorje, Nawang Thokmey, Damchoe Gyaltsen, Rinchen Dorje, Tashi Dekyid, Khamokyit, and countless others. I will not soon forget their kindness. During my fieldwork, performed during the 2015-2016 academic year with the generous support of the Fulbright-Hays Doctoral Dissertation Research Abroad Award, I benefitted immensely from the formal lessons of my many teachers at the Qinghai University for Nationalities and the Qinghai University School of Medicine in Xining, as well as the less formal instructions and hospitality of my many friends throughout Qinghai. Following my fieldwork, I have been assisted during the writing process by a dissertation fellowship from the Robert H. N. Ho Family Foundation Program in Buddhist Studies administered by the American Council of Learned Societies. Without this generous support, the present project may never have come to completion.

My hope is that the above narrative of my many adventures in learning-from conception to dissertation-provides even just a small glimpse into the vast generosity that has been extended to me by my family, teachers, friends, and colleagues. As I conducted this research and began presenting it at conferences, I have also benefitted immensely from conversations with Janet Gyatso, Yang Ga, Olaf Czaja, Pierce Salguero, Dan Martin, Tsering Samdrup, Frances Garrett, Henk Blezer, Geoffrey Samuel, Ronit Yoeli-Tlalim, Elisabeth Hsu, Zhen Yan, Sam van Schaik, Tawni Tidwell, Sonam Kachru, Michael Allen, and Stephanie Bernhard (\#thanksforeverything), among many others. I would also like to extend a special gesture of gratitude to my teacher's teacher, Leonard van der Kuijp, for his encouragement and generosity in regard to both his understanding and his resources, including the Beijing manuscript of the Expanded Elucidation of Enlightenment that forms the core of the present dissertation. Finally, I would also like to thank the kind members of my dissertation committee-Ellen Zhang, John Nemec, Kurtis Schaeffer, and David Germano-for their continued advice and encouragement throughout this entire doctoral process. It has been a long road, and I would not be here without you. 


\section{Introduction: On the Very Idea of Buddhist Medicine in Tibet}

Ever since the fourteenth century, Tibetan medicine has traditionally been depicted as the primordial teachings of the Buddha, Master of Medicine-instructions that were transmitted throughout the Buddhist networks of Asia by enlightened sages, assimilated by Tibetan physicians during the imperial period (ca. 600-850), and transmitted within the Tibetan tradition due to the efforts of the Yutok school in the twelfth century. This orthodox narrative has long inspired students of the Tibetan medical tradition to revere its terachings, but careful consideration reveals logical tensions regarding their provenance: are the origins and transmissions of Tibetan medicine one or many? Continuous or interrupted? Cosmopolitan or vernacular? Such questions have long provoked debate among scholars of Tibetan medicine, such that, as Zurkhar Lodrö Gyelpo (b. 1509) once quipped, "in this snowy land of Tibet, as soon as three or more people get together ... they discuss them." ${ }^{\mathrm{I}}$ These discussions have continued into the present age of Euro-American scholasticism, wherein a growing corpus of articles and monographs on the Tibetan medical tradition continues to treat these very same question of provenance. ${ }^{2}$ Entering into dialogue with this corpus, the present study seeks not to describe the origin and definitive history of the Tibetan medical tradition, but to explore the many origins and many histories of Tibetan medicine, and to retrieve the many voices of Tibetan physicians and scholars that have long fallen silent. ${ }^{3}$

I Rgyud bzhi bka' dang bstan bco rnam par dbye ba mun sel sgron me zhes bya ba bzhugs so, in Bod kyi sman rtsis ched rtsom phyogs bsdus (Lhasa: Bod ljongs mi dmangs dpe skrun khang, 1986), 64: bod gangs can gyi khrod 'dir mi gsum tshogs pa yan gyis sman dpyad kyi rgyud bzhi 'di bka' yin nam bstan bcos yin zhes gleng zhing [...]. Cited in Janet Gyatso, Being Human in a Buddhist World: An Intellectual History of Medicine in Early Modern Tibet (New York, NY: Columbia University Press, 20I5), I43. The ellipsis in the translation provided above elides the specific reference to the topic of conversation being the status of the Four Tantras as either the teachings of the Buddha or a treatise composed by subsequent scholars, which, as we shall see, bears upon questions of unified origins, transmission, and geographical provenance for the Tibetan medical tradition as a whole.

${ }^{2}$ For just a small sampling of studies treating the provenance of the Four Tantras in particular, as well as the implications for the Tibetan medical tradition as a whole, see Ronald E. Emmerick, "Sources of the rGyud-bzhi," in Zeitschrift der Deutschen Morgenländischen Gesellschaft, ed. Wolfgang Voigt, supplement 3.2 (Wiesbaden: Franz Steriner, I977), II35-42; Samten G. Karmay, "The Four Tibetan Medical Treatises and Their Critics," in The Arrow and the Spindle (Kathmandu: Mandala Publications, 1998 [repr. I989]), 228-37; Yang Ga, Sources for the Writing of the Rgyud bzhi, Tibetan Medical Classic (Cambridge, MA: Doctoral Dissertation at Harvard University, 20I0); and, most recently, Gyatso, Being Human in a Buddhist World, I43-92. I use the word "Euro-American" to refer to the academic institutions at which these scholars work(ed) and not to comment upon their nationalistic affiliation.

${ }^{3}$ Compare these sentiments with the desiderata outlined in Henk Blezer et al., "Brief Outlook: Desiderata in the Study of the History of Tibetan Medicine," in Soundings in Tibetan Medicine: 
Medicine has not always been framed as a Buddhist practice in Tibet. In the earliest datable instructions for medical practices in the Tibetan language, for example, the etiological conceptions required for surgery and other external therapies (dpyad) reflect a tradition that is largely distinct from those required for ritual healing. ${ }^{4}$ Although there is no evidence for a Tibetan medical tradition that operated in total isolation from traditions of ritual healing, the etiological conceptions of disease as being caused by humoral and visceral imbalances persist in both contrast to and dialogue with notions of pathological demons, each implying distinct approaches to diagnostics and therapeutics. Bridging both surgical and ritual approaches to healing is the prescription of materia medica (sman); herbal, animal, and mineral medicaments can be found accompanying instructions for moxa-cauterization (me btsa) and acuphlebotomy (gtar kha), as well as ransom rituals (glud) and other forms of exorcism..$^{5}$ Thus, even in these earliest examples of Tibetan-language medicine found at Dunhuang, instructions for therapies involving materia medica and surgery (sman dpyad) were transmitted in dialogue with those involving materia medica and rituals (sman sgrub) - a dialogue that would continue throughout the history of the Tibetan medical tradition. ${ }^{6}$

Scholars have long contrasted modes of medical therapy and ritual healing in Buddhist medical traditions. Observing the "empirico-rational" nature of the medical prescriptions found in the Vinaya Discipline and Sūtra Discourse sections of the Pāli Buddhist canon, for example, K. G. Zysk contrasts these traditions from the "magico-religious" approaches to healing found in the Vedas. ${ }^{7}$ While definitively differentiating rational medicine from magical

Anthropological and Historical Perspectives. Proceedings of the Ioth Seminar of the International Association of Tibetan Studies, ed. Mona Schrempf (Leiden: Brill, 2007), 427-38.

${ }^{4}$ See, for example, the three Tibetan-language works found at Dunhuang that describe and illustrate moxibustion practices in PT I27, PT I044, and PT 1058. These have been published in Luo Bingfen 罗秉芬, Huang Bufan 黄布凡, and Byams pa 'phrin las, Tun hong nas thon pa'i bod kyi gso rig yig cha bdams bsgrigs [Dunhuang ben Tubo yixue wenxian xuanbian 敦煌本吐蕃医学文献选编; An Anthology of Tibetan Medical Texts from Dunhuang] (Beijing: Mi rigs dpe skrun khang, 1983); and Luo Bingfen 罗秉芬, Huang Fukai 黄福开, Byams pa 'phrin las, Tun hong nas thon pa'i bod kyi gso rig yig cha gces bsdus [Dunhuang ben Tubo yixue wenxian jingyao 敦煌本吐蕃医学文献精要; A Selection of Tibetan Medical Texts from Dunhuang] (Beijing: Mi rigs dpe skrun khang, 2002).

${ }^{5}$ For instructions that combine prescriptions for materia medica with both external and ritual therapies, see IOL Tib J 756, PT I057, and IOL Tib J I246. On the combination of medicine and ritual in IOL Tib J 756, see Ronit Yoeli-Tlalim, "Between Medicine and Ritual: Tibetan 'Medical Rituals' from Dunhuang," in Tibetan and Himalayan Healing: An Anthology for Anthony Aris, ed. Charles Ramble and Ulrike Roesler (Kathmandu: Vajra Books, 2015), 749-55.

${ }^{6}$ For a study of medical rituals in a contemporary context, see Cathy Cantwell, "The Medicinal Accomplishment (sman sgrub) Practice in the Dudjom Meteoric Iron Razor (gnam lcags spu gri) Tradition: Reflections on the Ritual and Meditative Practice at a Monastery in Southern Bhutan," Journal of the Oxford Centre for Buddhist Studies 8 (2015): 49-95.

${ }^{7}$ Kenneth G. Zysk, Aceticism and Healing in Ancient India: Medicine in the Buddhist Monastery (Delhi: Motilal Banarsidass, 2000 [repr. 199I]). Zysk also argues that these heterodox theories 
healing is compelling for an evolutionary account of religion and science-that is, depicting empiricism and science as a teleological departure from ritual and religion-a careful engagement with the theories and practices of the Tibetan medical tradition reveals a continued dialogue between both religious and medical mentalities throughout the entire history of these traditions. ${ }^{8}$

The separate but interpenetrating nature of the early medical and ritual healing traditions in Tibet is further illustrated by the Buddhist canonical sources translated during the imperial period. Fragments of Tibetan-language translations of the Sutra of Golden Light were also found at Dunhuang, for example, ${ }^{9}$ in which one can find theories and practical instructions for both [I.] ritual healing involving spells, materia medica, and exorcism, ${ }^{10}$ and [2.] medical therapy involving materia medica, surgery, and other external therapies. ${ }^{\text {II }}$ Unlike the Sutra of Golden Light, which frames the practice of medicine within an explicitly altruistic motivation to ease the sufferings of sentient beings, the aforementioned medical instructions found at Dunhuang do not discuss motivation or ethics. Similarly, unlike the canonical Questions of Subāhu explored in Chapter One, which evokes Buddhist goddesses and Indian deities, ritual instructions for prasenā divination found at Dunhuang generally evoke local gods and demons. In a tenth-century ritual manual found at Dunhuang, for example, the Sky-soaring Khyung is evoked in a prasena divination ritual-which allows the ritual master to know the

and practices were ultimately appropriated by orthodox Brāhmanical traditions, leading to the rise of Âyurveda in the first few centuries of the Common Era. See Kenneth G. Zysk, "Mythology and the Brāhmanization of Indian Medicine: Transforming Heterodoxy into Orthodoxy," in Categorisation and Interpretation: Indological and Comparative Studies from an International Indological Meeting at the Department of Comparative Philology, Göteborg University, ed. Folke Josephson (Göteborg: Novum Grafiska AB, 1999), I25-45.

${ }^{8}$ For an account of the "medical mentality," see Gyatso, Being Human in a Buddhist World.

9 See Claus Oetke, Die aus dem Chinesischen übersetzten tibetischen Versionen des Suvarnaprabhāsasūtra: philologische und linguistische Beiträge zur klassifizierenden Charakterisierung übersetzter Texte (Wiesbaden: Franz Steiner Verlag GmbH., 1977). The Denkar catalogue also indicates that the Sutra was translated from both Sanskrit and Chinese into Tibetan before the early ninth century. See the listing of three translations of the Sutra of Golden Light (Skt. suvarña[pra]bhāsottama-sūtra = Chi. Jin guangming zuisheng wang jing 金光明最勝王經 $=$ Tib. 'phags pa gser 'od dam pa mchog tu rnam par rgyal ba'i mdo sdei rgyal po theg pa chen po"i mdo) in the early ninth-century Lhenkar/Denkar catalog: Adelheid HerrmannPfandt, ed., Die Lhan Kar Ma: Ein früher Katalog der in Tibetische übersetzten buddhistischen Texte (Wien: Verlag der Österreichischen Akademie der Wissenschaften, 2008), 49-50, 134-36, and I38-4O (entries 87, 25I, and 256, respectively).

${ }^{10}$ See Catherine Ludvik, Sarasvatī, Riverine Goddess of Knowledge: From the Manuscript-carrying Vināa-player to the Weapon-wielding Defender of the Dharma (Leiden: Brill, 2007), I62-82; and Natalie Gummer, Articulating Potency: A Study of the Suvarṇa(pra)bhāsottamasūtra (Cambridge, MA: Harvard University Doctoral Dissertation, 2000), 239-56.

${ }^{\text {II }}$ See C. Pierce Salguero, "'On Eliminating Disease': Translations of the Medical Chapter from the Chinese Versions of the Sutra of Golden Light," eJournal of Indian Medicine 6 (2013): 2I-43; and Gummer, Articulating Potency, 258-62. 
events and actions of the past, present, and future through divine revelation. Thus, for early physician (sman pa) and tantric diviner (lha pa, sngags pa) traditions alike, the ninth and tenth centuries involved the vernacular practice of cosmopolitan instructions, generally involving creative interpretation, assimilation, and local adaptation. ${ }^{\text {.2 }}$

The traditions of both medical physicians and tantric healers continued to maintain theoretical and practical dialogues well into the eleventh and twelfth centuries. As described in the Testament of $B a$, for example, Padmasambhava famously performed a prasena divination ritual to evoke the Four Great Kings and reveal the identities of demons that had caused fires, floods, and epidemics throughout Central Tibet. This application of prasena divination for the identification of pathogenic demons appears to have been widespread for, with the introduction of channel examination in the tenth or eleventh century, these two modes of divination and diagnosis came to be conflated. When channel examination was first described in some early Tibetan-language sources, for example, it was called a form of prasenā (rtsäi pra) - that is to say, the pulsations of the channels were interpreted not unlike the visionary interpretations involved in prasena. In response to the popularity of channel examination for the diagnosis of disease, a genre of channel prasenā rituals (rtsa'i pra sgrub) developed among tantric communities in which the diviner is explicitly instructed to avoid palpating the channels of the patient, seeking divine revelation instead. This theoretical and practical conflict between the physicians and the diviners was ultimately resolved in the Four Tantras by replacing all references to prasenā divination with the "seven wonder channels" (ngo mtshar rtsa bdun), in which the creative interpretation of channel pulsations would allow for divinatory revelation. Divination rituals would not soon be removed from the repertoire of physicians, however, for instructions regarding channel prasena rituals continued to be transmitted and newly redacted within the Tibetan medical tradition well into the sixteenth and seventeenth centuries. This paired transmission of instructions for diagnosis and divination synecdochically reflects the sustained dialogue of medicine and religion in Tibet, an unceasing controversy that continues to proceed within the amalgamation of diverse healing practices in the Tibetan medical tradition.

By the thirteenth century, following several hundred years of textual accretion, the extent and diversity of medical works-including cosmopolitan textual cycles translated from Sanskrit, as well as vernacular instructions specifically suited for the context of medical practice on the Tibetan plateau - had begun to cause a crisis for both the organization and transmission of medical knowledge in Tibet. The teachings of early Tibetan physicians like Zhangtön Zijibar and Yutok Gönpo-which were primarily summaries of cosmopolitan instructions deriving from South, East, and Central traditions-were in turn summarized, expanded, and transmitted by their students across early medical schools. Following Buddhist models of scholasticism in which a formative root text would be transmitted along with a

\footnotetext{
${ }^{12}$ For a relevant analysis of the cosmopolitan and the vernacular, the utopian and the local, see Sheldon Pollock, "The Cosmopolitan Vernacular," the Journal of Asian Studies 57, no. I
} 
corpus of supplementary materials, the different schools of the thirteenth century ultimately came to form around a limited number of seminal works. This corpus included the Essence of the Eight Branches, a complex work of Indian provenance that was purportedly composed by a South Asian pandit and translated into Tibetan in the early eleventh century; and the Essence of Ambrosia, an instructional tantra of the Yutok school that purportedly represents the emanated teachings of the Master of Medicine himself; among others. As these different communities of scholar-physicians came into communication and competition during the thirteenth century, polemics centering around the non-Buddhist affiliation of the Essence of the Eight Branches and the Tibetan provenance of the Essence of Ambrosia began to ensue.

While the different schools of learned physicians were competing to identify a single formative text for the practice of medicine in Tibet, larger debates regarding the organization of knowledge at the Buddhist monastery also affected this conversation. Celebrated literati of Buddhist centers of learning-such as Sakya Pandita of Sakya, Chomden Rikpé Reldri of Nartang, and Butön Rinchendrup of Zhalu-came to be invested in the mastery of all five Indian fields of knowledge, including Buddhist philosophy, but also logic, grammar, medicine, and arts and crafts. Such pursuits resulted in the institutional promotion of the Indian-authored treatise, the Essence of the Eight Branches, at the expense of the Tibetan scripture, the Essence of Ambrosia, at powerful centers of scholastic Buddhist learning. The emphatic identification of Buddhist scriptures as wholly separate from treatises authored by Indian and Tibetan scholars that took place during the thirteenth and fourteenth centuries allowed for the incorporation of the Eight Branches and its related materials into the Canon of Translated Treatises (bstan 'gyur), and the total disregard for the Essence of Ambrosia. Despite allegations that the latter was actually composed by a Tibetan author, resulting in its exclusion from both the Canon of Translated Treatises and the Canon of Translated Scriptures (bka' 'gyur), the power of its Buddhist framing narrative and its suitability for the practice of medicine in Tibet allowed for the Essence of Ambrosia to ultimately eclipse the Essence of the Eight Branches as the seminal work of the Tibetan medical tradition.

Although the Essence of Ambrosia was formally rejected by the Indocentric literati communities of the thirteenth and fourteenth centuries, it only gained popularity among the practicing physician-scholars of the Yutok school. Commentaries and instructions based on this formative text continued to proliferate, resulting in further summaries and practical works, such as the Secret Essence of Ambrosia and the commentary on the Small Practical Manual described in Chapter Two. This proliferation of instructions was accompanied by a proliferation of framing narratives regarding the origins and transmission of medical teachings in India and Tibet, resulting in contradictory historical accounts within the Tibetan medical tradition. The rise the of khokbuk curriculum in the thirteenth century-a genre of literature outlining the institutional course of study for some of the religious and medical schools in Tibet-necessitated the reconciliation of these disparate narratives: did medical

(1998): 6-37. 
instructions originate in the teachings of Brahmā or the Buddha? Were they redacted by sages that were Indian or Tibetan? Were they first transmitted to Tibet during the Tibetan empire (ca. 600-850) or the Tibetan renaissance period (ca. 950-I200)? Although the earliest examples of khokbuk curricula would generally only promote one of these narrative scenarios at the expense of the other, it was Drangti Penden Tsojé at the Sakya Medical House that came to reconcile the dichotomies of these diverse accounts.

The turn of the fourteenth century marked a new period of flourishing in the Tibetan intellectual tradition at Sakya. Kublai Khan-the powerful leader of the Mongol Yuan dynasty and opponent of Daknyi Chenpo Zangpopel of the Khön clan-died in I294, allowing for the return of Daknyi Chenpo from exile and the reinstatement of the Khön scion upon the throne at Sakya. Around the year I30o Daknyi Chenpo invited the famed physician and scholar, Drangti Jampel Zangpo, to Sakya, leading to his establishment of the Sakya Medical House. The son of Jampel Zangpo, Drangti Penden Tsojé, took monastic vows and studied both Buddhist and medical literature at the Sakya Medical House, resulting in his intimate familiarity with both the scholastic and practical approaches to medicine. Penden Tsojé came to master the five cosmopolitan fields of Indian knowledge as well as the vernacular details of Tibetan medical practice, both the Essence of the Eight Branches and the Essence of Ambrosia, resulting in the standardization of the narratives, theories, and instructions of the Yutok school, and their canonization in the Eighteen Partial Branches collection. Furthermore, he helped finalize a Subsequent Tantra that had been appended to the Essence of Ambrosia at the end of the thirteenth century, and promoted the work under a new title: the Secret Essence of Ambrosia in Eight Branches: An Instructional Tantra (bdud rtsi snying po yan lag brgyad pa gsang ba man ngag gi rgyud), now commonly known as the Four Tantras (rgyud bzhi). Thus, with his standardization and promotion of the Four Tantras as the seminal work of the Tibetan medical tradition, along with its supplementary works in the Eighteen Partial Branches collection, Drangti Penden Tsojé finalized approximately two centuries of accretion, amalgamation, and revision in the Essence of Ambrosia cycle of medical instructions.

Building upon the narratives of the Yutok school, Drangti Penden Tsojé framed the Essence of the Eight Branches and other treatises translated from South Asia-that is, the medical teachings remembered by Brahmā and transmitted to South Asian sages-as teachings that ultimately derive from the Buddha, Master of Medicine. Unlike his predecessors, however, Penden Tsojé was careful not to contradict previously established narratives relating the life of Śākyamuni Buddha, and placed the origins of medical teachings in India in the mouth of Kanakamuni Buddha instead. As described in Chapter Three, Penden Tsojé emphasized the fact that Brahmā "remembered" (Tib. dran pa = Skt. smrrti) medicine in Indian accounts, weaving together multiple Indian narratives about the churning of the ocean of milk, the bifurcation of poison and ambrosia, Rāhu's theft of ambrosia from the gods, and his injuring of Brahmā. The result is a composite narrative in which Brahmā remembers the medical teachings transmitted to him from Kanakamuni Buddha in the form of the Collection of Medicine (gso dpyad 'bum sde) in one hundred thousand verses, miraculously curing his 
wounds and easing his suffering. According to Drangti, it was the mythical Collection of Medicine - rooted in the primordial teachings of a buddha and never extant in this worldthat was transmitted by Brahmā to the retinue of sages and that was summarized to form the Essence of the Eight Branches. By framing the origins of the Indian medical tradition in such a way, Penden Tsojé built upon previously established narrative traditions to effectively create a Buddhist provenance for the entire tradition of Āyurveda-including the Essence of the Eight Branches-rendering the ultimate origins of both the cosmopolitan and the vernacular, of both scripture and treatise, as being the undifferentiated teachings of the Buddha.

Drangti Penden Tsojé also unified and standardized the varied narratives of lineages within the Yutok school of Tibetan medicine. In Chapter Four we analyze the creative rhetoric used by Penden Tsojé to unite the many lineages of physicians practicing in thirteenthcentury Tibet into two: [I.] the so-called "student lineage" (slob brgyud) deriving from Yutok and extending through Sumtön Yeshé Zung and his disciples, as well as [2.] the so-called "familial lineage" (sras brgyud), which includes members of the Yutok family that are not attested in any other sources. While the former lineage extends to Penden Tsojé from his otherwise unknown tutor and mentor, Paktön Shākya Gönpo, the latter familial linage of Yutok connects to the familial lineage of Drangti through the education of Penden Tsojés father, Jampel Zangpo, and his elder brother, Gyelwa Zangpo. Due to his successful unification of different lineages within the Yutok school of Tibetan medicine, subsequent traditions of Tibetan medical history have come to remember Penden Tsojé as the physician that united the distinct teachings of the student and familial lineages, just before the Tibetan medical tradition would branch once again into the Jang (byang) and Zur schools in the fifteenth century.

All of these unifying developments that took place at the turn of the fourteenth centurythe canonization of the Four Tantras, as well as the standardization of the narratives regarding the origins and transmission of medicine in Tibet-were made possible by the institutionalization of the Tibetan medical tradition at the Sakya Medical House. As described in Chapter Five, Drangti Penden Tsojé connects the narratives of cosmopolitan origins with those of vernacular transmissions by crafting new legends of foreign physicians disseminating medical instructions at the courts of imperial Tibet, and promoting a professional code of medical ethics in the prcoess. Adapting narrative motifs that were employed by his teacher, Lama Dampa Sönam Gyentsen, Penden Tsojé narratively institutes an ethical code through the pronouncements of emperor Tri Songdetsen and descriptions of harmonious relations between early Tibetan physicians and patients. He also simultaneously promotes the newly canonized Four Tantras as the essence of the all the teachings transmitted by nine legendary foreign physicians that were purportedly invited to Lhasa in the eighth century, and the Tibetan medical tradition as the essence of all medical traditions governed under the aegis of the Yuan dynasty. Even if different medical traditions once surrounded Tibet in all directions, after Drangti these traditions all came to be understood as implicitly deriving from the teachings of the Buddha, and explicitly united within the Tibetan medical tradition. 
Precedents for the narrative systematization and unification of the Tibetan medical tradition actualized by the Drangti family at the Sakya Medical House can also be found within the narratives of the Four Tantras itself. In the first chapter of the first tantra, the Root Tantra, the teachings of the Buddha, Master of Medicine, are heard as four unique sets of instructions by four distinct retinues - those of the gods, the sages, the Buddhist bodhisattvas, and the non-Buddhist deities, including Brahmā. Although the Root Tantra presents the Four Tantras as the teachings heard by the retinue of the sages - as one teaching among three other untold teachings - the Subsequent Tantra includes a three-stanza account in which [I.] the primordial buddhas emanated in India, China, Dölpo, and Tibet to teach different methods for healing and diagnosis; [2.] taught four distinct medical texts to the retinues of the gods, sages, Buddhists, and non-Buddhist extremists, all of which have been summarized in the Four Tantras; and [3.] just like a single moon that reflects in many ladles of water, "although there is one teaching, there are many individual understandings." 13 Unlike the Root Tantra, which presents the Four Tantras as just one medical teaching among many, the Subsequent Tantra presents itself as the essence of all medical teachings, even those that appear to originate in distant spaces and times. With the promotion of the Four Tantras as the seminal work of the Tibetan medical tradition - along with the standardization of narratives of origins and transmissions, as well as the prescription of professional ethics - the Drangti family at the Sakya Medical House effectively created a tradition of medicine in Tibet that is simultaneously both cosmopolitan and vernacular, both one and many, all within an emphatically Buddhist context of origins, transmission, and ethics.

Before carefully analyzing the corpus of recently published and previously unstudied manuscripts that form the core of the present dissertation, ${ }^{\mathrm{I}}$ let us briefly return to the very idea of Buddhist medicine in Tibet. Throughout South, East, and Central Asia, Buddhist medicine has come to be defined as the medical theories and practices that have been integrated into Buddhist texts and transmitted through Buddhist institutions. ${ }^{15}$ Although the theories and practices of the Tibetan medical tradition came to be framed as the primordial

${ }^{13}$ Dpal ldan rgyud bzhi dpe bsdur ma, vol. 3, 288: 'phags pa'i thugs rje phyogs ris med mod kyang //_gang zag mos pa'i mthong snang so sor shar//_dper na mkha' la zla ba gcig shar nall_chu yi skyogs rer zla ba re re bzhin//_gcig tu gsungs kyang so sos du mar go//.

${ }^{\text {I4 }}$ Thirty volumes of facsimiles of over nine hundred medical and astrological manuscripts that are currently stored in the Potala Palace were published at the end of 20I4, opening up a new era in the study of the Tibetan medical tradition. See Krung go'i bod lugs gso rig rtsa che'i dpe rnying kun btus: Pho brang po ta la'i gsung rab gter mdzod las btus [Zhongguo yiyao yingyin guji zhenben 中国藏医药影印古籍珍本; China's Traditional Tibetan Medical Texts: A Treasury of Scriptures from the Potala Palace], ed. Bod ljongs bod lugs gso rig slob grwa chen mo (Lha sa: Bod ljongs mi dmangs dpe skrun khang, 20I4), 30 vols.

${ }^{15}$ For an early study of medicine in Buddhist literature, see Paul Demiéville, Buddhism and Healing: Demiéville's Article "Byō" from Hōbōgirin, trans. Mark Tatz (Lanham, MD: University Press of America, I985 [1937]). For examples and translations, see C. Pierce Salguero, ed., Buddhism and Medicine: An Anthology (New York, NY: Columbia University Press, 20I7). 
teachings of the Buddha, transmitted to Tibet by Buddhist sages and bodhisattvas, and institutionalized within the Buddhist monastery, are all of these factors sufficient to describe Tibetan medicine as Buddhist? As Nathan Sivin once quipped, "We do not, after all, assume that rice was Taoist because Taoists ate it." ${ }^{" 16}$ But what if that same bowl of rice eaten by our hypothetical Taoists was sowed in the fields of Laozi, reaped and brought to earth by Taoist transcendents, and prescribed as a means for immortality? The contention of the present dissertation is that, leaving our rice metaphor behind, the narrative and ethical framing of potentially non-Buddhist theories and instructions within a Buddhist context transforms those theories and instructions into a form of Buddhist teachings. ${ }^{17}$ Let us now turn to descriptions of two distinct instructional traditions - those of prasenā divination and channel examination - that came to be separately transmitted and performed within the respective context of Buddhist and medical traditions in Tibet, until they finally came into dialogue within the Buddhist medical tradition of Tibet.

\footnotetext{
${ }^{16}$ Nathan Sivin, "On the Word 'Taoist' as a Source of Perplexity: With Special Reference to the Relations of Science and Religion in Traditional China," in Medicine, Philosophy and Religion in Ancient China: Researches and Reflections (Chicago, IL: University of Chicago, 1978), 319. Also published in History of Religions I7 (I978): 303-30.

${ }^{17}$ For a similar description of religion as a repertoire of resources, framed within narratives of imagined communities, see Robert F. Campany, Making Transcendents: Ascetics and Social Memory in Early Medieval China (Honolulu, HI: University of Hawai'i Press, 2009).
} 


\section{Chapter One: Divination and Diagnosis in the Early Tibetan Medical Tradition}

Beginning in the eleventh century, following the introduction of channel examination to Tibet, a professional tension grew between medical modes of observation and ritual modes of revelation. As exemplified by early instructional texts, the palpation of the channels found at the radial artery of a patient would provide a physician with insights into the nature and severity of a patient's illness. If a physician were to interpret these haptic observations according to conceptions of breath or wind in the channels, then he or she would be able to provide external therapies for either supporting deficiencies or clearing repletions. If a physician were to interpret these haptic observations according to an etiology of the humors, then he or she would be able to provide materia medica to correct any thermal or humoral imbalances. Finally, if one were to interpret these haptic observations according to a cosmology of pathogenic demons, then one would perform appropriate rituals to exorcise the offending spirit. More than the others, it was this final mode of interpretation that caused the traditions of early physicians and those of tantric diviners to be conflated.

In what was perhaps the most consequential exorcism in all of Tibetan history-that is, Padmasambhava's exorcism of the mischievous demons that were preventing the flourishing of the Buddhist doctrine in Tibet-it was the revelations of visionary prasena divination that led to the identification of the offending spirits. Padmasambhava would have had to rely on alternative ritual techniques to subdue these spirits, but it was prasena that allowed him to identify them. Similarly, the instructions for prasenā rituals in relation to channel examination also allow for the tantric diviner to identify the precise class of demon that is to be exorcised. Differentiating these two instances of prasena rituals, however, is the fact that the former was addressing an illness that had spread throughout a large population, while the latter refers to the illness of an individual identified through the medium of a messenger. Variations on this mediated identification of demonic illness came to be known as the examination of the wonder channels, which were transmitted and redacted repeatedly for at least half a millennium.

Following the canonization of the wonder channels in the Subsequent Tantra, however, the oracular revelations unique to channel prasenā rituals came to be replaced by a combination of haptic observation elemental divination. With this new representation of the wonder channels, a physician could still determine the fate and fortune of his patients by means of mediated channel examination, but unlike channel prasena rituals, the instructions found in the Subsequent Tantra rely exclusively on the interpretation of haptic signs. Despite this elision of prasenā from the Subsequent Tantra, it was not uncommon for instructions on channel examination to conflate the practice with the word prasena. Therefore, by the redaction of the Subsequent Tantra, which probably occurred in the thirteenth century, the physicians 
responsible for its compilation made explicit efforts to separate the elemental divination of channel examination from the oracular divination of prasenā.

\section{The Social Context of the Medical Tradition in Twelfth-century Tibet}

Prior to the institutionalization of Tibetan medical traditions in the thirteenth and fourteenth centuries, the authority and reputation of the unaffiliated Tibetan physician largely rested upon his or her successful diagnosis, prognosis, and treatment of patients. If a physician were able to successfully interpret the symptoms of a patient, identify a probable cause for the illness, predict the chance of fatality for the patient, and decide whether or not to actually treat the patient based upon that prediction, such a physician would generally be able to maintain their reputation as a successful healer. The social and ethical repercussions of the pre-institutional practice of medicine have been identified not only in the context of Tibetan medical traditions, ${ }^{18}$ but also those found throughout the pre-modern world, ${ }^{19}$ revealing a primary concern for reputation and the prognosis upon which it depends. Although the Buddhist institutionalization of medicine may have diminished this emphasis on personal reputation, ${ }^{20}$ successful diagnostic examination, prognostic interpretation, and therapeutic intervention have all continually remained central to the medical enterprise in Tibet and beyond.

${ }^{\mathrm{I} 8}$ For a study on the social realities of pre-institutional Tibetan medical practice, see Kurtis R. Schaeffer, "Death, Diagnosis, and the Physician's Reputation in Tibet," in Heroes and Saints: The Moment of Death in Cross-cultural Perspectives, ed. Phyllis Granoff and Koichi Shinohara (Newcastle: Cambridge Scholars Publishing, 2007), I59-72.

${ }^{19}$ See, for example, G. E. R. Lloyd, ed., Hippocratic Writings (London: Penguin Books, 1978), I70: "It seems to be highly desirable that a physician should pay much attention to prognosis. If he is able to tell his patients when he visits them not only about their past and present symptoms, but also to tell them what is going to happen, as well as to fill in the details they have omitted, he will increase his reputation as a medical practitioner and people will have no qualms in putting themselves under his care. Moreover, he will the better be able to effect a cure if he can foretell, from present symptoms, the future course of the disease." Cited in Schaeffer, "Death, Diagnosis, and the Physician's Reputation in Tibet," I6I. On the social circumstances of pre-institutional medicine in Europe, see Darrel W. Amundsen, Medicine, Society, and Faith in the Ancient and Medieval Worlds (Baltimore, MD: Johns Hopkins University Press, 1996); Michael R. McVaugh, Medicine Before the Plague: Practitioners and Their Patients in the Crown of Aragon 1285-I345 (Cambridge: Cambridge University Press, 1993); and Ludwig Edelstein, "Hippocratic Prognosis," in Ancient Medicine: Selected Papers of Ludwig Edelstein, ed. Owsei and C. Lilian Temkin, 65-86 (Baltimore, MD: Johns Hopkins University Press, 1967).

${ }^{20}$ For a discussion of medical ethics in thirteenth-century Tibet, see Janet Gyatso, Being Human in a Buddhist World: An Intellectual History of Medicine in Early Modern Tibet (New York, NY: Columbia University Press, 2015), 343-96. For the contextualization of Tibetan medical traditions within the bodhisattva ethical framework at the seventeenth-century court of the Fifth Dalai Lama, see Kurtis R. Schaeffer, "Textual Scholarship, Medical Tradition, and Mahāyāna Buddhist Ideals in Tibet," Journal of Indian Philosophy 3I (2003): 62I-4I. 
If much has been written about the importance of reputation and personal success in the early period of Tibetan medical history, less has been written about the actual performance of diagnosis and prognosis. While it is probably safe to assume that there was some degree of competition among early physicians-each seeking out the best methods for the diagnosis and treatment of his or her patients-the diverse nature of this competition has been obscured following the standardization of medical practice in the Four Tantras (rgyud bzhi) at the Sakya Medical House (sa skya sman grong). Despite claims of perennial coherence and continuity, the prescribed methods for medical examination and interpretation found in prefourteenth-century medical instructions, some of which contribute to the instructions found in the Four Tantras itself, include an accretion of unresolved controversies regarding the fundamental details of medical theories and practices-from etiology to prognosis, from diagnosis to therapy. ${ }^{21}$ Indeed, even the synthetic efforts of the Four Tantras retain a complex combination of humoral, elemental, and demonological etiologies that persist in perpetual dialogue down to the present day.

In an attempt to disaggregate the etiological controversies of the Four Tantras specifically, as well as the intellectual trajectories of the Tibetan medical tradition as a whole, the present chapter focuses upon the cosmological controversies found in an interrelated web of prefourteenth-century medical instructions. One obstacle that has heretofore prevented a clear description of these early traditions and their developments is the scarcity of medical instructions that can be dated with any significant degree of confidence. Fortunately, perhaps due to the centrality of diviners (lha pa) in the early establishment of Buddhism in Tibet, a series of instructions for and descriptions of prasenā divination (pra se na) - that is, a series of related rituals designed to reveal clairvoyant knowledge of the past, present, and future in reliance upon reflective surfaces and divine inspiration-were redacted in the Tibetan and Chinese Buddhist canons, a ritual manual found at Dunhuang, and the early narrative of the Tibetan empire, the Testament of $W a$ ( $d b a$ ' bzhed). By focusing not upon the act of literary creation in these works, but on the datable acts of compilation and redaction, I herein seek to demonstrate the complex processes in which pan-Asian divination rituals were transmitted in Buddhist scriptures and adapted to local practices and sensibilities.

Although instructions for channel examination (Tib. rtsa la brtag pa = Chi. maizhen 脉诊)— that is, pulse diagnosis or sphygmology — can be found in the earliest works of Chinese medical literature, detailed instructions for these diagnostic techniques cannot be found in the Tibetan language until the redaction of the Medicine of the Moon King (sman dpyad zla ba'i rgyal po) in the eleventh or twelfth century. ${ }^{22}$ Following the introduction of channel

${ }^{21}$ On the notion of "undecided controversies" the Chinese medical tradition, see Jürgen Kovacs and Paul U. Unschuld, Essential Subtleties on the Silver Sea: The Yin-hai jing-wei, a Chinese Classic on Ophthalmology (Berkeley, CA: University of California Press, 1998), I9 et passim.

${ }^{22}$ The dating of this early Tibetan medical scripture is still the subject of some controversy. For a translation and analysis of the ten channel examination chapters found in the Moon 
examination up to its inclusion in the Subsequent Tantra (phyi rgyud, redacted $13^{\text {th }} \mathrm{c}$. ?), ${ }^{23}$ a deluge of works elaborating upon channel examination instructions began to appear in Tibet. Some of these instructions merely served to summarize the ten chapters on channel examination found in the Moon King, rendering them more comprehensible and appropriate for practice, while others came to expand upon elements found in the Moon King, combining disparate modes of diagnosis and divination, and providing entirely new modes of medical examination and interpretation. One innovative cycle of practices combining the techniques of channel examination with the revelations of prasena divination came to be called "channel prasenā rituals" (rtsa'i pra sgrub), while a distinct but related cycle of divinatory practices came to be called the "seven [or sometimes eight] wonder channels" (ngo mtshar rtsa bdun), the latter of which came to be canonized in the Subsequent Tantra of the Four Tantras. By tracing the development of these medico-divinatory practices in response to the introduction of channel examination in the Tibetan medical tradition, I seek to not only establish a relative chronology of instructional texts for the first time, but also illuminate the interpenetrating developments of divination and diagnosis in the ritual and clinical traditions of Tibetan medicine.

The precise provenance of the channel prasenā ritual is not entirely clear, for many of these and other instructions for channel practices are simply attributed to Nāgārjuna (klu sgrub), the mythological redactor featured in the frame narrative of the Moon King. ${ }^{24}$ Subsequent redactions mention early figures involved in the transmission of religious and medical teachings in Tibet, however, such as the inconsistent attribution of the channel prasenā rituals found in the Three Indispensable Rituals (med thabs med pa'i 'phyong gsum) to Drapa Ngönshé (gra pa mngon shes, IOI2-I090) and Yutok Gönpo (g.yu thog mgon po, I2 ${ }^{\text {th }}$ c.). Perhaps due to this illustrious attribution, the entire Three Indispensable Rituals collection was then included as a sub-collection in the Eighteen Partial Branches (cha lag bco brgyad, redacted early $\mathrm{I} 4^{\text {th }} \mathrm{c}$.), which was compiled during the life of Drangti Penden Tsojé (brang ti dpal ldan 'tsho byed, ca. I3IO-I380). Two specific channel prasenā rituals found in both the Three Indispensable Rituals and the Eighteen Partial Branches collections-the Three Goddess Sisters and the Black-lipped Brahminess-also come to be included with three other channel prasena rituals in a cycle that forms the opening five chapters of the Great Gold Measure (gser bre chen mo, redacted late $I 4^{\text {th }}$ c.), a collection of instructions compiled by the nephew of Penden Tsojé, Drangti Penden Gyentsen ( $4^{\text {th }}$ c.). One of these new channel prasenā rituals-the Yellow Sage-also appears once again in the later Essential Nucleus of Yutok (g.yu thog snying thig, redacted $\mathrm{I}^{{ }^{\text {th }}}$ c.?) collection. Thus, despite the fact that prasenā divination and channel examination have generally been performed by different figures-the diviner (lha pa, mo pa)

King, see my forthcoming chapter, "Vessel Examination in the Medicine of the Moon King," in Buddhism and Medicine: An Anthology, edited by C. Pierce Salguero (NewYork, NY: Columbia University Press, 20I7), in press.

${ }^{23}$ For an explanation of this late redaction date, see below.

${ }^{24}$ On Nāgārjuna's role in the redaction of the Moon King, see Chapter Three. 
and the physician (sman pa), respectively-hybrid techniques like the channel prasenā rituals described below flourished for over half a millennium following the introduction of channel examination to Tibet, permeating the boundaries of divination and diagnosis in particular, as well as ritual and medicine in general.

\section{Mirror Divination, Child Mediums, and Oracular Revelation: The Tibetan Assimilation of Prasenā Divination}

The Tibetan practice of prasena divination is a complex web of related rituals variously involving mirror divination, child spirit mediums, and oracular revelation. The term appears to have a South Asian provenance, but was a late addition to the Sanskrit lexicon. Frederick Smith, ${ }^{25}$ building upon the work of Michel Strickmann ${ }^{26}$ and in communication with Alexis Sanderson, has proposed that the Sanskrit word prasenā "is a back formation, derived from a non-Sanskrit word that has been subsequently Sanskritized," ${ }^{27}$ and that the practice probably "derived from village spirit-mediums, women, or others of lower social rank." 28 Instructions for prasena divination were propagated in the seventh and eighth centuries among pan-Asian Buddhist networks, particularly in the Questions of Subāhu Tantra (Skt. subāhu-pariprcchānämatantra = Tib. dpung bzang gis zhus pa’i rgyud = Chi. Sipohu tongzi qingwen jing 蘇婆呼童子請問經), where a ritual practitioner is instructed to interview a child medium who is able to look into a mirror or some other reflective surface and divine the events of the past, present, and future. ${ }^{29}$ Rather than representing one coherent practice, however, the Questions of Subāhu appears to be a collection of several distinct but related divinatory practices that were redacted together at an early stage. Moving beyond its initial introduction to Tibet, prasenā divination comes to encompass a broad repertoire of divinatory practices that were assimilated from cosmopolitan Buddhist networks and then adapted to vernacular sensibilities, including the diagnosis of demonic disease.

${ }^{25}$ For his discussion of prasena , which is perhaps the best available in the English language, see Frederick M. Smith, The Self Possessed: Deity and Spirit Possession in South Asian Literature and Civilization (New York, NY: Columbia University Press, 2006), 42I-27.

${ }^{26}$ Michel Strickmann, Chinese Magical Medicine, edited by Bernard Faure (Stanford, CA: Stanford University Press, 2002), 210-I4.

${ }^{27}$ Smith, The Self Possessed, 423.

${ }^{28}$ Smith, The Self Possessed, 448.

${ }^{29}$ For a study of prasenā in the Sekoddeśa section of the Wheel of Time Tantra (kālacakratantra) and associated commentaries, see Giacomella Orofinao, "Divination with Mirrors: Observations on a Simile Found in the Kālacakra Literature," in Tibetan Studies: Proceedings of the 6th Seminar of the International Association for Tibetan Studies, Fagernes 1992, edited by Per Kvaerne (Oslo: Institute for Comparative Research in Human Culture, I994), 6I2-28. Therein she also briefly mentions the contents of the Questions of Subāhu Tantra, among many other appearances in subsequent Tibetan literature. Herein I build upon her foundational study. 


\section{On the Meaning of the Word Prasenā}

Although there are numerous mentions of the word prasena throughout the Chinese (Chi. bosina 鉢私那 or botian 鉢天) and Tibetan (Tib. pra [se na]) canons, the Questions of Subāhu Tantra contains the most detailed canonical description of the ritual. Subāhu was famously translated into Chinese in 726 by Śubhakarasiṃha (Shan Wuwei 善無畏; 637-735), preserved in two different editions, ${ }^{30}$ and once more in the tenth century by Dharmadeva (Fa Tian 法天; d. IOOI) and/or other members of the Northern Song Institute for Canonical Translation (Yijing yuan 譯經院; later known as the Institute for the Transmission of the Dharma [Chuanfa yuan 傳法院]). ${ }^{31}$ Lacking any Chinese-language commentarial literature, the Questions of Subāhu Tantra appears to have primarily served as a work of practical instructions during the Tang and Song dynasties.

Surpassing the materials found in the Chinese Buddhist canon, the Tibetan canon contains not only an edition of the Questions of Subāhu Tantra root text found in the Translated Scriptures (bka' 'gyur), ${ }^{32}$ but also three exegetical works that were presumably translated from

${ }^{30}$ Sipohu tongzi qingwen jing 蘇婆呼童子請問經 (TI8no895). There are two texts under this title that appear to be distinct but related translations (a twelve-chapter Ti8no895a and a thirteenchapter Ti8no895b). Only Ti8no895b lists Subhakarasimha as the translator in its colophon (CBETA pp. I6-I7): “Translated by Master Śubhakarasimha (Shan Wuwei), from the west of the Central Kingdom of the Great Tang (and a group of śrämana monks). Redacted by Master $\mathrm{Da} \mathrm{Gu}$ on the first day of the third month of the third year of the Cheng era. It was offered [to the emperor] and received with respect" (右大唐中天竺國三藏輸波迦羅[唐云善無畏]譯[沙門一行筆]

承曆三年三月一日於大谷阿闍梨御 房奉受了). The Nanjio Catalog lists this edition as being translated in 724 with the help of Yixing 一行 (683-727): Bunyiu Nanjio, A Catalogue of the Chinese Translation of the Buddhist Tripitaka: The Sacred Canon of the Buddhits in China and Japan (Oxford: Clarendon Press, I883), \#53I (pp. I22-23). On the role of Subhakarasimha in the establishment of esoteric Buddhism in China see, for example, Charles D. Orzech, “The 'Great Teaching of Yoga' the Chinese Appropriation of the Tantras, and the Question of Esoteric Buddhism," Journal of Chinese Religions 34 (2006): 29-78.

${ }^{3 \mathrm{I}}$ Miaobi pusa suowen jing 妙臂菩薩所問經 (TI8no896) in twelve chapters. The colophon does not mention Dharmadeva, but the Nanjio Catalog attributes the work to him: Bunyiu Nanjio, A Catalogue of the Chinese Translation of the Buddhist Tripitaka, \#822 (p. I89). On Fa Tian and the Institute for Canonical Translation, see Tansen Sen, "The Revival and Failure of Buddhist Translations During the Song Dynasty," Toung Pao 88 (2002): 27-80; and, more recently, Charles D. Orzech, "Translation of Tantras and Other Esoteric Buddhist Scriptures," in Esoteric Buddhism and the Tantras in East Asia, ed. Charles D. Orzech, Henrik H. Sørensen, and Richard K. Payne (Leiden: Brill, 20II), 439-50.

32 'Phags pa dpung bzang gis zhus pa zhes bya ba'i rgyud, in Bka' 'gyur dpe bsdur ma, ed. Krung go'i bod rig pa zhib 'jug ste gnas kyi bka' bstan dpe sdur khang, rgyud 'bum, text 0835, vol. 96 (wa), pp. 434-508 (full text); pp. 464-70 (ch. 7). This should not be confused with 'Phags pa lag bzangs kyis zhus pa zhes bya ba theg pa chen po'i mdo, which can be found in the Jewel Heap Sutra (Tib. dkon brtsegs = Skt. ratnakūța) section of the Kangyur. See Bka' 'gyur dpe bsdur ma, dkon brtsegs, 
Sanskrit and canonized in the Translated Commentaries (bstan 'gyur) — two anonymous, ${ }^{33}$ and one attributed to Buddhaguhya (fl. early $8^{\text {th }}$ c.). ${ }^{34}$ Despite lacking any colophon information, the Questions of Subāhu Tantra and an unnamed commentary (de'i'grel pa) are both included in the Denkarma catalogue, demonstrating the fact that they were both translated into Tibetan before the early ninth century. ${ }^{35}$ Thus, at least from the time of its redaction in the early seventh century until the time of its retranslation into Chinese in the late tenth century, the Questions of Subāhu Tantra and its associated commentarial literature were transmitted widely, from the Tang capital at Chang'an, to the Denkar Palace in Central Tibet, and back to the Institute for Canonical Translation in Kaifeng.

All three extant Chinese-language editions of the work include a description of the prasenā divination ritual in chapter eight, the “Descent of Bosina [=Prasena] " (xia bosina 下鉢私那) ${ }^{36}$ or the "Evocation of Celestial Bo[sina] for Prognostication" (zhaoqing botian shuoshi 召請鉢天說事). ${ }^{37}$ Despite diverse descriptions of revelation through inanimate media, reflective surfaces, dreams, and child mediums, the Chinese-language renderings of the term prasenā in the Questions of Subāhu exclusively refer to the evocation of a deity named Bosina or Celestial Bo. ${ }^{38}$ Although the Tibetan edition of and commentaries on Subāhu also contain an

text 0087 , vol. 43 (ca), pp. 433-510. Colophon of the latter (p. 497): “Translated, edited, supplemented with new language, and redacted by the Indian master Dānashīla, Jinamitra, and the Editor-in-Chief, translator mendicant Yeshé Dé" (rgya gar gyi mkhan po dā na shī la dang /_dzi na mi tra dang /_zhu chen gyi lotstsha ba ban de ye shes sdes bsgyur cing zhus te skad gsar chad kyis kyang bcos nas btan la phab pa//). The relationship between the Subāhu Sutra and Subāhu Tantra, if indeed there is one, deserves further investigation.

33 'Phags pa dpung bzangs kyis zhus pa'i rgyud kyi tshig gi don bshad pa'i brjed byang, in Bstan 'gyur dpe bsdur ma, rgyud, text I579, vol. 7I (thu), pp. I50-273 (full text). The second anonymous commentary on the Questions of Subāhu Tantra does not treat the seventh chapter: 'Phags pa dpung bzangs kyis zhus pa'i rgyud kyi bsdus pa'i don dgrol ba'i brjed byang, in Bstan 'gyur dpe bsdur ma, rgyud, text I580, vol. 36 (thu [7I]), pp. 274-319 (full text).

${ }^{34}$ Dpung bzangs kyis zhus pa'i rgyud kyi bsdus pa'i don, in Krung go'i bod rig pa zhib 'jug ste gnas kyi bka' bstan dpe sdur khang, ed., Bstan 'gyur dpe bsdur ma, rgyud, text 1578, vol. 36 (thu [7I]), pp. I02-49 (full text), II9-23 (ch. 7) by Master Buddhaguhya (slob dpon sangs rgyas gsang ba). Chapter Seven of Buddhaguhya's commentary is effectively just an abridged retelling of the root text with very little added information. On Buddhaguhya, see Stephen Hodge, The MahaVairocana-Abhisambodhi Tantra: With Buddhaguhya's Commentary (New York, NY: Routledge, 2003).

35 Adelheid Herrmann-Pfandt, ed., Die Lhan Kar Ma: Ein früher Katalog der in Tibetische übersetzten buddhistischen Texte (Wien: Verlag der Österreichischen Akademie der Wissenschaften, 2008), I78-79 (\#325).

${ }^{36}$ Ti8no895a, pp. I4-I5; Ti8no895b, pp. IO-II.

${ }^{37}$ Ti8no896, pp. I2-I3.

${ }^{38}$ For another Chinese-language reference to bosina ("Po-ssu-na"), see Strickmann's analysis of the Medicine Buddha Contemplation Ritual (yaoshi rulai guanxing yigui fa 藥師如來觀行儀軌法) translated by Vajrabodhi (Jingang Zhi 金剛智; 67I-74I) in the early eighth century. The term is 
accretion of prasenā rituals involving the descent of deities, the Tibetan translational and interpretive approaches to the term prasena differ significantly from those of their Chinese counterparts.

Despite the presence of extensive descriptions of prasenā rituals in chapter seven of the root text, common Tibetan terms for prasenā divination - that is, the "descent of pra[senā]" (pra phab pa) or the "evocation of pra[sena]]" (pra dbab pa)-do not appear in the root text of the Questions of Subāhu. Instead, the Tibetan transcription of the term prasenā (Tib. pra se na) appears in only one of the three commentaries. To assert that the term prasena was not in use when the Sanskrit root text of the Questions of Subāhu was presumably redacted in the early seventh century would be an argumentum ex silentio, but Smith's conclusion that prasenā is a non-Sanskrit back formation, compounded by its absence in Buddhaguhya's early eighthcentury commentary, supports the notion that the term prasena was not always associated with these divinatory practices during the seventh century. From this evidence, we can tentatively propose that the divination ritual practices described below predate the appellation of prasenā, even in South Asia, but by the early eighth century-that is, by the time of Subhakarasimha's 726 Chinese translation-the term prasenā would have gained a wider purview.

While a comprehensive comparison of the Chinese and Tibetan editions of the Questions of Subāhu would be beyond the purview of the present discussion, it is important to note that the prasenā chapter of the Tibetan edition begins not with the prasenā rituals described above, but with detailed instructions for the offering of human flesh ( $m i$ sha'i sbyin bsreg) to a group of carnivorous yoginī demonesses (sha za ma mo drag mo srin mo’i tshogs). ${ }^{39}$ One is also encouraged to recruit older female relatives (best), friends (middling), or spouses (worst) to engage in sexual union and evoke the demoness(es), ${ }^{40}$ and in doing so one should seek to receive secret mantras for gaining their favor (gsang sngags mnyes byas grub pa)..$^{4 \mathrm{I}}$ The relationship between

mentioned in passing in the context of asking a prasena child to make an offering (fengqing bosina tongzi 奉請鉢私那童子) in Tigno923, p II. Strickmann, Chinese Magical Medicine, 2IO-I4.

${ }^{39}$ Bka' 'gyur dpe bsdur ma, rgyud 'bum, text 0835, vol. 96 (wa), 465. Although the Chinese editions of Subhähu do contain references to such charnel offerings, they are not in the chapter describing the prasenā ritual. See the offering of human flesh and blood (ren rouxie 人肉血) at the end of chapter six in Ti8no895a (p. I2); the offering of human flesh (renrou 人肉) at the end of chapter five in Ti8no895b (p. 8); and the consumption of flesh and blood (dan xierou 噉血肉) at the end of chapter eleven in Ti8no896 (p. 20). These elements, of course, are contrary to the supposed prohibition of blood rites (Sen, "The Revival and Failure of Buddhist Translations During the Song Dynasty," 56). For a brief note on the discretion used in translating the blood rites in the Questions of Subāhu, see Orzech, "Translation of Tantras and Other Esoteric Buddhist Scriptures," 445.

${ }^{40}$ Bka' 'gyur dpe bsdur ma, rgyud 'bum, text 0835, vol. 96 (wa), 466: 'dod chags zil gyis non pa'i bud med dag/_gnod pa byed pa nges par gnas par 'gyur//. The commentary renders these lines even more explicitly sexual.

${ }^{41} B k a$ ' 'gyur dpe bsdur ma, rgyud 'bum, text 0835, vol. 96 (wa), 465. 
these somewhat varied evocation ritual cycles themselves is not entirely clear, let alone their relationship with the subsequent cycles included in the same chapter. Following these instructions is an abrupt list of reflective implements that could potentially be used in prasenā rituals:

[Potential ritual implements:] Thumb, mirror, sword, water, a crystal, a butter lamp, earth, iron, space, a begging bowl, or a jewel in firelight. Clear revelations of the past, present, and future shall always arise [in these]. One shall understand the clear and timeless revelations of all the virtuous and non-virtuous actions of the higher realms and those of the earth. $^{42}$

Shall always arise: Such implements (rdzas) are the bases of prasena $\bar{a}$ revelation; the capacity for visions. ${ }^{43}$

In the anonymous commentary, "prasenā revelation" is placed in apposition with the "capacity for visions" inherent in such ritual containers and reflective implements. This reading is also supported by the Mahāvyutpatti (Tib. Bye brag tu rtogs par byed pa [chen mo]), which glosses prasenam with "bright appearance," or "clear vision" (gsal snang). ${ }^{44}$ Thus, despite indications in the Chinese editions that the word prasena may be the name of a deity, it would seem that in the Tibetan-language exegetical materials on the Questions of Subāhu, the term prasenā refers not to the deity him- or herself, but to oracular appearances of divine inspiration.

\section{Child Mediums, Prasenā Revelation, and Possession}

Although the instructions for prasenā described above are terse, they still come to represent a complete ritual act in which an implement is examined and revelations of the past, present, and future arise. Following this first prasenā ritual cycle found in the Questions of Subāhu are several subsequent cycles that are not typographically separated, but contain redundancies and logical inconsistencies between them. Therefore, in the present discussion "ritual cycle" should be heuristically understood as the instructions for a complete ritual act that usually

${ }^{42}$ Bka' 'gyur dpe bsdur ma, rgyud 'bum, text 0835, vol. 96 (wa), 467: mthe bong me long ral gri chu dang shel//_mar me sa gzhi lcags dang nam mkha' dang//_lhung bzed nor bu dag dang me 'bar bal/_di la gsal bar ston pa rtag tu 'byung //_'das pa dang ni ma 'ongs da ltar byung //_mtho ris sa steng dus dang mi ldan yang //_lha dang lha min dge dang mi dge ba'i//_las rnams thams cad gsal bar ston par rtogs//.

43 Bold font and indented passages indicate quotations from the anonymous commentary. These quotations are selective, but influence my reading and insertions throughout the rest of the translation: Bstan 'gyur dpe bsdur ma, rgyud, text I579, vol. 36 (thu [7I]), 216: rtag tu 'byung zhes bya ba ni rdzas de rnams pra se na ston pa'i gzhi yin te/_snang tu btub ces bya ba'i tha tshig go/.

${ }^{44}$ Bye brag tu rtogs par byed pa, in Bstan 'gyur dpe bsdur ma, sna tshogs, text 3590, vol. II5 (co [219]) p. 135 . 
involves some kind of preparation, evocation, and revelation. As we shall see, the Tibetanlanguage edition of the Questions of Subāhu is composed of approximately three distinct cycles of instructions for prasenā rituals that each culminates in revelation and clairvoyance. While the first ritual involves the direct observation and interpretation of visions and spontaneous appearances, the second and third involve children as mediums for divine revelation.

The second ritual cycle begins with detailed instructions about when to perform the ritual, how to set up the ritual space, how to bathe and clothe the child, how to make offerings, how to prepare the ritual implements, and so forth. Regarding the actual performance of the ritual, we are told:

Within that [ritual space], [the practitioner] should perform all of the following actions: One should wash [oneself and the child medium], dress him or her in clean white clothes, and have him or her sit atop a kuśa straw mat. [Both the child and the practitioner] should face the east. Meanwhile one should also recite secret mantras and engage in mindfulness. ${ }^{45}$

Wipe the mirror seven, eight, or ten times with the pure ashes [of a fire consecration ritual]. Then, with a one-pointed focus [evoking the deity], recite secret mantras. Meanwhile, as the young child faces the east, he or she will begin to stare with divine eyes and come to see the past, present, and future. ${ }^{46} \ldots$

With divine eyes: One should spread the ash from a fire consecration ritual on one's fingers and, while reciting secret mantras, request "Pray, bless this one with divine eyes!" And smear [the ash on] the eyes of the child....

Come to see: Seeing the visual form of things, the conveyance of meaning with written syllables, and some have said that one can even hear the sound of an explanation. ${ }^{47}$

${ }^{45}$ Bka' 'gyur dpe bsdur ma, rgyud 'bum, text 0835, vol. 96 (wa), 468: de nas nang par cho ga 'di kun byal/_khrus byas lus la gos dkar gtsang bgos tel/_shar phyogs kha bltas ku sha'i stan steng du//_dug nas gsang sngags rjes su dran par byal/.

${ }^{46}$ Bka' 'gyur dpe bsdur ma, rgyud 'bum, text 0835, vol. 96 (wa), 468: me long thal ba gtsang mas lan bdun nam//_brgyad dam yang na bcur ni phyis nas su//_rtse gcig sems kyis gsang sngags zlos bzhin du//_bus pa gzhon nu nub tu kha bstan nas//_lha yi mig gis bltas na 'das pa dang //da ltar dang ni ma 'ongs mthong bar'gyur//.

${ }^{47}$ Bstan 'gyur dpe bsdur ma, rgyud, text 1579, vol. 36 (thu [7I]), 2I7: lha yi mig gis zhes bya ba ni sbyin sreg byas pa'i thal bas sor mo la bskus te/_gsang sngags dag kyang bzlas nas/_lha'i mig tu byin gyis brlab tu gsol//_zhes bskul tshig bcug nas/_byis pa'i mig la bsku ba'i don to//... mthong bar gyur zhes bya ba ni dngos po rnams gzugs su mthong ba 'am/_yi ge'i 'bras bus kyang brda sprod par byed do//_kha cig na re gzhi bsnyen na sgrar yang grag ce'o//. 
One should offer perfumed ointments and flowers to the body [of the inspired medium]. Then the young child should look [at the ritual implements]. With clear revelations, dreams, and so forth, one will realize manifest accomplishments, and one should recite [mantras]. If one does not come to believe, then [the practitioner] should recite nonharmful awareness mantras. ${ }^{48}$

If one does not come to believe: If one doubts whether prasen $\bar{a}$ has come to be established ...

Non-harmful awareness mantras: Regarding the deities of the awareness mantras, there are two kinds: there are those of the buddhas and the bodhisattvas that emerge from gnosis, and there are those of Íśvara and so forth that engender maturation. Similarly, there are the blessings [of the former] — the fierce and frightening fires and so forth-that are utilized for the sake of as many sentient beings as there are in the limits of cyclic existence. And there also are the mundane blessings that are harsh and harmful, those of the mother goddesses and so forth that have reached the end of eras. If such [blessings] descend, there is a danger that the child might die, and therefore it is advised that [the practitioner] recite non-harmful secret mantras that are not like these. ${ }^{49} \ldots$

In this second ritual cycle the child medium clearly plays a central role, but the ritual master is also instructed to please the deity with offerings in order to compel it to appear in a dream. The language of the commentary indicates that it is the blessings (byin gyis rlabs) of the buddhas, bodhisattvas, and even İśvara that are to be evoked, although there is a danger that the recitation of harmful mantras might lead to harmful blessings. The work continues with further directives in case the initial ritual was ineffective, including mantra recitation and

${ }^{48}$ Bka' 'gyur dpe bsdur ma, rgyud 'bum, text 0835, vol. 96 (wa), 468: sku gzugs la ni byug spos me tog dbul//_de nas bus pa gzhon nus blta bar bya//_gsal bar ston dang rmi lam la sogs pas//_dngos grub brtags te de nas bzlas brjod bya//_gal te yid ches par ni ma gyur nal/_de nas rig sngags mi gdug bzlas brjod byal/.

${ }^{49}$ Bstan 'gyur dpe bsdur ma, rgyud, text I579, vol. 36 (thu [7I]), 2I7-I8: gal te yid ches par ni ma gyur nal_zhes bya ba ni pra se nas gtan la ma phebs su dogs na zhes bya ba'i tha tshig go//_rig sngags mi gdug ces bya ba ni rig sngags kyi lha la yang rnam pa gnyis te/_sangs rgyas dang byang chub sems dpa' dag ni ye shes las byung ba'ol/_dbang phyug la sogs pa ni rnam par smin pas bskyed pa'o//_de bzhin du de dag gi byin gyi rlabs las 'khor ba'i mtha' ji tsam par sems can gyi don mdzad pa khro bo 'jigs pa'i me la sogs pa dang /_jig rten pa'i yang bskal pa'i mthar thug par ma mo la sogs pa drag cing gdug par byin gyis brlabs pa dag yod de/_de dag phab na byis pa 'chi ba'i nyen yod pas de lta bu ma yin pa'i gsang sngags mi gdug pa bzlas par bstan to//. 
visits to holy Buddhist sites. This ritual cycle closes and the next begins abruptly with an emphatic remark: "My secret mantra, hüm, will cause [a deity] to descend even into a tree; not to mention a human being!" ${ }^{50}$ This shift from a mood of supplication to a mood of coercion defines the shift from prasenā revelation to possession.

Here I must again emphasize that, although there is no clear demarcation between these sets of ritual instructions, it is the manner of expression and the logic of the text that shifts. For example, in the prasena a revelation ritual cycle the child medium is called "young child" (byis pa gzhon $n u$ or bus pa gzhon $n u$ ), while in the possession ritual he or she is exclusively called the "vessel of descent" (dbab pa'i snod). The nature of this descent shifts as well; in the second cycle of prasenā instructions reflective materials are central to the communication between the child and the deity, while they are not mentioned at all in the latter ritual. Finally, unlike the Chinese editions mentioned above, in neither the Tibetan-language edition of the root text of the Questions of Subāhu nor its related exegetical material is the word prasenā used to describe the possession ritual.

In the possession ritual the ritual master is first told to inspect the "vessels"-in this case one is advised to use multiple child mediums, all with very specific physical characteristics. Again, one is told how to wash them, dress them, and make offerings, and again, one is told to recite mantras. Unlike the ambiguously referenced secret mantras of the prasene $\bar{a}$ ritual, however, the possession ritual provides a phrase to be said: "Hūṃ! Take possession!" (grahaṇa àveśa):

[Following descent, the children's] eyes will be bright and unblinking. Recognizing the completion [of the descent], without doubt, one should ask questions. Present consecrated water and burn incense as offerings and, concentrating upon the secret mantra of supreme awareness, prostrate and ask, "What manner of deity are you? Pray, what must I do in the three times? Please consider this and tell me carefully." ${ }^{51}$

After learning of whether one shall achieve pleasure or pain, success or failure, and holding such explanations in memory, one should immediately release [the spirit] again. Reciting harmless mantras and performing such rituals, if [the spirit] does not come to descend into the

${ }^{50}$ Bka' 'gyur dpe bsdur ma, rgyud 'bum, text 0835, vol. 96 (wa), 468: nga yi gsang sngags hūm zhes bya ba'dis//_shing la'ang 'bab na mi la smos ci dgos//.

${ }^{51}$ Bka' 'gyur dpe bsdur ma, rgyud 'bum, text 0835, vol. 96 (wa), 468: mig ni gdangs shing 'dzums par mi byed nal/_rdzogs par gyur par shes par byas nas sul/_jigs pa med par de tshe dri bya bal/ mchod yon dang ni bdug pa phul nas su//_rig pa mchog gi gsang sngags dran byas nas//_phyag 'tshal nas ni lha phyogs gang yin dri//_dus gsum dag gi bdag gi dgos pa gang //_de ni legs par dgongs la bka' stsol cig//. 
vessel, others will consider [the practitioner] to be a foolish individual and they will all come to blame him. ${ }^{52}$

[The children's eyes] should be relaxed and, in terms of width, they should be big and wide open. They should also be stable and the pupils should be big, radiant, and appear to have a reddish tinge. Not closing and not opening, they should be like the eyes of the deities. If a deity has descended upon the vessel, they will come to be like this. If their eyes become extremely red and round, however, wide open, extremely unattractive, and frightening - if they stare without closing them and without fear-such are the eyes of a descended räkșasa, yakșa, or slithering spirit. ${ }^{53}$

The possession ritual closes with advice on how to exorcize the unwanted spirits with powerful mantras and rituals, and closes with the assurance that the practitioner shall achieve the attainments that he or she desires. Thus, unlike the prasena revelation ritual that involves reflective ritual implements and divine blessings for communication, the àveśa ritual centers around the coercion of a powerful but potentially capricious deity, forcing him or her to descend into the child mediums, asking questions about the past, present, and future, followed by a speedy release.

The seamless apposition of prasenā divination and possession rituals is telling. Despite differences in detail, both of these rituals may involve child mediums, divine inspiration, and oracular revelation. Even our anonymous commentator does not neatly differentiate between the two, as indicated by the admonition against unwanted blessings caused by the recitation of dangerous mantras. As our careful reading of the different Chinese- and Tibetan-language editions shows, however, the prasenā chapter of the Questions of Subāhu involves several separate but related ritual cycles, each involving evocation, descent, and revelation. First, there is a brief cycle in which a practitioner induces visions with reflective implements and mantras, communicating directly with the deity that may or may not descend into the implement itself. Second, there is a more detailed cycle in which an inspired child medium sees or hears the blessed revelations of a deity through reflective implements, but is not necessarily possessed. Third, there is a cycle in which a possessed child medium allows the

${ }^{52}$ Bka' 'gyur dpe bsdur ma, rgyud 'bum, text 0835, vol. 96 (wa), 468: bde dang sdug bsngal dngos grub thob mi thob//_shes nas de yang de bzhin bzung nas su//_de ma thag tu slar yang gtang bar byal/_mi gdug sngags bzlas cho ga 'di rnams kyis//_dbab pa'i snod la mi yis phebs gyur gyi//_gang zhig blun pas gzhan du brtsams na ni//_de ni mi rnams kun gyis dpyas par'gyur//.

${ }_{53}$ Bka' 'gyur dpe bsdur ma, rgyud 'bum, text 0835, vol. 96 (wa), 468: zhi zhing gzhungs la rgya che dkyus kyang ring //_brtan zhing gzi chen mdangs ldan dmar bar snang //_dzums zhing 'byed med lha yi mig dang 'dral/_dbab pa'i snod la lha babs de ltar 'gyur//_mig ni rab tu dmar zhing zlum por 
practitioner to directly communicate with the divine without the medium of reflective implements. Each of these three modes of divination-if they ever were distinct-came to interpenetrate during transmission and translation of the Questions of Subāhu, resulting in a family of related ritual cycles that could all appropriately be called prasenā.

\section{Prasenā Divination in Tibetan Literature}

Following the transmission and translation of prasenā ritual instructions to Tibet during the eighth or ninth century, vernacular instructions for and descriptions of prasenā rituals also began to proliferate in Tibet. Despite the fact that in the Tibetan and Chinese Buddhist canons prasena $\bar{a}$ represents a diverse family of practices, they all center around mediated communication with the divine. Such characteristics can also be seen in the prasena ritual featured in the tenth-century ritual manual of Bhikṣu Prajñāprabhā (Tib. b-ig kru prad nya pra ba '-i no pyi ka = Skt. [sādha]naupayika?; IOL Tib J 4OI) found at Dunhuang. ${ }^{54}$ The section detailing prasenā rituals in Bhikṣu Prajñāprabhā's manual begins with the title "Ritual of the Sky Soarer" (nam ka lding gi cho ga), and an interlinear note on the second page of the section assures us, "if one wishes to see prasenā, one should engage in this meditative method." notion of "seeing" praseñ is reminiscent of the reflected appearances described in the Questions of Subāhu, and, like the Questions, here too we see evidence for several distinct but interrelated ritual instructions whose boundaries are difficult to discern.

Perhaps attesting to its early and widespread influence, prasenā divination is also featured centrally in the pre-twelfth-century story narrating the establishment of Buddhism in Tibet, the Testament of $\mathrm{Wa} / \mathrm{Ba}(\mathrm{dba} / \mathrm{sba} b z h e d){ }^{56}$ As is well known, with the repeated occurrence of calamities following the introduction of Buddhist scriptures to Tibet, an exasperated Sāntarakșita recommends that Tri Songdetsen invite the ritual master Padmasambhava to identify and subdue these demons. In the words of Sāntarakṣita, we are told of the Indian master's abilities:

'dug/_bgrad cing rab tu mi sdug 'jigs 'jigs ltal/_dzums pa med cing 'jigs med blta ba nal/_srin po lto 'phye gnod sbyin babs pa'i mig/.

${ }^{54}$ Jacob Dalton and Sam van Schaik, eds., Tibetan Tantric Manuscripts from Dunhuang: A Descriptive Catalogue of the Stein Collection at the British Library (Leiden: Brill, 2006), 136-42. See also Cathy Cantwell and Robert Mayer, Early Tibetan Documents on Phur pa from Dunhuang (Wien: Verlag der Österreichischen Akademie der Wissenchaften, 2008), 20I-203; and Sam van Schaik, "A Tibetan Book of Spells," Early Tibet (19 February 2009), <earlytibet.com/2009/02/19/a-tibetan-book-of-spells/>.

${ }^{55}$ IOL Tib J 4OI, I2v.7: pra se na mthong bar'dod na bsgom ba'i thabs 'di ltar bya'o.

${ }^{56}$ On the complex question of dating the Testament of $\mathrm{Wa}$, see Per Sørensen, "Preface," in $\mathrm{Dba}$ ' bzhed: The Royal Narrative Concerning the Brining of the Buddha's Doctrine to Tibet, trans. Pasang Wangdu and Hildegard Diemberger (Wien: Österreichischen Akademie der Wissenschaften, 2000), $i x-x v$. For an indication that at least parts of this story date back to the ninth or tenth century, see Sam van Schaik and Kazushi Iwao, "Fragments of the Testament of Ba from Dunhuang," Journal of the American Oriental Society 128, no. 3 (2008): 477-87. 
This master of mantra [Padmasambhava] will call the pra[senā] of the Four Great Kings to descend, asking "Last year there was a great flood that overcame Pangtang, there was a fire that raged in the Rasa castle, and so forth. Who are the dark deities and wicked serpent spirits that have prohibited the Tsenpo from propagating the doctrine?" He will examine the prasena, and call the wicked deities and common serpent spirits to descend to his presence. If he binds them and commits them under oath, commanding them and disciplining them, the land will become peaceful. ${ }^{57}$

Following this description, Padmasambhava then goes on to perform the ritual in order to identify the demonic causes of the recent calamities in Tibet:

That day, along with the chamberlain and internal affairs officer, Senggo Lhalung Tsopzher Nyenlek, the Khenpo [Padmasambhava] called the prasenā of the [Four] Great Kings to descend, saying "Two years ago, there was a great flood that overcame Pangtang, there was a fire that raged in the Rasa castle, and there were diseases that spread among both man and beast. Who are the gods and serpent spirits that caused these [calamities]?" [Padmasambhava] ascertained the names and clans of all the wicked ones and summoned them to manifest ... $5^{8}$

Upon this successful performance, Padmasambhava then famously summons these demonic agents of flood and fire, plague and starvation, threatening them and binding them by oath to protect the doctrine. At the core of this narrative is Padmasambhava's extraordinary capacity for identifying and naming the malicious gods and serpent spirits responsible for the disasters throughout the Tibetan kingdom. His mode of divination is somewhat ambiguous, however,

${ }^{57}$ Rba bzhed phyogs bsgrigs (Beijing: Mi rigs dpe skrun khang, 2009), 253: sngags mkhan 'dis ni na ning 'phang thang du chu bo che byung ba dang lha sa'i sku mkhar mes tshig pa la sogs tel_lha klu gnag cing mi srun pa rnams kyis btsan po'i zha snga nas chos mdzad du mi ster ba gang lags pa rgyal po chen po bzhi'i pra phab ste dri ba dang /_pra se na lta ba dang /_lha klu mi srun pa phal ba gnad la dbab cing dam 'og tu stsal cing mna' bsgag pa dang /_bsgo zing nan tur bgyis na yul zhi ste [...]. Translated in consultation with Wangdu and Diemberger, Dba' bzhed, I7 (summary), 54 (translation), f. IIb (Tibetan).

${ }^{58}$ Rba bzhed phyogs bsgrigs, 254: de [bzhin] du mdzad par chad nas mkhan pos de'i gdugs la gzims mal ba gnang chen seng mgo lha lung 'tsho bzher gnyan legs la rgyal po chen po dgu [=bzhi?] pra'i phab ste smrar stsal/_gzhe[s] ni[ng] 'phang thang du cho bo che 'bebs pa dang /_ra sa'i [sku] mkhar mes tshig par byed pa dang /_mi nad phyugs nad dang mu ge gtong ba'i rgyu bgyid pa'i lha klu gang lags rmas nas/_mi srun pa kun gyi ming rus bzung nas dngos su bkug ste/. Translated in consultation with Wangdu and Diemberger, Dba' bzhed, 55 . 
for it is not entirely clear that he is working with reflective implements or child mediums. Regardless, it is clear that in this story Padmasambhava communicates with the Four Great Kings through to identify and summon the wicked gods and spirits that had maliciously caused calamities throughout Tibet in previous years.

In sum, the term prasenā was transmitted from the Indian subcontinent to the Tibetan plateau in a canonical Buddhist form by the eighth century or earlier, and it came to represent a family of related ritual cycles involving either the direct inspection of divine signs in reflective implements, the inspection of divine signs in reflective implements mediated by a child medium, or the direct interrogation of a deity through a possessed child medium. As evinced by Bhikṣu Prajnāprabhā's ritual manual, by the tenth century the term prasenā was being used to describe oracular rituals involving local Tibetan deities and ritual implements in the context of tantric visualization, but also could potentially involve a child medium. The Testament of $W a$ takes the term prasenā one step further from its canonical Buddhist representation, however, for not only does the tale deemphasize the use of reflective ritual implements, but Padmasambhava also is able to question the Kings directly without the aid of a medium. Perhaps most importantly for present purposes, in this latter description Padmasambhava engages in prasenā divination to identify the mischievous demons responsible for the illnesses befalling the people and animals of Central Tibet. Thus, whatever the cosmopolitan transmission of the term prasenā may have been, it quickly came to represent vernacular ritual sensibilities-local modes of summoning local deities for local purposes - and continued to flourish across the Tibetan Plateau in diverse contexts. ${ }^{59}$

\section{Channel Examination and Prasenā Divination}

Although instructions for channel examination (rtsa brtag pa) are not present among the earliest available Tibetan-language medical texts found at Dunhuang, ${ }^{60}$ a sophisticated system of channel examination can be found in the early and influential Tibetan medical

${ }^{59}$ See, for example, Hildegard Diemberger, "Female Oracles in Modern Tibet," in Women in Tibet, ed. Janet Gyatso and Hanna Havnevik (New York, NY: Columbia University Press, 2005), I33-36.

${ }^{60}$ See, for example, Zhen Yan, " $r T s a$ in the Tibetan Manuscripts from Dunhuang," trans. Vivienne Lo, Asian Medicine 3 (2007): 296-307. Here she observes that, despite the plethora of Chinese-language materials on channel examination found at Dunhuang, there is a visible lack of such tecniques in the Tibetan-language manuscripts. For more on Chinese-language channel examination at Dunhuang (including some problematic speculations regarding its relation to the Tibetan tradition), see Elisabeth Hsu, "A Hybrid Body Technique: Does the Pulse Diagnostic cun guan chi Method Have Chinese-Tibetan Origins?" Gesnerus 65, nos. I-2 (2008): 5-29; and, more recently, "Le diagnostic du pouls dans la chine mediévale d'apres les manuscrits de Dunhuang (with notes on P2II5, P3106, P3287, P3477, P348I, P3655, P4093, S79, SI8I, S202, S56I4, S6245, S8289, plus index," in Médecine, religion et société dans la Chine médiévale : Étude de manuscrits chinois de Dunhuang et de Turfan, ed. C. Despeux (Paris: College de France, Institut des Haute Etudes Chinoises, 20IO), book I, pp. I07-84. 
scripture, the Medicine of the Moon King (sman dpyad zla ba'i rgyal po, redacted $\mathrm{II}^{\text {th }}$ or $\mathrm{I}^{\mathrm{th}} \mathrm{c}^{\text {??). The }}$ Moon King provides detailed instructions for the examination of both the channels $(r t s a)$ and the urine $(c h u)$ of patients - examinations that continue to be the primary modes of diagnosis in nearly all traditions of Tibetan medicine down to the present day. ${ }^{61}$ The Tibetan-language instructions for channel examination display a clear indebtedness to Chinese traditions, for they include translations of Chinese terms like the "power of yin-darkness" (sribs kyi ngad), "the power of yang-brightness" (gdags kyi ngad), and pathogenic "cold qi-breath" (Tib. dbugs grang mo = Chi. hanqi 寒氣). ${ }^{62}$ Notions of yin, yang, and cold qi also appear in the Four Tantras, but only in the channel examination chapter that is largely based on this presentation from the Moon King, ${ }^{63}$ supporting my hypothesis that the Moon King served as the basis of all subsequent developments in Tibetan channel examination.

Although the Tibetan practice of channel examination described in the Moon King could confidently be deemed "empirical" - that is, it constitutes the investigation of an object based on haptic observation - these empirical observations were also interpreted within the medical and cosmological frameworks available during the eleventh and twelfth centuries. After describing potential interfering conditions like the age or sex of a patient, for example, the Moon King provides very explicit instructions on the location for channel palpation and how to interpret those observations:

Regarding diseases of repletion or depletion-as indicated by fast or slow pulsations - if the patient's channels pulsate more than five times during each respiratory cycle of the physician, this is indicative of heat. If the patient's

${ }^{61}$ For a brief analysis of urinalysis in the Moon King, see Ronit Yoeli-Tlalim, "On Urine Analysis and Tibetan Medicine's Connections with the West," in Studies of Medical Pluralism in Tibetan History and Society, ed. Sienna Craig, Mingji Cuomu, Frances Garrett, and Mona Schrempf, eds. (Halle: International Institute for Tibetan and Buddhist Studies GmbH, 20IO), I95-2II.

${ }^{62}$ The recently published manuscript editions of the Moon King differ slightly from the modern print editions. Compare Sman dpyad zla ba’i rgyal po, in Krung go’i bod lugs gso rig rtsa che'i dpe rnying kun btus: pho brang po ta la'i gsung rab gter mdzod las btus, vol. 5, text I, p. 23 (f. 34a): dus ni snang pa byung pa dang /_/mun pa dag dang ri rtse la/_/nyi ma dag ni shar ba ni/_/sribs kyi [ngad la] [mun pa] gyes pa dang /_/gdags kyi ngad la ma g.yos nal_/dus bzhi'i dbang thang de dus rgyu; with Sman dpyad zla ba’i rgyal po, Bod kyi gso rig pa'i gna' dpe phyogs bsgrigs dpe tshogs, vol. 33 (Beijing: Mi rigs dpe skrun khang, 2005), 60: dus ni snang ba byung ba dang //_mun pa med dang ri rtse la//_nyi ma dag ni shar ba dang //_sribs kyi dwangs ma [nub pa] gyes pa dang //_gdags kyi dwangs ma [nyi ma 'das] g.yos pa dang //_dus bzhi'i dbang thang de dus brtsi//.

${ }^{63}$ For the sources of the channel examination chapter in the Four Tantras, see Yang Ga, Sources of the Rgyud bzhi, 242-45. For a detailed comparison of the channel examination instructions found in the Moon King and the Four Tantras, see Sgrol dkar skyabs, "Zla rgyal dang rgyud bzhi'i rtsa brtag thad la cung tsam bsdur te dpyad pa" [Comparative Studies on Pulsology in the Texts: King of Moon and rGyu-Zhi (sic)], Krung go'i bod kyi gso rig [Tibetan Medicine in China] 7, no. 3 (2008): I03-IIO. 
channels pulsate less than five times during each respiratory cycle of the physician, this is indicative of cold. Slow pulsations indicate cold. Fast and elevated pulsations indicate heat. Yin channels are cold. Yang channels are hot. $^{64}$

The physician should examine the characteristics of heat and cold in the upper and lower parts of the six openings. If, at the patient's two gan-gate openings, the physician's middle fingers detect repletion, depletion, emptiness, strength, weakness, and so forth, this corresponds to the area between the diaphragm and the head of the patient. If, at the patient's two tsön-inch openings, the physician's forefingers detect powerful pulsations and so forth, this corresponds to the area between the diaphragm and the navel of the patient. Pulsations detected by the physician's ring fingers at the patient's two chak-foot openings correspond to the area from below the navel [down to the soles of the patient's feet.] ${ }^{65}$ Thus the physician should examine the channels for strength or weakness - that is, for heat or cold. ${ }^{66}$

Cold corresponds to weakness, dullness, frailty, and crookedness in the channels. Cold corresponds to submerged, unclear, slow, and fragile pulsations. Heat corresponds to firmness, fullness, twists, and strength in the channels. Heat corresponds to floating and empty pulsations. In sum, such is the dyad of heat and cold... ${ }^{67}$

In these rich passages we gain a fairly clear understanding of the mechanics of channel examination in the Tibetan tradition. The physician is instructed to primarily investigate the channels of a patient for fast or slow pulsations - the counts of which are measured in relation to the breath cycles of the physician-which correspond to diseases of heat or cold,

\footnotetext{
${ }^{64}$ Sman dpyad zla ba'i rgyal po (Lhasa Msi), p. 23 (f. 34b): lhag chad drag dal nad dag ni//_lnga las mang ba tsha ba ste//_lnga las nyung ba grang ba’i rtsa//_dal ba grang ba’i rtsa yin tel/_myur zhing mtho ba tsha ba 'o//_sribs kyi rtsa ni grang pa ste//_tsha ba rtags kyi rtsa yin no//.

${ }^{65}$ Sman dpyad zla ba'i rgyal po (Beijing print), 6I: chag gnyis lte ba man chad nas//_rkang pa'i mthil ni yan chad do//. The latter line is not included in Sman dpyad zla ba'i rgyal po (Lhasa MsI), p. 23 (f. 34 b).

${ }^{66}$ Sman dpyad zla ba'i rgyal po (Lhasa Msi), p. 23 (f. 34b): tsha grang dag gi khyad par stel/_stod smad sor mo drug la 'o//_kan gnyis lhag chad stong pa stel/_drag zhan dag kyang de bzhin no//_mchin dri 'go'i bar dag go/_tshon gnyis drag tu 'phar ba nal/_mchin dri lte ba'i bar dag stel/_chag gnyis lte ba man chad smad//_drag zhan tsha grang brtag par bya'o//.

${ }^{67}$ Sman dpyad zla ba'i rgyal po (Lhasa Msi), p. 23 (f. 34b): nyams chung mnyen pa drang pa ste//_zhan dang 'khyog par mthun pa yin//_bying dang zhar ba dag dang ni//_dal dang g.yung bar mthun pa'o//_ mkhrang ba [tsha ba] dang ni rgyas pa ste//_'phril ba dang ni drag pa 'o//_rkyal pa dang ni stong pa ste//_bsdus pas tsha grang gnyis su'o//.
} 
respectively. By haptically observing three points along the radial artery at the wrist of the patient, the physician is also able to assess the health of the three tiers of organs in the body: the upper tier, which is above the diaphragm and refers to organs primarily involved in the cardiovascular and respiratory systems; the middle tier, which is between the diaphragm and the navel and refers to organs primarily involved in the digestive system; and the lower tier, which is below the navel and refers to organs primarily involved in the excretory system. ${ }^{68}$ Other haptic characteristics of hot and cold diseases are also given, indicating an emphasis on observation through palpation.

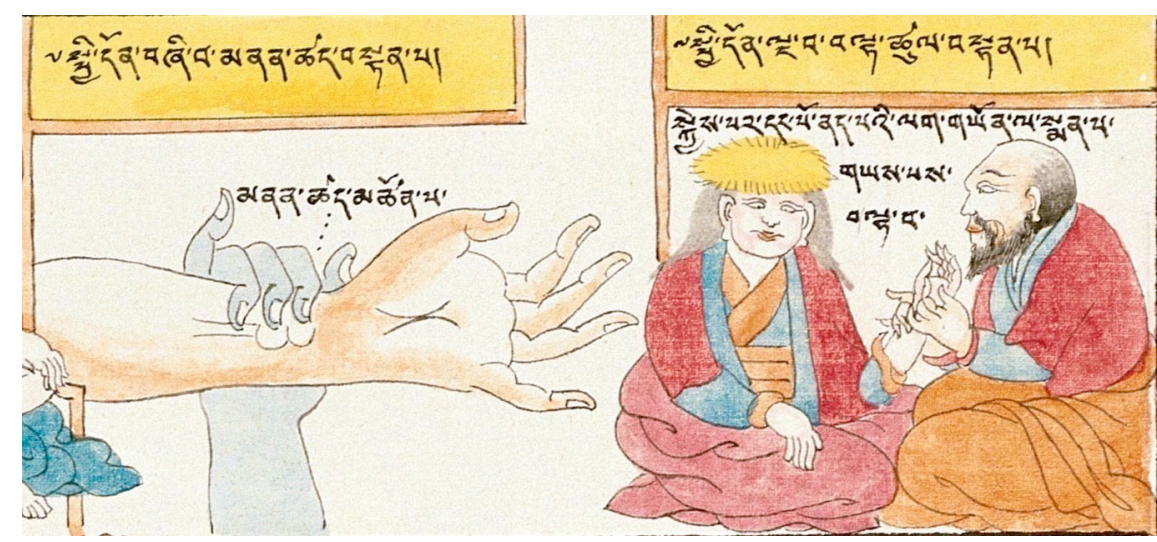

Figure I.I. Detail of channel examination from the medical painting series commissioned by Desi Sanggyé Gyatso (I653-1705) in the late seventeenth century. ${ }^{69}$

Even in these early instructions for channel examination, we already can see two competing etiological systems in the interpretation of haptic signs. We are told that fast pulsations should be interpreted as a symptom of both pathogenic heat as well as the repletion of qi (lhan), while slow pulsations should be interpreted as a symptom of pathogenic cold as well as the depletion of $q i$ (chad). While these two notions need not be mutually exclusive, they ultimately indicate different conceptions of disease and different approaches to therapeutics. Diseases of repletion and depletion, particularly in regard to specific organs, are often addressed through the external therapies (dpyad) of moxa-cauterization and phlebotomy, which serve to cleanse the channels and improve the circulation of $q i$ or winds (rlung).$^{70}$ Diseases of heat and cold,

${ }^{68}$ For a similar hierarchy of viscera, see Susan Sontag, Illness as Metaphor (New York, NY: Farrar, Straus and Giroux, 1977), I7-18.

69 Reproduced from Yuri Parfionovitch, Fernand Meyer, and Gyurme Dorje, eds., Tibetan Medical Paintings: Illustrations to the Blue Beryl Treatise of Sangye Gyamtso (I653-I705) (New York, NY: Harry N. Abrams, 1992), vol. I, p. I24, plate 54. For the history of these illustrations, see Janet Gyatso, Being Human in a Buddhist World: An Intellectual History of Medicine in Early Modern Tibet (New York, NY: Columbia University Press, 20I5), 23-80.

${ }^{70}$ For external practices in the Tibetan medical tradition, see Pasang Yontan Arya, "External Therapies in Tibetan Medicine: The Four Tantras, Contemporary Practice, and a Preliminary 
however, are often treated with materia medica concoctions (sman sbyor) with thermal properties appropriate for counterbalancing the diseases of the patient. ${ }^{7 \mathrm{I}}$ Thus, even in this short passage, we already can find two competing—although, not mutually exclusive-modes of interpretation for the same haptic observation.

Following these initial instructions for the observation of the channels, subsequent chapters of the Moon King are largely dedicated to the interpretation of these observations. One such chapter, dedicated to "Demonic Channels" (gdon rtsa), describes the means for identifying afflictions caused by serpent spirits (Tib. klu = Skt. näga), mother goddesses (Tib. $m a$ mo = Skt. mātrkā), haunting spirits (btsan), goblins (the'u rang), bewitching spirits ('gong po), worm spirits (srin po), masters of death (gshin rje), scent-eaters (Tib. dri za = Skt. gandharva), and so forth, all on the basis of haptic observation. ${ }^{72}$ These instructions for the creative interpretation of haptic observations-particularly for the identification of uniquely Tibetan pathogenic demons like haunting spirits, goblins, bewitching spirits, worm spirits, and so forth $^{73}$ - were paired with other instructions for identifying "Signs of Death" ('chi ltas), seasonal characteristics of the channels, and so forth, allowing Tibetan physicians to adapt their haptic interpretations to a variety of etiologies, predictions, and therapies.

\section{Channel Examination as Prasenā Divination}

Taking the practical breadth of prasena divination and the interpretive breadth of channel examination into account, one might not be surprised to find that early Tibetan physicians came to interpret channel examination as a type of prasenā divination. Transcending the projected dichotomy of medical diagnosis and religious divination, these physicians brought a divinatory hermeneutics and vocabulary to the interpretation of a patient's channels. Guiding instructions for channel prasenā divination (rtsa yi pra khrid) or, more generally, guiding instructions for prasenā divination (pra khrid) appear in some of the earliest literature on channel examination, which was most probably composed under the influence of the instructions found in the Moon King. Although there are few features of these guiding instructions on channel prasen $\bar{a}$ that resemble canonical forms of prasen $\bar{a}$ that we saw above, the nebulousness of the very concept of prasenā itself may have allowed its practitioners to be some of the first figures that took up foreign practices like channel examination. Thus,

History of Surgery," in Bodies in Balance: The Art of Tibetan Medicine, ed. Theresia Hofer and Barbara Gerke (New York, NY: Rubin Museum of Art, 20I4), 64-89.

${ }^{71}$ For material medica in the Tibetan medical tradition, see Theresia Hofer, "Illustrated Materia Medica Prints, Manuscripts, and Modern Books," in Bodies in Balance: The Art of Tibetan Medicine, ed. Theresia Hofer and Barbara Gerke (New York, NY: Rubin Museum of Art, 20I4), 226-45. See also Chapter Three of the present dissertation.

${ }^{72}$ For translated excerpts from this chapter, see McGrath, "Vessel Examination in the Medicine of the Moon King."

${ }^{73}$ For more on these and other non-obvious beings in Tibet, see René de Nebesky-Wojkowitz, Oracles and Demons of Tibet: The Cult and Iconography of the Tibetan Protective Deities (The Hague: Mouton, 1956). 
following the introduction of channel examination to Tibet in the tenth or eleventh century, physicians came to incorporate a modified prasena divination into their repertoires, while diviners also adapted the semblance of channel examination for their predictions.

Most descriptions of channel prasenā divination appear in works attributed to Nāgārjuna, the illustrious Indian sage and mythological redactor of the Moon King. Distinct cycles of medical teachings attributed to Nāgārjuna number in the dozens, with a majority of these works including at least a small section on channel examination. ${ }^{74}$ One such work, the Lamp of Sunbeams: A Channel Manual (rtsa yig nyi zer sgron me) attributed to Nāgārjuna, provides "guiding instructions for channel prasena divination" (rtsa yi pra khrid), which includes not the three humors of Āyurvedic provenance, but five-blood (khrag), bile (mkhris pa), wind (rlung), black phlegm (bad kan smug po), and yellow phlegm (bad kan skya bo)—as well as many other common descriptions of disease. ${ }^{75}$ The analysis also involves terminology for the three fingers/sites of palpation that is found in the Moon King and clearly derives from the Chinese language - that is, the tsön-inch (Tib. tshon < Chi. cun 寸), kan-gate (Tib. gan < Chi. guan 關), and chak-foot (Tib. chag < Chi. chi 尺) openings, located along the radial artery of the patient (see Figure 1.I) ${ }^{76}$ After a brief explication of observable haptic phenomena and their corresponding disorders, the Lamp of Sunbeams assures us: "Having understood the above [correspondences] thusly, one should then diagnose individual diseases." ${ }^{.77}$ Thus, the Lamp of Sunbeams provides instructions for the observation and interpretation of a patient's channels according to a humoral conception of disease and, with the exception of the label of prasena, these instructions for channel examination found in the Lamp of Sunbeams are no different than those found in the Moon King.

This labelling of channel examination as prasenā divination continues into one of the few extant instructions that might historically be attributable to Yutok Gönpo (g.yu thog mgon po, I2 ${ }^{\text {th }}$ c.), the Thousand Session Channel Tutorial (rtsa'i stong thun). The genre of the "thousand session tutorial" (stong thun) is not limited to the literature of medicine, and refers to the experiential knowledge that derives from one thousand (stong) repetitions or sessions (thun) of any particular practice. ${ }^{78}$ As we will see in Chapter Four (Fig. 4.2), a collection of thousand

\footnotetext{
${ }^{74}$ For an anthology of such works, see Slob dpon klu sgrub kyi sman yig gces btus.

${ }^{75}$ Rtsa yig nyi zer sgron me, in Slob dpon klu sgrub kyi sman yig gces btus, 365-66.

${ }^{76}$ For more on the $t s o ̈ n$-inch, kan-gate, and chak-foot channel openings and their historical relationship to Chinese vessel examination, see Zhen Yan and Cai Jingfeng, "Tibetan and Chinese Pulse Diagnostics: A Comparison-With Special Reference to Locations for Pulse Taking," in Soundings in Tibetan Medicine: Anthropological and Historical Perspectives. Proceedings of the Ioth Seminar of the International Association of Tibetan Studies, ed. Mona Schrempf (Leiden: Brill, 2007), 327-43.

${ }^{77}$ Rtsa yig nyi zer sgron me, in Slob dpon klu sgrub kyi sman yig gces btus, 365: yin par gong ma dag gis shes//_de ltar so sor nad ngos bzung //.

${ }^{78}$ See, for example, José Cabezón's A Dose of Emptiness: An Annotated Translation of the sTong thun chen mo of mKhas grub dGe legs dpal bzang (Albany, NY: State University of New York Press, 1992). Perhaps due to the subject of Khedrup Jé's tutorial, Cabezón appears to have been
} 
session tutorials is one of the few works attributed to Yutok Gönpo in the Indispensable Account of Transmission, and a collection of eleven tutorials can be found in the Eighteen Partial Branches (cha lag bco brgyad) collection promoted by Drangti Penden Tsojé. Individual manuscript witnesses of several tutorials have recently come to light, as well as one complete collection of the Eleven Thousand Session Tutorial Cycle (skor tshoms stong thun bcu gcig), including the Thousand Session Channel Tutorial chapter. ${ }^{79}$ Although these medical instructions may indeed derive from the twelfth century, polemics found at the end of the Thousand Session Fluid Tutorial (chu'i stong thun) reveals the role of the Drangti family in the redaction of the tutorials. ${ }^{80}$ Thus, regardless of their ultimate origins, the Eleven Thousand Session Tutorial Cycle was first redacted during the life of either Drangti Jampel Zangpo (ca. 1276-1335), Penden Tsojé (ca. I3IO-I380), or Penden Gyentsen (I $4^{\text {th }}$ c.), and was then included as a sub-collection in the Eighteen Partial Branches by the middle of the fourteenth century.

The Channel Tutorial also has a section on channel prasenā, but rather than use prasenā as a general rubric for the interpretation of channel examination like in the Lamp of Sunbeams, the author of the Channel Tutorial assigns channel prasena the specific function of identifying

misled into thinking that the word stong refers to "emptiness" (stong pa nyid) instead of the number one thousand (stong). I opt to include the word "tutorial" in the translation because the thousand session genre is didactic in nature, with the effect of imparting the aforementioned experiential knowledge on to the student.

${ }^{79}$ In the Krung go'i bod lugs gso rig rtsa che'i dpe rnying kun btus, see the following works: Skor tshoms stong thun bcu gcig las dang po rtsa'i stong thun, vol. 3, text 5; Rtsa chu'i stong thun g.yu thog gi bzhed pa, vol. 3, text 7; Grang ba'i stong thun, vol. 3, text 9; Grang ba'i stong thun, vol. I4, text 4; Bad kan smug po'i stong thun, vol. I4, text 5; Skor tshoms stong thun bcu gcig, vol. I4, text 4.

${ }^{80}$ Skor tshoms stong thun bcu gcig, in Krung go'i bod lugs gso rig rtsa che'i dpe rnying kun btus, vol. I4, text 4, p. 22 (8b): "May Master Yutok Gönpo bless us! Mangalam! I am the retainer of this textual tradition. Although there are many others that claim to understand it, what can they do other than find the section on the practical instructions or the section on the measurements in the text? These days here in the Snowy Land of Tibetans, although there are many people that claim to be physicians, other than Master Drangti and his students, there are no others that I would consider to be healers. A 'physician' once claimed that only practices are important, and had long abandoned the commentaries. But, if the discussion of essential meanings is important, professing doctrines with no textual basis is laughable. Similarly, a physician that does not understand textual meanings and claims to know practices would be like a star appearing in daylight. Ha ha!" (mkhas pa g.yu thog mgon po'i byin gyi brlobs//_mang gha lam//_gzhung lugs 'di la kho bo'i yongs 'dzin 'khas [=mkhas]//_bzhan [=gzhan] dag shes par rlom pa mang yod kyang //_bzhung [=gzhung] gdams lag len gang gi phyogs la yang //_tshod tsam phyogs tsam ma gtogs ci byar yod//_ding sang kha ba can gyi ljongs 'di nal/_sman par rlom pa'i skye bo rab mang mod//_brang ti mkhas pa slob mar bcas ma gtogs//_mtsho [='tsho] byed yin snyam bdag gi sems la med//_sman pa kha cig lag len kho na tso [=gtso]//_ces smras 'grel trig [=tī ka] ring du spong pa yod//_o na mtshan nyid pa la sgro [=bgro] gleng tso [=gtso]//_gzhung don med pa'i chos gtam gzhad [=bzhad] dgad gnas//_de bzhin sman pa gzhung don mi shes pa'i//_lag len shes rlom nyin mo'i rgyu skar lags//_he he//). One might recall that this work also claims to be within the system of Yutok Gönpo, but the special teaching of Lharjé Sanggyé Pelrin (mkhas pa g.yu thog mgon po'i lugs so//_lha rje sangs rgyas dpal rin gyis khad nor yin//). See p. 40 (f. 35b). 
pathogenic demons (log non gyi gdon ngos bzung pa), ${ }^{8 \mathrm{I}}$ much like the chapter on "Demonic Channels" (gdon rtsa) found in the Moon King that lacks the label of prasenā. As evinced by the Lamp of Sunbeams and the Thousand Session Channel Tutorial, early Tibetan medical traditions established following the precedents of the Moon King assimilated channel examination using the language and demonic hermeneutics of prasenā divination. In the clinical instructions expressed in the Lamp of Sunbeams and the Channel Tutorial, channel prasena does not differ significantly from the instructions for channel examination featured in the Moon King, albeit with new semantic labels. In other contexts, however, the practice of channel prasena divination diverges significantly from the channel examination instructions found in the Moon King, deemphasizing the role of haptic observation in favor of oracular revelation.

\section{Prasenā Divination as Channel Examination}

By the end of the thirteenth century, the term prasena had come to signify such a broad array of divinatory practices-including the oracular interpretation of reflected visions, dreams, possessed mediums, and so forth-that the application of this label to the diagnostic interpretation of haptic signs was a natural progression. Perhaps in reaction to the conflation of prasen $\bar{a}$ and channel examination by physicians, diviners also came to incorporate the guise of channel examination - the haptic examination of a patient's wrist-while still primarily relying upon divine revelation for the identification of pathogenic demons. Despite the abandonment of haptic signs as a valid source of diagnostic knowledge, these channel prasen $\bar{a}$ rituals were still adopted and transmitted by physicians that also would perform channel examination. These divinatory channel prasena a rituals came to be called the examination of the "wonder channels," and the interpretation of mental and aural revelations, not haptic signs, ultimately came to be transformed into the divinatory interpretation of channel palpation, canonized in the Four Tantras as the "seven wonder channels." Regardless, the divergent interpretations of both oracular and haptic signs remain in dialogue throughout the Tibetan medical tradition, with the former continuing to compliment the latter from instructional collections outside the purview of the canonical Four Tantras.

\section{The Indispensable Channel Prasenā Rituals}

In addition to the instructions for channel prasena divination in the Thousand Session Channel Tutorial, other instructions for channel prasenā divination can also be found in the Eight Partial Branches collection. Two distinct ritual instructions for channel prasenā divination-the Channel Divination of the Three Goddess Sisters of Medicine (sman gyi lha mo spun gsum gyi rtsa'i pra sgrub) and the Channel Evocation of the Black-lipped Brahminess (bram ze mchu nag ma'i rtsa'i

\footnotetext{
${ }^{81}$ Skor tshoms stong thun bcu gcig, in Krung go’i bod lugs gso rig rtsa che’i dpe rnying kun btus, vol. I4, text 4 , pp. 19-20 (5a-5b).
} 
sgrub thabs) $)^{82}$ - are included in a subcollection of texts within the Partial Branches that is entitled the Three Indispensable Rituals (med thabs med pa'i 'phyong gsum). Regarding the contents of the Three Indispensable Rituals, which were probably redacted as a collection during the late thirteenth century, we find a history, instructions for channel prasena rituals, and instructions for pediatric care:

The teachings of the Three Indispensable Rituals are the precious oral instructions transmitted from the King of Tantras, the Essence of Ambrosia. Because it demonstrates reasons for trust, the Account of Transmission is indispensable. For examining the seven wonder channels, the Channel Prasena Rituals are indispensable. For healing children so that one may spend time with them, the Instructions for Pediatrics is indispensable. ${ }^{83}$

This introduction was added when the Three Indispensable Rituals was first redacted, but was removed when (or after) it was integrated into the Eighteen Partial Branches collection in the fourteenth century. The Indispensable Account of Transmission is, of course, the early history of the Essence of Ambrosia, King of Tantras-now referred to as the Four Tantras-attributed to Sumtön Yeshé Zung. Thus, the redaction of the Indispensable Account and the Indispensable Channel Prasenā Rituals together in the Three Indispensable Rituals was also effectively linking these works to the cycle of the Essence of Ambrosia. ${ }^{84}$ Ultimately this cycle was standardized in the fourteenth century and redacted once again into the Eighteen Partial Branches.

Unlike the instructions for prasenā divination that we saw in the Questions of Subāhu, or the instructions for channel prasenā divination in the Thousand Session Channel Tutorial, the Indispensable Channel Prasenā Rituals - that is the Three Goddess Sisters and the Black-lipped Brahminess - each call for the creation of an effigy, the evocation of a deity, the recitation of

${ }^{82}$ Herein I use boldface to indicate the short titles of these works that I shall be using throughout the rest of the dissertation.

${ }^{83}$ Med thabs med pa'i mchong [sic] gsum, in Krung go'i bod lugs gso rig rtsa che'i dpe rnying kun btus, vol. 3, text 3, p. 257 (f. Ib): rgyud rgyal bdud rtsi snying po las//_snyan rgyud man ngag gces pa'i mchong //_med thabs med pa rnams gsum bstan//_yid ches pa'i khungs bstan phyir//_rgyud pa'i rnam thar med thabs med//_ngo mtshar rtsa bdun brtag pa la//_rtsa'i pra sgrub med thabs med//_byis pa nyer spyod gso ba la//_sriu gso ba med thabs med//.

${ }^{84}$ The inclusion of a historical work in the Three Indispensable Rituals seems puzzling at first, but further investigation reveals that the Indispensable Channel Prasenā Rituals actually contains two separate ritual cycles, potentially accounting for the title, the Three Indispensable Rituals. Furthermore, the Indispensable Instructions for Pediatrics also includes a subsection in which three rituals ('phyong gsum) — the "ritual for healing spirit [possession]" (gdon gso ba'i 'phyog), the "ritual for fortunate connections" (rten 'brel gyi 'phyong), and the "ritual for medicines" (sman gyi 'phyong) — are to be performed. Thus, the title of the Three Indispensable Rituals probably derives from its first redaction, when the Indispensable Account was combined with the Indispensable Channel Prasenā Rituals and the Indispensable Instructions for Pediatrics, deriving from the latter, but coming to represent all three works collectively. 
mantras, and finally, following proper performance, divine revelation. Thus, if the instructions in the Thousand Session Channel Tutorial were thought of as channel examination in the guise of prasenā divination, the instructions in the Indispensable Channel Prasenā Rituals would then be prasenā divination in the guise of channel examination.

Regardless of their similarity to the instructions found in the Questions of Subāhu, there still are important differences between the instructions for prasen $\bar{a}$ divination found in the Indispensable Channel Prasenā Rituals and those found in the Tibetan canon. The Three Goddess Sisters, for example, does not involve a child medium, but instead calls for the creation of a small birchwood effigy of a child (stag pa la byas pa’i bu chung). Following ritual preparations involving a square mandala and an eight-petalled lotus, one is instructed to give the effigy a white silken cape (dar dkar gyi ral ka) to wear, and make offerings of medicines (sman sna tshogs), five types of silk (dar sna lnga), three types of myrobalan (a ru ra gsum), and one reed flute or thigh-bone trumpet (rtsa'am rkang gi gling bu gcig). Dissolving into emptiness, one should then reemerge as the Buddha, God of Medicine (sangs rgyas sman gyi lha): ${ }^{85}$

Then one should generate the three white bodies of the Medicine Goddesses in front of oneself. With each of their three right hands they are holding a reed, and with each of their three left hands they are holding a golden myrobalan fruit. One should visualize that these three will achieve one's purpose. ${ }^{86}$

After thousands of mantra recitations - interspersed with supplications like "descend!" (phob); "tell all that exists!" (srid pa shod); and "reveal all that exists!" (srid pa ston)—one should make the following requests: "Tell me what to do! Tell me the causes and conditions of disease! Tell me in a clear voice! As soon as I grasp the channels of the wrist of the messenger, reveal to me all of the classifications of the diseases of sentient beings." ${ }^{\prime 7}$ After reciting further mantras, one will come to know whatever any worldly being ('jig rten pa) is thinking. After more

85 This, of course, is an alternative rendering of the more common epithet, the "Buddha, Master of Medicine" (sangs rgyas sman bla). In light of the three medical goddesses (sman gyi lha mo) featured below, however, the choice of tha instead of bla seems rather significant.

${ }^{86}$ Med thabs med pa'i mchong [sic] gsum, in Krung go'i bod lugs gso rig rtsa che'i dpe rnying kun btus, vol. 3, text 3, pp. 259 (f. 4a): de nas bdag gi mdun du/_sman gyi lha mo sku mdog dkar mo gsum skyed//_g.yas sum [sic] na gling bu//_gyon gsum na a ru ra gser mdog bsnams pal/_de gsum gyis bdag gi don sgrub par bsam mo//.

${ }^{87}$ Med thabs med pa'i mchong [sic] gsum, in Krung go'i bod lugs gso rig rtsa che'i dpe rnying kun btus, vol. 3, text 3, pp. 259 (f. 4b): nga yi ci bya zer ba dang /_nad kyi rgyu dang rkyen 'di yin zer ba dang //_sgra lhang lhang po'ang //_de byang pa dang /_sems can rnams kyis nad kyis rigs su gyur pa thams cad bdag gi bang chen pa’i lag pa’i rtsa la bzungs pa tsam gyis shes par ston gcig ces brjod de/. 
recitation, "Regardless of whether one examines the channels or performs mo divination, one will come to recall with one's mind and hear with one's ears." ${ }^{\prime 8}$

All of the above instructions are for preparatory rituals that are to be performed before meeting the patient or, as it were, a messenger (bang chen) of the patient. "When examining the channels," we are told,

one should shave off a little myrobalan fruit and roast it on a smokeless fire. Reciting the twenty-one mantras, one should mentally request, "Reveal the hundred [sic] wonder channels - that of the messenger, that of the parent and the child, that of the husband and wife, and so forth-as well as the etiology, the prognosis, indications, and contraindications!" And so they all shall be revealed. ${ }^{89}$

Until the myrobalan fruit has been incinerated, a misdiagnosis is impossible. If [the diagnosis] is not slowly revealed aurally, one should shave some birchwood from the small child statue and roast it, and it shall immediately be revealed. If [the statue] says that it will not be summoned, one should replace the ritual substances with water and, after the myrobalan fruit has been incinerated, if you still cannot see [the cause of the disease], repeat the ritual..$^{90}$

As mentioned above, the primary ritual implement of the Three Goddess Sisters is neither a reflective object nor a child, but a birchwood effigy. This is not unprecedented, of course, for the Chinese-language Subhakarasimha edition of the Questions of Subāhu suggests a statue as an appropriate vessel for the descent of Bosina, but neither the Dharmadeva Chineselanguage edition nor the Tibetan-language edition mentions a statue as a vessel. Thus, this emphasis on a birchwood effigy may indeed be interpreted as a relic of Chinese prasena traditions rooted in the Subhakarasimha edition of the Questions of Subāhu, as opposed to the Tibetan-language translation that was made during the Tibetan empire.

${ }^{88}$ Med thabs med pa'i mchong [sic] gsum, in Krung go'i bod lugs gso rig rtsa che'i dpe rnying kun btus, vol. 3, text 3, pp. 259 (f. 4b): rtsa lta ba dang //_mo 'debs pa gang byed kyang //_snying gis dran pa dang //_rna bas thos te'ong ngo //.

${ }^{89}$ Med thabs med paii mchong [sic] gsum, in Krung go'i bod lugs gso rig rtsa che'i dpe rnying kun btus, vol. 3, text 3, pp. 259 (f. 4b): rtsa lta ba’i dus su/_a ru ra la bag tsam re bzhar la mes du ba med pa la bsreg/_sngags nyi shu rtsa gcig bzlas la//_bang chen pa dang //_pha ma bu tsha dang //_khyo dang chung ma la sogs pa/_ngo mtshar gyi rtsa brgya dang /_nad bzhi [sic] gang yin pa dang /_sos mi sos dang /_ci phan ci snod [sic] thams cad ston gcig/_ces yid la bya'o//.

${ }^{90}$ Med thabs med pa'i mchong [sic] gsum, in Krung go'i bod lugs gso rig rtsa che'i dpe rnying kun btus, vol. 3, text 3, pp. 259 (f. 4b-5a): a ru ra ma zad bar du nad ngos mi zin mi srid do//_rna bar dal du mi ter bar ton na/_stags pa'i mi chung la bzhar te bsreg pas ston par lam 'gyur ro//_mi bzlos pa'don na rdzas tsho chu la skur ro//_a ru ra zad nas ma mthong na yang skyar la sgrub pol/. 
Second, the ritual instructions explicitly name the subject of the ritual not as the patient, but the patient's messenger (bang chen). Indeed, the attainments of the Three Goddess Sisters ritual are described as being the revelation of the "hundred wonder channels" (ngo mtshar gyi rtsa brgya) - which are described as being that of the "messenger" (bang chen pa), that of the "parent and the child" (pha ma bu tsha), that of the "husband and wife" (khyo dang chung ma), and so forth—as well as the "etiology" (nad bzhi [=gzhi]), the "prognosis" (sos mi sos, lit. "whether they can be healed or not"), "indications" (ci phan, lit. "what will benefit them"), and contraindications (ci snod [=gnod], lit. "what will harm them"). Thus, the proper performance of the Three Goddess Sisters promises the so-called "hundred wonder channels" —which may be a scribal error for the "eight wonder channels"-representing the oracular revelation of all desired medical knowledge. We shall return to the wonder channels again below.

Like the Three Goddess Sisters ritual, the Brahminess ritual involves neither reflective implements nor a child medium, but does involve an effigy. Unlike the Three Goddess Sisters ritual, however, the Brahminess ritual does not include any mention of emptiness or evocation of the Medicine Buddha. Instead it begins with evocative instructions for the creation of a ritual space and the effigy medium:

The secret channel prasena $\bar{a}$ ritual of the mind: In secrecy, one should proceed clockwise to create a circle with the tail of a dark yellow horse and inspect its ear in one's right hand. For ritual substances, one should assemble the meats of the four great ones, ${ }^{91}$ [the meats of the four spraying ones, $]^{92}$ and a clump of clay for the head. One should create a foot-tall figure of the Brahminess with vibrant black-blue lips. ${ }^{93}$

Placing the foot-tall effigy made of meat and clay in the center of a mandala, one is then instructed to make offerings and prepare ritual substances. One is instructed to recite mantras and exhort the Brahminess to "take these water-blister eyes and reveal sights of the divine realm!" ${ }^{4}$ After five days of recitation, signs (rtags) should appear, and after seven days, the

9I These are commonly understood to be human flesh, dog meat, horsemeat, and donkey meat.

${ }^{92}$ The manuscript adds these as an interlinear note, along with the following list: "skunk, hoopoe, fox, and wolf" (sre mong pu shud wa spyang).

${ }^{93}$ Med thabs med pa'i mchong [sic] gsum, in Krung go'i bod lugs gso rig rtsa che'i dpe rnying kun btus, vol. 3, text 3, p. 259 (f. 5a): gsang pa yid kyi rtsa sgrub/_gsang rten du rta bra nag gi rnga ma g.yas skor byas la rna lag g.yas su rtags/_sgrub rdzas la chen po bzhii shal/_[bse dri can bzhi'i sha/]_khams pas mgo bsdus la/_bram ze mo’i gzugs chags [gang] pal/_mchu sngo yal ba le ba gcig byas la//.

${ }^{94}$ Med thabs med pa'i mchong [sic] gsum, in Krung go'i bod lugs gso rig rtsa che'i dpe rnying kun btus, vol. 3, text 3, p. 259 (f. 5a): chu burdmig gi go sol/_mthong pa lha’i yul ston//. 
goddess will come to manifest in reality (dngos su 'ong). ${ }^{95}$ "When examining the channels," again we are told,

one should recite the mantra seven times and then perform the examination with the six fingers. Thus [the diagnosis] shall be revealed in one's ears, and shall suddenly and clearly come to mind. Thus the disease, the demon, and the seven wonder channels shall come to be revealed. ${ }^{96}$

Like the Three Goddess Sisters described above, the instructions for the Black-lipped Brahminess ritual involve an ornate ritual setting, the creation of an effigy, the evocation of that effigy, divine revelation, and reference to the wonder channels. Also in line with the Three Goddess Sisters, the attainment gained from the Black-lipped Brahminess is described in terms of not eight, and not one hundred, but seven wonder channels (ngo mtshar gyi rtsa bdun). These seven wonder channels are revealed in connection with the disease (nad) and the demon (gdon) causing the disease, such that the practitioner might exorcise the ultimate source of his patient's suffering. Thus, the instructions for both the Three Goddess Sisters and the Black-lipped Brahminess include many similar elements - such as the centrality of the effigy, the evocation of a goddess (or three), the feigned examination of a patient's channels, and the divine revelation of wonder channels-which indicates that they were part of the same teaching cycle even before being redacted in the Three Indispensable Rituals.

The colophons of the Three Goddess Sisters and Black-lipped Brahminess in the Three Indispensable Rituals manuscript witness also indicate that they derive from a similar tradition:

The Channel Divination of the Three Goddess Sisters of Medicine:

Colophon: Master Vairocana translated this work in the land of China. It is the personal commitment of Drapa Ngönshé. ${ }^{97}$

The Channel Evocation of the Black-lipped Brahminess:

Colophon: This Channel Evocation of the Brahmin was translated by Master Vairocana in the land of China. It is the personal commitment of Drapa

${ }^{95}$ Interestingly, later editions add the caveat that "For middling practitioners, she will come in a dream. For inferior practitioners, she will come to appear in the mind" ('bring rmi lam du 'ong /_tha ma yid snang du 'ong ngo //). See Brang ti lha rje'i rim brgyud kyi man ngag gser bre chen mo, I3.

${ }^{96}$ Med thabs med pa'i mchong [sic] gsum, in Krung go'i bod lugs gso rig rtsa che'i dpe rnying kun btus, vol. 3, text 3, pp. 259-6o (ff. 5a-5b): rtsa lta ba’i dus su/_so mo drug po la sngags bdun btab nas ltas pas/_rna bar ston pa dang /_yid la wal gyis gsal btang ngo //_nad dang gdon dang ngo mtshar gyi rtsa bdun ston par'gyur ro//.

${ }^{97}$ Med thabs med pa'i mchong [sic] gsum, in Krung go'i bod lugs gso rig rtsa che'i dpe rnying kun btus, vol. 3, text 3, p. 259 (f. 5a): slob dpon be ro tsa nas rgya nag yul nas sgyur/_gra pa mngon shes kyis thugs dam lags so//. 
Ngönshé. This Lamp Illuminating the Seven Wonder Channels taught in the tantras was appended to the tantra by Vairocana. ${ }^{98}$

Both colophons cite Chinese (rgya nag yul) origins, both claim to have been translated by Vairocana (bai ro tsa na), and both indicate that they were the personal practices of Drapa Ngönshé (gra pa mngon shes, IOI2-I090). An alternative title is also listed after the Black-lipped Brahminess, indicating that both works were included in a Lamp Illuminating the Seven Wonder Channels (ngo mtshar gyi rtsa bdun gsal bar byed pai sgron ma) before being added to the Three Indispensable Rituals. Perhaps most importantly, the narrative told in these colophons is repeated in the Indispensable Account of Transmission, with Master Vairocana translating the Four Tantras, which are then hidden as a treasure text and ultimately revealed by Drapa Ngönshé. This may clarify the mystery regarding his role in the transmission of the Four Tantras. ${ }^{99}$

When the Three Indispensable Rituals was included as part of the Eighteen Partial Branches collection, these colophons remained mostly intact. ${ }^{100}$ When they, along with three other rituals, were added to the Great Gold Measure (gser bre chen mo) collection by Drangti Penden Gyentsen, however, they were altered significantly:

The Channel Divination of the Three Goddess Sisters of Medicine:

Colophon: Master Vairocana translated this work in the land of China and then it was sequentially transmitted to Drapa Ngönshé and Yutok Gönpo. Drangti Jampel Zangpo taught it to Drangti Gyelwa Zangpo and Drangti Penden Tsojé, from whom I, Drangti Penden Gyentsen,

${ }^{98}$ Med thabs med pa'i mchong [sic] gsum, in Krung goi bod lugs gso rig rtsa che'i dpe rnying kun btus, vol. 3, text 3, p. 260 (f. 5b): bram ze'i rtsa sgrub 'di//_slob dpon bai ro tsa na yis//_rgya nag yul nas bsgyur ba yin//_gra pa mngon shes thugs dam mo//_rgyud nang [?]sung paï ngo mtshar gyi rtsa bdun [ston par 'byung] gsal bar byed pa'i sgron ma 'dis/_be ro tsa nas rgyud kyi btsas su bzhag pa'o/_rdzogs s.hol/.

${ }^{99}$ Indeed, Drapa Ngönshé is also listed as the treasure revealer of the Four Tantras by Drangti Penden Tsojé and most later accounts. For one expression of the confusion that Drapa Ngönshe's involvement in medical traditions has caused, see Ronald Davidson, Tibetan Renaissance: Tantric Buddhism in the Rebirth of Tibetan Culture (New York, NY: Columbia University Press, 2005), I05: "The two most important tantric centers for Eastern Vinaya teaching, Pukpoché and Dratang (IO8I), were directly connected to Drapa Ngönshé, his teacher Yamshü, and his disciples. ... Much later, Drapa became a figure of rather free association, like many of the eleventh-century personalities, and was credited for the discovery of the Four Medical Tantras in I038, although there seems to be little historical basis for this assignment." On the cosmopolitan influences in the art of Dratang monastery, see Amy Heller, "The Paintings of Gra thang: History and Iconography of an IIth century Tibetan Temple," The Tibet Journal 27, nos. I-2 (2002): 37-70.

Ioo See Rtsa'i pra sgrub med thabs med pa, in Cha lag bco brgyad, 493-94. Note that further instructions have been added to the second colophon.

W. A. McGrath | Buddhism and Medicine in Tibet | 38 
requested it. I have put it into writing for the sake of my son, Namgyel Pelzangpo. ${ }^{\text {IOI }}$

The Channel Evocation of the Black-lipped Brahminess:

Colophon: This Channel Evocation of the Brahminess was translated by Master Vairocana in the land of China. This Lamp Illuminating the Seven Wonder Channels taught in the tantras was appended to the tantra by Vairocana. I, Drangti Penden Gyentsen, requested this [work] from the exact teachings and practices of Drangti Penden Tsoje. ${ }^{\text {I02 }}$

In addition to recording the activities of the Drangti physicians in redacting these channel prasenā rituals, Drangti Penden Gyentsen also appears to have removed Drapa Ngönshé from the latter colophon and added Yutok Gönpo to the former. The emendations, of course, effectively align these early channel prasena $\bar{a}$ rituals with the narrative frame and instructions of the Four Tantras, which is not unusual to see for extra-canonical medical instructions of the fourteenth century. What is unusual, however, is to have demonstrable evidence of such emendations, which is why I have spent so much space emphasizing these alterations.

${ }^{\text {IoI }}$ Reg pa rtsa'i spra sgrub klu sgrub gyis mdzad pa bzhugs s+ho, in Krung go'i bod lugs gso rig rtsa che'i dpe rnying kun btus, vol. I, text IO, p. 55 (ff. 6a-6b): slob dpon be ro tsa nas rgya nag yul nas rgyur/_de nas gra pa mngon shes/_de nas g.yu thog mgon po nas rim par rgyud de/_brang ti ’jam dpal bzang po/_brang ti rgyal ba bzang po/_brang ti dpal ldan 'tsho byed/_de la brang ti dpal ldan rgyal mtshan bdag gis zhus nas bu rnams rgyal dpal bzang po'i ched du yi ger bkod/.

${ }^{102}$ Reg pa rtsa'i spra sgrub klu sgrub gyis mdzad pa bzhugs s+ho, in Krung go'i bod lugs gso rig rtsa che'i dpe rnying kun btus, vol. I, text IO, p. 57 (f. Iob): bram ze mo'i rtsa sgrub 'di//_slob dpon bai ro tsa na yis//_rgya nag yul nas bsgyur ba yis//_rgyud nas gsungs pa'i ngo mtshar [can gyi] rtsa bdun gsal ba[r] byed pa'i sgron me 'di/_bai ro tsa nas rgyud kyi btsas su bzhag go/_ithi//_brang ti dpal ldan 'tsho byed kyi gsung ngag phyag len ji bzhin du/_brang ti dpal ldan rgyal mtshan bdag gis zhus pa'o//. 


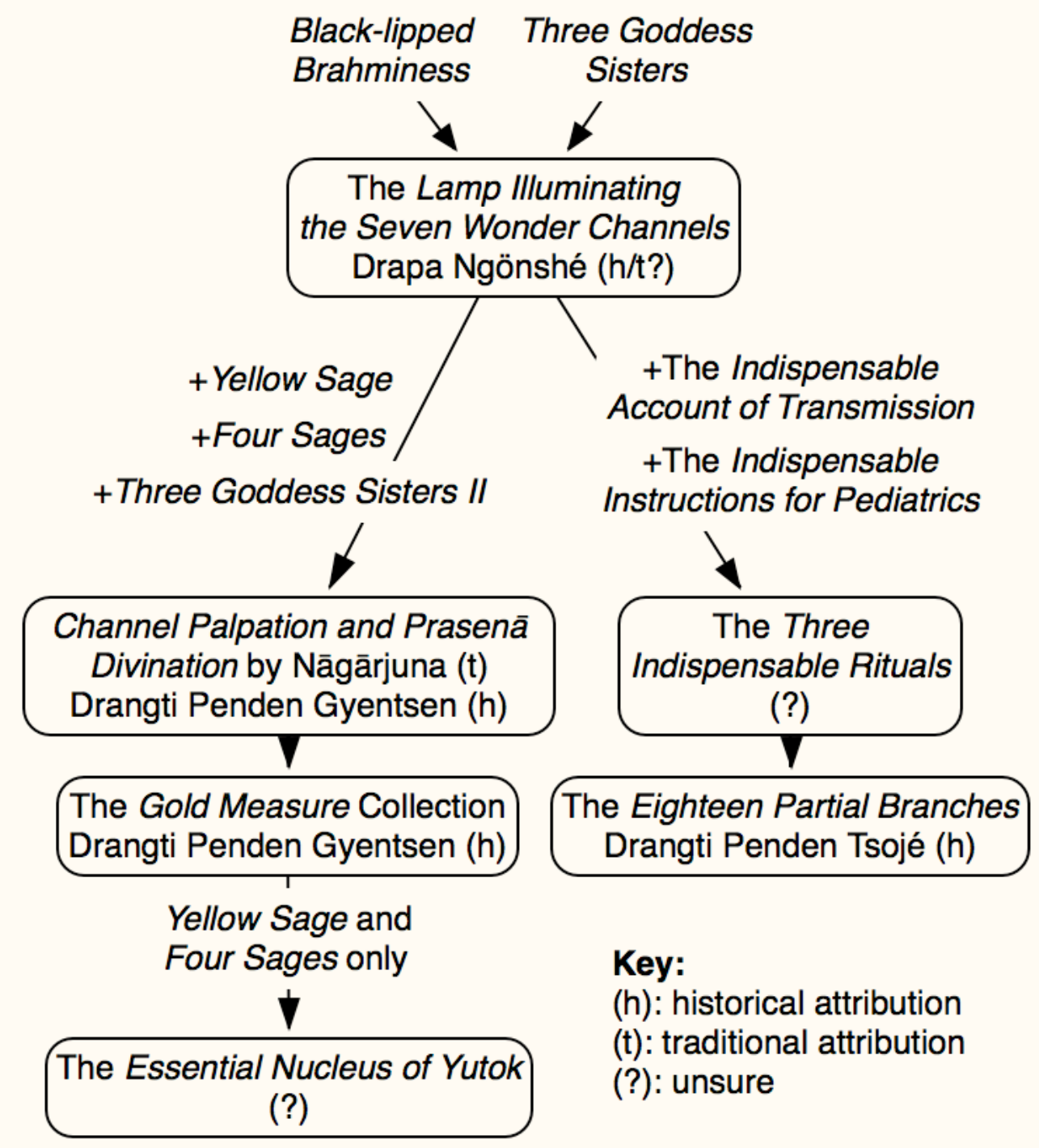

Figure 1.2. A Proposed Sequence of Influences in Regard to Channel Prasenā Rituals ${ }^{103}$

The Indispensable Channel Prasena Rituals - that is the Three Goddess Sisters and the Black-lipped Brahminess-are important for several reasons. They were popular enough to have been redacted as many as five separate times from the eleventh century to the fourteenth: [I.] first they were combined in the Lamp Illuminating the Seven Wonder Channels, which is no longer extant, but was potentially the practice of Drapa Ngönshé, [2.] then they were redacted along with the Indispensable Account and the Indispensable Instructions for Pediatrics in the Three Indispensable Rituals, [3.] the Three Indispensable Rituals were then redacted once again in the Eighteen Partial Branches by Drangti Penden Tsojé in the early fourteenth century, which is

${ }^{103}$ Regarding historical (h) and traditional (t) attributions, see Sheldon Pollock, "Philology in Three Dimensions," Postmedieval: A Journal of Medieval Cultural Studies 5, no. 4 (2014):398-4I3. 
extant in xylographic prints, [4.] the Three Goddess Sisters and the Black-lipped Brahminess were again compiled along with three other channel prasenā rituals to form the Channel Palpation and Prasenā Divination manuscript attributed to Nāgārjuna, which was redacted by Drangti Penden Gyentsen in the late fourteenth century, [5.] which were included in the larger Gold Measure collection that is also attributed to the redactive efforts of Drangti Penden Gyentsen. Finally, two of the channel prasenā rituals in the Gold Measure that were not discussed here were also included in the later Essential Nucleus of Yutok collection that is still being practiced today. ${ }^{104}$ Thus, despite being entirely outside the purview of the Four Tantras, this cycle of channel prasenā rituals has remained important in the Tibetan medical tradition as peripheral, but continually transmitted practices.

\section{The Wonder Channels and the Subsequent Tantra}

The redactors of the Subsequent Tantra - that is, the fourth of the Four Tantras, the seminal work of the Tibetan medical tradition-were presented with a problem: if channel prasenā divination can refer to the interpretation of both haptic signs as well as oracular revelation, how can these two disparate practices be incorporated in the same set of instructions? Instead of including instructions for channel examination labeled as prasenā divination, as in the Lamp of Sunbeams and the Thousand Session Channel Tutorial, or including instructions for prasenā divination labeled as channel examination, as in the Indispensable Channel Prasenā Rituals, the redactors of the Subsequent Tantra chose a third option. In the channel examination chapter of the Subsequent Tantra, they declined to use the term prasena at all, and instead appropriated the promised attainments of the Indispensable Channel Prasenā Ritualsthe coveted knowledge of the wonder channels-but redefined their mode of achievement. Rejecting the ritual instructions and divine revelation of the Indispensable Channel Prasenā Rituals, the instructions for understanding the wonder channels in the Subsequent Tantra came to involve the interpretation of haptic signs according to yet another system of prediction: elemental divination ('byung rtsis). ${ }^{\text {IO5 }}$

In what is perhaps the earliest description of wonder channels (ngo mtshar can gyi rtsa), we find no hint of divinatory practices, but rather an expression of wonder at the fundamental act of diagnosis through haptic observation. Specifically, in one of the many channel instructions

${ }^{104}$ This refers to the Evocation Ritual of the Yellow Sage and Sons (drang srong ser skya spun gsum gyi sgrub thabs) and the Evocation Ritual of the Four Sages (drang srong bzhi'i sgrub thabs), which are collectively called the Evocation Ritual of the Yellow Sage from the Silver Collection (dngul [sic!] bre las drang srong ser skya'i sgrub thabs), in G.yu thog snying thig, Bod kyi gso ba rig pa'i gna' dpe phyogs bsgrigs dpe tshogs vol. 43 (Beijing: Mi rigs dpe skrun khang, 2007), 6I9-23.

${ }^{105}$ For more on elemental divination in Tibet, see Philippe Cornu, Tibetan Astrology (Boston, MA: Shambhala, 2002); and Gyurme Dorje, trans., Tibetan Elemental Divination Paintings: Illuminated Manuscript from the White Beryl of Sangs-rgyas rGya-mtsho with the Moonbeams Treatise of Lo-chen Dharmaśrī (London: John Eskenazi and Sam Fogg, 200I). 
attributed to Nāgārjuna, the Lamp of Sunbeams: A Channel Manual (rtsa yig nyi zer sgron me), the eight wonder channels (ngo mtshar can gyi rtsa brgyad) are listed as:

The three diseases exist in relation to the three poisons; understanding this from the channels is truly wondrous!

Understanding the diseases of the body using surgical instruments is extremely wondrous!

Bile induces fever; corroborating this using one's sense faculties and understanding this from the [patient's] channels is truly wondrous!

Phlegm induces stupidity; ${ }^{106}$ understanding the channels as being polluted and obscured is truly wondrous!

Wind induces desire and cold; regardless of whatever [qualities in the] channels that one comes to encounter, understanding this from the channels is truly wondrous!

Understanding how to heal empty [fevers] and prevent their expansion from the channels is truly wondrous!

The fluids induce envy and lymph; corroborating this using the sense faculties and understanding this from the channels is truly wondrous!

To understand the prognoses of both life and death, conquering birth and passing [?] without error, from the channels is truly wondrous! ${ }^{107}$

In addition to correlating the characteristics of a patient's channels with specific diseases, the Lamp of Sunbeams also provides a map of corresponding afflictive emotions, or poisons. Thus, here we find an incomplete attempt at correlating the characteristics of the three poisons ( $d u g$ gsum po) with the so-called "three diseases" (nad gsum), which appear to refer to the unusual triad of fever (tsha ba), cold (grang ba), and lymph (chu ser).

\section{\begin{tabular}{|l|l|l|}
\hline [Four Humors] & Three Poisons (dug gsum po) & Three Diseases (nad gsum) \\
\hline
\end{tabular}}

I06 Although the phrase gti mug bad kan bskyed pa seems to indicate that stupidity induces phlegm, the parallel structure of the previous and subsequent passages appears to indicate that it is phlegm that induces stupidity.

${ }^{107}$ Rtsa yig nyi zer sgron me, in Slob dpon klu sgrub kyi sman yig gces btus, Bod kyi gso ba rig pa'i gna' dpe phyogs bsgrigs dpe tshogs vol. 73 (Beijing: Mi rigs dpe skrun khang, 2008), 372-73: dug gsum po la nad gsum yod//_rtsa yi shes pa ngo mtshar che//_thur [=thur] ma'i sgo nas lus kyi nad//_shes pa shin tu ngo mtshar che//_mkhris pa'i tsha ba bskyed pa yin//_dbang po'i sgo nas 'grigs pa stel/_rtsa yi shes pa ngo mtshar chel/_gti mug bad kan bskyed pa stel/_dbang po'i sgo nas 'grib cing 'thib//_rtsa yi shes pa ngo mtshar chel/_'dod chags grang ba rlung gis bskyed//_rtsa ni gang phrod ['phrod] 'gyur ba ste//_rtsa yi shes pa ngo mtshar che//_stong ba gso zhing rgyas pa gsod//_rtsa yi shes pa ngo mtshar chel/_phrag dog chu ser chu yis bskyed//_dbang po'i sgo nas 'grib [='grigs] pa de//_rtsa yi shes pa ngo mtshar che//_tsho 'chi gnyis kyi bye brag rnams//_ma nor skye bre [?] rgyal ba ni//_rtsa yi shes pa ngo mtshar che//. 


\begin{tabular}{|l|l|l|}
\hline Bile (mkhris pa) & & Fever (tsha ba) \\
\hline Phlegm (bad kan) & Stupidity (gti mug) & \\
\hline Wind (rlung) & Desire ('dod chags) & Cold (grang ba) \\
\hline Fluids (chu) & Envy (phrag dog) & Lymph (chu ser) \\
\hline
\end{tabular}

Table I.I. Systematic Correspondences Between the Humors, the Poisons, and Diseases in the Lamp of Sunbeams

This series of correspondences contrasts with the respective equation of wind, bile, and phlegm with desire, hatred (zhe sdang), and stupidity found in the Four Tantras, wherein the equation to the so-called "three diseases" is expanded to the four hundred and four diseases. ${ }^{108}$ Nowhere is envy mentioned in relation to the humors or classes of disease in the Four Tantras, however. Thus, the Lamp of Sunbeams provides a haphazard and unorthodox presentation of systematic correspondence in which the three poisons and the three diseases are identified as coemergent from the ultimate source of the three (or four) humors. In addition to this imperfect set of relationships, the passage cited above also wonders at the use of surgical instruments ('thur ma) to understand disease, as well as the examination of the channels to heal fevers and predict the prognosis of a terminally ill patient. Indeed, it is only this eighth wonder channel listed here that corresponds closely to the seven wonder channels of the Four Tantras.

As indicated in the introduction to the Three Indispensable Rituals cited above, the seven wonder channels are a prominent component in the textus receptus of the Subsequent Tantra. Curiously, the seven wonder channels are not mentioned in the Secret Essence of Ambrosia: An Instructional Tantra (bdud rtsi snying po gsang ba man ngag gi rgyud) —otherwise known as the Little Tantra (rgyud chung)—despite the close correlation of the Channel Examination chapters of the two works. ${ }^{109}$ Thus, the seven wonder channels appear to represent a separate lineage of practices that was integrated into the Subsequent Tantra, but not its precedents in the Secret Essence of Ambrosia. In the Subsequent Tantra, the seven wonder channels are listed as family divination (khyim phywa), guest divination (mgron phywa), enemy divination (dgra phywa), fortune divination (grogs [=grog] phywa), spirit divination (gdon phywa), the reversal of fire and water (me chu go ldog), and the pregnancy channel (bu rtsa). ${ }^{\text {IIO }}$ The first of the seven classes of wonder channels—-that is, family divination—describes:

${ }^{108}$ Rje bstan 'dzin don grub, ed., Dpal ldan rgyud bzhi dpe bsdur ma (Chengdu: Si khron dpe skrun khang, 20IO), vol. I, 35: de la 'dod chags zhe sdang gtig mug gsum//_rlung mkhris bad kan rim pas skyed paì rgyud//.

${ }^{109}$ Yang Ga, Sources for the Writing of the Rgyud bzhi, 242-46.

${ }^{\text {IIо }}$ For descriptions and illustrations of the seven wonder channels, see Yuri Parfionovitch, Feranand Meyer, and Gyurme Dorje, eds. Tibetan Medical Paintings: Illustrations to the Blue Beryl Treatise of Sangye Gyamtso (I653-I705) (New York, NY: Harry N. Abrams, 1992), I27-34 (plates 56-59). 
First [Family Divination]: Regarding sunken, obscured, and unclean channels, that is, if the [pulsations in the] channels are sluggish and obscure, such channels [portend] that pain will occur. If they are torrential and faint, such channels [portend] that a terrifying [experience] will occur. If they are prickly like a thorn, such channels [portend] suffering without escape. If they are like the boiling of hot spring, such channels [portend] that defamation will occur. If they are like intermittent flames, such channels [portend] a coming loss of wealth. ${ }^{\text {III }}$

Regarding these [predictions], when the "self" channel that corresponds to the current season flourishes, whatever [prediction] emerges in the "self" channel, that will happen to oneself. If it is in the mother channel, then it will happen to the mother or maternal uncle. If it is in the child channel, then it will happen to one's child, nephew, or grandson. If it is in the friend channel, then it will happen to one's livestock. If it is in the enemy channel, then it will happen to one's enemies. ${ }^{\text {II2 }}$

Interestingly, "obscured" ('thibs) channels and channels that are polluted or "unclean" (mi gtsang) are described in both the Lamp of Sunbeams and the Four Tantras. The only difference is that in the latter, such characteristics do not indicate afflictive emotions or even disease in the patient, but rather foretell the coming of future pain (mya ngan), terror (bred dngangs), suffering (sdug bsngal), defamation ( $m i k h a$ ), loss of wealth (nor god), and so forth. But for whom? Depending upon the relationship of the channel to the season, the prediction will affect a different individual. For example, if the patient's channels are examined in the spring (which corresponds to the wood element), and obscurity ('thibs) is detected in the liver channel (mchin rtsa; which also corresponds to wood), this would be considered the "self" channel (rang rtsa) for the spring and, therefore, would portend future pain for the patient. If the kidney channel (mkhal rtsa; which corresponds to water) is found to be boiling like a hot spring (chu tshan khol 'dra) in the spring, however, this would be considered the mother channel ( $m a$ rtsa) in the spring, and either one's mother or maternal uncle (ma zhang) would come to be slandered ( $m i$ kha 'ong $b a$ ). Thus, the family divination wonder channel technique

${ }^{\text {III }}$ Rje bstan 'dzin don grub, ed., Dpal ldan rgyud bzhi dpe bsdur ma (Chengdu: Si khron dpe skrun khang, 20IO), vol. 3, 23-24: dang po bying zhing 'thibs na mi gtsang rtsal/_rmugs shing 'thibs na mya ngan 'ong ba'i rtsa//_brub cing brgyal na bred dngangs 'ong ba'i rtsal/_skyer tsher'dra na sdug bsngal thar med rtsal/_chu tshan khol 'dra mi kha 'ong ba'i rtsal/_me lce chad 'dra nor god 'ong ba'i rtsal/.

${ }^{\text {II2 }}$ Rje bstan 'dzin don grub, ed., Dpal ldan rgyud bzhi dpe bsdur ma, vol. 3, 24: de dag gang yang rang rtsa dar dus sul/_rang gi rtsa la gang byung rang la 'ong //_ma rtsa ma zhang bu rtsa bu tsha la/I_grogs rtsa nor la dgra rtsa dgra la 'ong //. 
provides a means for the physician to foretell future pains and losses for a patient and his or her family members.

Similarly, the guest divination (mgron phywa) wonder channel examination reveals whether a guest is still at home (gzhi la yod), is on the road (lam du zhugs pa), has almost arrived (nye bar sleb), is about to leave (phyin la khad pa), or if an enemy of the traveler is coming ('gron dgra 'ong $b a$ ) based on the emergence of a fierce (drag pa) pulsation in the self, mother, child, friend, or enemy channels. Thus, guest divination is performed to determine whether a guest will successfully arrive or not. ${ }^{\mathrm{II} 3}$ The enemy divination (dgra phywa) wonder channel examination predicts one's fate in battle, both when attacking (phar rgol) and defending (tshur rgol). When attacking, if the lung channel (glo rtsa) is fierce (drag), one will win (thub), but if the spleen channel (mcher rtsa) is fierce, one will not win (mi thub) and the enemy will have the upper hand (dgra g.yul mtho). When defending, similar predications are given regarding whether the enemy can be averted (tshugs) or not (tshugs mi 'gyur). " The "friend" divination (grogs phywa) wonder channel relates to one's fortune in terms of wealth and livestock (nor). ${ }^{\mathrm{II}}$ If the liver channel is fierce, one's wealth will increase (nor 'phel) and one will not experience any losses (god mi 'ong), but if the heart channel (snying rtsa) or spleen channel (mcher rtsa) is frail (zhan), however, one will suffer losses (god $k a$ 'ong). We are told that the friend channel is best $(r a b)$, the mother channel is middling ('bring), and the self channel is the worst (tha ma). If such pulsations occur in the child channel, one will have no fortune (grog med), and if they occur in the enemy channel, an enemy will take away one's fortune (grog dgras khyer). ${ }^{\mathrm{II}}$ These last two descriptions of "fortune" (grog) instead of "friend" (grogs) imply that this is probably better referred to as the "fortune divination" (grog phywa) rather than the more common phonetic equivalent, "friend divination" (grogs phywa).

The final three types of wonder channel examination are more medically oriented than the first four: diagnosing spirits, death, and pregnancy. The spirit divination (gdon phywa) wonder channel examination helps identify the pathogenic spirit that has come to afflict the patient. For example, if the wood channel (shing rtsa; that is, the liver channel) has a distinct pulsation, the afflicting spirit is a nyen demon (gnyan) or a king spirit (rgyal po), and so forth. Other spirits include tsen demons (bstan), dü demons (bdud), property lords (dkor bdag), earth lords (sa bdag), mother spirits ( $m a$ mo), serpent spirits $(k l u)$, flesh-eating serpent spirits $(k l u$ srin), transgression spirits (dam sri), and so forth. Less typical spirits are different classes of ghosts ('dre), including the ghost of a child haunting its parents (?, pha ma'i chags 'dre), the ghost of a child's maternal uncle (bu tsha'i zhang 'dre), the ghost of an enemy's curse (dgra bos rbad 'dre), the ghost of the livestock outside (nor gyi phyi 'dre), and the ghost of a contaminated

\footnotetext{
${ }^{\mathrm{II} 3}$ Rje bstan 'dzin don grub, ed., Dpal ldan rgyud bzhi dpe bsdur ma, vol. 3, 24.

${ }^{\mathrm{II} 4}$ Rje bstan 'dzin don grub, ed., Dpal ldan rgyud bzhi dpe bsdur ma, vol. 3, 24-25.

${ }^{\text {II5 }}$ The very term for wealth used here (nor) also has the connotation of livestock. Thus, the increase or loss of wealth also implies the increase or loss of livestock.

${ }^{\text {II6 }}$ Rje bstan 'dzin don grub, ed., Dpal ldan rgyud bzhi dpe bsdur ma, vol. 3, 25.
} 
friend (grogs kyi 'gos dre). ${ }^{117}$ Thus, while the former classifications of possession refer to generally afflictive demons that are common causes of disease in the Tibetan imaginaire, the latter classes of spirits refer to ghosts that derive from specific family members, social transgressions, or outside forces.

The so-called "reversal of fire and water" (me chu go ldog) divination refers to the examination of a relative in the place of a patient. For example, if a father is ill, the physician could examine the son (pha na bu la blta) and determine whether or not the disease is terminal ('chi) or not (mi 'chi). The same is true that if a son is ill, the physician could examine the channels of the father (bu na pha yi rtsa la bltas pa), or if a mother is ill, one could also examine her daughter (ma dang bu mo'i rtsa yang de ltar blta), or if a husband is ill, one could examine his wife (khyo na chung ma'i rtsa la bltas pa), and vice versa. ${ }^{\text {II8 }}$ In sum, the "reversal of fire and water" refers to the prognosis of distant patients that may or may not be terminally ill. The seventh wonder channel divination, the pregnancy channel (sbrum mai rtsa), provides the means for predicting the gender of the child in utero, as well as the ease (sla) or difficulty $\left(d k a^{\prime}\right)$ for the mother during postpartum recovery (btsas nas gso). ${ }^{119}$ Thus, these final three modes of spiritual diagnosis, distant prognosis, and predictions regarding pregnancy have the most obvious practical implications for the physician of medicine, while the former four appear to be the tools of the generic soothsayer.

Despite their differences, the eight wonder channels listed above in the Lamp of Sunbeams and the seven wonder channels listed in the Subsequent Tantra each provides the physician with tools for creatively interpreting the pulsations in the channels of his or her patients. In the case of the former, the eight wonder channels remain grounded in the conception of the four humors-bile, phlegm, wind, and the fluids-and, based on whichever humor is dominant, also provides some information regarding predominant diseases and afflictive emotions (Table I.I). The instructions are vague, however, and other comments regarding the use of surgical tools and the use of the channels to prognosticate the life and death of patients are also lauded as wondrous. Thus, the Lamp of Sunbeams appears to represent an early example of the wonder channels in which the instructions for the practice-if this short passage can even be considered an independent practice-remain incomplete and imprecise. The instructions in the Subsequent Tantra, by contrast, are totally explicit and consummately described, despite overlapping with the more detailed instructions found in the "Death Channels" ('chi rtsa) and "Demonic Channels" (gdon rtsa) subsections of the Subsequent Tantra. Thus, despite the differences in their textual instantiations, the wonder channels generally refer to a set of diagnostic practices in which the physician creatively interprets the haptic characteristics of a patient or a patient's relative to determine future fortunes and misfortunes. These seem to have first appeared in early Tibetan medical works attributed to Nāgārjuna as eight wonder channels used for the prediction of both disease and afflictive emotions, but

\footnotetext{
${ }^{\text {II7 }}$ Rje bstan 'dzin don grub, ed., Dpal ldan rgyud bzhi dpe bsdur ma, vol. 3, 25.

${ }^{\text {II8 }}$ Rje bstan 'dzin don grub, ed., Dpal ldan rgyud bzhi dpe bsdur ma, vol. 3, 25-26.
} 
were then transformed in a more generally applicable set of seven distinct divinatory practices.

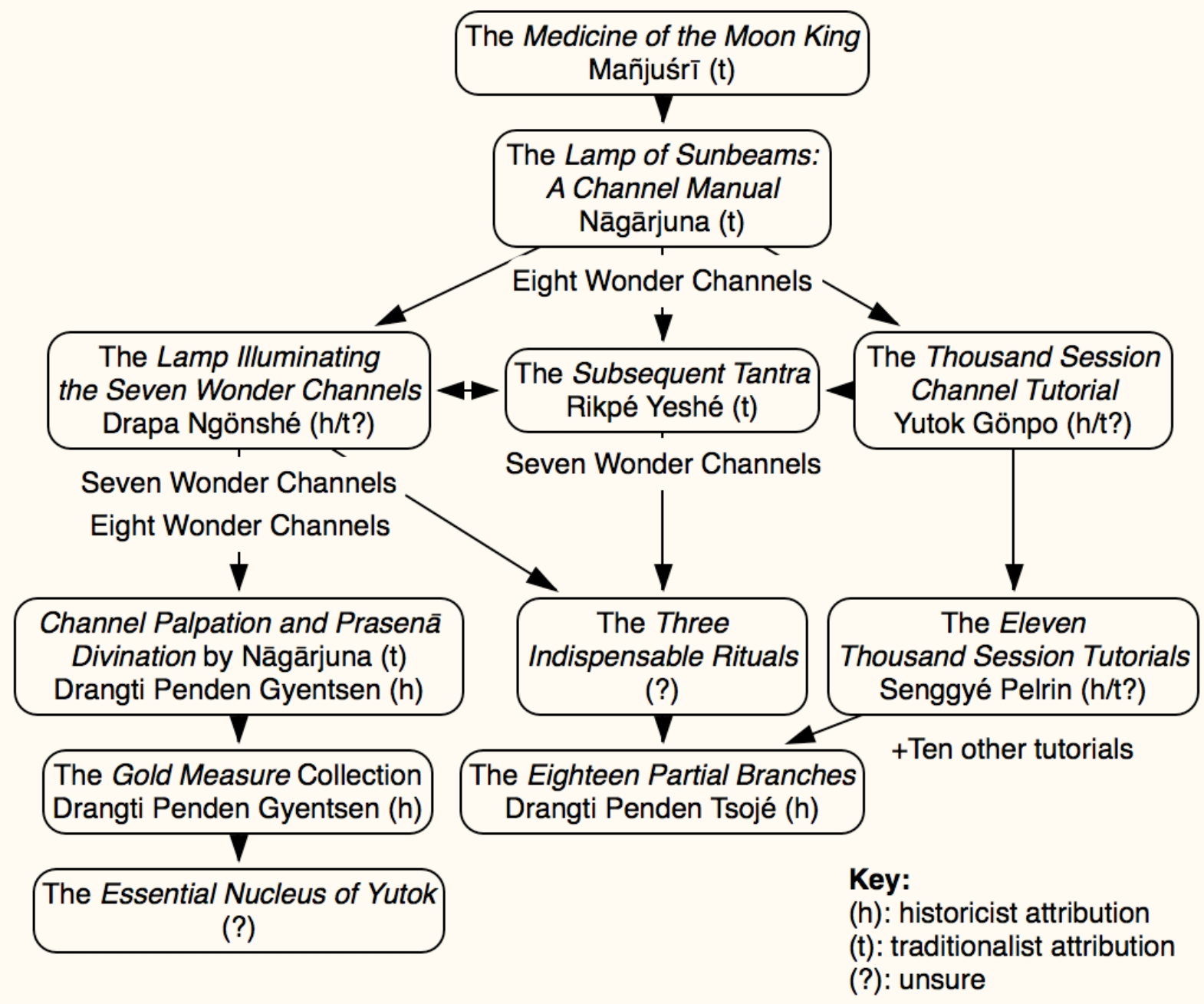

Figure I.3. A Proposed Sequence of Influences in Regard to the Wonder Channels and Channel Prasenā

When we compare the seven wonder channels of the Subsequent Tantra to the seven, eight, or one hundred wonder channels that we saw in the Indispensable Channel Prasenā Rituals, the results of the different divination rituals are remarkably similar. In both the Three Goddess Sisters and the Subsequent Tantra, for example, the physician is able to examine the channels of a patient's relative and still determine the prognosis for that particular patient. This would obviously be of great use for a physician when deciding whether to travel and see a distant patient that might potentially die anyway. Perhaps the most important detail distinguishing the instructions for examining the wonder channels in the Subsequent Tantra from those of the

${ }^{\text {II9 }}$ Rje bstan 'dzin don grub, ed., Dpal ldan rgyud bzhi dpe bsdur ma, vol. 3, 26. 
Indispensable Channel Prasena Rituals is the return to empirical observation. In the case of the latter, the physician was instructed to perform the motions of grabbing the wrist of the patient or messenger, but was not instructed to examine any channels! Instead, knowledge of the wonder channels was promised by means of divine revelation instead of divinatory interpretation. By pairing the attained results of the wonder channels with empirical processes, the physician would merely need to be skilled in haptic observation, and not necessarily the performance of tantric ritual. Indeed, if the wonder channels of the Indispensable Channel Prasena Rituals represent an attempt by tantric professionals to coopt the diagnostic practices of rival physicians, then the wonder channels of the Subsequent Tantra represent a more successful reappropriation of both diagnosis and divination on the part of the physician.

\section{Conclusion: Observation and Revelation in the Tibetan Medical Tradition}

Returning to the family responsible for the ultimate redaction of these channel prasena aituals, the Eighteen Partial Branches and Gold Measure collections redacted by members of the Drangti clan reveal a clear investment in both channel prasena divination as well as observational diagnosis. In fact, Drangti Penden Tsojé-lineage holder of all channel prasenā divination rituals and channel examination instructions-wrote an extensive commentary on the channel examination chapter of the Subsequent Tantras, emphasizing the entire range of interpretations that one might derive from observing the channels. ${ }^{\mathrm{I20}}$ In contrast to the rather nihilistic instructions contained in the Indispensable Channel Prasenā Rituals examined above, let us now close with a homage found at the very opening of the Gold Measure collection in which these instructions are found-one that reaffirms both the clairvoyance of the sages as well as diagnostic knowledge derived from observation and textual study, all while situating these teachings within a traditional and historical context:

To the blessed lineage extending from the sages,

To the mandala of texts, instructions, and knowledge,

To he whose intellect understands objects just as they are, whose eyes are open,

At the feet of Drangti Penden Tsojé, I pay homage. ${ }^{\text {I2I }}$

Unlike the distinct traditions of diviners and physicians that occupied competing positions in the healing arenas of thirteenth-century Tibet, by the time of the fourteenth century with the

${ }^{\text {I2O }}$ Brang ti dpal ldan 'tsho byed, Rtsa mdo'i 'grel pa nyi ma'i 'od zer, in Krung go'i bod lugs gso rig rtsa che'i dpe rnying kun btus, vol. I, text I4, pp. 207-I6 (ff. I-I9).

${ }^{\text {I2I }}$ Reg pa rtsa'i spra sgrub klu sgrub gyis mdzad pa bzhugs s+ho, in Krung go'i bod lugs gso rig rtsa che'i dpe rnying kun btus, vol. I, text IO, p. 53 (f. Ib): drang srong brgyud pas rgyud la byin brlabs 
institutionalization of medicine at the Sakya Medical House, the rival approaches of oracular revelation found in channel prasen $\bar{a}$ rituals and haptic interpretation found in elemental divination came to be combined within the repertoire of the Drangti physician. Perhaps the physicians of the Drangti family would both externally palpate the wrist of a patienthaptically seeking empirical evidence of elemental, humoral, or thermal symptoms-while secretly reciting mantras and listening to the revelations of divinities. Indeed, the confidential significance afforded by subjunctive evocation need not contradict that which is derived from empirical observation, neither in the case of the Drangti physicians of the fourteenth century, nor in the case of modern physicians today.

shing __lung rigs man ngag shes bya'i dkyil 'khor la/_ji bzhin rtogs pa'i blo gros spyan yangs pa/_brang sti [sic] dpal ldan mtsho [sic] byed zhabs la gus phyag mtshal// [sic]. 


\section{Chapter Two: Adaptation and Innovation in Tibetan Medical Scholasticism}

In the colophon for the Evocation Ritual of the Yellow Sage and Sons, one of the five channel prasenā rituals transmitted by Drangti Penden Tsojé and redacted by Drangti Penden Gyentsen in the fourteenth century, we find what is perhaps the earliest mention of Drangti Gyelnyé Kharbu (brang ti rgyal mnyes mkhar bu), the famed physician and ancestor of the Drangti clan:

The Guru Nāgārjuna, thinking [this teaching] to be extremely profound, [transmitted] it to Padmasambhava. He taught it to Lord Tri Songdetsen, who then hid it inside the capitals of the thirteen levels above the celestial realm [?]. Drangti Gyelnyé Kharbu revealed the teaching and, with practice came attainments and the emergence of signs [of attainment]. From him it has been sequentially transmitted, from Drangti Jampel Zangpo to [Drangti Gyelwa Zangpo], ${ }^{\mathrm{I} 22}$ and finally to Drangti Penden Tsojé. I, Drangti Penden Gyentsen, requested the teaching from him [Drangti Penden Tsojé] and, for the sake of my sons and students, have abandoned secrecy and miserliness and put the teaching into writing. ${ }^{123}$

According to this colophon, the profound teachings of prasena divination began with Nāgārjuna, who then passed it on to Padmasambhava. The latter, who famously traveled to Tibet during the reign of Tri Songdetsen (ca. 742-8oo; r. ca. 755-80o) and performed a prasenā divination when exorcising the demons of Tibet, transmitted these divinatory instructions to the emperor of Tibet, who hid them in the capital of a pillar, presumably in Samyé

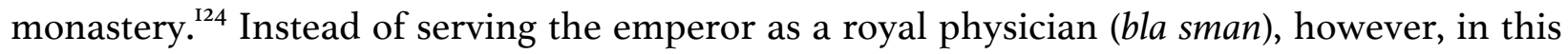
colophon Drangti Gyelnyé Kharbu is fashioned as a treasure revealer who, by definition,

${ }^{122}$ The transmission to Drangti Gyelwa Zangpo is only included in Reg pa rtsa'i spra sgrub klu sgrub gyis mdzad pa bzhugs s+ho, in Krung go'i bod lugs gso rig rtsa che'i dpe rnying kun btus, vol. I, text IO, p. 54 (f. 4a); and Brang ti lha rje'i rim brgyud kyi man ngag gser bre chen mo, 4 . He is included in neither Gser khri [=bre] rgyas pa zhes bya ba bzhugs so, in Krung go'i bod lugs gso rig rtsa che'i dpe rnying kun btus, vol. I8, text I3, p. 195 (f. 5a); Man ngag gser bre ma dang dngul bre ma, 3; nor G.yu thog snying thig, 622.

${ }^{123}$ Reg pa rtsa'i spra sgrub klu sgrub gyis mdzad pa bzhugs s+ho, in Krung go'i bod lugs gso rig rtsa che'i dpe rnying kun btus, vol. I, text IO, p. 54 (f. 4a): gu ru nā gā rdzu nas shin tu zab par dgongs nas pad ma 'byung gnas la/_des mnga' bdag khri srong lde btsan la/_des gnam steng bcu gsum ka gzhu'i nang du sbas/_de brang ti rgyal mnyes mkhar bus ston nas sgrub pas grub cing rtags thon pa'o//_de nas rim par brgyud de/_brang ti ’jam dpal bzang po/_des brang ti rgyal ba bzang po//_des brang ti dpal ldan 'tsho byed/_de la brang ti dpal ldan rgyal mtshan bdag gis zhus nas//_bu dang slob ma'i don du gab sbas ser sna spangs nas yi ger bkod pal/_ithi//. 
would have been active during the Tibetan renaissance period (ca. 950-I300), and not the imperial period (ca. 600-850).

In all subsequent narrative traditions, Drangti Gyelnyé Kharbu is remembered not as a post-imperial treasure revealer, but as the celebrated royal physician of Tri Detsuktsen ( $k$ hri lde gtsug btsan, 704-755), also known as the "Bearded Grandfather," Mé Aktsom (mes ag tshom). The narrative projection of ancestors back into the glorious period of the Tibetan empire is by no means unique to the Drangti clan, ${ }^{125}$ and a complete telling of this story can be found in the opening section of the Lamp that Illuminates the Red Register (dmar byang gsal ba'i sgron me). Although the Red Register probably does contain instructions that derive from an early stage in the Tibetan medical tradition (II ${ }^{\text {th }}$ c.?), ${ }^{126}$ this framing narrative most probably was formulated in the thirteenth or even fourteenth century, following a narrative tradition distinct from that of the Yellow Sage colophon. In the opening to the Red Register-which refers to itself as a Discourse on Healing: ${ }^{27}$ A Practical Text for Treating the Emperor (bla spyad [=dpyad] kyi gzhung 'tsho ba'i mdo)—we learn that Drangti Gyelnyé Kharbu had acted as the minister of Eastern Tibet for Tri Dhé Aktsom, and in return for his services, the emperor bestows upon him a textual corpus of medical root texts, commentaries, and summaries. ${ }^{\text {I28 }}$

Upon receiving these instructions, Gyelnyé Kharbu is distraught by the sheer mass of textual materials. There are seventeen extensive explanations of the Thoracic Cavity and supplemental works, two systems of the condensed Brown Manual, and the extremely condensed Small Red Text, in a root text, commentary, and commentary on oral instructions. ${ }^{\text {I29 }}$ "My Lord," he supplicates, "although these instructions that we have are profound, they still require that one seek out a master. Are there any treasure texts or instructions that do not

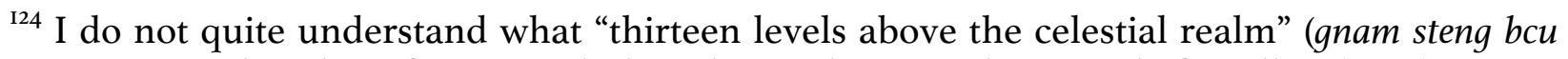
gsum) means, but the reference to hiding the teachings in the capital of a pillar (ka gzhu'i nang $d u$ sbas) are reminiscent of narrative motifs common to the treasure tradition.

${ }^{125}$ See Géza Uray, "A Chronological Problem in the Old Tibetan Chronicle," Acta Orientalia Academiae Scientiarum Hungaricae II (1968): 258-69; cited in Daniel A. Hirshberg, Remembering the Lotus-born: Padmasambhava in the History of Tibet's Golden Age (Boston, MA: Wisdom Publications, 20I6), I4, n. 34 .

${ }^{126}$ Yang Ga Sources for the Writing of the Rgyud bzhi, 44-45.

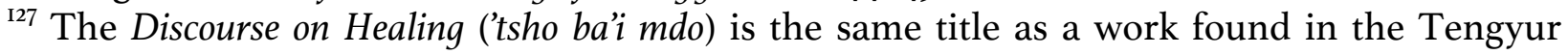
attributed to Nāgārjuna. See Krung go'i bod rig pa zhib 'jug ste gnas kyi bka' bstan dpe sdur khang, ed., Bstan 'gyur dpe sdur ma (Beijing: Krung go'i bod rig pa dpe skrun khang, 2004), text 3544, vol. he (III).

${ }_{128}$ Byang khog dmar byang gsal ba’i sgron me, Bod kyi gso ba rig pa'i gna' dpe phyogs bsgrigs dpe tshogs vol. IOI (Beijing: Mi rigs dpe skrun khang, 20I4), 205: bla spyad kyi gzhung 'tsho ba'i mdo/_'phrin las su mdzad pa thugs rje can la phyag 'tshal lo//_rje khri dhe ag tsom gyi sku ring la//_brang ti rgyal mnyes mkhar bu yis//_khams kyi mdo' glon [=blon] lo gsum byas//.

${ }^{129}$ Byang khog dmar byang gsal ba'i sgron me, Bod kyi gso ba rig pa'i gna' dpe phyogs bsgrigs dpe tshogs vol. IOI (Beijing: Mi rigs dpe skrun khang, 20I4), 205: rtsigs su 'phrul gyi yi ge bkas rnang [=gnang]/_ries byang khog rgyas par bshad pa ma bu bcu bdun gnang /_bsdus pa be bum smug po lugs gnyis gnang/_shin tu bsdus pa yi ge mar cung rtsa ba 'grel ba ti ka gsum gnang /. 
require a teacher?" 30 The emperor is confused by his query-these are the root texts and commentaries that have been transmitted from one expert to another, hidden as treasure texts, and finally set into writing for use in the modern period. What could be more profound than these traditional instructions? ${ }^{131}$

Amidst an assembly of ministers and subjects, the emperor ultimately offers Drangti Gyelnyé Kharbu a deal: if Drangti agrees to act as minister in the frontier regions of Eastern Tibet for one more year, then the emperor will provide him with the kind of instruction that he is seeking. ${ }^{132}$ Upon returning from his final year of service, Drangti visits the emperor seeking out his reward. Not only does the emperor bequeath unto him the Lamp that Illuminates the Red Register - an essential summary of the revered Thoracic Cavity collection that is both small in size and great in reasoning-but he also appoints the Drangti scion as his own royal physician. ${ }^{\mathrm{I} 3}$ Gyelnyé Kharbu comes to master the instructions of the Red Register and enacts them whenever necessary, pleasing the emperor with his abilities. Subsequently Gyelnyé Kharbu is said to have "naturally liberated all [of his patients from disease?]," and a final interlinear note proclaims that, following Gyelnyé Kharbu, the Drangti familial lineage have all continued to act as royal physicians. ${ }^{134}$

Although the Red Register probably includes medical instructions that predate those found in the Gold Measure collection, the drastically differing narrative accounts of Gyelnyé Kharbu included in the Gold Measure collection and the Red Register indicate that the colophon of the Yellow Sage ritual was probably recorded before, or at the very least independently of, the Red Register opening narrative. Instead of describing an interrupted lineage of instructions that are narratively connected by motifs of treasure texts, the Red Register describes a continuous

${ }^{130}$ Byang khog dmar byang gsal ba'i sgron me, 205: des kyang rgyal mnyes kho thag ma chod nas/_rje lags 'di rnams pas kyang zab pa cig bdog ste mchi bas/_di rnams la slob dpon 'tshal bar gda' bal_gter ma lags par gda' ba dang /_bla ma mi dgos pa’i man ngag cig bdog ste mchi bas/_de thugs la rtags par zhu byas pas/.

${ }^{131}$ Byang khog dmar byang gsal ba'i sgron me, 205: rje'i zhal nas byang khog gong ma rnams las/_yi ge mar cung rtsa 'grel yang //_mkhas pa rnams kyi zhal nas zhal du brgyud pa las/_gter du sbed kar yi ge btab pas nal/_yi ge mar chung bya bar ming btags pa yin/_de bas zab pa cig gang nas 'ong gsung nas magnang $/$.

${ }^{132}$ Byang khog dmar byang gsal ba'i sgron me, 205: der glon [=blon] 'bangs thams cad bsogs te thams cad kyis zhus pas/_rje'i zhal nas gal te zab pas 'dra ba'dug nal_da rung blon po byed dam gsung der bya bar [blon po] byas te sngar lo gsum/_phyis lo gcig ste lo bzhi glon po byas so//.

${ }^{133}$ Byang khog dmar byang gsal ba'i sgron me, 205-206: lo dus khyer ba dang zhus pas rje'i zhal nas/_byang khog gong ma rnams las khyad pardu 'phags pa/_bungs su chung la tshigs su che ba/_bla ma mi dgos pa/_ming yang dmar byang gsal ba'i sgron me zhes bya ba 'di khyer lal_nga'i bla sman rgyud par gyis cig gsungs te/.

${ }^{134}$ Byang khog dmar byang gsal ba'i sgron me, 206: stan [=gtan] la phebs pa dang 'di gnang nas dbu' snying [=snyung] bzhes so//_smad la dmar byang 'phrul gyi me long gnang /_bla sman byas pas mkhas par byung bas rje dges so//_'di gnang bas zhal la dris thams cad rang grol du go'o//_lo rgyus so// [rgyal mnyes kyi rgyud [=brgyud] pa thams cad kyis bla sman bya bar byas so]. 
lineage of both instruction and practice within the Drangti family, extending all the way back to the Tibetan empire.

Another detail indicating the later composition of the Red Register narrative is the explicit critique of medical scholasticism. Unlike the channel prasena rituals found in the Gold Measure, which do not make reference to any other texts or instructions, the Red Register describes Gyelnyé Kharbu's exasperation with the opaque nature of root texts, commentaries, and summaries. Even if the Thoracic Cavity (byang khog), the Brown Manual (be bum [=be'u bum?] smug po), and the Small Red Text (yi ge [d]mar cung) do not refer to real texts of the Tibetan imperial period-and instead are intentionally ambiguous titles that were fabricated later, when the Red Register narrative was composed in the early thirteenth century-the reference to seventeen "mother and son" exegeses on the Thoracic Cavity (byang khog rgyas par bshad pa ma bu bcu bdun), the two systems of summarizing in the Brown Manual (bsdus pa be bum smug po lugs gnyis), and the root text, commentary, and explanation of the extremely abridged Small Red Text (shin tu bsdus pa yi ge mar cung rtsa ba 'grel ba ti ka gsum), combine to subtly critique the textual proliferation of medical scholasticism. Faced by so many root texts, summaries, and commentaries, Gyelnyé Kharbu asks, "Are there any treasure texts or instructions that do not require a teacher?" The emperor ultimately supplies such a work, of course, and the Red Register comes to be transmitted in the familial line of the Drangti clan from Gyelnyé Kharbu down to Jampel Zangpo, Penden Tsojé, and others.

Despite the importance of the Red Register to the Drangti school, it was not the only essential commentary that was composed in response to the proliferation of medical scholasticism during the Tibetan renaissance period. Indeed, it was the translation of medical treatises from Sanskrit in the eleventh century that prompted the proliferation of medical literature described above, as well as the organization of that literature into root texts, commentaries, and summaries. Such works were translated as part of a larger transmission of cosmopolitan South Asian knowledge into Tibet, which came to be described as the five fields of knowledge (Skt. pañcavidy $\bar{a}=$ Tib. rig [pa'i] gnas lnga), and a master of medicine along with Buddhist philosophy, logic, grammar, and arts and crafts-usually, but not always, described in Tibet within a Buddhist narrative and soteriological context - would be called a literatus or pandit (Tib. and Skt. pandita). In the thirteenth and fourteenth centuries, even with the canonization of these medical treatises translated from Sanskrit, Tibetan physicians continued to compose their own summaries and commentaries due to the simple fact that, by that point, many aspects of the Tibetan medical tradition had developed independently of South Asian Āyurveda.

During this period of canonization, two distinct approaches to medical scholasticism developed. Unlike the prasenā divinatory tradition explored in Chapter One, the scholastic traditions would posit scriptures and treatises as the formative texts of their medical instructions, depicting the extensive treatises as commentaries and summaries of the terse scriptures. The difference between these traditions becomes most obvious when we engage the criteria used to make these choices-as the literatus tradition of Tibetan medical 
scholasticism came to produce lists of translated medical scriptures taught by the Buddha (Skt. buddhavacana $=$ Tib. sangs rgyas kyi bka'), as opposed to treatises (Skt. śāstra = Tib. bstan bcos) composed by subsequent literati, the primary criterion for inclusion was the cosmopolitan provenance of the text. While some Tibetan literati preferred only works translated from South Asian medical traditions, others opened up space for those form East or Central Asia, depending upon the context. In either case, however, the literatus tradition of Tibetan medical scholasticism came to exclude Tibetan-authored vernacular treatises as inappropriate for study and undeserving of transmission among scholars.

During the twelfth century there was not a great discrepancy between the non-practicing literati and the practicing scholar-physicians of the Tibetan medical tradition. Both groups looked to the Compendium of the Essence of the Eight Branches (Tib. yan lag brgyad pa'i snying po'i bsdus $p a=$ Skt. aștāñgahṛayasaṃhita) attributed to Vāgbhața ( $p h a k h o l$ ), as well as its commentaries, as a source of inspiration and instruction, with figures like Zhangtön Zijibar (zhang ston gzi brjid 'bar, b. mid IIth c.) and Yutok Gönpo (g.yu thog mgon po, fl. $\mathbf{2}^{\text {th }}$ c.) both working to provide vernacular instructions based on this corpus of translated Âyurvedic instructions. In response to this corpus of translated textual instructions and the growing corpus of Tibetan-language summaries, a deluge of vernacular scriptures and instructional collections began to emerge in the eleventh and twelfth centuries, including the famed Essence of Ambrosia (bdud rtsi snying po), a twelfth-century precedent for the seminal work of the Tibetan medical tradition, the Four Tantras (rgyud bzhi), that probably corresponds closely to the textus receptus of the Explanatory Tantra (bshad rgyud). Not unlike Gyelnyé Kharbu in the story described above, thirteenth-century physicians continued to summarize and adapt both translated and vernacular scriptures and treatises, resulting in relatively clear and practical collections like the Secret Essence of Ambrosia (bdud rtsi snying po gsang ba) of the Yutok tradition and the Small Practical Manual (lag len spod chung) of the Drangti tradition. As illustrated by the redaction and conservative reframing of innovative practical works like the Red Register that we saw above, and the Secret Essence of Ambrosia and Small Practical Manual that we shall see below, the medical traditions of Tibet did not lack a concern for efficacy, but would rarely transmit such innovations outside the frame of timeless tradition.

\section{Medicine as a Scholastic Field of Knowledge}

Buddhist scholasticism - understood as the interpretation and explanation of literature, ${ }^{\mathrm{I} 35}$ especially within the bounds of authoritative texts ${ }^{136}$ - has had a long and dynamic career on

${ }^{135}$ For an important work on the defining qualities of European scholasticism, see George Makdisi, "The Scholastic Method in Medieval Education," Speculum 49 (I974): 640-6I. For the relationship between European and Middle Eastern modes of scholasticism, see George Makdisi, The Rise of Colleges: Institutions of Learning in Islam and the West (Edinburgh, 198I). Adding Buddhist scholasticism to the mix, see Christopher I. Beckwith, Warriors of the 
the Indian Subcontinent, the Tibetan Plateau, and beyond. ${ }^{137}$ Medicine appears to have first entered the intellectual realm of Buddhist scholasticism around the fourth century when it was described as one of the five fields of knowledge (Skt. pañcavidyā = Tib. rig [pa'i] gnas lnga) in the Ornament for the Discourses of the Greater Vehicle (Skt. mahāyānasūtrālaṃkāra = Tib. theg pa chen po mdo sde'i rgyan), attributed to Maitreya: ${ }^{\mathrm{I} 8}$

If one is not diligent in the five fields of knowledge, even the most noble will not become omniscient. For the sake of refuting and supporting others, and for the sake of knowing everything oneself, one should be diligent in these [five sciences]. ${ }^{139}$

In his commentary on the Ornament (Skt. sūtrālaṃkārabhāṣya = Tib. mdo sde’i rgyan gyi bshad pa), Vasubandhu elaborates:

There are the five sciences: the science of the Insiders [Buddhist philosophy], the healing science, logic, grammar, and arts and crafts. This verse shows that the bodhisattva should generally pursue all of these in order to attain omniscience. Specifically, one should investigate logic and grammar in order to criticize those that have no faith. [One should

Cloisters: The Central Asian Origins of Science in the Medieval World (Princeton, NJ: Princeton University Press, 2012).

${ }^{136}$ For a thorough explanation of scholasticism in a Tibetan context, particularly in regard to scriptural authority, see Georges Dreyfus, The Sound of Two Hands Clapping: The Education of a Tibetan Buddhist Monk (Berkeley, CA: The University of California Press, 2003), especially pp. 98-IIo. For more on Tibetan Geluk scholasticism, see José Cabezón, Buddhism and Language: A Study of Indo-Tibetan Scholasticism (Albany, NY: State University of New York Press, I994); José Cabezón, Scholasticism in Cross-Cultural and Comparative Perspectives (Albany, NY: State University of New York Press, 1998); and Matthew T. Kapstein, "What is "Tibetan Scholasticism'? Three Ways of Thought," in The Tibetan Assimilation of Buddhism: Conversion, Contestation, and Memory (Oxford: Oxford University Press, 2000), 85-I20.

${ }^{137}$ For an overview of one particular school of Buddhist scholasticism, see Charles Willemen, Bart Dessein, and Collett Cox, Sarvāstivāda Buddhist Scholasticism (Brill: Leiden, 1998). Again, for the inter-continental career of this particular school of scholasticism, see Beckwith, Warriors of the Cloisters.

${ }^{138}$ On the composition and redaction of this work in the fourth century, see Mario D'Amato, The Mahāyānasūtrālaṃkāra: A Terminological Analysis (Chicago, IL: University of Chicago Doctoral Dissertation, 200o).

${ }^{139}$ Theg pa chen po mdo sde'i rgyan zhes bya ba'i tshig le'ur byas pa bzhugs so, in Bstan 'gyur dpe bsdur ma, ed. Krung go'i bod rig pa zhib 'jug ste gnas kyi bka' bstan dpe sdur khang (Beijing: Krung go'i bod rig pa dpe skrun khang, 2004), sems tsam, vol. 70 (phi [138]), text 3252, p. 837: rig pa'i gnas lnga dag la brtson par ma byas nal/_phags mchog gis kyang thams cad mkhyen nyid mi 'gyur te//_de lta bas na gzhan dag tshar bcad rjes bzung dang //_bdag nyid kun shes bya phyir de la de brtson byed//. Cited and translated in Kurtis R. Schaeffer, "Textual Scholarship, Medical Tradition, and Mahāyāna Buddhist Ideals in Tibet," Journal of Indian Philosophy 3I (2003): 633. 
investigate] healing science and arts and crafts in order to care for others that do have faith. One should investigate the science of the Insiders for one's own omniscience. ${ }^{\text {I }}{ }^{\mathrm{O}}$

These verses echoes throughout the works of many great scholars of the Tibetan sciences, including those of Sakya Pandita (sa skya pandi ta, II82-I25I) ${ }^{14 \mathrm{I}}$ and, not incidentally, Drangti Penden Tsojé. Thus, following the deluge of newly translated Indian materials in the tenth and eleventh centuries, scholastics like Sakya Pandita began to utilize the five sciences as a means for the organization of textual sources and knowledge, ${ }^{\mathrm{I} 22}$ and medical sources were an important auxiliary for this Buddhist scholastic project.

One of the earliest examples, and certainly the most successful early example, of medical scholasticism in the Tibetan intellectual tradition is the cycle of the Essence of the Eight Branches. The two most prominent works of this cycle include the Compendium of the Essence of the Eight Branches attributed to Vāgbhața (pha gol), ${ }^{143}$ and the Connotative Moonbeams: An Extensive Commentary on the Essence of the Eight Branches attributed to the Kashmiri Candranandana (zla ba la dga' $b a) .{ }^{\mathrm{I} 44}$ Both of these works are traditionally said to have been

See also David Seyfort Ruegg, Ordre Spirituel et Ordre Temporel dans La Pensée Bouddhique de l'Inde et $d u$ Tibet (Paris: Collège de France, Institut de Civilisation Indienne), IoI.

${ }^{140}$ Bstan 'gyur dpe bsdur ma, sems tsam, vol. 70 (phi [138]), text 3258, p. I248-49: rig pa'i gnas ni rnam pa lnga ste/_nang rig pa dang /_gso ba rig pa dang /_gtan tshigs rig pa dang /_sgra rig pa dang I_bzo'i las kyi gnas rig pa'o/_/de dag gang gi phyir byang chub sems dpas btsal bar bya ba de ston te/_bye brag med par ni thams cad mkhyen pa nyid thob par bya bai phyir ro/_/bye brag tu ni gtan tshigs rig pa dang I_sgra rig pa ni gzhan de dag la ma mos pa rnams tshar bcad pa'i phyir yongs su tshol lo/_/gso ba rig pa dang/_bzoi las kyi gnas rig pa ni gzhan de dag la mos pa rnams la phan gdags pa'i phyir yongs su tshol lo/_/nang rig pa ni bdag nyid kun shes par bya ba’i phyir yongs su tshol lo/. Translated in consultation with Robert Thurman, trans. The Universal Vehicle Discourse Literature (Mahāyānasūtrālaṃkāra) by Maitreyanātha/Āryāsañga, Together with Its Commentary (Bhāṣya) by Vasubandhu (New York, NY: American Institute of Buddhist Studies at Columbia University, 2004), I4I.

${ }^{141}$ For this citation, translation, and analysis of Sapan's interpretation, see Jonathan C. Gold, The Dharma's Gatekeepers: Sakya Paṇdita on Buddhist Scholarship in Tibet (Albany, NY: State University of New York Press, 2007), 15-24.

${ }^{142}$ Gold, The Dharma's Gatekeepers, 19-20: "Of course, the MSA verse does not say that the allknowing scholar is, necessarily, an advanced bodhisattva; omniscience is not described as a sufficient but only a necessary condition for the bodhisattva's advancement. Yet by equating the 'five sciences' with the objects of knowledge of 'that scholar,' Sa-pan does seem to suggest that mastering the five sciences is a sufficient condition for attainment of a kind of scholarly omniscience."

${ }^{143}$ Yan lag brgyad pa’i snying poii bsdus pa [= Skt. așțāngahṛdayasaṃhita], in Bstan 'gyur dpe sdur $m a$, ed. Krung go'i bod rig pa zhib 'jug ste gnas kyi bka' bstan dpe sdur khang (Beijing: Krung go'i bod rig pa dpe skrun khang, 2004), text 3547, vol. III (he [213]).

${ }^{144}$ Yan lag brgyad pa'i snying pöi rnam par 'grel pa tshig gi don gyi zla zer [= Skt. padārthacandrikāprabhāsa-nāma-așțāngahṛdayavivṛti], in Bstan 'gyur dpe sdur ma, text 3549, vols. II3-I4 $(k h o-g o)$. 
translated from Sanskrit into Tibetan by the Kashmiri scholar, Jārandhara, ${ }^{\mathrm{I} 45}$ and the renowned Tibetan translator, Rinchen Zangpo (rin chen bzang po, 958-1055). ${ }^{\mathrm{I} 6}$ These are not the only two works in the Essence of the Eight Branches cycle that are contained in the "Medical Science" (gso ba rig pa) section of the Translated Treatises (bstan 'gyur) canon, however. In addition to Connotative Moonbeams, for example, there is another Commentary on the Essence of the Eight Branches of Medicine also attributed to Candranandana, ${ }^{\mathrm{I}}{ }^{7}$ and an "autocommentary" (rang 'grel), the Essence of the Eight Branches: An Explanation of Medicine, attributed to Vāgbhața himself. ${ }^{\mathrm{I} 8}$ Thus, although many later authors refer to the root text and commentary of the Eight Branches (yan lag brgyad pa'i rtsa 'grel), it is not always clear to which of these root texts and commentaries they may be referring.

Candranandana's Explanation of Medicine is a short text that primarily lists the names of medicines found in the Essence of the Eight Branches and other sources, with brief descriptions interspersed throughout the lists. ${ }^{49}$ Vāgbhața's Essence of the Eight Branches autocommentary is an extensive explanation of the topics covered in the Compendium of the Essence of the Eight

${ }^{I 45}$ This scholar (mkhan po) is variously called Jārandhara, Janārdana, Jarandāna, Jārandana, Jarandhara, and Jārandhara. See Vogel, Vāgbhaṭa's Așțāngahṛdayasaṃhita, I9, n. Io.

${ }^{146}$ Bka' bstan dpe sdur khang, ed., Bstan 'gyur dpe sdur ma, vol. III (he [213]), text 3547, p. 840: rgya gar gyi mkhan po dzā ran dha ra dang /_zhu chen gyi lotstsha ba dge slong rin chen bzang pos bsgyur cing zhus te gtan la phab pa//. A similar colophon appears in the complete manuscript witness recently published as "Gso dpyad yan lag brgyad pa'i snying po bsdus pa las phyi ma'i gnas bzhugs so," in Krung go'i bod lugs gso rig rtsa che'i dpe rnying kun btus, vol. 2, text 6, p. 375 (f. 235a): rgya gar gyi mkhan po dza na ra da na dang /_zhu chen gyi lotstsha ba dge slong rin chen bzang pos bsgyur cing zhus te gtan la phab pa'o//. The other manuscript editions of this text found in the latter volume (vol. 5, text 3; and vol. IO, text I) are incomplete and do not include colophons. For a list of texts attributed to Jārandhara and Rinchen Zangpo, see Vogel, Vāgbhața's Așțāngahṛdayasaṃhita, I9-20.

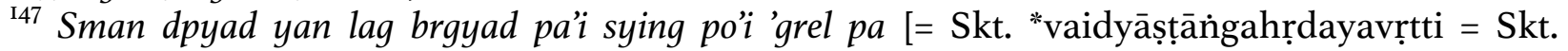
madanādinighaṇțu], in Bstan 'gyur dpe sdur ma, text 3546, vol. III (he [213]). Meulenbeld appears to have been confused about the equation of the "Vaidyāșțāngahṛdayavrtti and the Madanädinighaṇțu (A History of Indian Medical Literature, Ib, p. 732, n. I58). This confusion may derive from the difference of titles provided in the different editions of the Tengyur. For a detailed study of this text, see Bhagwan Dash, Illustrated Materia Medica of Indo-Tibetan Medicine (Delhi: Classics India Publication, 1987).

${ }^{148}$ Yan lag brgyad pa'i snying po zhes bya ba'i sman dpyad kyi bshad pa [= Skt. "aștāingahrdayanāma-vaiḍūryakabhāṣya] in Bstan 'gyur dpe sdur ma, text 3548, vols. III-I2 (he-e [213-I4]).

${ }^{149}$ The description of the text found in the colophon aptly reflects its contents. Bka' bstan dpe sdur khang, ed., Bstan 'gyur dpe sdur ma, vol. he (III), text 3546, p. I2I: “A commentary by Candranandana on the Essence of the Eight Branches of Medicine, a categorization of the medicines in the Eight Branches, and so forth" (sman dpyad yan lag brgyad pa'i snying po'i 'grel pa mdzad pa'i slob dpon zla ba la dga' bas yan lag brgyad pa la sogs pa'i sman gyi ming gi rnam grangs mdzad pa rdzogs so//). For a summary of the contents of this text and information on Candranandana in general, see Meulenbeld, A History of Indian Medical Literature, vol. 2a, pp. I20-22. 
Branches, and unlike all of the other texts cited above, it is not available in Sanskrit. ${ }^{150}$ The autocommentary is said to have been translated during the life of the famed monarch of Western Tibet, Lha Lama Yeshé Ö (lha bla ma ye shes 'od), by a team of translators, including the Indian Master Dharmaśrīvarma, the Tibetan translator Shākya Lodrö, and the redactors Rikpa Zhönnu and Yikgi Rinchen. ${ }^{\text {I5I }}$ Although the so-called "autocommentary" of the Essence of the Eight Branches does explain the same topics found in the Compendium and in the same order, it does not cite the Compendium explicitly, indicating that it may represent an alternative translation tradition instead of an autocommentary. ${ }^{152}$ This notion is further supported by the absence of a Sanskrit original. Although there are further works attributed to figures like Nāgārjuna, Ravigupta, and so forth in the "Medical Science" section of the Translated Treatises canon, this short survey should suffice in demonstrating the fact that, due to the productive activities of Kashmiri pandits and Tibetan translators in Western Tibet around the turn of the eleventh century, Tibetans came to have accesses to a vast corpus of medical scholasticism in the Essence of the Eight Branches cycle.

Just this cursory review of the medical works found in the Translated Treatises canon is enough to warrant an echo of Drangti Gyelnyé Kharbu's call: although these translated works are indeed profound, are there not practical teachings that can be easily understood and implemented in a clinical setting? Indeed, following the introduction of scholastic medicine in the eleventh century, much of the intellectual activity in the Tibetan medical tradition centered around the interpretation, summarization, and exegesis of the Essence of the Eight Branches cycle. One of the earliest figures to intellectually engage the Essence of the Eight

${ }^{150}$ Meulenbeld, A History of Indian Medical Literature, vol. Ia, p. 683.

${ }^{151}$ Bka' bstan dpe sdur khang, ed., Bstan 'gyur dpe sdur ma, text 3548, vol. e (II2), p. IoII: “At the order of the Divine Emperor of Tibet, Master Jangchup Lha Lama Jñānaprabhā [=Yeshé Ö], requesting that this explanation of the Essence of the Eight Branches of Medicine from the ocean of the science of life (äyurveda) too be translated, the Indian Master Dharmaśrivarma and the Great Translator, Venerable Shakya Lodrö of Igu, translated the text in the presence of the lama. Venerable Rikpa Zhönnu of Marlo, and Venerable Yikgi Rinchen of Nyelchor revised the text" (bod kyi lha btsan po slob dpon byang chub sems dpa' lha bla ma dznyA na pra bhä' bkas/_tshe'i rig byed kyi rgya mtsho sman dpyad yan lag brgyad pa'i snying po zhes bya ba'i bshad pa 'di'ang bsgyur cig ces bka' stsal nas bla ma'i zhabs drung du/_rgya gar gyi A tsarya dharma shri warma dang /_zhu chen gyi lo tsA ba i gu dge slong shäkya blo gros kyis bsgyur cing mar lo dge slong rig pa gzhon nu dang /_mnyel bcor dge slong dbyig gi rin chen dang gsum gyis tshad la phab ste mjug bsdus nas rdzogs par bgyis so//). Although the word "Marlo" (mar lo) appears to refer to the home of Rikpa Zhönnu, others have interpreted him as a separate individual. See Meulenbeld, $A$ History of Indian Medical Literature, vol. ib, p. 753, n. 577.

${ }^{152}$ Note that the Collection of the Essence of the Eight Branches (aștāngahridayasamgraha), as opposed to the Compendium of the Essence of the Eight Branches (așțāngahṛdayasaṃhita), appears to never have been translated into Tibetan. Philological studies of the Eight Branches have largely ignored this "autocommentary" and further investigation may reveal a connection between these two works. On the Așțāngahṛdayasaṃraha, see Meulenbeld, A History of Indian Medical Literature, vol. Ia, pp. 475-593; and for unresolved questions regarding the relationship between the Collection and the Compendium, see pp. 613-56.

W. A. McGrath | Buddhism and Medicine in Tibet $\mid 58$ 
Branches is Zhangtön Zijibar (zhang ston gzi brjid 'bar, b. $\mathrm{II}^{\text {th }} \mathrm{c}$.). Despite the importance of this figure in relation to the early transmission of the Sakya Path and Fruit teachings (sa skya lam 'bras), ${ }^{153}$ and the early development of medicine in Tibet, very little has been written about him in modern scholarship. ${ }^{154}$ This is perhaps due to the fact that he was writing before the Four Tantras and, until very recently, few texts attributed to Zijibar have been available. The medical history of Drangti Penden Tsojé only mentions him briefly, as being the author of the Illuminating Lamp: Thirty[-Three?] Instructions (sgron gsal gdams pa sum cu [so gsum] pa), ${ }^{155}$ as belonging to a group of twelve physicians dedicated to the benefit of others (gzhan don mdzad pa'i sman pa bcu gnyis), ${ }^{156}$ and as belonging to a group of five physicians that created treatises of perfected eloquence (phul du phyin pa'i legs bshad bstan bcos mdzad pa'i sman pa lnga). ${ }^{157}$ In addition to his Illuminating Lamp, however, we also now have a work called the Rays of Sunlight (nyi ma'i 'od zer) that is attributed to Zhangtön. ${ }^{158}$ Following obeisance to the teachers and the buddhas - Kings of Physicians (sman pa'i rgyal po rnams) —Zhangtön provides a rather detailed exposition regarding the woes of this "cyclical prison in the ocean of existence" (srid pa'i rgya mtsho'i 'khor ba'i btson ra can)—detailing the three poisons (dug gsum), their associated pollution (sdig pa), and finally potential solutions to these problems in the form of faith (dad $p a$ ) and offerings (mchod $p a)$. He finally closes with a statement of his intention:

To atone for these polluting deeds,

To teach the youth, like opening the eyes

Of a blind man with surgery, I have respectfully composed

This text of mine, the Illuminating Rays of Sunlight.

I gathered selections from the Eight Branches and the treatises,

${ }^{153}$ For a short history of how Zijibar gained the Path and Fruit teachings from Drokmi Lotsawa ('brog mi lo tsa ba, IIth c.), see Zhang ston gyi lo rgyus 'bri 'phro (Unpublished manuscript scanned in New Delhi for TBRC, WICZI873).

${ }^{154}$ Yang Ga only mentions Zijibar tangentially: Yang Ga, Sources for the Writing, 62. On the role of Zijibar and his famous brother, Zhangtön Chömbar (zhang ston chos 'bar, IO53-II35), in the early education of Sachen Künga Nyingpo (sa chen kun dga' snying po, I092-II58), see, for example, Cyrus Stearns, Luminous Lives: The Story of the Early Masters of the Lam 'bras Tradition in Tibet (Boston, MA: Wisdom Publications, 200I), I25.

${ }^{155}$ Brang ti dpal ldan 'tsho byed, Rgyud bzhi'i spyi don shes bya rab gsal rgyas pa (Delhi: TY Tashigang, 2005), 72. This text has been recently published in manuscript facsimile for the first time. It generally refers to itself as the Illuminating Lamp: A Medical Treatise (gso' rig bstan bcos sgron ma gsal ba) or, despite having approximately fifty chapters, Illuminating Lamp: Thirty Instructions (sgron ma gsal ba'i gdams pa sum bcu' pa). See Ga las pa sum cu pa, in Krung go’i bod lugs gso rig rtsa che'i dpe rnying kun btus, vol. I, text I2, pp. 66-I64 (ff. Ia-I56a). It is unclear to me whence derives Drangti's number thirty-three.

${ }^{156}$ Brang ti dpal ldan 'tsho byed, Shes bya rab gsal rgyas pa (Delhi), 88.

${ }^{157}$ Brang ti dpal ldan 'tsho byed, Shes bya rab gsal rgyas pa (Delhi), 90. 
Neither to flaunt [my learning], nor to seek wealth.

In order to obtain the great vehicle of human being without fault, I shall teach this very lesson with eloquence.

Though obscured by the darkness of ignorance and delusion, The flowing river of the lama's blessed compassion Has eliminated the diseases of cyclical perversion.

I shall faithfully teach this supreme medicine of ambrosia.

I have surveyed many different textual traditions,

Both the inner and outer classes of Insider [Buddhist] tantras,

And the class of Outsider [non-Buddhist] tantras, such as the

[Compendium of] Caraka,

And I shall teach this knowledge of yore. ${ }^{159}$

In this introductory statement of intention Zhangtön places himself within a decidedly Buddhist lineage by repeatedly referring to Buddhist doctrine and proclaiming his faith in his guru. As stated above, in composing this text, he seeks to teach future generations, accrue merit, display his devotion to his teacher, and transmit the knowledge of past generations. Furthermore, in the final stanza describing the sources of the text, Zhangtön contrasts the inner and outer classes of Buddhist tantras with the class of non-Buddhist extremist tantras, explicitly naming the Compendium of Caraka as an example of the latter category. Thus, despite his outspoken Buddhist affiliation, Zhangtön expresses no qualms in referring to a class of non-Buddhist tantras as a source of medical knowledge.

Following Zhangtön's riveting introduction is a series of practical instructions on the treatment of specific diseases and disorders. Although such compendia of concise instructions are not inherently different from their practical precedents found at Dunhuang, for example, the explicit engagement with formative texts-here described as the Eight Branches, but also the Buddhist and non-Buddhist tantras-marks the emergence of Tibetan medical scholasticism. Indeed, the formative texts of the Tibetan medical tradition are those with "which progress in the field is made through interpretation of the text itself. A text-centered

${ }^{158}$ Zhang gzi brjid 'bar, Gzhung dri med gzi brjid kyi 'grel ba nyi ma'i 'od zer, Bod kyi gso ba rig pa'i gna' dpe phyogs bsgrigs dpe tshogs, vol. IOI (Beijing: Mi rigs dpe skrun khang, 20I4).

${ }^{159}$ Zhang gzi brjid 'bar, Gzhung dri med gzi briid, 6: sdig pa'i las 'di bshags par bya ba'i phyir//_nyi ma'i 'od gzer gyis bsal kho bo'i gzhung //_gzhon nu 'jug pa long ba lta bu lal/_mig 'byed thur ma 'di ni gus pas brtsam par bgyi//_yan lag brgyad dang bstan bcos rnams las btus//_bskul phyir ma yin longs spyod'dod phyir myin//_myi yi gru chen skyon myed thob byai phyir//_legs pa nyid du 'di nyid bshad par byal/_myi shes gti mug mun pas bsgribs gyur kyang //_bla ma'i byin brlabs thugs rje'i chu rgyun can//_log sred 'khor ba'i nad rnams 'joms mdzad pal/_bdud rtsi sman mchog 'di ni dad pas bshad par byal/_nang pa sangs rgyas rgyud sde phyi nang gnyis//_phyi rol mu stegs rgyud sde tsa ra kal_myi 'dra'i gzhung lugs sna tshogs rnams las mthong //_rig pa sngon du byung'di bshad par bya//.

W. A. McGrath | Buddhism and Medicine in Tibet $\mid 60$ 
culture that has formative texts proceeds in that mode; its achievements are interpretative." 160 Following this early scholastic engagement with formative texts that served to render the opaque instructions of translated treatises suitable for practice in a Tibetan context, later scholars of the five fields of knowledge came to promote the translated root texts and commentaries over these vernacular summaries, sacrificing practical instructions for an Indian provenance.

Continuing the scholastic project of Zhangtön Zijibar, Cherjé Zhangtön Zhikpo explicitly lauds the Essence of the Eight Branches as the formative text of Tibetan medical scholasticism and describes Zijibar as in the "Lineage of Worthy Tibet[ans]" (rigs ldan bod kyi lugs), along with Yiong Lekpé Gyen (yid 'ong legs pa’i rgyan), Gyongmen Penné (gyong sman phan ne), and himself. ${ }^{16 \mathrm{I}}$ Later in the thirteenth century, Chomden Rikpé Reldri (bcom ldan rig pa'i ral gri, I227-I305), the Kadampa (bka' gdams pa) scholar and bibliophile of Nartang (snar thang) monastery, ${ }^{162}$ writes in his Ornamental Flower of Healing Science (gso ba rig pa rgyan gyi me tog) a slightly more inclusive account of the formative texts of the Tibetan medical tradition:

A brief account of medicine was taught by [Śākya]muni in a few sutras and tantras. The venerable Nāgārjuna composed the One Hundred Formulae. ${ }^{163}$ The Eight Branches-the essence of the entire compendium of scriptures that were created by Atriputra, Agniveśa, and many other sages - was composed by the Lord of Medicines, son of Samghaguhya, the great physician, Vāgbhața. ${ }^{164}$ Its commentary was composed by the Kashmiri son of Kāmānandana, Candranandana. ${ }^{165}$ The Garland of Formulae in the Eight Branches, ${ }^{166}$ the

I60 Moshe Halbertal, People of the Book: Canon, Meaning, and Authority (Cambridge, MA: Harvard University Press, I997), 94. Cited in Dreyfus, The Sound of Two Hands Clapping, Ioo.

${ }^{161}$ Martin, "Greek and Islamic Medicines' Historical Contact with Tibet," I40.

${ }^{162}$ On the life and work of Chomden Rikpé Reldri, see Kurtis R. Schaeffer and Leondard W. J. van der Kuijp, An Early Tibetan Survey of Tibetan Buddhist Literature: The Bstan pa rgyas pa rgyan gyi nyi 'od of Bcom ldan ral gri, Harvard Oriental Series vol. 64 (Cambridge, MA: Harvard Oriental Series, 2009).

${ }^{\text {I63 }}$ The One Hundred Formulae (Skt. yogaśataka = Tib. sbyor ba brgya ba). Bka' bstan dpe sdur khang, Bstan 'gyur dpe bsdur ma, text 3543, vol. III (he [213]), 3-22.

${ }^{164}$ The Collection of the Essence of the Eight Branches (Skt. aștāngahṛayasaṃitā = Tib. yan lag brgyad pa'i snying po bsdus pa). Bka' bstan dpe sdur khang, Bstan 'gyur dpe bsdur ma, text 3547, vol. III (he [2I3]), I43-944.

${ }^{165}$ Connotative Moonbeams: An Expanded Commentary on the Essence of the Eight Branches (Skt. padārthacandrikāprabhāsa-nāma-așțāngahṛdayavivṛti = Tib. yan lag brgyad pa'i snying po'i rnam par 'grel pa tshig gi don gyi zla zer). Bka' bstan dpe sdur khang, Bstan 'gyur dpe bsdur ma, text 3549, vol. II3 (ko [215] and go [216]), 3-1716; vol. II4 (go [217]), 3-840.

${ }^{166}$ The Garland of Formulae in the Eight Branches (yan lag brgyad pa sbyor ba'i phreng ba) probably refers to Commentary on the Essence of the Eight Branches of Medicine (Skt. madanädinighanțu ["vaidyāștāñgahṛdayavrtti = Tib. sman dpyad yan lag brgyad pa'i sying po’i 'grel pa]) also attributed to Candranandana in the Tengyur colophon. Bka' bstan dpe sdur khang, Bstan 'gyur dpe bsdur ma, text 3546, vol. III (he [213]), 39-I42. 
Essence of Healing, ${ }^{167}$ the Vessel of Ambrosia, ${ }^{168}$ the Numerology of Addition and Subtraction, ${ }^{169}$ and so forth were composed by other masters. Thus medicine should be taught from the scriptures of these scholars. ${ }^{170}$

The above account is a concise prescription for a limited body of formative texts, all of which refer to the Tibetan translations of Indian medical works. ${ }^{171}$ With the potential exception of the latter two works, this is one of the earliest descriptions of the Science of Healing (gso ba rig pa) corpus that would come to be immortalized in the Translated Treatise canon. On the notion of Buddhist and non-Buddhist medical works, he continues:

Others have said that there are both Outsider [non-Buddhist] and Insider [Buddhist] medical texts-that there are Outsider [non-Buddhist] tantras and Insider [Buddhist] sutras and tantras, wherein the [Buddhist] tantras include the Root Tantra, the Explanatory Tantra, the Instructional Tantra, the Subsequent Tantra, and so forth. But these treatises, sutras, and tantras were all composed in Tibet; they are treatises that were composed by

${ }^{167}$ The Essence of Healing ('tsho ba'i snying po) may refer to the Discourse on Healing (Skt. jīvasūtra = Tib. sman 'tsho ba'i mdo) attributed to Nāgārjuna in the Tengyur colophon. Bka' bstan dpe sdur khang, Bstan 'gyur dpe bsdur ma, text 3544, vol. III (he [213]), 23-33.

${ }^{168}$ The Vessel of Ambrosia (bdud rtsi za ma tog). I have been unable to locate this work in the Tengyur and, interestingly, may refer to the early medical work attributed to Padmasambhava, the Vase of Immortal Ambrosia ('chi med bdud rtsi bum pa). For a modern publication of the latter, see "Chi med bdud rtsi bum pa'i rgyud man ngag," in Slob dpon pad 'byung gi sman yig gces btus, Bod kyi gso ba rig pa'i gna' dpe phyogs bsgrigs dpe tshogs, vol. 24 (Beijing: Mi rigs dpe skrun khang, 2006), I-I93. For a manuscript version, see TBRC work \#W4CZ20873. The notion of a vase or vessel of ambrosia, of course, evokes the iconography of the Medicine Buddha and, therefore, is widely attested. See also the medical work of Bodong Choklé Namgyel (bo dong phyogs las rnam rgyal, I375-I45I), which, of course, postdates the writing of Chomden: Sman dpyad bdud rtsi'i bum pa, Bod kyi gso ba rig pa'i gna' dpe phyogs bsgrigs dpe tshogs, vol. 97 (Beijing: Mi rigs dpe skrun khang, 2013).

${ }^{169}$ The Numerology of Addition and Subtraction (zad 'phel rtsi). I have also been unable to locate this exact work in the Tengyur, but there are a number of works about astrological and divinatory numerology (rtsis), particularly in relation to the Wheel of Time Tantra (rgyud vol. $\mathrm{pa}$ ) and in the Miscellaneous section (sna tshogs vols. ngo and po).

${ }^{170}$ Gso ba rig pa rgyan gyi me tog, in Krung go'i bod lugs gso rig rtsa che’i dpe rnying kun btus, vol. 3, no. 4O, p. 472 (ff. Ib-2a): thub pas mdo rgyud 'ga' las cung zad gsungs/_klu sgrub zhabs kyi sbyor ba brgya ba mdzad/_/rgyun shes bu dang me bzhin 'jug la sogs/_drang srong mang pos byas pa'i gzhung rnams kyi/_/gang gces bsdus pa'i snying po yan lag brgyad/_[2a] sman pa'i bdag po dge 'dun gsang ba'i bu/_sman pa chen po pha khol byas pa stel_de 'grel kha che chags la dga' ba'i bu/_zla ba mngon par dga' bas byas pa yin/_yan lag brgyad pa sbyor ba'i phreng ba dang /_tsho ba'i snying po bdud rtsi za ma tog_/zad 'phel rtsi sogs slob dpon gzhan gyis byas/_mkhas pa'i gzhung las gso rig de skad bshad/.

${ }^{171}$ On Chomden's role in the early formation of the Kangyur and Tengyur, see Schaeffer and van der Kuijp, An Early Tibetan Survey of Tibetan Buddhist Literature. 
an individual [and that have been presented] as if they were the teachings and medical science of the Ones Gone Thus. ${ }^{172}$

Because Kyebu Melha, the physician from Oḍdiyāna and the son of Jinamitra, was amputated by the king [of Oḍḍiyāna], he came to Tibet during the life of Tselha (I057I088), Lord of Ngari. He then passed many of his instructions on to Tongmen and so forth. Many Chinese medical works, such as the Somarajja and so forth, were translated at the time of Samyé and are famed for having been transmitted from Mañjuśrī. Thus it has been said that medicine originated in the three lands of India, Oḍ̣iyāna, and China. ${ }^{173}$

Chomden Rikpé Reldri is unequivocal about his views: all valid medical knowledge derives from the "sages of yore" (sngon gyi drang srong rnams)—including Sākyamuni, Nāgārjuna, Vāgbhața, and even Kyebu Melha-as well as the medical traditions of India, Oḍ̣iyāna, and China. ${ }^{74}$ There is no such division as Buddhist and non-Buddhist medical scriptures, and the Four Tantras was composed in Tibet itself, not in India, rendering its contents outside the bounds of valid medical scholasticism. Thus, between the turn of the twelfth century and the middle of the thirteenth century a debate appears to have developed regarding the criteria of valid sources of knowledge in Tibetan medical scholasticism.

\section{Practical Scholasticism in the Tibetan Medical Tradition}

One of the earliest and most explicit endorsements of practical scholasticism in the Tibetan medical tradition can be found in the so-called Lesser Tantra (rgyud chung)-

${ }^{172}$ Gso ba rig pa rgyan gyi me tog, in Krung go’i bod lugs gso rig rtsa che’i dpe rnying kun btus, vol. 3 , no. 40, p. 472 (f. 2a): kha cig gso spyad gzhung las phyi nang gnyis/_phyi pa'i rgyud dang nang pa'i mdo rgyud gnyis/_rgyud la rtsa rgyud bshad rgyud man ngag rgyud/_/rgyud phyi la sogs rnam pa gzhan smra bal_/de kun bod kyi byas pa'i bstan bcos te/_/mdo rgyud de bzhin gshegs pa'i gsung rabs dang /_/gso rig gang zag byas pa'i bstan bcos yin/.

${ }^{173}$ Gso ba rig pa rgyan gyi me tog, in Krung go’i bod lugs gso rig rtsa che’i dpe rnying kun btus, vol. 3, no. 40, p. 472 (ff. 2a-2b): u rgyan sman pa dzī na mi trī bu/_skyes bu me lha rgyal po chad pa'i sa [=pas]/_mnga' bdag rtse lha'i [=lde'i] tshe na bod du byon/_stong sman sogs la man ngag mang po byin/_so ma rā dzā la sogs rgya nag gi/_sman spyad mang po bsam yas dus su sgyur/_jam pa'i dbyangs la brgyud pa yin zhes grags/_de ltar rgya gar u rgyan rgya nag yul/_gsum nas gso rig legs par byung tshul bshad/.

${ }^{174}$ Interestingly, Chomden does allow space for works of astrology and, potentially, treasure works like the Vessel of Ambrosia (or whatever this may have meant for him). Indeed, a brief survey of Chomden's own medical instructions reveals topics of East and Central Asian provenance, like "Treating Diseases of the Five Viscera" (don lnga'i nad bcos pa; ch. II) and "Treating Diseases of the Six Cavities" (snod drug gi nad bcos pa; ch. I2). An important desideratum for determining early scholastic views on the practice of medicine, particularly outside the purview of the Yutok school, would be a careful analysis of this clearly written and clearly organized work. 
with a less derogatory appellation, the Secret Essence of Ambrosia: An Instructional Tantra (bdud rtsi snying po gsang ba man ngag gi rgyud). ${ }^{175}$ As Yang Ga has definitively shown, the Secret Essence of Ambrosia is conceptually and textually interrelated with the Four Tantras-also known as the Essence of Ambrosia in Eight Branches (bdud rtsi snying po yan lag brgyad pa), and also often called the King of Tantras (rgyud rgyal) in early medical literature-and both the Secret Essence of Ambrosia and the Four Tantras reveal a significant degree of intertextuality with the Essence of the Eight Branches. ${ }^{176}$ Since Yang Ga's proposition that the Secret Essence of Ambrosia was effectively an early draft for the Four Tantras written by Yutok Yönten Gönpo, ${ }^{177}$ a manuscript edition of the Secret Essence of Ambrosia has become available, revealing further details of this complex triangle of texts. ${ }^{178}$

The self-presented provenance of this presumably early manuscript witness of the Secret Essence of Ambrosia is utterly distinct from that which we find in the textus receptus in the Eighteen Partial Branches (cha lag bco brgyad). As is well known, the textus receptus conventionally attributes its instructions to the teachings of Candranandana, ${ }^{179}$ but, as we shall see below, this was most probably a later formulation. Following an opening evocation to the Buddha, God of Medicine, Beryl Light (sangs rgyas sman gyi lha be durya'i 'od) and stanza dedicated to the Unprecedented Physician (sman pa sngon med) that is identical to that which opens the Essence of the Eight Branches, ${ }^{180}$ the Secret Essence of Ambrosia describes the process whence it was derived:

All of medical science has been anthologized in scriptures and treatises.

Regarding medical texts: the Holy [Sutra] of Golden Light,

The Great Tantra of Naked Awareness, ${ }^{181}$

The Medical Collection, ${ }^{182}$ and so forth are scriptures.

There also are treatises that were composed by Outsider [non-Buddhist] and Insider [Buddhist] sages.

${ }^{175}$ This work is usually included as the sixteenth text in the Eighteen Additional Branches. See, for example, Cha lag bco brgyad, 566-776.

${ }^{176}$ See Yang Ga, Sources for the Writing of the Rgyud-bzhi.

${ }^{177}$ For Yang Ga's hypothesis that the Essence of Ambrosia, the Rosary of Jewels (nor bu'i phreng $\mathrm{ba}$ ), and the Familial Instructions (bu don ma) served as drafts for the Four Tantras, see Yang Ga, Sources for the Writing of the Rgyud-bzhi, I03-120, et passim.

${ }^{178}$ This manuscript has many significant discrepancies when compared with the textus receptus of the Essence of Ambrosia found in the Eighteen Partial Branches, totally altering the meaning of the passages cited below, and therefore I have forsaken any attempt to convey the meaning of the textus receptus.

${ }^{179}$ See Yang Ga, Sources for the Writing of the Rgyud-bzhi, II3.

${ }^{180}$ On the Unprecedented Physician, see Meulenbeld,

${ }^{\mathrm{I} 8 \mathrm{I}}$ As far as I know this is a famed, but probably mythical, tantric medical teaching.

${ }^{182}$ As far as I know this is a famed, but probably mythical, Āyurvedic medical teaching. 
According to some systems, the [Compendium] of Caraka, ${ }^{183}$ the Five Discourses, ${ }^{184}$ and so forth,

Are also known as being divided into four parts. ${ }^{185}$

The Essence of Ambrosia in Eight Branches [that is, the Instructional Tantra]

Is like the essence of medical practices.

It is the essence of practices that were further distilled from the essence

By the Tibetan Sage Yutok Gönpo.

After extracting the elixir from the majority [of the Essence of Ambrosia in Eight Branches] with extreme selectiveness,

He composed this Tantra of the Secret Essence of Ambrosia. ${ }^{186}$

He expanded upon the [Essence of the] Eight [Branches], the Yogaśataka, ${ }^{187}$ the Somaräja, ${ }^{188}$ and so forth,

Such that those of inferior intellect might take these as objects of practice.

Because it is difficult for one to see the inconsistencies,

In the structures of the head, limbs, torso, and so forth,

In the Lamp of the Secret Nucleus, ${ }^{189}$ the Pebble Cycle, ${ }^{190}$ and the Illuminating Lamp,${ }^{191}$

${ }^{183}$ This refers to the famed work of Āyurveda, the Compendium of Caraka (carakasaminhitā).

${ }^{184}$ Five discourses ( $m$ do lnga) are often attributed to Nāgārjuna, but authors seem to disagree regarding what, exactly, these five are. For a list of nine discourses, see the Lamp of the Secret Nucleus below.

${ }^{185}$ Bdud rtsi snying po gsang ba man ngag gi rgyud, in Krung go'i bod lugs gso rig rtsa che’i dpe rnying kun btus, vol. 4, text 5, p. I56 (f. 2a): gso rig kun kyang bka' dang bstan bcos gnyis su 'dus//_sman gyi lung dang gser 'od dam pa dang /_cer mthong rig pa'i rgyud sde chen po dang //_gso dpyad 'bum pa la stsogs bka' yin te//_phyi nang drang srong gis mdzad bstan bcos yin//_tsa ra ka dang mdo lnga la stsogs pa'di//_de yang lugs sde gtum [=dum] bzhi ru grags//.

${ }^{186}$ Bdud rtsi snying po gsang ba man ngag gi rgyud, in Krung go'i bod lugs gso rig rtsa che'i dpe rnying kun btus, vol. 4, text 5, p. I56 (f. 2b): gso spyad kun gyi snying po lta bu ni//_bdud rtsi snying po yan lag brgyad pa yin//_bod kyi drang srong g.yu thog mgon po yis//_snying po las kyang snying por dril ba'i spyad//_rab tu ces pa phal che’i spyud [=bcud] phyung nas/_bdud rtsi snying po gsang ba'i rgyud 'di $m d z a d / /$.

${ }^{187}$ I am not entirely sure what the title yu sa pa may refer to, but the Yogaśataka seems like an appropriate possibility. See the One Hundred Formulae (sbyor ba brgya ba) cited above.

${ }^{188}$ This, of course, refers to the famed Medicine of the Moon King (sman dpyad zla ba'i rgyal po).

${ }^{189}$ For a modern reproduction of this work, see the "Gsang tig sgron ma," in Slob dpon klu sgrub kyi sman yig gces btus, Bod kyi gso ba rig pa'i gna' dpe phyogs bsgrigs dpe tshogs vol. 73 (Beijing: Mi rigs dpe skrun khang, 2008), I80-308.

${ }^{190}$ For a modern reproduction of this work, see the Be'u bum nag po, Bod kyi gso ba rig pa'i gna' dpe phyogs bsgrigs dpe tshogs, vol. 34 (Beijing: Mi rigs dpe skrun khang, 2005); wherein the work describes itself variously as the White Pebble (rde'u dkar) cycle, the Black Pebble (rde'u nag) cycle, the Mother and Son Pebble Cycles (rde skor ma bu), and so forth. See Be'u bum nag po, 570. For more on this work, see below. 
These instructions have been eloquently arranged without lacunae, obscurity, or errors. With these instructions one will not have to consult all others. ${ }^{192}$

Despite the fact that this presentation is emphatically scholastic-claiming that all of valid medical knowledge has been anthologized ('dus) in written texts-the author of this opening takes a much more inclusive approach than Chomden Rikpé Reldri and those that solely promote translated works as formative texts. Here our author acknowledges the importance of translated works-distinguishing those that are scriptures $\left(b k a^{\prime}\right)$ from those that are treatises (bstan bcos) authored by Buddhist (nang) and non-Buddhist (phyi) sages (drang srong)—but he places greater emphasis on the summary created by an explicitly Tibetan sage (bod kyi drang srong), Yutok Gönpo. Recognizing that the Essence of Ambrosia in Eight Branches (bdud rtsi snying po yan lag brgyad pa) - that is, an early version of the Four Tantras-is a Tibetan creation involved clear explanations of foreign scriptures and treatises, as well as improved syntheses from mutually contradictory works, our author calls its practical instructions the essence of the essence (snying po las kyang snying por dril ba'i spyad). The Secret Essence of Ambrosia, however, is the elixir (spyud [ =bcud]) extracted from that quintessence, such that one does not have to consult all other works (kun la ltos mi dgos).

It is this last caveat that separates the scholasticism presented by Chomden Rikpé Reldri and that which is presented here in the Secret Essence of Ambrosia. For the proponents of the former, the corpus of formative texts is confined to a select body of static works that were translated from foreign languages. Therefore these texts were to be transmitted as such and any variation of understanding was to come in the form of hermeneutics and summary. The static corpus of translated scriptures and treatises also provided an important source of instructions for the followers of Yutok Gönpo, including the author of the Secret Essence of Ambrosia, but the formative texts of the field of medicine as a whole was much larger and more fluid. As the essence of these translated works was distilled by Tibetan sages, even the essence of Tibetan works could be further distilled and extracted into new formative texts. Indeed, if the Secret Essence of Ambrosia represents the extracted quintessence of the Four Tantras - which, in turn is the essence of the translated scriptures and treatises-why would anyone consult a work other than this?

${ }^{191}$ The Illuminating Lamp (sgron gsal) is an extremely generic title, but probably refers to the Illuminating Lamp: Thirty Instructions (sgron ma gsal ba'i gdams pa sum bcu' pa) attributed to Zhangtön Zijibar. See the Ga las pa sum cu pa cited above.

${ }^{192}$ Bdud rtsi snying po gsang ba man ngag gi rgyud, in Krung go’i bod lugs gso rig rtsa che'i dpe rnying kun btus, vol. 4, text 5, p. I56 (f. 2b): brgyad pa yu sa pa so ma ra tsa sogs//_rgyas par gsungs kyang blo sman [=dman] spyod yul len//_gsang tig sgron ma rde'u skor sgron gsal dang //_go dang yan lag byang khog khrems pa stsogs//_gcig gis chog min btsal'] pa dka' bas//_ma tshang gab 'khrugs med par legs bsdebs pa'i//_gdams pa'di yis kun la ltos mi dgos//.

W. A. McGrath | Buddhism and Medicine in Tibet $\mid 66$ 


\section{The Small Practical Manual}

It is in this milieu of an established essentialist medical scholasticism of the Yutok schools butting heads with the neo-conservative medical scholasticism evoked by Chomden Rikpé Reldri that the Commentary on the Practical Guide for the Five Classes of Medicine (lag len dmar khrid sde tshan Inga'i 'grel pa) or, more commonly, the Commentary on the Small Practical Manual (lag len spod chung gi 'grel pa), arose. ${ }^{193}$ The Commentary on the Small Practical Manual appears to be a composite work, for it has been attributed to Drangti Jampel Zangpo (brang ti 'jam dpal bzang po; ca. 1276-I335), but as both of these cited titles indicate, it is also a commentary on a Small Practical Manual that has been attributed to Yutok Yönten Gönpo. On this subject, the Desi Sanggyé Gyatso (sde srid sangs rgyas rgya mtsho, I653-1705) warns:

Jampel Zangpo composed the Commentary on the Five Classes of Medicine, also known as the Small Practical Manual, which includes measurements for medical formulae in the Subsequent Tantra. This serves as an authoritative source for measurements in medical formulae and is often confused with Yutok's Small Practical Manual. ${ }^{194}$

Indeed, Yutok's Small Practical Manual appears to have been buried in the sands of time, leaving this commentary as the only extant window into his manual. There are at least four discernible parts in the work - a framing narrative clearly attributed to Drangti Jampel Zangpo, a concise set of instructions for diagnosis, a commentary on medical formulae, and a dedication. The framing narrative seems to be a later addition and, regardless of whether Drangti Jampel Zangpo actually penned the narrative or not, we shall refer to it as such. Deep in the instructions on medicinal butter (sman mar), the author of the commentary humbly

${ }^{193}$ This work is presently available in two manuscript witnesses and one modern print editions. For the manuscripts, see Lag len spod chung gyi 'brel [sic] pa, in Krung go'i bod lugs gso rig rtsa che'i dpe rnying kun btus: Pho brang po ta la'i gsung rab gter mdzod las btus [Zhongguo yiyao yingyin guji zhenben 中国藏医药影印古籍珍本; China's Traditional Tibetan Medical Texts: A Treasury of Scriptures from the Potala Palace], ed. Bod ljongs bod lugs gso rig slob grwa chen mo (Lha sa: Bod ljongs mi dmangs dpe skrun khang, 20I4), vol. 3, text 2, pp. 230-56 (ff. Ia40a); and Rgyud rgyal bdud rtsi snying po las lag len dmar khrid sde tshan lnga'i 'grel pa in Krung go'i bod lugs gso rig rtsa che'i dpe rnying kun btus, vol. 8, text 6, pp. 307-25 (ff. Ia-38a). For the modern print edition, see Rgyud rgyal bdud rtsi snying po las lag len dmar khrid sde tshan lnga'i 'grel pa, in Phyi ma rgyud kyi 'grel ba phyogs bsgrigs, Bod kyi gso ba rig pa'i gna' dpe phyogs bsgrigs dpe tshogs vol. 89 (Beijing: Mi rigs dpe skrun khang, 2008), 265-325. I have found the Lag len spod chung manuscript to be the most reliable and will use this as the basis for discussion below. I also cite other editions whenever I find it interesting to do so.

${ }^{194}$ Gso rig sman gyi khog 'bugs, Bod kyi gso ba rig pa'i gna' dpe phyogs bsgrigs dpe tshogs vol. 6 (Beijing: Mi rigs dpe skrun khang, 2005), 212: sde tshan lnga 'grel lam phyi ma rgyud kyi sbyor tshad yod pa lag len pod chung du grags pa tshad ldan sbyor ba rnams kyi khungs su byed cing /_phal che ba g.yu thog lag len pod chung dngos dang 'khrul gzhi yod pa/. Translated in consultation with Mirror of Beryl, 26I-62. 
refers to himself as the Drangti Cripple (bdag brang ti theng po), ${ }^{195}$ further supporting the notion that the author of the commentary was, indeed, Drangti Jampel Zangpo. Regardless, other than the opening narrative frame there is little evidence that Yutok clan was involved with the work and, as we have seen, early narratives like the Indispensable Account of Transmission make no mention of it. The author of the narrative claims to have also outlined the rest of the text, so it probable that the Small Practical Manual represents a composite of several distinct textual layers that were either both authored and redacted by Drangti Jampel Zangpo, or potentially even authored by Jampel Zangpo and redacted and outlined by Drangti Penden Tsojé.

\section{The Account of Transmission}

The Commentary begins with a short overview of its history of transmission, outlining the passage of the Small Practical Manual from Yutok Gyagar Vajra (rgya gar badzra) to his son, Khungpo Dorjé, and finally to the famed Yutok Yönten Gönpo. As we shall see below, this account is parallel to the so-called "familial lineage" (sras brgyud) of the Four Tantras as told by Drangti Penden Tsojé. Importantly, the Commentary is explicit in stating that this is the transmission of these instructions (man ngag 'di'i rgyud [=brgyud] pa), and not the Four Tantras: ${ }^{196}$

During the transmission of the teachings under the authority of the Tri Songdetsen, King of Tibet, ${ }^{197}$ the nine expert doctors of yore were active. In the west, there was Cherjé, Ukpa, and Biji. In the middle, there was Yutok, Drangti, and Minyak. In the east, there was Tong, Tapzhi, and Nya. ${ }^{198}$

Among these [physicians] famous for their work, those named Yutok include the expert exorcist, Yutok Gyagar Vajra. His son was Khyungpo Dorjé, and his son was the Teacher

Gönpo. This master wrote down the medical teachings without exception. In particular, he

${ }^{195}$ Lag len spod chung gyi 'brel [sic] pa, in Krung go'i bod lugs gso rig rtsa che'i dpe rnying kun btus, vol. 3, text 2, p. 252 (f. 35a).

${ }^{196}$ Such is the rendering in Lag len spod chung gyi 'brel [sic] pa, in Krung go'i bod lugs gso rig rtsa che'i dpe rnying kun btus, vol. 3, text 2, p. 230 (f. Ib). Rgyud rgyal bdud rtsi snying po las lag len dmar khrid sde tshan lnga'i 'grel pa in Krung go'i bod lugs gso rig rtsa che’i dpe rnying kun btus, vol. 8, text 6, p. 307 (f. Ia), as well as the modern edition derived from the latter, have the somewhat more ambiguous: man ngag rgyud pa ni... .

${ }^{197}$ Mnga' dar ba'i dus su: this phrase, of course, is homophonous with the "early transmission [of the teachings]" (snga dar). Both editions of Lag len dmar khrid sde tshan lnga (Lhasa manuscript and Beijing print) add the syllable thang: mnga' thang dar ba'i dus su ... .

${ }^{198}$ Lag len spod chung gyi 'brel [sic] pa, in Krung go'i bod lugs gso rig rtsa che'i dpe rnying kun btus, vol. 3, text 2, p. 230 (f. Ib): bla ma dang 'jam pa'i dbyangs la byag 'tshal lo//_man ngag 'di'i rgyud pa ni/_bod kyis rgyal po khri srong lde rtsan mnga' dar ba'i dus su/_lha rje la mnga' [=snga] ba mkhas pa mi dgu bya 'byung ste/_de yang stod na/_cher rje 'ug pa be ci gsum/_bar na g.yu thog dang /_brang ti mi nyag sum/_smad na stong dang /_mtha' bzhi snya dang gsum/. 
composed this small practical manual, which is of few words but great meaning. After growing old, he taught it to his son, Master Bumseng. Although he had many sons, because they were of inferior capacity, [Bumseng] taught [the Small Practical Manual to] Master Jampel. I, Drangti Jampel Zangpo, have received this textual transmission from both the father [Yutok Jampel] and his son Tsojé. In reliance upon that transmission, I have outlined and put this teaching into writing. ${ }^{199}$

We are told that Yönten Gönpo transmitted the Manual to his son Bumseng, who then taught it to his son, Yutok Jampel, who then taught it to his own son, Yutok Tsojé-uncannily parallel names to the father and son duo of Drangti Jampel (Zangpo) and Drangti (Penden) Tsojé. The Small Practical Manual was finally transmitted to Drangti Jampel Zangpo after he went to study with both Yutok Jampel and Yutok Tsojé. Thus the Small Practical Manual is presented as the familial instructions of the Yutok clan that were passed down exclusively within the family until they finally came to Drangti Jampel Zangpo.

Confusingly, this lineage of transmission also aligns with the so-called "familial lineage" (sras brgyud) of the Four Tantras. As we will see in Chapter Four (Figure 4.2.), the "student lineage" (slob brgyud) of the Four Tantras extends from Drapa Ngönshé, who revealed the work as a treasure text, to Üpa Dardrak, Tötön Tsojé Könkyap, and finally Yutok Yönten Gönpo. Thus, before Yutok Yönten Gönpo, the Four Tantras unequivocally derives from outside of the Yutok family lineage. The work then proceeded from Sumtön Yeshé Zung-the redactor of the Essence of Ambrosia in Eight Branches- to Tsojé Zhönnu Yeshé, where it becomes unclear. From there the lineage picks up again with Geshé Gönrin and Paktön Shākya Gönpo before finally coming to Drangti Penden Tsojé himself. Seeming to recreate the transmission of the Small Practical Manual provided above, Penden Tsojé appears to describe the familial transmission of the Four Tantras as beginning with Yutok Gyagar Vajra:

Furthermore, because Yutok Gyagar Vajra had achieved the attainments of the sixty sages, six [sages] came to manifest in reality. They said, "We will bless you and you alone." [Yutok Gyagar Vajra] was the third to receive the blessings of the transmission [of the Four Tantras]. [Yutok Gyagar Vajra] also studied and came to know the majority of scriptures, treatises, transmitted texts, and oral instructions of medicine that were known in Tibet. Of all the expert sages that came to the Land of Snows, he was manifestly blessed by the sages that were famed like the top of the victory banner, and came to know the three times. This

${ }^{199}$ Lag len spod chung gyi 'brel [sic] pa, in Krung go'i bod lugs gso rig rtsa che’i dpe rnying kun btus, vol. 3, text 2, p. 230 (ff. Ib-2a): bya bar grags pa'i nang nas/_g.yu thog zhes grags pai' 'bre [='dre?] rje mkhas pa rgya gar badzra byon/_de'i sras khyung po rdo rje/_de'i sras yon tan mgon byon/_mkhas pa des gso spyad mang du brtsams/_khyad par du tshig'dus la don che ba lag len spod chung bya ba 'di brtsams/_de'i sgres kha'i sras dpon 'bum seng la gnang /_des sras mang du yod pai bcud kyi chung pa slob dpon 'jam dpal la gnang /_de’i sras mtsho byed yab sras gnyis la/_bdag brang ti 'jam dpal bzang pos lung thob po/_lung de la bsten nas/_bdag gis [??] sa bcad dam/_lung grangs 'di yi ger btab po/. 
adept [Yutok Gyagar Vajra] who acted to dispel the pains of beings, commented clearly and methodically upon scriptures and vanquished the arguments of the mistaken and the doubtful. He composed in writing many textual annotations, commentaries, practical instructions, and experiential accounts. ${ }^{200}$

Despite the fact that the Four Tantras is not named explicitly in this passage, it seems to indicate that Yutok Gyagar Vajra miraculously received the transmission of the Four Tantras directly from the six sages. Alternatively, this transmission could refer to another work, like the Small Practical Manual or the Essence of the Eight Branches, for example, ${ }^{201}$ but, again, this is not clear from the passage. The fact that Gyagar Vajra was "third to receive the blessings" (byin gyis rlobs par gsol ba'i gsum pa) is also confusing and may refer to the fact that Üpa Dardrak and Tötön Könkyap received the transmission of the Four Tantras from Drapa Ngönshé before Yutok. Although it is clear that Yutok Gyagar Vajra received blessed teachings from the sages, the nature of those teachings remains ambiguous in this passage, perhaps purposefully so.

Drangti Penden Tsojé does not provide much more detail about Yönten Gönpo's ancestors than this. After describing the merits of Yutok Gyagar Vajra's works, lauding him as an "emanated physician" (sprul pa'i sman pa), he continues the familial and student lineages of the Four Tantras:

Master Yutok Yönten Gönpo had both a familial lineage and a student lineage. Among these lineages, there were those famed for having the complete scriptural lineage, those for having the complete instructional lineage, and those for having both. Furthermore, [after (Yutok) finished training his five sons and (just before he) passed beyond pain, (Yutok) hid the (Four) Tantras, and composed the (Small) Practical Manual and the Experiential Account of Miscellaneous Practices.] ${ }^{202}$ Dza Yeshé Zung, the most faithful and

${ }^{200}$ Rgyud bzhii spyi don shes bya rab gsal rgyas pa (Delhi), IO2: de yang g.yu thog rgya gar badzra gyis/_drang srong drug cu bsgrubs pas drug dngos su byon/_drug kas khyod kho na byin gyis brlab gsungs pas/_brgyud [=brgyad] pa la byin gyis rlobs par gsol ba'i gsum pa yin la/_de yang gso ba rig pa'i bka' bstan bcos lung man ngag bod la grags pa phal mo che gsan nas mkhyen par mdzad pas/_gangs can du byon pa'i drang srong mkhas pa rnams kyi nang nas rgyal mtshan gyi rtse mo ltar grags la/_drang srong gis dngos su byin gyis brlabs pas dus gsum mkhyen cing/_'gro ba'i zug rngu sel bar mdzad pa'i grub thob des/_gzhung lugs gsal zhing rig par 'chad pa dang /_log par rtog pa'i the tshom gyi rgol ba tshar gcod cing /_gzhung mchan bu 'grel bshad/_man ngag phyag len rnams nyams yig tu $\mathrm{mdzad} /$.

${ }^{20 I}$ This is the interpretation of the later tradition, as summarized by Yang Ga, Sources for the Writing of the Rgyud bzhi, 83 et passim.

${ }^{202}$ The bracketed passage here is not included in the Delhi edition of the Expanded Elucidation of Knowledge. It can only be found in an unpublished manuscript held at the Nationalities Cultural Palace Museum (Minzu wenhua gong 民族文化宫) in Beijing. Gsang ba man ngag gis [sic] rgyud kyi spyi don shes bya rab gsal rgyas pa (Beijing Ms), 37a: sras lnga tshar byang zug sde 
committed of [Yutok's] students, is famed for having the complete [Four Tantras together with the Partial Branches]. ${ }^{203}$

And so, with the death of Yutok Yönten Gönpo at the end of the twelfth century, ${ }^{204}$ the only figure that is said to have received all of his teachings is Dza Yeshé Zung, also known as Sumtön Yeshé Zung. Interestingly, a passage that only appears an early manuscript witness of the Expanded Elucidation of Knowledge further stipulates that Yutok hid the Four Tantras and composed the Small Practical Manual (lag len spo ti) and the Experiential Account of Miscellaneous Practices (thor spyad nyams yig) just before his death. This important passage explains the conditions for the creation of two separate familial and student lineages. Before he passed away, Yutok Gönpo wrote the Small Practical Manual and other instructional works-probably prophesying to the Familial Instructions ( $b u$ don $m a$ ) and other such works that are still extant today-for his children, thus creating the familial lineage. Confusingly, he also taught the Four Tantras to Sumtön Yeshé Zung and then hid it from all of his other students, thereby creating the student lineage. This important detail explains the fact that it was only Sumtön Yeshé Zung that received both the complete scriptural lineage (gzhung rdzogs pa) as well as the complete instructional lineage (man ngag rdzogs pa). Importantly, this is the very same "lineage of one" that also came to Drangti Penden Tsojé.

Returning to the familial lineage of the Four Tantras, it is important to note that Yutok Gönpo's supposed son, Yutok Bumseng, as well as his other descendants, Yutok Jampel and Yutok Tsojé, are not mentioned by contemporary documents outside of the Commentary on the Small Practical Manual and the Expanded Elucidation of Knowledge (which, admittedly, are not contemporary). Sumtön Yeshé Zung describes in the Indispensable Account of Transmission the fact that Yutok had two sons and two sons-in-law, but provides no further details regarding their identities. This lack of identification is, perhaps, unsurprising because no works have been attributed to any of these figures, but if we are to accept this familial lineage, we would have to greatly modify our chronology of events. If Yutok was active during the twelfth century, Yutok Bumseng would have been born by the end of the twelfth century, with Yutok Jampel having been born twenty or thirty years after. He would have had to live approximately one hundred years for him to have taught Drangti Jampel Zangpo in the late thirteenth century. This is not impossible, however, and perhaps Yutok Gönpo flourished

'das/_rgyud sbas shing lag len spo ti dang thor spyad nyams yig tu grags pa rnams mdzad/_rgyud bzhi cha lag dang bcas pa'di nyid/.

${ }^{203}$ Rgyud bzhi'i spyi don shes bya rab gsal rgyas pa (Delhi), I02: g.yu thog mkhas pa yon tan mgon po la/_sras brgyud slob brgyud gnyis byung zhing /_de la gzhung rdzogs pa/_man ngag rdzogs pa/_gnyis ka rdzogs pa dang gsum du grags la/_de yang [sras lnga tshar byang zug sde 'das/_rgyud sbas shing lag len spo ti dang thor spyad nyams yig tu grags pa rnams mdzad/_rgyud bzhi cha lag dang bcas pa 'di nyid/_sslob ma'i nang nas dad gus dam tshig dang ldan pa'i mchog rdza ye shes gzungs la gzhungs rdzogs par grags te/.

${ }^{204}$ For an analysis of the dates of Yutok Yönten Gönpo, see Yang Ga, Sources for the Writing of the Rgyud bzhi, 97-99. 
during the thirteenth century, for his dates are far from clear. More chronological issues arise, however, with Penden Tsojé's description of the familial lineage:

Yutok Gönpo, coming to old age, transmitted blessings, the evocation ritual of the water goddess, and other such special instructions to his son, Bumseng. Thus, he came to have the full transmission of the instructions. [Yutok Gönpo] also explained the scriptures to Shakrampa Belmen Nyimapel of Nyemo. Because [Shakrampa] was taught the complete set of profound practical instructions, he was the great son [?] with the complete teachings for both oral and textual instructions. He created something like the institutional seat of Yutok Gönpo and, evoking the water goddess, he entrusted the sealed teachings of the master to Yutok Bumseng. Because [Shakrampa] became a supreme master, he acted as the royal physician for Kublai Khan. ${ }^{205}$

In the valley of Lharidro [Kublai Khan] sent an ordinance appointing [Shakrampa] to the rank of dargen. [Shakrampa] created many temples and stupas, copied many scriptures, and composed many medical commentaries, anthologies, and thousand session tutorials. By examining the channels and fluids of a patient, [Shakrampa] was able to know their lifespan within seven years, as well as things like their virtuous and polluting actions. With his attainments in alchemy, he performed lectures and made extensive contributions for the sake of beings until the age of fifty-five [or ninety-five?]. ${ }^{206}$

Teaching with devotion for his masters, the father Yutok Gönpo and the son [Bumseng], [Shakrampa] came to be responsible for the entire education of Bumseng. Shakrampa also bestowed [instructions] upon Bumseng's son, Jampel. [Jampel] came to be a supreme expert in the Four Tantras, the root text and commentary of the [Essence of the] Eight

${ }^{205}$ Gsang ba man ngag gis [sic] rgyud kyi spyi don shes bya rab gsal rgyas pa (Beijing Ms), 38b: g.yu thog mgon po bgres kha'i sras/_bum seng la byin rlabs dang chu'i lha mo'i sgrub thabs la sogs khyad par gyi man ngag rnams gnang bas/_man ngag rdzogs pa yin zhing/_snye mo shag ram pa 'bal sman nyi ma dpal la gzhung bshad/_phyag len zab don lhag yongs su rdzogs par gnang bas gzhung gdams pa gnyis char rdzogs pa'i bu chen yin la/_g.yu thog mgon po'i gdan sa lta bu mdzad cing /_chu'i lha mo'i grub pa/_slob dpon gyi bka' rgya ltar g.yu thog 'bum seng la gtad cing /_mkhas pa'i mchog tu gyur pas/_bse chen gyi bla sman mdzad/.

${ }^{206}$ Gsang ba man ngag gis [sic] rgyud kyi spyi don shes bya rab gsal rgyas pa (Beijing Ms), 38b: lha ri sgro'i lung pa la dar rgan gyi 'ja'sa gnang /_gtsug lag khang dang rten gsung rab mang du bzhengs shing /_sman dpyad kyi 'grel pa gces bsdus stong mthun [=thun] yig cha mang du mdzad/_rtsa chu gzigs pa'i mi rnams kyis tshe’i tshad lo bdun tshun chad kyi dge sdig ji lta ba bzhin mkhyen cing /_bcud len grub pas dgung lo lnga bcu rtsa lnga'i bar du/_'chad nyan dang 'gro don rgya cher mdzad de/. Rgyud bzhi'i spyi don shes bya rab gsal rgyas pa (Delhi), I08, indicates that Shakrampa lived for ninety-five years instead of fifty-five. 
[Branches] treatise, as well as the practices of his ancestors. [Yutok Jampel] bestowed [these instructions] upon Drangti Jampel Zangpo. ${ }^{207}$

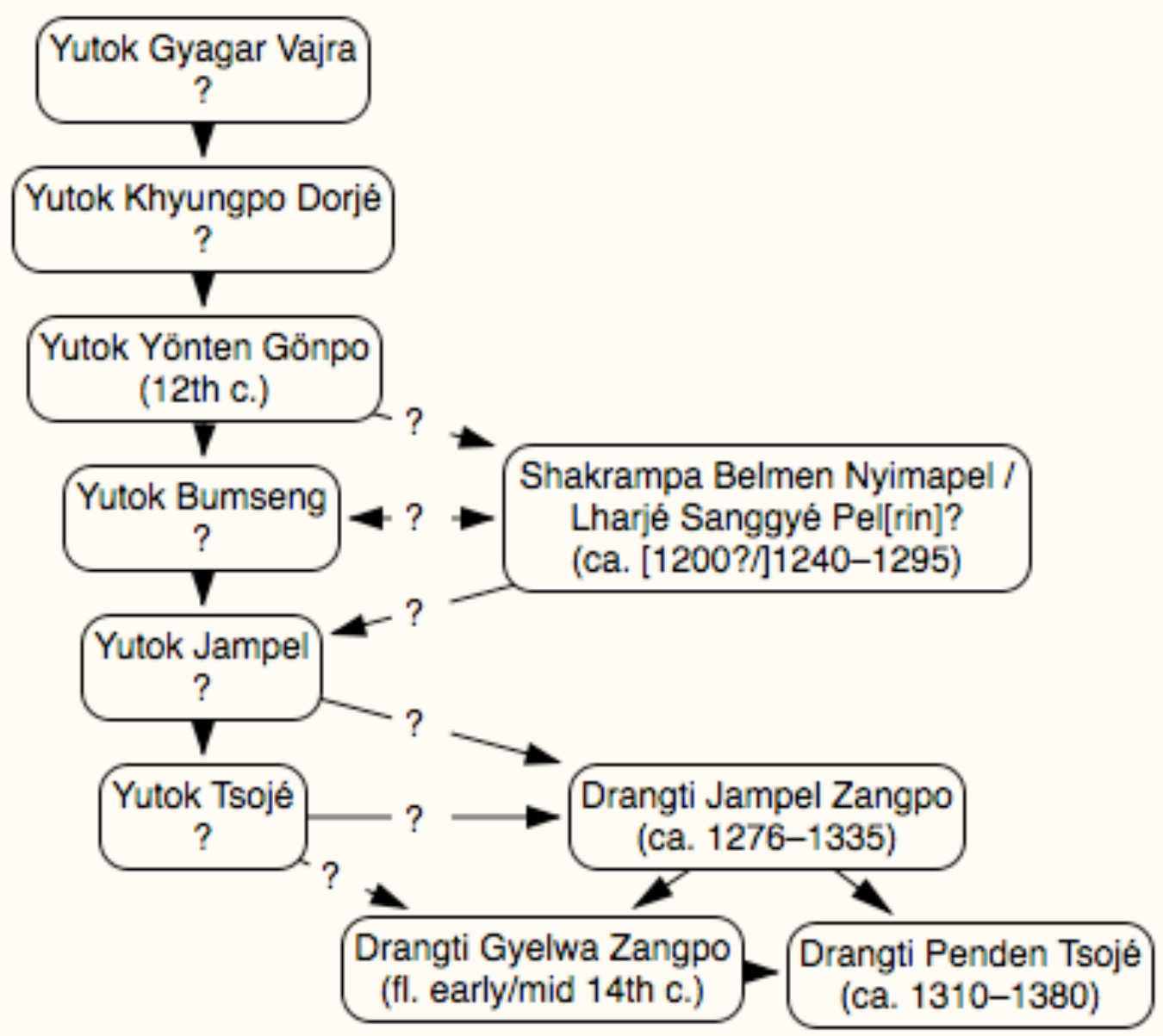

Figure 2.I. A Confused Familial Lineage from the Expanded Elucidation of Knowledge

As we will see in Chapter Four, Shakrampa Belmen Nyimapel-who we may or may not be able to identify as Lharjé Sanggyé Pelrin from an extant ordinance issued by Kublai Khan and the colophon of Thousand Session Tutorial (stong thun) manuscripts-is identified by Drangti Penden Tsojé as being the royal physician (bla sman) for Kublai Khan (I215-I294; r. I260-I294). An early manuscript witness of the Expanded Elucidation of Knowledge lists that Shakrampa lived for fifty-five years, but this was later emended to ninety-five years, perhaps to account for the chronological inconsistencies that I am currently addressing. Indeed, how could a life

${ }^{207}$ Gsang ba man ngag gis [sic] rgyud kyi spyi don shes bya rab gsal rgyas pa (Beijing Ms), 38b-39a: slob dpon la mos pas g.yu thog mgon po yab sras kyi zhabs spyi bos len pa gsungs pa mdzad kyang/_bum seng gi slob sbyong thams cad mdzad pa yin no/_shag ram pa 'bum seng gi sras ’jam dpal la gnang /_de yang rgyud bzhi bstan bcos brgyad pa rtsa 'grel dang bcas pa dang /_yab mes kyi phyag len rnams la mkhas pa’i mchog tu gyur pa yin no/_des brang ti ’jam dpal bzang po la gnang/. 
of fifty-five years overlaps with the lives of Yutok Gönpo (I2 ${ }^{\text {th }}$ c.), Yutok Bumseng, and Yutok Jampel, the latter being the teacher of Drangti Jampel Zangpo (ca. I276-I335)? As indicated previously, the chronology of the Yutok clan presented in the Expanded Elucidation of Knowledge-along with the historical veracity of Yutok Bumseng, Yutok Jampel, and Yutok Tsojé themselves-is highly suspect. This, compounded with the fact that each of the members of the Drangti clan had teachers that do not fall in the Yutok lineage (Figure I.I.), or the lineage of otherwise unattested Yutok scions ending with Geshé Gönrin (Figure I.3.), causes me to suspect that there was no such familial lineage of the Four Tantras. Perhaps evidence from works that were not composed or edited by Drangti Penden Tsojé from the twelfth and thirteenth centuries might serve to clarify the chronologically obscure segment separating Yutok Yönten Gönpo and Sumtön Yeshé Zung from Drangti Jampel Zangpo and Drangti Penden Tsojé.

\section{Diagnostics in the Small Practical Manual}

Drangti Penden Tsojé, in addition to describing a Practical Manual (lag len spo ti) that was hidden by Yutok Gönpo's children after his death, ${ }^{208}$ also lists a Practical Manual by Yutok Gönpo (g.yu thog mgon pos mdzad pa'i lag len pu ti) under "scriptures that were indisputably composed by people that undoubtedly hail from the Snowy Land of Tibet." both of these references to the Practical Manual are only found in the manuscript witness of the Expanded Elucidation of Knowledge held at the Nationalities Palace Museum in Beijing. In later editions both of these instances have been changed to the Familial Instructions (bu don ma). Therefore, despite the language that the composition was indisputably (rtsod med) composed by Yutok Gönpo, who undoubtedly (tshad mar gyur pa) hailed from Tibet, it is less clear what the composition actually was.

The commentary attributed to Jampel Zangpo, according to the admonition of Desi Sanggyé Gyatso, should not be confused with the Small Practical Manual attributed to Yutok Yönten Gönpo. As we have seen, the Desi also informs us that the latter was associated with measurements for medical formulae (sbyor tshad) that are also found in the "Five Classes of Medicine" (sde tshan lnga) section of the Subsequent Tantra of the Four Tantras. In line with the Desi's assessment, and due to the lack of this original Small Practical Manual, the Commentary on the Small Practical Manual has been generally treated as a commentary on the Subsequent

${ }^{208}$ Again, this is only in the Beijing Nationalities Palace Museum edition (37a) and not the others.

${ }^{209}$ Rgyud bzhi'i spyi don shes bya rab gsal rgyas pa (Delhi), 72: bod gangs can du tshad mar gyur pa'i skyes bu rnams kyis rtsod med kyi gzhungs ji ltar mdzad pa'i rnam dbye mdo tsam mo/. Note that the Delhi edition lists the Practical Instructions for My Sons (lag len bu don), while the Beijing manuscript lists the Practical Manual (lag len pu ti; see f. 26b). 
Tantra. ${ }^{210}$ This is understandable, because the outline of the text-for which, the careful reader may recall, the author of the account of transmission, Drangti Jampel Zangpo, claims credit-is nearly identical to that of the Subsequent Tantra.

The Subsequent Tantra is composed of twenty-seven chapters, but also four discourses (mdo): the "Discourse on the Examination of the Channels and Urine" (brtag pa rtsa chu'i $m d o),{ }^{211}$ the "Discourse on Pacifying Medications" (zhi byed sman gyi mdo), ${ }^{212}$ the "Discourse on Cleansing Activities" (sbyong byed las kyi mdo), ${ }^{213}$ and the "Discourse on Gentle and Harsh Practices" ('jam rtsub dpyad kyi mdo). ${ }^{214}$ These four discourses account for twenty-five of the twenty-seven chapters of the Subsequent Tantra, with the "Summary" (don bsdus pa) and the "Complete Entrustment" (yongs su gtad pa) constituting the final two chapters. ${ }^{215}$ The organization of the Small Practical Manual is less clear, however. Following the account of transmission seen above, we are told:

This Small Manual of the Guardian [Gön] of the Yutokpa has three topics of explanation:

I. Diagnosis of disease according to the channels, urine, tongue, blood, and so forth.

2. Pacifying and Invasive Cleansing therapies.

3. Therapies that prevent the recurrence of disease, and the dedication of merit. ${ }^{216}$

Again we are told that this is the Small Manual of Yutok Gönpo (g.yu thog pa'i mgon spod chung 'di), and that the explanation has three topics ('chad pa la don gsum). Therefore, according to this opening presentation, the Small Manual is a teaching by Yutok Gönpo that was explained in three parts. Although the second part is clearly a commentary, the section on diagnosis appears to be an original synthesis. Regardless, it does begin with a few remarks positioning the work in terms of scholastic precedents:

${ }^{210}$ See, for example, its inclusion in the Anthology of Commentaries on the Subsequent Tantra (phyi ma rgyud kyi 'grel ba phyogs bsgrigs) cited above.

2II This discourse corresponds to chapters one and two of the Subsequent Tantra. For an overview, see Yang Ga, Sources for the Writing of the Rgyud-bzhi, 242-46.

${ }^{212}$ This discourse corresponds to chapters three through twelve of the Subsequent Tantra. For an overview, see Yang Ga, Sources for the Writing of the Rgyud-bzhi, 246-5I.

${ }^{213}$ This discourse corresponds to chapters thirteenth through nineteen of the Subsequent Tantra. For an overview, see Yang Ga, Sources for the Writing of the Rgyud-bzhi, 252-56.

${ }^{214}$ This discourse corresponds to chapters twenty through twenty-five of the Subsequent Tantra. For an overview, see Yang Ga, Sources for the Writing of the Rgyud-bzhi, 256-6I.

${ }^{215}$ For an overview of these two chapters, see Yang Ga, Sources for the Writing of the Rgyud-bzhi, 26I-64.

${ }^{216}$ Lag len spod chung gyi 'brel [sic] pa, in Krung go'i bod lugs gso rig rtsa che'i dpe rnying kun btus, vol. 3, text 2, p. 230 (f. 2a): g.yu thog pa'i mgon spod chung 'di 'chad pa la don gsum tel_dang po rtsa chu lce khrag las sogs pa/_rnam kyi nad kyi ngos bzung ba dang gcig/_bar du zhi sbyang gcad kyi bcos pa dang gnyis/_tha ma bcos pa phyir mi ldog cing dge ba'i rtsa ba sngo ba'o/. 
One should not think of medical formulae before diagnosing the disease, just as one must recognize the target when sheeting an arrow. As stated in the [Compendium of] Caraka: ${ }^{217}$

First, one must examine the disease,

And only then should one take action.

Otherwise, even if one knows what to do,

One will only manage to damage one's own reputation. ${ }^{218}$

And as Master Nāgārjuna once taught:

If even after examining the channels and urine, one does still not understand [a patient's condition] well,

Revealing the mode of regression through surgical techniques

Is like jackals and wolves ambushing goats and sheep. ${ }^{219}$

And so forth. It has been frequently taught that the initial diagnosis of disease is extremely important. Furthermore, from the interlocution of Master [Kyebu Melha]:

With regard to that which is manifested in the channels, the urine, stools, vomit, mucus, blood, and so forth,

One should inquire about the [character of their] heat and cold alone. ${ }^{220}$

${ }^{217}$ Lag len spod chung gyi 'brel [sic] pa, in Krung go'i bod lugs gso rig rtsa che'i dpe rnying kun btus, vol. 3, text 2, p. 230 (f. 2a): nad ngos ma zin par sman sbyar du mi 'dod te/_dper na mda' 'phen pa la 'ben ngos zin dgos pa dang'dra ste/_de yang a rtsa ra ka las/.

${ }^{218}$ Lag len spod chung gyi 'brel [sic] pa, in Krung go'i bod lugs gso rig rtsa che'i dpe rnying kun btus, vol. 3, text 2, p. 230 (f. 2a): dang po 'di ltar nad brtags la//_de nas las ni brtsam bya zhing //_gzhan du rang don rig pa ni//_grags pa nyams pa nyid thob 'gyur//. Compare with the same quotation found in Candranandana's Moonbeams (zla zer) commentary on the Essence of the Eight Branches, Yan lag brgyad pa'i snying po'i rnam par'grel pa'i tshig gi don gyi zla zer, in Bstan 'gyur dpe bsdur ma, ed. Krung go'i bod rig pa zhib 'jug ste gnas kyi bka' bstan dpe sdur khang (Beijing: Krung go'i bod rig pa dpe skrun khang, 2004), gso rig, vol. II3 (ko [2I5]), text 3149, p. 45: de yang gzhung las/_dang por'di ltar nad brtags la//_de nas las ni brtsam bya yi//_gzhan du rang don rig pa dang //_grags pa nyams pa nyid thob 'gyur//.

${ }^{219}$ Lag len spod chung gyi 'brel [sic] pa, in Krung go'i bod lugs gso rig rtsa che'i dpe rnying kun btus, vol. 3, text 2, p. 230 (f. 2a): slob dpon klu sgrub kyis/_rtsa chu nad brtags legs par mi shes pa'i//rtsags spyad thogs nas 'gyings pa'i tshul ston pal/_'phar spyang ra dang lug la 'jab pa 'dra//. I am confident that this quote does not appear in the Tengyur works attributed to Nāgārjuna, but I have been unable to locate this quote in other sources.

${ }^{220}$ Lag len spod chung gyi 'brel [sic] pa, in Krung go'i bod lugs gso rig rtsa che'i dpe rnying kun btus, vol. 3, text 2, p. 230 (f. 2a): [ces] bya ba dang mang du gsungs pas/_thog mar nad rtags gal che/_de yang a rtsa ra'i zhus lan las/_[rtsa chu 'khru skyug lud pa khrag la sogs/_dngos su bston pa rnams la tsha grang dris gcig bu/_ces pa dang /]. The bracketed quotation does not appear in the Rgyud rgyal bdud rtsi snying po las lag len dmar khrid sde tshan lnga'i 'grel pa manuscript witness. 
As stated in the [Essence of the] Eight [Branches]:

A complete examination involves: visually examining a patient, Haptically examining a patient, and questioning a patient. ${ }^{22 I}$

And as stated in the Stainless Radiance:

The fluids, the eyes, the tongue, and blood,

Such are the objects of knowledge derived from vision.

The channels, the chest, the genitals, and so forth,

Such are the objects of knowledge derived from practice.

Questions, conditions, and the basis of the disease,

Such are the sounds of knowledge derived from hearing. ${ }^{222}$

This passage containing four consecutive quotations scholastically orients the Small Practical Manual. The first citation from the Compendium of Caraka can also be found in the Moonbeams commentary on the Essence of the Eight Branches, which must be where Jampel Zangpo draws the quote, for the Compendium of Caraka is cited throughout Sanskrit-language Āyurvedic treatises, but was not translated until the twenty-first century. ${ }^{223}$ Regrettably I have been unable to locate the Nāgārjuna quotation, but the mention of channel and urine diagnosis indicates that it does not derive from his Tengyur works. The third quote I have been able to find in the so-called Black Calf's Nipple (be'u bum nag po) attributed to the Master Kyebu Melha

Compare with an expanded quotation in the Be'u bum nag po, 571: nad gzhi khong par yod pa yil/_rtsa chu 'khru skyugs lud pa khrag/_rang gsang bu gur [=gar] 'byung ba yin//_dngos po de las nad ngos brtag/.

${ }^{221}$ Lag len spod chung gyi 'brel [sic] pa, in Krung go'i bod lugs gso rig rtsa che'i dpe rnying kun btus, vol. 3, text 2, p. 230 (f. 2a): brgyad pa las/_nad pa lta dang reg pa ltal_gris [=dris] pa yis ni yongs su brtag/_ces pa dang /. Compare with the Yan lag brgyad pa'i snying po bsdus pa, in Bstan 'gyur dpe sdur ma (Beijing: Krung go'i bod rig pa dpe skrun khang, 2004), text 3547, vol. III (he [2I3]), p. I45: nad pa blta dang reg pa dang //_dris pa yis ni yongs su brtag//.

${ }^{222}$ Lag len spod chung gyi 'brel [sic] pa, in Krung go'i bod lugs gso rig rtsa che'i dpe rnying kun btus, vol. 3, text 2, pp. 230-3I (ff. 2a-2b): dri med gzi brjid las/_chu dang mig dang lce dang khrag/_di ni mthong ba lus reg [=yul rig?] yin/_rtsa dang brang dang gsang las sogs/_di ni spyod pa lus rig [=yul rig?] yin/_dri ba rkyen dang nad kyi bzhi [=gzhi]/_di ni thos pa sgra rig yin/_zhes bshad pas/. Compare with the Gzhung dri med gzi brjid kyi 'grel ba nyi ma'i 'od zer, 5I: ngos 'dzin khyad par bstan pa la gsum ste/_mthong ba yul gyi khyad par/_thos pa sgra’i khyad par dang /_reg pa nyams myong gi khyad par dang gsum mo//. Clearly these are distinct but related passages.

${ }^{223}$ See Lobsang Tenzin and Losang Norbu Shastri, trans., Drang srong chen po me bzhin 'jug gis mdzad pa'i tsa ra ka'i bsdu ba [Caraka-saṃhitā of Maharṣi Agniveśa] (Varanasi: Central Institute of Higher Tibetan Studies, 2006). 
(a tsa rya skyes bu me lha) of Oḍ̣iyāna mentioned by Chomden Rikpé Reldri above. ${ }^{224}$ The final citation approximately aligns with a passage found in the Commentary on the Stainless Radiance attributed to Zhangtön Zijibar described above. Thus, Drangti Jampel Zangpo presents his approach to medicine as ecumenical and scholastic.

Drangti Jampel Zangpo also appears to align himself with the author of the Secret Essence of Ambrosia. The authors of each of these four quotations cited here in the Small Practical Manual-Caraka, non-canonical Nāgārjuna, Kyebu Melha, and Zhangtön Zijibar-are also described in the Secret Essence of Ambrosia. This is not to suggest identical authorship, but rather a shared scholastic lineage in which the Secret Essence of Ambrosia most probably predates the Small Practical Manual. The latter continues with a list of all possible objects (yul) for observational diagnosis:

[the patient's] channels (rtsa), urine (chu), eyes (mig), tongue (lce), blood (khrag), mucous (lud pa), excrement ('khru ba), vomit (skyug pa), shape (dbyibs), hue (kha dog), body hair (ba spu), tumors (skrangs), pus (nag [=rnag?]), wounds (rma), bones (rus pa), body heat (lus grod [=drod]), genitals (gsang sgo), swelling (skran), dropsy (dmu chu), the emergence of pox [?] (rde 'u chag pa 'thon pa), evidence for the causes and conditions [of disease] (rgyu rkyen 'phrod mi 'phrod), the temporal extent of the disease (nad yun), [the patient's] bodily strength (lus stobs), diet (lto), warmth (me grod [=drod]), hygiene [?] (dang ka [=dwangs ma?]), degree of thirst (skom dad), sleep (gnyid), and pain (gzer). ${ }^{225}$

This list exceeds any comparable list for objects of diagnosis that I have ever seen in a Tibetan-language medical text. Interestingly, regarding the examination of the first two objects - that of the channels and urine, the only two modes of diagnosis given a complete chapter in the Subsequent Tantra-Jampel Zangpo directs his readers to consult the Thousand Session Tutorials (bstong [=stong] thun), the textus receptus of which can be found in the Eighteen Partial Branches. ${ }^{226}$ The choice of directing curious readers to the Thousand Session Tutorials

${ }^{224}$ As noted above, the Black Calf's Nipple is alternatively called the Pebble Cycle (rde'u skor). For a description of the "calf's nipple" (be'u bum) genre, see Bryan Cuevas, "The 'Calf's Nipple' (Be'u bum) of Ju Mipam ('Ju Mi pham): A Handbook of Tibetan Ritual Magic," in Tibetan Ritual, ed. José I. Cabezón (Oxford: Oxford University Press, 20I0), I65-86. His mention of related oral instructions entitled lde'u may explain the somewhat idiosyncratic appellation of the Pebble Cycle (rde’u).

${ }^{225}$ Lag len spod chung gyi 'brel [sic] pa, in Krung go'i bod lugs gso rig rtsa che'i dpe rnying kun btus, vol. 3, text 2, p. 23I (f. 2b).

${ }^{226}$ Lag len spod chung gyi 'brel [sic] pa, in Krung go'i bod lugs gso rig rtsa che'i dpe rnying kun btus, vol. 3, text 2, p. 23I (f. 2b): rtsa chu gnyis bstong [=stong] thun du gsal lo/. For the received editions of the Thousand Session Tutorial of Channel Examination (rtsa'i stong thun) and Thousand Session Tutorial of Urinalysis (chu'i stong thun), see the Eleven Thousand Session Tutorials (stong thun bcu gcig) found in the Eighteen Partial Branches collection: Cha lag bco brgyad, Bod kyi gso ba rig pa'i gna' dpe phyogs bsgrigs dpe tshogs vol. 25 (Beijing: Mi rigs dpe skrun khang, 2005), 243-5I, and 
instead of the Subsequent Tantra is certainly surprising if Jampel Zangpo did indeed have access to the textus receptus of the Four Tantras. He goes on to provide details for the examination of each other object, continuing to quote Indian sources and displaying expertise in Tibetan medical scholasticism. ${ }^{227}$ Thus, this opening section on diagnosis is practically organized according to different techniques that might prove useful for the practicing physician, along with scholastic supporting quotations.

\section{The Five Classifications of Medicine}

The middle section (bar) of the Small Practical Manual consists of instructions for the concoction of specific formulae. Unlike the practical descriptions of different methods for diagnosis, this middle section takes on the format of a commentary in which each word or phrase is described at some length. Confusingly, the middle section of the Small Practical Manual also has its own opening section (klad kyi don) cum commentary, further indicating that the opening narrative and diagnostic sections were redacted together with this commentary at a later stage of editing:

[1. The Transmission of the Small Practical Manual]

[2. Diagnostics]

3. The Practices of Pacifying and Cleansing Therapeutics

3.I. Pacifying Therapeutics

3.I.I. The Opening Section

3.I.I.I. The Homage

3.I.I.I.I. The Object

3.I.I.I.2. The Individuals

3.I.I.I.3. The Method

3.I.I.I.4. The Necessity

3.I.I.2. The Commitments for Explanation and the Abandonment of Fabrication 3.I.2. The Main Text

[The Abridged Explanation]

3.I.2.I. Concoctions

3.I.2.2. Powders

25I-55, respectively. For separate manuscript witnesses of these works, see: Skor tshoms stong thun bcu gcig las dang po rtsa'i stong thun, in in Krung go'i bod lugs gso rig rtsa che'i dpe rnying kun btus, vol. 03, text 05; Rtsa chu'i stong thun g.yu thog gi bzhed pa, vol. 03, text 07; and Skor tshoms stong thun bcu gcig, vol. I4, text 03.

${ }^{227}$ Only the Lag len spod chung gyi 'brel [sic] pa manuscript provides this complete overview of diagnosis. The fourth folio of the Rgyud rgyal bdud rtsi snying po las lag len dmar khrid sde tshan lnga'i 'grel pa manuscript is missing (p. 308) and the corresponding section, of course, is missing from the modern reproduction (p. 27I). This evidence, in combination with their identical titles, demonstrates that the Arura reproduction derives from this very manuscript. 


\subsubsection{Pills}

\section{I.2.4. Ointments}

3.I.2.5. Medicinal Butter

[The Expanded Explanation]

3.I.2.6. Medicinal Alcohol

3.I.2.7. Khaṇda Treacle

3.I.2.8. Medicinal Ashes ${ }^{228}$

3.I.3. The Closing Section

3.2. Cleansing Therapeutics

3.3. Ordinary Practices for Pacifying and Cleansing Therapeutics

3.4. Instructions for the Extent of a Therapeutic Session ${ }^{229}$

Although this outline indicates sections for both "Pacifying Therapeutics" (zhi bas bcos pa) and "Cleansing Therapeutics" (sbyangs pas bcos pa) and other elaborations, the actual content of the work closely follows the "Closing Section" (rjes kyis don). Thus the original text of the Small Practical Manual - which is no longer extant-probably included further sections that are outlined here but were not ultimately included in the commentary.

It is in this outline that we see some of the earliest quotations from the Subsequent Tantra in Tibetan medical literature. For example, when listing the five classifications of pacifying therapeutics (zhi byed sde tshan lnga), Drangti cites, "furthermore, as stated in the tantras, 'there are not any [pacifying materia medica] that are not included in the five classifications."'230 In the third chapter of the Subsequent Tantra, Sage Rikpé Yeshé teaches Sage Yilekyé:

Antidotes that can be manually performed include materia medica and external surgeries. Regarding materia medica, there are those that are pacifying and those that are cleansing. Regarding pacifying [materia medica], there are concoctions, powders, pills, ointments, and medicinal butters. They are generally known as the five classifications [of medicine].

${ }^{228}$ Lag len spod chung gyi 'brel [sic] pa, in Krung go'i bod lugs gso rig rtsa che'i dpe rnying kun btus, vol. 3, text 2, pp. 232-33 (ff. 5a-b): gzhung don gnyis las/_mdor bstan dang rgyas bshad do//_dang po ni zhi byed sde tshan lnga yin te ces pas sbyang ba ma yin pa lnga/_thang /_phye ma/_ril bu/_de [=lde] gu sman mar dang lnga'o/_de yang rgyud las/_sde tshan lnga ru ma 'dus gang yang med//_ces pa'o/_rgyas bshad la brgyad/_thang /_phye ma/_ril bu/_de gu/_sman mar/_sman chang/_khan dhal_thal smano//.

${ }^{229}$ Lag len spod chung gyi 'brel [sic] pa, in Krung go'i bod lugs gso rig rtsa che'i dpe rnying kun btus, vol. 3, text 2, p. 232 (f. 4b): da bar du zhi sbyangs spyad [=dpyad] kyi sgo nas bcos pa la bzhi ste/_zhi bas bcos pa dang [gcig]/_sbyangs pas bcos pa dang [gnyis]/_zhi sbyangs thun mong gis spyad kyis bcos pa dang [gsum]/_thun tshad kyi gdams ngag gis bcos pa dang bzhi'o/_de la dang po zhi bas bcos pa la gsum stel_klad kyi don/_gzhung gi don/_rjes kyis dono/_klad don la gnyis phyag brtsal [='tshal] ba dang /_bshad par dam bca' zhing rang so [=bzo] spang bso [=ba'o]/_dang po la bzhi ste/_yul dang gang zag dang /_tshul dang /_dgos pa'o/.

${ }^{230}$ de yang rgyud las/_sde tshan Inga ru ma 'dus gang yang med//_ces pa'o/.

W. A. McGrath | Buddhism and Medicine in Tibet | 80 
Including medicinal ashes, khanda treacle, and medicinal alcohol, however, there are eight classifications of pacifying formulae. Including the precious pacifying [medicines] that prevent the recurrence [of disease], there are nine. Including the herbal formulae that [pacify disease] as soon as it is encountered, there are ten. Regardless, there are no [pacifying materia medica] that are not included in the five classifications. ${ }^{231}$

The five preliminary actions for cleansing include oil therapeutics, purgatives, emetics, nasal medications, light suppositories, strong niruha suppositories. Including the prevention of recurrence and channel cleansing, there are seven. The five external surgeries are phlebotomy, cauterization, bathing, compresses, and massage. Including the practice of invasive surgery for the prevention of recurrence, there are six. ${ }^{232}$

In general, there is a total of twenty-three expanded explanations [for pacifying and cleansing therapeutics]. These eighteen practices that have been included in sutra sections are our weapons against the gathered enemy hordes of disease. ${ }^{233}$

Other than the switching of "medicinal alcohol" and "medicinal ashes" in these lists of pacifying therapeutics, these two lists are nearly identical. More importantly, with the exception of the intensifier "not any" (gang yang) found in the Practical Manual, this quotation is identical as well. Jampel Zangpo was clearly consulting the Subsequent Tantra when he composed this outline for the Small Practical Manual commentary.

I emphasize the congruence of the outline provided here and the outline of the Subsequent Tantra because this is the only similarity between the two works. Despite the clear connection between the pacifying therapeutics of the Practical Manual and Chapters Three through Nineteen of the Four Tantras - not to mention the general correlation between the diagnostics section and Chapters One and Two, as well as the presumed similarity of the "Cleansing Therapeutics" and Chapters Twenty through Twenty-Five-the "Opening Section" of the Small Practical Manual shows no relationship with the narrative frame of the Four Tantras. While the very first chapter of the Four Tantras begins with an homage to the Buddha, Master of Medicine, King of Beryl Light (sangs rgyas sman gyi bla bai dürya 'od kyi rgyal po) and all subsequent chapters are narrated within the frame of an interlocution between the emanated sages Rikpé Yeshé and Yilekyé, there is no mention of such passages in the Small Practical

${ }^{231}$ lag tu blang ba'i gnyen po sman dpyad gnyis//_sman la zhi sbyang gnyis te zhi byed la//_thang phye ril bu lde gu sman mar lnga//_sde tshan lnga zhes spyi ru grags pa yin//_on kyang thal sman khanḍa sman chang gsum//_sde tshan brgyad kyis zhi byed sbyor ba bstan//_zhi byed log gnon rin po che dang dgu//_blo bur thug phrad sngo sbyor sde dang bcu//_de yang sde tshan lnga ru ma'dus med//.

${ }^{232}$ sbyong byed las lnga'i sngon 'gro snum 'chos dang //_bshal skyug sna sman 'jam rtsi ni ru hal/_sbyongs kyi log gnon rtsa nas sbyang dang bdun//_dpyad la gtar bsreg dugs lums byug pa lnga//_de yi log gnon thur ma’i dpyad dang drug/. 
Manual. Indeed the homage in the mysterious root text of the Small Practical Manual is dedicated to "Mañjunātha, Nāgārjuna, and Vāgbhața," about which Jampel Zangpo writes:

"Mañjunātha—the Soft Protector": refers to Mañjughośa-Soft Speech. ["Soft":] his body is soft because he appears as a youth of sixteen years, with a hue like that of gold that is pleasing to the mind. Thus his body is soft. His speech is soft because he is endowed with the sixty branches of melodious speech, such that whenever anyone hears it they are pleased. Thus his speech is soft. His mind is soft because he does not have the stains of afflictive emotions and his intention is to help beings. Thus his mind is soft. "Protector": he is the protector and refuge of beings. "Nāgārjuna" refers to Master Nāgārjuna, and "Vāgbhața" refers to the Glorious Master Vāgbhața. ${ }^{234}$

The object (3.I.I.I.I.) is that which an individual (3.I.I.I.2.) seeks. As Yutok Gönpo once said, "[The object] is that which one brings into being after the present." The method (3.I.I.I.3.) is "with the three gates, sincerely": with the five limbs bent low for the body gate, with a song of praise for the speech gate, and with faith and reverence for the mind gate. "Sincerely": extremely reverent. "Pay homage": joining the palms, making offerings, and seeking refuge. This is all necessary (3.I.I.I.4.) for the sake of dispelling obstacles. ${ }^{235}$

Putting all of this together, we have the opening homage of the root text: "To Mañjunātha, Nāgārjuna, and Vāgbhața, with the three gates I sincerely pay homage." Although this homage is nowhere to be found in the Four Tantras, variations on this homage can be found throughout several other collections of instructions attributed to Yutok Yönten Gönpo. For example, in the Familial Instructions ( $b u$ don $m a$ ), the first chapter beings with "To the Master of Medicine, the sages, and the teacher, with the three gates I sincerely pay homage. ${ }^{\text {"236 }}$ Again,

${ }^{233}$ spyi ru sdoms pas rgyas bshad nyi shu gsum//_mdo ru bsdus pa'i lag len bco brgyad 'di//_nad kyi dgra dpung 'dzoms pa'i mtshon cha yin//.

${ }^{234}$ Lag len spod chung gyi 'brel [sic] pa, in Krung go'i bod lugs gso rig rtsa che'i dpe rnying kun btus, vol. 3, text 2, p. 232 (ff. 4b-5a): 'jam mgon klu grub gol la/_zhes pa'o//_jam mgon ni 'jam dbyangs ste/_sku ’jam ste gzhon nu lang tsho bcu drug pa/_gser mog lta bu yid du 'ong bas na sku ’jam mo//_gsung dbyangs yan lag drug bcu dang ldan ste/_kun gyi thos pas dga' bas na gsung 'jam mo/_thugs ni nyon mongs dri ma mi mnga' zhing /_'gro la phan par dgongs pas na thugs 'jam mo//_mgon zhes pa ni 'gro ba rnams kyi mgon dang skyabs su gyur pa'o//_klu grub ni slob don klu sgrub/_pha gol ni slob dpon dpal ldan pha gol lo//.

${ }^{235}$ Lag len spod chung gyi 'brel [sic] pa, in Krung go'i bod lugs gso rig rtsa che'i dpe rnying kun btus, vol. 3, text 2, p. 232 (f. 5a): yul de la bdag gis btsal na/_sngon slob dpon g.yu thog mgon pos/_da lta de’i rjes su 'drang [='brang] pa rnams kyis so//_tshul ni/_sgo gsum dang bas/_ces pas/_lus kyi sgo yan lag lnga pa brtud nas/_ngag gis sgo stod [=bstod] dbyangs dang bcas pa'ol/_yid kyi sgo dad pa dang gus pa'o//_dang ba ni shin tu gus pa'ol/_phyag ni thal mo sbyar ba'o//_tshal lo zhes pa ni phul nas mgon skyabs zhu ba'o//_dgos pa ni bar gcod sel phyir ro//.

${ }^{236} \mathrm{Bu}$ don ma, Bod kyi gso ba rig pa'i gna' dpe phyogs bsgrigs dpe tshogs vol. I2 (Beijing: Mi rigs dpe skrun khang, 2002), I: sman bla drang srong bla ma la/l_sgo gsum dang pas phyag 'tshal lo//. 
after several variations on this format, in the sixth chapter we get an homage that is identical to that of our root text. ${ }^{237}$ This general format is also true for the homages found in the summary of the Essence of the Eight Branches attributed to Yutok, the Rosary of Jewels. ${ }^{238}$ Finally, even instructions attributed to Yutok Gönpo included in the Eighteen Partial Branches collection, also fit this format, such as "To Brahmā, the sages, and Vāgbhața, with the three gates I sincerely pay homage."239 This approach to obeisance does not appear in every chapter of every work attributed to Yutok Gönpo, but there does indeed appear to be a pattern. Thus, it would appear that the Yutok school of the thirteenth century, including Drangti Jampel Zangpo, were paying homage to Mañjuśrī, expounder of the Medicine of the Moon King, Nāgārjuna and Vāgbhața, authors of several medical works found in the Tibetan canon, and even Brahmā and his student sages, the famed scene of instruction for the Compendium of Caraka and so forth.

The "tantric collections": regarding their origins, these occur in accord with the teachings of one that has mastered the medical tantras and instructions. The abandonment of fabrication (3.I.I.2.): the medical scriptures and treatises were created by masters of the past that took the common tantras and, after correcting and selecting from them based on their own experience, set them into writing. "Pacification" refers to those [therapeutics] that are not cleansing [therapeutics]. "Wrote" has four components: Yutok Gönpo is who wrote; the Small Practical Manual is what he wrote; how it appears below is how he wrote it; and so that those who want to know medical practice do not have to encounter difficulties is why he wrote it. $^{240}$

The opening section finishes with a commitment to the "abandonment of fabrication" (rang bzo spang $b a$ ), in which practical scholasticism is reiterated. These works are not mere fabrications, but the instructions of the masters of the past (sngar gyis mkhas pa) that edited and improved the tantric collections (rgyud sde) based on their own experiences (nyams

\footnotetext{
${ }^{237} \mathrm{Bu}$ don ma, 33: 'jam mgon klu sgrub pha gol la//_sgo gsum dang pas phyag 'tshal lo//.

${ }^{238}$ Yan lag brgyad pa'i gzhung las bsdus pa nor bu'i 'phreng ba, Bod kyi gso rig dpe rnying phyogs sgrig vol. 9 (Chengdu: Si khron mi rigs dpe skrun khang, 2003), I2: sman lha drang srong bla ma la/_sgo gsum dag pas phyag 'tshal lo. See also p. 80: 'jam mgon klu grub sku la 'dud/.

${ }^{239}$ Stong thun bcu gcig, in Cha lag bco brgyad, Bod kyi gso ba rig pa'i gna' dpe phyogs bsgrigs dpe tshogs vol. 25 (Beijing: Mi rigs dpe skrun khang, 2005), I: tshangs [pa] dang drang srong pha gol la//_sgo gsum gus pas phyag 'tshal nas//.

${ }^{240}$ Lag len spod chung gyi 'brel [sic] pa, in Krung go'i bod lugs gso rig rtsa che'i dpe rnying kun btus, vol. 3, text 2, p. 232 (f. 5a): rgyud sde zhes bya ba ni byung pa ni gso spyad kyi rgyud man ngag mkhas pa’i gsung las byung pas na byung ba'o/_rang bzo spang ba ni/_gso spyad kyi bka' dang bstan chos [=bcos]/_rgyud phal nas slangs pa dang /_sngar gyis mkhas pa rnams kyis nyams myong nas 'thad pa sgrugs nas yi ger bkod pa'o//_zhi byed ces pa ni sbyang ba ma yin pa'o//_bri zhes pa ni bzhi te/_gang gis bris na slob dpon g.yu thog mgon pos/_gang bris na/_lag len spod chung /_ji ltar bri nal_og nas 'byung ba ltar/_dgos pa ci’i phyir na/_gso spyad shes 'dod la/_dka' tshegs mi dgos pa rnams kyi don du//.
} 
myong). Here we also find the attribution of the Small Practical Manual root text to Yutok Gönpo, who wrote the work exactly as it appears so that "those who want to know medical practice do not have to encounter difficulties." Thus, in the commentary to the Small Practical Manual, we find a combination of literary scholasticism and practical scholasticism in which a Tibetan commentator (Drangti Jampel Zangpo) is treating the summarized product of a past Tibetan master (Yutok Gönpo) as his own formative text. As displayed by the diagnostic section preceding this commentary, however, Jampel Zangpo did not feel constrained to only comment on the writings of Yutok Gönpo.

The mention of a condensed five classifications (sde tshan lnga) and an expanded eight, nine, or ten classifications of pacifying therapeutics is also conspicuous. It is almost as if the outliner of the Small Practical Manual and the Subsequent Tantra were aware of a shorter list of five classifications and thought it was necessary to add several more potential categories. Three earlier lists of pacifying therapeutics that are limited to five classificationsconcoctions (thang), powders (phye ma), pills (ril bu), ointments (lde gu), and, every Tibetan physician's favorite, ${ }^{24 \mathrm{I}}$ medicinal butter (sman mar) — can be found in the Lamp of the Secret Nucleus attributed to Nāgārjuna and the Secret Essence of Ambrosia discussed above, as well as the Medicine of the Moon King (sman dpyad zla ba'i rgyal po). ${ }^{242}$ As we have seen above, the Secret Essence of Ambrosia explicitly cites the Secret Nucleus as a source, and as well shall see in Chapter Three, the Secret Nucleus is largely indebted to the Moon King. The Moon King makes no mention of pacifying therapeutics (zhi byed bcos pa), but does state, "Regarding medical formulae, there are five: powders, ointments, concoctions, pills, and medicinal butter." 243 The treatment in the Moon King is largely composed of lists with little in the way of practical instruction. Many of formulae listed in the Moon King appear in the Secret Nucleus, however, which teaches the five classifications in the "Pacification Cycle: The Discs of the Sun and Moon" (zhi skor nyi zla'i 'khor lo), a subcollection that spans the five pacification chapters. The Secret Nucleus also appears to be the first to use the language of classifications, referring to the "classification of concoctions" (thang gi sde tshan) in one instance, ${ }^{244}$ and introduces lists of

${ }^{24 \mathrm{I}}$ Lag len spod chung gyi 'brel [sic] pa, in Krung go'i bod lugs gso rig rtsa che'i dpe rnying kun btus, vol. 3, text 2, p. 252 (f. 34b): [in reference to medicinal butter] "furthermore, such are the medical formulae of Tibet; and because there also are many medical practices that are famous from the great texts of India, there are many instructions [for medicinal butter]" (gzhan yang 'di bod kyi sman kyi sbyor [ba]* yin/_rgya gar gyi gzhung chen mo rnams las grags pa'i sman spyad yin pa'i phyir man ngag mang ngo //). "Sadly, the ba has been replaced with a headed-script (dbu can) $m a$ in this manuscript. In the modern book edition the text properly reads: 'di bod kyi sman yin ("Lag len dmar khrid sde tshan lnga'i 'grel pa," 3i6).

${ }^{242}$ See "Gsang tig sgron ma," in Slob dpon klu sgrub kyi sman yig gces btus, 209-222; "Rgyud chung bdud rtsi snying po," in Cha lag bco brgyad, 554-63; and Sman dpyad zla ba'i rgyal po, 2II22; respectively.

${ }^{243}$ Sman dpyad zla ba’i rgyal po, 2II: de nas sman gyi sbyor ba ni//_phye ma lde gu thang dang ni//_ril bu sman mar lnga dag go/.

244 "Gsang tig sgron ma," in Slob dpon klu sgrub kyi sman yig gces btus, 2IO. 
lists—such as the four types of powder formulae: those of king camphor, minister saffron, lord pomegranate, and the common subjects $-{ }^{245}$ in an attempt to render the content of the Moon King comprehensible. The notion of such lists is implicit within the Moon King, but is not clearly or completely stated. ${ }^{246}$ Thus, from this brief survey, it seems that the Moon King provided a general structure for the classification of materia medica, that was then organized and expanded by the Secret Nucleus.

The Secret Essence of Ambrosia continues the organizational structure of the Secret Nucleus, including the five classifications and also the specific types of powder formulae mentioned above. The Secret Essence of Ambrosia adds further information regarding the practical uses for such powder medicines and the numbers of each type: "Regarding the formulae that dispel heat, there are the kingly camphor formulae, the seven ministerial saffron formulae, and the eight primary lord formulae." 247 The Small Practical Manual continues the classification provided in the Secret Essence of Ambrosia, providing even more detail. Both the former and the latter organize the section on powders into those that dispel heat (tsha sel) and cold (grang sel) and proceed through king camphor (ga bur rgyal po), saffron (not called minister in the Small Practical Manual), and the eight primary lord formulae (gtso bo brgyad pa rje'u'i sbyor ba) for the powders that dispel heat. The Small Practical Manual is much more detailed regarding the properties and uses for each item, but approximately follows the order of the Secret Essence of Ambrosia. The Secret Essence of Ambrosia informs us that a "preparation of Costus speciosus (manu-puśkara), coriander, Costus amarus, and chrysanthemum dispels brown phlegm," ${ }^{248}$ for example, while the Small Practical Manual devotes a lengthy passage just to chrysanthemum:

The chrysanthemum is the flower of the rhododendron tree. Yutok once asserted, "The leaves of the rhododendron are called 'rhododendron,' while the flowers are called 'chrysanthemum."' The red flowers that have been frozen are the best. The leaves are middling. Khampas call it pukar, Central Tibetans also call it balu sulu, but it has come to be known by the Uighur-language dali. ${ }^{249}$

245 "Gsang tig sgron ma," in Slob dpon klu sgrub kyi sman yig gces btus, 2II: phye ma sbyar lugs rnam pa bzhi//_rgyal po ga bur sbyar ba dang //_blon po gur gum sbyar ba dang //_rje'u se'u 'bru sbyar ba dang //_phal ba 'bangs kyi sbyar ba'o//.

${ }^{246}$ Sman dpyad zla ba'i rgyal po, 2II: phye ma’i rgyal po ga pur ni//...

247 "Rgyud chung bdud rtsi snying po," in Cha lag bco brgyad, 556: tsha sel ga bur rgyal po'i sbyor ba dang //_gur kum bdun pa blon po'i sbyor ba dang //_gtso bo brgyad pa rje’u'i sbyor ba'o//.

248 "Rgyud chung bdud rtsi snying po," in Cha lag bco brgyad, 559: ma nu puśkara 'u su ru rta dang //_da lis bsdebs pas bad kan smug po sel//.

${ }^{249}$ Lag len spod chung gyi 'brel [sic] pa, in Krung go'i bod lugs gso rig rtsa che'i dpe rnying kun btus, vol. 3, text 2, p. 243 (f. 2Ia): da lis ni/_ba lu'i me tog yin te g.yu thog pa[s] ba lu'i 'dab ma la ba lu/_me tog la da lis zhes 'dod do//_me tog dmar po sad kyi khyer ba de rab/_dab ma 'bring /_kham [=khams] pa ni pu kar zer/_bod pa ni ba lu su lu bya ba yang zer/_yu gur gyi skad na/_da li[s] bya bar grag[s]o //. The modern book edition has several different spellings and notes that "the red flowers that 
The passage continues beyond this to discuss related materia medica that are also called the Uighur term dali (!!). The fact that Drangti Jampel Zangpo names and describes a vast array of materia medica in such a consummate fashion, let alone the fact that he is familiar with the Uighur etymology for chrysanthemum, is remarkable. ${ }^{250}$ The Small Practical Manual truly represents an exceptional degree of detail and description, one that is perhaps unprecedented by the turn of the fourteenth century. The root text is rarely quoted in the Small Practical Manual commentary, but in the powders that dispel cold section we have several quotes from the Essence of Ambrosia: "for indigestion and gastrointestinal pain, khyung formula number five is supreme." ${ }^{251}$ This quotation directly corresponds to no parts of the textus receptus of the Four Tantras, but approximately corresponds to two. ${ }^{252}$ Another quotation from the Essence of Ambrosia is no longer in the textus receptus: "river pebbles dispel urinary obstructions." 253 Although the textus receptus of the Four Tantras recommends many different remedies for urinary obstructions (chu 'gags), river pebbles (gtsang kha'i rde'u) does not appear in the text. Thus, Drangti Jampel Zangpo appears to have had access to the Essence of Ambrosia, but this does not appear to have corresponded to the textus receptus of the Four Tantras.

have not been frozen are the best" (me tog dmar po sad kyis ma khyer ba de rab). See "Lag len dmar khrid sde tshan lnga'i 'grel pa," in Phyi ma rgyud kyi 'grel pa phyogs bsgrigs, 295.

${ }^{250}$ This knowledge is perhaps indicative of the cosmopolitan exchanges that were happening during the Yuan dynasty. For the role of Central Asian physicians at the Imperial Academy of Medicine during the Yuan dynasty, for example, see Angela Schottenhammer, "Huihui Medicine and Medicinal Drugs in Yuan China," in Eurasian Influences on Yuan China, ed. Morris Rossabi (Singapore: Institute of Southeast Asian Studies, 2013), 75-IO2.

${ }^{251}$ Lag len spod chung gyi 'brel [sic] pa, in Krung go'i bod lugs gso rig rtsa che'i dpe rnying kun btus, vol. 3, text 2, p. 245 (f. 24b): bdud rtsi snying po las kyang /_pho klog glang thabs nad la bya khyung lnga sbyor mchog bya ba dang /.

${ }^{252}$ See, for example, in the Explanatory Tantra, Rgyud bzhi dpe bsdur ma, vol. I, p. 247: pho long gnyan srin sad mda' bya khyung lnga/; and in the "Back Section," Rgyud bzhi dpe bsdur ma, vol. 3, p. 277:

gnyan srin nad la bya khyung lnga ba mchog.

${ }_{253}$ This comes within a discussion of sal ammoniac (rgya tsha) ointment, for which "river pebbles" (gtsang kha'i rde'u) may be a synonym. Lag len spod chung gyi 'brel [sic] pa, in Krung go'i bod lugs gso rig rtsa che'i dpe rnying kun btus, vol. 3, text 2, p. 250 (f. 3Ib): bdud rtsi snying po las kyang /_gtsang kha'i rde'us chu'gags sel//_zhes bshad do//.

W. A. McGrath | Buddhism and Medicine in Tibet | 86 


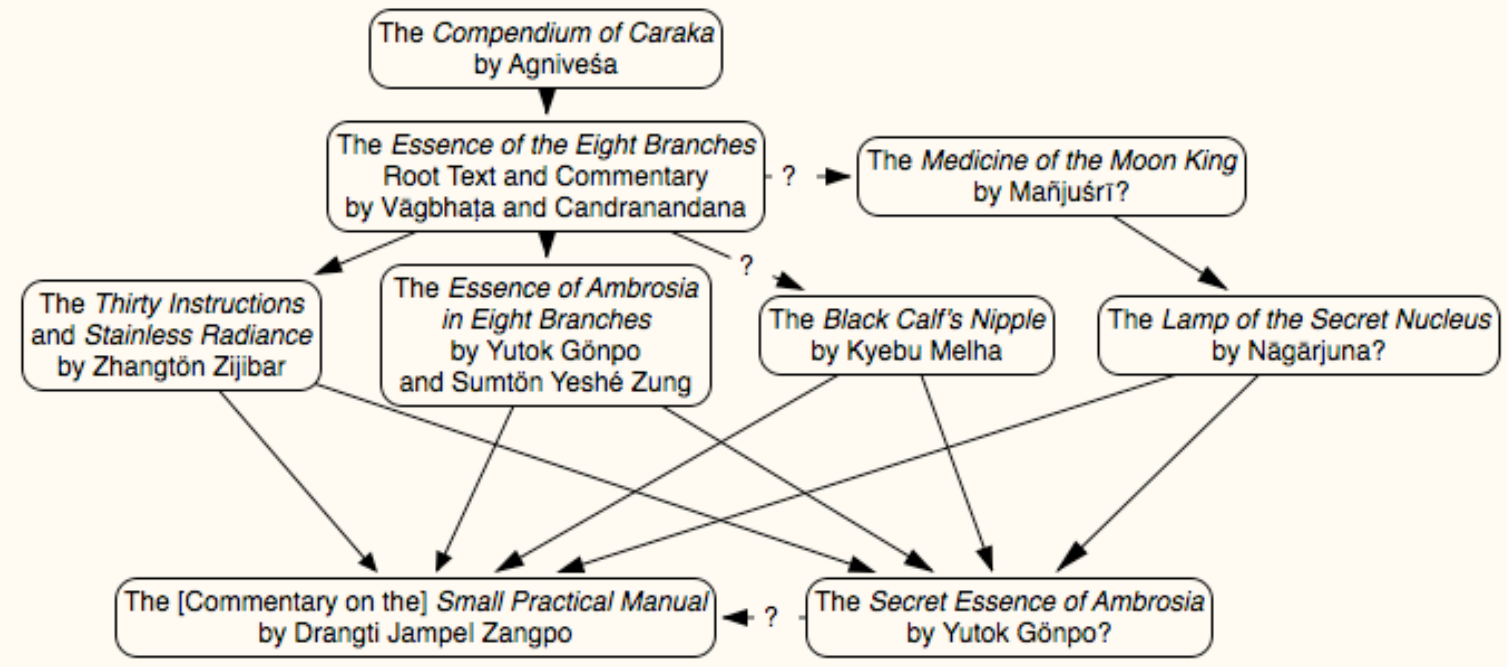

Figure 2.2. A Proposed Web of Intertextuality and Scholastic Influence

\section{The Closing Section}

The Small Practical Manual is a scholastic work of medical instructions that was written by Drangti Jampel Zangpo and, although the Desi warns us not to confuse it with the Small Practical Manual by Yutok Yönten Gönpo, the detailed contents of the work are the product of Jampel Zangpo's commentary and not Yutok's non-extant source text (Figure 2.2.). As the above survey also demonstrates, the continuum of instructions passing from the Medicine of the Moon King to the Lamp of the Secret Nucleus, the Essence of Ambrosia in Eight Branches, the Secret Essence of Ambrosia, and finally the Small Practical Manual follows a self-proclaimed process of practical scholasticism in which each text attempts to summarize, organize, interpret the teachings of previous generations. The "Opening Section" of the Small Practical Manual described above is quite explicit about this scholastic process, as is the "Closing Section":

The dedication of merit: "from the sufferings of disease, may the two-legged ones...": among the six [classes] of beings, the two-legged ones are primary. The "two-legged ones" are humans. "Suffering": the feeling of imbalance in the humoral aggregations is suffering. [Therapeutics] are for the sake of freeing [beings] from such a state. ${ }^{254}$

"Tantras": the Essence of Ambrosia, the Somaradza, the Thirty Instructions, and so forth. "Oral instruction": instructions that have been given orally. "Experience": previous

${ }^{254}$ Lag len spod chung gyi 'brel [sic] pa, in Krung go'i bod lugs gso rig rtsa che'i dpe rnying kun btus, vol. 3, text 2, pp. 255-56 (ff. 39b-40a): dge ba’i rtsa bar bsngo ba ni/_rkang gnyis nad kyis sdug bsngal las/_ces pa ni/_'gro drug gi nang nas rkang gnyis gtso bo ste/_rkang gnyis ni mi 'o/_bsdug sngal ni/_du ba ma snyoms pa’i tshor ba bsdug sngal lo/_de dang bral bar bya ba’i phyir/. 
practice that has entered into one's acquaintance. "Without exception": having collected all of the topics that are not mutually contradictory, for the sake of benefitting his sons and students that are endowed with commitments, Master Yutok Yönten Gönpo, Lord of Dré, put this into writing. ${ }^{255}$

"With this merit, may [beings] achieve the final ground": with the arrangement of this work and with its putting into writing, may other students understand [medicine] and be free from disease. With a joyful mind that has been freed from disease and whose pain has been assuaged, "may beings come to attain the final ground, the eleventh ground of total luminosity."

The one called Drangti Jampel Gyentsen, ${ }^{257}$ bowing at the feet of Yutok Jampel [and Yutok Tsojé], father and son, put this into writing. If there are mistakes and errors, I beg the pardon of the sages and teachers. Mangalamśubhavatu. ${ }^{258}$

This closing section serves to affirm themes that we saw above. Drangti Jampel Zangpo names his teachers as Yutok Jampel and his son (g.yu thog 'jam dpal yab sras), Yutok Tsojé, for example, and he also explicitly states that Yutok Yönten Gönpo put the Small Practical Manual into writing (yig ger bkod pa) based on medical tantras (rgyud) — that is, the Essence of Ambrosia,

${ }^{255}$ Lag len spod chung gyi 'brel [sic] pa, in Krung go'i bod lugs gso rig rtsa che'i dpe rnying kun btus, vol. 3, text 2, p. 256 (f. 40a): rgyud ni bdud rtsi snying po/_so ma ra tsa bsdams [=gdams] pa sum bcu lasogs pa'o/_man ngag ni zhal gyi gdams pa/_nyams myong ni mngar [=sngar?] lag du blangs pal_nyams su chu [=chud?] tshud pa ma lus pa ni/_don dang mi 'gal bar bsdus nas bu dang slob ma dam tshig can la phan pa'i don du/_g.yu thog mkhas pa 'bre rje yon tan mgon gyis yig ger bkod pa'o//.

${ }^{256}$ For an analysis of the "ground of total luminosity" (kun du 'od kyi sa) in the Nyingma tradition, see Carmen Meinert, "The Conjunction of Chinese Chan and Tibetan Rdzogs chen Thought: Reflections on the Tibetan Dunhuang Manuscripts IOL Tib J 689-I and PT 699," in Contributions to the Cultural History of Early Tibet, ed. Matthew Kapstein and Brandon Dotson (Leiden: Brill, 2007), 275-77. Lag len spod chung gyi 'brel [sic] pa, in Krung go'i bod lugs gso rig rtsa che'i dpe rnying kun btus, vol. 3, text 2, p. 256 (f. 40a): dge bas thar pa'i sa thob shog/_ces ni/_di yig ger bkod pa dang/_bris pas gzhan slob mas shes te nad las grol ba dang /_'gro ba nad las grol te zug du chag pa'i dga' sems la bsten nas/_thar pa'i sa bcu gcig kun du 'od kyi sa thob par gyur cig/_ces pa'o/. Interestingly, the Rgyud rgyal bdud rtsi snying po las lag len dmar khrid sde tshan lnga'i 'grel pa has the "ground of total thought/desire" (kun du'dod kyi sa).

${ }^{257}$ Although the Lag len spod chung has Jampel Gyentsen (jam dpal rgyal mtshan), the Rgyud rgyal bdud rtsi snying po las lag len dmar khrid sde tshan lnga'i 'grel pa has Jampel Zangpo ('jam dpal bzang po). Is the former just an alternative name for Jampel Zangpo? Or does this refer to his elder son, Drangti Gyelwa Zangpo (brang ti rgyal ba bzang po)?

${ }^{258}$ Lag len spod chung gyi 'brel [sic] pa, in Krung go'i bod lugs gso rig rtsa che'i dpe rnying kun btus, vol. 3, text 2, p. 256 (f. 40a): zhi byed sde tshan lnga'i 'grel pa [b]rjed byang zhib tshags su/_g.yu thog 'jam dpal yab sras kyis zhabs la btud pa'i brang ti 'jam dpal rgyal mtshan zhes bya bas yig ger btab pa la nor cing 'khrul ba mchis nal_drang srong bla mas bzod par gsol/_mamgha lam/_shu bha zhan du//_gcig zhus/_dge'o//. 
the Medicine of the Moon King, and the Thirty Instructions by Zhangtön Zijibar-oral instructions (man ngag), and his own experience (nyams myong). Despite the fact that Jampel Zangpo's "commentary" appears to have merely followed the general sequence of topics found in the currently non-extant Small Practical Manual, he attributes the inspirations for the instructions that he received to Yutok and his lineage. Such was common practice in the thirteenth-century Yutok school, for there is a proliferation of works that were composed later and then retroactively attributed to Yutok during this time.

As seen in the discussion above and summarized in Figure 2.2., both the Small Practical Manual and the Secret Essence of Ambrosia cite a set of similar sources: the Essence of Ambrosia, the Essence of the Eight Branches root text and commentary, the Medicine of the Moon King, and the canonical and non-canonical works of Nāgārjuna, Kyebu Melha, and Zhangtön Zijibar. This, of course, is only a sampling of the kinds of works available in the thirteenth century, but they also form the core formative texts for the school of Yutok ( $g . y u$ thog lugs). Both the Small Practical Manual and the Secret Essence of Ambrosia represent attempts at creating a more legible and more practically applicable rendition of the instructions found in the aforementioned formative works. In the milieu of essentialistic scholasticism in the thirteenth century, the followers of the Yutok school appear to have accepted, or even encouraged, the labeling of one's own work as the experiential treatise of Yutok Gönpo himself. By the fourteenth century, however, following the critiques of figures like Chomden Rikpé Reldri and attacks on any works composed by Tibetans themselves, be they sages or not, the essential summaries of previous works would have to be disguised as conservative commentaries or translations. As we have seen, the Small Practical Manual took the approach of the former, despite maintaining Yutok's experiential instructions as its formative text, while the Secret Essence of Ambrosia took the latter. The aforementioned early manuscript witness of the Secret Essence of Ambrosia reaffirms the role of Yutok in its composition in its final passage:

Due to previous trainings, a sage that was born in India, seeing the needs of beings, extended his life and came to be known by the kings and masters of the Four Horns of Central Tibet as a physician born to the Yutok clan in Tibet. He condensed the elixir of all tantras and instructions from the medical traditions of both India and Tibet and, in accordance with his previous commitments, he composed this medical tantra. It did not spread widely, and has descended among his sons. Because you are one that is endowed with good fortune you have encountered this Great Tantra that is the quintessence of the instructions [...] . The Secret Essence of Ambrosia: An Instructional Tantra, the essence of the instructions of the science of medicine, is complete. ${ }^{259}$

${ }^{259}$ Bdud rtsi snying po gsang ba man ngag gi rgyud, in Krung go’i bod lugs gso rig rtsa che'i dpe rnying kun btus, vol. 4, text 5, pp. 5IO-II (ff. 258b-259a): sngon sbyangs rgya gar yul du 'khrungs pa'i//_drang srong 'gro don gzigs de tshe 'phel nas//_bod yul g.yu thog sman pa'i rigs su 'khrungs//_dbus rtsang ru bzhir mkhas pa'i rgyal por grags//_khong gis brgya bod gnyis gso spyad las/_rgyud dang man ngag kun gyi bcud bsdus tel/_thugs dams brtuns [=brten?] gso rig rgyud 'di mdzad//_kun la ma spel 
This is the earliest evidence of the apotheosis of Yutok Gönpo that is still extant. It was so emphatic, in fact, that the entire colophon had to be elided in later editions, along with the opening verses quoted above. Instead of a narrative in which an Indian sage extends his life (tshe 'phel) so that he may help beings in Tibet, a later manuscript witness frames the Secret Essence of Ambrosia, the Great Tantra, as a treatise composed not by a learned Tibetan, but a Kashmiri scholar:

The Secret Essence of Ambrosia: An Instructional Tantra, composed by the Kashmiri Master, Candranandana, is complete. [This work was] translated, edited, and redacted by the Indian Scholar Jarandhana and the translator Rinchen Zangpo. ${ }^{260}$

I, Master Jeji [=Biji?] Wangpel, ${ }^{26 I}$ with the power of having become accustomed [to medicine] in previous lives, like the powerful flow of the Ganges river, have trained in the nature of beings and the five sciences. This manuscript copy of the Essence of Ambrosia, belongs to me, nephew of [...], emanation of Mañjuśrī. May the merit derived from this writing cause me to achieve buddhahood swiftly. ${ }^{262}$

Thus, as the Secret Essence of Ambrosia faded more deeply into history, it was displaced as the instructional tantra of the Tibetan Sage Yutok, and rendered as a commentarial treatise by a Kashmiri pandit. ${ }^{263}$ The tension inherent within the depiction of Tibetan medical works as

sras kyi babs su bzhag//_gdams pa'i nying khur gyur pa'i rgyud chen 'di/_[erased half line] las gcig skal bar ldan bas 'phrad pa yin//_bdud rtsi snying po gsang ba man ngag gi rgyud ces bya bal/_gso ba rig pa man ngag gi snying po//_rdzogs s+hyo//_//.

${ }^{260}$ Bdud rtsi snying po kha che zla dga' yis mdzad pa, in Krung go'i bod lugs gso rig rtsa che'i dpe rnying kun btus, vol. II, text I, p. 99 (f. I58a): bdud rtsi snying po gsang ba man gag gi rgyud ces bya ba kha che'i slob dpon zla ba la mngon bar dga' bas mdzad pa rdzogs sho/_rgya gar gyi mkhan po dza ran dha na dang /_lo tsa ba rin chen bzang pos bsgyur cing zhus te gtan la phab pa'o//.

${ }^{26 \mathrm{I}}$ I am unable to identify this figure and the erasing of his uncle's name is frustrating. Based on this colophon, I would tentatively identify him as a figure from the fifteenth or sixteenth century.

${ }^{262}$ Bdud rtsi snying po kha che zla dga' yis mdzad pa, in Krung go'i bod lugs gso rig rtsa che'i dpe rnying kun btus, vol. II, text I, p. 99 (f. I58a): mkhas pa bye ji dbang dpal ngas//skye ba lnga mar goms pa'i mthus/_gang ga'i chu bo rab 'bab bzhin/_skye gnas rig gnas lnga la sbyangs/_bdud rtsi snying po 'di//_jam dbyangs gis sprul pal/_[...] dbon po nga'il/_phyag dpe yino am//_di bris dge ba des//_sangs rgyas myur thob shog//

${ }^{263}$ As noted above, the Secret Essence of Ambrosia was carved into xylographic blocks at the court of the Great Fifth Dalai Lama and given an even more elaborate colophon: "Extremely well known in the western land of Kashmir, Master Candranandana took up the intentions of the Glorious Master Vāgbhața, and delved into the mental treasury of the scholar sages. After extracting the elixir from the tantras and all the branches, he composed this instructional tantra of medical science. Emanated supreme beings transmitted these instructions from one to another, and they ultimately came to the hands of Yutok Gönpo. The Essence of Ambrosia: A 
tantras versus treatises-that is, between practrical scholasticism and fundamentalist translation-appears in the final line of this same work. The verso of the Secret Essence of Ambrosia colophon depicts several verses that poetically redeems the Tibetan medical enterprise:

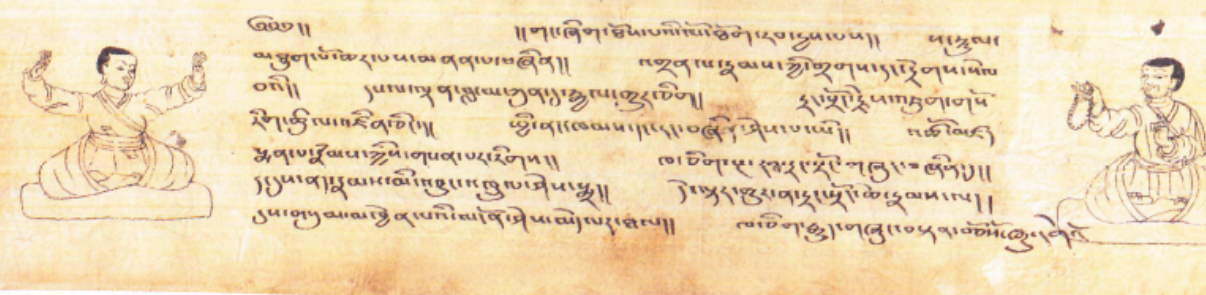

Figure 2.3. Verso of the final folio of the Secret Essence of Ambrosia manuscript.

The bountiful harvest of one's studies

Leaves an impression like the earth after a heavy rain.

Dispelling the fame and arrogance of competitors,

May the lama achieve complete victory. ${ }^{264}$

We must listen to physicians and doctors,

Those who follow the sages and hold the methods for medical practice,

Those that understand the constitutions and natures [of patients], both external and internal. $^{265}$

Some propound the mistaken view that, in accord with the texts of the ancient sages,

In this age illness will cease to occur.

But for this to be the case, it would follow that the great sages

Tantra of Secret Instructions, the essence of all medical practices, is complete" (nub phyogs kha che'i yul du rab grags pa/_slob dpon zla ba mngon par dga' ba yis/_slob dpon dpal ldan pha gol dgongs pa blangs/_drang srong mkhas pa rnams kyi thugs mdzod brus/_rgyud dang yan lag kun gyi bcud phyung nas/_gso ba rig pa'i man ngag rgyud 'di mdzad/_sprul pa'i skyes mchog gcig la gcig brgyud nas/_tha mar g.yu thog mgon po'i phyag tu babs/_bdud rtsi snying po gsang ba man ngag gi rgyud ces bya ba gso dpyad thams cad kyi snying po rdzogs so//). See Rgyud chung bdud rtsi snying po bzhugs so, in Cha lag bco brgyad, Bod kyi gso ba rig pa'i gna' dpe phyogs bsgrigs dpe tshogs, vol. 25 (Beijing: Mi rigs dpe skrun khang, 2005), 744.

${ }^{264}$ Bdud rtsi snying po kha che zla dga' yis mdzad pa, in Krung go'i bod lugs gso rig rtsa che'i dpe rnying kun btus, vol. II, text I, p. IOO (f. I58b): gang zhig thos pa'i lo thog rab rgyas pas//_sa skul [=rdul] mthug po char pas mnan pa bzhin//_'gran pa rnams kyi grags dang dregs sel ba'i//_dpal ldan bla ma kun du rgyal gyur cig/. 
Did not have the clairvoyance of knowing the three times.

Others say that tantric texts are treatises. Virtue! $!^{266}$

With training and experience derived from study, particularly within the context of an educational lineage extending from the sages of ancient times down to one's own lama, the physician is capable of dispelling the arrogance of his competitors and achieving complete success in the medical market. Unlike the traditions of diviners promoted in the channel prasenā instructions of Chapter One, physicians representing the clinical medical traditions of Tibet examine and interpret the symptoms of their patients according to textual traditions, and do not rely upon sages to miraculously dispel the diseases of the world. Indeed, why would the sages have promoted these traditions of study and practice in the first place if they were able to miraculously dispel disease? Such reliance upon oracular diagnosis and ritualized therapy is the object of one critique in this concluding verse, and the curt rejection of vernacular scholasticism in the literatus tradition is another.

Despite the imbrication of diviner, literatus, and physician traditions in the eleventh and twelfth centuries-as exemplified by the promotion of channel prasena rituals and the practical summarizing of translated instructions by Zhangtön Zijibar, Yutok Gönpo, and their followers - with the proliferation of scholastic material in the thirteenth century, distinct traditions began to crystalize. Unlike Zhangtön and Yutok, whose instructions were expressly designed for legibility and practicality, the literatus tradition promoted cosmopolitan provenance as the primary criterion for literary value-regardless of whether the work derives from South, East, or Central Asian traditions-at the expense of vernacular Tibetan expressions. Also emerging in the thirteenth century is a tradition that is primarily concerned with practical efficacy and Buddhist provenance. As evinced by the vicissitudes of the Secret Essence of Ambrosia, in the late thirteenth century, the boldly vernacular instructions of the Yutok school were initially disguised as the cosmopolitan transmissions of Kashmiri pandits. By the turn of the fourteenth century, however, the dominance of cosmopolitan provenance promoted by the literatus school came to be eclipsed by the Buddhist mythologies of the physician school. As a result, the innovations of the Secret Essence of Ambrosia of Yutok-asliteratus, Vāgbhața, come to be incorporated into the Secret Essence of Ambrosia in Eight Branches of Yutok-as-sage, Rikpé Yeshé, with the former being demoted as the Lesser Tantra (rgyud chung) and the latter as the King of Tantras (rgyud rgyal). How, then, did the King of Tantras, now known as the Four Tantras, come to ascend its throne as the seminal formative

${ }^{265}$ Bdud rtsi snying po kha che zla dga' yis mdzad pa, in Krung go'i bod lugs gso rig rtsa che'i dpe rnying kun btus, vol. II, text I, p. IOO (f. I58b): drang srong rjes 'jug gso rig tshul 'dzin cing //_phyi nang khams dang rang bzhin shes pa yi//_tsho mdzad sman pa rnams kyis gsan par rigs//.

${ }^{266}$ Bdud rtsi snying po kha che zla dga' yis mdzad pa, in Krung go'i bod lugs gso rig rtsa che'i dpe rnying kun btus, vol. II, text I, p. IOO (f. I58b): kha cig snga rabs drang srong gzhung bzhin du//_da dus nad rnams mi 'byung 'khrul shes smral/_de ltar gyur na drang srong che rnams lal/_dus gsum mkhyen pa'i mngon shes med par thal//_kha cig rgyud gzhung bstan bcoso zhu dge'o//. 
text of Tibetan scholasticism, eclipsing even its cosmopolitan inspiration, the Essence of the Eight Branches? The answer lies in primordial time and utopian space. 


\section{Chapter Three: Origin Myths and the Buddhist Narration of Medicine}

Brahmā, remembering the Science of Life (āyurveda), taught it to Prajāpati, [Prajāpati] in turn taught it to Aśvin, [Aśvin] taught it to Śakra (Indra), [Indra] taught it to Atri and other sages. They taught it to Agniveśa and others, and [Agniveśa and the other sages] each individually composed tantras. Extracting only the best from these tantras, which are extremely comprehensive, the Essence of the Eight Branches is neither too succinct nor too elaborate. $^{267}$

Thus begins the Compendium of the Essence of the Eight Branches (yan lag brgyad pa'i snying po bsdus pa, aștāingahṛdayasaṃhita), introducing a problem for the Tibetan medical tradition. If the Essence of the Eight Branches is to be considered a formative medical text, then how are these Brāhmanic origins of medicine to be understood? The religious connotations of the Essence of the Eight Branches have long been debated, ${ }^{268}$ particularly those of the opening homage, ${ }^{269}$ for the work references the three Brāhmanic aims of life (Skt. trivarga), for example, while also paying homage to the Buddha, Master of Medicine. Regarding the latter, many of the Tibetan xylographic editions of the Eight Branches begin with the homage, "To the Victoriously Transcendent One Gone Thus, to the Spirit of Medicine, King of Beryl Light, I pay homage," ${ }^{270}$ while manuscript editions lack any such opening homage. ${ }^{271}$ Although this

${ }^{267}$ Yan lag brgyad pa'i snying po bsdus pa, in Bstan 'gyur dpe sdur ma, ed. Krung go'i bod rig pa zhib 'jug ste gnas kyi bka' bstan dpe sdur khang (Beijing: Krung go'i bod rig pa dpe skrun khang, 2004), vol. III (he [213]), text 3547, pp. I43-I44: tshangs pas tshe yi rig byed dran//_skye dgu'i bdag la bshad pa yin//_de yis tha skar des brgya byin//_des rgyun shes stsogs drang srong la'o//_de yis me bzhin 'jug la stsogs//_de rnams kyis rgyud so sor byas//_shin tu 'thob pa de rnams las//_rab ces phal cher btus pa ni//_shin tu bsdus min rgyas min par//_yan lag brgyad pa'i snying po byas//. Translated in consultation with Murthy, Vāgbhața's Aștāñ ga Hṛdayam, vol. I, 4-5; and Vogel, Vāgbhața's Aștāngahṛdayasaṃhitā, 45-50.

${ }^{268}$ For an overview of the debates regarding the religious affiliation of Vāgbhața, author of the Eight Branches, see Meulenbeld, A History of Indian Medical Literature, vol. Ia, pp. 602-6I2.

${ }^{269}$ Yan lag brgyad pa'i snying po bsdus pa, in Bstan 'gyur dpe sdur ma, vol. III (he [213]), text 3547, p. I43: "To the dispeller of all disease without exception-such as desire and so forth, which, due to their perpetual associations, spread throughout the entire body without exception, and cause desire, stupidity, and belligerence-to the Unprecedented Physician, I pay homage" ('dod chags la sogs ma lus pa yi nad//_rgyun du 'brel pas lus kun ma lus khyab//_dod dang gti mug khro ba sel ba yil/_sman pa sngon med de la phyag 'tshal lo//).

${ }^{270}$ Yan lag brgyad pa'i snying po bsdus pa, in Bstan 'gyur dpe sdur ma, vol. III (he [213]), text 3547, p. I43: bcom ldan 'das de bzhin gshegs pa sman gyi bla baidūrya 'od kyi rgyal po la phyag 'tshal lo/.

${ }^{271}$ See, for example, Gso spyad [=dpyad] yan lag brgyad pa'i snying po bsdus pa, in Krung go'i bod lugs gso rig rtsa che'i dpe rnying kun btus: pho brang po ta la'i gsung rab gter mdzod las btus [China's Traditional Tibetan Medical Texts: A Treasury of Scriptures from the Potala Palace], ed. Bod 
homage appears in a mantra that is included in subsequent chapters of the Essence of the Eight Branches, the translation and reduplication of this mantra as an epigraph in xylographic editions of the Translated Treatises Canon (bstan 'gyur) may be a reflection of Tibetan apprehensions regarding the religious provenance of the work. ${ }^{272}$

The editors of the Translated Treatises Canon were right to be concerned, for much of the narrative frame described here derives from a long-standing origin myth in Āyurvedic literature. Indeed, in what is perhaps the earliest account of Ayurveda that is still extant, the Compendium of Caraka (carakasamhitā), the Science of Life is said to ultimately derive from Brahmā, although, as K. Zysk points out, Indian commentarial literature insists that Brahmā is the redactor, and not the creator, of the Indian medical tradition. ${ }^{273}$ The Compendium of Suśruta (suśrutasaṃhitā) continues this narrative with Dhanvantari, a patron deity of surgical medicine, explaining that Brahmā composed one hundred thousand verses on Āyurveda, a subsection of the Atharvaveda, when he created the world. ${ }^{274}$ Thus, with the translation of the Essence of the Eight Branches, the Tibetan physician-scholars inherited a long tradition of abridged works reflecting divinely authored ur-texts that are themselves branches of the Vedas.

ljongs bod lugs gso rig slob grwa chen mo (Lha sa: Bod ljongs mi dmangs dpe skrun khang, 20I3), vol. 2, text I, p. I. I have not been able to precisely date this manuscript, but judging by the mention of the "patrons of the teachings-His and Her Majesties and the Prince(s)" (bstan pa'i sbyin bdag gong ma yab yub [=yum] sras bcas rnams) in the colophon (Krung go'i bod lugs gso rig rtsa che'i dpe rnying kun btus, vol. 2, text 6, p. 375 [235a]) as well as the figures included-the most famous, but not the most recent, of which is Tsangtö Darma Gönpo (gtsang bstod [sic] dar ma mgon po, IIth or I2th c.?)- the manuscript was probably not created earlier than the Pakmodru period (ca. I350-I450) and is more likely to derive from either the fifteenth or sixteenth century. A detailed analysis of this complete and beautifully written manuscript certainly remains a desideratum. On the life and times of Tsangtö Darma Gönpo, see the first half of Leonard W. J. van der Kuijp, "Za hor and Its Contribution to Tibetan Medicine, Part Two: Sources of the Tibetan Medical Tradition," Bod rig pa'i dus deb [Zangxue xuekan 藏学学刊; Journal of Tibetology] I2 (2016): 63-I08. For modern reproductions of his works, see Gtsang stod zin thig dang yang thig, Bod kyi gso ba rig pa'i gna' dpe phyogs bsgrigs dpe tshogs, vol. 42 (Beijing: Mi rigs dpe skrun khang, 2006); and, more recently, Zin thig bsam 'phel nor bu and Yang thig rdo rje pha lam, Bod kyi gso ba rig pa'i gna' dpe phyogs bsgrigs dpe tshogs, vol. 98 (Beijing: Mi rigs dpe skrun khang, 2013). Finally, four instructional works attributed to Dargön are also available in in Krung go’i bod lugs gso rig rtsa che”i dpe rnying kun btus: vol. 9, texts 60-62; and vol. I2, text 6.

${ }^{272}$ "Om! To the Victorious One, the Medicine Master, the King of Beryl Light, the One Gone Thus, the Saint, the Fully Enlightened One." See Vogel, Vägbhața's Așțāngahṛdayasaṃhitā, 45: om namo bhagavate bhaișajyagurave vaị̂uryaprabharājāya tathāgatāyārhate samyakasambuddhāya. For the Tibetan canonical editions, see Yan lag brgyad pa'i snying po bsdus pa, in Bstan 'gyur dpe sdur ma, vol. III (he [213]), text 3547, pp. 236-37: om na mo bha ga ba te/_/bhai șa dzya gu ru bai dūrya pra bha rā dzā ya/_ta thä ga tā ya/_arha te/_saṃ myag saṃ buddhā ya. For more on this mantra, see Meulenbeld, A History of Indian Medical Literature, vol. ra, 604.

${ }^{273}$ Zysk, "Mythology and the Brāhmanization of Indian Medicine," I3I.

${ }^{274}$ Zysk, "Mythology and the Brāhmanization of Indian Medicine," I36.

W. A. McGrath | Buddhism and Medicine in Tibet $\mid 95$ 
For Tibetan authors reading the Essence of the Eight Branches in translation, much is at stake regarding the meaning of the verb, "to remember" (Tib. dran pa = Skt. smrti) in the origins of medicine. In both Tibetan and Sanskrit the semantic range of the term extends to English-language notions of "mindfulness," "cognition," and engaging in mnesis, ${ }^{275}$ but, beyond the divide between "memory" and "mindfulness" in English-language translations, the term as rendered in the Āyurvedic Compendia has even further connotations in line with the "heard" (Skt. śruti) and "remembered" (Skt. smrti) teachings of the Vedas. ${ }^{276}$ Just as Manu is traditionally said to have remembered teachings based on inferences from the Vedas, ${ }^{277}$ so too do the Âyurvedic Compendia contain inferences from or even branches of Vedic teachings that are no longer heard in full. ${ }^{278}$ Indeed, in the words of S. Pollock, "It is thus only a slight exaggeration to say, in the elite discourse of traditional India, there exists no cultural memory-smrti-separate from the memory of the eternally given." ${ }^{279}$

The same could be said—again, with only slight exaggeration-for the Tibetan medical tradition. Some authors would deemphasize the role of Brahmā in this framing narrative, instead highlighting the role of religiously ambiguous sages in the transmission of medicine, while others came to embrace and totally reframe the recollection of Brahmā. Expanding upon this inherited narrative of the origins of medicine, one narrative tradition provided a name for the celestial one-hundred-thousand-verse teaching that Brahmā remembers, calling it the Collection of Medicine (gso dpyad 'bum sde), and provided the context for its recollection with yet another narrative inspired by Indian traditions. Regardless of the details, physicans and scholars of medicine needed to develop new narratives for the history of medicine as the tradition grew because the sources of tradition presented untenable and conflicting narratives. The scholastic traditions of both Tibetan literati and practicing physicians

${ }^{275}$ Matthew Kapstein, “The Amnesic Monarch and the Five Mnemic Men: 'Memory' in Great Perfection (Rdzogs-chen) Thought," in the Mirror of Memory: Reflections on Mindfulness and Remembrance in Indian and Tibetan Buddhism, ed. Janet Gytaso (Albany, NY: State University of New York Press, 1992), 239-69. For further remarks on the notion of memory and mindfulness in both Tibetan- and Sanskrit-language contexts, see the other articles included in the Mirror of Memory.

${ }^{276}$ On these two terms in Indian intellectual history, see Sheldon Pollock, "The Revelation of Tradition: śruti, smriti, and the Sanskrit Discourse of Power," in Boundaries, Dynamics and Construction of Traditions in South Asia, ed. Federico Squarcini (New York, NY: Anthem Press, 20II [originally published in 1997]), 50-5I: "In short, śruti means nothing other than '(Veda) actually now perceived aurally (in recitation)', i.e. extant or available; smrrti, nothing other than '(Veda) that is remembered', i.e. material that, having once been heard in recitation, no longer is, but remains inferentially recoverable from present reformulations (in language or practice) as having once existed as part of a Vedic corpus."

${ }^{277}$ Pollock, "The Revelation of Tradition," 57-58.

${ }^{278}$ On the relation of the Āyurvedic Compendia to the Vedas, see Meulenbeld, A History of Indian Medical Literature, vol. Ia, 348.

${ }^{279}$ Pollock, "The Revelation of Tradition," 57.

W. A. McGrath | Buddhism and Medicine in Tibet | 96 
necessitated formative narratives for their formative texts, but as the instructions of these formative texts continued to diverge, so too did their memories of the eternally given.

\section{Narrative and Polemics in the Tibetan Medical Tradition}

With the transmission of medical theories and practices and the formation of distinct traditions, narratives of origins and lineages also became increasingly distinct. The eleventhand twelfth-century collections of summaries and commentaries based on the Essence of the Eight Branches - such as the works of Yutok Gönpo and Zhangtön Zijibar-convey a penchant for efficacy over religious affiliation and polemics, unabashedly pulling from both Buddhist and non-Buddhist sources alike. ${ }^{280}$ By the thirteenth century, however, proponents of Indocentrism in the Tibetan literati tradition came to reject the labeling of the Essence of the Eight Branches and so forth as deriving from Brahmā and the non-Buddhist Vedas, instead promoting potentially Buddhist sages like Nāgārjuna as the source of medical teachings:

Although it has been said that the Science of Healing was remembered by Brahmā and taught to Prajāpati, and thus derives from Outsider [non-Buddhist] scriptures, it is the knowledge of the sages of yore. ${ }^{28 \mathrm{I}}$

Although there are few extant voices from the thirteenth century that wholly reject the Essence of the Eight Branches as non-Buddhist, the centering of a Brāhmaṇic work as the formative text in the Buddhist medical traditions of Tibet would be a troubling feature indeed. If the Eight Branches were to continue to have a place in the Tibetan medical tradition, it would have to become Buddhist. As Maurice Bloch reminds us, although one cannot argue with a song, ${ }^{282}$ one can adapt a song, interweave separate songs together, or even wholly reject a song and replace it with another. ${ }^{283}$

${ }^{280}$ Zhang gzi brjid 'bar, Gzhung dri med gzi brjid, 6: "I have surveyed many different textual traditions, both the inner and outer classes of Insider [Buddhist] tantras, and the class of Outsider [non-Buddhist] tantras, such as the [Compendium of] Caraka, and I shall teach this knowledge of yore (nang pa sangs rgyas rgyud sde phyi nang gnyis//_phyi rol mu stegs rgyud sde tsa ra ka/_myi 'dra'i gzhung lugs sna tshogs rnams las mthong //_rig pa sngon du byung'di bshad par bya//).

${ }^{281}$ This citation derives from the opening of Chomden Rikpé Reldri's Gso ba rig pa rgyan gyi me tog, in Krung go'i bod lugs gso rig rtsa che’i dpe rnying kun btus, vol. 3, no. 40, p. 472 (Ib): tshig nyung gso rig rgya chen bshad par byal_/gso rig tshangs pas dran nas skye dgu'i bdag_/bshad ces phyi rol gzhung las 'byung mod kyi/_/'di ni sngon gyi drang srong rnams kyi shes/. For an extended citation of this passage, see Chapter Two.

${ }^{282}$ Maurice Bloch, "Symbols, Song, Dance and Features of Articulation," European Journal of Sociology I5, no. I (1974): 7I. Cited and discussed in Catherine Bell, Ritual Theory, Ritual Practice (Oxford: Oxford University Press, I992), 2I4-I5, et passim.

${ }^{283}$ Pierre Bourdieu, Outline of a Theory of Practice, trans. Richard Nice (Cambridge: Cambridge University Press, 1977), I88: "the most successful ideological efforts are those which have no 
The narrative frame for the Four Tantras, as illustrated in the Root Tantra, for example, involves the interlocution of two sages-Rikpé Yeshé and Yilé Kyé-that have each been emanated from the Buddha, Master of Medicine. Sumtön Yeshé Zung (sum ston ye shes gzungs, fl. late $\mathbf{I}^{\text {th }} \mathrm{c}$.?) begins his Indispensable Account of Transmission (brgyud pa'i rnam thar med thabs med $p a$ ) with a subjunctive appeal to the reader-or, more appropriately, the listener-to enter the as-if land of Oḍdiyāna, in the city of Beautiful to Behold, where these two sages are engaged in dialogue. ${ }^{284}$ This narrative frame is described as "demonstrating reasons for trust," ${ }^{285}$ for it playfully intertwines the author and his teacher, Yutok Gönpo, with the two sages, stating "I think that it is like Master Yuthok Gönpo is the Sage Rikpé Yeshé, and I really am Yilekye." ${ }^{286}$ After this brief glimpse of sincerity, however, the subjunctive mood returns with requests for blessings from Yutok Gönpo himself. ${ }^{287}$ Thus, unlike the religiously ambiguous narrative of the Essence of the Eight Branches, the narrative frame of the Four Tantras, as envisioned by Sumtön Yeshé Zung, invites the reader to view his or her teacher as a sage emanated from the Buddha, Master of Medicine, and to view his or her teachings as the teachings of the Buddha.

The author of the early khokbuk curriculum (khog dbug [='bubs]), the Flight of the Great Khyung (khyung chen lding $b a$ ), whom I tentatively identify as the explicitly Nyingma teacher of

need of words, and ask no more than complicitous silence." Bell, Ritual Theory, Ritual Practice, 215: "The only real alternative to negotiated compliance is either total resistance or asocial selfexclusion."

${ }^{284}$ Med thabs med pa'i mchong [='phyong] gsum, in Krung goi bod lugs gso rig rtsa che'i dpe rnying kun btus, vol. 3, text 3, p. 257 (f. Ib-2a): sku lnga lhun grub las byung ba'i/_gso ba rig pa'i rgyud chen 'di/_sngun [=sngon] gyi bskal pa dang po la/_bstan pa'i gtso bo gzhugs dus su/_u rgyan yul gyi zhing khams der/_blta na sdug gi grong khyer du/_sangs rgyas sman lha'i byin brlabs kyis/_drang srong rig pa'i ye shes dang /_drang srong yid las skyes pa yis/_rgyud rje [=sde] bzhi yis zhus lan mdzad/_sdud pa”i rta [=bdag] po drang srong yid las skyes kyis/_rin chen gser gyi glegs bam la/_bhe du rgya'i zhun mas bris/_za 'og nyi ma ris kyis bris/_de steng shel ras dar men dril/.

${ }^{285}$ Med thabs med pai mchong [='phyong] gsum, in Krung go'i bod lugs gso rig rtsa che'i dpe rnying kun btus, vol. 3, text 3, p. 257 (f. Ib): yid ches pa'i khungs bstan phyir//_rgyud [=brgyud?] päi rnam thar med thabs med//.

${ }^{286}$ Med thabs med pa'i mchong [''phyong] gsum, in Krung go'i bod lugs gso rig rtsa che'i dpe rnying kun btus, vol. 3, text 3, p. 258 (f. 3a): mkhas pa g.yu thog mgon po del_drang srong rig pa'i ye shes lag[s] pa'dral_dngos rang yid las skyes sam mnyam [=snyam]/.

${ }^{287}$ Med thabs med pa'i mchong ["'phyong] gsum, in Krung go'i bod lugs gso rig rtsa che'i dpe rnying kun btus, vol. 3, text 3, p. 258 (f. 3a): "I think that surely he was my teacher in previous lives, for his kindness is immense, and I shall never forget to place him on my crown. Pray, continue to grant me your blessings" (tshe rabs kyis bla ma yin par nges/_bsam kyin sku drin che ba'i phyir/_mi [b]rjed rgyun du tsugs [=gtsug] tu 'khur/_rgyun chad med par byin gyis rlobs/). For an explanation of the sincere and the subjunctive in terms of ritual, see Adam B. Seligman, Robert P. Weller, Michael J. Puett, and Bennet Simon, Ritual and Its Consequences: An Essay on the Limits of Sincerity (Oxford: Oxford University Press, 2008), 17-42. For a helpful discussion of the sincere and the subjunctive in Greek historiography, see Arnaldo Momigliano, "The 
Drangti Penden Tsojé, Paktön Shākya Gönpo (phag ston shākya mgon po, fl. early I4 ${ }^{\text {th }}$ c.?), continues the didactic historiographical enterprise begun in the Indispensable Account. The Flight has an explicitly pedagogical raison d'être, and as a khokbuk curriculum, the Flight serves to "penetrate" ('bug/dbug) or "arrange" ('bub/dbub) the contents (khog) of the Tibetan medical tradition in general, as well as the Four Tantras in particular. Following an explication about how the Four Tantras is not only a tantra (rgyud), but also a textual instruction (lung) and an oral instruction (man ngag), the Flight explicitly refers readers to the Indispensable Account. ${ }^{288}$ Thus, in the historiography of the Tibetan medical tradition, the Flight of the Great Khyung should be considered a scholastic continuation of the pedagogical narration enterprise begun in the Indispensable Account of Transmission, addressing the audience of the reader-as-disciple.

As has already been described in secondary literature, the Flight of the Great Khyung presents medical literature as one of the five sciences (rig gnas lnga) and, like the Buddhist teachings, divides medical literature into works that are the scriptural Word of the Buddha (sangs rgyas kyi bka) and those that are the commentarial treatises (bstan bcos) of subsequent sages and scholars. ${ }^{289}$ After placing its instructions within an emphatically Nyingma cosmological narrative, ${ }^{290}$ the Flight imparts the life story of Śākyamuni Buddha at length, beginning with his incarnation as the Devaputra Dampa Tokkar (lha'i bu dam pa tog dkar po; lit. the Divine Son, Holy White Tip), his descent from the heavens, his birth, and many of the other famous acts of Sākyamuni Buddha. Interestingly, Paktön intersperses information about

Herodotean and Thucydidean Tradition," in The Classical Foundations of Modern Historiography (Berkeley, CA: University of California Press, 1990), 29-53.

${ }^{288}$ Khyung chen lding ba, in Cha lag bco brgyad, I8: "Similarly, regarding the origins of how this tantra is not only a tantra, but also a textual instruction and an oral instruction, it is clear in the Sealed Account" (de ltar rgyud lung man ngag gsum ldan gyi rgyud 'di ji ltar yin pa'i khungs ni rnam thar bka' rgya can na gsal lo/). Here Paktön refers to the Indispensable Account by its alternative title, the Sealed Account (rnam thar bka' rgya can). It is also known as the Sealed Teaching (bka' rgya ma).

${ }^{289}$ See Frances Garrett, "Buddhism and the Historicising of Medicine in Thirteenth-century Tibet," Asian Medicine 2, no. 2 (2006): 204-24; and, more recently, Gyatso, Being Human, I52 et passim. In the latter Gyatso notes that the Indispensable Account appears to serve as a "revelation account," while the Flight of the Great Khyung serves as an "origin account" (p. I52), referencing her own article for these two terms: "The Logic of Legitimation in the Tibetan Treasure Tradition," History of Religions 33, no. 2 (1993): 97-I34.

${ }^{290}$ Khyung chen lding ba, in Cha lag bco brgyad, 4: "Thus, if one realizes, one will be a buddha. If one does not realize, one will diverge as a sentient being. With experience of All Good's awareness, one should engage in preaching the doctrine, and the buddhas of the three times shall appear like the sands of the Ganges river. Erroneously not recognizing the mind, the erroneous cycle in which sentient beings of the three realms neither wane nor wax shall appear" (de'i phyir rtogs te sangs rgyas ma rtogs par sems can du rgya gyes so/_kun tu bzang po'i rig pa'i nyams de chos su smras pa'i rjes su zhugs pa la dus gsum gyi sangs rgyas gang+ga'i klung gi bye ma tsam byung ngo /_sems ngo ma shes te 'khrul pa las/_khams gsum gyi sems can zad pa med cing 'phel ba med pa'i 'khrul 'khor 'byung ngo /). Compare this cosmogonic narrative to those found in Erik Pema Kunsang, Wellsprings of the Great Perfection.

W. A. McGrath | Buddhism and Medicine in Tibet | 99 
Sākyamuni's medical training, explicitly stating that he "trained in sports and the five sciences" (sgyu rtsal dang rig pa'i gnas lnga la blo sbyangs so) as a youth, that "all of his peccant humors arising from the illusory body were purified" (sgyu lus las byung bai nyes pa thams cad dag) when he was practicing austerities, and so forth. Following his enlightenment, he went on to turn the three wheels of the medical teachings:

Furthermore, while [turning] the first wheel [of the teachings], [Śākyamuni] imparted the medical texts of the Vinaya Discipline. While [turning] the second [wheel of the teachings], he imparted the Great Tantra of Nakedly Seeing Awareness in 3,500 chapters to Ānanda, as well as the Tantra of the Crystal Mirror in fifty chapters. While [turning] the third [wheel of the teachings], he imparted the chapter from the Holy Sutra of Golden Light to the Noble Goddess Bodhisattvasamuccayā in which Jalavāhana, son of the merchant captain, totally pacified disease. ${ }^{291}$

At that very moment, the Buddha emanated as the Master of Medicine and imparted the Secret Essence of the Ambrosia of the Science of Healing in Eight Branches: An Instructional Tantra. Emanating as Viśvakarman, he composed [works for] the Science of Creation, and so forth. Emanating however necessary for their training, he composed works for the sake of sentient beings. After the Buddha passed beyond sorrow, his teachings were compiled into the Three Baskets. ${ }^{292}$

Again we see a mingling of the sincere and the subjunctive. Works that have been considered Buddha Word for thousands of years-such as the medical instructions found in the Discipline ('dul ba) and the chapter on medical instructions found in the Sutra of Golden Light ( $m$ do gser'od dam pa) — as listed alongside massive and eternally given works that are no longer extant. ${ }^{293}$ In the second paragraph cited above, Paktön effectively links the overarching narrative found in the Four Tantras - the narrative in which Sage Rikpé Yeshé and Sage Yilé Kyé each emanate from the Master of Medicine (sman gyi bla)-with the life story of

${ }^{291}$ Khyung chen lding ba, in Cha lag bco brgyad, 7-8: de yang 'khor lo dang po'i dus su 'dul ba sman gyi lung bka'stsal/_gnyis pa'i dus su kun dga' bo la gcer mthong rig pa'i rgyud chen po le'u sum stong lnga brgya dang /_shel gyi me long gi rgyud le'u lnga bcu pa bka' stsal to/_gsum pa’i dus su mdo gser 'od dam pa las/_rigs kyi lha mo byang chub yang dag par sdud pa la tshong dpon gyi bu chu 'bebs kyi nad rab tu zhi bar byas pa'i le'u bka'stsal to/.

${ }^{292}$ Khyung chen lding ba, in Cha lag bco brgyad, 8: de'i tshe de'i dus na sangs rgyas sman gyi bla ru sku sprul nas/_gso ba rig pa bdud rtsi snying po yan lag brgyad pa gsang ba man ngag gi rgyud bka' stsal to/_bi shwa karmar sprul nas bzo'i rig pa rnams mdzad do/_gzhan yang de la sogs pa gang la gang 'dul du sprul nas sems can de dang de’i don mdzad do/_sangs rgyas mya ngan las 'das nas bka' ste snod gsum du bsdus so/.

${ }^{293}$ See David B. Gray, "On the Very Idea of a Tantric Canon: Myth, Poilitics, and the Formation of the Bka' 'gyur," Journal of the International Association of Tibetan Studies 5 (2009): I37. www.thlib.org?tid=T5690; as well as the discussion below. 
Sākyamuni Buddha. In doing so he collapses the provisional boundaries of the five sciences as all actually being the teachings of the Buddha. ${ }^{294}$

This lengthy telling of the life story of Śākyamuni Buddha effectively serves to ground the contested status of the Four Tantras as Buddha Word in the universally accepted life narrative of the Buddha. Paktön does not solely rely upon these narrative accomplishments, however, because in a subsequent section he shifts to scholastic criteria for distinguishing Buddha Word from treatises. He states clearly that "eloquent speech in which a buddha acts as the controlling condition and speaks is Buddha Word,"295 where the notion of a "buddha acting as the controlling condition" (sangs rgyas kyis bdag rkyen mdzad) is the operative phrase. The controlling condition (bdag rkyen) is one of four conditions (rkyen bzhi) that are used to describe the epistemological processes involved in perception, as well as the conditions for the straying of sentient beings and so forth. ${ }^{296}$ Paktön also refutes neo-conservative (gsar ma) notions that only speech spoken by the lips of a buddha is considered Buddha Word and anything taught after his death would be considered treatise. ${ }^{297}$ For Paktön, Sākyamuni Buddha does not have to be the "immediately antecedent condition" (de ma thag pa'i rkyen)that is, the as-is speaker of a teaching - for that teaching to be considered Buddha Word. Instead, he proposes three criteria:

[I.] Actual Buddha Word that was spoken from the lips [of Śākyamuni Buddha],

[2.] Word that has been blessed [by the Buddha], and

[3.] Word that has been permitted [by the Buddha] for the retinue. ${ }^{298}$

Elaborating upon the above narrative, Paktön also provides the following examples:

${ }^{294}$ On this passage Garrett writes: "Many readers will recognise this common literary trope, in which, as Timothy Barrett puts it, all Buddhist history is located in the personal history of the Buddha" (Garrett, "Buddhism and the Historicising of Medicine in Thirteenth-century Tibet," 215; citing Timothy Barrett, "History," in Critical Terms for the Study of Buddhism, ed. Donald Lopez [Chicago, IL: University of Chicago Press, 2005], 134). This notion directly contradicts Gyatso's hypothesis that khokbuk curricula serve to create "alternate textual space" for medical history, which she contrasts with religious (Buddhist) history. See Gyatso, Being Human, I33 et passim.

${ }^{295}$ Khyung chen lding ba, in Cha lag bco brgyad, IO: legs par gsungs pa'i sangs rgyas kyis bdag rkyen mdzad nas gsungs pa de bka' 'o/.

${ }^{296}$ The four conditions are the causal condition (rgyu'i rkyen), the objective condition (dmigs pa'i rkyen), the controlling condition (dbag po'i rkyen), and the immediately antecedent condition (de ma thag pa'i rkyen). On these four conditions, see Germano, Poetic Thought, 7I, I78-82, 887.

${ }^{297}$ Khyung chen lding ba, in Cha lag bco brgyad, IO: de ltar ma gyur te sangs rgyas zhal bzhugs pa'i dus su gzhungs tshad bka'/_mya ngan las 'das nas gsungs tshad bstan bcos so zer ba dang /_zhal nas gsungs pa bka'_ma gsungs pa bstan bcos so zer ba mi rigs te skyon yod/.

${ }^{298}$ Khyung chen lding ba, in Cha lag bco brgyad, IO-II: zhal nas gsungs pa dngos kyi bka'/byin gyis brlabs pa'i bka'/'khor la rjes su gnang ba'i bka' 'o/. 
Regarding the specific identification of Buddha Word and treatises in the Science of Healing, if one were to ask what constitutes such [medical] Buddha Word: [I.] the medical texts in the Vinaya Discipline, the Holy Sutra of Golden Light, the Great Tantra of Nakedly Seeing Awareness, and the Tantra of the Crystal Mirror are all Buddha Word spoken from the lips [of Śākyamuni Buddha]. ${ }^{299}$

[2.] The Secret Essence of the Ambrosia in Eight Branches: A Tantra of Instructions was blessed [by Sākyamuni Buddha] because the emanated teacher, the Sage Rikpé Yeshé, and the Sage Yilé Kyé engaged in dialogue with the blessings of the Victoriously Transcendent One Gone Thus, Victor over Enemies, Completely Perfect Buddha, Master of Medicine, King of Beryl Light, after he entered into the balanced absorption of the King of Medicines That Pacify the Four Hundred and Four Diseases. Furthermore, because its [teachers] are emanations that cannot be differentiated from [Śākyamuni Buddha] himself, [the Four Tantras] was also taught as [I.] actual Buddha Word. ${ }^{300} \ldots$

[3.] Regarding permitted Buddha Word, [the buddhas] have given permission to the Lord Protectors of the Three Families in India, China, and the Upper Western Regions. As stated in another text:

The knowledge holder lineages of all medicine Were first created by the Protectors of the Three Families. ${ }^{301}$

Therefore, [works composed by the Protectors of the Three Families] are permitted Buddha Word. They also are treatises composed by bodhisattvas. ${ }^{302}$

${ }^{299}$ Khyung chen lding ba, in Cha lag bco brgyad, II: khyad par gso ba rig pa'i bka' dang bstan bcos ngos gzung ba ni 'di'i bka' gang la bya zhe na/_dul ba sman gyi lung dang /_mdo gser 'od dam pa gcer mthong rig pa'i rgyud chen po/_shel gyi me long gi rgyud rnams ni zhal nas gsungs pa'i bka' 'o//.

${ }^{300}$ Khyung chen lding ba, in Cha lag bco brgyad, II: bdud rtsi snying po yan lag brgyad pa gsang ba man ngag gi rgyud 'di dang /_de yang byin gyis ji ltar brlab na/_bcom ldan 'das de bzhin gshegs pa dgra bcom pa yang dag par rdzogs pa'i sangs rgyas sman gyi bla bai Dūrya 'od kyi rgyal po del_nad bzhi brgya rtsa bzhi zhi bar byed pa'i sman gyi rgyal po zhes bya ba'i ting nge 'dzin la snyoms par zhugs pa'i byin gyis brlabs la/_sprul pa'i ston pa drang srong rig pa'i ye shes dang /_drang srong yid las skyes gnyis kyis zhu lan mdzad pa'i phyir ro/_gzhan yang tha mi dad pa nyid las sprul pa yin pa'i phyir dngos kyi bka' ru yang 'gro gsung ngo /.

30I On the provenance of this quotation, see the discussion below.

${ }^{302}$ Khyung chen lding ba, in Cha lag bco brgyad, I3: rjes su gnang ba'i bka' ni jo bo rigs gsum mgon po la/_rgya gar rgya nag_stong [=stod] phyogs gsum gyis rjes su gnang ba byin pas tel_de yang lung gzhan las/_sman kun brgyud pa'i rigs 'dzin nil/_dang por rigs gsum mgon pos mdzad//_ces pa rjes gnang gi bka' yin la/_byang chub sems dpas mdzad pa’i bstan bcos kyang yin no//. 
Thus, Paktön is relatively clear in his proposal. Works that were [I.] spoken by buddhas, [2.] taught by emanations of buddhas, and [3.] taught by bodhisattvas in association with buddhas should all be considered Buddha Word. The most ambiguous category of the three is the third, for Paktön neglects to provide any examples and writes that this category of Buddha Word could also be called "treatises composed by bodhisattvas" (rjes gnang gi bka' yin la/_byang chub sems dpas mdzad pai bstan bcos kyang yin no//). ${ }^{303}$ Regardless, as he explicitly states, the Four Tantras was not only [2.] taught by emanations of buddhas but also, because these emanations cannot be distinguished from an actual buddha, they also should be considered [I.] actual Buddha Word (dngos kyi bka').

For Paktön, medical scriptures effectively constitute the formative texts of medical scholasticism that we explored in Chapter Two. He describes many categories of treatises, but the largest distinction is between those that rely upon scripture ( $b k a$ ' la brten pa) and those that do not (ma brten pa). Among treatises that do rely upon scripture, there are those that are composed of scriptural exegeses (lung 'grol ba) and those that are scriptural summaries (lung bsdus pa). Among the treatises that do not rely upon scripture, there are those that are meaningful (don yod pa), those that are not meaningful (don med $p a$ ), and those that are perverse in meaning $(\operatorname{lon} \log p a){ }^{304}$ Thus, although all treatises that properly rely upon scripture appear to be meaningful, such is not necessarily the case for treatises that do not.

With this great emphasis upon scripture as the root of all valid medical meaning, Paktön is surprisingly creative in his classification of what should and should not be considered as scripture. For example, few Tibetan Buddhists would argue with the designation of the medical teachings found in the Vinaya Discipline and the Holy Sutra of Golden Light as being the actual Word of the Buddha, but, as far as I am aware, the Great Tantra of Nakedly Seeing Awareness and the Tantra of the Crystal Mirror-particularly the former, which is said to be 3,500 chapters long-are not widely attested. The evocation of conspicuously lengthy and presently non-extant ur-texts is not unique to the Tibetan medical tradition, of course. In the words of David Gray, such works collectively act as "empty signifier[s], pointing toward an absent corpus that served as a displaced locus of authority... [and] vital ideological links to the Buddhas, d़̄kiniss, and siddhas who are thought to have manifested them." ${ }^{305}$ Thus, in addition to verifying the status of the Four Tantras as Buddha Word, Paktön creates intellectual space for thousands of chapters of medical elaborations that could also be considered Buddha Word.

Although the Great Tantra of Nakedly Seeing Awareness is not, as far as I know, cited before the propagation of the Flight of the Great Khyung, it is indeed attested in subsequent khokbuk curricula! Drangti Penden Tsojé, redactor of the Eighteen Partial Branches and student of Paktön Shākya Gönpo, cites the Great Tantra of Nakedly Seeing Awareness, as well as other mythological ur-texts, to great effect. Regarding the quotation from "another text" (lung gzhan

${ }^{303}$ Compare, for example, the Heart Stura that was technically taught by Avalokiteśvara. ${ }^{304}$ Khyung chen lding ba, in Cha lag bco brgyad, II. 
las) found above, for example, Drangti Penden Tsojé also cites this verse to explain permitted (rjes su gnang ba) Buddha Word, but in a slightly expanded fashion:

Regarding permitted [Buddha Word], just as [the buddhas] have commanded the Protectors of the Three Families to heal the diseases of beings, as stated in the Heap of Jewels: $:^{06}$

On Five-peaked Mountain (Chi. wutai shan 五台山) in China,

Mañjuśrī emanated as a parrot in order to teach.

On Rooster Claw Mountain (Skt. kukkuțakapādagiri) near Bodh Gaya,

Avalokiteśvara emanated as a sage in order to teach.

On Gou Shanti Mountain in Oḍḍiyāna,

Vajrapāni emanated as a demon in order to teach. ${ }^{307}$

And, as stated in the Diagonal Thread of the Essence of Mañjuśri:

In India, China, and the Upper Western Regions,

Are the three traditions of the great bodhi[sattvas].

The knowledge holder lineages of all medicine

Were first created by the Protectors of the Three Families. ${ }^{308}$

As the careful reader may have already recognized, Drangti Penden Tsojé appears to have taken the germ of Paktön's quotation, along with a segment of his introduction to that quotation, and located it within the mythical Diagonal Thread of the Essence of Mañjuśri ('jam dpal snying gi zur thig). Unlike the Heap of Jewels (rin po che spungs pa)-another mythological ur-tantra passed from Paktön to Drangti-the Diagonal Thread of the Essence of Mañjuśri appears only once in Drangti's Expanded Elucidation of Knowledge. Regardless of the clear discrepancy between the details of Drangti's own citation and that of his teacher Paktön, this elusive Diagonal Thread of the Essence of Mañjuśrī appears again in the influential writings of

${ }^{305}$ Gray, "On the Very Idea of a Tantric Canon," 22.

${ }^{306}$ Gsang ba man ngag gis [sic] rgyud kyi spyi don shes bya rab gsal rgyas pa (Beijing Ms), 22a: rjes su gnang ba ni/_rigs gsum mgon po la 'gro ba'i nad gsos cig par gnang ba lta bu stel_rin po che spungs parl.

${ }^{307}$ Gsang ba man ngag gis [sic] rgyud kyi spyi don shes bya rab gsal rgyas pa (Beijing Ms), 22a: sprul pas rgya nag ri bo rtse lnga rul/_'jam dpa'i dbyangs kyis ne tsor sprul nas bshad//_rdo rje gdan drung ri bo bya rkang dul/_spyan ras gzigs kyis drang srong sprul nas bshad//_dbu rgyan yul du go'u shan ti la//_phyag na rdo rjes bdud du sprul nas bshad//_ces gsungs shing /.

${ }^{308}$ Gsang ba man ngag gis [sic] rgyud kyi spyi don shes bya rab gsal rgyas pa (Beijing Ms), 22a: 'jam dpal snying gi zur thig tul/_rgya gar rgya nag stod phyogs gsum//_lugs gsum byang chub chen po yin//_sman kun brgyud paï rigs'dzin yang //_dang po rigs gsum mgon pos mdzad//_ces so/. 
Zurkhar Lordö Gyelpo (zur mkhar blo gros rgyal po, b. 1509), ${ }^{309}$ the Desi Sanggyé Gyatso, ${ }^{310}$ and others, but never beyond the context of this single quotation. Thus, despite the trend of increasingly sincere historiography that gains traction in the sixteenth and seventeenth centuries, this particular instance of subjunctive scholasticism persists undetected and unedited.

\section{The Collection of Medicine}

As we have seen above, Paktön Shākya Gönpo, the presumed author of the Flight of the Great Khyung, effectively presents Buddha Word scriptures as the formative texts of medical scholasticism, and treatises as the meaningful derivatives of such scriptural foundations. Although he promotes several different scriptures as the core of the Tibetan medical tradition, including the Four Tantras, his discussion of treatises is dominated by a single work: the Collection of Medicine (gso dpyad 'bum sde).

Regarding the treatises of the Science of Healing, those that were composed in reliance upon the Collection of Medicine: the Essence of the Secret: A Summary by the Great Brahmā; the Magic Mirror of Medical Practices by Prajāpati Kaśyapa; the text on the Structure of the Thoracic Cavity, the Radiant Jewel Tantra, and so forth, including many other works on medical practice by Śakra [Indra], Lord of the Gods; and the Somarāja, the Five Discourses, the Umuta [?], the Lamp of the Secret Nucleus, and so forth by Nāgārjuna. ${ }^{\text {II }}$

This list is a collection of both extant (most of the works attributed to Nāgārjuna) and nonextant (everything else) works that all mythically extend from the primordial teachings of the Collection of Medicine. The part of the title that I translate as "collection" ('bum sde) literally refers to a series of one hundred thousand verses, but also comes to have a generic sense of a collection writings. Brahmā is said to have summarized this lengthy ur-text, followed by several other prominent figures that are said to be involved in the primordial transmission of the Science of Healing (gso ba rig pa), or the Science of Life (Tib. tshe yi rig byed = Skt. àyurveda).

Alluding to the origin narrative found in the Essence of the Eight Branches and translated above, Paktön provides precise titles for the contributions of Prajāpati (skye dgu'i bdag), Indra

${ }^{309}$ See Sman pa rnams kyis mi shes su mi rung ba’i shes bya spyii khog dbubs (Chengdu: Si khron mi rigs dpe skrun khang, 200I), I75.

3 Iо See his Mirror of Beryl: A Historical Introduction to Tibetan Medicine, trans. Gavin Kilty (Boston: Wisdom Publications, 2009), IOI.

${ }^{3 I I}$ Khyung chen lding ba, in Cha lag bco brgyad, I3: gso ba rig pa'i bstan bcos ni tshangs pa chen pos gso dpyad 'bum sde la brten nas/_gsang ba'i snying po'i don bsdus mdzad/_skye rgu'i bdag po myur bas gso dpyad 'phrul gyi me long mdzad/_lha'i dbang po brgya byin gyis byang khog stod khrems kyi lung dang /_rin po che 'od 'phro ba'i rgyud la sogs pa gso dpyad gzhan du ma mdzad/_slob dpon klu sgrub kyis so ma rā dza la sogs/_mdo lnga dang /_u mu ta dang /_gsang thig sgron ma la sogs pa mdzad do//. 
(brgya byin), and so forth, instead of leaving them as vaguely conceived tantras. In addition to Atri (rgyun shes) and Agniveśa (me bzhin ’jug), Paktön names six other sages and asserts that each of them composed one of eight tantras in the [Compendium of] Caraka in Eight Sections. ${ }^{312}$ Although there is no evidence of a pre-modern translation of the Caraka in Tibetan, ${ }^{313}$ Paktön provides a detailed list of contents for the work. ${ }^{314}$ His list of contents does not clearly map upon the textus receptus of the Caraka, however-he lists eight sections in seventy-eight books (sde brgyad kyi bam po bdun cu rtsa brgyad) and I048 chapters in total, for example, compared to the eight sections in 120 chapters in the textus receptus $-{ }^{315}$ perhaps again propagating an imagined library of medical ur-texts. Paktön provides further lists of treatises authored by sages, ${ }^{316}$ filling in the inherited mythology of Indian medicine with further details and perhaps inviting future scholars to participate in such a project.

Paktön's elaborations are not limited to lists, however. He takes the seminal opening of the Essence of the Eight Branches and, indeed, all of the Indian medical tradition, ${ }^{317}$ and provides context for Brahmā's remembering (dran) of the Science of Life (tshe yi rig byed, àyurveda). He begins with the story of the aforementioned Collection of Medicine:

${ }^{312}$ Khyung chen lding ba, in Cha lag bco brgyad, I3-I4: drang srong rgyun shes dang nam [nab] so skyes dang /_thang la 'bar dang /_rkang [dka'] gnyis spyod dang /_drob skyong gi bu dang /_me bzhin 'jug dang /_lug nag dang /_rgya skyag [skyegs] sna dang /_brgyad kyis tsa ra ka sde brgyad mdzad/.

${ }^{313}$ Neither the Compendium of Caraka nor that of Suśruta were translated into Tibetan before the modern age. For a modern translation of the Caraka, see Lobsang Tenzin and Losang Norbu Shastri, trans., Drang srong chen po me bzhin 'jug gis mdzad pa'i tsa ra ka'i bsdu ba [Carakasaṃhitā of Maharși Agniveśa] (Varanasi: Central Institute of Higher Tibetan Studies, 2006).

${ }^{314}$ Khyung chen lding ba, in Cha lag bco brgyad, I4: de la sman gyi rkos gdab pa'i sde le'u brgya dang bco lnga/_bsgrub lugs kyi sde le'u lnga bcu/_sman gyi sde tshan bstan pa'i le'u brgya dang bcu drug_'jigs med mtshon cha'i sde le’u lnga bcu rtsa gsum/_bdud rtsi bsgrub pa'i sde le’u brgyad/_srog gi sgrom bu'i sde le'u lnga bcu rtsa bzhi/_gso byed sman sbyor gyi sde le'u brgya dang bcu gsum/_sbyong byed las lnga'i sde le'u bco lnga ste/_spyir bsdoms pas le’u lnga brgya dang nyi shu rtsa bzhi/_sde brgyad kyi bam po bdun cu rtsa brgyad mdzad do//.

${ }^{315}$ For a description of the contents of the Caraka, see Meulenbeld, A History of Indian Medical Literature, vol. Ia, pp. 7-I8o (esp. p. 93). For an English translation, see P. V. Sharma, Caraka Saṃhitā (Varanasi: Chaukhambha Orientalia, 198I-I994), 4 vols.

${ }^{316}$ Khyung chen lding ba, in Cha lag bco brgyad, I4: drang srong rgyun shes kyis yan lag brgyad pa chen mo mdzad/_nam [nab] so skyes kyis brgyad pa la 'jug pa mdzad/_drang srong dpal ldan 'phreng bas stod 'grel glo'i spar khab dang /_smad 'grel 'phrul gyi lde mig ste tsa ra ka'i 'grel pa mdzad/_smad gzer 'phrul gyi lde mig mdzad/.

${ }^{317}$ On the Brāhmaṇic appropriation of medicine, see Kenneth G. Zysk, "Mythology and the Brāhmaṇization of Indian Medicine: Transorming Heterodoxy into Orthodoxy," in Categorisation and Interpretation: Indological and Comparative Studies from an International Indological Meeting at the Department of Comparative Philology, Göteborg University, ed. Folke Josephson (Göteborg: Novum Grafiska AB, I999), I25-45.

W. A. McGrath | Buddhism and Medicine in Tibet | 106 
Regarding the Collection of Medicine, it is the blessed [teachings] of the World Grandfather, Brahmā. Furthermore, as stated in the Heap of Jewels: ${ }^{318}$

Sākyamuni, in this Uncreated Sahā World, ${ }^{319}$

Composed the great medical text to heal the diseases of the five poisons.

With the blessings of Sāk[y]amuni, the Supreme God Brahmā remembered them.

Some non-Buddhist extremists assert that that Brahmā taught it earlier, but this is mistaken. ${ }^{320}$

Again citing the unattested Heap of Jewels, Paktön explicitly states his agenda: Sākyamuni Buddha composed a great medical text, the Collection of Medicine, and taught these instructions to Brahmā. Brahmā later remembered these teachings with the blessings of Sākyamuni and therefore, as stated above, the Collection should be considered "blessed Buddha Word" (byin gyis brlabs pa'i bka'). Expanding upon this citation with extensive details-just as he does in regard to the origin myth of the Essence of the Eight Branches-Paktön provides the context of Brahmā's remembering of the Collection:

If one were to ask, how was Brahmā blessed, ${ }^{321}$ long ago, when the gods and the anti-gods were both churning the ocean of milk, they used Mount Meru as the churning stick, and Ananta, King of the Serpent Spirits, and Nimindhara [the furthest of seven mountain ranges surrounding Mount Meru] as the churning rope. From the peak of Mount Meru, Grandfather Brahmā pressed down and they churned the ocean. ${ }^{322}$

At that moment, from the constituents of the world lacking a sun and moon, first the sun emerged: it's seed was established with the five types of jewels, its surrounding [rays] were established with fire crystals, and its extent of fifty-one yojana miles was established from the collective merit of sentient beings. "This is like the mother $(\mathrm{ma})$ of all sentient beings!"

${ }^{318}$ Khyung chen lding ba, in Cha lag bco brgyad, II: gso dpyad 'bum sde ni' ’ig rten gyi mes po tshangs pas byin gyis brlabs pa ste/_de yang rin po che spungs pa las/.

319 The Fearless Sahā World (Tib. mi ’jed ’jig rten = Skt. sahāloka) is here rendered as the Uncreated World (mi 'byed 'jig rten), which, in light of all the creation that ensues, may be an intentional play on words.

${ }^{320}$ Khyung chen lding ba, in Cha lag bco brgyad, II: shākya thub pa mi 'byed 'jig rten 'dir//_dug nga'i nad sel sman gzhung chen po brtsams//_shAk[y]a thub byin rlabs lha mchog tshangs pas dran//_mu stegs kha cig tshangs pa snga zer 'khrul//_zhes pas shes so/.

${ }^{32 \mathrm{I}}$ The grammar of this passage makes it appear that Brahmā was the agent of the blessings and not the subject, but this is not supported by the story.

${ }^{322}$ Khyung chen lding ba, in Cha lag bco brgyad, II-I2: tshangs pas ji ltar byin gyis brlabs she nal_sngon lha dang lha ma yin gnyis kyi 'o ma can gyi mtsho bsrubs te/_ri rab la srub shing byas/_klu'i rgyal po mtha' yas dang /_mu khyud'dzin gnyis la srubs thag byas/_mes po tshangs pas ri rab kyi spyi bo nas mnan nas bsrubs pas/. 
they exclaimed, and it came to be called the "sun" (nyi ma). After putting [the aforementioned ingredients?] in a box of the four winds, they threw it into a rift in the sky and the sun emerged. ${ }^{323}$

After further churning, the moon emerged. [The moon] also has and [extent of] fifty-one yojana miles, and the surrounding [rays] were established with water crystals. "Now what is this companion (zla bo) of the [sun]?" they asked. Thus, it came to be called the "moon" (zla $b a)$, and they threw it into the sky. ${ }^{324}$

After further churning, the Poison Grandfather emerged, with flaming hair and beard, filling up the rift in the sky, and all the gods and anti-gods became frightened. From the lips of Brahmā: ${ }^{325}$

You are the Poison Grandfather, You are the Poison Grandmother, Om a tha! $!^{226}$

Thus, animate poisons-such as the [poison of the] alangka bug, dog poison [=rabies], snake [poison], and so forth—each dissolved [into its host], the inanimate poisons—such as the strong poison [=aconite], goat poison [=aconite], sun spurge, nightshades, and so forth-each dissolved [into its host], and the Black Man [=Poison Grandfather] dissipated. ${ }^{327}$

Although we are far from finished churning the ocean of milk, let us pause for a brief discussion. This origin story of the Collection of Medicine is clearly a Tibetan adaptation of the "Churning of the Ocean" (samudra manthana) story, which came to be known throughout most

${ }^{323}$ Khyung chen lding ba, in Cha lag bco brgyad, I2: de'i dus na 'jig rten gyi khams na nyi zla med pa las/_dang po nyi ma byung ste de yang rgyu rin po che sna lnga las grub/_mu khyud me shel las grub pal_rgyar dpag tshad lnga bcu rtsa gcig yod pa zhig sems can spyi mthun gyi bsod nams las grub pa byung ngo /_'di sems can thams cad kyi ma ru 'dug go zhes grags pas nyi ma zhes btags nas/_rlung bzhi'i sgrom du bcug nas nam mkha'i mthongs su btang ba las nyi ma byung ngo/.

${ }^{324}$ Khyung chen lding ba, in Cha lag bco brgyad, I2: yang bsrubs pas zla ba byung ste/_de yang dpag tshad lnga bcu yod pa/_mu khyud chu shel las grub pa zhig byung bas 'di da ci'i de'i zla bor'dug go zer nas zla ba zhes btags te nam mkha' la btang ngo /.

${ }^{325}$ Khyung chen lding ba, in Cha lag bco brgyad, I2: yang bsrubs pa las dug gi mes po skra dang ag tshom mer 'bar bal_nam mkha'i mthongs khengs pa zhig byung ba la/_lha dang lha ma yin rnams skrag par gyur to/_tshangs pa'i zhal nas/.

${ }^{326}$ Khyung chen lding ba, in Cha lag bco brgyad, I2: khyod ni dug gi mes po ste/_khod ni dug gi phyi mo stel_om a thal.

${ }^{327}$ Khyung chen lding ba, in Cha lag bco brgyad, I2: zhes brjod pas/_rgyud ba'i dug_srin po a lang ka dang /_khyi dug sbrul la sogs pa rang rang la thim mo/_mi rgyu ba'i dug ni/_btsan dug dang /_ra dug_thar nu/_kha shog la sogs pa rang rang la thim nas mi nag po de dngos med du gyur to/. 
of Asia. ${ }^{328}$ In the Mahābhärata telling of the tale, however, the Tibetan-language folk etymologies of the sun and moon are nowhere to be found and, perhaps most importantly, it is Siva that famously defeats the embodiment of poison, not Brahmā. ${ }^{329}$ Indeed, even in the Gold Measure (gser bre) collection of the Drangti family, several chapters dedicated to toxicology are also explicitly framed within Saiva mythology. ${ }^{330}$ Precedents for this removal of Siva from his classical account can be found in the Four Tantras itself, for in the "Section on the Healing of Poisoning" (dug nad gso ba'i skabs) in the Instructional Tantra (man ngag rgyud), we find several Āyurvedic categories for toxicology, but no mention of Śiva himself. ${ }^{331}$ Indeed, Chapter Eight-Nine on the "Healing of Animate and Inanimate Poisons" (rgyu ba dang mi rgyu ba'i dug gso ba'i le'u ste brgyad cu rtsa dgu ba) begins with a parallel narrative:

Hey, Great Sage, listen! The natural poisons can be divided into two classes: animate and inanimate [poisons]. During a previous age, the gods and the anti-gods desired to have ambrosia and so they churned the ocean. A being with golden hair, eyes blazing with fire, and a frightening form [emerged]. Thus Brahmā uttered hūm and, [after the being] disintegrated, ${ }^{332}$ [poison] dissolved into animate and inanimate [forms]. Inanimate [poisons] include: aconite, strong poison [=aconite], wolfsbane, goat poison [=aconite], poison oak, nightshades, horse hair [poison], and so forth. Animate [poisons] include: mad dog [poison; =rabies], snake [poison], scorpion [poison], bug poison, and so forth. ${ }^{333}$

${ }^{328}$ Different versions of the tale can be found in the Bhägavata Purāna, Mahäbhärata, and the Viṣnu Purāna. For a brief description, see Wendy Doniger O'Flaherty, The Origins of Evil in Hindu Mythology (Berkeley, CA: University of California Press, 1976), 332-33.

329 See, for example, Pratap Chandra Roy, The Mahabharata of Krishna-Dwaipayana Vyasa (Calcutta: Oriental Publishing Co., I883-I896), book I (Adi Parva), sections I7-I9 (Astika Parva), pp. 64-69.

${ }^{330}$ See Brang ti lha rje'i rim brgyud kyi man ngag gser bre chen mo (Lhasa: Bod ljongs mi dmangs dpe skrun khang, 2005), 82-I42. Note that several of these chapters (especially those associated with Siva) have been elided from alternative volumes. On the tantric healing of poison in Saiva tantra, see Michael Slouber, Early Tantric Medicine: Snakebite, Mantras, and Healing in the Gāruḍa Tantras (Oxford: Oxford University Press, 20I6).

${ }^{331}$ On these chapters and their precedents, see Yang Ga, Sources for the Writing of the Rgyud bzhi, 235-38.

332 The term I translate here as "disintegrating" (pra yas) involves the word pra, which surely refers to prasenā described in Chapter One, and yas, which much mean something like "to transcend" or even "to lack." I interpret pra to refer to the appearance of the poison being and yas to refer to its loss of appearance.

${ }_{333}$ Dpal ldan rgyud bzhi dpe bsdur ma, vol. 2 b (smad), p. 603: kye drang srong chen po nyon cig/_rang bzhin dug la rgyu dang mi rgyu gnyis//_sngon gyi dus su lha dang lha min gyis//_bdud rtsi'dod nas rgya mtsho bsrubs pa las//_skyes bu skra ser mig nas me 'bar bal/_jigs pa'i gzugs can don de tshangs pa yis//_hüm brjod pra yas rgyu mi rgyu la thim//_mi rgyu bong nga btsan dug spyang dug dang //_ra dug bse shing thang phrom rta spu sogs//_rgyu ba khyi smyon sbrul dang sdig pa dang //_sring bu ba yi dug la sogs pa yin//. 
Thus, although the author of this chapter of the Subsequent Tantra, as well as Paktön, or whoever the author of the Flight of the Khyung may be, are both indebted to South Asian mythological traditions and the Âyurvedic terminology of "animate" (Tib. rgyu ba = Skt. jangama) and "inanimate" (Tib. mi rgyu ba = Skt. sthāvara) poisons, the actual poisons listed under each category and, indeed, the very details of the story itself reflect Tibetan sensibilities. ${ }^{334}$

Moving on to the second half of the "Churning of the Ocean," we witness the production of the essential opposite of the Poison Grandfather (dug gi mes po; as he is called in the Flight) or the "unnamed being with golden hair, eyes blazing with fire, and a frightening form" (skyes bu skra ser mig nas me 'bar bal/_'jigs pa'i gzugs can; as he is called in the Four Tantras) - that is, ambrosia ( $b d u d r t s i)$, the nectar of immortality. With the ambrosia having been stolen by Rāhu (sgra gcan), we finally learn of the primordial origins of the Collection of Medicine:

After further churning, a jar filled with ambrosia emerged. Then, atop Mount Meru in the Mansion of Complete Victory, Brahmā and the rest of the gods, along with the leaders of the anti-gods, arranged themselves hierarchically. After the jar had been opened and the gods and anti-gods were all beginning to pass it around, Rāhu thought, "This ambrosia is extremely difficult to find. I had better drink it and run away!" And, with such dualistic conceptions, he drank the ambrosia and fled. ${ }^{335}$

As Brahmā and the others were chasing after him, as soon as they were able to catch him, Rāhu hurled his blade wheel, which had been established from his own merit and endowed with the four commitments, and struck the cheeks of Brahmā. Brahmā, hurling the blade wheel back, cut the neck of Rāhu. Regarding this, as stated by Master Nāgārjuna: $:^{336}$

Previously, the astrological being Rāhula, Having drunk the ambrosia, Had his head cut off by a wheel, the Sonorous One.

334 Again, see Yang Ga, Sources for the Writing of the Rgyud bzhi, 235-38; for a discussion of precedents for these chapters.

${ }^{335}$ Khyung chen lding ba, in Cha lag bco brgyad, I2: yang bsrubs pa las/_bdud rtsi bum pa gang byung ste/_de nas ri rab steng du rnam par rgyal ba'i khang bzang du/_tshangs pa la sogs pa'i lha rnams dang I_lha ma yin gyi dbang po rnams gral rim par bshams te/_sgra gcan gyis bum pa kha phye nas lha dang lha ma yin thams cad la 'dren par brtsam pa las/_sgra gcan gyi bsam pas/_bdud rtsi 'di ni shin tu rnyed par dka' ba yin na rang gis 'thungs te bros pa legs snyam nas/_gnyis 'dzin gyi rtog pas bdud rtsi 'thungs nas bros so/.

${ }^{336}$ Khyung chen lding ba, in Cha lag bco brgyad, I2-13: tshangs pa la sogs pas phyi bzhin du ded pas zin la khad pa dang /_sgra gcan gyis kho rang gi bsod nams las grub pa'i mtshon cha'i 'khor lo dam bca' bzhi ldan bya ba yod pa 'phangs pas/_tshangs pa'i mkhur tshos la phog pas/_yang tshangs pas mtshon cha'i 'khor lo 'phangs pas sgra gcan gyi ske bcad do//_de yang slob dpon klu sgrub kyi zhal nas/. 
Brahmā aided Viṣṇu in battle. ${ }^{337}$

Because his cheeks had been pierced, Brahmā came to suffer. Because he had not been fully trained by Śākyamuni, with his blessings [Brahmā] remembered the Collection of Medicine and immediately his wounds healed naturally. Regarding this: $:^{338}$

Previously, the sound of the two syllables [sic], om and atha,

Manifestly coincided with the

Damaging of the cheeks of Brahmā.

Thus, these two [syllables] are auspicious. ${ }^{339}$

The latter half of Paktön's tale approximately follows that of the "Churning of the Ocean" tale found in the Mahābhārata, which culminates in Rāhu's theft and consumption of the gods' hard-earned ambrosia. ${ }^{340}$ Again Paktön adapts the tale to fit his own sensibilities, however, for instead of Nārāyaṇa (Viṣnu) hurling his famed weapon, the Wheel of Auspicious Vision (Skt. sudarśanacakra) and immediately chopping off the head of Rāhu, here it is Rāhu who has wounded Brahmā with his own blade wheel (mtshon cha'i 'khor lo), before ultimately being decapitated himself. In his citation that I have been unable to trace, we do learn of Viṣnu's involvement, however, as well as his weapon, the Sonorous One (sgra ldan). ${ }^{34 \mathrm{I}}$

But what is at stake in this creative wounding of Brahmā? Following the piercing of his cheeks by Rāhu, Brahmā is said to have remembered (dran pa) the Collection of Medicine (gso dpyad 'bum sde) with the blessings of Saakyamuni Buddha, thereby miraculously healing his wounds. By telling this story Paktön has effectively: [I.] specified the origins of (Indian) medicine as being the mythical Collection of Medicine, whence derives all other works of Āyurveda, and [2.] established Sākyamuni Buddha as the ultimate teacher of the Collection,

${ }^{337}$ Khyung chen lding ba, in Cha lag bco brgyad, I3: sngon tshe gza' skar rā hu las//_bdud rtsi 'thungs tshe mgo bo ni//_sgra ldan gyis ni 'khor los bcad//_tshangs pas khyab 'jug 'thab grogs btang //. I have been unable to locate this quote in the vaste ouvre attributed to Nāgārjuna.

${ }^{338}$ Khyung chen lding ba, in Cha lag bco brgyad, 13: tshangs pa mkhur mtshos kyi thor bas sdug bsngal du gyur pa la shākya thub pas dngos su ma thul te/_byin gyis brlabs pa las/_gso dpyad 'bum sde dran pa tsam gyis rma rang bzhin gyis gsos so//_de yang/.

${ }^{339}$ Khyung chen lding ba, in Cha lag bco brgyad, I3: yi ge om dang a tha'i sgral/_gnyi po 'di dag sngon tshangs pa'i//_mkhur tshos rdol te mngon par byung //_des na 'di gnyis bkra shis yin//_zhes pas mngon te/.

${ }^{340}$ Again, see Pratap Chandra Roy, The Mahabharata of Krishna-Dwaipayana Vyasa (Calcutta: Oriental Publishing Co., I883-I896), book I (Adi Parva), sections I7-I9 ("Astika Parva”), pp. 6469. On the role of Rāhu in this and other tales, see also Cameron Baily, "The Demon Seer: Rāhula and the Inverted Mythology of Indo-Tibetan Buddhism," Journal of the International Association of Buddhist Studies 38 (2015): 33-72.

${ }^{34 I}$ I have been unable to identify a Sanskrit precedent for this name, but apparently the "suddenly sonorous one" ('ur sgra can) is an old term that refers to an arrow. As we shall see below, this term was not understood by later authors either.

W. A. McGrath | Buddhism and Medicine in Tibet | III 
positioning Brahmā as the blessed redactor. In doing so, Paktön was also able to relativize the medical teachings of Brahmā as derivative from fundamentally Buddhist teachings, thereby [3.] appropriating all of Âyurveda (including the Essence of the Eight Branches) as a Buddhist derivative. Finally, Paktön was also able to [4.] weave several distinct Indian narratives into one cohesive history-including Indian myths like Brahmā's remembering of medicine and the "Churning of the Ocean"-while also [5.] incorporating distinctly Tibetan sensibilities, like the origins of distinctly Tibetan poisons and the Tibetan etymologies of the sun and moon. Thus, despite the generally scholastic nature of the Flight of the Khyung, Paktön is also able to seamlessly weave together disparate literary sources and incorporate powerful arguments into his overarching narrative.

\section{Precedents for the Mythology of the Four Tantras}

These remarkable achievements in successfully weaving disparate non-Buddhist Indian myths and framing them within both Tibetan and emphatically Buddhist sensibilities are not unprecedented. As we have seen in the previous discussion, the narrative frame of the Four Tantras has provided an influential foundation for the entire history of the Tibetan medical tradition. In Sumtön's Indispensable Account of Transmission, for example, the teaching of the Four Tantras is set in the primordial interlocutions of the sages Rikpé Yeshé and Yilé Kyé, with the latter ultimately acting as the redactor. In Paktön's Flight of the Great Khyung, following his three turnings of the wheel of the medical doctrine, Sākyamuni Buddha emanates as the Master of Medicine and imparts the Four Tantras, among other teachings. Thus, despite the discrepancies between the narrated voices-the Master of Medicine emanating as Rikpé Yeshé in the former, and Sākyamuni emanating as the Master of Medicine in the latter-the narrative device of emanation (sprul pa) acts to smooth over any dissonance that might disrupt the coherence of the combined narratives.

\begin{tabular}{|c|c|c|c|c|c|c|}
\hline & $\begin{array}{c}\text { "Basis of } \\
\text { Discussion" } \\
\text { in the Root } \\
\text { Tantra } \\
\text { (ch. I) }\end{array}$ & $\begin{array}{c}\text { Root } \\
\text { Tantra } \\
\text { (chs. 2-6) }\end{array}$ & $\begin{array}{c}\text { Explanatory } \\
\text { Tantra } \\
\text { (3I } \\
\text { chapters; } \\
\text { chs. 7-37) }\end{array}$ & $\begin{array}{c}\text { Instructional } \\
\text { Tantra } \\
(92 \\
\text { chapters; } \\
\text { chs. 38-I29) }\end{array}$ & $\begin{array}{l}\text { Subsequent } \\
\text { Tantra (27 } \\
\text { chapters; } \\
\text { chs. I30- } \\
\text { I56) }\end{array}$ & $\begin{array}{c}\text { "Summary" } \\
\text { and } \\
\text { "Complete } \\
\text { Entrustment" } \\
\text { (chs. I55 and } \\
\text { I56) in the } \\
\text { Subsequent } \\
\text { Tantra }\end{array}$ \\
\hline Teacher & Victoriously & Rikpé & Rikpé & Rikpé & Rikpé & Rikpé Yeshé \\
\hline
\end{tabular}

${ }^{342}$ Dpal ldan rgyud bzhi dpe bsdur ma, 29: de ltar rtsa ba’i rgyud la le 'u drug/_bshad pa'i rgyud la le 'u sum cu gcig/_man ngag rgyud la le 'u dgu bcu gnyis/_phyi ma'i rgyud la le 'u nyi shu lnga/_rgyud bzhi bsdoms pas brgya dang lnga bcu bzhi/_mjug don yongs su gtad dang lnga bcu drug/. 


\begin{tabular}{|c|c|c|c|c|c|c|}
\hline (ston pa): & $\begin{array}{l}\text { Transcende } \\
\text { nt } \\
\text { Physician, } \\
\text { King of } \\
\text { Medicinal } \\
\text { Beryl Light }\end{array}$ & $\begin{array}{l}\text { Yeshé, } \\
\text { emanate } \\
d \text { from } \\
\text { the heart } \\
\text { (thugs) of } \\
\text { the King } \\
\text { of Beryl } \\
\text { Light }\end{array}$ & $\begin{array}{l}\text { Yeshé, } \\
\text { emanated } \\
\text { from the } \\
\text { body }(s k u) \\
\text { of the King } \\
\text { of Beryl } \\
\text { Light }\end{array}$ & $\begin{array}{l}\text { Yeshé, } \\
\text { emanated } \\
\text { from the } \\
\text { qualities } \\
\text { (yon tan) of } \\
\text { the King of } \\
\text { Beryl Light }\end{array}$ & $\begin{array}{l}\text { Yeshé, } \\
\text { emanated } \\
\text { from the } \\
\text { actions } \\
\text { (phrin las) } \\
\text { of the King } \\
\text { of Beryl } \\
\text { Light }\end{array}$ & \\
\hline $\begin{array}{c}\text { Medical } \\
\text { Concen- } \\
\text { tration } \\
\text { (sman } \\
\text { gyi ting } \\
\text { nge } \\
\text { 'dzin): }\end{array}$ & & $\begin{array}{l}\text { "King of } \\
\text { Medicine } \\
\text { s That } \\
\text { Pacify } \\
\text { the Four } \\
\text { Hundred } \\
\text { and Four } \\
\text { Diseases" } \\
\text { (nad bzhi } \\
\text { brgya rtsa } \\
\text { bzhi zhi } \\
\text { bar byed } \\
\text { pa'i sman } \\
\text { gyi rgyal } \\
\text { po) }\end{array}$ & $\begin{array}{l} \\
\text { "Roaring } \\
\text { Lion" (smra } \\
\text { ba'i seng ge) }\end{array}$ & $\begin{array}{l}\text { "Fulfillment } \\
\text { of Needs } \\
\text { and } \\
\text { Desires" } \\
\text { (dgos'dod } \\
\text { 'byung ba) }\end{array}$ & $\begin{array}{l}\text { "Lacking } \\
\text { Obstructio } \\
\text { n" } \\
\text { (thogs pa } \\
\text { med pa) }\end{array}$ & \\
\hline $\begin{array}{c}\text { Retinue } \\
\text { ('khor): }\end{array}$ & $\begin{array}{l}\text { The four } \\
\text { retinues }\end{array}$ & $\begin{array}{l}\text { Yilé Kyé, } \\
\text { emanate } \\
\text { d from } \\
\text { the } \\
\text { speech } \\
\text { (gsung) of } \\
\text { the King } \\
\text { of Beryl } \\
\text { Light }\end{array}$ & $\begin{array}{l}\text { Yilé Kyé, } \\
\text { emanated } \\
\text { from the } \\
\text { speech } \\
\text { (gsung) of } \\
\text { the King of } \\
\text { Beryl Light }\end{array}$ & $\begin{array}{l}\text { Yilé Kyé, } \\
\text { emanated } \\
\text { from the } \\
\text { speech } \\
\text { (gsung) of } \\
\text { the King of } \\
\text { Beryl Light }\end{array}$ & $\begin{array}{l}\text { Yilé Kyé, } \\
\text { emanated } \\
\text { from the } \\
\text { speech } \\
\text { (gsung) of } \\
\text { the King of } \\
\text { Beryl Light }\end{array}$ & $\begin{array}{l}\text { Yilé Kyé and, } \\
\text { briefly, the } \\
\text { four retinues }\end{array}$ \\
\hline
\end{tabular}

Table 4.I. Detailed Comparison of the Frame Narratives within the Four Tantras. 
Indeed, a certain degree of narrative dissonance can be found in the Four Tantras itself. ${ }^{343}$ As illustrated by Table 4.I, the majority of the Four Tantras is said to be the teachings of Rikpé Yeshé recorded by Yilé Kyé, but each of these interlocutions are placed within a larger frame of emanation. In each of the Four Tantras Rikpé Yeshé is said to emanate from a different quality of the Master of Medicine, King of Beryl Light, connecting the frame established in the first chapter of the Root Tantra, the so-called "Basis of Discussion" (gleng gzhi). Like other bases of discussion found in Buddhist scriptures-particularly Buddhist tantras - ${ }^{344}$ this opening narrative frame of the Four Tantras describes the five sublime contexts (phun sum tshogs pa lnga) of the teaching of the Four Tantras as being, in addition to the [I.] place of Beautiful to Behold (lta na sdug):

[2. Teacher:] Upon a jeweled throne made of blue beryl in the center of the inestimable mansion sits the teacher, the Victoriously Transcendent Physician, King of Medicinal Beryl Light. ${ }^{345}$

[3.] The Retinues of the Teacher: Retinues of gods and sages, [non-Buddhists] Outsiders and [Buddhists] Insiders all gather around. ${ }^{346}$

[3a.] The Retinues of Gods: The physician of the gods Prajāpatikșipra, the physician of the gods Aśvin, the lord of the gods Sahasrākșa [Indra], the goddess Amṛtavatī, and so forth. Many retinues of gods abide together. ${ }^{347}$

[3b.] The Retinues of Sages: The great sages Atriputra, Agniveśa, Nimindhara, Kaśyapanandana, Hārīta, Dvipadacarya, Dhanvantari, Punarvasutva [Viṣnu], and so forth. Many retinues of sages abide together. ${ }^{348}$

${ }^{343}$ For an overview of the contents of the Four Tantras, see Barbara Gerke, "The Art of Tibetan Medical Practice," in Bodies in Balance: The Art of Tibetan Medicine, ed. Theresia Hofer and Barbara Gerke (New York, NY: Rubin Museum of Art, 20I4), 2I, Table I.I.

${ }^{344}$ For a discussion of the term, "basis of discussion" (gleng gzhi) in a different context, see Christopher Hatchell, Naked Seeing: The Great Perfection, the Wheel of Time, and Visionary Buddhism in Renaissance Tibet (Oxford: Oxford University Press, 2014), 385-86, n. 27.

${ }^{345}$ Dpal ldan rgyud bzhi dpe bsdur ma, I9: gzhal yas khang de’i dbus na nor bu baiḍūrya’i [gdan/khri] la ston pa bcom ldan 'das 'tsho_mdzad sman gyi bla baidūurya 'od kyi rgyal po zhes bya ba bzhugs so/. This translation was prepared in consultation with Barry Clark, trans., The Quintessence Tantras of Tibetan Medicine (Ithaca, NY: Snow Lion, 1995), 23-25.

${ }^{346}$ Dpal ldan rgyud bzhi dpe bsdur ma, 19: ston pa de la 'khor ni lha dang drang srong dang phyi pa dang nang pa'i 'khor bzhis yongs su bskor ba ste/.

${ }^{347}$ Dpal ldan rgyud bzhi dpe bsdur ma, I9: gang zhe na lha'i 'khor ni 'di lta stel_lha'i sman pa skye [rgu'i/dgu'i] bdag po myur ba dang /_lha'i sman pa tha skar dang /_lha'i dbang po brgya byin dang /_lha mo bdud rtsi ma la sogs pa lha'i 'khor mang po dang thabs cig tu bzhugs so/.

${ }^{348}$ Dpal ldan rgyud bzhi dpe bsdur ma, I9: drang srong gi 'khor ni 'di lta ste/_drang srong chen po rgyun shes kyi bu dang /_me bzhin 'jug dang /_mu khyud 'dzin dang /_['gro ba/'drob] skyong gi bu dang /_gshol 'gro skyes dang /_dka' gnyis spyod dang /_thang la 'bar dang /_[nabs/nams] so skyes la sogs pa drang srong gi 'khor mang po dang thabs cig tu bzhugs so/.

W. A. McGrath | Buddhism and Medicine in Tibet | II4 
[3c.] The Retinues of [non-Buddhist] Outsiders: The [non-Buddhist] extremist Grandfather Brahmā, Mahādeva Śrī Jațika, Viṣnu, the six-faced Kumāra, and so forth. Many such retinues of [non-Buddhist] extremists abide together. ${ }^{349}$

[3d.] The Retinues of [Buddhist] Insiders: Noble Mañjuśrī, Avalokiteśvara, Vajrapāṇi, Ānanda, Jīvaka Kumāra, and so forth. Many such retinues of insider [Buddhists] abide together. ${ }^{350}$

[4.] Time: That very moment. ${ }^{351}$

[5. The Teaching:] With every word spoken by the teacher, the four kinds of retinues would each hear a teaching of their own individual system. This is called the "System of the Sages (drang srong)," for it straightens out (drang por bsrangs [=srong]) one's body, speech, and mind such that there are no peccant humors and one can balance the imbalanced peccant humors of others. ${ }^{352}$

Curiously, Rikpé Yeshé and Yilé Kyé are nowhere to be found in this opening chapter of the Four Tantras (see also Table 4.I). The Retinue of the Sages (drang srong gi 'khor) is described in detail, for example, and the teaching of the Four Tantras is called the "System of the Sages" (drang srong gi lugs), and yet neither Rikpé Yeshé nor Yilé Kyé is named explicitly. This could be easily explained away by the fact that they are merely emanations of the King of Beryl Light who is, of course, present, but as we have seen in the writing of Paktön, emanations are wonderfully effective in reconciling narrative dissonance. Furthermore Brahmā, who plays the important role as the propagator of the Collection of Medicine for Paktön's narrative, is also conspicuously placed in a Retinue of the Outsiders (phyi pa'i 'khor) and derogatorily called the "extremist Grandfather Brahmā" ( $m u$ stegs kyi mes po tshangs pa), instead of being placed in the Retinue of the Gods (lha'i 'khor) where we might initially expect to see him. Thus, the opening narrative found in the "Basis of Discussion" in the Four Tantras appears to represent a relatively early and polemic layer in the narration of the Four Tantras.

Further narrative dissonance can be found when we compare the "Basis of Discussion" chapter of the Root Tantra with the "Back Section Summary" (mjug don bsdus pa) and "Complete Entrustment" (yongs su gtad pa) chapters of the Subsequent Tantra. In the "Summary" there is another reference to the four retinues described in the "Basis of Discussion," except instead of describing four unique understandings of the same teaching

${ }^{349}$ Dpal ldan rgyud bzhi dpe bsdur ma, I9-20: phyi pa'i 'khor ni 'di lta ste/_mu stegs kyi mes po tshangs pa dang /_mahā de ba shrī ral pa can dang /_khyab jug dang /_gzhon nu gdong drug la sogs pa mu stegs kyi 'khor mang po dang thabs cig tu bzhugs so/.

350 Dpal ldan rgyud bzhi dpe bsdur ma, 20: nang pa'i 'khor ni 'di lta ste/_phags pa 'jam dpal dang /_spyan ras gzigs dbang phyug dang /_phyag na rdo rje dang /_kun dga' bo dang /_tsho byed gzhon nu la sogs pa nang pa'i 'khor mang po dang thabs cig tu bzhugs so/.

${ }^{351}$ Dpal ldan rgyud bzhi dpe bsdur ma, 20: de’i tshe de’i dus na...

${ }^{352}$ Dpal ldan rgyud bzhi dpe bsdur ma, 20: ston pas gsungs pa'i tshig gcig la 'khor rnam pa bzhi so so rang rang gi ston pa'i lugs su go bar zad do/_'di ni rang gi lus ngag yid gsum nyes pa med par drang por bsrangs nas gzhan gyi nyes pa ma snyoms pa snyoms par byed pas drang srong gi lugs zhes bya'o/.

W. A. McGrath | Buddhism and Medicine in Tibet | II5 
('khor rnam pa bzhi so so rang rang gi ston pa'i lugs su go bar zad) as we saw above, the "Summary" lists four unique texts that were produced by each retinue and then summarized into the Four Tantras:

To the Retinue of Gods, the Collection of Medicine was taught;

To the Retinue of Sages, the [Compendium] of Caraka in Eight Sections;

To the Retinue of [Non-Buddhist] Extremists, the Tantra of Great İsvara;

To the Retinue of [Buddhist] Insiders, the Cycle of the Protectors of the Three Families;

All of these teachings have been summarized in this medical tantra. ${ }^{353}$

If we take this Collection of Medicine as the inspiration for the Collection of Medicine described in Paktön's narrative-which it undoubtedly is-it would appear that by the Subsequent Tantra, or the Flight of the Great Khyung at the very latest, the extremist Grandfather Brahmā has been relocated from his Outsider Retinue to the Retinue of the Gods. Other important transformations in these retinues are apparent as well, for the teaching of the Outsider Retinue-or, as it is called here, the Extremist Retinue-is explicitly linked to Śiva (İ́vara), potentially reflecting the same hostility toward Siva that we saw in the poison origin myth. Finally, although the Root Tantra describes its own teaching as that of the sages, in the Subsequent Tantra we learn that the Compendium of Caraka is the teaching of the sages, despite Caraka not being mentioned in the "Basis of Discussion." Thus, from the narration of the Root Tantra to that of the Subsequent Tantra there appears to have been a move from the total rejection of the Vedic pantheon to the selective assimilation of certain divine figures at the expense of Śiva alone. How are we to reconcile these apparent discrepancies?

Continuing the terminology introduced in Chapter Two, I propose that the author of the narrative found in the Subsequent Tantra-who, I argue, is a distinct figure from that of the Root Tantra-was writing under the assumptions of essentialist scholasticism. Instead of presenting the Four Tantras as just one of four potential systems-as is the case for the Root Tantra, leaving the other three teachings separate and ambiguous interpretations-the author of the Subsequent Tantra presents the Four Tantras as the essence of all four systems, which are each represented as mythical texts. Thus, just as Paktön was answering the call of the Subsequent Tantra in elaborating upon the mythology surrounding these medical ur-texts of the four retinues of the Master of Medicine, the Subsequent Tantra elaborates upon the precedents of the Root Tantra in the Tibetan assimilation of Indian gods and sages, Buddhist and otherwise.

${ }^{353}$ Dpal ldan rgyud bzhi dpe bsdur ma, 288: lha yi 'khor la gso dpyad 'bum pa gsungs/_drang srong 'khor la tsa ka sde brgyad/_mu stegs 'khor la dbang phyug [chen/nag] po'i rgyud/_nang pa'i 'khor la rigs gsum mgon po'i skor/_/gso dpyad rgyud 'dir thams cad'dus par bstan/. 


\section{Narrative Echoes from Mt. Wutai}

As we have seen previously, an important narrative character in the transmission of medicine to Tibet is the Indian—and emphatically Buddhist—sage Nāgārjuna. There are several works attributed to Nāgārjuna in the Tengyur canon of Translated Treatises (bstan 'gyur)—including the One Hundred Formulae (Skt. yogaśataka = Tib. sbyor ba brgya ba), ${ }^{354}$ the Sutra of Medical Healing (Skt. jīvasūtra = Tib. sman 'tsho ba'i mdo), ${ }^{355}$ and the Medical Ritual of Ava (Skt. ācāryanāgārjunabhāșitāvabheșajakalpa = Tib. slob dpon klu sgrub kyis bshad pa sman a ba'i cho ga). ${ }^{356}$ There also is a corpus of alchemical and medical materials that have been attributed to Nāgārjuna but remain outside of the Tengyur, such as the prasenā rituals of Chapter One or the influential Lamp of the Secret Nucleus (gsang tig sgron ma) mentioned in Chapter Two, and these works have an unclear relationship with the aforementioned canonical works. ${ }^{357}$ Regardless of his historical veracity, ${ }^{358}$ Nāgārjuna played an important role in Indian and Tibetan Buddhist narratives for he served as a Buddhist sage linking the known human world to the divine teachings of the gods. In one of the earlier and more explicit depictions of Nāgārjuna playing this role-the Medicine of the Moon King (sman dpyad zla ba'i rgyal po), also known as the Somarāja $a^{359}$-Nāgārjuna, surrounded by other Indian sages, acts as the requestor and redactor of the medical teachings given by Mañjuśrī.

${ }^{354}$ Bka' bstan dpe sdur khang, Bstan 'gyur dpe bsdur ma, vol. III (he [213]), 3-22. See Jean Filliozat, Yogaśataka; texte médical attribué à Nāgārjuna (Pondicherry: Institut Français d'Indologie, 1979); and Bhagwan Dash, "Sbyor-ba brgya-pa, vis-à-vis Yogaśataka: A Very Critical Study," in Tibetan Medicine: Theory and Practice (Dharamsala: Library of Tibetan Works and Archives, I976), 69-250.

${ }^{355}$ Bka' bstan dpe sdur khang, Bstan 'gyur dpe bsdur ma, vol. 213 (he), 23-33.

${ }^{356}$ Bka' bstan dpe sdur khang, Bstan 'gyur dpe bsdur ma, vol. 213 (he), 34-38.

${ }^{357}$ See, for example, the various medical works included in the Slob dpon klu sgrub kyi sman yig gces btus [A Selection of Medical Texts by Nāgārjuna], Bod kyi gso ba rig pa’i gna' dpe phyogs bsgrigs dpe tshogs, vol. 73 (Beijing: Mi rigs dpe skrun khang, 2008). See also David Gordon White, The Alchemical Body.

${ }^{358}$ Again, see Walser, Nāgārjuna in Context.

${ }^{359}$ For an overview of this work in Tibetan intellectual history, both traditional and modern, see van der Kuijp, "Za hor and Its Contribution to Tibetan Medicine, Part Two: Sources of the Tibetan Medical Tradition." The subsequent analysis is indebted to the insights presented by Professor van der Kuijp and is based on the following editions of the Moon King: Sman dpyad zla ba'i rgyal po, Bod kyi gso rig pa'i gna' dpe phyogs bsgrigs dpe tshogs, vol. 33 (Beijing: Mi rigs dpe skrun khang, 2005) [digitally input modern book edition of the Degé xylographic edition = MKDI]; Sman dpyad zla ba'i rgyal po: The Somarājabhaisajyasādhanā, an Indian medical work by Nāgärjuna, in its Tibetan translation, by Hashang Mahayana and Vairocana: Reproduced from a set of prints from the Sde-dge blocks from Library of Tashigang, Smanrtsis shesrig spendzod, vol. I35 (Leh: T. Y. Tashigang, 1989) [facsimile of the Degé xylographic print edition = MKDP]; Krung go'i bod lugs gso rig rtsa che'i dpe rnying kun btus, vol. 5, I-I38 [Moon King Manuscript A = MKMsA]; Krung go’i bod lugs gso rig rtsa che’i dpe rnying kun btus, vol. 5, 139-223 [Moon King Manuscript $\mathrm{B}=\mathrm{MKMsB}$; ; and just the first folio of an illuminated manuscript [MKMsC] referenced in van der Kuijp, "Za hor and Its Contribution to Tibetan Medicine, Part Two: 
The Degé xylographic edition of the Moon King, prepared with the help of Situ Panchen Chökyi Jungné (si tu pan chen chos kyi 'byung gnas, I700-I774) ${ }^{360}$ begins with several folios that are not included in the manuscript editions, explicitly stating that Mañjuśrī was teaching upon the central mountain of the "Five Peak Mountain," or Mt. Wutai, in China (Tib. gnas rgya”i ri bo rtse lnga’i dbus kyi ri la [= Chi. wutai shan 五台山]) to five retinues of four sages. ${ }^{361}$ Following a table of contents and a homage to both Mañjuśrī and Nāgārjuna, the scene of instruction begins with the description of five mountain peaks-one in each of the four cardinal directions and one in the center-in which each peak hosts four sages that are then each taught a different medical teaching by Young Mañjuśrī. This is all said to have been redacted by Nāgārjuna, one of the four great sages (drang srong chen po bzhi) atop the central mountain.

\begin{tabular}{|c|c|c|c|}
\hline $\begin{array}{l}\text { Mountain Name and } \\
\text { Position }\end{array}$ & Retinue & Teaching & Teacher \\
\hline $\begin{array}{l}\text { Center: Bhenḍā [?] }(b[h] e \\
\quad \text { ta ri })^{362} \\
\text { Okra (Abelmoschus } \\
\text { Esculentus L.)? }\end{array}$ & $\begin{array}{l}\text { Nāgārjuna (klu sgrub), the } \\
\text { redactor (sdud pa po) } \\
\text { [Jīvaka?] Kumāra, holding a } \\
\quad \text { blue lotus and a book } \\
\quad \text { (gzhon nu utpala po ti 'dzin) } \\
\text { Brahmā (tshangs pa) } \\
\text { Śakra [Indra] (brgya byin) }\end{array}$ & $\begin{array}{l}\text { Chapters I-5: } \\
\text { skeletal and bodily } \\
\text { anatomy (keng rus } \\
\text { [lus kyi rnam } \\
\text { gzhag]) })^{363}\end{array}$ & $\begin{array}{l}\text { Mañjuśrī: golden } \\
\text { body (gser mdog lta } \\
\text { bu’i sku) }\end{array}$ \\
\hline East: Aksota (akso ta ri) & Krsna [?] (sngo) & Chapter 6: etiology & \\
\hline
\end{tabular}

Sources of the Tibetan Medical Tradition"; and Rin chen rgyal, Sman dpyad zla ba'i rgyal po'i gzhung don la dpyad pa [An Analysis of Text and Meaning in the Medicine of the Moon King], Bod kyi 'bum rams pa'i dpyad rtsom dpe tshogs [Tibetan Doctoral Dissertation Publication Series] (Zi ling: Mtsho sngon mi rigs dpe skrun khang, 20II). In my translations I primarily rely on the Degé edition and note differences in the manuscripts when I deem it necessary.

${ }^{360}$ van der Kuijp, "Za hor and Its Contribution to Tibetan Medicine, Part Two: Sources of the Tibetan Medical Tradition," 83; citing Si tu Pan chen [Chos kyi 'byung gnas], The Autobiography and Diaries of Si tu Pan chen, edited by L. Chandra (New Delhi: Internatonal Academy of Indian Culture, I968), 696; and Si tu Pan chen [Chos kyi 'byung gnas] and 'Be Lo tsā ba [Tshe dbang kun khyab], Sgrub brgyud karma kam tshang brgyud pa rin po che'i rnam par thar pa rab 'by-ams nor bu zla ba chu shel gyi phreng ba, (New Delhi, 1972), vol. 2, 627.

${ }^{361}$ Sman dpyad zla ba'i rgyal po (MKDP), I-5 (ff. Ia-3a); Sman dpyad zla ba'i rgyal po (MKDI), 5-7. ${ }^{362}$ van der Kuijp, "Za hor and Its Contribution to Tibetan Medicine, Part Two: Sources of the Tibetan Medical Tradition," 84: "Bhe ta [=Vedali/Vidarbha]."

${ }^{363}$ The closing chapter (II3) gives a different description: "methods for dispelling diseases of wind, bile, phlegm, and their combination - which derive from desire, hatred, and stupidity." Sman dpyad zla ba'i rgyal po (MKDP), 406-407 (203b-204a):

be ta ri yi rste mo lal/_drang srong chen po bzhi rnams lal/_dod chags zhe sdang gti mug las/_rlung dang mkhris pa bad kan dang/_ldan pa 'dus pa 'byar bas nad/_bsal thabs 'khor la bka' stsal gtad//. 


\begin{tabular}{|c|c|c|c|}
\hline $\begin{array}{l}\text { Walnut Tree (Juglans } \\
\quad \text { Regia L.) }\end{array}$ & $\begin{array}{l}\text { Caraka (tsa ra ka) } \\
\text { Kāmajāta [= Kāmadeva?] } \\
\quad \text { ('dod pa skyes) } \\
\text { Kumāra (gzhon nu) }\end{array}$ & $\begin{array}{l}\text { (nad gzhi ci ltar } \\
\text { gnas pa) }\end{array}$ & \\
\hline $\begin{array}{l}\text { South: Gunjāàs [?] (gu ṇas) } \\
\text { Indian Licorice (Abrus } \\
\text { Precatorius L.)? }\end{array}$ & $\begin{array}{l}\text { Devaputra [Aśvinī] (lha yi bu } \\
\quad \text { [tha skar]) } \\
\text { Ātreya (rgyun shes) } \\
\text { Divyaguṇa [?] (lha yi yon tan) } \\
\text { Dhanvantari (thang [la] gnas) }\end{array}$ & $\begin{array}{l}\text { Chapters 7-52: } \\
\text { diagnosis (gnas } \\
\text { pa ngos bzung } \\
\text { ba) }\end{array}$ & $\begin{array}{l}\text { Mañjuśrī: saffron } \\
\text { body (gur gum lta bu'i } \\
\text { sku), equipped with } \\
\text { the "all-elucidating" } \\
\text { sword (ma lus gsal } \\
\text { mdzad ral dri'dzin) }\end{array}$ \\
\hline $\begin{array}{l}\text { West: Ava[rtakī ?] (a ba ri) } \\
\text { Tea Tree (Melaleuca } \\
\text { Alternifolia Cheel)? }\end{array}$ & $\begin{array}{l}\text { Agnīśa [= Agniveśa?] (me yi } \\
\quad \text { bdag) } \\
\text { [Mahā]kāla (nag po) } \\
\text { Kāśyapa ('drob skyong) } \\
\text { Kāya [?] (ka ya) }\end{array}$ & $\begin{array}{l}\text { Chapters 53-94: } \\
\text { magical } \\
\text { remedies and } \\
\text { practices (sman } \\
\text { dang dpyad kyi } \\
\text { rdzu'phrul) }\end{array}$ & $\begin{array}{l}\text { Mañjuśrī: golden } \\
\text { body of expansive } \\
\text { qualities (yon tan } \\
\text { rgyas pa'i sku mdog } \\
\text { gser dang 'dra), } \\
\text { equipped with the } \\
\text { sword and book of } \\
\text { "natural insight" } \\
\text { (shes rab rang bzhin } \\
\text { ral gri po ti'dzin) }\end{array}$ \\
\hline $\begin{array}{l}\text { North: Sītā Aśoka (si ta } \\
\text { a[k]śo ta) } \\
\text { Ashoka Tree (Saraca } \\
\text { Asoca) }\end{array}$ & $\begin{array}{l}\text { Kāṣṭhādeva [?] (shing gi lha) } \\
\text { Śyāmanīla [= Kṛṣna?] (ljang } \\
\quad \text { sngon) } \\
\text { Candra (zla ba) } \\
\text { Sūrya (nyi ma) }\end{array}$ & $\begin{array}{l}\text { Chapters 95-II2: } \\
\text { the potencies of } \\
\text { medicine made } \\
\text { from earth, } \\
\text { water, wood, } \\
\text { and stone (sa } \\
\text { dang chu dang } \\
\text { shing dang rdo } \\
\text { ste sman gyi nus } \\
\text { pa) }\end{array}$ & \\
\hline
\end{tabular}

${ }^{364}$ See discussion in Philologia Tibetica.

365 The opening chapter has a much more extensive description: "On earth and water, trees and herbs; how astringent and salty [flavors] dispel wind disease; how bitter and sweet [flavors] overcome bile disease; how sour and hot [flavors cure] phlegm disease; and methods for dispelling the combined wind, bile, and phlegm." Sman dpyad zla ba'i rgyal po (MKDP), IO (5b): sa dang chu dang shing dang sngo/_/bska dang lan tshwas rlung nad sel/_/kha dang mngar bas mkhris pa 'joms/_/skyur dang tsha bas bad kan no//_/rlung dang mkhris pa bad kan dang /_/ldan dang 'dus pa sbyar bas nad/_/sel thabs 'khor la bka' stsal to/. 
Table 4.2. The Narrative Frame of the Medicine of the Moon King ${ }^{366}$

As noted above, the editors of Degé edition explicitly identify the five peaks in the frame story of the Moon King as the famed Mt. Wutai that is currently found in Shanxi Province of the People's Republic of China. Other than this preface added by the editors of the Degé edition, however, nowhere in the texts available to me is there an explicit reference to Mt. Wutai. As Professor van der Kuijp observes, in addition to the relationship between Mt. Wutai and Mañjuśrī, in yet another manuscript available to him,

Of fundamental significance is that ... the manuscript of the Sman dpyad zla ba'i rgyal po (ms.: Ib-2b) ... consistently has ghe'u de shan for the Sde dge xylograph's be ta ri. Tibetan ri surely reflects Chinese shan 山, "mountain." Further, there is little doubt that we should see in ghe'u de an early pronunciation of wutai 五台. For this reason, I am inclined to submit that Ghe'u de shan reflects Chinese 五台山. ${ }^{367}$

The names of the mountains as they are listed in other editions are not as easily identified, but each probably refers to Indian medicinal trees and herbs. The name bhe ta may refer to bheṇ̂ā, which is Sanskrit for "okra" (Abelmoschus Esculentus L.); akșo ta probably refers to akṣota, or "walnut tree" (Juglans Regia L.); gu ṇa sa may refers to gunjās, or "Indian licorice" (Abrus Precatorius L.); a ba may refer to avartakī, or "tea tree" (Melaleuca Alternifolia Cheel); and sita aśo ta probably refers to sītā aśoka, the "ashoka tree" (Saraca Asoca). Thus, despite the widely understood connection between Mañjuśrī and Mt. Wutai, if it were not for later editors the identification of the five peaks featured in the Moon King with Mt. Wutai would remain almost entirely implicit.

Returning to the peak of the central mountain, Bheṇ̣ā, the Noble Youth Mañjuśrī ('phags pa 'jam dpal gzhon nu) appears in a golden body (gser mog lta bu'i sku) with the four sages gathered around him. Requesting teachings on anatomy and so forth, Master Nāgārjuna, bodhisattva of the first ground (dang po sa ni thob pa), sings his praises:

${ }^{366}$ See Sman dpyad zla ba'i rgyal po (MKDP), 8-10 (4b-5b), and 406-407 (203b-204a). The closing chapter is essentially a restatement of the opening chapter, and both MKMsA and MKMsB each lack this account in their closing chapters, causing me to think that later editors added the II3th chapter of the Degé edition, "The Entrustment [of the Text] to the Four Sages and Master Nāgārjuna's Praise for Noble Mañjuśrī” (drang srong bzhi la gtad pa dang //_slob dpon klu sgrub kyis 'phags pa 'jam dpal la bstod pa).

${ }^{367}$ van der Kuijp, "Za hor and Its Contribution to Tibetan Medicine, Part Two: Sources of the Tibetan Medical Tradition," 85, n. 83. On the importance of Mt. Wutai for Tibetans even during the eighth, ninth, and tenth centuries, see Christopher Beckwith, "The Tibetans in the Ordos and North China: Considerations on the Role of the Tibetan Empire in World History," in Silver on Lapis: Tibetan Literary Culture and History, ed. Christopher I. Beckwith (Bloomington, IN: Tibet Society, I987), 9, n. 30; cited in Sam van Schaik and Imre Galambos, Manuscripts and Travellers: The Sino-Tibetan Documents of a Tenth-Century Buddhist Pilgrim (Berlin: Walter de Gruyter GmbH \& Co. KG, 20I2), 39, n. I4.

W. A. McGrath | Buddhism and Medicine in Tibet | 120 
Mañjuśrī, sitting upon your throne of a fearless lion,

To you, whose brilliance dispels pain like the body of the sun,

To you, whose clear light dispels disease like the moon,

To you, professing supreme being, I pay homage and sing praises. ${ }^{368}$

Following this stanza of praise, Nāgārjuna requests the teachings that go on to form the majority of the Moon King:

Mañjuśrī, how should sentient beings of the world

Establish [positive] karmic causes?

How should they understand illness and suffering?

How should they relieve pain ? $^{369}$

Noble Mañjuśrī then smiles three times ('dzum pa lan gsum) and responds:

I shall teach the scriptures

To you, the one endowed with compassion,

The one endowed with the strength of profound insight,

To you, Nāgārjuna, I shall transmit the teachings. ${ }^{370}$

Not unlike the Four Tantras, the Moon King is also generally organized according to several teachings that are given by Mañjuśrī to distinct retinues. Unlike the Four Tantras, howeverwhere all teachings are framed as an interlocution between Rikpé Yeshé and Yilé Kyé-each of the topics in the Moon King is taught to a distinct retinue on a distinct mountain space (Table 4.2). This central focus on an interlocution between Mañjuśrī and Nāgārjuna can be found most explicitly in this cited passage from the "Basis of Discussion" (gleng gzhi), but is

${ }^{368}$ This stanza is included in both the opening and the final chapter of the Moon King. Sman dpyad zla ba'i rgyal po (MKDP), Io (5b): mi 'jigs seng ge’i khri la bzhugs//_nyi ma'i sku ltar gzi brjid zug rngu [nad kyi] sel//_zla ba [bsil bas tshad nad] lta bur 'od gsal nad rnams sel//_smra ba'i skyes mchog sku la phyag 'tshal bstod//. Ibid., 407 (204a): 'jam dpal mi 'jigs seng ge’i khri la bzhugs/_nyi ma'i sku ltar gzi brjid zug ngu sel/_zla ba lta bus 'od gsal nad rnams sel/_smra ba’i skyes mchog sku la phyag 'tshal bstod/.

${ }^{369}$ Sman dpyad zla ba'i rgyal po (MKDP), Io (5b): jam dpal bcud kyi sems can [kyad par can] rnams//_las dang rgyu ni ci las grub//_nad dang [rgyu rkyen shes] sdug bsngal ci ltar [bshad kyis nyon] shes//_zug rngu dag ni ci ltar bsal//.

${ }^{370}$ Sman dpyad zla ba'i rgyal po (MKDP), Io (5b): gsungs pa ston pas lung bstan pal/_khyod ni thugs rje ldan pa'i sku//_shes rab zab mo'i stobs ldan pa'i//_klu sgrub khyod la bshad par bya'o//. The lack of plurality in the second-person pronouns of this stanza is rather important. Had it been plural (khyed) instead of singular (khyod), the addressee of the second line may have been all the 
restated only once more in Chapter Two, the "Anatomy of the Body and Skeleton" (lus keng rus kyi rnam par gzhag pa). ${ }^{371}$ Instead, despite the shift of setting found in Chapters Six, Seven, Fifty-Three, and Ninety-Five (see Table 4.2), each one merely begins by restating the name of the mountain and that four unnamed sages had formed the retinue (drang srong bzhi yis bskor $b a) .{ }^{372}$ Other interlocutors are interspersed throughout the chapters, however, such as the Aśvinī (tha skar dag) and Indra, Lord of the Gods (lha dbang brgya byin), indicating that Nāgārjuna may not have always been the central redactor of the Moon King. ${ }^{373}$ Importantly, both chapters that explicitly name the Aśvinì are instructions for urinalysis and are within the specified range of chapters for which the Aśvinī were part of the retinue (Table 4.2). In fact, all of these chapters (chs. IO-I4) that outline instructions for urinalysis repeatedly reference the audience of Devaputra Aśvinī. ${ }^{374}$ Thus, like the ten subsequent channel examination chapters (chs. I5-24), ${ }^{375}$ chapters IO-I4 seem to form a sub-collection of related teachings but, unlike other chapters throughout most of the work, it also maintains a recurring narrative frame referenced throughout the teachings of the chapters.

Another aberration in the narrative frame of the Moon King can be found in chapter fortyeight, the "Cranial Skeleton and the Characteristics of Wounds" (mgo"i keng rus dang rma'i mtshan nyid). The observant reader may have noticed that this chapter title treats the skeleton (keng rus), which is also listed as the first teaching at Mt. Bhenḍa in the narrative frame (Table 4.2). Thus, here again we find redundancy:

And then [Mañjuśrī] spoke again:

Such is the teaching for each of the four hundred and four diseases,

sages. With the exception of the modern book edition (MKDI, 9), all editions (including the Degé xylograph facsimile, MKDP) read singular (khyod) instead of plural (khyed).

${ }^{371}$ Even this reference is somewhat implicit, however, for only the phrase "Master" (slob dpon) is written, with "Nāgārjuna" (klu grub) added as an interlinear note. See MKMsA, 3 (f. 5a).

${ }^{372}$ See MKMsA, p. II (f. I6a), p. I4 (f. 2Ib), p. 58 (f. 87a), and p. IIO (f. I66a), respectively.

${ }^{373}$ For the Aśvinī, see Chapters Eleven and Fourteen, each of which begins with Noble Mañjuśrī teaching the Aśvinī. See MKMsA, p. I9 (f. 28a): de nas 'phags pa 'jam dpal gyis//_tha skar dag la gsungs pa ni//; and MKMsA, p. 22 (f. 32b): de nas yang bcom ldan 'das kyis//_lha'i bu tha skar la bka' stsal pal/.

${ }^{374}$ For the only English-language study that has focused on any of these chapters-although, she only focuses on Chapter Ten-see Ronit Yoeli-Tlalim, "On Urine Analysis and Tibetan Medicine's Connections with the West," in Studies of Medical Pluralism in Tibetan History and Society, ed. Sienna Craig, Mingji Cuomu, Frances Garrett, and Mona Schrempf (Halle: International Institute for Tibetan and Buddhist Studies, 20IO), 195-2II. Despite all the merits of this essay, herein she makes no mention of the Aśvinī (or chapters II-I4, for that matter).

${ }^{375}$ For selected translations from these chapters, see my "Vessel Examination in the Medicine of the Moon King," in Buddhism and Medicine: An Anthology, edited by C. Pierce Salguero (New York, NY: Columbia University Press, 2016 [forthcoming]). See also Zhen Yan. 
As well as the sudden diseases. ${ }^{376}$

Then Śakra [Indra], Lord of the Gods asked:

The causes of disease are: wind, bile, and phlegm, ${ }^{377}$

The communion of the seeds of one's parents and one's karmic actions, Flesh, channels, and bones,

And fluids, as well as sudden injury to the essential viscera and bowels, And so forth. But what are their external manifestations? $?^{378}$

[To which Mañjuśrī replied:]

Upon the peak of the eastern mountain, I shall teach the etiology of disease.

Upon the peak of the southern mountain, I shall teach visual, interrogational [or olfactory], and haptic examination.

Upon the peak of the western mountain, I shall teach alchemical extraction and [medical] formulae.

Upon the peak of the northern mountain, I shall teach the magic of [medical] practice.

In the center, to the four sages,

I shall teach the anatomy of the skeleton and body. ${ }^{379}$

Now, with the exception of "[medical] formulae" (sbyor ba) being taught on the western peak and the "magic of [medical] practice" (dpyad kyi rdzu 'phrul) being taught in on northern peak, this schema approximately corresponds to that of Table 4.2. Of fundamental importance, though, is the fact that this is not Nāgārjuna requesting the teachings of Mañjuśrī, but Indra, the Vedic Lord of the Gods! With the exception of this excerpt, I am not aware of Indra acting as interlocutor in any other chapters, but he is listed as one of the sages on the central

${ }^{376}$ MKMsA, p. 47 (f. 7ob): de nas yang gsungs pal/_so so bzhi brgya rtsa bzhi’i nad /_glo 'ur [=bur] nad dag bstan nas ni/.

${ }^{377}$ Importantly, MKMsA lists this entire stanza as "causes" (rgyu) of disease, while ???? list only the three humors as causes, and relegates the other constituents as the "conditions" (rkyen) of disease.

${ }^{378}$ MKMsA, p. 47 (f. 7ob): de nas lha dbang brgya byin gyis/_rgyu ni rlung 'khris bad kan dang /_pha ma'i sa bon 'tshogs pa las/_sha dang rtsa dang rus pa dang /_chu ba don snod glo 'ur gyi/_mtshon tssogs bsbun rtags gang yin pa/.

${ }^{379}$ MKMsA, p. 47 (ff. 7ob-7Ia): shar phyogs ri’i rtse mo la/_nad gzhi ci ltar gnas pa bstan/_lho'i ri’i rtse mo la/_blta dang dri dang reg pa bstan/_nub phyogs ri’i rtse mo la/_bcud len sbyor ba bstan pa yin/_byang phyogs ri’i rtse mo la/_dpyad kyi rdzu 'phrul bstan pa dang /_dbus su drang srong bzhi dag la/_keng rus lus kyi rnam gzhag bstan/. 
mountain (Table 4.2). Thus, this conversation may indeed be a relic of a previous narrative frame in which the Moon King was requested not by Nāgārjuna, but by Indra, where the first chapter began not in the center, but in the east. ${ }^{380}$

Indra and the Aśvinī are, of course, important figures found in the narrative frames of Āyurveda. They both appear in the Essence of the Eight Branches (see above), and Indra is particularly central in the transmission of medical teachings to the sages in the Compendium of Caraka. ${ }^{381}$ Although when compared with the narrative frame of the Four Tantras, the Tibetan assimilation of Indian narratives and mythical characters in the frame of the Medicine of the Moon King is not nearly as explicit or consistent, the core of each narrative is the same: the origin of all medical teachings - both Buddhist and non-Buddhist - is inherently Buddhist. In the case of the Four Tantras, this was achieved through complex emanation schemes, paired with polysemous understandings of the Buddha's emanated teachings. In the case of the Moon King, it is Mañjuśrī at the central mountain teaching the retinue of sages, who appear to have shifted from Vedic gods depicted as sages, to more commonly recognized Buddhist sages like Nāgārjuna and Jivvaka Kumāra. ${ }^{382}$ Although we may not have the documents necessary to demonstrate the Nāgārjuna's replacement of Indra as the central interlocutor in the Moon King, a lost textual link preserved in the writings of a later author may provide enough evidence to confidently link the mountainous landscape of the Moon King with the interlocutions of Rikpé Yeshé and Yilé Kyé found in the textus receptus of the Four Tantras.

\section{The Great Tantra, the Lesser Tantra, the King of Tantras, and the Four Tantras}

Very little is known about the early transmission of the Four Tantras. The Indispensable Account of Transmission describes an Essence of Ambrosia in Eight Branches (bdud rtsi snying po yan lag brgyad pa) that was redacted by Sumtön Yeshé Zung based on the teachings of Yutok Gönpo in a jina horse year (rgyal po rta lo; probably II74). Outside the descriptions found in the Indispensable Account of Transmission-which itself has been demonstrably expanded upon and edited by subsequent authors (Figure I.2) - we know very little information about this proto-Four Tantras, if you will. In light of the centrality of Rikpé Yeshé and Yilé Kyé in the Indispensable Account, however, I would argue that we can extrapolate that these two figures

${ }^{380}$ Colophon discrepancies between the Degé xylograph edition and the two manuscripts available to me already indicate a significant degree of editing. I would not be surprised if this trend of editing continued deeper into the reaches of time, but only further manuscript evidence could prove this hypothesis.

${ }^{381}$ See Meulenbeld, A History of Indian Medical Literature, vol. Ia, pp. 7-I8o (esp. p. 93); Sharma, Caraka Saṃitā, vol. I.

${ }^{382}$ For the role of Jivvaka Kumāra in Indian and Chinese Buddhist medical traditions, see Demiéville, Buddhism and Healing; Zysk, Asceiticism and Healing in Ancient India; and C. Pierce Salguero, "The Buddhist Medicine King in Literary Context: Reconsidering an Early Medieval Example of Indian Influence on Chinese Medicine and Surgery," History of Religions 48, no. 3 (2009): I84-2IO. 
were also central in the narrative frame of an early edition of the Four Tantras, the Essence of Ambrosia in Eight Branches. But, if the narrative of Rikpé Yeshé and Yilé Kyé are interspersed throughout the Four Tantras, how did they come to be associated with the city of Beautiful to Behold (blta na sdug gi grong khyer) and all of the retinues described in the "Basis of Discussion" in the Four Tantras?

Again, lacking any manuscripts that can be confidently dated to before the fourteenth century, we have few direct glimpses into the textual evolution of this seminal work of Tibetan medicine. As Yang Ga has indicated, however, close textual comparison with the socalled Little Tantra (rgyud chung) has revealed intimate intertextuality and a high probability of direct influence. He interprets this literary imbrication as evidence for Yutok Gönpo having first written the Little Tantra and then expanded upon it in writing the Four Tantras. ${ }^{383}$ Since this breakthrough, most scholars have confidently cited the Four Tantras as being the twelfthcentury composition and/or compilation of Yutok Gönpo. ${ }^{384}$ As these narrative discrepancies in the Root and Subsequent Tantras reveals, however, it is unlikely that a single figure is responsible for the compilation of the entire work. Furthermore, based on the admittedly sparse evidence of its early transmission, I propose that the Four Tantras-that is, the Secret Essence of Ambrosia in Eight Branches: An Instructional Tantra (bdud rtsi snying po yan lag brgyad pa gsang ba man ngag gi rgyud) — was not compiled by one figure, but instead represents the collective contributions and continuous compilation of twelfth- and thirteenth-century Tibetan scholarship.

An important citation that supports Yang Ga's hypothesis that the Little Tantra served as an exemplar for the Four Tantras can be found in the writings of Zurkhar Lodrö Gyelpo. In a section in which he is discussing the five sublime contexts for the Four Tantras, Zurkhar summarizes the various scholastic positions that have been offered regarding the location of Beautiful to Behold (Tib. [b]lta na sdug [pa] = Skt. darśaniya) in space-that is, the location of the teaching of the Four Tantras. ${ }^{385}$ One of the positions that he cites purportedly derives from the so-called Lesser Tantra (rgyud chung ba) —a common derogatory appellation for the Secret Essence of Ambrosia: An Instructional Tantra (bdud rtsi snying po gsang ba man ngag gi rgyud):

\footnotetext{
${ }^{383}$ Yang Ga, Sources for the Writing of the Rgyud bzhi.

${ }^{384}$ See, for example, Janet Gyatso, Being Human in a Buddhist World, I44.

${ }^{385}$ For an insightful summary and analysis of this debate in Tibetan commentarial literature, see Gyatso, Being Human in a Buddhist World, I43-9I. Despite the consummate nature of her discussion, Gyatso decides not to include this particular passage. For an earlier analysis of this discussion in the writings of Zurkhar, see also Olaf Czaja, "Zurkharwa Lodro Gyalpo (I509I579) on the Controversy of the Indian Origin of the rGyud bzhi," the Tibet Journal 30, no. 4; and 3I, no. I (2005-2006): I3I-52. For the first and only mention of the passage below in Englishlanguage secondary literature, albeit brief, see Yang Ga, Sources for the Writing, II2.
} 
Thus have I heard at one time. In the abode of sages, atop the mountain of medicines called "Beautiful to Behold," in an inestimable mansion made from seven kinds of jewels, adorned with wish-fulfilling jewels, ${ }^{386}$

The four hundred and four diseases - the diseases of wind, the diseases of bile, the diseases of phlegm, and combination diseases-are dispelled. Diseases of heat are cooled, diseases of cold are heated, the eighty thousand types of obstructions are pacified, and all needs and desires are fulfilled. ${ }^{387}$

The southern side of the mountain is endowed with the power of the sun, and there are medicines-such as pomegranate, Indian rose chestnuts (Mesua ferrea), long peppers (piper longum), chili peppers (capsicum annum), and so forth-that dispel cold diseases with hot, sour, and salty flavors, and a heating potency. There also is a forest of pungent medical herbs endowed with roots, trunks, branches, leaves, flowers, fruits, and a wonderful fragrance that beautifully and intoxicatingly pervades the forest. ${ }^{388}$

${ }^{386}$ Zur mkhar blo gros rgyal po, Rgyud bzhi'i 'grel pa mes po'i zhal lung, Bod kyi gso rig pa'i gna' dpe phyogs bsgrigs dpe tshogs, vol. I9 (Beijing: Mi rigs dpe skrun khang, 2005), vol. I (stod cha), p. 34: de ltar rgyud chung ba las/_'di skad bdag gis thos pa dus gcig na/_drang srong gi gnas sman gyi ri bo lta na sdug ces bya ba ni rin po che sna budn las grub pa'i gzhal yas khang yid bzhin gyi nor bus brgyan pa ste/. Compare with Rje bstan 'dzin don grub, ed., Dpal ldan rgyud bzhi dpe bsdur ma (Chengdu: Si khron dpe skrun khang, 2010), vol. I, I5-I6: 'di skad bdag gis [bshad / thos] pa'i dus gcig nal_drang srong gi gnas sman gyi grong khyer [lta] na sdug ces bya ba rin po che sna lnga las grub pa’i gzhal yas khang yod de/_khang ba de'i rgyan ni sman gyi nor bu rin po che rnam pa sna tshogs pas brgyan pa ste/.

${ }^{387}$ Zur mkhar blo gros rgyal po, Rgyud bzhi'i 'grel pa mes po’i zhal lung, vol. I (stod cha), p. 34: des rlung gi nad dang mkhris pa'i nad dang bad kan gyi nad dang ldan pa'i nad las gyur pa'i nad bzhi brgya rtsa bzhi sel bar byed de/_tsha ba'i nad la bsil du 'gyur ba/_grang ba'i nad la drod du 'gyur ba/_bgegs rigs stong phrag brgyad cu zhi bar byed pa/_dgos 'dod thams cad yid bzhin du skyong bar byed pa/. Compare with Dpal ldan rgyud bzhi dpe bsdur ma, I6: nor bu rin po che des ni rlung gi nad dang mkhris pa'i nad dang bad kan gyi nad dang ldan pa'i nad dang 'dus pa'i nad las gyur pa'i nad bzhi brgya rtsa bzhi sel bar byed pa/_tsha ba’i nad la bsil du gyur pal_grang ba’i nad la drod du gyur pa/_bgegs rigs stong phrag brgyad cu zhi bar byed pal_dgos'dod thams cad yid bzhin du grub par byed pa yod do/.

${ }^{388}$ Zur mkhar blo gros rgyal po, Rgyud bzhi'i 'grel pa mes po'i zhal lung, vol. I (stod cha), p. 34: ri de'i lho phyogs ni nyi ma'i stobs dang ldan zhing /_se 'bru dang na le sham dang /_pi pi ling dang /_tsi tra ka la sogs pa grang ba'i nad sel bar byed pa'i sman ro tsha ba dang skyur ba dang lan tsha ba dang nus pa tsha ba dang rno ba’i sman gyi nags tshal yod de/_rtsa ba dang /_sdong po dang /_yal ga dang /_lo ma dang /_me tog dang /_bras bur ldan pa'i sman dri zhim pa lta na sdug pa yid du 'ong ba'i dris khyab pa yod do/. Compare with Dpal ldan rgyud bzhi dpe bsdur ma, I6-17: grong khyer de'i lho phyogs ni ri bo 'bigs byed ces bya ba nyi ma'i stobs dang ldan pa'i ri la se 'bru dang na le sham dang pi pi ling dang tsi tra ka la sogs pa grang ba sel bar byed pa'i sman ro tsha ba dang skyur ba dang lan tsha ba dang nus pa tsha ba dang rno ba'i sman gyi nags tshal/_rtsa ba dang ldon bo dang yal ga dang lo ma dang me tog dang 'bras bur ldan pa'i sman dri zhim pa lta na sdug pa yid du 'ong ba sman gyi dris khyab pa rnams su grang ba'i nad mi 'byung ba yod do/.

W. A. McGrath | Buddhism and Medicine in Tibet | 126 
The northern side of the mountain is endowed with the power of the moon, and there are medicines - such as sandalwood, camphor, eagle wood, neem trees (Azadirachta indica), and so forth - that dispel heat diseases with bitter, astringent, and sweet flavors, and a cooling potency. There also is a forest of subtle medical herbs endowed with roots, trunks, branches, leaves, flowers, fruits, and a wonderful fragrance that beautifully and intoxicatingly pervades the forest. ${ }^{389}$

To the east of the mountain is a forest of myrobalan trees-such as the completely victorious myrobalan, the golden myrobalan, so forth-whose roots dispel bone diseases, whose trunks dispel flesh diseases, whose branches dispel channel and ligament diseases, whose bark dispels skin diseases, whose leaves dispel bowel diseases, whose flowers dispel sensory diseases, whose fruits dispel cardiac diseases. They are endowed with the six flavors, the eight potencies and the seventeen perfect qualities. They dispel all types of diseases and a wonderful fragrance that beautifully and intoxicatingly pervades the forest. $^{390}$

${ }^{389}$ Zur mkhar blo gros rgyal po, Rgyud bzhi'i 'grel pa mes po’i zhal lung, vol. I (stod cha), p. 34: ri de’i byang phyogs ni zla ba'i stobs dang ldan te/_tsandana dang /_ga bur dang /_a ga ru dang /_nim pa la sogs pa tsha ba’i nad sel ba’i sman ro kha ba dang /_bska ba dang /_mngar ba dang /_nus pa bsil ba dang rtul ba’i sman gyi nags tshal yod de/_rtsa ba dang sdong po dang yal ga dang lo ma dang me tog dang 'bras bur ldan pa'i sman dri zhim pa lta na sdug pa yid du 'ong ba'i dris khyab pa yod do/. Compare with Dpal ldan rgyud bzhi dpe bsdur ma, I7: grong khyer de’i byang phyogs na ri bo gangs can zhes bya ba zla ba'i stobs dang ldan pa'i ri la tsan dan dang ga bur dang a ga ru dang nim pa la sogs pa tsha ba sel bar byed pa'i sman ro kha ba dang mngar ba dang bska ba dang nus pa bsil ba dang rtul ba'i sman gyi nags tshal/_rtsa ba dang sdon bo dang yal ga dang lo ma dang me tog dang 'bras bur ldan pa'i sman dri zhim pa lta na sdug pa yid du 'ong ba sman gyi dris khyab pa rnams su tsha ba'i nad mi 'byung ba yod do/.

390 Zur mkhar blo gros rgyal po, Rgyud bzhi'i 'grel pa mes po’i zhal lung, vol. I (stod cha), p. 34-35: re de’i shar na a ru ra’i nags tshal yod de/_rnam par rgyal ba dang gser mdog la sogs pa'i rtsa bas rus pa'i nad sel ba/_sdong pos sha’i nad sel ba/_yal gas rtsa rgyus kyi nad sel ba/_shun pas pags pa’i nad sel ba/_lo mas snod kyi nad sel ba/_me tog gis dbang po'i nad sel ba/_bras bus don snying gi nad sel ba/_ro drug dang ldan pa/_nus pa brgyad dang ldan pal_yon tan bcu bdun rdzogs pal_nad kyi rigs thams cad sel bal_dri zhim pa lta na sdug pa yid du 'ong ba'i dris khyab pa yod do/. Compare with Dpal ldan rgyud bzhi dpe bsdur ma, I7-I8: grong khyer de'i shar phyogs na ri bo spos ngad ldan zhes bya ba'i ri la a ru ra’i nags tshal/_rtsa bas rus pa’i nad sel ba/_sdong bos sha’i nad sel ba/_yal gas rtsa rgyus kyi nad sel bal_shun pas pags pa’i nad sel ba/_lo mas snod kyi nad sel ba/_me tog gis dbang bo’i nad sel bal_'bras bus don snying gi nad sel bal_rtse mo na a ru ra rnam pa lnga smin pa/_ro drug dang ldan pa/_nus pa brgyad dang ldan pa/_[zhu rjes gsum dang ldan pa/_]yon tan bcu bdun rdzogs pa/_nad kyi rigs su gyur pa thams cad sel bal_dri zhim pa lta na sdug yid du 'ong ba sman gyi dris khyab pa rnams su nad bzhi brgya rtsa bzhi mi 'byung ba yod do/. 
On the western face of the mountain is a garden of the six excellent herbs-endowed ${ }^{391}$ with all flavors - that dispel all diseases with a subtly cooling potency and so forth. They are endowed with roots, trunks, branches, leaves, flowers, fruits, and a wonderful fragrance that beautifully and intoxicatingly pervades the forest. ${ }^{392}$

Zurkhar provides this citation without much further comment, but this passage is of great significance for several reasons. First, as I have demonstrated in the footnotes citing each paragraph, the present passage is not identical to the "Basis of Discussion" in the Root Tantra, but a careful comparison reveals more similarities than differences. The description in the Root Tantra is generally more extensive, providing relatively more verbose elaborations in places where the Lesser Tantra is somewhat ambiguous. With the exception of the western side, the descriptions of the four mountain sides in the Lesser Tantra effectively matches that of the four mountains surrounding the city in the Four Tantras. In the Lesser Tantra the description of the western face of the mountain is rather brief, while the description of the western mountain in the Four Tantras is quite extensive, describing rivers endowed with the five kinds of calcite (cong zhi rigs lnga), the five kinds of bitumen (brag zhun rigs lnga), the five kinds of medical waters (sman chu rigs lnga), the five kinds of hot springs (chu tshan rigs lnga), and so forth. Thus, indeed, it would appear that the framing narrative of the Root Tantra is either an embellishment of the Lesser Tantra, or that of the Lesser Tantra is an abridgment of the Root Tantra.

From Drangti to the Desi, Tibetan scholars of medicine have variously disagreed about the location for generations. ${ }^{393}$ Perhaps more fundamental than the question of where, though, is the question, what is Beautiful to Behold? Despite the specific significance of this location for the Tibetan medical tradition, it is by no means unique to the Four Tantras. The name, "Beautiful to Behold," appears as an epithet in both early Tibetan and early Sanskrit literature, ${ }^{394}$ as well as a general adjective for things and people that are visually attractive in

${ }^{391}$ The six excellent herbs (bzang po drug) are generally listed as including: dza ti snying gi bzang po / cu gang glo ba'i bzang po / gur kum mchin pa'i bzang po / li shi srog rtsa'i bzang po / sug smel mkhal ma'i bzang po / ka ko la mtsher ba'i bzang po'o/.

${ }^{392}$ Zur mkhar blo gros rgyal po, Rgyud bzhi'i 'grel pa mes po'i zhal lung, vol. I (stod cha), p. 35: ri de’i nub phyogs kyi ngos na bzang po drug gi tshal yod de/_ro kun dang ldan pa/_nus pa bsil rtul la sogs pas nad thams cad sel ba/_rtsa ba dang sdong po dang yal ga dang lo ma dang me tog dang 'bras bur ldan pa/_dri zhim pa lta na sdug pa yid du 'ong ba'i dris khyab pa yod do/_zhes gsungs pa... Compare with Dpal ldan rgyud bzhi dpe bsdur ma, I8: grong khyer de'i nub phyogs na ri bo ma la ya zhes bya ba la bzang bo drug gi sman 'khrungs pa ste/_nad thams cad zhi bar byed pa'i sman cong zhi rigs lnga dang /_brag zhun rigs lnga dang /_sman chu rigs lnga dang /_chu tshan rigs lnga dang ldan pa’i ri bo yod do/...

${ }^{393}$ Again, see Gyatso, Being Human in a Buddhist World, I43-9I.

${ }^{394}$ For a monk named Blta na sdug pa, see the History of the Cycle of Birth and Death (skye shi'i lo rgyus) found in nine incomplete copies at Dunhuang and described in Yoshiro Imaeda, "The History of the Cycle of Birth and Death: A Tibetan Narrative from Dunhuang," in Contributions to the Cultural History of Early Tibet, ed. Matthew T. Kapstein and Brandon Dotson (Leiden: 
canonical literature. ${ }^{395}$ Perhaps most significant for the present context, however, the term Beautiful to Behold (lta na sdug) refers to a specific mountain, Sudarśana, which is the name of one of the Seven Golden Mountains (gser gyi ri bdun) - that is, the seven mountain ranges that surround Mt. Meru at the center of the world-in the Great Volume of Precise Understanding (Tib. bye brag tu rtogs par byed pa chen po = Skt. mahāvyutpatti) and Meta-Doctrine Abhidharma literature. ${ }^{396}$ Thus, despite being the name of a mountain in canonical Abhidharma literature, as well as the above-cited passage from the Lesser Tantra, Beautiful to Behold is explicitly named as a "city of medicine" (sman gyi grong khyer) in the Four Tantras.

As we have seen, the Medicine of the Moon King takes place atop five mountains wherein the name of each mountains derives from the transcribed Sanskrit name for five different medicinal plants. The Tibetan names and properties of these plants are not specified, however, so it remains difficult to precisely identify any relationship that there might be between the direction of the mountain and the properties of the plants that might grow in that direction (Table 4.2). In the Degé xylograph edition, the setting for the Moon King is explicitly related to Mt. Wutai-and, as L. W. J. van der Kuijp has indicated, in an early manuscript edition as well-but it remains only implicit in intermediate manuscript editions. ${ }^{397}$ This shift away from a geographically identifiable Wutai echoes further in the Lesser Tantra and the Root Tantra, which respectively take place in the geographically ambiguous mountains and city called Beautiful to Behold. The setting of the Lesser Tantra retains the mountainous geography of the Moon King, despite the shift from five separate mountains to a single mountain with four distinct faces and one peak. In the Root Tantra the geographic transformation continues, returning to four surrounding mountains, but transforming the center into a city instead of a mountain itself. Thus, between the Moon King, the Lesser Tantra, and the textus receptus of the Root Tantra we appear to have a fairly clear progression-although not necessarily a linear one-from simplicity to detail while still maintaining a continuous thread of spatial relationships.

Tantalizing is the fact that Zurkhar's edition of the Lesser Tantra is no longer extant. While we can guess that the Lesser Tantra (rgyud chung ba) may refer to the Little Tantra (rgyud chung) - that is, the Secret Essence of Ambrosia: An Instructional Tantra (bdud rtsi snying po gsang ba man ngag gi rgyud) that was redacted in the Eighteen Partial Branches in the fourteenth century - the opening passage of the Lesser Tantra is nowhere to be found in the textus receptus of the Secret Essence of Ambrosia. As we have already seen, however, the narrative frame of the

Brill, 2007), I05-8I (pp. I44-46 for Blta na sdug pa). For Darśanìya as an epithet for Nakula in the Mahābhärata, see Douglas Frame, Hippota Nestor (Washington, DC: Center for Hellenic Studies, 2009), \$I.48. <http://chs.harvard.edu/CHS/article/display/5466>.

395 See, for example, the description of a beautiful complexion in Yan lag brgyad pa'i snying po bsdus pa in Bstan 'gyur dpe sdur ma, vol. III (he [213]), text 3547, p. 33I-32.

${ }^{396}$ For references in Abhidharma literature, see Gyatso, Being Human, 435, n. 59.

${ }^{397}$ See the discussion above. Perhaps this shift follows the fall of the Tangut and the rise of the Mongols. The explicit return to Wutai corresponds, of course, to Qing hegemony. 
Secret Essence of Ambrosia in which it is attributed to Vāgbhata is itself the willful creation of a later editor, and it would not be so surprising if the narrative frame in which it is attributed to Yutok Gönpo were also just an earlier fabrication. Unlike the Four Tantras and even the earlier Moon King-which feature a narrative frame that continues throughout nearly every chapter-only the opening and closing chapters of the Secret Essence of Ambrosia actually describe a narrative frame, making it relatively easy to emend. Alternatively the Lesser Tantra could also be identified with yet another unattested proto-edition of the Four Tantras, such as the Essence of Ambrosia in Eight Branches (bdud rtsi snying po yan lag brgyad pa) described in the Indispensable Account. Regardless of the specific details, the available evidence indicates that not one edition of the Essence of Ambrosia was compiled in the twelfth and thirteenth centuries, but several, which were ultimately reconciled in late thirteenth and early fourteenth centuries.

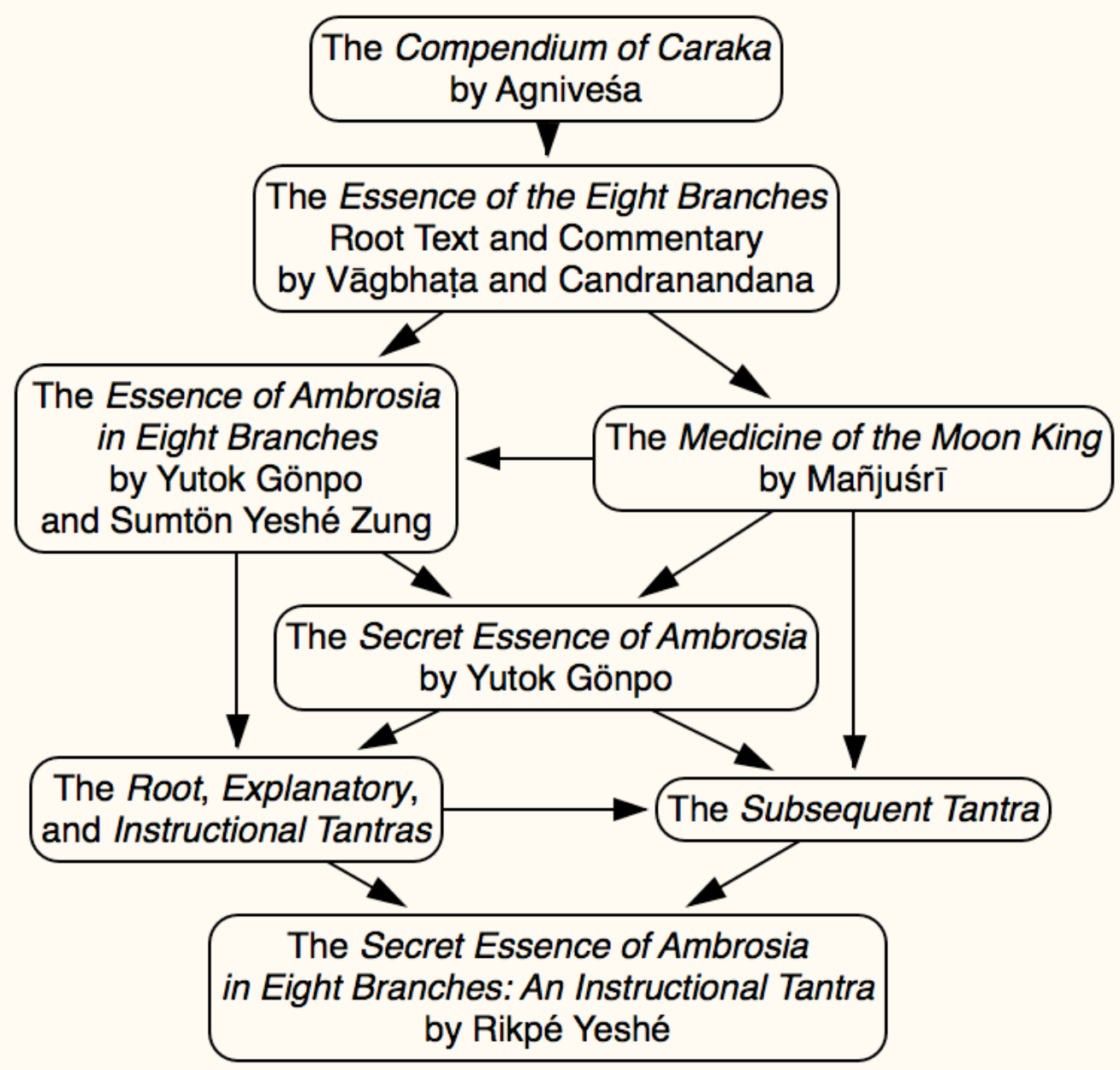

Figure 4.I. A Proposed Web of Narrative Influences in Early Tibetan Medical Works 
Regarding the retinues of the framing stories, in the Moon King we saw an early positing of Buddhist origins to the teachings of medicine, conspicuously adding Indian teachers of medicine like Brahmā, Indra, and Caraka to the retinues of students. The Root Tantra continued this trend, asserting that the teachings of the Master of Medicine were simultaneously interpreted by the four retinues of gods, sages, non-Buddhist Outsiders, and Buddhist Insiders as being the teaching of their own tradition. Connecting to the narrative frame of Sage Rikpé Yeshé teaching Sage Yilé Kyé inherent in the earliest layers of the Essence of Ambrosia, the teaching of the Four Tantras represents that of the sage retinue, leaving the teachings of the gods, non-Buddhists, and Buddhists for other unnamed textual traditions. The frame of the Subsequent Tantra revises this story, however, providing the names for all four textual traditions, including that of the sage retinue. Thus, the Four Tantras is then claimed to be the essence of all four explicit textual traditions, the King of Tantra (rgyud rgyal). Perhaps, indeed, the textus receptus of the Four Tantras does represent the accretive sum of Tibetan medical knowledge even more-so than has been previously recognized, continuing to include materials through the thirteenth and potentially even into the fourteenth century.

\section{The Expanded Elucidation of Knowledge and the Reconciling of Narratives}

The relationships between the aforementioned narratives and narrative frames support the hypothesis implicitly presented above that the Essence of Ambrosia in Eight Branches (bdud rtsi snying po yan lag brgyad pa) described by Sumtön Yeshé Zung in his Indispensable Account of Transmission and the Secret Essence of Ambrosia (bdud rtsi snying po gsang ba) represent separate instructional lines of transmission that were ultimately combined to form the Secret Essence of Ambrosia in Eight Branches: An Instructional Tantra (bdud rtsi snying po yan lag brgyad pa gsang ba man ngag gi rgyud). With so many essences of ambrosia, it is no wonder that later authors came to refer to the Secret Essence of Ambrosia, and potentially the Essence of Ambrosia in Eight Branches, as the Little Tantra (rgyud chung) or the Lesser Tantra (rgyud chung ba), while the Secret Essence of Ambrosia in Eight Branches came to be the King of Tantras (rgyud rgyal), or, as we know it now, the Four Tantras. Although kernels of the textus receptus of the Four Tantra most probably derive from the teachings of Yutok Gönpo ( $\left(2^{\text {th }} \mathrm{c}\right.$.) and the pen of Sumtön Yeshé Zung (including the majority of the Explanatory Tantra and potentially the Instructional Tantra), these teachings were also undoubtedly expanded over the thirteenth century, culminating in separate works like the Secret Essence of Ambrosia and the Small Practical Manual that were ultimately reintegrated into the Essence of Ambrosia cycle. With each moment of expansion and redaction also came narrative modifications and specifications, such as those that were appended to the Subsequent Tantra in the "Back Section Summary" (mjug don bsdus pa) and "Complete Entrustment" (yongs gtad) chapters (Table 4.I).

In perhaps the earliest effort to effectively "close" the teachings of the Essence of Ambrosia

and establish as standard Four Tantras, the author of the Flight of the Khyung provides a table of contents. Thus, the general form of the textus receptus of the Four Tantras-which is now 
distinct from the rest of the cycle included in the Eighteen Partial Branches-was decided by the end of the thirteenth century or beginning of the fourteenth century, when it is described in the Flight of the Khyung:

For the sake of summarizing the roots [of the other chapters], the Root Tantra was taught in terms of [I.] the etiology of disease, [2.] methods for the examination of disease, and [3.] methods for the healing of disease. ${ }^{398}$

For the sake of understanding the intention of the Root Tantra, the Explanatory Tantra was taught in terms of ten parts. ${ }^{399}$

The Instructional Tantra, which includes the instructions for the practice of both the Root Tantra and the Explanatory Tantra, was taught in terms of fifteen sections. ${ }^{400}$

For the sake of completing lacunae and teaching the supreme practices, the Subsequent Deed Tantra was taught in terms of four discourses. ${ }^{40 I}$

After being combined into four tantras, the branches of the essential meaning of the tantras came to be taught in terms of eight branches and one hundred and fifty-six chapters. $^{402}$

The author of the Flight of the Khyung is not ambiguous about the notion that the Subsequent Deed Tantra (phyi ma 'phrin las kyi rgyud) — or perhaps the "subsequent Deed Tantra" would be a better rendering?-was added for the sake of "completing lacunae" (ma tshang ba kha bskang), referring to the supreme diagnostic and therapeutic practices (lag len mchog) that had been withheld from early editions of the Essence of Ambrosia. Although the total number of chapters listed here in the Flight corresponds exactly to that found in the textus receptus of the Four Tantras, some other discrepancies are also worth noting. The textus receptus of the Root Tantra, for example, includes topics beyond the three listed here; ${ }^{403}$ the textus receptus of the

${ }^{398}$ Khyung chen lding ba, in Cha lag bco brgyad, I6: de yang rtsa ba 'dus pa'i phyir rtsa rgyud de/_nad gzhi brtag thabs gso thabs gsum gyis bshad/.

${ }^{399}$ Khyung chen lding ba, in Cha lag bco brgyad, I6: rtsa ba'i dgongs pa khrol bar bya ba'i phyir bshad rgyud de gnas bcu'i bshad/.

${ }^{400}$ Khyung chen lding ba, in Cha lag bco brgyad, I6: rtsa rgyud/_bshad rgyud gnyis lag tu len pa la man ngag bstan pa'i man ngag rgyud de/_skabs bco lngas bshad/.

${ }^{40 \mathrm{O}}$ Khyung chen lding ba, in Cha lag bco brgyad, I6: ma tshang ba kha bskang zhing lag len mchog tu ston pa'i phyir/_phyi ma 'phrin las kyi rgyud de mdo bzhi yis bshad/.

${ }^{402}$ Khyung chen lding ba, in Cha lag bco brgyad, I6: rgyud bzhi dril bas rgyud don ngo bo'i yan lag ste/_yan lag brgyad/_le'u brgya dang lnga bcu rtsa drug gis bshad do//.

${ }^{403}$ The six chapters of the textus receptus of the Root Tantra are: [I.] the aforementioned "Basis of Discussion" (gleng gzhi), [2.] the "Enumeration of Topics" (gleng slong rnam grangs rnam par bkod pa), [3.] "Anatomy and Etiology" (gnas lugs nad gzhi), [4.] "Diagnosis and Examination" (ngos 'dzin rtags), [5.] "Methods for Healing" (gso thabs), and [6.] the "Enumeration of Exemplars" (dpe don gyi rnam grangs rnam par bkod pa). For summaries and discussion, see Yang Ga, Sources for the Writing of the Rgyud bzhi, I52-55.

W. A. McGrath | Buddhism and Medicine in Tibet | 132 
Explanatory Tantra was taught in eleven parts (gnas bcu gcig), not ten; ${ }^{404}$ and the notion that the Instructional Tantra was organized into eight branches only after these four works were combined into four tantras (rgyud bzhi dril bas rgyud don ngo bo'i yan lag ste/_yan lag brgyad ... bshad do) is also an intriguing one. Indeed, as indicated by this translation, even the common title for the work, the Four Tantras, does not appear to have been common parlance until the fourteenth century. ${ }^{405}$

Drangti Penden Tsojé continues the work of the Flight-which potentially is that of his mentor, Paktön Śākya Gönpo-and also specifies the contents of the Four Tantras on several separate contexts throughout the Expanded Elucidation of Knowledge. On three such occasions Drangti describes the contents within a context that is identical to the narrative frame described in the "Basis of Instruction" of the Four Tantras, and each time he routinely specifies that the Essence of Ambrosia is composed of "four tantras, eight branches, eleven parts, fifteen sections, four discourses, and one hundred and fifty-six chapters." ${ }^{406}$ On one other occasion, citing the direct speech of the sage Rikpé Yeshé that is not attested in the textus receptus of the Four Tantras, he neglects to add the "four tantras" and describes the Essence of Ambrosia as consisting of:

This tantra which I have taught in eight branches of knowledge, the eleven parts about [medical] topics, the fifteen sections of differentiations, the four discourses of summarized meanings, and the one hundred and fifty-six chapters of specific topics, is supreme among all [other works in] the science of healing. ${ }^{407}$

As we can see, each of these lists are consistent with the textus receptus of the Four Tantras, despite the fact that not all citations found in the Expanded Elucidation of Knowledge are

\footnotetext{
${ }^{404}$ For a schematic diagram of the contents of the Four Tantras, see Gerke, "The Art of Tibetan Medical Practice," 2I, Table I.I.

${ }^{405}$ Drangti only refers to "four tantras" (rgyud bzhi, or rgyud sde bzhi) when referring to the structure of the Secret Essence of Ambrosia in Eight Branches. Recall from Chapter Two, for example, the fact that Chomden Rikpé Reldri (I227-I305) did not actually use the title Four Tantras in his early reference to the work. Gso ba rig pa rgyan gyi me tog, in Krung go'i bod lugs gso rig rtsa che'i dpe rnying kun btus, vol. 3, text 40, p. 472 (f. 2a): kha cig gso spyad gzhung las phyi nang gnyis/_phyi pa'i rgyud dang nang pa'i mdo rgyud gnyis/_rgyud la rtsa rgyud bshad rgyud man ngag rgyud/_/rgyud phyi la sogs rnam pa gzhan smra bal_/de kun bod kyi byas pa'i bstan bcos te/_/mdo rgyud de bzhin gshegs pa'i gsung rabs dang /_/gso rig gang zag byas pa'i bstan bcos yin/.

${ }^{406}$ Gsang ba man ngag gis [sic] rgyud kyi spyi don shes bya rab gsal rgyas pa (Beijing Ms), 24a, 34b, and 42b: rgyud bzhi/_yan lag brgyad/_gnas bcu gcig_skabs bco lnga/_mdo bzhi/_le'u brgya dang lnga bcu rtsa drug.

${ }^{407}$ Gsang ba man ngag gis [sic] rgyud kyi spyi don shes bya rab gsal rgyas pa (Beijing Ms), 4ob: shes par bya ba'i yan lag brgyad/_sde tshan gyi gnas bcu gcig_rnam par phye ba’i skabs bco lnga/_don mdor bsdus pa'i mdo bzhi/_khyad par gyis le'u brgya lnga bcu rtsa drug gi bdag nyid can gyi gsungs pa ni rgyud 'di gso ba rig pa thams cad kyi mchog tu gyur pa yin te/.
} 
consistent with the textus receptus of the Four Tantras. ${ }^{408}$ At the end of his magnum opus, Drangti is even more explicit than his predecessor as well, for he goes as far as to list the very number of stanzas in the Four Tantras, distinguishing the "Complete Entrustment" from the Subsequent Tantra:

There are I20 śloka-stanzas in the Root Tantra, There are 774.5 [śloka-stanzas] in the Explanatory Tantra, There are 4,028 [śloka-stanzas] in the Instructional Tantra, There are 867 [śloka-stanzas] in the Subsequent Tantra, And there are I47 [śloka-stanzas] in the "Complete Entrustment." In sum, there are 5,936.5 [śloka-stanzas]. ${ }^{409}$

Because [stanzas] of the tantras have been calculated according to nine-syllable [lines], and those of the [Essence of the] Eight [Branches] have been calculated according to sevensyllable [lines], the [Four Tantras] has an extra eight or ten [syllables] for every ślokastanzas of the [Essence of the] Eight [Branches]. There are 9,242 [śloka-stanzas] in the [Essence of the] Eight [Branches]. Sarva-mangalam! $!^{4 \mathrm{IO}}$

As these lines indicate, Drangti Penden Tsojé had a very specific vision of the length and contents of the Four Tantras. These very precise numbers are confusing, however, for how, exactly, did Drangti calculate a stanza? In the second paragraph cited above, he states that the Four Tantras would have "eight or ten extra" syllables (brgyad bcu lhag) for each stanza of the Essence of the Eight Branches, indicating that each stanza should be four or five lines long. But not all of the Four Tantras is in verse, so how are we to count the "stanzas" of the long prose sections found in the first two chapters of the Root Tantra, for example? I went through and did a preliminary count of all stanzas that are in verse in the Root Tantra of the Dratang Four Tantras (grwa thang rgyud bzhi) and come up with approximately 75 stanzas, which is

${ }^{408}$ See Chapter Three, for example, for entire stanzas missing from the textus receptus that are included the passages from the Four Tantras that are cited throughout the Expanded Elucidation of Knowledge.

${ }^{409}$ Because the photocopy given to me of the Beijing Ms is incomplete in these final folios (they have only been partially copied on the page), I have supplemented my incomplete photocopies with the Delhi edition [as indicated in square brackets]. Gsang ba man ngag gis [sic] rgyud kyi spyi don shes bya rab gsal rgyas pa (Beijing Ms), 4ob: rtsa [rgyud la sho lo ka brgya dang nyi shu/_bshad rgyud la bdun brgya bdun cu] don phyed dang bzhi/_man ngag rgyud la stong phrag bzhi dang nyi shu rtsa brgyad/_phyi ma rgyud la brgyad brgya drug cu ra bdun/_yongs gtad la brgya bzhi bcu rtsa bdun/_dril bas stong [phrag lnga dang dgu brgya sum cu so phyed dang drug. See also Rgyud bzhi'i spyi don shes bya rab gsal rgyas pa (Delhi), I35.

${ }^{410}$ Gsang ba man ngag gis [sic] rgyud kyi spyi don shes bya rab gsal rgyas pa (Beijing Ms), 4ob: rgyud tsheg bar dgu ma/_brgyad pa bdun ma/_rtsi pas brgyad pa sho lo ka brgyad bcu lhag/_brgyad pa sho lo ka dgu stong nyis brgya bzhi bcu rtsa gnyis yod/_sarba manga lam. 
considerably less than the I20 cited by Drangti. If I were to disregard meter and just consider groups of approximately four lines of any length I could approximately make up for the missing 45 stanzas of my earlier count, but not confidently, and this process also renders Drangti's precise specifications as generally meaningless. Regardless of their accuracy, these figures provided by Drangti provide the impression that the Four Tantras was a completely closed document whose contents were immutable.

Although both Drangti and Paktön appear to have been interested in the closing of the Four Tantras as a source of medical instructions, their approaches to the standardization of the narratives surrounding the Four Tantras involve important differences. Unlike Paktön, who conflates the life story of Sākyamuni Buddha with the "Churning of the Ocean" narrative, Drangti chooses to separate these rather disparate narratives of Indian inspiration. We will see Drangti's telling of the life of Saakyamuni Buddha in Chapter Five, so let us now turn to Brahmā and his remembering of medicine. The Vedic significance of Brahmā's remembering is lost, perhaps intentionally, on Paktön, but not on Drangti Penden Tsojé, who creatively lists the four Vedas:

A few [non-Buddhist] extremists have asserted that, [at the beginning of existence], ${ }^{4 I}$ Brahmā, the Creator of All, taught the Four Vedas from his four faces: the Science of Life (āyurveda), the Protection of Existence (atharvaveda), Poetics (kāvya), and Sacrifice (yajñadatta). But, because this contradicts textual transmissions, and because remembering necessitates the manifestation of listening, to suggest that this occurred during the life of the Teacher [Śākyamuni], as some have, would also be incorrect. As stated in the Eight Fascicles of Ambrosia: ${ }^{412}$

After passing beyond pain, Kanakamuni reemerged and taught [Brahmā].

Thus, it should be understood that [Brahmā] remembered before the subsequent [buddha], Śākyamuni. ${ }^{413}$

Thus, the [emergence] of poison and ambrosia, as well as Brahmā's remembering of the Science of Life, [occurred] at the same time, and these [events] preceded the entrance of [Śăkya]muni into the world. If one were to inquire about the specific date, as stated in the

${ }^{4 I I}$ TYT (6o), AR (46): "at the beginning of existence" (srid pa thog ma'i dus na). PMa (23b) and NPM (22a) do not include this specification.

${ }^{42}$ Gsang ba man ngag gis [sic] rgyud kyi spyi don shes bya rab gsal rgyas pa (Beijing Ms), 22a: $m u$ stegs 'ga' zhig_[srid pa thog ma'i dus na/_]thams cad kyi byed pa po tshangs pa'i zhal bzhi las/_tshe'i rigs byed/_srid bsrungs/_snyan ngag /_mchod sbyin te/_rig byed bzhi bstan zhes pa ni/_lung dang yang 'gal zhing /_dran pa la thos pa mngon du byed dgos la/_ga' zhig ston pa zhal bzhugs pa'i tshe/_zhes smra ba'ang mi rigs te/_bdud rtsi bam po brgyad du/.

${ }^{413}$ Gsang ba man ngag gis [sic] rgyud kyi spyi don shes bya rab gsal rgyas pa (Beijing Ms), 22a-22b: gser thub mya ngan las 'das nas 'byung bar gsung la/_shäkya thub pa phyi ma'i mngon [=sngon] du dran par go ste ces nal. 
Eight Fascicles of Ambrosia, [Brahmā's remembering of the Science of Life occurred on] the full moon of a spring month of a male metal-tiger year, one hundred and twenty-five years after the passing of Kanakamuni. ${ }^{44}$

Seeming to respond directly to Paktön's conflation of Brahmā's remembering of the Science of Life with the life of Sākyamuni Buddha, Drangti maintains the relationship between the remembering and the churning of the ocean, but propels the date of these events backward in time to just after the life of Kanakamuni Buddha (gser thub), well before the life of Śākyamuni Buddha. Importantly, despite the churning of the ocean narrating the primordial origins of the world, both of these events occurred on a specific year and even a specific date-the full moon of the spring month of a male metal-tiger year (lcags pho stag gi lo dpyid zla ba nya'i tshes). Again, we should not mistake Drangti's precision for accuracy.

Like Paktön, Drangti classifies Brahmā's remembering of the Science of Medicine as "blessed Buddha Word" (byin gyis brlabs pa'i bka), and cites a quotation from the presently non-extant Heap of Jewels (rin po che spung pa) to support this claim. Unlike Paktön, however, Drangti relies on the similarly unattested Eight Fascicles of Ambrosia (bdud rtsi bam po brgyad) to prove that the teaching remembered by Brahmā was not (only) the Collection of Medicine attributed to Śākyamuni, but the Tantra of Nakedly Seeing Awareness (cer mthong rig pa'i rgyud) attributed to Kanakamuni. One may recall that this text was also described as being the teachings of Saakyamuni given to Ānanda in the Flight of the Khyung, but appear to have been repurposed here. Emphasizing the fact that Brahmā remembered the Science of Life, but did not create it, he briefly cites the Essence of the Eight Branches and an unnamed commentary:

As stated in the [Essence of the] Eight [Branches]:

Brahmā recollected the Science of Life.

And in a commentary:

"Brahmā" refers to Grandfather Brahmā;

Thus he remembered [the Science of Life], but did not create it.

Such is Grandfather Brahmā. ${ }^{415}$

${ }^{414}$ Gsang ba man ngag gis [sic] rgyud kyi spyi don shes bya rab gsal rgyas pa (Beijing Ms), 22b: dug bdud rtsi tshangs paii tshe’i rig byed dran pa rnams dus mtshungs la/_di rnams thub pa ’jig rten du ma byon pa'i gong du yod pa'i phyir ro/_o na dus nam zhe na/_sangs rgyas gser thub mya ngan las 'das nas lo brgya nyi shu rtsa lnga nas/_lcags pho stag gi lo dpyid zla ba nya'i tshes zhes bdud rtsi bam brgyad du gsungs so/. Later editions of the Expanded Elucidation of Knowledge add even more detail: "on fourth day of the first month of spring" (dpyid zla ra ba'i tshes bzhir). See TYT 6o, and PMa 23b. 
Although I have been unable to locate this citation in the Tengyur, Drangti's use of canonical citations is scholastically convincing. He also cites the Instructional Tantra, as we did above, in addition to the Essence of the Eight Branches in describing the scene in which Halahhala poison arises and the casing of Rāhu. ${ }^{416}$ Drangti continues to exercise creative license even in his citing of the Eight Branches, however, for he freely weaves citations from the Flight with those from the Eight Branches. For example, the following citation can be found in the textus receptus of the Eight Branches:

When Rāhu stole the ambrosia,

His throat was slit and [his blood] began to trickle.

A drop of ambrosia fell to the earth,

Which transformed into white garlic. ${ }^{417}$

Drangti takes the first two lines of this citation, alters them, and then appends a quote in the Flight that is attributed to Nāgārjuna:

As stated in the subsequent section of the [Essence of the] Eight [Branches]:

It has been said that when Rāhu stole the ambrosia,

Viṣnu slit his throat.

Previously, the astrological being Rāhula,

Having drunk the ambrosia,

Had his head cut off by the Rivaled One's Wheel.

It should be understood that Viṣnu and the Rival are the same, but Rāhu and Viṣnu are not the same. ${ }^{418}$

${ }^{415}$ Gsang ba man ngag gis [sic] rgyud kyi spyi don shes bya rab gsal rgyas pa (Beijing Ms), 22b: brgyad par/_tshangs pa tshe yi rigs byed dran/_zhes pa dang /_de'i 'brel [='grel] par/_tshangs pa ni mes po tshangs pa ste/_des dran pa yin gyis byas pa ni ma yin no/_zhes pa ni/_mes po tshangs pa'o/.

${ }^{416}$ Gsang ba man ngag gis [sic] rgyud kyi spyi don shes bya rab gsal rgyas pa (Beijing Ms), 23a-23b.

${ }^{417}$ Yan lag brgyad pa'i snying po bsdus pa, in

Bstan 'gyur dpe bsdur ma, text 3548, vol. III (he [213]), p. 823: sgra gcan bdud rtsi brkus pa na//_rke bcad pa las 'dzag gyur pa'i//_bdud rtsi'i thigs pa sar lhung bal/_sgog skya nyid du gyur pa yin//.

${ }^{418}$ Gsang ba man ngag gis [sic] rgyud kyi spyi don shes bya rab gsal rgyas pa (Beijing Ms), 23b: brgyad pa'i phyi mar gsungs tel_sgra gcan bdud rtsi rku ba nal/_khyab jug gis ni ske bcad pas zhes pa dang //_sngon ni gza' skar rā hu la//_bdud rtsi 'thungs ba'i mgo bo ni//_dgra ldan gyis ni 'khor los bcad//_ces pas/_khyab 'jug dang dgra ldan gcig la/_sgra gcan dang khyab ’jug mi gcig par go'o/. 
Thus, Drangti is able to retain a non-canonical passage that is cited in the Flight through the practice of ambiguous citation. Interestingly, Drangti confuses the penultimate line and elides the ultimate line in the Flight citation:

Previously, the astrological being Rāhula, Having drunk the ambrosia, Had his head cut off by a wheel, the Sonorous One. Brahmā aided Viṣnu in battle. ${ }^{419}$

Instead of reading the "Sonorous One" (sgra ldan), apparently the name of a weapon, Drangti reads "Rivaled One" (dgra ldan) and asserts that this refers to Viṣnu himself, and should not be confused with the similarly named Rāhu (sgra gcan). As this example demonstrates, the creative citing and blending of quotations can often lead to confusion regarding the fundamental terms and concepts of the citation. Indeed, these confounding delights have confounded ends. Drangti concludes his retelling of Paktön's tale in a fashion similar to that of the Flight, but with his own emphases inserted:

Thus, Rāhula, upset that his throat had been slit, took the wheel in his hand and, endowed with the characteristics of the four commitments, threw it back. The wheel pierced Brahmā's cheek and, because he had power over life but not over death, and because Rāhu's wheel was endowed with commitments, he was unable to heal himself and suffered. ${ }^{420}$

From the blessings of the Buddha, the sounds of om a th tha emerged in the cheeks [of Brahmā], and he remembered the Tantra of Nakedly Seeing Awareness: The Collection of Medicine that he had previously heard from Kanakamuni. He performed the medical procedures and returned to good health. As stated in the [Essence of the] Eight [Branches]: ${ }^{42}$

Previously, the sound of the two syllables [sic], om ah thā, Manifestly coincided with the

Damaging of the cheeks of Brahmā.

${ }^{419}$ Khyung chen lding ba, in Cha lag bco brgyad, I3: sngon tshe gza' skar rā hu las//_bdud rtsi 'thungs tshe mgo bo ni//_sgra ldan gyis ni 'khor los bcad//_tshangs pas khyab 'jug 'thab grogs btang //.

${ }^{420}$ Gsang ba man ngag gis [sic] rgyud kyi spyi don shes bya rab gsal rgyas pa (Beijing Ms), 23b: de ltar rā hu la mgrin pa bcad pas khros tel_lag gis 'khor lo dam bcwa [=bca'] bzhi ldan mtshan nyid ldan/_phyir 'phangs pas/_tshangs pa'i mkhur tshos la phog ste/_tshangs pa tshe la dbang bas 'chi bar ma nus/_sgra gcan gyi 'khor lo dam bca' dang ldan pas 'tsho bar yang ma nus te sdug bsngal ba'i tshe/.

${ }^{42 \mathrm{I}} \mathrm{Gsang}$ ba man ngag gis [sic] rgyud kyi spyi don shes bya rab gsal rgyas pa (Beijing Ms), 23b: sangs rgyas kyi byin rlabs las mkhur tshos la/_om ah thā zhes pa’i sgra byung stel_sngon gser thub la mthos [=thos] pa'i gcer mthong rig pa'i rgyud gso dpyad 'bum pa dran te gso ba'i las la sbyar bas bde ba dang ldan par gyur te/_brgyad par/. 
Thus, these two [syllables] are auspicious. ${ }^{422}$

Again, instead of the teachings of Saakyamuni, here Brahmā is remembering the teachings of Kanakamuni in the form of the Tantra of Nakedly Seeing Awareness, which is appositionally equated with the Collection of Medicine (gcer mthong rig pa'i rgyud gso dpyad 'bum pa). Regardless of whether we are to understand these works as separate teachings or as being one and the same, the message is clear: Kanakamuni taught mythical ur-texts to Brahmā, which he spontaneously remembered when he was suffering from injury. The passage attributed to the Essence of the Eight Branches can also be found in the Flight of the Khyung, where the syllables have been rendered "om and atha" (yi ge om dang a tha'i sgra), instead of the more explicit "om ah thä" (yi ge om ah thä $\dot{i}$ sgra) found here. Both renderings are, of course, three syllables that are being referred to as two (gnyis po 'di dag), because the source for this quotation actually is referring to the sound and written syllable of om and its efficacy (yi ge om dang de nas sgra), not om $a$ h tha.$^{423}$ Again, the willful confounding of sources often leads to confusion for all subsequent readers.

Drangti closes the section by citing a Master Tsalungpa (slob dpon tsha lung pa), whom we can identify with a fair level of certainty as the student of Zhangtön Zijibar and teacher of Yutok Yönten Gönpo, Tötön Könkyap (stod ston dkon skyabs) of Mangkhar Tsalung (mang mkhar tsha lung) in Upper Lhartsé (stod lha rtse). ${ }^{424}$ He explains:

As stated by Master Tsalunpa:

By arousing the supreme nuclei of his cakra-wheels and so forth, the sounds of om ah thā arose in Brahmā's cheeks, and he recited the one hundred thousand [verses] of the Science of Life. ${ }^{425}$

The fact that Brahmā heard these [teachings] previously and wished to remember them later contradicts the notion that the piercing [of his cheeks] was caused by a human being. It is also incorrect to propose that, when Brahmā was suffering, it was the Buddha that

${ }^{422}$ Gsang ba man ngag gis [sic] rgyud kyi spyi don shes bya rab gsal rgyas pa (Beijing Ms), 23b-24a: yi ge om a h thä'i sgral/_gnyis po 'di dag sngon tshang pa'i mkhur tshos brtol te mngon par byung //_des na'di gnyis bkra shis yin//_zhes gsung la/.

${ }^{423}$ The following passage appears in the Moonbeams commentary on the Essence of the Eight Branches, but not the root text itself. Candranandana appears to be citing another source, which is not clear to me.

Yan lag brgyad pa’i snying po’i rnam par'grel pa'i tshig gi don gyi zla zer, in Bstan 'gyur dpe bsdur ma, text 3549, vol. II3 (ko [215]), p. 6: yi ge om dang de nas sgral/_gnyis po 'di dag sngon tshangs pa'i//_mkhur tshos brtol te mngon par byung //_des na 'di gnyis bkra shis yin//_zhes smos pa yin la//.

${ }^{424}$ Although early sources do not describe this twelfth-century figure in such detail, later sources identify the home of Tötön Könkyap as being Tsalung.

${ }^{425}$ Gsang ba man ngag gis [sic] rgyud kyi spyi don shes bya rab gsal rgyas pa (Beijing Ms), 24a: slob dpon tsha lung pas/_khor lo thig le mchog ma la sogs pas bskul bas/_tshangs pa'i mkhur tshos la om ạ thä'i sgra byung pas/_tshe'i rig byed 'bum phrag gcig zhugs zhes smra mod/. 
directly pacified him. Brahmā's recollection of the Science of Life and the time [of Sākyamuni Buddha] are not the same. ${ }^{426}$

Despite confusing an epithet for Viṣnu for a reference to his weapon, as well as the specifics of the trisyllabic om a h tha mantra replacing the oral and visual forms of om, both Drangti in the Expanded Elucidation of Knowledge and Paktön in the Flight of the Great Khyung appeal to scripture in order to support their points. Interestingly, many of these scriptures-such as the Heap of Jewels, the Eight Fascicles of Ambrosia, or the Diagonal Thread of the Essence of Mañjuśrino longer are extant and probably were not even available to Paktön and Drangti themselves. Their lack of access is supported by the continual editing, expanding, and weaving of these citations together with each other and even extant canonical works like the Essence of the Eight Branches. Thus, the efforts of Paktön and Drangti in closing the Four Tantras-in limiting the contents to specified numbers of chapters and even stanzas - come as something of a surprise. Alongside an effort to creatively expand the space of medical scriptures to myriad unattested chapters of mythical ur-texts, also was an effort to precisely limit the size and scope of the Four Tantras itself.

As the Four Tantras came to be systematized in both form and narrative framing, the teaching of the Tibetan medical tradition also was coming to be systematized with khokbuk curricula like the Flight of the Great Khyung and the Expanded Elucidation of Knowledge. As the teaching and practice of Tibetan medical traditions were integrated into the larger monastic institution of the Sakya Medical House, however, the dissonance between medical narratives like those found in the Four Tantras and the Flight of the Khyung and increasingly orthodox Buddhist narratives like the life of Saakyamuni Buddha also needed to be reconciled. As we shall see below, Drangti was able to take the narrative initiatives found in the Flight of the Khyung and successfully integrate them into the narratives of prominent and powerful Sakya figures like Butön Rinchen Drup and Lama Dampa Sönam Gyentsen. In doing so, he created a narrative frame that continued to form the basis for monastic Buddhist medicine in Tibet down to the present.

${ }^{426}$ Gsang ba man ngag gis [sic] rgyud kyi spyi don shes bya rab gsal rgyas pa (Beijing Ms), 24a: sngon thos pa phyis dran par'dod kyis/_rtol skye bus byas pa 'gal la/_tshangs pa sdug bsngal ba'i tshe sangs rgyas kyis dngos su thul zer ba mi 'thad/_tshe'i rig byed dran pa dang dus ma mtshungs pa'o/. 


\section{Chapter Four: The Yutok Student and Familial Lineages at the Sakya Medical House}

At the turn of the fourteenth century, following his return from exile, the Khön scion Daknyi Chenpo Zangpopel (I262-I323; r. I298-I323) invited the famed physician, Drangti Jampel Zangpo (ca. 1276-I335), to act as his royal physician at Sakya monastery. Prior to the thirteenth century, the medical traditions of Tibet tended to be transmitted outside of the monastery, operating within the familial lineages of famed clans and rarely in the context of inter-familial schools and practical organizations. Little is known about the social circumstances of these early Tibetan medical traditions, but by the turn of the thirteenth century the practical lineages of famed physicians like Yutok Gönpo and Cherjé Zhangtön Zhikpo began to attract enough students to warrant the establishment of educational lineages and collections of practical institutions, resulting in the composition of unifying narratives and scholastic curricula that have been transmitted down to the present day. Building upon these curricular precedents, Drangti Penden Tsojé (ca. I3IO-I380) composed the Expanded Elucidation of Knowledge (shes bya rab gsal rgyas pa) around the year 1372, delineating the institutional curriculum for the study and practice of medicine at the Sakya Medical House, and establishing standards for all subsequent Buddhist medical institutions in Tibet.

As we have seen, prior to this unification of political, religious, and medical institutions at Sakya, the Tibetan medical tradition was rife with practical, scholastic, and ideological controversy. Engaging both divinatory and diagnostic modes of examination, theoretical and practical modes of scholasticism, and Indocentric and Buddhocentric modes of narration, the Drangti approach to medical theory and practice at the Sakya Medical House was primarily one of accretion and reconciliation. Following his father's establishment of the Sakya Medical House and his own training as both a monk and a physician at Sakya, Drangti Penden Tsojé creatively elaborated upon the early records of the Yutok school to depict his own clan as the scions of the Yutok lineage of medical practice. Despite the creativity of these elaborations and due to these efforts, Drangti Penden Tsojé came to be remembered as an integral figure in the standardization and transmission of medicine in Tibet.

In addition to this narrative posturing of the Drangti clan in Tibetan medical history, Penden Tsojé also built upon diverse precedents to establish his own curriculum for the study and practice of medicine. Although much has already been written about the khokbuk genre in modern secondary scholarship, interpreting such works within the context of Tibetan social history reveals their importance for not only medical history, but also medical pedagogy. Read as curricula for medical schools and institutions in Tibet, the histories of khokbuk become creative narratives designed to engender trust and support among students, and the doxographies become prescriptive syllabi for the study and practice of Tibetan medicine. Continuing the enterprise of his teacher, Paktön Shākya Gönpo, Drangti Penden Tsojé

promotes the Four Tantras as the seminal work of the Tibetan medical tradition, relegating the 
cycle of related instructions and commentaries to the Eighteen Partial Branches collection, and effectively establishing a canonical cycle of works for the study and practice of Tibetan medicine. These efforts, combined with the political and institutional clout of fourteenthcentury Sakya monastery, allowed Penden Tsojé to establish a unified vision for the history, theory, and practice of Buddhist medicine in Tibet - a tradition that would continue to be refined, but never replaced, down to the modern era.

\section{The Mongols, the Drangti Clan, and the Sakya Medical House}

Shortly after taking command of the eastern Mongol sphere of influence, and before even establishing the Yuan dynasty (I27I-I368), Kublai Khan (I2I5-I294; r. I260-I294) began directly regulating the medical institutions of his empire. As is well known, the Mongolian court had already begun extracting taxes from Tibetan religious institutions by the 1260 s, ${ }^{427}$ but the influence of Mongolian bureaucracy on Tibetan medical institutions has not yet been established. In an apparent attempt to standardize and regulate the sale and taxation of medicine, in 1262 Kublai Khan issued the following ordinance in regard to the role of "medical houses" (yihu 醫戶) as institutional centers throughout the empire:

Regarding the taxes and labor service that medical houses owe, they should pay silk, cotton, and dye taxes. Also, if they produce rice, they shall pay rice tax, and if they trade, they owe trade taxes. However, they shall be exempt from all miscellaneous service duties such as providing military supplies, raising horses and taking care of messengers in the postal relay system, and taking care of cows and personnel. When officials in appanages (touxia 投下) buy medicines from physicians, they should pay reasonable price and should never just take it by force. Following annual practice, medical houses under the jurisdiction of government (xiguan 係官; that is, not in appanages), should pay three taels of silver tax, and now they should pay with our paper money. Wang Zijun and other officials should consider a physician's wealth and status and determine their tax, and provide according to the necessities of members of Imperial Academy of Medicine (taiyi yuan 太醫院) who are serving in the court. ${ }^{428}$

As this passage indicates, even in the first several years of his reign, Kublai Khan had already come to closely manage the affairs of both the Imperial Academy of Medicine in Dadu 大都

${ }^{427}$ See, for example, the 1254 ordinance in which the Sakya were exempted from taxation: Luciano Petech, Central Tibet and the Mongols: The Yüan-Sa-skya Period of Tibetan History (Rome: Instituto Italiano per il Medio ed Estermo Oriente, I990), I4-I5.

${ }^{428} \mathrm{Da}$ Yuan shengzheng guochao dianzhang 大元聖政國朝典章 (Taibei: Guoli Gugong bowu yuan, I976) 32.Ib; translated in Shinno, The Politics of Chinese Medicine under Mongol Rule, 3I; and reproduced here with minor edits. 
(modern Beijing), as well as all of the registered medical houses throughout his area of influence. ${ }^{429}$ Despite the sparse availability of documents directly linking such policies to Tibetan medical practitioners, one extant ordinance issued in an ox year (probably 1277 or I289) ${ }^{430}$ attests to this historical reality. A Mongolian-language edict in Pakpa script from the office of Kublai Khan exempting a Lharjé Sanggyepel (lha rje sangs rgyas dpal) from tax responsibilities is still extant, ${ }^{43 \mathrm{I}}$ and, regarding just such a phenomenon, Drangti Penden Tsojé writes:

Because [Shakrampa Belmen Nyimapel of Nyemo] became a supreme master, he acted as the royal physician for Kublai Khan. In the valley of Lharidro [Kublai Khan] sent an ordinance appointing [Shakrampa] to the rank of dargen. [Shakrampa] created many temples and stupas, copied many scriptures, and composed many medical commentaries, anthologies, and thousand-session tutorials. By examining the channels and fluids of a patient, [Shakrampa] was able to know their lifespan within seven years, as well as things like their virtuous and polluting actions. With his attainments in alchemy, he performed lectures and made extensive contributions for the sake of beings until the age of fifty-five [or ninety-five?]. ${ }^{432}$

Elsewhere in the Expanded Elucidation of Knowledge Penden Tsoje lists these many illustrious physicians of the thirteenth and fourteenth centuries, stating that there were "seven physicians, such as Shakrampa Belmen Nyima and so forth, that were appointed by powerful kings." ${ }^{333}$ Although the details of this appointment are still far from clear, let it suffice to say

${ }^{429}$ On the cosmopolitan nature of this institution, see Angela Schottenhammer, "Huihui Medicine and Medicinal Drugs in Yuan China," in Eurasian Influences on Yuan China, ed. Morris Rossabi (Singapore: Institute of Southeast Asian Studies, 20I3), 75-IO2.

430 The Pakpa script was first announced in an ordinance dating to 1269 , so it is unlikely that this ordinance would have been made prior to I277 (1265?). See Petech, Central Tibet and the Mongols, 22.

${ }^{431}$ See Sgrolkar, et al., eds., A Collection of Historical Archives of Tibet [Xizang lishi dang'an huicui 西藏历史档案荟萃] (Lhasa: Wenwu chubanshe, I995), I.I-I.3.

${ }^{432}$ Gsang ba man ngag gis [sic] rgyud kyi spyi don shes bya rab gsal rgyas pa (Beijing Ms), 38b: mkhas pa'i mchog tu gyur pas/_bse chen gyi bla sman mdzad/_lha ri sgro'i lung pa la dar rgan gyi 'ja' sa gnang /_gtsug lag khang dang rten gsung rab mang du bzhengs shing /_sman dpyad kyi 'grel pa gces bsdus stong mthun [=thun] yig cha mang du mdzad/

rtsa chu gzigs pa'i mi rnams kyis tshe’i tshad lo bdun tshun chad kyi dge sdig ji lta ba bzhin mkhyen cing /_bcud len grub pas dgung lo lnga bcu rtsa lnga'i bar du/_chad nyan dang 'gro don rgya cher mdzad de/. Rgyud bzhi'i spyi don shes bya rab gsal rgyas pa (Delhi), I08, indicates that Shakrampa lived for ninety-five years instead of fifty-five.

${ }^{433}$ Gsang ba man ngag gis [sic] rgyud kyi spyi don shes bya rab gsal rgyas pa (Beijing Ms), 33a: bshag ram gyi 'bal sman nyi ma la sogs pa'i stobs ldan rgyal pos bkur ba'i sman pa bdun/. These lists were expanded and specified in later editions. Compare with Rgyud bzhi'i spyi don shes bya rab gsal rgyas pa (Delhi), 9I: stobs ldan hor gyis bkur ba'i sman pa drug ni/_snye mo shag ram gyi 'bal sman nyi ma/_g.yas rung shangs kyi sbas sman dkar nag_snang mtha' sman grong gi brang ti grags 
that, as stated by Drangti Penden Tsojé, Shakrampa Belmen Nyimapel of Nyemo served as the royal physician (bla sman) for Kublai Khan (bse chen) in some capacity during the late thirteenth century. The notion of royal physician probably refers to the fact that Kublai Khan sent an ordinance (Tib. 'ja' sa < Mon. jasaq) appointing him the rank of dargen (Tib. dar rgan < Mon. darqan), which implies tax-exempt status, ${ }^{434}$ but may also indicate further responsibilities.

Shakrampa also appears to have made several important contributions to Tibetan religious and medical traditions, building temples, sponsoring the production and proliferation of medical texts, and composing many medical commentaries, anthologies, and thousand-session tutorials. While the terms "commentary" ('grel pa) and "anthology" (gces $b s d u s$ ) remain rather vague - and, indeed all of these categories may be in apposition in this passage- "thousand-session tutorials" (stong mthun [=thun] yig cha) refer to a very specific corpus of instructional materials. These tutorial manuals appear to have circulated independently as well as in a collection of eleven tutorials, for the Channel [Examination] Tutorial, Channel and Fluid [Examination] Tutorial, Cold [Disease] Tutorial, Brown Bile Tutorial, and the Combined Cycles of the Eleven Tutorials are each still extant as separate manuscripts. ${ }^{435}$ Indeed, the colophon of the latter manuscript indicates that it derives from the "tradition of Master Yutok Gönpo," and also is the "special jewel of Lharjé Sanggyé Pelrin." ${ }^{436}$ Although this evidence remains tenuous, it is enough to show that both Lharjé Sanggyé Pel[rin] and Shakrampa Nyimapel [I.] received tax exempt status from Kublai Khan, and [2.] provided medical instructions in the form of thousand-session tutorials. Based on these facts, I propose that Lharjé Sanggyé Pelrin may, indeed, be an alternative title for Shakrampa Nyimapel, but further evidence would be needed to verify such a claim.

In order to conform to the Mongol tax structure, Tibetan physicians would have needed to break from the celebrated familial lineages that we see throughout Tibetan medical biographical accounts and form registered institutions. Indeed, the first and most famous Tibetan "medical house" (Tib. sman grong = Chi. yihu 醫戶) would be the Sakya Medical House, established by Drangti Jampel Zangpo (ca. 1276-I335) with the support of Daknyi Chenpo Zangpopel (I262-I323; r. I298-I323) during the Yuan period. Although this institutional

'bum/_yar klung dgon thang gi lhar rje pag the/_yar stod g.yu srid kyi lha rje phag mo gru pa/_khye re 'bras kyi lo ston yon tan no//.

${ }^{434}$ See entries for darqan and jasaq in Christopher P. Atwood, Encyclopedia of Mongolia and the Mongol Empire (New York, NY: Facts on File, Inc., 2004), I33, and 264-65, respectively.

${ }^{435}$ In the Krung go'i bod lugs gso rig rtsa che'i dpe rnying kun btus, see the following works, respectively: Skor tshoms stong thun bcu gcig las dang po rtsa'i stong thun, vol. 3, text 5; Rtsa chu'i stong thun g.yu thog gi bzhed pa, vol. 3, text 7; Grang ba'i stong thun, vol. 3, text 9; Grang ba'i stong thun, vol. I4, text 4; Bad kan smug po'i stong thun, vol. I4, text 5; Skor tshoms stong thun bcu gcig, vol. I4, text 4 .

${ }^{436}$ Skor tshoms stong thun bcu gcig, in Krung go'i bod lugs gso rig rtsa che'i dpe rnying kun btus, vol. I4, text 4, p. 40 (f. 35b): mkhas pa g.yu thog mgon po'i lugs so//_lha rje sangs rgyas dpal rin gyis [sic] khyad nor yin//. 
title cannot be found in the writings of Peden Tsojé, some of the earliest literary uses of the name Sakya Medical House appear in the interlinear spaces of the Silver Measure (dngul bre $m a$ ) collection redacted by Drangti Penden Gyentsen (brang ti dpal ldan rgyal mtshan, fl. late $4^{\text {th }}{ }^{\text {th }}$ c.). In a colophon of the Treatment for Pediatric Lung Disease: A Practice of the Master Doctor, for example, we are told that these instructions are "the practice of the master doctor [of the Sakya Medical House]." ${ }^{437}$ The Special Method for Subduing the Jangpa Beetle also begins with the following homage: "I bow with respect to the Sakyapa [Dorjé Pelgön Zangpo, physician of the Sakya Medical House]." ${ }^{38}$ I have been unable to identify Dorjé Pelgön Zangpo, but he appears to have been a descendent of Penden Tsojé and Penden Gyentsen, indicating that these Gold and Silver Measure collections probably remained open collections beyond the fourteenth century. The Sakya Medical House title also does not appear anywhere in the Gold Measure (gser bre), potentially indicating that the Silver collection remained open to additions even beyond the closing of the Gold Measure.

By the sixteenth and seventeenth centuries the name Sakya Medical House appears to have been well established. In his Abbatial Successions of Ngor Monastery (ngor gdan rabs), for example, Sanggyé Puntsok of Ngari (mnga' ris pa sangs rgyas phun tshogs, 1649-1705) narrates the lineage of the Drangti family in a fashion similar to that of the Expanded Elucidation of Knowledge, culminating in the story of the Thirteenth Ngor Khenchen (ngor mkhan chen), Drangti Panchen Namkha Pelzang (brang ti pạ chen nam mkha' dpal bzang, I532-I602):

Ever since the Sakya Lama Daknyi Chenpo Zangpopel invited Drangti Jampel Zangpo to Sakya and he became initiated as the royal physician, this branch of [Namkha Pelzang's] ancestry has been known as the Sakya Medical House. ${ }^{439}$

As is well known, Zangpopel, the final Khön scion of his generation, was sent into exile following questions of his legitimacy and general disapproval by Kublai Khan. Following Kublai Khan's death in 1296, however, Temür Khan (I265-1307; r. I294-I307) not only allowed Zangpopel to return to Sakya, but also entrusted his own daughter, Princess Müdegen, to him in marriage. ${ }^{400}$ Zangpopel was enthroned as the Eleventh Sakya Throne Holder (sa skya khri

${ }^{437} \mathrm{Bu}$ chung gi glo nad bcoa pa lha rje dpon po'i phyag len, in Bod rang skyong ljongs sman rtsis khang, ed., Sa skya sman grong pa'i man ngag dngul bre ma (Lhasa: Bod ljongs mi dmangs dpe skrun khang, 2005), 85: lha phye [=rje] [sa skya sman grong] dpon po'i phyag len yin.

${ }^{438}$ Byang pa'dul thabs khyad par can, in Sa skya sman grong pa'i man ngag dngul bre ma, i26: sa skya pa [sman grong pa 'tsho byed rdo rje dpal mgon bzang po] la gus btud nas/.

${ }^{439}$ Mnga' ris pa Sangs rgyas phun tshogs, Dpal e wam chos ldan gyi gdan rabs nor bu'i phreng ba, in Lam 'bras Tshogs bśad: The Sa-skya-pa Teachings of the Path and the Fruit, According to the Norpa Transmission (Dehra Dun: Sakya Centre, 1985), vol. 27 (sha), p. 283 (f. I7a): sa skya’i bla ma bdag nyid chen po bzang po dpal gyis brang ti ’jam dpal bzang po sa skyar spyan drangs nas/_bla sman du dbang bskur ba nas bzung ste/_rje'di sku mched yan sa skya sman grong par grags so/.

$44^{\circ}$ For details about these and many other complex political relationships and events, see Petech, Central Tibet and the Mongols, 72-74 et passim.

W. A. McGrath | Buddhism and Medicine in Tibet | I45 
'dzin) after his return to Sakya in I298 and it is presumably around this time that Drangti Jampel Zangpo was summoned to Sakya. Thus, the institution of the Sakya Medical House began with the institutionalization of the Drangti medical lineage at Sakya monastery around the year 1300, under the aegis of Khön and Mongol support.

\section{The Drangti and the Yutok Familial Lineage}

Although it was Drangti Jampel Zangpo that founded the Sakya Medical House, the single greatest contribution made by the Drangti clan to Tibetan religious and medical thought is the Expanded Elucidation of Knowledge (shes bya rab gsal rgyas pa, 1372) by Drangti Penden Tsojé (brang ti dpal ldan 'tsho byed, ca. I310-I380). The work is ambitious in scope, explicitly building upon the Buddhist worldview depicted in the Elucidation of Knowledge (shes bya rab gsal) by Drangti's Sakya predecessor and Mongol collaborator, Drogön Chögyel Pakpa ('gro mgon chos rgyal 'phags pa, I235-I280), and implicitly promoting the Yutok and the Drangti clans as the seminal lineages of physicians, the Four Tantras as the seminal work of Tibetan medical tradition, and medicine as an inherent part of the path to buddhahood. Aptly titled, Penden Tsojé continues the work of Pakpa by placing his story in an Indian cosmology of Vedic gods, hinging upon the life of Śākyamuni Buddha himself, and connecting the mythic past to the historic present by means of lineage and genealogy. ${ }^{441}$ Penden Tsojé also explicitly frames the Expanded Elucidation of Knowledge within the genre of the khokbup or khokbuk curriculum (khog 'bubs/'bugs; lit. "arranging/penetrating the contents"), ${ }^{42}$ creating a pedagogical framework for the education of future physicians within the Sakya Medical House.

Penden Tsojé also builds upon previous historical accounts and curricula of the Tibetan medical tradition, such as the Indispensable Account of Transmission (brgyud pa'i rnam thar med thabs med pa, II74?) attributed to Sumtön Yeshé Zung (fl. mid/late $\mathbf{I}^{\text {th }} \mathrm{c}$.) and the Flight of the Great Khyung (khyung chen lding ba) ${ }^{443}$ that was probably authored by Paktön Shākya Gönpo in the early fourteenth century. ${ }^{444}$ Both of these works can be found in the Eighteen Partial

${ }^{441}$ For a translation of the more historiographical section of the Elucidation of Knowledge, see Prince Jin-gim's Textbook of Tibetan Buddhism: The Shes bya rab gsal by 'Phags-pa Blo-gros rgyalmtshan dPal-bzan-po of the Sa-skya-pa, trans. Constance Hoog (Leiden: Brill, 1983), 39-43. For representative excerpts, see also "Lama Pakpa's Elucidation of the Knowable," in Sources of Tibetan Tradition, ed. Kurtis R. Schaeffer, Matthew T. Kapstein, and Gray Tuttle (New York, NY: Columbia University Press, 2013), 328-37.

${ }^{442}$ The khog 'bubs (or 'bugs, dbub, dbug and so forth) has been the subject of much discussion in secondary literature. Most recently, see Gyatso, Being Human in a Buddhist World, 13I-35, and 43I, n. 266. For more on this term and my choice of translation, "curriculum," see below.

${ }^{443}$ For an overview of this work, see Frances Garrett, "Buddhism and the Historicising of Medicine in Thirteenth-century Tibet," Asian Medicine 2, no. 2 (2006): 204-24.

${ }^{444}$ The first extant khokbuk curriculum is, of course, the Blazing Peak of the Victory Banner: Arranging the Contents of the Origins of Medicine (sman gyi byung tshul khog dbubs rgyal mtshan rtse mo 'bar ba, I2O4 or I264?) by Cherjé Zhangtön Zhikpo (che rje zhang ston zhig po, fl. early/mid I3th c.?). As far as I am aware, this text only exists in manuscript and is not currently available 
Branches collection - an anthology of instructional works, summaries, and commentaries all centered around the Yutok school—which was probably compiled by Drangti Penden Tsojé in the fourteenth century. The Indispensable Account narrates the life stories of several individuals, focusing on the efforts of Yutok Yönten Gönpo ( $I 2^{\text {th }} c_{\text {. }}$ ) and his students, and culminating in the transmission of a text - the seminal work of the Tibetan medical tradition, the Essence of Ambrosia (bdud rtsi snying po), commonly called the Four Tantras (rgyud bzhi). Unlike accounts of liberation (rnam thar) that relate the life story of an individual, the early narratives of Tibetan medicine center upon the transmission of the Essence of Ambrosia from primordial utopia down to contemporary Tibetan physicians. ${ }^{445}$ Such narratives were then reframed by subsequent generations of Yutok's lineage and incorporated into a khokbuk curriculum, the Flight of the Great Khyung, around the turn of the fourteenth century. Having received the teachings of the Yutok lineage, Penden Tsojé expanded upon the narratives of the Indispensable Account and Flight of the Great Khyung to create an institutional curriculum for the Sakya Medical House, synthesizing previous accounts of the Yutok lineage with his own.

An important figure for the conflation of both Yutok and Drangti lineages is Drangti Jampel Zangpo, who Penden Tsojé depicts as having studied with both Yutok Jampel and Yutok Tsojé, descendants of Yutok Gönpo. Other than this account written by his son, not much is known about Jampel Zangpo. As we saw in Chapter Two, Jampel Zangpo is said to have composed a commentary on Yutok Gönpo's Small Practical Manual (lag len spod chung), which also includes a narrative of transmission. Therein we also learn that Jampel Zangpo studied with Yutok Jampel and Yutok Tsojé, continuing the so-called familial lineage (sras brgyud) of Yutok Gönpo, but this narrative also may have been a later addition on account of the fact that it is not included in the table of contents examined in Chapter Two. Thus, in examining the life of Jampel Zangpo, it is to the writings of Penden Tsoje that we must turn.

Penden Tsojé begins his family history with an account of the celebrated Drangti ancestor, Drangti Gyelnyé Kharbu, minister and primary royal physician for the Bearded Grandfather, King Tri Detsukten (704-755). As we have seen in Chapter Two, the career of this figure was probably narratively projected back into the empire around the turn of the fourteenth century, for he is described as a treasure revealer in an earlier alternative account. Regardless, Penden Tsojé notes that from the time of this primary ancestor and imperial royal physician,

to me (or anyone else without access to the Giuseppe Tucci collection in Rome, Dan Martin, personal communication, 28 May, 20I5). Regardless, the contents of this early history are summarized in Dan Martin, "An Early Tibetan History of Indian Medicine," in Soundings in Tibetan Medicine: Anthropological and Historical Perspectives. Proceedings of the Ioth Seminar of the International Association of Tibetan Studies, ed. Mona Schrempf (Leiden: Brill, 2007), 307-25.

${ }^{445}$ For similar such accounts about the transmission of the Great Perfection (rdzogs chen) teachings, see Erik Pema Kunsang, Wellsprings of the Great Perfection: The Lives and Insights of the Early Masters (Kathmandu: Rangjung Yeshe Publications, 20I2). 
"the Drangti have been virtuous medical scholars without interruption." ${ }^{466}$ He names Drangti Sönam Bum as the father of Jampel Zangpo, who was apparently a scholar and physician, for it was with his father that Jampel Zangpo studied the oral commentary cycle, the esoteric instructions, and the practical instructions for the root text and commentary of the Essence of the Eight Branches treatise, the mother and son texts of the Red Register, and the Three Medical Cycles of the Ācarrya [=Bharo Chakdum=Kyebu Melha]. When Jampel Zangpo was young, the Karmapa II Künkhyen Pakshi (I204-I283) also prophesied that he would be a "bodhisattva of benefit to beings." 447

After this initial education within the medical lineages of the Drangti family, we are told that Jampel Zangpo traveled to Gozhi Retang in the Upper Nyang river valley ${ }^{448}$ to study the Four Tantras along with the Partial Branches, as well as other oral instructions of the Yutok lineage with Yutok Jampel. ${ }^{449}$ This particular detail is historically problematic for, as we shall see, even if Yutok Jampel were a well-attested member of the Yutok lineage beyond the writings of Drangti Penden Tsojé-which is he is not - the mention of "the Four Tantras along with the Partial Branches" (rgyud bzhi cha lag dang bcas pa) is anachronistic due to the fact that the Essence of Ambrosia is first described as the Four Tantras around the turn of the fourteenth century and the partial branches are first described as a discrete corpus by Penden Tsojé himself. In addition to these studies with the Yutok lineage, Jampel Zangpo is also said to have studied an expanded edition of the Essence of the Eight Branches with the Jang physician, Master Yeshé Zangpo, in Tsibu Jangmo Khü, along with a classmate named the Minyak Mendicant. ${ }^{450}$ Although we do not learn much about this physician from Jang (ljang [=byang?] sman pa), Jampel Zangpo and the Minyak Mendicant are both said to have been sons born

${ }^{446}$ Gsang ba man ngag gis [sic] rgyud kyi spyi don shes bya rab gsal rgyas pa (Beijing Ms), 39a: de yang rgyal po khri sde gtsug stan mes ag tshom du grags pa de’i blon po dang /_bla sman gyi gtso bo brang ti rgyal brnyes mkhar phug nas bzung ste/_sman pa’i dge bshes bar ma chad par byung ba/.

${ }^{447}$ Gsang ba man ngag gis [sic] rgyud kyi spyi don shes bya rab gsal rgyas pa (Beijing Ms), 39a: brang ti bsod nams 'bum zhes pa'i sras su 'khrungs shing /_gzhon nu nas thugs rab dang byang sems mthu stobs shin tu che ba/_karma kun mkhyen dpag shis kyang /_byang chub sems dpa' 'gro la phan pa 'byung ngo /_zhes lung bstan cing /_yab la bstan bcos brgyad pa rtsa 'grel dmar byang ma bu/_a tsa ra’i gso dpyad skor gsum la sogs pa'i bshad skor man ngag phyag len gsan/.

${ }^{448}$ A modern gazetteer identifies Gozhi Ritang - that is, the "mountain plain of the four gates," a corruption of Gozhi Retang - as a site near the Nyang river valley (myang chu phar ka) in Tsang and the birthplace of Yutok Yönten Gönpo. See Si tu chos kyi rgya mtsho, Dbus gtsang gnas yig (Chengdu: Si khron mi rigs dpe skrun khang, 200I), 356.

${ }_{449}$ Gsang ba man ngag gis [sic] rgyud kyi spyi don shes bya rab gsal rgyas pa (Beijing Ms), 39a: sgo bzhi re thang du g.yu thog 'jam dpal can byon nas rgyud bzhi cha lag dang bcas pa dang /_g.yu thog pa'i phyag len man ngag rnams gsan zhing thugs su chud par mdzad de/.

${ }^{450}$ Gsang ba man ngag gis [sic] rgyud kyi spyi don shes bya rab gsal rgyas pa (Beijing Ms), 39a: rtsis dus [=tsi bu?] byang mo khud du ljang sman pa slob dpon ye shes bzang po yun ring du bsten nas/_bstan bcos brgyad pa rgyas par gsan/_mi nyag bandhe dang gnyis thugs las 'khrungs pa'i sras su grags/. 
from his heart (thugs las 'khrungs pa'i sras). Combining each of these narrative threads, Penden Tsojé depicts his father as being the scion of the Drangti, Yutok, and Jang medical lineages.

Having come to be known as a master of nearly all therapeutics in the Tibetan tradition, ${ }^{451}$ as a physician's physician (sman pa'i sman par grags), Jampel Zangpo was invited to Sakya and appointed as both an official physician ${ }^{452}$ and the primary royal physician for Lama Daknyi Chenpo. ${ }^{453}$ As prophesied by the Karmapa II, Jampel Zangpo is said to have generated the mind of enlightenment, giving out food and medications to the poor and disenfranchised by day, and dedicating the merit to all sentient beings by night. ${ }^{454} \mathrm{He}$ is also said to have maintained his esoteric commitments for the generation and perfection phases of practice, teaching the medical tantras, the Essence of the Eight Branches, and the Small Practical Manual during his seasonal lectures (dus chos). ${ }^{455}$ Jampel Zangpo is said to have announced his own death during the summer teachings of his fifty-ninth year, declaring "This year shall be my final lecture," causing many people to come and visit him. ${ }^{456}$ Even up to his death he continued to selflessly work for the sake of others, encouraging them to prepare offerings for the Supreme Jewels, and finally passed on while practicing guru yoga and the transference of consciousness. ${ }^{457}$ Having acted in accordance with the bodhisattva ideals, relieving the

${ }^{451}$ Gsang ba man ngag gis [sic] rgyud kyi spyi don shes bya rab gsal rgyas pa (Beijing Ms), 39a: mdor na bod du grags pa'i gso dpyad phal mo che la dbang 'byor pa mkhas pa'i mchog tu grags shing /.

${ }^{452}$ Gsang ba man ngag gis [sic] rgyud kyi spyi don shes bya rab gsal rgyas pa (Beijing Ms), 39b: rgya mtsho phyed [='tsho byed] kyi go sa dang /. The printed edition has a corrupt version of this line: Rgyud bzhi'i spyi don shes bya rab gsal rgyas pa (Delhi), I09: "He was appointed to care for Lady Gyatso" (rgya mtsho bud med phyed kyi go sa dang dpyad). In accord with the Beijing manuscript, Kilty interprets "half an ocean" (rgya mtsho phyed) as a provincial officer of some kind (Mirror of Beryl, 530, n. 570), asserting that rgya mtsho is a subdivision of a rdzong, but without any further information. I read rgya to refer to the kingdom in general (rgya gar, rgya nag, and so forth), and mtsho phyed to be a misspelling of "physician" ('tsho byed). I have not seen any other uses for this designation, however.

${ }^{453}$ Gsang ba man ngag gis [sic] rgyud kyi spyi don shes bya rab gsal rgyas pa (Beijing Ms), 39a-38b: bla ma bdag nyid chen pos gdan sar spyan drangs tel_brgyad pa'i 'chad nyan btsugs/_rgya mtsho phyed kyi go sa dang /_bla sman gyi mthil mdzad la/.

${ }^{454}$ Gsang ba man ngag gis [sic] rgyud kyi spyi don shes bya rab gsal rgyas pa (Beijing Ms), 39a-38b: snga dro sems bskyed mdzad nas/_chen po rnams kyi dbang du mi gtong bar phongs pa dang mgon med pa kho na la gzigs shing /_sman zas sbyin/dgongs mo gzhan phan gyi dge ba sems can gyi don du bsngo ba ma chag par mdzad/.

${ }^{455}$ Gsang ba man ngag gis [sic] rgyud kyi spyi don shes bya rab gsal rgyas pa (Beijing Ms), 38b: dus chos lal_rgyud dang brgyad pa lag len spu ti rnams ma chag par gsungs shing /_gzig rtogs chos gsung ba'i gzhan don rim gnyis kyi thugs dam kho nas dus 'da' la/.

${ }^{456}$ Gsang ba man ngag gis [sic] rgyud kyi spyi don shes bya rab gsal rgyas pa (Beijing Ms), 38b: dgung lo lnga bcu rtsa dgu bzhes pa'i dbyar chos kyi tshe da lo 'chad nyan gyi tha ma yin zhes pa dang mthun par cung zad snyung pa nas zhal lta rnams legs par byon zhing /.

${ }^{457}$ Gsang ba man ngag gis [sic] rgyud kyi spyi don shes bya rab gsal rgyas pa (Beijing Ms), 38b: de phan rang 'dod med pa'i sems can gyi don ci 'grub byas pa de yin gsungs shing /_dges pa'i gnang nas dkon mchog la mchod pa bshoms gsungs tel_bla ma'i rnal 'byor sgom pa'i skabs la 'pho ba mdzad de [...]. 
sufferings of sentient beings throughout his life, all of the people praised him as being a great bodhisattva. ${ }^{458}$ Thus, in addition to his great scholastic learning and practical skill in medicine, it was Jampel Zangpo's compassionate service to his community that secured his place in their hearts and memories.

Here Drangti Penden Tsojé provides the dates for neither the birth nor the death of his father, but he does tell us that he announced his own death at the age of fifty-nine. Due to the fact that at least some time must separate this announcement from his actual passing, combined with the fact that new-born babies are considered to be one year old in the Tibetan tradition, let us assume that Drangti Jampel Zangpo lived for fifty-eight or fifty-nine years after he was born. If we take the prophesy told by the Karmapa II into account-although we do not know how old Jampel Zangpo was when this prophecy was made-we can determine that Jampel Zangpo was born no later than Karma Pakshi's death in I283, and probably around the time that Karma Pakshi returned to Tsurpu (tshur phu) monastery from Mongolia in 1276.459

In addition to this story of his father, Drangti Penden Tsojé also describes the life of his elder brother, Drangti Gyelwa Zangpo. Gyelwa Zangpo is not only said to have studied with his father, but also Biji Jowo Pelgön, potentially referring to the transmission of Bijis Yellow Volume (bi ji po ti kha ser). Finally, Gyelwa Zangpo is also said to have traveled to Gozhi Retang to study the Small Practical Manual, as well as the Four Tantras along with the Partial Branches with Yutok Tsojé, the son of his father's purported teacher, Yutok Jampel ${ }^{460}$ Again, the abrupt placement of the Four Tantras and the Partial Branches at Gozhi Retang around the turn of the fourteenth century seems anachronistic, and may represent a creative elaboration on the part of Penden Tsojé. Regardless, Gyelwa Zangpo is said to have been such a skilled scholar and physician-composing new commentaries and teaching from the throne of the doctrine ${ }^{461}$ that Yutok Tsojé appointed him as the lead of the Gozhi Retang medical school and passed all

${ }^{458}$ Gsang ba man ngag gis [sic] rgyud kyi spyi don shes bya rab gsal rgyas pa (Beijing Ms), $38 \mathrm{~b}$ : gshegs pa de nyid skye bo thams cad kyi mthun par byang chub sems dpa'chen po yin/_zhes bsngags par brjod pa lags so/.

459 For a detailed analysis of the dates of Karma Pakshi, see Leonard W. J. van der Kuijp, "'Bayši' and Bayši-s in Tibetan Historical, Biographical and Lexicographical Texts," Central Asiatic Journal 39, no. 2 (I995): 280-86.

${ }^{460}$ Gsang ba man ngag gis [sic] rgyud kyi spyi don shes bya rab gsal rgyas pa (Beijing Ms), 39b-40a: des sras brang ti rgyal ba bzang po la gnang /_des yab dang be ji jo bo dpal mgon rnams la brten nas gzhung man ngag phyag len thugs su chud par mdzad/_g.yu thog 'jam dpal gyi sras/_g.yu thog 'tsho byed kyi spyan sngar byon nas/_rgyud bzhi cha lhag dang bcas pa dang /_lag len spod chung la sogs pa'i gdams pa du ma gsan/.

${ }^{46 \mathrm{I}}$ Gsang ba man ngag gis [sic] rgyud kyi spyi don shes bya rab gsal rgyas pa (Beijing Ms), 39b: sgo bzhi re thang du bshad gsar mdzad cing /_gshan bshad gsar ba la chos khri chung sa logs na yod pa la/. Compare with Rgyud bzhi'i spyi don shes bya rab gsal rgyas pa (Delhi), IIO-II: sgo bzhi re thang du bshad par mdzad cing /_gzhan bshad 'khrid gnang tshul sogs logs su yod la/. 
of his students on to him. ${ }^{462}$ Upon returning to Sakya, Gyelwa Zangpo acted as the royal physician for the scions of the Sakya Khön clan and taught medical teachings to many students hailing from both the western and eastern parts of the Tibetan plateau. ${ }^{463}$ Thus, despite the fact that we lack any works explicitly attributed to Gyelwa Zangpo, Penden Tsojé lauds him as a learned scholar, expert physician, and celebrated teacher, which is supported by the fact that many instructions are attributed to him in the colophons of the Gold and Silver Measure collections. Perhaps most importantly, the late thirteenth-century Yutok lineage introduced in the life story of Jampel Zangpo is superseded by and fully integrated into the early fourteenth-century Drangti lineage, effectively subsuming the Yutok familial lineage (sras brgyud) into the Sakya Medical House.

Penden Tsoje concludes his narration of the Drangti lineage with a brief account of his own life. He reports to have studied the Four Tantras and Partial Branches with his elder brother and another unrelated figure, Paktön Shakya Gönpo, but not his own father. ${ }^{464}$ Due to the anachronistic depiction of the Four Tantras and Partial Branches, the self-serving synthesis of the Yutok and Drangti lineages at the Sakya Mendrong, as well as the fact that each of the Drangti scions here studied with teachers representing lineages outside of the Yutok lineage-such as Jampel Zangpo with the Jang, Gyelwa Zangpo with the Biji, and Penden Tsojé with Paktön-it seems possible, if not likely, that Penden Tsojé actually first studied the Four Tantras with Paktön Shakya Gönpo, compiling the Partial Branches collection under his tutelage. True to his pedigree, Penden Tsojé describes teaching the Essence of the Eight Branches based on commentaries by Yutok Gönpo, his own father Jampel Zangpo, his father's teacher Jangmo Khüpa Yeshé Zangpo, his father's classmate the Minyak Mendicant, as well as works by Cherjé [Zhangtön Zhikpo?] and Lodrö Tsungmé of Nedruk. ${ }^{465}$ Thus, despite his

${ }^{462}$ Gsang ba man ngag gis [sic] rgyud kyi spyi don shes bya rab gsal rgyas pa (Beijing Ms), 39b-40a: sgo bzhi re thang du bshad par gsar mdzad cing /_gzhan bshad gsar ba la chos khri chung sa logs na yod pa/_di sa dpon tsho ba'i gsung gis bar gyis mkhas pa gsum gyis gtso bo/_snang ba rigs kyi sman pa brgyud pa khyed las che ba med pas/_g.yu thog mgon po'i chos kyi khri nas chos gsungs par zhu gsungs nas slob ma rnams sprad/.

${ }^{463}$ Gsang ba man ngag gis [sic] rgyud kyi spyi don shes bya rab gsal rgyas pa (Beijing Ms), 39b: sras kyis thu bor mdzad/_slar gdan sar byon nas yab kyi gdan sa mdzad nas rgyud gsungs/_gdung brgyud rin po che rnams kyi bla sman mdzad/_stod smad kyi slob ma du ma la gzhung man gnag phyag len legs par gnang /_thugs dges zhing yon tan rgya che la/_ser sna med pas slob ma mgo thon shin tu mang po lags/.

${ }^{464}$ Gsang ba man ngag gis [sic] rgyud kyi spyi don shes bya rab gsal rgyas pa (Beijing Ms), 40a: gcen po de nyid dang /_phag ston shākya mgon po la bdag gi gus pas yun ring du bsten cing /_rgyud bzhi cha lhag 'grel tika phyag len dang bcas pa tshig don rnams yongs su rdzogs par zhus shing thos pa tsam min pa khongs du chud par byas lal

${ }^{465}$ Gsang ba man ngag gis [sic] rgyud kyi spyi don shes bya rab gsal rgyas pa (Beijing Ms), 40a: bstan bcos brgyad pa la g.yu thog mgon po'i mdzad pa'i țikka byang mo khud pa'i yab kyi mdzad pa 'grel pa/_che rje dang mi nyag pa'i bshad sgros/_mkhas pa sde snod 'dzin pa chen po'i gnas drug pa blo gros mtshungs med kyi mdzad pa'i mchan bu rnams la bsten nas rgyud brgyad pa zung 'grel gyi 'chad nyan/. 
promotion of the Four Tantras as a central work at the Sakya Medical House, Penden Tsojé was also dedicated to teaching the Essence of the Eight Branches, even using a commentary composed by Yutok Gönpo.

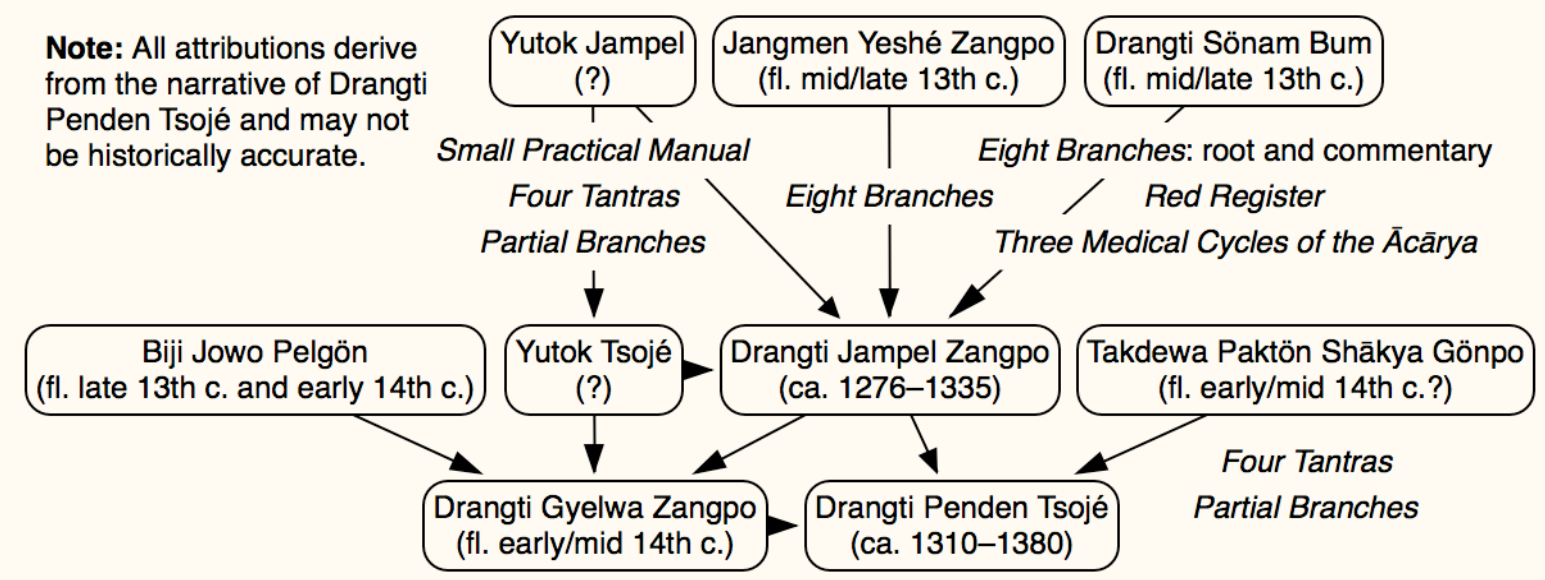

Figure 3.I. Drangti physicians and their teachers according to the Expanded Elucidation of Knowledge.

Thus concludes Drangi Penden Tsojé's account of the medical lineages that came to be taught at the Sakya Medical House. Regardless of its historical veracity, this creative merging of the Yutok and Drangti lineages was effective to the extent that, in subsequent histories, Drangti Jampel Zangpo, Drangti Gyelwa Zangpo, and Drangti Penden Tsojé are generally depicted as the first non-Yutok members of the Yutok familial lineage (sras brgyud). ${ }^{466}$ Following the historical schema invented by Drangti Penden Tsojé, the familial lineage, extending directly back to Yutok Gönpo, came to be understood in contrast to the student lineage (slob brgyud) that extended through Sumtön Yeshé Zung down to Paktön Shākya Gönpo and on to Penden Tsojé himself. As Figure 3.I demonstrates, it was only Drangti Penden Tsojé that could confidently represent both familial and student lineages, and it is to the history of the latter that we now turn.

\section{The Yutok Student Lineage}

Although the Yutok familial lineage only first appears in the writings of the Drangti family, the details of the Yutok student lineage (slob brgyud) can be found in the Indispensable Account of Transmission (brgyud pa'i rnam thar med thabs med pa, II74?) attributed to Sumtön Yeshé

${ }^{466}$ See, for example, Mirror of Beryl, 29I, and 532, n. 6I4: "In the section on the Drangti lineage it states that the father of Drangti Jampal Sangpo [=Jampel Zangpo] was Drangti Sönam Büm and that the latter only met Yuthok Jampal [=Yutok Jampel] later as a teacher. Therefore, the term 'son lineage' means only that it began with the sons of Yuthok and not that each successive transmission has to be passed down from father to son." 
Zung. The textus receptus of the Indispensable Account of Transmission is an account of the transmission of the Essence of Ambrosia (bdud rtsi snying po) - a work that is not called the Four Tantras until the fourteenth century-beginning with its mythical composition in Oḍdiyāna during the first eon, and concluding with its transmission in Tibet in the twelfth and thirteenth centuries. The Three Indispensable Rituals collection was probably first redacted within a generation or two of Yutok Gönpo-either by Sumtön Yeshé Zung, Tsojé Zhönnu Yeshé, or another figure not named in the Indispensable Account-based on teachings that have ultimately been attributed to Drapa Ngönshé (gra pa mngon shes, IOI2-I08I), the Clairvoyant One from Dranang valley. As we have already seen in Chapter One, the Three Indispensable Rituals collection represents one of the earlier collections of teachings in the Tibetan medical tradition, indicating that the Indispensable Account may also really derive from the late twelfth or early thirteenth century.

Although the textus receptus of the Three Indispensable Rituals begins with a reference to the five bodies of the buddhas (sku lnga) — which Drangti Penden Tsoje misrepresents as the name of a text in his Expanded Elucidation of Knowledge - a recently published manuscript facsimile of the work uniquely begins with a short description of its contents:

The teachings of the Three Indispensable Rituals are the precious oral instructions transmitted from the King of Tantras, the Essence of Ambrosia. Because it demonstrates reasons for trust, the Account of Transmission is indispensable. For examining the seven wonder channels, the Channel Prasena Rituals are indispensable. For healing children so that one may spend time with them, the Instructions for Pediatrics is indispensable. ${ }^{467}$

We have already seen this description in the context of the Channel Prasenā Rituals in Chapter One, but in this introductory passage we also learn the motivation for teaching the history of transmission of the Essence of Ambrosia, which is to inspire trust in the listener. This statement of intent points to the pedagogical function of the Indispensable Account, which is not to relate "what actually happened," but to provide a narrative that might cause students to study the Four Tantras with a greater sense of its importance and thus personal commitment.

The Indispensable Account begins with a mythological narrative not unlike that which is found in the Root Tantra, except with further elaborations regarding the specific time and location of its teaching:

${ }^{467}$ Med thabs med pa'i mchong [='phyong] gsum, in Krung go'i bod lugs gso rig rtsa che'i dpe rnying kun btus, vol. 3, text 3, p. 257 (f. Ib): rgyud rgyal bdud rtsi snying po las//_snyan rgyud man ngag gces pa'i mchong [='phyong]//_med thabs med pa rnams gsum bstan//_yid ches pa'i khungs bstan phyir//_rgyud pa'i rnam thar med thabs med//_ngo mtshar rtsa bdun brtag pa la//_rtsa'i pra sgrub med thabs med//_byis pa nyer spyod gso ba la//_sri'u gso ba med thabs med//. 
This great tantra of the science of healing that emerged from the five spontaneous bodies, previously, in the first eon, when the primary teaching was entering [this world], in the [Pure] Land of Oḍdiyāna, in the city of Beautiful to Behold, with the blessings of the Buddha, God of Medicine, the Sage Rikpé Yeshé [lit. Gnostic Awareness] and the Sage Yilé Kyepa [lit. Mind Born] performed interlocutions in four tantras. The master of redactors, Sage Yilekyé wrote this down in a precious golden tome with melted beryl, and then wrapped it in satin adorned with suns and, on top of that, crystal and silken fabrics. ${ }^{468}$

The city of Beautiful to Behold is explicitly located in the land of Oḍdiyāna, ${ }^{469}$ for example, and Yilekyé is explicitly named as the scribe that first wrote the teaching. Unlike the presentation in the Four Tantras where Beautiful to Behold is an unspecified utopia and the exchange between Rikpé Yeshé and Yilekyé is variously heard, the author brings the revelation of the Four Tantras into space and into text.

As mentioned above, some scholars, both past and present, have interpreted this opening line, "emerged from the five spontaneous bodies" as a quotation from a text called the Five Spontaneous Bodies. ${ }^{470}$ This is probably due to the fact that whenever Drangti Penden Tsojé quotes the Indispensable Account, he calls the work the Five Spontaneous Bodies. ${ }^{41}$ While I concede that the grammar here is slightly awkward, rendering "spontaneous" (lhun grub) as an adjective describing the "five bodies" (sku lnga) of the buddhas, I propose that the "five spontaneous bodies" here refers not to some otherwise unattested text, but to one of five common pentads in the so-called "twenty-five phenomena of fruition" ('bras chos nyer lnga): the five bodies (skulnga), the five speeches (gsung lnga), the five heart/minds (thugs lnga), the five qualities (yon tan lnga), and the five activities (phrin las lnga). In the "Complete Entrustment" (yongs su gtad pa) chapter found in the "Back Section" (mjug don) of the Subsequent Tantra, ${ }^{42}$ for example, Sage Rikpé Yeshé proclaims in verse:

${ }^{468}$ Med thabs med pa'i mchong [='phyong] gsum, in Krung go'i bod lugs gso rig rtsa che’i dpe rnying kun btus, vol. 3, text 3, p. 257 (f. Ib-2a): sku lnga lhun grub las byung ba'i/_gso ba rig pa'i rgyud chen 'di/_sngun [=sngon] gyi bskal pa dang po la/_bstan pa'i gtso bo gzhugs dus su/_u rgyan yul gyi zhing khams der/_blta na sdug gi grong khyer du/_sangs rgyas sman lha'i byin brlabs kyis/_drang srong rig pa'i ye shes dang /_drang srong yid las skyes pa yis/_rgyud rje [=sde] bzhi yis zhus lan mdzad/_sdud pa'i rta [=bdag] po drang srong yid las skyes kyis/_rin chen gser gyi glegs bam la/_bhe du rgya'i zhun mas bris/_za 'og nyi ma ris kyis bris/_de steng shel ras dar men dril/.

${ }^{469}$ On the debate regarding the location of Beautiful to Behold, see Gyatso, Being Human, I5764; wherein Beautiful to Behold is called Tanaduk.

${ }^{470}$ Sku lnga lhun grub las byung ba. See Yang Ga, Sources for the Writing of the Rgyud bzhi, 93; and Gyatso, Being Human in a Buddhist World, 434, n. 34 .

${ }^{471}$ See, for example, Rgyud bzhi'i spyi don shes bya rab gsal rgyas pa (Delhi), I03.

${ }^{472}$ Manuscript witnesses attest to the fact that the "Back Section" (mjug don) of the Subsequent Tantra - that is, the "Summary" (don bsdu) and the "Complete Entrustment" (yongs su gtad $p a$ - - once circulated independently of the rest of the Four Tantras. See, for example, the following manuscripts in Krung go'i bod lugs gso rig rtsa che'i dpe rnying kun btus: Rgyud bzhi' 'jug don gyis dbu', vol. 4, text 6, pp. 5I2-22 (ff. Ia-I6b); Bdud rtsi snying po bsang ba yan lag brgyad pa 
Hey! Teacher, Doctor, King of Physicians!

The Heart of the Teacher lacks the darkness of non-awareness. Lacking conceptuality and free from elaborations, Rikpé Yeshé is the Heart. The light beams of the Heart illuminate the darkness of beings. The Root Tantra, a summary of all [other tantras], emerges from the Heart. Homage and praise to the sameness of the Reality Body. ${ }^{473}$

The Body of the Teacher does not age, or grow frail and forgetful. The Body is like beryl, apparent and empty, free from elaborations. The light beams of the Body dispel the diseases of beings. The Explanatory Tantra, with designations that are not obscured, emerges from the Body. Homage and praise to the marks and signs of the Complete Enjoyment Body. ${ }^{474}$

The Qualities of the Teacher neither decrease nor increase. The Buddha, God of Medicine, knows all things. The light beams of the Qualities dispel the sufferings of beings. This necessity fulfilling Instructional Tantra emerges from the Qualities. Homage and praise to the Body of Emergent Preciousness. ${ }^{475}$

The Activities of the Teacher are totally unobstructed. The great king has perfected the four activities of pacification, enhancement, coercion, and violence. The light beams of the Activities dispel the pathogenic demons of beings. The unobstructed Subsequent

phyi ma 'phrin las kyi rgyud las/_jug don yongs su dpyad pa, vol. 4, text 6, pp. 523-30 (ff. Ia-I6a); and Rgyud bzhi'i mjug don yongs gtad, vol. 8, text 8, pp. 332-37 (ff. Ia-IIb).

${ }^{473}$ Rgyud bzhi' 'jug don gyis dbu', in Krung go'i bod lugs gso rig rtsa che'i dpe rnying kun btus, vol. 4, text 6, p. 520 (ff. I3a-I3b): kyāī ston pa mtsho [='tsho] mdzad sman pa'i rgyal po la [=nyid]/_ston pa'i thugs la ma rigs [=rig] mun pa med/_rtogs [=rtog] med spros bral rig pa'i ye shes thugs [=nyid]//_thugs kyis 'od zer [thugs rje'i 'od kyis] 'gro ba'i mun pa gsal [=sel]//_thams cad 'dus pa'i rtsa rgyud thugs las byung //_mnyam nyid chos kyi sku la phyag 'tshal stod [=lo]//. The brackets indicate alternative readings found in Dpal ldan rgyud bzhi dpe bsdur ma, vol. 3, p. 310. Bdud rtsi snying po bsang ba yan lag brgyad pa phyi ma 'phrin las kyi rgyud las/_jug don yongs su dpyad pa, vol. 4, text 7, pp. 529 (ff. I3a-13b) generally corresponds to the reading found in the other manuscript, Rgyud bzhi' 'jug don gyis dbu'.

${ }^{474}$ Rgyud bzhi' 'jug don gyis dbu', in Krung go'i bod lugs gso rig rtsa che'i dpe rnying kun btus, vol. 4, text 6, p. 520 (f. I3b): ston pa'i sku la sgres gud mnyel [=rgud bsnyel] ba med//_snang [=gsal] stong spros bral be durya [baidūrya] 'dra'i sku//_sku'i [sku yi] 'od zer'gro ba'i nad rnams sel//_tha snyad ma smongs [=rmongs] bshad rgyud thugs [=sku] las byung //_mtshan dpe' longs spyod rdzogs la phyag 'tshal stod [=lo]//. The brackets indicate alternative readings found in Dpal ldan rgyud bzhi dpe bsdur ma, vol. 3, p. 3II.

${ }^{475}$ Rgyud bzhi' 'jug don gyis dbu', in Krung go'i bod lugs gso rig rtsa che'i dpe rnying kun btus, vol. 4, text 6, p. 520 (f. I3b): ston pa'i yon tan zad cing 'phel ba med//_thams cad mkhyen pas [=pa] sangs rgyas sman gyis lha [=gyi bla]//_yon tan 'od zer'gro ba'i sdug sngal [='phongs] sel//_dgos 'byung man ngag rgyud 'di yon tan 'byung [=man ngag rgyud ni yon tan nyid las byung] //_rin chen 'byung ldan sku la phyag 'tshal stod [=lo]//. The brackets indicate alternative readings found in Dpal ldan rgyud bzhi dpe bsdur ma, vol. 3, p. 3 II. 
Tantra emerges from the Activities themselves. Homage and praise to the heroic Emanation Body. ${ }^{476}$

The Speech of the Teacher is the unceasing speech of Brahmā. If one understands it, one can summon the desires of the entire retinue. The light beams of the Speech dispel the vocal pollution of beings. The interlocution of the Four Tantras emerges from the Speech of the Teacher. Homage and praise to the luminous purity of lotus speech. ${ }^{477}$

And, again, just to reiterate the fact that the Root Tantra emerges from the Heart of the Buddha, the Explanatory Tantra emerges from the Body, the Instructional Tantra emerges from the Qualities, the Subsequent Tantra emerges from the Activities, and the redactor, Yilekyé, emerges from the Speech, Rikpé Yeshé continues:

É ma ho! Great Sage Yilekyé!

This Root Tantra of the Mind is like a seed,

For if it does not grow form here, it will not come to be a medical practice.

The Explanatory Tantra of the Body is like the sun and the moon appearing in the sky,

For it clearly reveals the meaning of every word without exception and without obscuration.

The Instructional Tantra of the Qualities is like a jewel,

For there is not a single part that is lacking or incomplete.

The Subsequent Tantra of the Activities is like a diamond,

For it enters into disease without obstruction.

Rikpé Yeshé is like the treasury of the sky,

For he teaches his responses to questions without knowing any limits.

Emanation of Speech, Yilekyé, is like a lion,

For the words of his questions lack both timidity and fear. ${ }^{478}$

${ }^{476}$ Presumably due to scribal error, most of these lines are missing from Rgyud bzhi' 'jug don gyis dbu'. Alternatively, Bdud rtsi snying po bsang ba yan lag brgyad pa phyi ma 'phrin las kyi rgyud las/_jug don yongs su dpyad pa, vol. 4, text 7, pp. 529 (f. I3b): ston pa'i phrin las gang yang thogs pa med//_zhi rgyas dbang drag bzhi rdzogs rgyal chen po//_phrin las 'od zer 'gro ba'i nad gdon sel//_thogs med phyi rgyud [phyi ma rgyud ni] phyin las nyid las byung //_dpa'o sprul pa'i sku la phyag 'tshal bstod [=lo]//. The brackets indicate alternative readings found in Dpal ldan rgyud bzhi dpe bsdur ma, vol. 3, p. 3II.

${ }^{477}$ Rgyud bzhi' 'jug don gyis dbu', in Krung go'i bod lugs gso rig rtsa che'i dpe rnying kun btus, vol. 4, text 6, p. 520 (f. I3b-I4a): ston pa'i gsung ni 'gag med tshangs pa'i gsung //_cig las [gcig la] kun go 'khor tshogs 'dod pa [b]skong //_gsung gis [=gi] 'od zer 'gro ba'i ngag sgrib gsal [=sel]//_rgyud bzhi['i] zhu lan ston pa'i gsungs las byung //_gsal dag pad ma'i gsungs [=sku la] phyag 'tshal stod [=lo]//. The brackets indicate alternative readings found in Dpal ldan rgyud bzhi dpe bsdur ma, vol. 3, pp. 3II-I2.

${ }^{478}$ Rgyud bzhi' 'jug don gyis dbu', in Krung go'i bod lugs gso rig rtsa che'i dpe rnying kun btus, vol. 4, text 6, p. 520 (f. I4a): e ma ho : drang srong chen po yid las skyes//_rtsa ba'i thugs kyi rgyud 'di sa bon 'dra//_di las ma skyes gso' spyad [=gso dpyad] yong mi 'gyur [= yod ma yin]//_sku'i spyad [=sku yi bshad] rgyud bar snang nyi zla 'dral/_tshig don ma lus gsal bar sgrib med bston [=sgrib med gsal bar 
Although these appellations only appear in this "Back Section" of the Subsequent Tantra, these associations continue throughout the tradition of Tibetan medical theory and scholarship. Thus, based on this common motif, I propose that the "great tantra of the science of healing that emerged from the five spontaneous bodies" mentioned by Sumtön Yeshé Zung above refers to the fact that the Root Tantra is associated with the five bodies of the buddhas, and not an otherwise unattested long-lost text.

After providing the sequence of transmission among Indian sages, Sumtön describes the way in which the Four Tantras were ultimately transmitted to Tibet:

The physician Kumāra Jīvaka transmitted the [Four Tantras] to Master Nāgārjuna. Nāgārjuna taught them to Candraprabha, who explained them to Vāgbhața. [Vāgbhața] taught them to the Kashmiri Candranandana, whence Vairocana requested them. [Vairocana] entrusted them to Tri Songdetsen, and the Sovereign Tri Songdetsen concealed them in a pillar in the center of the upper chapel of the Three Families at Samyé monastery. After three days in the heavens of the desire realm, Drapa Ngönshé [lit. the Clairvoyant One from Dranang] revealed them, and became the mater of the world. ${ }^{479}$

As has been long observed, this important passage is the locus classicus for Vairocana's involvement with the translation of the Four Tantras, as well as the framing of the Four Tantras as a treasure text hidden by Tri Songdetsen and revealed by Drapa Ngönshé. ${ }^{400}$ The passage is rather ambiguous about what, exactly, is being transmitted, but in light of the previous passage detailing the material reality of the Four Tantras, it is probably safe to assume that it is the Four Tantras that are purportedly being transmitted here. Importantly, this passage also emphasizes the transmission of the Four Tantras among Buddhist sages in India, including

ston]//_man ngag yon tan rgyud'di nor bu 'dra//_dgos pa ma tshang ba ni [g]cig kyang med//_phyi ma 'phrin [=phrin] las rgyud 'di rdo rje pha lam 'dral/_nad kyi steng du thogs pa med par 'gro [=yod ma yin]//_rig pa'i ye shes nam mkha'i mdzod dang 'dra//_dris pa'i lan la zad mi shes par ston//_gsung sprul yid las skyes ni seng ge 'dra//_zhu ba'i tshig la zhum zhing skrag pa med//. The brackets indicate alternative readings found in Dpal ldan rgyud bzhi dpe bsdur ma, vol. 3, p. 3 I2.

${ }^{479}$ Med thabs med pa'i mchong [='phyong] gsum, in Krung go'i bod lugs gso rig rtsa che'i dpe rnying kun btus, vol. 3, text 3, pp. 257-58 (ff. 2a-2b): sman pa 'tsho byed gzhon nu yis/_slob dpon klu sgrub nyid la brgyud/_klu sgrub zla ba'i 'od zer gyis/_dpal ldan pha gol nyid la bshad do/_de yis kha che zla [dga'] \{grags\} la/_de la bai ro tsa nas zhus/_khri srong [lde] \{sde\} btsan khong la [gtad] \{stad\}/_mnga' bdag khri \{b\}srong lde btsan des/_bsam yas dbu rtse rigs gsum gyi/_bar khang ka ba'i nang du sbas/_de nas 'dod lha'i zhag gsum nas/_grwa ba mngon shes can gyis bton/_dzam bu gling gi bdag por gyur/.

${ }^{480}$ See Samten Karmay, "The Four Tibetan Medical Treatises and Their Critics," in The Arrow and the Spindle: Studies in History, Myths, Rituals and Beliefs in Tibet (Kathmandu: Mandala Book Point, I998), 229; which is a reprint of Samten Karmay, "Vairocana and the Rgyud-bzhi," Tibetan Medicine I3 (1990): 19-3I. Therein Karmay refers to the Indispensable Account as the rNam thar bka' rgya can. 
Kumāra Jivvaka, the famed physician of Sākyamuni Buddha, ${ }^{48 I}$ and Master Nāgārjuna. Vāgbhața and Candranandana are, of course, responsible for the Essence of the Eight Branches and its commentary, Moonbeams (zla zer), respectively, while Candraprabha is a bodhisattva associated with the Buddha, Master of Medicine. After placing the transmission of the Four Tantras in an Indian Buddhist context, also conspicuously encompassing the Essence of the Eight Branches tradition, we arrive at eleventh-century Tibet.

The role of Drapa Ngönshé-famed founder of Dratang (gr[w]a thang) monastery in the Dranang ( $g r[w]$ a nang) valley ${ }^{482}$ - as the revealer of the Four Tantras has long puzzled modern scholars. ${ }^{483}$ Although Sumtön is not explicit in describing the role of Drapa Ngönshé in the Tibetan medical tradition-other than revealing and transmitting the Four Tantras, of course - as we shall see in Chapter Two, he was a pivotal figure in the transmission of prasenā divination rituals within a medical context. Drangti Penden Tsojé also recognizes the importance of Drapa Ngönshé, summarizing the previous passage from the Indispensable Account, and quoting the next (albeit without citation):

Üpa Dardrak convinced [Drapa Ngönshé to transmit the teachings] with fees of gold, turquoise, and cavalry armor. Tötön Tsojé Könkyap requested them by offering [Üpa Dardrak] a large turquoise with a light red tint, clear as the sky, and a thousand bushels of fruit. Yutok Gönpo requested them by offering [Tsojé Könkyap] a stallion with saddle and bridle, as well as two expanded collections. ${ }^{484}$

Unlike the previous passage-which describes the vague activities of famous figures from distant times and spaces - this passage illustrates relatively unknown figures and their very specific activities. Indeed, the description of specific jewels and goods is intriguing, for the

${ }^{48 \mathrm{I}}$ On Kumāra Jīvaka, see Paul Demiéville, Buddhism and Healing: Demiéville’s Article "Byō" from Hōbōgirin, trans. Mark Tatz (Lanham, MD: University Press of America, 1985); and C. Pierce Salguero, "The Buddhist Medicine King in Literary Context: Reconsidering an Early Medieval Example of Indian Influence on Chinese Medicine and Surgery," History of Religions 48, no. 3 (2009): I83-2IO.

${ }^{482}$ On the features and history of Dratang monastery, see Roberto Vitali, Early Temples of Central Tibet (London: Serindia Publications, 1990).

${ }^{483}$ Ronald M. Davidson, Tibetan Renaissance: Tantric Buddhism in the Rebirth of Tibetan Culture (New York, NY: Columbia University Press, 2005), I05: "Much later, Drapa became a figure of rather free association, like many of the eleventh-century personalities, and was credited for the discovery of the Four Medical Tantras in I038, although there seems to be little historical basis for this assignment."

${ }^{484}$ Med thabs med pa'i mchong [='phyong] gsum, in Krung go'i bod lugs gso rig rtsa che'i dpe rnying kun btus, vol. 3, text 3, p. 258 (f. 2b): de la dbus pa dar grags kyis/_gser g.yu rta khrab yon gyis blus/_de la 'tsho byed dkon skyabs kyis/_drug dmar dkar chen nam mkha' gsal/_sil [=bsil] khal stong dang bsdos nas zhus/_de la g.yu thog mgon po yis/_sga srab bcas pa'i rta po [=pho] dang /_rgyas pa 'bum gnyis phul nas zhus/. For this same passage, see Rgyud bzhii spyi don shes bya rab gsal rgyas pa (Delhi), IOI. 
Subsequent Tantra admonishes its readers to not be deceived by just such offerings of "gold, turquoise, and cavalry armor" (gser g.yu rta khrab yon). ${ }^{485}$ Perhaps this textual imbrication indicates that Sumtön's "lineage of one" agenda can be found even in the "Back Section" of the Four Tantras itself.

Contrary to the claims that it was Yutok Gönpo that authored the Four Tantras, Sumtön Yeshé Zung describes the contributions of his teacher in a much more limited fashion:

The Sage Yutok Gönpo composed the Thousand Session Tutorials that arrange the contents of the topics [of medical practice], outlined the abridged topics in the scriptures, composed the small lexical commentary on the collection of [meanings that are] difficult [to understand]. He elided that which was incomplete and redacted that which was clear. He also was committed to not disseminating these teachings to others and achieved fame throughout the world. ${ }^{486}$

According to Sumtön, Yutok Gönpo composed the Thousand-session Tutorials that arrange the contents of the topics of medical practice (don gyi khog dbubs tongs [=stong] thun mdzad), outlined the abridged topics in the scriptures (bsdus don gzhung las sa mtshams phye), and authored the small lexical commentary on the collection of meanings that are difficult to understand ( $r k a$ 'phrang [=dka' 'phreng] 'bru 'grel yig chung bkod). While the verbs for the former two examples are rather ambiguous ( $m d z a d$ and phye), the verb for the latter clearly indicates that Yutok authored a small lexical commentary ('bru 'grel yig chung bkod). As we have seen before, the Thousand-session Tutorials are still extant in the Eighteen Partial Branches as well as individual manuscript witnesses, ${ }^{487}$ and the aforementioned "outline" probably refers to the Rosary of Jewels (nor bu'i 'phreng ba) that was also probably redacted by Sumtön Yeshé Zung. ${ }^{48}$

Nowhere in the Indispensable Account does Sumtön describe the Four Tantras as being the composition of Yutok Yönten Gönpo. Instead he explicitly describes the Four Tantras as being written by Yilekyé with melted beryl in the first eon in the Pure Land of Oḍdiyāna. Despite the potential contradiction, Sumtön also explicitly states that Yutok asked him to write a small manual for medical practice:

\footnotetext{
${ }^{485}$ Rje bstan 'dzin don grub, ed., Dpal ldan rgyud bzhi dpe bsdur ma (Chengdu: Si khron dpe skrun khang, 20I0), vol. 4, 3I4: gser g.yu rta khrab yon gyi mi blu barl/_kha 'jam brid po'i lag tu shor ra rel/.

${ }^{486}$ Med thabs med pa'i mchong [='phyong] gsum, in Krung go'i bod lugs gso rig rtsa che'i dpe rnying kun btus, vol. 3, text 3, p. 257 (f. 2b): drang srong g.yu thog mgon po yis/_don gyi khog dbubs tongs [=stong] thun mdzad/_bsdus don gzhung las sa mtshams phye/_rka 'phrang [dka' 'phreng] 'bru 'grel yig chung bkod/_ma tshang gab 'khrugs gsal bar bsdebs/_gzhan la ma spel yi dam mdzad/_dzam bu gling du grags pa thob/.

${ }^{487}$ See note above.

${ }^{488}$ Again, see Yan lag brgyad pa’i gzhung las bsdus pa nor bu'i 'phreng ba.
} 
I, Jñānadhāranīi [=Yeshé Zung], son of Rutsam of Sum, heard of the fame of my master from afar, and merely hearing his name filled me with joy. Enduring the journey's hardships, I came into his presence, and merely seeing his face bestowed on me his blessings. Although I had nothing great to offer, I exchanged my family's land for horses and made offerings. ${ }^{489}$

Although I did not serve him with body and speech, whatever he commanded I never disobeyed. Although my capacity for parsing his words was not great, I studied for three years without distraction. While staying in Gyaché Kendrong, though I had not ascertained the fundamentals of his teachings, I worked and prayed such that, by his great compassion, he gave me these tantras on the science of healing. He made the pledge to grant [the Four Tantras] without omission or excess, and impart the blessings of the sage lineage: ${ }^{490}$

[One should not rely upon those of previous generations. $]^{491}$ So that the lineage of one remains unbroken, I now entrust it to you. For the time being, do not expound it but conceal it under a stone as a treasure, and unseen by your companions, write it down secretly as a small manual of notes. If you are able to keep it secret for one [twelveJyear cycle, you will come to achieve attainments. ${ }^{492}$

${ }^{489}$ Med thabs med pa'i mchong [='phyong] gsum, in Krung go'i bod lugs gso rig rtsa che'i dpe rnying kun btus, vol. 3, text 3, p. 258 (f. 2b): kho bo ru mtshams sum pa'i bu/_gnya' na 'dar ni bdag 'dra yis/_dpon khong gi snyan pa rgyang nas phums [=thos?]/_mtshan thos pa tsam gyis mos pa skyes/_lam rka [=dka'] ba spyad te spyan sngar phyin/_zhal mthong ba tsam gyis byin gyis rlabs/_longs spyod gyi dbul nor mi che yang /_pha zhing rta ru btsongs nas phul/.

${ }^{490}$ Med thabs med pa'i mchong [='phyong] gsum, in Krung go'i bod lugs gso rig rtsa che'i dpe rnying kun btus, vol. 3, text 3, p. 258 (f. 2b): lus ngag gi zhabs rtog [=tog] ma grub/_bla mas ci gsung bka' ma bcab [=bcag]/_tshig don gcod [=spyod] khams mi che yang /_g.yel 'khrul med par lo gsum bslabs/_rgya phyed kan [=sman?] grong sdod dus su/_gdams pa'i rtsa ba ma chod kyang /_las dang smon lam thugs rje yis/_gso ba rig pa'i rgyud 'di gnang /_zab lhag med pa'i dbu snying bzhes/_drang srong brgyud pa'i phyin rlabs $\mathrm{mdzad} /$.

${ }^{491}$ sngan chad mi la ma rten te/. This curious line can only be found in the manuscript witness, Med thabs med pa'i mchong [='phyong] gsum, in Krung go'i bod lugs gso rig rtsa che'i dpe rnying kun btus, vol. 3, text 3, p. 257 (f. 2b); and Bdud rtsi snying po yan lag brgyad pa gsang ba man ngag gi rgyud gyi dkar chag med thabs med pa rnam gsum/_rgyud pa'i rnam thar dang bcas pa, in Krung go'i bod lugs gso rig rtsa che'i dpe rnying kun btus, vol. 20, text I5, p. 275 (f. 2b); indicating that these are probably two related and/or early manuscript witnesses.

${ }^{492}$ Med thabs med pa'i mchong [='phyong] gsum, in Krung go'i bod lugs gso rig rtsa che'i dpe rnying kun btus, vol. 3, text 3, p. 258 (ff. 2b-3a): snang chad mi la ma tan [=brten] te/_chig brgyud rgyun mi gcad pa'i phyir/_da res khyod la byin pa yin/_da yang mi spel du gter rdor du sbed/_mched grogs gzhan gyis ma 'thongs [=mthong] bar/_phag tu zin bris yig chung thob/_lo skor gcig tu gsang thub gyis/_de yis dngos grub 'byung ngo gsung /. 
As he commanded, so I acted. Sometimes I wrote on mountaintops, sometimes in the deepest valleys, sometimes in the deepest forest. Thirteen years later, in the jina horse year [II74?], in Pakhor temple in Yeru, I put my notes into writing. [A teaching] previously unheard, unexperienced, and unseen, now shines like the sun in the sky. May it shine in glory for all living beings. ${ }^{493}$

In this riveting story, we are told of Yeshé Zung's great efforts to study with the famed Yutok Yönten Gönpo at the Officially Designated Medical House (?) (rgya phyed [s]kan [=sman?] grong). Following Yutok's instructions, Sumtön writes for thirteen years in isolation, copying his notes into a text that, although "previously it was an incomplete list without experience or observation ... now shines like the sun in the sky." In this passage Sumtön obliquely describes his authoring of a text based on the writings of Yutok Gönpo, a work that may have come to be called the Essence of Ambrosia, which was then framed as having been written by Yilekyé in Oḍ̣ịāna.

This date of completion provided by Sumtön Yeshé Zung is perhaps the single most important piece of chronological evidence in relation to the life of Yutok Yönten Gönpo in particular, as well as the Four Tantras in general. As we have seen above, the Indispensable Account is largely told in the subjunctive mood-it is a narrative that is meant to inspire trust in its audience, not to tell things as they really happened. Regardless, there are some moments where Sumtön corroborates the sincere with the subjunctive:

I think that it is like Master Yuthok Gönpo is the Sage Rikpé Yeshé, and I really am Yilekyé. I think that surely he was my teacher in previous lives, for his kindness is immense, and I shall never forget to place him on my crown. Pray, continue to grant me your blessings. ${ }^{494}$

As Janet Gyatso rightly points out, the modifiers of "I think" (snyam) and "that it is like" (lags pa 'dra) indicate a "hesitancy about the apotheosis the author is pursuing for himself and his teacher." 495 But what if Sumtön Yeshé Zung is merely playing with allusion, as he does when

${ }^{493}$ Med thabs med pa'i mchong [='phyong] gsum, in Krung go'i bod lugs gso rig rtsa che'i dpe rnying kun btus, vol. 3, text 3, p. 258 (f. 3a): gsung pa bzhin du lag len byas/_res 'gal'] ri bo'i rtse la bris/_res 'ga['] drog [=grog] po'i phug du bris/_res 'ga' shing gi tshig khar bris/_de nas mi lo bcu gsum nas/_rnam [=gnam] lo rgyal po rta lo la/_g.yas ru dpa' khor [dpal 'khor?] lha khang du/_phyi mo zin bris dpe la bshus/_sngan chab [=chad] thos tshor mthong ba med/_da ni mkha' la nyi shar bzhin/_'gro ba'i dpal du shar bar shog.

${ }^{494}$ Med thabs med pa'i mchong [='phyong] gsum, in Krung go'i bod lugs gso rig rtsa che'i dpe rnying kun btus, vol. 3, text 3, p. 258 (f. 3a): mkhas pa g.yu thog mgon po del_drang srong rig pa'i ye shes lag[s] pa 'dra/_dngos rang yid las skyes sam mnyam [=snyam]/_tshe rabs kyis bla ma yin par nges/_bsam kyin sku drin che ba'i phyir/_mi [b]rjed rgyun du tsugs [=gtsug] tu 'khur/_rgyun chad med par byin gyis rlobs/. ${ }^{495}$ Gyatso, Being Human in a Buddhist World, 153.

W. A. McGrath | Buddhism and Medicine in Tibet | I6I 
he refers to himself as Jñānadhāraṇī? Indeed, as we saw above, it was Yilekyé that explicitly put the Four Tantras into writing, and it was Sumtön Yeshé Zung that spent thirteen years writing a "manual of notes" (zin bris yig chung) and converting those notes into a work that "shines like the sun in the sky." The parallel image of Yilekyé redacting the teachings of Rikpé Yeshé in the first eon, and Sumtön Yeshé Zung redacting the teachings of Yutok Gönpo from II6I-II74 is so evocative that a later physician, Tsojé Zhönnu Yeshé, repeats it in an extended edition of the Indispensable Account, but in a slightly less hesitant fashion:

Émaho! Yutok Gönpo was Rikpé Yeshé, Master Lharjé [Sumtön Yeshé Zung] was Yilekyé, and I really am Tsojé Zhönnu Yeshé. [Yeshé Zung] has been my master for limitless lives, and I have been held by the compassion of the lama. How kind the teacher has been to this vessel! ${ }^{496}$

The distinction between the contributions of Sumtön Yeshé Zung, Tsojé Zhönnu Yeshé, and other potential authors is not entirely clear. As mentioned above, a manuscript witness of the Indispensable Account of Transmission that includes a unique introduction was recently republished, and this edition also includes a unique colophon. After describing and criticizing the multitude of Yutok's students-including Jangmen Leppo of Tsida (rtsis mda'i 'jangs [=byang?] sman leb po [also known as dpe le]), Tönpa Atsé of Kham (khams kyis [sic] ston pa a tshes), Geshé Rokchung of Nup (nub kyi dge bshes rog chung), and two unnamed sons (sras po gnyis) and two unnamed sons-in-law (mag pa gnyis) — this particular manuscript witness uniquely closes the Indispensable Account with the following passage:

Before requesting this Essence of Ambrosia in Eight Branches, Śrī [Jñāna]dhāra [Sumtön Yeshé Zung] offered a golden vase that weighs half a pound, $z i$ agate stones, one bolt of cloth, and one hundred loads of salt to Master Yutok Gönpo. Instructions such as these are special. Like the udumbara flower, these instructions are one of a kind. ${ }^{497}$ Like the jewels contained in the throats of water monsters, even in times of bad fortune they should not leave one's mouth. Iti! ${ }^{498}$

${ }^{496}$ Bdud rtsi snying po yan lag brgyad pa gsang ba man ngag gi rgyud gyi dkar chag med thabs med pa rnam gsum/_rgyud pa'i rnam thar dang bcas pa, in Krung go'i bod lugs gso rig rtsa che'i dpe rnying kun btus, vol. 20, text I5, pp. 276-77 (ff. 4b-5a): e ma ho//_rig pa'i ye shes g.yu thog mgon po lags/_yid las skyes ni slob dpon lha rje lags/_dngos rang 'tsho byed gzhon nu ye shes lags/_tshe rabs thog ma med pa'i bla ma lags/_bla ma'i thugs rjes kho bo zin pa lags/_snod ldan bdag la bla ma bka' drin che/. This passage, along with the latter half of this edition, is not included in the Med thabs med pa'i mchong [='phyong] gsum.

${ }^{497}$ Literally "lack a class" ( $k$ u la med $\left.p a\right)$.

${ }^{498}$ Med thabs med pa'i mchong [='phyong] gsum, in Krung go'i bod lugs gso rig rtsa che'i dpe rnying kun btus, vol. 3, text 3, pp. 258-59 (ff. 3b-4a): bdud rtsi snying po yan lag brgyad pa 'di la//_dpon g.yu thog mgon pos la/_shri dha ras gser gyi bum pa srang phyed zi ba [=gzi?] dang dar yug gcig dang tsha khal brgya thams pa phul nas zhus sol/_'di 'dra'i gdams pa khyad par can//_u dum 'bar ba'i me tog 
This passage-including the Sanskrit honorific title "noble" (śrî) and lacking any indication that this was expressed by Yeshé Zung himself (such as the words bdag and kho bo that we saw above) — was probably added by one of Yeshé Zung's later disciples and was thereby used to close the work in this earliest of manuscript witnesses. This also is the first mention of the Essence of Ambrosia in Eight Branches (bdud rtsi snying po yan lag brgyad pa) in the Indispensable Account, the title of which distinguishes the Four Tantras from the so-called Lesser Tantra (rgyud chung). ${ }^{499}$ Again, the textus receptus of the Indispensable Account found in the Eighteen Partial Branches does not include this closing passage and continues with an account of the aforementioned Tsojé Zhönnu Yeshé. Zhönnu Yeshé's account mirrors that of Yeshé Zung, except it depicts the transmission of the Four Tantras from Yeshé Zung to Zhönnu Yeshé instead of Yutok Gönpo to Yeshé Zung. In light of these unique manuscript witnesses that each entail distinct opening descriptions and closing colophons, the Indispensable Account appears to have been an open document for at least several generations, entailing edits and additions well into the thirteenth century.

\section{The Later Layers of the Indispensable Account}

The same concerns that dominated the first layer of the Indispensable Account attributed to Sumtön Yeshé Zung - the authorship and transmission of the Essence of Ambrosia-are found in this second layer attributed to Tsojé Zhönnu Yeshé. As mentioned by Gyatso, working only from the textus receptus of the Indispensable Account, the work emphasizes the importance of a "lineage of one" (chig brgyud) and in this second layer the notion of the Essence of Ambrosia and its associated literature as "sealed teachings" (bka' rgya ma) comes to the fore. The competition among physicians in the thirteenth century must have been significant enough to produce such anxieties, for Tsojé Yeshé Zung is cited as saying:

If it is possible that a vessel [student] that has assembled the six types of causes has emerged, and he or she offers delightful gifts of gold, turquoise, and calvary armor, one should bestow the teachings along with promises and pledges to keep them sealed. Such [a student] will keep the transmission [of the teachings] sealed as if they had not received them. Minyak, Rok, Jang, Kochungwa - the families that have proceeded properly-have kept [these teachings] with extreme discipline..$^{500}$

bzhin /_ku la med pa'i gdam pa yin//_chu srin gre bar rin chen chud pa bzhin//_skal pa 'khrugs kyang kharmigdon//_ithi//.

499 The Lesser Tantra is also called the Essence of Ambrosia, but only the Four Tantras is called the Essence of Ambrosia in Eight Branches.

${ }^{500}$ Bdud rtsi snying po yan lag brgyad pa gsang ba man ngag gi rgyud gyi dkar chag med thabs med pa rnam gsum/_rgyud pa'i rnam thar dang bcas pa, in Krung go'i bod lugs gso rig rtsa che'i dpe rnying kun btus, vol. 20, text I5, p. 276 (f. 4a): rgyu drug tshogs pa'i snod ldan 'byung srid na /_gser g.yu rta 
If [these teachings] were to spread widely, it would be like a king with many relatives. Just as a king with many relatives has little control over the execution of power, and [just as] trees that surround the elderberry tree are its competitors, if [these teachings] were to spread to all [physicians], who would be considered authoritative? ${ }^{50 r}$

As evinced by this passage, the precise composition of the Indispensable Account is not entirely clear. Although the latter portion of the text clearly attributes itself to Tsoje Zhönnu Yeshé, the account of the subsequent transmission varies across editions. In one manuscript witness we see that Zhönnu Yeshé transmitted the teachings to Lharjé Könkhar of Upper Yardrok (yar 'brog stod pa'i lhar rje skon khar) —an otherwise unattested figure-while in the textus receptus the subsequent line of transmission proceeds through the nephew of Zhönnu Yeshé, Sumtön Bummé (slob dpon chen po 'bum me khu dbon). ${ }^{502}$ In both editions the teachings are also described as being the "king of medical tantras" and the "instructional tantra together with chapters." 503 The work being transmitted is not called the Four Tantras, but the Essence of Ambrosia in Eight Branches and the fact that it is described as being "transmitted together with chapters" (le'u bcas pa) implies that it either was [I.] organized into chapters for the first time, or [2.] it was being transmitted together with supplementary chapters of instructions. Whatever the "king of medical tantras" may have been in these early generations, by the time of the Flight of the Khyung, the sealed teachings had come to be explicitly organized in four tantras, eight branches, eleven parts, fifteen sections, four discourses, and one hundred and fifty-six chapters. ${ }^{504}$

As this survey of the Indispensable Account has shown, the rhetoric and the attendant details of the early generations of transmission for the Four Tantras do not always match. Firstly, we are told that the interlocutions between Sage Rikpé Yeshé and Sage Yilekyé were

khrab mnyes pa'i yon phul na/_bka' rgya dam bca' sna [=mna'] dang bcas pa sbyin/_de ltar ma sbyin yin la sbyin rgya bdag/_me [=mi] nyag rog ljang ko chung ba dang bzhi/_leg [legs] tu 'gro ba'i rig [=rigs] la shin tu sdoms/.

${ }^{501}$ Bdud rtsi snying po yan lag brgyad pa gsang ba man ngag gi rgyud gyi dkar chag med thabs med pa rnam gsum/_rgyud pa'i rnam thar dang bcas pa, in Krung go'i bod lugs gso rig rtsa che'i dpe rnying kun btus, vol. 20, text 15 , p. 276 (ff. $4 \mathrm{a}-4 \mathrm{~b}$ ): yongs la 'phel [=spel] na rgyal po spun mang 'dra/_rgyal po spun mang mnga' thang spyad rig chung /_ltar yu shing la shor ba’i shing gi bshed [=gshed]/_kun la spel na mkhas pa su yis byed/.

${ }^{502}$ Bdud rtsi snying po yan lag brgyad pa gsang ba man ngag gi rgyud gyi dkar chag med thabs med pa rnam gsum/_rgyud pa'i rnam thar dang bcas pa, in Krung go'i bod lugs gso rig rtsa che'i dpe rnying kun btus, vol. 20, text I5, p. 277 (f. 5a).

${ }^{503}$ Bdud rtsi snying po yan lag brgyad pa gsang ba man ngag gi rgyud gyi dkar chag med thabs med pa rnam gsum/_rgyud pa'i rnam thar dang bcas pa, in Krung go'i bod lugs gso rig rtsa che'i dpe rnying kun btus, vol. 20, text I5, p. 277 (f. 5a): gso rig rgyud kyi rgyal po 'chad pa dang /_man ngag rgyud kyis le’u bcas pa phul/.

504 Cha lag bco brgyad, 23: rgyud bzhi/_yan lag brgyad/_gnas bcu gcig_skabs bco lngal_mdo bzhi/_le'u brgya dang lnga bcu rtsa drug yod pa'o//. 
composed and written down by the latter before they were transmitted through time and space. We are also told, however, that Sumtön Yeshé Zung redacted his notes from the teachings of Yutok Gönpo in isolation from the years of II6I-II74. We are explicitly told that Yutok Gönpo composed a work called the Thousand-session Tutorials, as well as an outline of topics in scriptures and a small lexical commentary, but are also later told that Yeshé Zung requested the Essence of Ambrosia in Eight Branches from Yutok himself. We are told that the Essence of Ambrosia was transmitted in a lineage of one, but we are also told that the physicians of the Minyak, Rok, Jang, and Kochungwa families kept the teachings sealed with great discipline. Finally, later editions of the Indispensable Account seem to indicate that Sumtön Yeshé Zung and Tsojé Zhönnu Yeshé were related-along with a third Sumtön generation in Sumtön Bummé-while earlier editions either do not describe Zhönnu Yeshé at all, or depict his transmission to a Lharjé Könkhar. Thus, the notion that the Essence of Ambrosia passed unchanged in a single lineage from Yutok to Sumtön and beyond is challenged by the Indispensable Account itself, rendering the teachings that were transferred and sealed, as well as the agents involved in this transfer, obscured by conflicting details. 


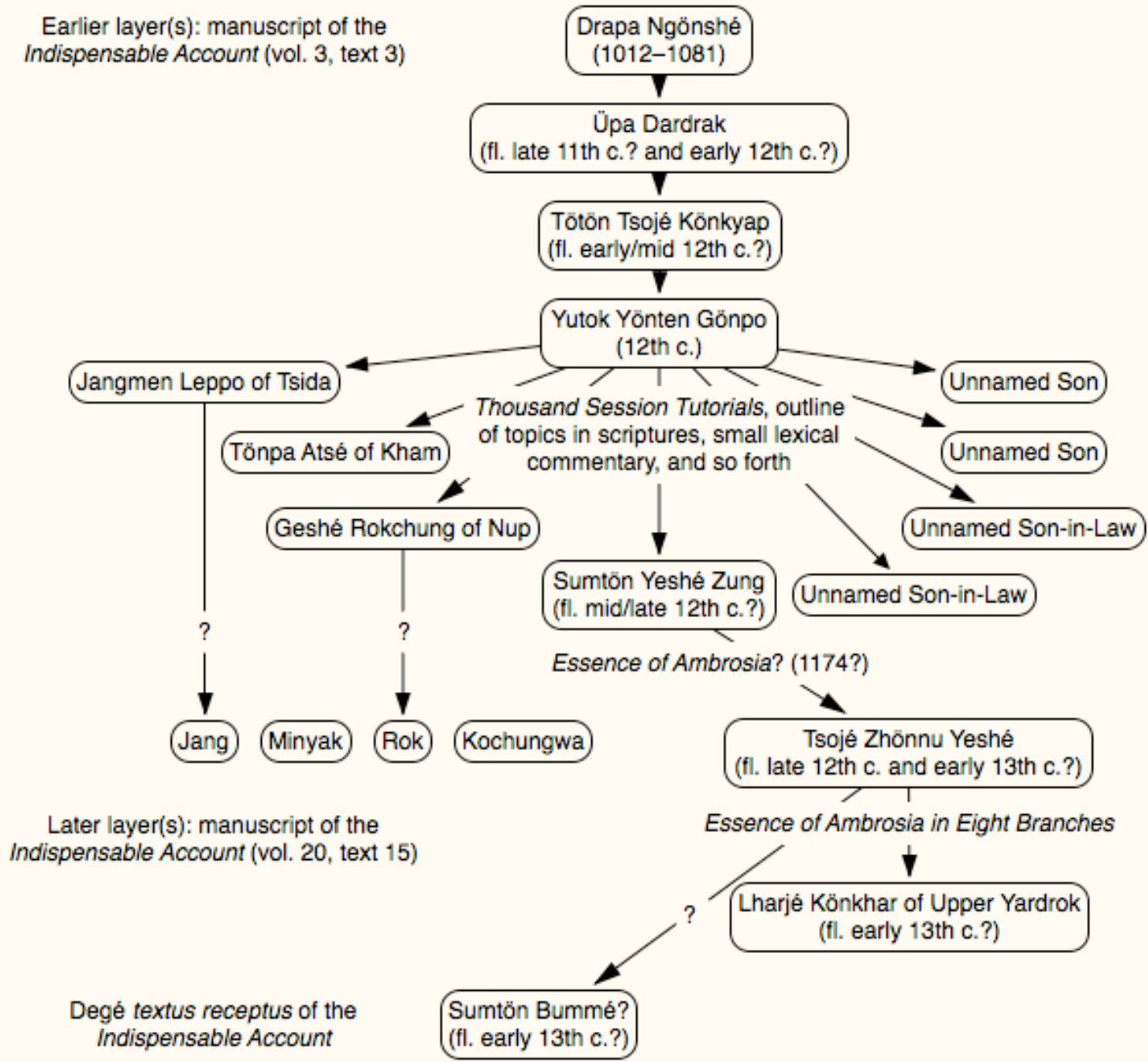

Figure 3.2. The "lineage of one" according to the Indispensable Account of Transmission

In the historical accounts found in the Expanded Elucidation of Knowledge, Drangti Penden Tsoje cites from the Indispensable Account frequently, mistakenly calling it the Five Spontaneous Bodies (sku lnga lhun grub). He appears to have been working from an alternative edition to the textus receptus and the manuscript witnesses available to me, however, or, more likely, he creatively altered some of the passages that he cited. For example, he cites the passage describing the compositions of Yutok translated above, but adds a single line originally describing the composition of Sumtön Yeshé Zung, implying that it was the works of Yutok that were "previously unheard, unexperienced, and unseen." ${ }^{505}$ Drangti also records that

${ }^{505}$ Gsang ba man ngag gis [sic] rgyud kyi spyi don shes bya rab gsal rgyas pa (Beijing Ms), 36b-37a: mkhas pa g.yu thog mgon po yis/_don go khog dbub stong mthun mdzad/_bsdus don gzhung la sa mtshams che [=phye]/_dka' 'phreng 'bru 'grel yig chung bkod/_ma tshang gab 'khrugs bsal [=gsal] bar bsdebs/_sngan chad thos tshor mthong ba med/. 
Sumtön finished his writing in a jina tiger year (rgyal po stag lo) instead of a jina horse year, ${ }^{506}$ and does not directly quote any part of the later layer of the Indispensable Account, wherein the work is also called the Sealed Teaching (bka' rgya ma).$^{507}$ Instead, he summarizes the subsequent transmission of the Four Tantras among the scions of the Sumtön clan:

Sumtön Yeshé Zung transmitted [the teachings] to Sumtön Yeshé Künga, [Yeshé Künga] transmitted them to Sumtön Bumseng [/Bummé], and [Bumseng] transmitted them to the Yutok hierarch, Geshé Gönrin of Lukmar. In the Yutok familial lineage, Lukmarwa received the complete teachings, which were passed from Yutok Nyima to Yutok Söseng, to Yutok Gaga, Yutok Trashi Gönpo, and finally to Yutok Geshé Gönrin. These mastersalso experts that performed great deeds for the sake of others-compassionately engaged in explication, debate, and composition for the sole purpose of clarifying continuum of the teaching of medicine for the sake of other beings..$^{508}$

${ }^{506}$ Gsang ba man ngag gis [sic] rgyud kyi spyi don shes bya rab gsal rgyas pa (Beijing Ms), 38a. Rgyud bzhii spyi don shes bya rab gsal rgyas pa (Delhi), I05, has horse, however.

${ }^{507}$ Drangti does make one mention of a sealed teaching in his description of the familial lineage, which shall be described in Chapter Two.

${ }^{508}$ Gsang ba man ngag gis [sic] rgyud kyi spyi don shes bya rab gsal rgyas pa (Beijing Ms), 38a: sum ston ye shes gzungs kyis/_gsum ston ye shes kun dga' la/_des sum ston 'bum seng la/_des g.yu thog gong ma lug dmar ba dge bshes mgon rin la/_yang g.yu thog mgon po'i sras bar sa lug dmar ba la bshad bka' rdzogs par gnang ste/_g.yu thog nyi mal_g.yu thog bsod seng_g.yu thog dga' dga'_g.yu thog bkra shis mgon po/_g.yu thog dge bshes mgon rin te/_slob dpon 'di rnams kyang ni mkhas shing gzhan gyi don gyis 'phrin las rgya chen po dang ldan pas/_chad rtsod rtsom pa 'gro ba'i don [...] kho nas gso dpyad bstan pa'i rgyun gsal bar mdzad/_bka' drin can sha dag yin no//. The ellipsis in this passage indicates a section in the Delhi edition that has a redundant and problematic insertion regarding the familial lineage. See Rgyud bzhii spyi don shes bya rab gsal rgyas pa (Delhi), I05I06. Also note that the Delhi version has Sumtön Bummé instead of Sumtön Bumseng. 


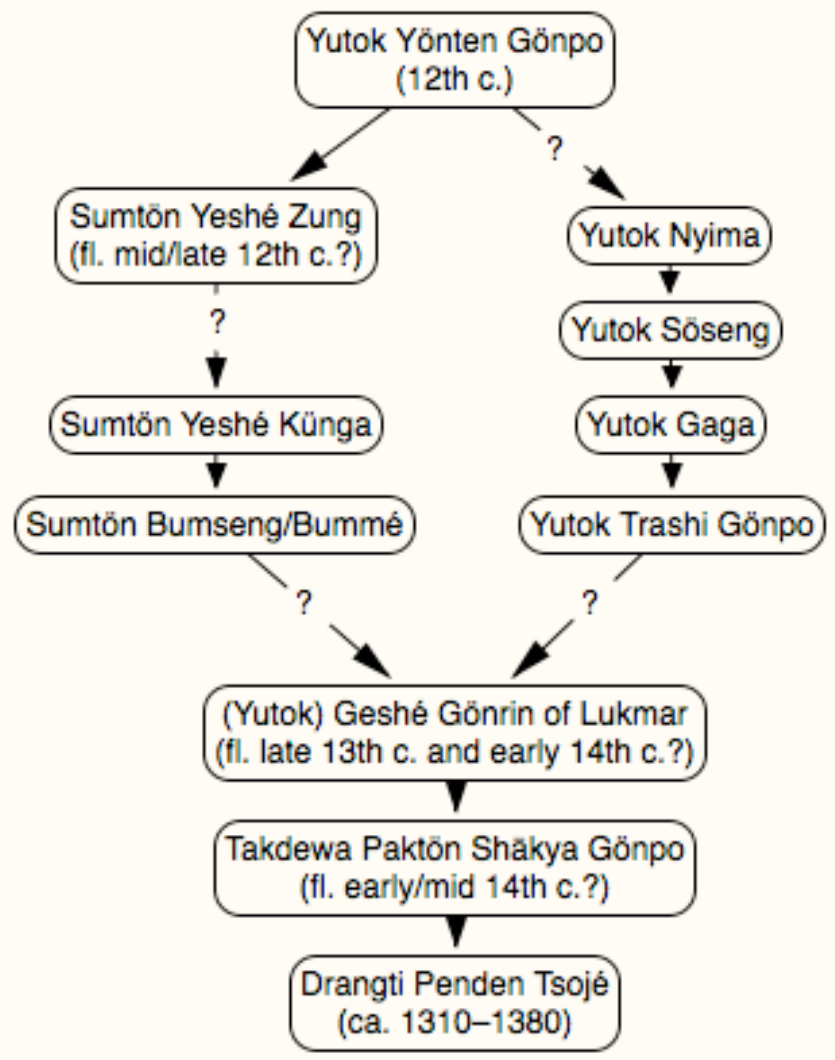

Figure 3.3. Problematic segments of the student and familial lineages in the Expanded Elucidation of Knowledge

Although this passage translated from the Expanded Elucidation of Knowledge follows a long quotation from the early layer of the Indispensable Account of Transmission, it appears to contradict the textus receptus of the Indispensable Account (compare Figures 3.2 and 3.3). Instead of Sumtön Yeshé Zung transmitting the Essence of Ambrosia to Tsojé Zhönnu Yeshé, Drangti has him transmitting it to Sumtön Yeshé Künga. And, while it is tempting to equate these two individuals and conflate Sumtön Bumseng with Sumtön Bummé of the textus receptus, the subsequent aspects of Drangti's account are enough to give pause. He identifies Lukmarwa Geshé Gönrin (lug [also sometimes lung] dmar ba dge bshes mgon rin), the teacher of his teacher, as a hierarch of the Yutok clan ( $g . y u$ thog gong $m a$ ) and supplies a lineage of otherwise unattested Yutok scions. In the end we can confidently assert a transmission of the Four Tantras from Geshé Gönrin to Paktön Shākya Gönpo and on to Drangti Penden Tsojé, but the teachers of Geshé Gönrin remain obscured by the constant temptation to shorten transmission lineages.

As we saw in the depictions of the familial lineage (Figure 3.I), the distance of transmission separating the Yutok and Drangti clans is shortened even more dramatically in other Drangti accounts. Regarding the transmission of the student lineage, Drangti Penden Tsojé describes the way in which Geshé Gönrinpa transmitted the Essence of Ambrosia to Paktön Shākya 
Gönpo of Takdé. He explicitly identifies the latter as being a scholar of the Secret Mantra and the Early Translation School, including the early treasure corpus. ${ }^{509}$ After traveling to Yutok Lungmar, he studied with Geshé Gönrin for a long time, delighting him with his devotion and respect. While there, he said: $:^{510}$

Offering an image of Orgyen Padma[sambhava],

The great Tantra of Liberation Through Realization,

The evocation ritual of immortality,

A mistaken formula [?] of the non-Buddhist extremists,

The cycle of Gönpo Mahākāla,

And the promise of more valuables later,

With these few things, I request the instructions. ${ }^{5 I}$

Following these offerings, Paktön Shākya Gönpo is said to have been taught the Four Tantras along with the practices of the Partial Branches. Importantly, Paktön is also said to have composed a khokbuk curriculum, outline, commentary, and synopsis of the Four Tantras. ${ }^{512}$ As we shall see below, the Flight of the Great Khyung is an early khokbuk curriculum that is found as the first text in the Eighteen Partial Branches, followed by the Methods for Satiating the Tigress: An Outline, the Lamp Dispelling the Darkness: A Commentary, and the Beautiful Rainbow: One Thousand Sessions. In light of the Nyingma cosmology described in the Flight of the Khyung and Drangti's explicit and implicit references to the Flight, ${ }^{513}$ it is tempting to identify the khokbuk curriculum of Paktön as none other than the Flight of the Great Khyung found in the Eighteen Partial Branches.

509 The "early treasure corpus" (gter kha gong $m a$ ) usually refers to the corpus of Nyangrel Nyima Özer, as opposed to the "later treasure corpus" (gter kha 'og ma) of Guru Chöwang.

${ }^{510}$ Gsang ba man ngag gis [sic] rgyud kyi spyi don shes bya rab gsal rgyas pa (Beijing Ms), 38a: dge bshes mgon rin pas/_rta [=stag?] sde ba phag ston shäkya mgon po la gnang /_phag ston pa 'di 'khrung yul byang gi stag sde sbu ma ba/_thugs rab dang/_brtson pa shin tu rgya che zhing /_lhag par gsang sngags snga 'gyur/_gter kha gong ma la mkhas lal_g.yu thog lung dmar du byon nas/_dge bshes mgon rin yun du bsten cing /_dad pa dang gus pas mnyes par mdzad do/.

${ }^{5 I I}$ Gsang ba man ngag gis [sic] rgyud kyi spyi don shes bya rab gsal rgyas pa (Beijing Ms), 38a-38b: dbu rgyan pad ma'i sku tshab dang //_rtogs pas grol ba'i rgyud chen dang //_chi med tshe'i sgrub thabs dang //_mu stegs rdzas sbyor log pa dang //_mgon po ma hä kā la'i skor//_zhan yang rjes su phangs pa yis//_gdam pa 'ga' re phul nas zhus//_zhes pa ltar/.

${ }_{512}$ Gsang ba man ngag gis [sic] rgyud kyi spyi don shes bya rab gsal rgyas pa (Beijing Ms), 37a-38b: rgyud cha lag lag len dang bcas pa gsan cing /_nyid kyi khog 'bugs bsdus don/_sa spyad [=bcad] 'grel pa yang mdzad la/_'chad nyan shin tu dmar bar bstan pa'i bya ba mdzad pa yin no/.

${ }^{513}$ See, for example, Cha lag bco brgyad, 4: dang po thun mong spyii tshul du khog dbug pa ni/_sangs yang ma rgyas/_sems can du yang ma 'khrul ba'i sngon rol na/_sems stong pa rgyu can gang la yang rag ma lus pa rang byung du grub pas/_dngos po dang mtshan mar ma grub cing /_rig pa 'gag med gsal bas gnyen po gang gis kyang bsad bcad kyis ma sdigs pal_phyogs ris su rgya ma chad pal_thog ma med pa'i dus nas ye nas srid pa'o/. 
While it is clear that Drangti Penden Tsojé received an edition of the Four Tantras from Paktön Shākya Gönpo, the early transmission of the Four Tantras-which was referred to as the Essence of Ambrosia during the thirteenth century-is far from clear. It appears that Yutok Gönpo was indeed prolific in his teachings, but it is unlikely that he was the author of the textus receptus of the Four Tantras, as is often claimed in secondary scholarship. Instead, he seems to have provided many teachings that were compiled into Thousand-session Tutorials (tsong thun), which were then transmitted to many students of many different familial lineages. Sumtön Yeshé Zung was the most successful of his students, writing an unprecedented work that was based on his notes from Yutok, and apparently transmitting this early edition of the Four Tantras - probably a work more similar to the Explanatory Tantra than to all of the Four Tantras - to Tsojé Zhönnu Yeshé. This figure was later presented as a scion of the Sumtön family, but the two manuscript editions of the Indispensable Account contradict this claim. Tsojé Zhönnu Yeshé is said to have transmitted the Essence of Ambrosia in Eight Branches to an otherwise unattested Lharjé Könkhar of Upper Yardrok, where the precise transmission of the work becomes unclear. The trail picks up again with Geshé Gönrin, whom Drangti Penden Tsojé confusingly attempts to identify as a member of the Yutok clan, but his direct connection to Yutok is unconvincing. It is more likely that Geshé Gönrin received the transmission of the Essence of Ambrosia from one of Yutok's many student lineages, potentially through Lharjé Könkhar, or scions of the Minyak, Jang, Rok, Kochung, or some other clan. From Geshé Gönrin the Essence of Ambrosia was systematized, finalized, and finally transmitted to Paktön Shākya Gönpo and Drangti Penden Tsojé.

\section{Canonization and Curriculum in the Tibetan Medical Tradition}

As the Essence of Ambrosia was transformed into the textus receptus of the Four Tantras over the thirteenth century, associated summaries and commentaries were also appended to the work. As we have seen, these works were called supplementary chapters in early generations, but by the time of Paktön Shākya Gönpo and Drangti Penden Tsojé they came to be called "partial branches." Eventually these partial branches came to represent eighteen complex summaries, commentaries, and instructional works and sub-collections that came to be called the Eighteen Partial Branches. It is likely that each of these works were composed and/or redacted by figures described in the narratives of the Indispensable Account of Transmission and the Expanded Elucidation of Knowledge-including Sumtön Yeshé Zung, Tsojé Zhönnu Yeshé, Geshé Gönrin, Paktön Shākya Gönpo, and perhaps even Drangti Penden Tsojé himself. As mentioned throughout the above descriptions, the Four Tantras was reportedly transmitted along with the Partial Branches for generations, but it is not until the Expanded Elucidation of Knowledge that we find a full set of Eighteen Partial Branches:

\section{Methods for Explaining [the Four Tantras]}


This very tantra [of the Four Tantras] has been famously explicated in the Eighteen Partial Branches: ${ }^{514}$

[I.] The Flight of the Great Khyung: a curriculum for arranging the general contents of the topics [of the Four Tantras], ${ }^{515}$

[2.] Methods for Satiating the Tigress: an outline for dividing the main topics [of the Four Tantras], ${ }^{516}$

[3.] The Lamp Dispelling the Darkness: a commentary on the difficult points [of the Four Tantras], ${ }^{517}$

[4.] The Beautiful Rainbow: thousand session tutorials for clearly teaching the Explanatory Tantra, ${ }^{518}$

[5.] The Eleven Thousand Session Tutorials: collected exegetical cycles on the difficult points of the Instructional Tantra, ${ }^{519}$

[6.] The Wheel of Dispelling Contradictions and Refuting Criticisms: for refuting the criticisms of opponents, ${ }^{520}$

[7.] The Lamp Illuminating the Black Collection: a commentary for expansively teaching the Explanatory Tantra, ${ }^{521}$

[8.] Displaying the Four Wonders: for differentiating experts from others, ${ }^{522}$

${ }^{514}$ Gsang ba man ngag gis [sic] rgyud kyi spyi don shes bya rab gsal rgyas pa (Beijing Ms), 42a: ji ltar bshad pa'i tshul/_rgyud 'di nyid 'chad byed kyis cha lhag [=lag] bco brgyad du grags te/.

${ }^{515}$ Gsang ba man ngag gis [sic] rgyud kyi spyi don shes bya rab gsal rgyas pa (Beijing Ms), 42a: don gyi spyi khog dbub pa la/_khyung chen lding pa/. The first text in Cha lag bco brgyad, pp. I-24, entitled the Khog dbug khyung chen lding ba. As we shall see, the functional descriptions provided here by Drangti were often assimilated into the titles of the textus receptus Degé edition.

${ }^{516}$ Gsang ba man ngag gis [sic] rgyud kyi spyi don shes bya rab gsal rgyas pa (Beijing Ms), 42a: gzhung don sa mtshams 'byed pa la/_sa bcad stag mo'i rngam thabs/. The third text in Cha lag bco brgyad, pp. 53-84, entitled the Sa dpyad stag mos rngam thabs.

${ }^{517}$ Gsang ba man ngag gis [sic] rgyud kyi spyi don shes bya rab gsal rgyas pa (Beijing Ms), 42a: bka' [=dka'] 'phreng 'grel pa tikka mun sel sgron me/. The fourth text in Cha lag bco brgyad, pp. 85-IIo, entitled the Tikka mun sel sgron me.

${ }^{518}$ Gsang ba man ngag gis [sic] rgyud kyi spyi don shes bya rab gsal rgyas pa (Beijing Ms), 42a: bshad rgyud gsal bar ston pa/_stong mthun [=thun] mdzes pa'i gzha' ris/. The second text in Cha lag bco brgyad, pp. 25-52, entitled the Stong thun mdzes pa'i 'ja' ris.

${ }^{519}$ Gsang ba man ngag gis [sic] rgyud kyi spyi don shes bya rab gsal rgyas pa (Beijing Ms), 42a: man ngag rgyud kyi bka' [=dka'] 'grel/_skor tshom stong mthun [=thun] bcu gcig. The seventh text in Cha lag bco brgyad, pp. 243-386, entitled the Skor tshoms stong thun bcu gcig.

${ }^{520}$ Gsang ba man ngag gis [sic] rgyud kyi spyi don shes bya rab gsal rgyas pa (Beijing Ms), 42a: phyi rgol rtsod pa bzlog pa/_gal [='gal] sel rtsod bzlog 'khor lo/. The sixth text in Cha lag bco brgyad, pp. 224-42, entitled the Rtsod bzlog gegs sel 'khor lo.

${ }^{52 \mathrm{I}}$ Gsang ba man ngag gis [sic] rgyud kyi spyi don shes bya rab gsal rgyas pa (Beijing Ms), 42a: bshad rgyud rgyas par ston pa/_'grel pa 'bum nag gsal sgron/. The fifth text in Cha lag bco brgyad, pp. III223, entitled the 'Grel pa 'bum chung gsal sgron nor bu'i 'phreng mdzes.

W. A. McGrath | Buddhism and Medicine in Tibet | I7I 
[9.] The Three Profound Specialties: cherished [teachings] that were concealed separately, ${ }^{523}$ [Io.] The Three Indispensable Rituals: orally transmitted instructions, ${ }^{524}$ [II.] The Heap of Jewels: miscellaneous methods for healing various diseases, ${ }^{525}$

[12.] The Heap of Precious Treasures: a practicum for summarizing the essence of [medical] practices, ${ }^{526}$

[13.] The Five Etymologies: for clarifying the meanings of medical terminology, ${ }^{527}$

[I4.] The Lesser Tantra, the Essence of Ambrosia: for those of inferior intellect that want a short summary [of medical teachings], ${ }^{528}$

[15.] The Eighteen Completely Hidden Arcane Appendices: oral instructions, ${ }^{529}$

[I6.] The Pearl Rosary of Medicine: practices summarized as discourses, ${ }^{530}$

[17.] The Small Manual of Direct Guidance: the practices of the Instructional Tantra, ${ }^{531}$

[18.] The White Mantra Collection of Beneficence: for fastening beautiful ornaments. ${ }^{532}$

${ }^{522}$ Gsang ba man ngag gis [sic] rgyud kyi spyi don shes bya rab gsal rgyas pa (Beijing Ms), 42a: gzhan dang mkhas khyad 'byed pa ngo mtshar bzhi sprugs/. The fifteenth text in Cha lag bco brgyad, pp. 53I-33, entitled the Mkhas khyad ngo mtshar bzhi sprugs.

${ }^{523}$ Gsang ba man ngag gis [sic] rgyud kyi spyi don shes bya rab gsal rgyas pa (Beijing Ms), 42a: gces nas gud du sbas pa khyad par zab pa rnam gsum/. The fourteenth text in Cha lag bco brgyad, pp. 522-30, Khyad par zab pa rnam gsum.

${ }^{524}$ Gsang ba man ngag gis [sic] rgyud kyi spyi don shes bya rab gsal rgyas pa (Beijing Ms), 42a: snyan brgyud man ngag/_med thabs med pa'i mchong gsum/. The twelfth text in Cha lag bco brgyad, pp. 487-97, entitled the Brgyud pa'i rnam thar med thabs med pa.

${ }^{525}$ Gsang ba man ngag gis [sic] rgyud kyi spyi don shes bya rab gsal rgyas pa (Beijing Ms), 42a: thor bu nad kyi gso thabs/_kha mthor [='thor] rin chen spungs pa/. The tenth text in Cha lag bco brgyad, pp. 44I-54, entitled Kha 'thor rin chen phung po.

${ }^{526}$ Gsang ba man ngag gis [sic] rgyud kyi spyi don shes bya rab gsal rgyas pa (Beijing Ms), 42a: lag len snying po bsdus pal_lag len rin po che'i gter spungs/. The ninth text in Cha lag bco brgyad, pp. 396-440, entitled the Lag len rin chen gter spungs.

${ }^{527}$ Gsang ba man ngag gis [sic] rgyud kyi spyi don shes bya rab gsal rgyas pa (Beijing Ms), 42a: sman gyi ming don gsal bal_brda sprod rnam lnga/. The eighth text in Cha lag bco brgyad, pp. 387-95, entitled the Ming don brda sprod rnam lnga.

${ }^{528}$ Gsang ba man ngag gis [sic] rgyud kyi spyi don shes bya rab gsal rgyas pa (Beijing Ms), 42a: blo dman nyung bsdus 'dod la rgyud chung bdud rtsii snying po/. The sixteenth text in Cha lag bco brgyad, pp. 534-744, entitled the Rgyud chung bdud rtsi snying po.

${ }^{529}$ Gsang ba man ngag gis [sic] rgyud kyi spyi don shes bya rab gsal rgyas pa (Beijing Ms), 42a: zhal gyi gdams pa kha skong yang sbas gab pa bco brgyad/. The thirteenth text in Cha lag bco brgyad, pp. 498-52I, entitled the Yang sbas gab pa bco brgyad.

${ }_{530}$ Gsang ba man ngag gis [sic] rgyud kyi spyi don shes bya rab gsal rgyas pa (Beijing Ms), 42a: lag len mdo ru bsdus pa gso dpyad mu tig 'phreng ba/. The seventeenth text in Cha lag bco brgyad, pp. 745-70, entitled the Gso dpyad mu tig 'phreng ba.

${ }^{531}$ Gsang ba man ngag gis [sic] rgyud kyi spyi don shes bya rab gsal rgyas pa (Beijing Ms), 42a: man ngag rgyud kyi lag len dmar khrid yig chung /. The eleventh text in Cha lag bco brgyad, pp. 455-86, entitled the Lag len dmar khrid yig chung. 
This collection has long puzzled modern scholars - variously translating it as the Eighteen Auxiliary Practices (emphasizing the lag and interpreting the title as indicative of "practice" [lag len] instead of "branches" [yan lag] of knowledge and practice) and the Eighteen Pieces from Yutok (emphasizing the cha and interpreting the traditional notion that these teachings derive from Yutok Gönpo himself). ${ }^{533}$ Drangti's detailed listing of the Eighteen Partial Branches is the first in Tibetan medical history and this, combined with the numerous mentions of Drangti found in the collection, indicate that the Drangti clan may have been involved in its redaction. ${ }^{534}$ Thus, despite the semblance of coherence often attributed to this collection, it actually is comprised of eighteen works and subcollections that were composed and collected by different agents and in different contexts over the thirteenth and fourteenth centuries. By providing a list of titles and descriptions, Drangti Penden Tsojé effectively closes the corpus of Partial Branches that were once accumulated and transmitted in conjunction with the Four Tantras.

Despite the importance of the Partial Branches for the early Yutok school—that is, Yutok Yönten Gönpo and his lineage of disciples - even by the fourteenth century they seem to have lost their distinction as a necessary supplement to the Four Tantras. Indeed, following this detailed table of contents, Penden Tsojé writes:

Although these [Eighteen Partial Branches] clarify the meaning of the [Four] Tantras, one should teach [the Partial Branches] to those of superior intellect as if they only need to hear them once and then no longer need them; one should teach them to those of middling intellect as a supplement to the other texts and instructions; and one should teach them to those of inferior intellect as a thorough introductory lesson. ${ }^{535}$

${ }^{532}$ Gsang ba man ngag gis [sic] rgyud kyi spyi don shes bya rab gsal rgyas pa (Beijing Ms), 42a: mdzes pa'i rgyan gyi gdags pa phan bya sngags 'bum dkar po/. The eighteenth text in Cha lag bco brgyad, pp. 77I-87, entitled the Phan bya sngags 'bum dkar po.

${ }^{533}$ For an early study of the colophons and authorship of the Eighteen Partial Branches that is helpful but not unproblematic, see Barbara Gerke, "The Authorship of the Tibetan Medical Treatise Cha lag bco brgyad (Twelfth Century AD) and a Description of its Historical Background," Traditional South Asian Medicine 6 (200I): 27-50. Again, see Garrett, "Buddhism and the Historicising of Medicine in Thirteenth-century Tibet"; and Gyatso, Being Human in a Buddhist World.

${ }^{534}$ See, for example, Cha lag bco brgyad, 257: ding sang kha ba can gyi ljongs 'di nal/_sman par rlom pa'i skye bo rab mang yod//_brang ti mkhas pa slob mar bcas ma gtogs//_tsho byed yin snyam bdag gi sems la med//.

${ }^{535}$ Gsang ba man ngag gis [sic] rgyud kyi spyi don shes bya rab gsal rgyas pa (Beijing), 42b: de rnams kyi rgyud don rnams gsal bar byas te/_blo rab thos pas grol te bshad/_blo 'bring gzhungs gdams spel te bshad/_blo dman nan gtan 'jug khrid kyis bshad do/. This passage can only be found in an unpublished manuscript of the Expanded Elucidation of Knowledge held at the Nationalities 
With the six chapters [of the Root Tantra], one shall apprehend the roots of the summarized teachings;

With the Explanatory Tantra, one shall realize the general contents of medical science;

With the Instructional Tantra, one shall cure any disease that may arise;

With the Subsequent Tantra, one shall [realize] the practices that have been bound in the topics of the discourses. ${ }^{536}$

Thus, while recognizing the relevance of the Eighteen Partial Branches for didactic purposes, Penden Tsoje ultimately directs his readers to the Four Tantras itself. By the time that Drangti Jampel Zangpo had either inherited or compiled this collection in the middle of the fourteenth century, he had already begun to write his own commentaries and compile his own instructional collections. This trend continued into the fifteenth, sixteenth, and seventeenth centuries, when the Eighteen Partial Branches collection was ultimately carved into a woodblock edition for antiquarian reasons, but largely replaced as a source for scriptural exegesis and practical instructions. ${ }^{537}$

As evinced by this deluge of medical summaries and commentaries, the thirteenth century marks a period in which Tibetan medical schools and Tibetan-language medical scholarship was blossoming. Not unlike the parallel developments of the Buddhist intellectual tradition, the thirteenth and fourteenth centuries also mark a period in which disparate strands of theory and practice were beginning to come in conversation, leading to debates about what does and does not constitute valid knowledge. ${ }^{538}$ Perhaps the earliest comprehensive history outlining the development of valid medical knowledge in Tibet can be attributed to a scion of the aforementioned Cherjé clan, the Blazing Peak of the Victory Banner: Arranging the Contents of

Cultural Palace Museum (Minzu wenhua gong 民族文化宫) in Beijing. It appears to have been elided in all other editions (along with the first line of a subsequent quotation, indication deletion rather than addition). This manuscript was copied by Leonard van der Kuijp and given to me by his student and my teacher, Kurtis Schaeffer. It goes without saying that, without their kindness and generosity, the present study would not be possible.

${ }^{536}$ Gsang ba man ngag gis [sic] rgyud kyi spyi don shes bya rab gsal rgyas pa (Beijing Ms), 42b: le’u drug pas mdo bstan rtsa ba bzung /_bshad pa’i rgyud kyi gso rig spyi khog khrol/_man ngag rgyud kyi gang byung nad kun sos/_phyi ma rgyud kyi lag len mdo don gril/. Compare with Dpal ldan rgyud bzhi dpe bsdur ma, vol. 7, p. 27I: le 'u drug pas mdor bstan rtsa ba bzung /_bshad pa'i rgyud kyis gso rig spyi khog khrol/_man ngag rgyud kyis gang byung nad rnams gso/_phyi ma rgyud kyis lag len mdo don dril/.

537 On the preparation of a xylographic edition of the Eighteen Partial Branches at Ganden Püntsok Ling in the seventeenth century, as well as the reservations of the Desi Sanggyé Gyatso regarding this collection, see Gyatso, Being Human in a Buddhist World, II9.

${ }^{538}$ See, for example, Ronald Davidson "Gsar ma Apocrypha: The Creation of Orthodoxy, Gray Texts, and the New Revelation." In The Many Canons of Tibetan Buddhism, edited by Helmut Eimer and David Germano (Leiden: Brill, 2002), 203-24. 
the Origins of Medicine (sman gyi byung tshul khog dbubs rgyal mtshan rtse mo 'bar ba, 1264?) by Cherjé Zhangtön Zhikpo (che rje zhang ston zhig po, fl. I3th c.?). ${ }^{539}$ Despite potential connections to the Old School (rnying ma) of Tibetan Buddhism, ${ }^{540}$ the thrust of Cherjé's history is the transmission of Indian medical knowledge to Tibet through the Essence of the Eight Branches, seemingly at the expense of indigenous traditions. ${ }^{54}$ Without access to this important early work, however, I will refrain from making any more unqualified judgements than I already have.

As we have seen, the Essence of the Eight Branches was ubiquitous in the medical circles of the thirteenth and fourteenth centuries. Drangti Penden Tsojé explicitly acknowledges that he and his family members received transmissions of the Eight Branches from multiple sources, and even cites the pedagogy (bshad sgros) of Cherjé and Minyak, presumably in regard to teaching the Eight Branches, and the latter of which is also named as an opponent in the Blazing Peak. ${ }^{542}$ Pedagogical elements can also be found in what is probably the second earliest khokbuk curriculum that is available to us: the Flight of the Great Khyung. Following "eleven [reasons] why the King of Tantras [that is, the Four Tantras] is greater than [all other medical tantras]," ${ }^{543}$ the Flight begins with several points regarding methods for the explanation of the Four Tantras, including the six faults of the teacher, the six duties of the teacher, the six duties of the listener, and the famous metaphor of the three vessels. ${ }^{544}$ With these opening lists, the reader is provided with the means by which not only students, but also the teachers, can be fitted to the mold of classical Buddhist scholarship. Indeed, beyond the historical narratives that they all include, the khokbuk curriculum came to be a core component in Tibetan medical pedagogy and the establishment of medical schools.

Although by the late thirteenth century the term khokbuk comes to refer to medical curricula that arrange (dbubs) the contents ( $k h o g)$ that are to be studied by students, the first usage of the term has a slightly different connotation. As we saw in the Indispensable Account of

${ }^{539}$ Martin, "An Early Tibetan History of Indian Medicine," 3II: "Now, since the main colophon supplies a clearly legible sixty-year cycle date, a Wood Mouse year, we might provisionally accept that the date of composition was I204 CE." Here I suggest I264 based on the present discussion. Currently lacking access to this work, however, I rely wholly on Dan Martin's consummate summary.

${ }^{540}$ Martin, "An Early Tibetan History of Indian Medicine," 3II.

54I Martin, "An Early Tibetan History of Indian Medicine," 319: "while the Rgyud bzhi as a medical scripture has no place even in the outermost horizons of Che rje's consciousness, the words brgyud bzhi are in fact used once." Perhaps this is evidence for an attempted appropriation of the referent for the Four Tantras.

${ }^{542}$ Martin, "An Early Tibetan History of Indian Medicine," 319: "Other commentators whom [Cherjé] finds worthy of mentioning, since he disagrees with their methods of outlining, are: I. Dge bshes Mi nyag, who must be Mi nyag Rong rje."

${ }^{543}$ Cha lag bco brgyad, Bod kyi gso ba rig pa'i gna' dpe phyogs bsgrigs dpe tshogs vol. 25 (Beijing: Mi rigs dpe skrun khang, 2005), I: rgyud rgyal gyi che ba bcu gcig dang ldan pa.

${ }^{544}$ The three vessels are, of course, the inverted vessel (snod kha sbub), the leaking vessel (zhabs rdol), and the poisoned vessel (dug can). See Cha lag bco brgyad, 2-3. 
Transmission outlined above, "The Sage Yutok Gönpo composed the Thousand-session Tutorials that arranges the contents of the topics [of medical practice...]." 545 This is perhaps the first usage of the term "arranging the contents of the topics" (don gyi khog dbubs), and here it appears to not be a part of the title, but rather a description of the way in which the Thousandsession Tutorials serve to organize medical instructions for study and practice. Even in this early usage, "arranging the contents" already has pedagogical and curricular connotations.

In the Flight of the Great Khyung, Paktön explicitly states that one should seek to "arrange the contents of the topics" (don gyi khog dbug pa) of the text, calling the khokbuk a method for explanation (bshad thabs) and parsing into four subbranches: [I.] The "Reason for Arranging the Contents," [2.] the "Nature [of Arranging the Contents]," [3.] "Etymological Exegesis [in Arranging the Contents]," and [4.] "Categorization [in Arranging the Contents]." 546 From these first three subbranches, we learn that the khokbuk curriculum involves pedagogical techniques that: [I.I.] are distinct from the object of knowledge itself; ${ }^{547}$ involve the topics (don) of [I.2.I.] origins, [I.2.2.] rhetorical techniques, and [I.2.3.] methods for how to explain; ${ }^{548}$ and [I.3.] should be used to understand a diverse body of topics. ${ }^{549}$ It is perhaps this particular emphasis on the origins of a subject and the general emphasis on historical approaches in the modern academy that has led to the misunderstanding of the khokbuk curriculum as a "medical history."

As this outline shows, however, the khokbuk curriculum is equally dedicated to the arrangement of materials for the study of a single subject, methods for teachings that subject, as well as methods for expanding one's knowledge of that subject to a wider body of topics. In addition to this more general outline of pedagogy, combined with descriptions for [2.] "Outlining the Contours [of the Contents]" and [3.] Closely Reading Each Syllable [of the Contents], ${ }^{550}$ the Flight also provides specific instructions for the study of the five fields of knowledge, as well as the Four Tantras itself. Thus, the Flight outlines methods for teaching the Four Tantras specifically, but also for indicating its position within the larger field of medical science and knowledge in general.

${ }^{545}$ Med thabs med pa'i mchong [='phyong] gsum, in Krung go'i bod lugs gso rig rtsa che'i dpe rnying kun btus, vol. 3, text 3, p. 257 (f. 2b): drang srong g.yu thog mgon po yis/_don gyi khog dbubs tongs [=stong] thun $\mathrm{mdzad} /$.

${ }^{546}$ Cha lag bco brgyad, 3: de yang dang po don gyi khog dbug pa la bzhi ste/_khog dbug pa’i dgos pa dang /_ngo bo/_nges tshig_dbye ba'o/.

${ }_{447}$ Cha lag bco brgyad, 3: de la khog dbug pa'i dgos pa ni/_chos thams cad kyi don go bas/_dang po bshad thabs su shes te phyi'i khog dbug pa'i dgos pa yod do/.

${ }^{548}$ Cha lag bco brgyad, 3: khog dbug pa'i ngo bo ni gang 'chad par byed pa'i chos de'i don go rna bar 'jog cing /_byung khungs dang /_bshad ral dang /_ji ltar bshad pa'i don rnams ston pa zhig la khog dbug ces bya'o/.

${ }^{549}$ Cha lag bco brgyad, 3: khog dbug pa'i nges tshig ni/_ji ltar bshad pa'i thabs rnams shes pas don gyi go ba thams cad lon pa'i khog dbug pa zhes bya'o/. 
Drangti Penden Tsojé was clearly aware of the Flight of the Great Khyung, for he lists it as first among the Eighteen Partial Branches in the Expanded Elucidation of Knowledge, stating that it "arranges the general contents of the topics [of the Four Tantras]." As As far as I can tell, the word "arrange" $(d b u b)$ and the word "penetrate" $(d b u g)$ are effectively interchangeable in this context-with Penden Tsoje preferring the former and the author of the Flight preferring the latter. ${ }^{52}$ In fact, the one instance in which Penden Tsojé uses the term khokbuk is in the context of the writings of his teacher, Paktön Shākya Gönpo. ${ }^{553}$ Penden Tsoje also treats the notion of khokbuk curricula in his section on "methods for explanation" (bshad thabs), or pedagogy. He opens the section by prescribing that one should teach scripture $\left(b k a^{\prime}\right)$ in terms of the five sublime contexts (phun sum tshogs pa lnga) and that one should teach treatises (bstan bcos) in terms of the five aspects (rtsis mgo lnga). Without citing his source or even the contextualizing first line, he begins with a common quotation from Vasubandhu's Vyākhyāyukti delineating the latter set of five:

One should state the purpose [of the work], its summarized meaning,

The meaning of the words, their connections,

And both the objections and responses. ${ }^{554}$

And continues without pause, proceeding into an unrelated quotation:

After ascertaining [the work's] ultimate meaning, one should arrange its contents.

By thoroughly parsing [the work], one should also outline [its contents].

One should expound upon each syllable that expresses [meaning],

And one should use such reasoning to dispel doubts regarding the meaning. ${ }^{555}$

${ }^{550}$ Cha lag bco brgyad, 3: de ltar 'chad nyan gyi gnyer du blangs nas nyan bshad byed pa la/_bshad thabs yan lag gsum gyi sgo nas 'chad de/_don gyi khog dbug pal_dkyus kyi sa gcad pal_tshig gi 'bru non pa gsum gyis 'chad dgos te/.

${ }^{551}$ Gsang ba man ngag gis [sic] rgyud kyi spyi don shes bya rab gsal rgyas pa (Beijing Ms), 42a: don gyi spyi khog dbub pa.

${ }_{552}$ I preferentially translate both terms as "arrange" because khokbuk probably derives from $k$ kokbup, with the ending - $k$ sound representing a phonetic duplication after the $-k$ of $k h o k$.

${ }^{553}$ See Gsang ba man ngag gis [sic] rgyud kyi spyi don shes bya rab gsal rgyas pa (Beijing Ms), 38b: rgyud cha lag lag len dang bcas pa gsan cing /_nyid kyi khog 'bugs bsdus don/_sa spyad [=bcad] 'grel pa yang mdzad la/_'chad nyan shin tu dmar bar bstan pa'i bya ba mdzad pa yin no/.

${ }_{554}$ Gsang ba man ngag gis [sic] rgyud kyi spyi don shes bya rab gsal rgyas pa (Beijing Ms), 4Ib: dgos pa bsdus pa'i don bcas dang //_tshig don bcas dang mtshams sbyor bcas//_rgan lan bcas de snyad par bya//. Compare with Rnam par bshad pa'i rigs pa, in Bstan 'gyur dpe bsdur ma, ed. Krung go'i bod rig pa zhib 'jug ste gnas kyi bka' bstan dpe sdur khang (Beijing: Krung go'i bod rig pa dpe skrun khang, 2004), sems tsam, vol. 77 (shi [I5I]), text 3290, p. 85: mdo don smra ba dag gis ni//_dgos pa bsdus pa’i don bcas dang //_tshig don bcas dang mtshams byor bcas//_brgal lan bcas par bsnyad par bya//. Translated in consultation with Richard F. Nance, Speaking for Buddhas: Scriptural Commentary in Indian Buddhism (New York, NY: Columbia University Press, 20I2), I32. 
Thus, building upon both Indian pedagogy described in Vasubandhu's Vyākhyāyukti as well as Tibetan medical pedagogy described in the Flight of the Great Khyung, Drangti Penden Tsojé recommends that one teaches [I.] the origins and scene of instruction of a work, [2.] a general explanation of the subject, [3.] methods for presenting and explaining the subject, and, expanding upon the list of three found in the Flight, [4.] textual works that might aid in the explanation of a subject. ${ }^{556}$ Combining the accounts of the Flight and the Expanded Elucidation of Knowledge, the khokbuk clearly emerges as an entire curriculum of a medical school, in which one not only learns the history of one's subject, but also the subject itself, and, most importantly, ways of explaining that subject.

\section{Conclusions: Education, Standardization, and Unification}

Following the direct regulation of Chinese and Tibetan Medical Houses by the Mongol government in the I260s, the khokbuk curriculum emerged as a distinct genre. There were precedents for these pedagogical works in the early instructions of the Tibetan medical tradition, but it was not until the late thirteenth century that khokbuk curricula were proliferated along with root texts, historical narratives of transmission, and scholastic commentaries and summaries, culminating in the intellectual and educational repertoire for burgeoning Tibetan medical schools. Just as the canon of theoretical and instructional texts had to be "closed" - that is, standardized and finalized, such that their transmission in the medical schools could also be standardized-so too did the narratives of these schools. With the social and political support of the Mongols and Sakya hierarchs at the turn of the fourteenth century, it was the Drangti clan that came to close the canons and standardize the narratives of transmission, culminating in a single Tibetan medical tradition centered around the Sakya Medical House-a Buddhist institution for the study and practice of medicine in Tibet.

With the implementation of taxation, as well as the possibility of exemption from it, Tibetan medical traditions were encouraged to develop into institutional medical houses that fostered scholastic approaches to the study of medicine. As these familial lineages and interfamilial schools came into contact and competition, so too did their standards for formative texts and unifying narratives. Following the success of the Essence of Ambrosia and the Yutok lineage, multiple lineages and schools claimed to be the sole representative of the

${ }^{555}$ Gsang ba man ngag gis [sic] rgyud kyi spyi don shes bya rab gsal rgyas pa (Beijing Ms), 4Ib: don dam nges pa'i [=pas] khog dbub cing //_rnam par dbye ba'i [=bas] sa yang bcad//_rjod byed tshig gi 'bru bsnan [=gnon] la//_gtan tshigs don gyi the tshom gsal//.

${ }^{556}$ Gsang ba man ngag gis [sic] rgyud kyi spyi don shes bya rab gsal rgyas pa (Beijing Ms), 4Ib: byung tshul gleng bzhii [=gzhi'i] khog dbub/_brjod bya don gyi khog dbub/_bshad thabs rnam gzhag gi khog dbub/_gsal byed lung sbyor gyi khog dbub dang gzhis [=bzhi]/_spyi dang khyad par gyis rnam gzhag ston pa yin la/. 
Yutok student lineage, particularly due to the absence of influential Yutok scions. Drangti Penden Tsojé, student of Paktön Shākya Gönpo and representative of the Yutok student lineage, was able to craft a new lineage - the Yutok familial lineage-in which the lineage narratives of the Drangti family were creatively merged with those of the Yutok, among others. Just as Drangti was able to effectively tout the Four Tantras as the essence of all medical teachings, so too was he able to promote the Sakya Medical House as the heir to all Tibetan medical lineages. Regardless of the historical veracity of these claims, the impression of an essential teaching, a unified lineage, and Sakya-Mongol institutional support culminated in the establishment of a "lineage of one" that had evaded so many others. To ensure the continuation of this lineage, particularly on the global stage, the teachings Sakya Medical House would have to represent the essence of not just the medical traditions of Tibet, but those of South, East, and Central Asia as well. As we shall see in Chapter Five, it was the pairing of historical creativity with ethical prescriptions that prophetically imagined the physician-as-bodhisattva, and socially established the medical profession at the Buddhist monastery for the rest of Tibetan history. 


\section{Chapter Five: Imperial Legends and the Establishment of Professional Ethics in the Tibetan Medical Tradition}

With the founding of the Sakya Medical House at the turn of the fourteenth century and the merging of monastic and medical institutions under the aegis of Sakya-Mongol hegemony, the very ethical foundations of medical practice in Tibet came to be reimagined. If the familial lineages of the twelfth century and the budding medical schools of the thirteenth century were operating within a context of competition, deception, and self-promotion, the fourteenth century came to offer a prophetic vision for harmonious cooperation between physicians and patients that had never before been actualized in Tibet. Regardless of whether or not Drangti Penden Tsojé's fourteenth-century articulation of eighth-century medical ethics ever "actually happened" in the Rankean sense, his prescribed rules for the behavior of both physicians and patients have continued to echo throughout centuries of subsequent histories in the Tibetan medical tradition, down to the present day. With the mirror of historiography at hand, Drangti was able to effectively reflect the future of the Tibetan medical tradition through his recreation of the imperial past.

The Four Tantras itself includes more than a few explicit ethical prescriptions. In the second chapter of the Root Tantra, for example, following our first introduction to the Sage Rikpé Yeshé, we are told, "Those that wish to achieve virtue (Skt. dharma), wealth (Skt. artha), and pleasure (Skt. kama), should train in the instructions of the science of healing." ${ }^{257}$ This triad refers, of course, to the Brahmanical aims of life (Skt. purușārtha), which constitutes both the rights and the duties of all humans that seek to have a full life. ${ }^{558}$ Rikpé Yeshé's advice is not a far cry from an opening passage found in the Essence of the Eight Branches in which these three aims are promised for those that engage in the teachings of the "science of life" (Tib. tshe yi rig byed = Skt. ayurveda). ${ }^{559}$ and similar sentiments also echo in the Four Collections ('bum

${ }^{557}$ Dpal ldan rgyud bzhi dpe bsdur ma, vol. I, 23: chos dang nor dang bde ba sgrub par 'dod pa'i gang zag gis gso ba rig pa'i man ngag la bslab par bya'o/. A similar line appears in the first chapter of the Explanatory Tantra; Dpal ldan rgyud bzhi dpe bsdur ma, vol. I, 55: 'gro drug gtso bor gyur pa mi lus la//_mi na gnas dang na ba gso ba dang //_tshe ring chos nor bde ba sgrub pa'i phyir//_gso ba rig pa’i don rnams mdor bsdu na/l ... .

${ }^{558}$ For an insightful overview of this triad within the larger context of Indian intellectual history, see Wendy Doniger, The Hindus: An Alternative History (New York, NY: The Penguin Press, 2009), I99-2II.

${ }^{559}$ Krung go'i bod rig pa zhib 'jug ste gnas kyi bka' bstan dpe sdur khang, ed., Bstan 'gyur dpe bsdur ma (Beijing: Krung go'i bod rig pa dpe skrun khang, 2004), vol.III (he [213]), text 3547, p. I43: "Those desirous of long life as a means for achieving virtue, wealth, and pleasure, should engage in the teachings of the science of life with the utmost sincerity" (tshe ni ring bar'dod pa yis//_chos dang nor dang bde ba bsgrub//_tshe yi rig byed lung bshad pal/_rab tu gus par bya bar gyis//). See also Claus Vogel, Vāgbhața’s Aștānngahṛdayasaṃhitā: The First Five Chapters of Its Tibetan Version (Wiesbaden: Franz Steiner Verlag GMBH, 1965), 48.

W. A. McGrath | Buddhism and Medicine in Tibet | 180 
bzhi), albeit with some explicitly Bönpo modifications. ${ }^{560}$ As indicated by these three distinct instantiations of early Tibetan medical traditions - that is, the Buddhocentric, Indocentric, and Bönpocentric, respectively-each of which conspicuously lacks any mention of soteriological "release" (Tib. thar pa = Skt. mokșa), it is the duties and rewards of this life that are the primary driving motivations of Tibetan medical practice in the twelfth and early thirteenth centuries. Regardless, however, the Explanatory Tantra ends with an emphatically soteriological promise: "As stated by the King of Physicians, 'By abstaining from deceit, desire, and so forth, while engaging in healing patients, the ultimate result is proceeding to the ground of an unexcelled buddha." "56 $T$ Thus, in this earliest layer of the Four Tantras we witness a shift from deceit to care, from the immediate to the ultimate, and from the worldly to the transcendent. ${ }^{562}$

With the rise of khokbuk curricula at Tibetan medical schools, we find different approaches for the inclusion of medical practices on the Buddhist path to enlightenment. In the Flight of the Great Khyung, for example, Paktön Shākya Gönpo creatively reinvents the story of Sākyamuni Buddha's enlightenment by inserting instances of medical learning and practice into his religious training. ${ }^{563}$ In the Expanded Elucidation of Enlightenment, however, Drangti Penden Tsojé mostly follows the more orthodox examples of his Sakya forbearssuch as the life narratives of Śākyamuni told by Butön Rinchen Drup and Lama Dampa Sönam Gyentsen-but with a few important embellishments. Indeed, despite the clear influence that the Flight had on the Expanded Elucidation in terms of organization and argument, Drangti's time at the Sakya Medical House left him with many other sources of historiographical inspiration for his own synthesis of a Buddhist medical curriculum. Following the precedents set by his Sakya teacher, Lama Dampa, Drangti Penden Tsojé reimagines imperial Tibet as the center of the medical world, providing a vision of medical

${ }^{560}$ Gso rig 'bum bzhi, 9: "Those that desire virtue (bon), wealth, and happiness should train in these instructions of the science of healing" (bon dang nor dang bde skyid 'dod pa'i gang zag gis gso ba rig pa'i man ngag'di la bslab par bya'o/).

56I Dpal ldan rgyud bzhi dpe bsdur ma, vol. I, 274-75: mthar thug 'bras bu g.yo sgyu 'dod pa rnams//_spang nas nad pa gso ba la 'jug pal/_bla med sangs rgyas sa la bgrod zhes//_thos mdzad sman pa'i rgyal bos bshad pa yin//.

${ }^{562}$ For a similar analysis of tensions between the so-called "way of humans" (mi chos) and the "way of the gods" (lha chos), also known as the "way of truth" (dam pa'i chos), in the Four Tantras and its early commentary, the Little Collection ('bum chung), see Gyatso, Being Human, 343-96. Therein she interprets the previous citation from the Four Tantras somewhat differently (pp. 358-59). See also Kurtis Schaeffer, "Death, Diagnosis, and the Physician's Reputation in Tibet," in Heroes and Saints: The Moment of Death in Cross-cultural Perspectives, ed. Phyllis Granoff and Koichi Shinohara (Newcastle: Cambridge Scholars Publishing, 2007), 159-72.

${ }^{563}$ Recall from Chapter One that Sākyamuni is said to have "trained in sports and the five sciences" (sgyu rtsal dang rig pa'i gnas lnga la blo sbyangs so) as a youth, that "all of his peccant humors arising from the illusory body were purified" (sgyu lus las byung ba'i nyes pa thams cad dag) when he was practicing austerities, and so forth. See Khyung chen lding ba, in Cha lag bco brgyad, 7 . 
ethics for both physicians and patients framed within the context of eighth-century cosmopolitanism.

\section{The Expanded Elucidation of Knowledge in the Tibetan Tradition of Buddhist Historiography}

Although Drangti Penden Tsojé primarily cites medical scriptures and treatises in the Expanded Elucidation of Knowledge-including the Four Tantras and the Essence of the Eight Branches, but also non-extant mythical tantras deriving from the Flight of the Great Khyung - he does name a handful of contemporary figures. In addition to his students and teachers in the medical tradition, Drangti also pays homage to his religious teacher, Chöjé Sönam Gyentsen Pelzangpo (chos rje bsod nams rgyal mtshan dpal bzang po, 1312-1375), commonly known in secondary scholarship as Lama Dampa (bla ma dam pa): ${ }^{564}$

The Teacher [Śākyamuni] was born on a male earth-dragon year [2213 BCE], achieved enlightenment on a male water-tiger year [2179 BCE], and passed away on a male fire-pig year [2134 BCE]. In the male water-mouse year [1372 CE] of the system explicated by Sakya Pandita-toward the end of the turning of the wheel of doctrine by Chöjé Sönam Gyentsen Pelzangpo in the year 3505 [1372] - I495 years [of the Dharma] remain. ${ }^{565}$

This citation follows Drangti's account of the life story of Sākyamuni Buddha. Lacking the references to medical training and practices in the life story told in the Flight, Drangti provides a much longer and more detailed version of the story, apparently based on the teachings of Lama Dampa Sönam Gyentsen. There are no other sources available to me that describe the relationship between Drangti and Lama Dampa, but considering the institutional proximity of Lama Dampa's Rinchen Gang Estate (rin chen sgang bla brang) and the Sakya Medical House (sa sky a sman grong) of the Drangti clan, their apparent association comes as no surprise.

Drangti's telling of the life story of Śākyamuni Buddha in the Expanded Elucidation of Knowledge and that which is found in Lama Dampa's Mirror Illuminating the Royal Genealogies

${ }^{564}$ On the life and work of Lama Dampa, see Leonard van der Kuijp, "Fourteenth-century Tibetan Culture III: The Oeuvre of Bla ma dam pa Bsod nams rgyal mtshan (I3I2-I375)," Berliner Indologische Studien 7 (I993): I09-I47.

${ }^{565}$ The first twenty folios of the Beijing Ms are missing, so herein I cite an alternative manuscript witness. Khog dbubs shes bya rab gsal rgyas pa, in Krung go'i bod lugs gso rig rtsa che'i dpe rnying kun btus, vol. 20, text 2I, p. 344 (f. IOb): ston pa sa pho 'brug la bltams/_chu pho stag la sangs rgyas/_me pho phag la mya ngan las 'das par/_sa skya pan di ta chen po bzhed pa'i lugs kyi chu pho byi ba'i lo/_chos rje bsod nams rgyal mtshan dpal bzang po chos 'khor mdzad pa yar spyad la/_lo sum stong lnga brgya dang lnga 'das la/_stong bzhi brgya dang dgu bcu rtsa lnga lhag par gnas so//. 
(rgyal rabs gsal ba'i me long, 1368$)^{566}$ share a canonical framing of events, but differ significantly in terms of detail. Lama Dampa's telling is rather brief and, at the end of his telling, much like that of Drangti, Lama Dampa also cites other works that were popular at Sakya:

The above [narrative] is an abridged outline. However, in case one should want a more exhaustive [treatment of the subject, one may find it] elucidated in the Vinaya and the Sutras. Those unable to read that much may consult the detailed [exposition in the] Religious History of Butön Rinpoché and the Elucidation of Knowledge composed by Lama Chökyi Gyelpo [Pakpa], who concurs in opinion with the Dharmasvāmin Butön. ${ }^{567}$

Following this trail of references, we are ultimately led to the work of Lama Dampa's teacher, Butön Rinchen Drup (bu ston rin chen grub, I290-1364), and the Sakya hierarch, Drogön Chögyel Pakpa ('gro mgon chos rgyal 'phags pa, I235-1280), after whose work the Expanded Elucidation Knowledge is named. Indeed, both of these works feature narratives surrounding the life and enlightenment of Sākyamuni Buddha, and although Pakpa's telling in the Elucidation of Knowledgie (shes bya rab gsal) is extremely brief, ${ }^{568}$ the life story of Sākyamuni Buddha as told by Butön is quite extensive and ornate, and it came to be highly influential by the middle of the fourteenth century. ${ }^{569}$

${ }^{566}$ See Rgyal rabs gsal ba’i me long (Beijing: Mi rigs dpe skrun khang, 2002), vol. I, 8-II. For an annotated translation, see Sørensen, Tibetan Buddhist Historiography, 52-57.

${ }^{567}$ Rgyal rabs gsal ba'i me long, vol. I, II: 'di ni zur tsam bsdus pa yin gyis/_rgyas par'dod na/_mdo sde dang /_'dul ba lung na gsal lo//_de tsam gzigs par mi nus pa rnams kyis bu ston rin po che'i chos 'byung dang I_bla ma chos kyi rgyal pos mdzad pa'i shes bya rab gsal/_chos rje bu ston gyi bzhed pa dang mthun pas zhib par gzigs shig. Translation based primarily on Sørensen, Tibetan Buddhist Historiography, 57; with slight edits.

${ }^{568}$ For a translation, see Constance Hoog, trans., Prince Jin-gim's Textbook of Tibetan Buddhism: The Shes bya rab gsal by 'Phags-pa Blo-gros rgyal-mtshan dPal-bzan-po of the Sa-skya-pa (Leiden: Brill, I983), 40. Despite the brevity of this mention, for an explanation of its importance, see Peter Schweiger, "History as Myth: On the Appropriation of the Past in Tibetan Culture," in the Tibetan History Reader, ed. Gray Tuttle and Kurtis R. Schaeffer (New York, NY: Columbia University Press, 2013), 82, n. 37.

${ }^{569}$ On the writing, transmission, and translation of the Religious History (chos 'byung) of Butön, see Leonard W. J. van der Kuijp, "The Lives of Bu ston Rin chen grub and the Date and Sources of His Chos 'byung, a Chronicle of Buddhism in India and Tibet," Revue d'Etudes Tibétaines 35 (2016): 203-308; and his "Some Remarks on the Textual Transmission and Text of $\mathrm{Bu}$ ston Rin chen grub's Chos 'byung, a Chronicle of Buddhism in India and Tibet," Revue d'Etudes Tibétaines 25 (2013): II5-93. As van der Kuijp expresses throughout these works, despite its age, E. Obermiller, trans., History of Buddhism (Chos h.byung) by Bu ston (Heidelberg: $\mathrm{H}$. Winter Verlag, I93I-I932), 2 vols.; remains an excellent contribution of scholarship. A more recent translation, Lisa Stein and Ngawang Zangpo, trans., Butön's History of Buddhism in India and Its Spread in Tibet: A Treasury of Priceless Scripture (Ithaca, NY: Snow Lion Publications, 20I3); frankly adds very little to Obermiller's nearly century-old work. On Butön, see also David Seyfort Ruegg, The Life of Bu ston Rin po che: With the Tibetan Text of the Bu ston rnam 
A close analysis of Drangti's telling of the life of Śākyamuni Buddha reveals that he, unlike Paktön's creative telling in the Flight, does indeed effectively summarize the telling of the Buddha's life found in Butön's Religious History (chos 'byung). First, for example, he "awakens his potential and generates the mind [of enlightenment]" (rigs sad zhing thugs bskyed), second he accomplishes the "two accumulations [of merit and gnosis]" (tshogs gnyis bsags), and finally he "descends to the earth and, having achieved enlightenment, turns the wheel of the doctrine" ('dzam bu'i gling du gshegs pa ste byang chub mnyes [=brnyed] nas chos kyi 'khor lo bskor). ${ }^{570}$ Following brief descriptions of the first two stages, Drangti then cites the Unsurpassed Continuum (Tib. [theg pa chen po] rgyud bla ma['i bstan bcos] = Skt. mahāyānottaratantraśästra) to outline the third aforementioned part, just as Butön does:

[I.] His Descent from Tuṣita Heaven,

[2.] His Entrance into the Womb, [3.] His Birth,

[4.] His Mastery of Arts and Crafts [and the Five Sciences],

And His Participation in Childhood Games,

[5.] His Being Surrounded by the Retinue of Queens,

[6.] His Definitive Renunciation, [7.] His Performance of Austerities,

[8.] His Entrance into the Essence of Enlightenment,

[9.] His Victory over the Demonic Hordes, [Io.] His Perfection,

[II.] His Wheel of Enlightened Doctrine, and

[12.] His Passing Beyond Suffering.

In the completely impure realms,

He will perform these deeds as long as existence endures. ${ }^{51}$

thar, Serie Orientale Roma XXXIV (Roma: Istituto Italiano Per il Medio ed Estremo Oriente, 1966).

${ }^{570}$ Khog dbubs shes bya rab gsal rgyas pa, in Krung go'i bod lugs gso rig rtsa che'i dpe rnying kun btus, vol. 20, text 2I, p. 342 (f. 5a). See also Sørensen, Tibetan Buddhist Historiography, 52-57; and E. Obermiller, History of Buddhism (Chos-hbyung) by Bu-ston: The Jewelry of Scripture (Leipzig: Heidelberg, I93I), vol. I, IOO-38; vol. 2, I-72.

${ }^{571}$ Khog dbubs shes bya rab gsal rgyas pa, in Krung go'i bod lugs gso rig rtsa che'i dpe rnying kun btus, vol. 20, text 2I, p. 342 (f. 5b): dga' ldan gnas nas 'phos ba dang //_lhums su 'jug dang bltams pa dang //_bzo rigs gnas la mkhas pa dang //_gzhon nu'i rol rtsed mdzad pa dang //_man mo'i 'khor gyis bskor ba dang //_nges 'byung dka' ba spyod pa dang //_byang chub snying por gshegs pa dang //_bdud sde 'joms dang rdzogs par ni//_byang chub chos kyi 'khor lo dang //_mya ngan 'das par gshegs mdzad pa rnams//_yongs su ma dag zhing rnam su//_srid pa ji srid gnas par ston//.

Compare with Theg pa chen po rgyud bla ma'i bstan bcos, in Bstan 'gyur dpe bsdur ma, ed. Krung go'i bod rig pa zhib 'jug ste gnas kyi bka' bstan dpe sdur khang (Beijing: Krung go'i bod rig pa dpe skrun khang, 2004), sems tsam, text 3256, vol. 70 (phi [138]), 958: dga' ldan gnas nas 'pho ba dang //_lhums su 'jug dang bltams pa dang //_bzo yi gnas la mkhas pa dang //_btsun mo'i 'khor dgyes rol pa dang //_nges 'byung dka' ba spyod pa dang //_byang chub snying por gshegs pa dang //_bdud sde 'joms dang rdzogs par ni//_byang chub chos kyi 'khor lo dang //_mya ngan 'das par gshegs mdzad 
For eleven of the twelve deeds of Śākyamuni Buddha's life, each citation of quoted speech and scripture found in the Expanded Elucidation of Knowledge can also be found in the Religious History. Each of these citations found in the writings of Butön and Drangti also ultimately derive from the Tibetan Buddhist canon, thereby lending a sense of orthodoxy to the tellings. ${ }^{572}$ Just like Butön, Drangti speaks of Śākyamuni teaching the Four Noble Truths at Varanasi (ba ra na se) during the first turning of the wheel, although in greatly summarized form. He then teaches the philosophical tenets of the Greater Vehicle at Vulture Peak (Tib. bya rgod phung po'i ri = Skt. grdhrakūța) and so forth during the second turning. ${ }^{573}$ The teachings of the third turning at Vaiśālì (yangs pa can) and so forth are said to helped students transcend extreme views, all of which is in agreement with Butön and Lama Dampa. ${ }^{574}$ Thus, Drangti's telling of the life of Sākyamuni appears to have been consciously fashioned after the Sakya historiographical tradition, as exemplified by the writings of Pakpa, Butön, and Lama Dampa.

Similar to Paktön's telling in the Flight, it is in the turnings of the wheel of doctrine that we begin to see some discrepancies between the Sakya telling and that of the Expanded Elucidation. After the turning of the third wheel and before the death of the Buddha, Drangti adds a scene in which Sākyamuni teaches the Secret Mantra (gsang sngags) at the peak of Mount Meru (ri rab kyi rtse) and at the base of the Śrī Dhānyakațaka reliquary (dpal ldan 'bras phung gi mchod rten), describing the empowerment of King Indrabodhi and so forth. ${ }^{575}$ These, of course, are all important places and people in the narratives of the Nyingma tradition that

rnams//_yongs su ma dag zhing rnams su//_srid pa ji srid gnas par ston//. And see Obermiller, History of Buddhism, vol. I, I36.

${ }^{572}$ See, for example, Khog dbubs shes bya rab gsal rgyas pa, in Krung go'i bod lugs gso rig rtsa che'i dpe rnying kun btus, vol. 20, text 2I, p. 343 (f. 8a): "Then Brahmā, Śakra, and so forth implored [the Buddha to teach]: 'Like the liberation of the full moon from the planet [Rāhu], your mind has been completely liberated. Pray, rise up, you who have conquered in battle, and may the light of your insight shine in the darkness of this world' (de nas tshangs pa dang brgya byin la sogs pas//_zla ba nya ba gza' las thar pa ltar//_khyod kyi thugs ni shin tu rnam par grol//_g.yul las rnam par grol ba bzhengs gsol te//_’jig rten mun par shes rab 'od dbyung gsol//). Compare with the Mdo rgya cher rol pa, in

Bka' 'gyur dpe bsdur ma, ed. Krung go'i bod rig pa zhib 'jug ste gnas kyi bka' bstan dpe sdur khang (Beijing: Krung go'i bod rig pa dpe skrun khang, 2004), mdo sde, vol. 46 (kha), text oII2, p. 46I: zla ba nya ba gza' las thar ba ltarl/_khyod kyi thugs ni rnam par grol ba lags//_g.yul las rnam par rgyal ba bzhengs su gsol//_jig rten mun par shes rab 'od dbyung gsol//. Also see Obermiller, History of Buddhism, vol. 2, 42.

573 Obermiller, History of Buddhism, vol. 2, 48.

574 Obermiller, History of Buddhism, vol. 2, 52; See also Sørensen, Tibetan Buddhist Historiography, 55-56.

${ }^{575}$ Khog dbubs shes bya rab gsal rgyas pa, in Krung go’i bod lugs gso rig rtsa che'i dpe rnying kun btus, vol. 20, text 2I, p. 343 (f. 8b): gsang sngags ni ri rab kyi rtse dang /_dpal ldan 'bras phung gi mchod rten la sogs par mchog gi bdul bya rnams la de nyid 'dus pa dang /_phyag na rdo rje dbang bskur ba'i rgyud la sogs pa gsungs shing /_u rgyan gyi rgyal po inda bho tis/_dod pa’i yon tan ma spangs par srid pa las grol bar gsol ba btab pas/. 
are conspicuously absent from the works of the Sakya historiographical tradition. The Wheel of Time Tantra (Tib. dus kyi 'khor lo = Skt. kälacakra-tantra), for example, was famously taught at the Śrī Dhānyakațaka reliquary, ${ }^{576}$ and King Indrabodhi/Indrabhūti of Oḍdiyāna/Zahor also famously received new teachings from Vajrapāni/Vajradhāra/Vajrasattva in the tantric historiographical tradition. ${ }^{577}$ Placing Nyingma narratives alongside those of the Sarma, Drangti also provides a three-stanza citation from the Compendium of Intentions Sutra (Tib. dgongs pa 'dus päi mdo = Skt. "samājavidyā-sūtra), a fundamental work of the Nyingma school. ${ }^{578}$ The combination of these historiographical lineages illustrates that, while Drangti is careful to propagate the established narratives of his Sakya forebears, he also does not completely discard the more creative elements of Paktön's Flight and later tantric historiography in general.

Unlike Paktön's telling, Drangti is careful to separate the history of medicine from the canonical history of Śākyamuni Buddha, and incidentally implying that Sākyamuni Buddha did not achieve enlightenment through the practice of medicine-not in his final life anyway. As evinced by his major additions to the eleventh deed of the life story of Śākyamuni Buddha, however, Drangti was also not strictly beholden to any particular historiographical tradition. He merely avoids contradicting established narratives of the Sakya tradition. Thus, Drangti's approach to history might be best described as one of synthetic accretion-that is to say, he generally accepts the canonical narratives of the Sarma schools, but not at the expense of "apocryphal" narrative traditions. In the end, Drangti seeks to integrate narrative traditions across previously established boundaries, building upon tradition but also creatively steering it into directions appropriate for his vision of Buddhist medical practice. Like Lama Dampa in his Mirror Illuminating the Royal Genealogies, Drangti also expands upon the history of the Tibetan imperial period (ca. 600-850) to present Tibet as the center of the medical world and direct the future practice of medicine.

\section{The Escape of Minister Gar}

In his narration of imperial medical history, much like his telling of Buddhist history, Drangti is sure to incorporate the precedents of his teacher at Sakya, Lama Dampa Sönam Gyentsen, while also integrating narrative threads found throughout the medical literary tradition. In his Mirror Illuminating the Royal Genealogies (rgyal rabs gsal ba'i me long, 1368), Lama Dampa

${ }^{576}$ For a normative history of the Wheel of Time Tantra, see John R. Newman, "A Brief History of the Kalachakra," in The Wheel of Time: The Kalachakra in Context, ed. Beth Simon (Madison, WI: Deer Park Books, 1985), 5I-90.

577 For a translation and analysis of this narrative, see Ronald M. Davidson, Indian Esoteric Buddhism: A Social History of the Tantric Movement (New York, NY: Columbia University Press, 2002), 242-45.

${ }^{578}$ On this work and its role in the Nyingma school, see Jacob P. Dalton, The Uses of the Dgongs pa 'dus pa'i mdo in the Development of the Rnying-ma School of Tibetan Buddhism (Ann Arbor, MI: Doctoral Dissertation at the University of Michigan, 2002). 
integrates the "way of the gods" (lha chos) exemplified in the Sakya historiographical tradition focused on India — such as Butön's Religious History ${ }^{579}$ — with the myths and legends of the "way of humans" (mi chos) exemplified by the Pillar Testament (bka' chems ka khol ma), the Book of Mani (ma ni bka' 'bum), and other such native narrative traditions. ${ }^{580}$ Composing the Expanded Elucidation (ca. 1372) in the same space and at the same time as Lama Dampa's Mirror, Drangti follows the same middle road between divine and human convention as his religious mentor, adding medical flourishes wherever he sees fit.

In a particularly entertaining example, we find an identical story shared by both Lama Dampa and Drangti Penden Tsojé, but told with fundamentally different characters and contexts..$^{81}$ In the former tale, after Minister Gar Tongtsen Yülzung (mgar stong btsan yul bzung, d. 667) ${ }^{582}$ was sent by Songtsen Gampo (srong btsan sgam po, ca. 617-650) to China to retrieve Princess Kongjo (Tib. kong jo < Chi. gongzhu 公主), also known as Princess Wencheng 文成公主 (628-680), he was initially asked by a jealous colleague to stay at the court in Chang'an as hostage (mi skyin), ensuring the safe transportation of the princess back to Tibet. Minister Gar is given a Chinese wife to keep him company but, growing weary of life at court, he feigns illness-becoming thin by refusing to eat, developing a stench by sleeping on moldy animal hides, and creating the image of bloody mucous by chewing on vermilion ( $m t s h a l$ ) and indigo (rams) —and Emperor Taizong 太宗 (598-649) arrives to check on him. The Emperor calls for a physician and, having dismissed his Chinese wife, Minister Gar builds a tall couch out of earth, ties a rope to it, and hoists the rope over the structural beam holding up the roof. He then ties the rope to his genitals and suspends himself in the air, with his head touching

579 On the conspicuous absence of specifically Tibetan Buddhist developments in Butön's Religious History, Leonard van der Kuijp writes, "the rather disappointing survey of Buddhism in Tibet ends in a listing of Indian and Indic Pandita-s and Tibetan translators." See "Some Remarks on the Textual Transmission and Text of Bu ston Rin chen grub's Chos 'byung: A Chronicle of Buddhism in India and Tibet," Revue d'Etudes Tibétaines 25 (2013): II9.

${ }^{580}$ For a summary and analysis of Lama Dampa's synthesis, see Sørensen, Tibetan Buddhist Historiography, I-27, et passim.

${ }^{581}$ Frances Garrett recognized the commonality between the Expanded Elucidation and the Mirror one decade ago but, lacking a consummate study of the Expanded Elucidation, failed to take into account the fact that these two works were both written at Sakya during the I360s. Regardless, she aptly concludes: "Modeling medical histories after Buddhist histories, scholars may have sought to emphasize links between the two traditions in this and other ways, hoping to take advantage of the growing authority of Buddhism in civil, intellectual, and political Tibet." See "Critical Methods in Tibetan Medical Histories," Journal of Asian Studies 66, no. 2 (2007): 383. The following translations and summaries are largely adaptations of Sørensen, Tibetan Buddhist Historiography, 235-36.

${ }^{582}$ On Minister Gar, see Sørensen, I80, n. 516. On his activities in China according to Chinese sources, see Beckwith 1987, 27. 
the ground. In doing so, he effectively disrupts the normal balance of his channels, agitating them with the pressure and pain of being suspended like this. ${ }^{583}$

Examining his channels, the physician determines that Minister Gar's channels have all come to be agitated and therefore it is difficult to examine them. "The disease derives neither from wind, nor bile, nor phlegm, nor a combination of the three," he concludes, but "his mind is unwell because there is something like phthisis that he has contracted at the center of his heart. Hardly any medical treatment or ritual procedure would be effective." ${ }^{184}$ The next day, instead of repeating his previous antics, Minister Gar decides to stuff a cat into his armpitpresumably concealed by his robe-and, tying a string to its paw, requests that the physician examine his channels through the string. "These are nothing more than the channels of the lowest beast of prey," the physician declares, and departs. ${ }^{585}$ The following day Minister Gar hides a rooster in his armpit and, tying a string to its foot, the physician again examines the string. "These are nothing more than the channels of the lowest beast of feather," the physician declares, and departs. ${ }^{586}$ Finally, Emperor Taizong returns and, distraught by the news of Minister Gar's poor health, pleads, "Great Minister! You are so clever, what should we do? Whatever your solution might be, we shall achieve it!" ${ }^{187}$ Having successfully fooled both the Emperor and his physician into thinking that he has contracted an incurable disease, Minister Gar describes the cause of his illness as being the displeasure of Tibetan protector deities, and reports that evoking them from the tall mountains of Tibet would surely be effective. ${ }^{58}$ And with this, following even more antics, Minister Gar is able to successfully escape from being held hostage and secure safe passage back to Tibet.

While this tale may tell us little about the practice of medicine during the time of Songtsen Gampo, we gain important insights into the conceptions of disease and medicine during the age of Lama Dampa Sönam Gyentsen. Dominating the tale is the cleverness (rig pa can) of

${ }^{583}$ Rgyal rabs gsal baï me long, vol. I, II7: blon pos sa phag gi khri mthon po cig brtsigs nas/_gdung ma la thi gu btags/_pho mtshan thi gus bcings te/_spyi bo sa la btsugs nas rtsa thams cad 'khrug tu bcug go/.

${ }^{584}$ Rgyal rabs gsal ba'i me long, vol. I, II7: sman pa mkhas pa des rtsa bltas pas/_sman pa na re/_lus kyi rtsa thams cad 'khrugs par gyur pas na brtag par dka'/_rlung las gyur pa yang ma yin/_mkhris pa las gyur pa yang ma yin/_bad kan kyang ma yin/_dus pa'ang min tel [...] sems ma bde ba snying gi dkyil du phog pa'i gcong cig'dra te/_sman dpyad rim gro gang gis kyang phan par dka' zer ro/.

${ }^{585}$ Rgyal rabs gsal ba'i me long, vol. I, II8: yang sang sman pa byung dus/_blon pos mchan du zhim bu bcug_de’i lag pa la thi gu btags/_thig sna la rtsa bltar bcug pas/_gcan gzan tha ma cig gi rtsa las mi'dug zer te song ngo //.

${ }^{586}$ Rgyal rabs gsal ba'i me long, vol. I, II8: yang blon pos/_de'i sang bya pho cig mchan du bcug nas/_de'i lag pa la thi gu btags/_thig sna la rtsa bltar bcug pas/_dab chags tha ma cig gi rtsa las mi'dug zer rol/.

${ }^{587}$ Rgyal rabs gsal ba'i me long, vol. I, II8: de nas rgyal po yang thugs shin tu ma bde bar/_blon po chen po khyed rang rig pa can yin pas thabs e yod/_de'i thabs gang'grub byed gsungs pas/.

${ }_{588}$ Rgyal rabs gsal ba'i me long, vol. I, II8: rgyal po chen po nga'i nad 'di khyed kyis nga bzungs bas/_bod kyi lha srungs ma dga' ba yin/_nga bod kyi ri mthong ba'i ri mtho ba cig gi khar phyin nas lha gsol na phan/. 
Minister Gar-knowing that he would not simply be released from his hostage situation in China, he devises an elaborate scheme to convince Emperor Taizong to allow him to leave. Importantly, it is the empirical signs of his agitated and extraordinary channels that confuses the physician, who makes no mistake in interpreting the signs presented to him. Instead, it is the naïveté of the Emperor and the physician that lead them into being duped, promoting channel examination as a valid form of diagnosis. The incompatibility of humoral and spiritual disease is also emphasized, for a physician trained in the Chinese traditions of channel examination and its attendant treatment is left impotent in the face of illness caused by displeased Tibetan deities. Thus, although the Chinese physician here is depicted as an honest servant of the emperor, his ability to cure disease is limited, maintaining a separate professional space for the exorcist.

Lama Dampa's telling of Minister Gar's escape is a particularly entertaining example, but it is not unique in the Tibetan historiographical tradition. As has been previously demonstrated, the Mirror Illuminating the Royal Genealogies derives from the narrative traditions that were first recorded in the twelfth and thirteenth centuries-in works like the Pillar Testament, the Book of Mani, the Honey Nectar, the Essence of Flowers: A History of Buddhism (chos 'byung me tog snying po'i sbrang rtsii bcud) by Nyangrel Nyima Özer (nyang ral nyi ma 'od zer, II24-II92), ${ }^{589}$ and so forth-and our tale of Minister Gar's escape is no exception. In fact, important details that are more explicit in these earlier recensions make Lama Dampa's narrative more full and meaningful. The Pillar Testament explicitly states that Minister Gar did not want to have children with his beautiful Chinese wife, ${ }^{590}$ for example, followed by the same techniques for developing a stench and the appearance of bloody mucous. In the Pillar Testament telling, however, the manner in which Minister Gar agitates his channels does not involve painful pulley systems, however, for he merely fastens his arms with horse ears, sleeps at an inverted incline, keeping his head closer to the ground than his feet. ${ }^{591}$ Thus, in the Pillar Testament - which is probably the earliest telling of this story $-{ }^{592}$ Minister Gar tricks his wife with his stench, tricks the Emperor with his bloody mucous, and tricks the physician with his agitated channels, conspicuously without any need to appeal to the channels of birds and beasts. Minister Gar's capacity for deception is, of course, being celebrated here, much like the instructions for duplicitousness found in early medical literature. ${ }^{593}$

${ }^{589}$ On the life and dates of Nyangrel Nyima Özer see, most recently, Daniel A. Hirshberg, Remembering the Lotus-born: Padmasambhava in the History of Tibet's Golden Age (Somerville, MA: Wisdom Publications, 2016), especially pp. 203-208.

590 Bka' chems ka khol ma (Lanzhou: Kan su'u mi rigs dpe skrun khang, 199I), I87: blon po chen pos rigs rgyud 'phel gyis dogs nas rgya mo dang 'grogs 'brel ma byas so//.

${ }^{591}$ Bka' chems ka khol ma, I88: de nas blon po kho rang ni nang du so phag gi mal sa zlum po mthon po cig bcos nas/_de’i nang la dar dang sring bal gyis g.yogs nas/_khong rang gi lag ngar gnyis rta rnas dam par bkyigs na/_so phag gi mal du mgo zhabs log nas spyi 'dren re byas kyin nyal lo/.

${ }^{592}$ Sørensen dates the redaction of the Pillar Testament to the eleventh century: Sørensen, Tibetan Buddhist Historiography, 640.

${ }^{593}$ Again, see Gyatso, Being Human, 343-96.

W. A. McGrath | Buddhism and Medicine in Tibet | I89 
The telling of Minister Gar's escape in the Essence of Flowers is nearly identical with that of the Pillar Testament in terms of content, but with some minor alternations and elaborations. When sleeping inverted, for example, we are told that Minister Gar built a tall round platform covered in cloth, like in the Pillar Testament, but in the Essence of Flowers we are told that he sleeps cross-legged (skyil krung). ${ }^{54}$ This new detail alters the logic of the story, however, for there are no other elaborate schemes for the purposeful agitation of the channels in the Essence of Flowers. By the end of the twelfth century, however, in the Book of Mani, we find several important additions to this story. After Minister Gar refuses to copulate with his Chinese wife and feigns illness like before, we gain some insight into the nervous thoughts of Emperor Taizong: "Because he is the capable minister of the king of the borderland, Songtsen Gampo, if he dies, five thousand emanations of Songtsen Gampo will each come with troops, which would not be good for me." ${ }^{\prime 595}$ We are also told for the first time why Minister Gar might be diagnosed at a distance instead of in person:

Minister Gar, staying within his quarters, said "I have a terrible stench that might afflict the physicians," and placed the end of a thread in water. He passed the other end of the thread out the window and the master physician said, "I should be able to know [your diagnosis] with this." The Chinese physician examined it and said, "Since the nature of this [disease] is the water element, it is nothing other than cold that needs to be treated." 596

The physician came again the next morning and the Minister placed one end of the thread in fire. He passed the other end of the thread out the window and the physician examined it, saying, "What is this? The Minister's illness has transformed! Now the nature of the [disease] is fire, and it is heat that needs to be treated." 597

When the physician came again the next morning, Minister Gar tied the thread to a handpestle and passed the other end to the physician. "What is this? The Minister's illness has

${ }^{594}$ Chos 'byung me tog snying po sbrang rtsii bcud (Lhasa: Bod ljongs mi dmangs dpe skrun khang, 1988), 223: gcan lpags la mal zlum po mthon po byas nas nang logs thams cad srin [bal] gyis bkab ste mtshan mo der tshugs tshad nyal ba skyil krung byas shing nyal lo/.

${ }^{595} \mathrm{Ma}$ ni bka' 'bum (Lhasa: Ser gtsug nang bstan dpe rnying 'tshol bsdu phyogs sgrig khang, 2008), vol. I, 305-306: 'di shi na ni mtha' 'khob kyi rgyal po srong btsan sgam po'i blon po rig can yin pas/_srong btsan sgam pos sprul pa lnga stong nang ma re la sprul nas dmag'ong bas nga la bde ba mi 'ong snyam nas bred de/.

${ }^{596}$ Ma ni bka' 'bum, vol. I, 306: blon mgar gyis brang khang gi nang du bsdad nas/_nga la dri mi zhim pa yod pas sman pa la gnod zer nas chu nang du thag pa'i sna bcug/_sna gcig skar khung na phar btang nas sman pa mkhas pas 'dis shes byas sol/_rgya'i sman pas bltas pas nad gzhan ci yang mi 'dug/_byung ba chu'i rang bzhin du'dug pas grang ba bcos dgos zer/.

${ }^{597}$ Ma ni bka' 'bum, vol. I, 306: de nas yang nang par sman pas 'ongs pa dang blon pos yang thag pa'i sna cig me la bcug/_sna cig skar khung nas phar btang nas sman pas bltas pas//_sman pa na re ci yin blon poì snyun nad 'gyur'dug me'i rang bzhin du'dug pas dro ba bcos dgos zer ro//. 
transformed again! The nature of the [disease] is stone cold, the channels have been agitated in the fashion of a hand-pestle, and I do not know how to treat it," the physician said and left. ${ }^{598}$

With his overpowering and potentially pathogenic stench, Minister Gar is able to keep the Chinese physician at bay and trick him with his three different elemental associations. Having bested this first physician, the Book of Mani then has the now extremely nervous emperor call yet another Chinese physician, whom Minister Gar again deceives using his inverted sleeping trick. Thus, the above-cited passage represents a unique insertion found in the Book of Mani, indicating that it was this narrative lineage that went on to influence the Mirror Illuminating the Royal Genealogies and, as we shall see, the Expanded Elucidation of Knowledge.

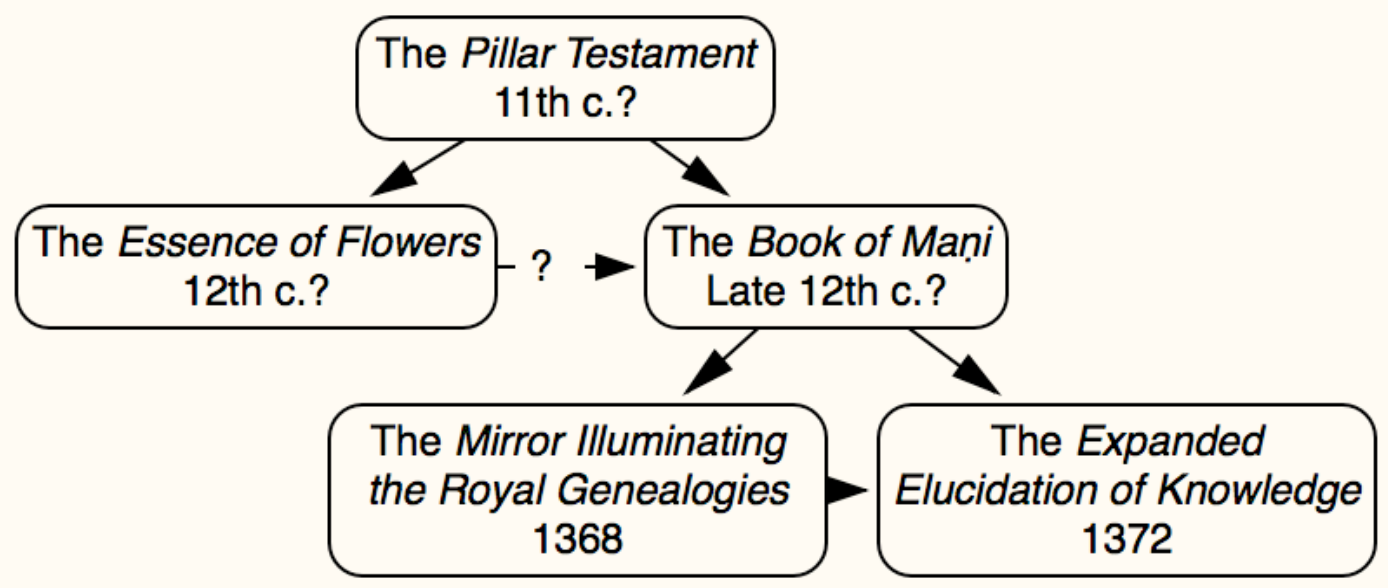

Figure 5.I. A Proposed Web of Influences Regarding the Story of Minister Gar's Escape from China.

Perhaps in light of the fantastical nature of a physician examining the channels of inanimate objects, the telling recorded by Lama Dampa replaces water and fire with a cat and a rooster. Lama Dampa takes the context of Minister Gar's pathogenic stench established by the Book of Mani for granted however, and does not describe the circumstances that would cause a physician to consent to examining a patient's channels through a thread. Without the emphatic description of the stench, again the logic of the story suffers. Writing around the same time as Lama Dampa, Drangti Penden Tsojé tells a similar tale, but totally redefines the moral of the story and its context. Taking place during the reign of Tri Songdetsen instead of Songtsen Gampo, it is the Tibetan emperor himself that feigns illness, testing the abilities of

${ }^{598}$ Ma ni bka' 'bum, vol. I, 306: yang nang par sman pa 'ongs nas bltas pas/_blon po mgar gyis thag pa’i sna cig lag skor la btags/_sna cig sman pa la btad pas sman pa na re/_ci yin blon pa'i snyun nad 'gyur nas 'dug/_grang ba rdo'i rang bzhin la rtsa lag bskor gyi ri mo bzhin du 'khrugs nas 'dug pas ngas 'chos mi shes par'dug zer nas song ngo //. 
visiting foreign doctors. Transforming deception into examination, Drangti Penden Tsojé redefines the narrative thread of Minister Gar's escape, appropriating it for the tradition of Tibetan medical historiography.

\section{Foreign Physicians and the Tibetan Assimilation of Medicine}

Like the introduction of Buddhism to Tibet by the emanated Tibetan emperors acting within the contexts of pan-Asian Buddhist networks-as told in the Pillar Testament, the Book of Mani, and so forth-Drangti Penden Tsojé's telling of the introduction of medicine to Tibet also centers around the activities of the Tibetan emperors. "At first there were no practices for the healing of disease in Tibet," we are told, "but thanks to the kindness of the Kings of the Doctrine-grandfather and grandson-medicine emerged [in Tibet] like the teachings of the Buddha." ${ }^{\text {"59 }}$ Perhaps inspired by his mentor at Sakya, Lama Dampa Sönam Gyentsen, Drangti successfully integrated legendary narratives of the Tibetan empire into his history of the Tibetan medical tradition, linking the lists of foreign physicians mentioned in thirteenthcentury sources to the rich legends of imperial glory that were circulating during the twelfth, thirteenth, and fourteenth centuries.

Unlike the bifurcation of early and late periods of translation that is found in most other religious histories, in the Expanded Elucidation of Knowledge Drangti Penden Tsojé narrates the emergence of medicine in Tibet according to three periods: the early (snga dar), middle (bar dar), and later (phyi dar) propagations. This schema is conspicuously similar to the periodization scheme found in the Ornamental Flower of the Buddha's Teaching (thub pa'i bstan pa rgyan gyi me tog) by Chomden Rikpé Reldri (bcom ldan rig pa'i ral gri, 1227-I305), ${ }^{600}$ but not in his short history of medicine. ${ }^{601}$ Thus, although Chomden appears to have held Buddhist and medical history as being separate narrative traditions with separate schemes of temporal organization, Drangti treats them as one and the same.

${ }^{599}$ Gsang ba man ngag gis [sic] rgyud kyi spyi don shes bya rab gsal rgyas pa (Beijing), 26b: dang po bod na nad gso ba’i dpyad med pa la/_chos rgyal mes dbon gyi sku drin las/_sangs rgyas kyi bstan pa bzhin du gso dpyad kyang byung te/.

${ }^{600}$ For an analysis of this and other periodization schemes in Tibetan historiography, see Bryan J. Cuevas, "Some Reflections on the Periodization of Tibetan History," in The Tibetan History Reader, ed. Gray Tuttle and Kurtis R. Schaeffer (New York, NY: Columbia University Press, 2013), 52 et passim.

${ }^{601}$ See Chapter Three for a translation and analysis of the Ornamental Flower of Healing Science (gso ba rig pa rgyan gyi me tog). 


\section{The Early Propagation: The Inception of Medical Lineages}

Drangti begins the early propagation of medicine with brief remarks on Lhatotori, the emanation of Samantabhadra, ${ }^{602}$ and his role as the one who introduced medicine to Tibet. ${ }^{603}$ Central to the story of the early period, however, is the establishment of physicians in Tibet during the life of Songtsen Gampo, the emanation of Avalokiteśvara. Recognizing that there were no physicians in Tibet, Songtsen Gampo feigned illness and sent his minsters out in each direction, bearing gifts and inviting the most skilled physicians of the surrounding lands back to Tibet. ${ }^{604}$ Not unlike Minister Gar and his role in bringing Buddhism back to Tibet, the unnamed ministers successfully escort Dhanarāja from India, ${ }^{605}$ Heshang Mahākyindha from China ${ }^{606}$ and Prince Tsen Pashilahā from Byzantium, son of King Mujeté Trom, ${ }^{607}$ back to Lhasa, where they successfully treat the ailing Songtsen Gampo. ${ }^{608}$ The three legendary physicians worked together to compose the aforementioned mythological urtext cycle of medicine, the Heap of Jewels (rin po che spungs pa), ${ }^{609}$ among other works. Thus, although the Heap of Jewels is first cited in the Flight of the Great Khyung, Drangti gives it narrative origins in the very beginnings of medicine in Tibet.

${ }^{602}$ For a similar description of Lhatotori's role in the introduction of Buddhism, see Sørensen, Tibetan Buddhist Historiography, 137.

${ }^{603}$ Gsang ba man ngag gis [sic] rgyud kyi spyi don shes bya rab gsal rgyas pa (Beijing), 27a: "During the reign of Lhatotori, the emanation of the bodhisattva Samantabhadra, some knowledge arose regarding etiology, the benefits and harms of diets, and the application of melted butter to and dressing of a fresh wound. Thus he introduced medicine [to Tibet]" (byang chub sems dpa' kun tu bzang po'i rnam sprul las tha tho tho ri snyan shal gyi ring la/_na lugs la zas kyis phan gnod shes dang /_rma gsar la mar gsar gzhu ba btang rtsa kha bsdam shes pa tsam byung ste/_sman dpyad dbu gnyengs [=brnyes]/).

${ }^{604}$ Gsang ba man ngag gis [sic] rgyud kyi spyi don shes bya rab gsal rgyas pa (Beijing), 27a: de nas gdung rabs lnga nas/_spyan ras gzigs kyi sprul pa srong btsan sgam po byon te/_des snyung ba'i tshul bstan/_gso ba la sman pa med pas/_blon po rnams bgros te gser gyi pa tra dang I_gser phye rgyal po’i bka' rnams bskur te/.

${ }^{605}$ I have been unable to definitively identify this reference but, as Meulenbeld describes, Dhanarāja Śreșthin was the father of a scholar-physician named Siṃha, and minister for 'Alāud-Dīn Khaljī, who captured Ranthambhor in I3OI. Although this Dhanarāja is a rather obscure figure, his flourishing in the fourteenth century keeps him a possibility as an inspiration for this reference. See Meulenbeld, History of Indian Medical Literature, vol. 2b, pp. 237-38, n. I230.

${ }^{606}$ We will explore this figure further below.

${ }^{607}$ For a thorough discussion of Tsen Pashilahā and his role in this history of Tibetan medicine, see Martin, "Greek and Islamic Medicines' Historical Contact with Tibet," I29-3I.

${ }^{608}$ Gsang ba man ngag gis [sic] rgyud kyi spyi don shes bya rab gsal rgyas pa (Beijing), 27a: rgya dkar gyi sman pa dha na ra dza/_rgya nag gi ha shang ma hā kyindha/_khrom rgyal mu rje the khrom gyi sras tsam pa shi la hā gsum spyan drangs te ra sa 'phrul snang du phyag phebs/.

${ }^{609}$ Gsang ba man ngag gis [sic] rgyud kyi spyi don shes bya rab gsal rgyas pa (Beijing), 27a: phyogs kyi sman pa gsum rgyal khams chen po gsum na grags shing mkhyen pa gcig tu dril/_rje’i sku' tsho ba'i don du mnga' bdag la gdams pa bslab bya/ rin po che spungs pa ma bu rtsa 'grel dang bcas pa mdzad/. 
Although Drangti describes the flurry of activity around translating legendary texts from India, China, and Central Asia in great detail, these works would not by themselves be enough to provide for the lack of physicians in Tibet. With Dhanarāja and Heshang Mahākyindha opting to return to their native lands, it was up to Prince Tsen Pashilahā to propagate the lineages of Tibetan medicine. Not unlike the tale about Drangti Gyelnyé Kharbu found in the opening of the Red Register, Tsen Pashilahā was appointed to the position of royal physician (bla sman) by Songtsen Gampo, given a wife, and procreated. His eldest son was sent to Tsang and began the Biji medical lineage (be cir grags pa'i brgyud pa), his second son went to Yorpo (g.yor po) in Lhoka and started the Southern Tongkha medical lineage (lho stong kha'i sman brgyud), and his youngest son went to the Central Horn ( $d b u r u$ ) and taught instructions that became popular among Mongolian physicians (sog po’i sman par grags). ${ }^{60}$ These teachers are also said to have taken students from the noble Nya (gnya') and Tapzhi ( $m$ tha' bzhi) families of Tibet, allowing the three lineages to continue beyond the lives of Tsen Pashilahā and his sons. ${ }^{6 I I}$ Thus, the early dissemination of medicine brought living medical traditions to Tibet from the three major surrounding cultural areas-India, China, and Central Asia—but only the Central Asian traditions of Tsen Pashilahā left a lasting lineage. It would not be until the great translation projects of Tri Songdetsen that we finally witness the translation of extant medical works, as well as the beginnings of lineages that continue down to the time of Drangti Penden Tsojé.

\section{The Middle Propagation: The Translation of Medical Texts}

If the early propagation was dedicated to the invitation and establishment of foreign lineages of living physicians in Tibet, the middle propagation of medicine in Tibet is primarily concerned with the translation of foreign medical works. Drangti begins the middle propagation with the rule of Tri Detsukden (khri lde gtsug brtan, 704-755), also known as the Bearded Grandfather (mes ag tshom), and the translation of the Red Register (dmar byang) instructional collection by Doctor Biji and Beklha. ${ }^{62}$ As we have seen in Chapter Three, the

${ }^{610}$ Gsang ba man ngag gis [sic] rgyud kyi spyi don shes bya rab gsal rgyas pa (Beijing), 27a-27b. The use of the word sog po in terms of the Tibetan imperial period appears to be anachronistic.

${ }^{6 I}$ For a detailed telling of this and other related passage regarding Tsen Pashilahā and his conflation with Galen, see Yang Ga, Sources for the Writing of the Rgyud bzhi, 36-40.

${ }^{612}$ Gsang ba man ngag gis [sic] rgyud kyi spyi don shes bya rab gsal rgyas pa (Beijing), 28a: “Then, during the fourth generation of emperors, during the time of Tri Detsukden, also known as "Bearded Grandfather," Doctor Biji and Beklha were invited to translate the medical and divination work [mos dbyig?], the root text and commentary of the Red Register. The emperor appointed Gyelnyé Kharbu and the Drangti lineage as a lineage of royal physicians, and bestowed upon him medical instructions via royal decree" (de nas btsan po'i gdung rabs bzhi nal_khri lde gtsug ldan [=brtan] mes ag tshom su grags pa'i ring la/_sman pa bi ci dang /_beg lha spyan drangs/_sman dpyad mos dbyig dmar byang rtsa 'grel bsgyur/_brang ti rgyal mnyes mkhar bu btsan 
opening narrative of this Drangti family instructional collection presents itself as being the gift of Tri Detsukden to Drangti Gyelnyé Kharbu (brang ti rgyal mnyes mkhar bu) upon his appointment as royal physician. Nowhere in the narrative are foreign doctors active, however. The central importance of Penden Tsojé continuing to present the first scion of the Drangti medical lineage as the royal physician of Tri Detsukden cannot be overstated. By adding the foreign provenance of Doctor Biji and Beklha to the story, Drangti Penden Tsojé effectively maintains the centrality of the Drangti lineage in Tibetan medical history as established narrative opening of the Red Register, while simultaneously promoting the work as one of the first teachings translated into Tibetan during the reign of Tri Detsukden.

Drangti lists many other works that were purportedly translated during the time of Tri Detsukden, but it was the reign of Tri Songdetsen that "caused medical practice to flourish." In a tale that combines the above motif of the Tibetan emperor feigning illness to attract foreign doctors with the tricks played by Minister Gar in the Book of Mani and the Mirror Illuminating the Royal Genealogies, Drangti Penden Tsojé describes the contributions of Tri Songdetsen to the practice of medicine in Tibet. Like Songtsen Gampo in the early propagation, during the middle propagation it is Tri Songdetsen that feigns illness and sends out ministers with gifts out to the physicians of border areas (phyogs rigs kyi sman pa). As has been described elsewhere, ${ }^{614}$ the ministers return with nine physicians-Ācārya Śāntigarbha from India, Guhyavajra from Kashmir, Sokpo Halashandhir from Persia, Senggé Öchen of the Turks, Khyoma Rutsé from Dölpo, Dhalaśila from Nepal, and Tongsum Gangwa, Bhama Heshang, and Hatipata from China ${ }^{6}{ }^{65}$ After they arrive in Pangtang, Tri Songdetsen decides to test their skills by hiding behind the palace gates, tying a thread to the foot of a rooster, and passing the thread through a window. ${ }^{616}$ The physicians agree to examine the thread and say, "The opening of these [channels] are like arrows, while the depths lack a core. These are the channels of a feathered beast!" ${ }^{\prime 17}$ Tri Songdetsen then ties the thread to a cat and, giving it to

po brgyud nas rgyud kyi bla sman du dbang bskur/_dpyad yid [=yig] ces pa nas phu dud du byas päi bka' yid [=yig] gnang ngo /).

${ }^{613}$ Gsang ba man ngag gis [sic] rgyud kyi spyi don shes bya rab gsal rgyas pa (Beijing), 28a-28b: khri srong sde btsan gyi sku ring la gso dpyad rgyas par mdzad/.

${ }^{614}$ For this same list of figures in later narratives, see Martin, "Greek and Islamic Medicines' Historical Contact with Tibet," I42. For a similar comparison of the writings of Drangti and Zurkhar, see Garrett, "Critical Methods in Tibetan Medical Histories," 369-72.

${ }^{615}$ Gsang ba man ngag gis [sic] rgyud kyi spyi don shes bya rab gsal rgyas pa (Beijing), 28b: rgya gar gyi sman pa a tsarya shan ti gharbha/_kha che’i sman pa ghu ya badzra/_rgya nag nas stong gsum gang ba/_bha ma ha shang __ha ti pa ta zhes bya ba dang /_stag gzig nas sog po ha la shan dhir/_gru gu nas seng ge 'od chen/_dol po nas khyo ma ru tse/_bal po'i sman pa dha la shi la rnams spyan'drongs nas 'phang thang du phebs te/.

${ }^{616}$ Gsang ba man ngag gis [sic] rgyud kyi spyi don shes bya rab gsal rgyas pa (Beijing), 28b: rje rgyal pos de dag mkhas rmongs tshod sad ba'i ched du/_pho brang gi sgo bsdams/_zhal ma mjal bar za'og gi thig gu sgril ma zhig bya pho'i rkang pa la btags te/_sgo thom gyi bu kha las brgyus te rtsa bstan pas/. ${ }^{617}$ Gsang ba man ngag gis [sic] rgyud kyi spyi don shes bya rab gsal rgyas pa (Beijing), 28b: 'di kha mdar gting spun pa'dab chags bya'i rtsa'o zhes zer zhing/. 
the physicians, they reply, "Both externally and internally these [channels] are rapid. These are the channels of a carnivorous beast!" 18 The King then ties the thread to a horn, and the physicians reply, "The opening of these [channels] are submerged and the depths are hard. These are the channels of a stone!"619 Finally Tri Songdetsen holds the thread in his own hand, and the physicians reply, "These are the channels of the Lord's hand! Because the interdependent signs have been reversed, indeed, your lifespan has not reached its end. Now you do not have any illnesses." ${ }^{620}$ Having demonstrated their expertise in the practice of medical diagnosis, the emperor then invites them into the palace and lavishes them with gifts.

Although Drangti Penden Tsojé's narrative of foreign physicians coming to Tibet during the reign of Tri Songdetsen does indeed owe a debt of inspiration to the tale recorded in the Book of Mani in general, and the Mirror Illuminating the Royal Genealogies more directly, the creative license expressed by Drangti deserves emphasis. Indeed, as noted by F. Garrett, by "[m]odeling medical histories after Buddhist histories," Drangti may have been "hoping to take advantage of the growing authority of Buddhism in civil, intellectual, and political Tibet." ${ }^{621}$ Although it is hard to know the precise goals that motivated Drangti Penden Tsojé, more specifically, Drangti appears to have been part of a larger historiographic project at Sakya-as represented by the Expanded Elucidation of Knowledge and Lama Dampa's Mirrorin which the Tibeto-centric narratives of the Pillar Testament, Book of Mani, and so forth were combined with the Indo-centric narratives of Chomden Rikpé Reldri's Ornamental Flower series, Cherjé's Blazing Peak, Butön's Religious History, and so forth. Unlike the Chinese master physicians in the Mirror that are outwitted by the tricks of Minister Gar, allowing for his escape, the foreign physicians that come to Tibet in the Expanded Elucidation pass the tests of Tri Songdetsen and are welcomed as guests in the capital. Compared to the tale featured in the Mirror, these foreign physicians - the same ones that contribute to the fundamental instructions of the Tibetan medical tradition and establish an ideal relationship between the institutions of governance and health care in Tibet-are not susceptible to the tricks of Minister Gar or Tri Songdetsen, and are implicitly superior to the naive Chinese physicians described in the Mirror.

Having established the unmatched skill of these nine physicians, Drangti then uses them as role models to demonstrate the ideal relationship between the Tibetan ruler and the Tibetan physician. Having given them extravagant and luxurious gifts, Tri Songdetsen addresses them on behalf of the Tibetan people and requests their instructions:

${ }^{618}$ Gsang ba man ngag gis [sic] rgyud kyi spyi don shes bya rab gsal rgyas pa (Beijing), 28b: yang thig gu byi bla [=la] la btags te sngar bzhin bstan pas/_di ni phyi la khong 'khyug gcan gzan gyi rtsa'o/.

${ }^{619}$ Gsang ba man ngag gis [sic] rgyud kyi spyi don shes bya rab gsal rgyas pa (Beijing), 28b: yang ra thag la btags te sngar bzhin bstan pas/_di kha byings gting sra rdo'i rtsa'o zhes zer/.

${ }^{620}$ Gsang ba man ngag gis [sic] rgyud kyi spyi don shes bya rab gsal rgyas pa (Beijing), 28b: de nas rje'i phyag gi thig gu nas bzung ste bstan pas/_di ni mnga' bdag nyid kyi phyag rtsa te/_rten 'brel log pas sku tshe mthar mi phyin/_da lta skyon mi mnga' zhes gsol bas/.

${ }^{621}$ Garrett, "Critical Methods in Tibetan Medical Histories," 383.

W. A. McGrath | Buddhism and Medicine in Tibet | 196 
Physicians, compassionate emanational bodies of Jīvaka,

You have traveled to Ngari in Tibet for the sake of beings.

The graciousness that you have displayed for us-lord and subjects-

And the medicine that you have practiced for us-lord and subjects-

Have never before appeared here [in Tibet]. And thus today we beseech you,

Please bestow upon us the [special and holy] medical instructions,

Which will heal the body of the lord and hold sway with the subjects,

Capable of inspiring confidence and dispelling our pains. ${ }^{622}$

The physicians appropriately respond in unison, paying their respects to the graciousness of the king. The physicians also draw a parallel between their own contributions to Tibetan medical traditions and the contributions of Samyé monastery to the establishment of the Buddhist religion in Tibet. ${ }^{623}$ They ultimately promise their services to the king and his subjects, and then proceed to translate an immense corpus of titles on medical instructions that are almost entirely non-extant. Titles that may have indeed once been extant works include a "commentary on [the Compendium of] Caraka composed by the sages" (drang srong gis mdzad pa'i tsa ra ka'i 'grel pa) and the "Channel Discourse composed by the Noble Nāgārjuna" ('phags pa klu sgrub kyis mdzad pa'i rtsa mdo) that were both taught by the Indian Master Sāntigarbha, but both of these are general categories of texts and lack specific referents that are still extant.

${ }^{622}$ Gsang ba man ngag gis [sic] rgyud kyi spyi don shes bya rab gsal rgyas pa (Beijing), 29a: mtsho [='tsho] byed sku yi sprul pa thugs rje'i sman pa rnams//_gro ba'i don du mnga' ris bod du byon//_bdag cag rje 'bangs rnams la bka' drin chel/_bdag cag rje 'bangs rnams la gso rig dpyad//_sngon chad ma byung de ring khyed la zhul/_[khyed kyis sman dpyad dam pa khyad par can//__rje yi sku 'tsho 'bangs kyis srid 'dzin cing //_blo gtad thub cing zug rngu sel ba yi//_sman dpyad gdam [=gdams] pa bdag la gnang du gsol//. The redundant insertion in brackets does not appear in the Beijing manuscript, but does appear in Shes bya rab gsal rgyas pa (Delhi), 78. Compare with the translation of the same passage in Garrett, "Critical Methods in Tibetan Medical Histories," 370.

${ }^{623}$ Gsang ba man ngag gis [sic] rgyud kyi spyi don shes bya rab gsal rgyas pa (Beijing), 29a: "Lord of Men, Divine Agent, Wondrous King, [people of] Pugyel, [people of] Tibet, we are extremely grateful. For the sake of the holy doctrine, the Tibetan monastery of Samyé was erected. For the sake of the future, the divine holy doctrine was translated. The conventional truth will dispel temporary pains, and create long-term health during a long life. We offer to you all that we have, including antidotes for diseases, medical practices, and so forth. A gracious king like you is rare indeed. The subjects of Tibet are completely effused with glory. Whatever your pronouncements may come to be, we shall strive to effectively achieve them" (mi rje lhas mdzad rgyal po ngo mtshar can//_spur rgyal bod la shin tu bka' drin che//_dam chos rten du bod kyi bsam yas bzhengs//_phyi ma'i don du dam pa'i lha chos bsgyur//_kun rdzob bden pas 'phral gyi zug rngu sel//_phugs kyi tshe ring yun du bde byed pa'i//_nad kyi gnyen po gso byed la sogs pal/_nged la yod tshad khyed la dbul bar byal/_bka' drin che ba'i rgyal po khyed 'dra dkon//_bod 'bangs yongs kyi dpal du shar ba stel/_khyed kyis bka' stsal ji ltar byon pa ltar//_bdag cag rnams kyis legs par bsgrub 'tshal lo//). 
Although the reception of the nine foreign physicians is said to have taken place in Pugyel in Ngari, their translation activities are said to have taken place in Chimpu (mchims phu) in Central Tibet near Samyé monastery. Despite the fact that there were nine physicians transmitting works-conspicuously similar to the nine young men chosen to become translators during the reign of Tri Songdetsen $-{ }^{624}$ they were working with only four translators. Operating under the supervision of Padmasambhava and Sāntarakṣita, Kawa Peltsek (ska ba dpal brtsegs), Chokro Lü Gyentsen (cog ro klu’i rgyal mtshan), Zhang Yeshé Dé (zhang ye shes sde), and Lang Pelgyi Senggé (rlangs dpal gyi seng ge) are said to have engaged these nine foreign physicians and helped translate their works into Tibetan. ${ }^{625}$ With the exception of Lang Pelgyi Senggé, ${ }^{626}$ all of these figures are prominently featured in the consecration of Samyé monastery and a list of nine translators found in the Mirror Illuminating the Royal Genealogies. ${ }^{627}$ As described by F. Garrett above and as explicitly indicated by Drangti Penden Tsojé in the voice of the nine foreign physicians, the details of the establishment of medicine closely align with those of the establishment of Buddhism during the reign of Tri Songdetsen.

Comparing the initial listing of nine foreign physicians that came to Tibet during the reign of Tri Songdetsen with the prose descriptions of their translation activities, some discrepancies become apparent. The earliest edition of the Expanded Elucidation, for example, leaves out the contributions of the Kashmiri physician, Guhyavajra, ${ }^{628}$ and describes the contributions of the Persian physician named "Sokpo Halashandhir" (stag gzig nas sog po ha la shan dhir) as being those of the "Mongolian physician" (sog po"i sman pa). Following the description of the Mongolian physician's contributions, Drangti also adds a disdainful aside:

\footnotetext{
${ }^{624}$ Both D. Martin and F. Garrett have made this observation. See Martin, "An Early Tibetan History of Indian Medicine," 3I7-I8; Martin, "Greek and Islamic Medicines' Historical Contact with Tibet," I35, n. 5I; and Garrett, "Critical Methods in Tibetan Medical Histories," 383.

${ }^{625}$ Gsang ba man ngag gis [sic] rgyud kyi spyi don shes bya rab gsal rgyas pa (Beijing), 29a-29b: sman pa rnams bgros te mchims phur mtshams bcad/_dkon mchog la gsol ba btab/_dbu rgyan gyi mkhan po pad ma bsam bha wa dang /_za hor mkhan po shan ti rakși tas dpangs po mdzad nas/_ka cog gnyis/_zhang ye shes seng ge [=sde]/_rlangs dpal gyi seng ge rnams kyis lo tsä ba byas te/.

${ }^{626}$ Lang Pelgyi Senggé is said to have been a student of Padmasambhava and the teacher of Nupchen Sanggyé Yeshé (gnubs chen sangs rgyas ye shes, b. 844?). For a brief description of this figure, see Leslie Bradburn, ed., Masters of the Nyingma Lineage (Berkeley, CA: Dharma Publications, 1995), 44.

${ }^{627}$ For a list of nine translators and further references regarding these figures, see Sørensen, Tibetan Buddhist Historiography, 398-99.

${ }^{628}$ Compare Gsang ba man ngag gis [sic] rgyud kyi spyi don shes bya rab gsal rgyas pa (Beijing), 29b; with Shes bya rab gsal rgyas pa (Delhi), 80: kha che'i sman pas/_sman gyi dpyad mdo dgu pal_dpyad kyis 'phrang [='phreng] sel mun pa'i sgron mel_man ngag gnad kyi 'phreng [=phra] tig zla dga'i gzhung chung ba mdor bsdus pa rnams bsgyur/.
} 
Although the Mongolians have profound healing methods involving warm animal flesh, blood, brains, and so forth, they were ordered not to translate these instructions because they are the therapies of [non-Buddhist] extremists. ${ }^{629}$

It appears that the so-called "shamanic" practices of the Mongolians were known to Drangti in fourteenth-century Sakya, ${ }^{630}$ although he clearly did not condone their practice due to the involvement of "warm animal flesh, blood, brains, and so forth," which would necessitate animal sacrifice, of course. ${ }^{631}$ As this passage shows, regardless of the intent, the so-called "physician from Persia," Sokpo Halashandhir, came to be represented as a physician from Mongolia, allowing for the anachronistic insertion of fourteenth-century criticism into a narrative about the eighth century.

In sum, Drangti's description of the nine foreign physicians that came to Tibet during the reign of Tri Songdetsen includes an examination that was creatively reappropriated from Tibetan Buddhist narrative traditions, the translation of legendary texts that probably never actually existed, as well as the conflation of Persian and Mongolian physicians, accompanied by anachronistic criticisms of the latter. Despite the inclusion of such creative elaborations found in Drangti's history of the reign of Tri Songdetsen - as well as those of Lha Totori, Tri Songdetsen, Tri Detsukden, and so forth - this is not to say that the imperial legends found in the Expanded Elucidation of Knowledge are complete fabrications. Instead, like Drangti's elaborations upon the life story of Śākyamuni Buddha, the imperial legends found in the Expanded Elucidation are also build upon the narrative precedents found in earlier Tibetan medical literature, including the Four Tantras itself. Throughout each of these narratives we find a variable world in which Indians and/or Nepalese are to the south, Kashmiris and/or Dölpopans are to the west, Turks and/or Mongolians are to the north, and Chinese are generally to the east. Regardless of the precise details, it is always a world in which Tibet is at the center.

\section{Geographical Precedents in Tibetan Medical Literature}

Although the origins of the Tibetan medical tradition have long been presented as the primordial teachings of Buddhas and sages, a new emphasis on local Tibetan agency began to find its expression in fourteenth-century Sakya. Cosmopolitanism cannot persist without local

${ }^{629}$ Gsang ba man ngag gis [sic] rgyud kyi spyi don shes bya rab gsal rgyas pa (Beijing), 29b: sog po la srog chags kyi sha khrag klad pa tron [=dron] mo sogs kyi gso ba zab par yod pa mu stegs kyi dpyad yin pa bsgyur du ma gnang zhing /_bkas bcad/.

630 For an overview of archeological evidence regarding the early culture of Mongolian medicine and disease, see Ruth Meserve, "The Science and Archaeology of Injury and Disease in Central Eurasia," in Archivum Eurasiae Medii Aevi I8 (2011): 225-69.

${ }^{631}$ For an anthropological study of cults involving animal sacrifice and their dialogue with monastic Buddhism, see Stan Royal Mumford, Himalayan Dialogue: Tibetan Lamas and Gurung Shamans in Nepal (Madison, WI: The University of Wisconsin Press, 1989). 
expression, of course, but the earliest Tibetan-language medical narratives portray traditions in which medicine consists of otherworldly and emphatically South Asian developments that happen to have been translated and transmitted by Tibetans. ${ }^{632}$ Indeed, as we have seen, even in the writings of Drangti Penden Tsojé we find the unlikely supposition that "At first there were no practices for the healing of disease in Tibet, but thanks to the kindness of the Kings of the Doctrine-grandfather and grandson-medicine emerged [in Tibet] like the teachings of the Buddha." ${ }^{133}$ Following the precedents of religious historiography being written at Sakya in the fourteenth century, Drangti Penden Tsojé transitioned from emphasizing the cosmopolitan origins of the Tibetan medical tradition, to the vernacular expressions of cosmopolitanism themselves.

\section{Geography in the Four Tantras}

The Four Tantras is a work of self-proclaimed utopian origins-it was requested by the Sage Yilé Kyé and taught by the Sage Rikpé Yeshé, both emanations from the Buddha, Master of Medicine, residing in the medicinal city of Beautiful to Behold. As J. Gyatso has demonstrated, the city of Beautiful to Behold can be found here, there, and nowhere. ${ }^{634}$ The Indispensable Account of Transmission places Beautiful to Behold in the "[Pure] Land of Oḍ̣iyāna" (u rgyan yul gyi zhing khams) - a specifically ambiguous place, the home of tantric origins, also neither here nor there- ${ }^{635}$ and Drangti Penden Tsojé tends to support this interpretation. ${ }^{636}$ Although the Four Tantras itself provides few clues regarding its geographic origins, there is one exception to this trend that can be found in the Subsequent Tantra:

Then Sage Yilé Kyé asked the following question:

${ }^{632}$ One need not look much further than the title of D. Martin's important article about Cherjé's Blazing Peak, “An Early Tibetan History of Indian Medicine."

${ }_{333}$ Gsang ba man ngag gis [sic] rgyud kyi spyi don shes bya rab gsal rgyas pa (Beijing), 26b: dang po bod na nad gso ba’i dpyad med pa la/_chos rgyal mes dbon gyi sku drin las/_sangs rgyas kyi bstan pa bzhin du gso dpyad kyang byung te/. For a parallel passage in the Mirror Illuminating the Royal Genealogies, as well as other early instances of Tibetan historiography, see Per K. Sørensen, Tibetan Buddhist Historiography: The Mirror Illuminating the Royal Genealogies, an Annotated Translation of the XIVth Century Tibetan Chronicle: rGyal-rabs gsal-ba'i me-long (Wiesbaden: Harrassowitz Verlag, 1994), I37-38, n. 356.

${ }^{634}$ For the location of Beautiful to Behold (lta na sdug) in space, see Gyatso, Being Human, ??.

${ }_{335}$ More than a few modern studies confidently have placed Oḍ̣iyāna in space, but little evidence "on the ground" has come to support all that has been interpreted to be Oḍdiyānan. See ??

${ }^{636}$ Gyatso. 
Hey, Great Sage Rikpé Yeshé-la, does this tantra have any part that is incomplete or are there any medical practices that it does not have? ${ }^{637}$

[Rikpé Yeshé] then provided three responses to his question:

The Bliss Gone Ones, emanating for the sake of beings, Taught medical compounds in the land of India,

Taught moxa-cauterization and channel cleansing in the land of China, Primarily taught phlebotomy in the land of Dölpo,

And taught the examination of channels and fluids in the land of Tibet. ${ }^{638}$

To the Retinue of Gods, the Collection of Medicine was taught;

To the Retinue of Sages, the [Compendium] of Caraka in Eight Sections;

To the Retinue of [Non-Buddhist] Extremists, the Tantra of Black İ́vara;

To the Retinue of [Buddhist] Insiders, the Cycle of the Protectors of the Three Families;

All of these teachings have been summarized in this medical tantra.

There are no other medical practices that are not included in this [tantra]. ${ }^{639}$

Although the care of the Noble Ones entails neither partiality nor bias,
They emerge as visual appearances according to individual conceptions.
For example, while there is a single moon that shines in the sky,
There is a moon [that also appears] in each ladle of water.
Similarly, although there is one teaching, there are many individual understandings. ${ }^{600}$

The attentive reader may recognize the middle paragraph of Rikpé Yeshé's tripartite response from Chapter One, wherein we observed the dissonance in the narratives of the Root and Subsequent Tantras. Here, with the larger context of this passage in mind, we find that the

${ }^{637}$ Dpal ldan rgyud bzhi dpe bsdur ma, vol. 3, 287: de nas yang drang srong yid las skyes kyis 'di skad ces zhus sol/_kye drang srong chen po rig pa'i ye shes lags//_rgyud 'dir ma tshang gso dpyad mi bdog gam $/ /$.

${ }_{638}$ Dpal ldan rgyud bzhi dpe bsdur ma, vol. 3, 287-88: de skad zhus paï don la lan gsungs pal/_bde shegs rnams kyis sprul pas 'gro don du//_rgya gar yul du sman gyi sbyor ba gsungs//_rgya nag yul du me btsa' rtsa sbyong gsungs//_dol poì yul du gtar ga gtso bor bstan//_bod kyi yul du rtsa chu'i brtag pa bstan//.

${ }^{639}$ Dpal ldan rgyud bzhi dpe bsdur ma, vol. 3, 288: lha yi 'khor la gso dpyad 'bum pa gsungs//_drang srong 'khor la tsa ka sde brgyad//_mu stegs 'khor la dbang phyug nag po'i rgyud//_nang pa'i 'khor la rigs gsum mgon po'i skor//_gso dpyad rgyud 'dir thams cad 'dus par bstan//_'dir ma 'dus pa'i gso dpyad gzhan med de/l.

${ }^{640}$ Dpal ldan rgyud bzhi dpe bsdur ma, vol. 3, 288: 'phags pai thugs rje phyogs ris med mod kyang I/_gang zag mos pa'i mthong snang so sor shar//_dper na mkha' la zla ba gcig shar nal/_chu yi skyogs rer zla ba re re bzhin//_gcig tu gsungs kyang so sos du mar go//_zhes gsungs sol/.

W. A. McGrath | Buddhism and Medicine in Tibet | $20 \mathrm{I}$ 
textus receptus of the Four Tantras represents not only the summary of four unique literary expressions - each deriving from four primordial understandings of the same teaching of the Master of Medicine-but also that of four different geographical directions: China in the east, India in the south, Dölpo in the west, and Tibet in the center (or north).

Following the highlighting and translation of this passage by Yang Ga nearly a decade ago, ${ }^{641}$ several scholars have marveled at its implications. ${ }^{642}$ As L. W. J. van der Kuijp argues, the inclusion of modern geo-political boundaries in the translation for the above passagethat is, the rendering of rgya gar yul as "India," rgya nag yul as "China," or even bod kyi yul as "Tibet," as are their standard modern interpretations-is fundamentally problematic, "since these prejudge the areas denoted by these toponyms and do not account at all for their shifting boundaries over time." ${ }^{143}$ With this caveat in mind, the specificity and limited size of Dölpo (dol po) - a relatively small Tibetan cultural region located in the northern part of modern Nepal, ${ }^{64}$ and the home of the famed Dölpopa Sherap Gyentsen (dol po pa shes rab rgyal mtshan, I292-I36I), ${ }^{645}$ student of Daknyi Chenpo Zangpo Pel (bdag nyid chen po bzang po dpal, I262-1324) at Sakya-is puzzling. Why would Rikpé Yeshé, the great sage emanation from the Master of Medicine, describe the geography of a first-eon pure land as such? And why would he put so much emphasis on Dölpo?

Placing these details in conversation with the larger corpus of Tibetan historiography and the work of Gray Tuttle, the emphasis on Dölpo found in the Subsequent Tantra fits neither the "Early Tibetan Histories (ca. II75-I362)," nor the "Expanded and Sectarian Religious Histories (1365-I450)."646 The representation of Tibet as the geographic center, perfectly situated between India to the south and China to the east, however, is representative of the latter category, ${ }^{647}$ but the exclusion of any medical traditions to the north and the inclusion of Dölpo

\footnotetext{
${ }^{641}$ Yang Ga, Sources for the Writing of the Rgyud bzhi, 262-63.

${ }^{642}$ See, for example, Gyatso, Being Human, 150.

${ }^{643}$ For his nuanced discussion, see L. W. J. van der Kuijp, "Za hor and Its Contribution to Tibetan Medicine, Part Two: Sources of the Tibetan Medical Tradition," Bod rig pa'i dus deb [Zangxue xuekan 藏学学刊; Journal of Tibetology] I2 (20I6): 65, n. 2.

${ }^{644}$ Kenneth Bauer, High Frontiers: Dolpo and the Changing World of Himalayan Pastoralists (New York, NY: Columbia University Press, 2004).

${ }^{645}$ For the definitive study on Dölpopa, see Cyrus Stearns, The Buddha from Dölpo: A Study of the Life and Thought of the Tibetan Master Dölpopa Sherab Gyaltsen (Ithaca, NY: Snow Lion, 2010 [repr. 1999]).

${ }^{646}$ On the geographic purview of "Early Tibetan Histories" and that of "Expanded and Sectarian Religious Histories," see Gray Tuttle, "Challenging Central Tibet's Dominance of History: The Oceanic Book, a I9th-century Politico-religious Geographic History," in Mapping the Modern in Tibet (??: International Institute for Tibetan and Buddhist Studies GmbH, 2OII), I55 (Figure 4), and I57 (Figure 5); respectively.

${ }^{647}$ On this phenomenon, see also Dan Martin, "Tibet at the Center: A Historical Study of Some Tibetan Geographical Conceptions Based on Two Types of Country-lists Found in Bon Histories," in Tibetan Studies, edited by Per Kværne (Oslo: The Institute for Comparative
} 
to the west instead of, say, Kashmir is unexpected. It is as if this passage were written in the thirteenth or fourteenth century, when "China" may have been associated with the unprecedented expanse of the Yuan dynasty (ca. I27I-I368), when the regions west of Dölpo were ruled by the expressly Muslim Swati dynasty (ca. 1339-156I), and when Buddhist India was becoming a more and more distant memory. If we revise our understanding of the Subsequent Tantra in general-and the "Summary" (don bsdus) and "Complete Entrustment" (yongs su gtad pa) chapters in particular-as products of not the twelfth, but fourteenth century, Rikpé Yeshé's response begins to fit larger trends in the geographic representations of Tibetan historiography.

\section{Geography in the Gold Measure Collection}

The Subsequent Tantras is not the only set of fourteenth-century medical instructions that narratively contextualizes its teachings within an expansive vision of Asian geography. Comparatively miscellaneous in nature, the collected instructions of the Gold Measure (gser bre) anthology also includes countless references to non-Tibetan figures and places. In relation to the channel prasenā rituals (rtsa'i pra sgrub) examined in Chapter Two, for example, the Yellow Sage ritual is said to derive from the instructions of Master Nāgārjuna, which were transmitted to Padmasambhava, and hidden at Samyé (?) by Lord Tri Songdeutsen. The instructions are said to have then been revealed by the great Drangti ancestor, Gyelnyé Kharbu, and finally transmitted down to the grandfather, Drangti Jampel Zangpo, the father, Drangti Gyelwa Zangpo, the uncle, Drangti Penden Tsojé, and the redactor Drangti Penden Gyentsen. ${ }^{648}$ Curiously, this early narration of Gyelnyé Kharbu describes him not as the royal physician of Tri Songdetsen, as we saw in the narrative of the Red Register in Chapter Three, but as a treasure revealer that, by implication, was active during the post-dynastic period. ${ }^{649}$ With the exception of China to the east, this narration also implicitly spans the gamut of geographic origins expressed above-with Nāgārjuna representing the south, Padmasambhava representing the west, and Tri Songdetsen representing the center. As I have argued in Chapter Two, if we take the first five ritual instructions of the Gold Measure as a set cycle that was redacted by the twelfth or thirteenth century, the lineages of China are also not

Research in Human Culture, 1994), vol. I, 517-32. For a revised edition, see $<$ https://sites.google.com/site/tibetological/tibet-at-the-center >.

${ }^{648}$ Reg pa rtsai spra sgrub klu sgrub gyis mdzad pa bzhugs s+ho, in Krung göi bod lugs gso rig rtsa che’i dpe rnying kun btus, vol. I, text Io, p. 54 (f. 4a): gu ru nā gā rdzu nas shin tu zab par dgongs nas pad ma 'byung gnas la/_des mnga' bdag khri srong lde btsan la/_des gnam steng bcu gsum ka gzhu'i nang du sbas/_de brang ti rgyal mnyes mkhar bus ston nas sgrub pas grub cing rtags thon pa'o//_de nas rim par brgyud de/_brang ti 'jam dpal bzang po/_des brang ti rgyal ba bzang po//_des brang ti dpal ldan 'tsho byed/_de la brang ti dpal ldan rgyal mtshan bdag gis zhus nas//_bu dang slob ma'i don du gab sbas ser sna spangs nas yi ger bkod pal/_ithi//.

${ }^{649}$ Unless Drangti Gyelnyé Kharbu lived beyond the reign of Tri Detsukden and revealed the Four Sages instructions shortly after Tri Songdetsen concealed them! 
unrepresented due to the translation efforts of Master Vairocana and propagation efforts of Drapa Ngönshé. ${ }^{60}$ Thus, despite the fact that these early colophons individually entail fragmented narratives, their combined impression is not entirely different from the macrospace that the Four Tantras also imaginatively comes to comprise.

In addition to these famed figures of both tradition and history, other prominent figures found scattered throughout the colophons of the Gold Measure include Machik Lapdrön ( $m a$ gcig lab sgron), ${ }^{651}$ Padampa Sanggyé (pha dam pa), ${ }^{652}$ and so forth. Budding narratives like the one we find at the end of the Subsequent Tantra can also be found in the Skull Ambrosia Formulae (bdud rtsi thod sbyor), for example:

These instructions in the Ambrosia of the Skull Formulae were first propagated in the land of Nepal, where they were known as the Nepalese Skull Formulae. Then they were propagated in the land of China, where they were the Brown Head of Master Dartsé. ${ }^{653}$ Then they were propagated in the land of Tibet, and appeared in the hand of Master Gortsé. Then they were transmitted as a single transmission. ${ }^{654}$

As in the geographic account found in the Subsequent Tantra above, here we see the same teaching being propagated in disparate lands and cultural regions, but ultimately coming together as a single transmission. The motif of geographic diversity appears to have also applied to specific herbs, for a section of a larger subcollection found in the Gold Measure entitled the Lamp Illuminating the Extraordinary Instructions (thun mong ma yin pa'i gdams pa gsal ba’i sgron me) includes a similar passage describing different names for the anti-poison sumi herb in the lands of India (rgya gar yul), Oḍ̣iyāna (o rgyan yul), Nepal (bal po), and Mön (mon $y u l){ }^{655}$ As these examples illustrate, from text to herb, the vernacular expressions of the

${ }^{650}$ Med thabs med pa'i mchong [sic] gsum, in Krung go'i bod lugs gso rig rtsa che'i dpe rnying kun btus, vol. 3, text 3, p. 259 (f. 5a): slob dpon be ro tsa nas rgya nag yul nas sgyur/_gra pa mngon shes kyis thugs dam lags so//; and Med thabs med pa'i mchong [sic] gsum, in Krung go'i bod lugs gso rig rtsa che'i dpe rnying kun btus, vol. 3, text 3, p. 260 (f. 5b): bram ze'i rtsa sgrub 'di//_slob dpon bai ro tsa na yis//_rgya nag yul nas bsgyur ba yin//_gra pa mngon shes thugs dam mo//_rgyud nang [?]sung pa'i ngo mtshar gyi rtsa bdun [ston par 'byung] gsal bar byed pa'i sgron ma 'dis/_be ro tsa nas rgyud kyi btsas su bzhag pa'o/_rdzogs s.ho//.

${ }^{651}$ Gser bre, 32.

${ }^{652}$ Gser bre, 36.

${ }^{653}$ Here Dartsé (dar rtse) may refer to the valley of Dartsemdo (dar rtsé mdo) in modern Kamdzé Prefecture (dkar mdzes khul) found on the eastern part of the Tibetan plateau, bordering the Chinese cultural regions of Sichuan.

${ }^{654}$ Gser bre, 38: bdud rtsi thod sbyor gdams pa 'di//_dang po bal po'i yul du dar//_bal po thod sbyor zhes su grags//_de nas rgya nag yul du dar//_dar rtse mkhas pa'i mgo smug yin//_de nas bod kyi yul du dar//_go rtse mkhas pa'i phyag tu 'byung //_de nas gcig tu gcig tu brgyud//.

${ }_{555}$ Gser bre, 124-25: rgya gar yul du klu 'dul khyung gshog zer//_o rgyan yul du bya bran phur slebs grags//_bal por bdud rtsi zar bu 'gyogs byed zer//_mon yul dpa' bo chig thub dug 'dul zhes//_su mi ma gi gangs khrom 'phrul 'dren rnams//_ming gi rnam grangs yin no sbyor thabs dgu//. I have been unable 
Tibetan medical tradition in the thirteenth and fourteenth centuries were part of a cosmopolitan network of medical theories and practices that were circulating throughout South, East, and Central Asia.

\section{Geography in Khokbuk Literature}

This diversity of instructions and practices came to be expressed in terms of "systems" or "schools" (lugs) in the thirteenth-century instructional and narrative frames of medical theories and practices. In what is potentially the earliest khokbuk curriculum of the Tibetan medical tradition, the Blazing Peak of the Victory Banner: The History of Medicine (sman gyi byung tshul khog dbubs rgyal mtshan rtse mo 'bar ba, 1205 or 1265 ?), ${ }^{656}$ for example, Cherjé Zhangtön Zhikpo (che rje zhang ston zhig po) describes cosmopolitan medicine as consisting of seven schools:

I. The Seven Schools [lugs bdun]:

I.I. The Bodhisattva School (rgyal sras byang chub sems dpai lugs)

I.2. The School [of Texts] Composed by the Gods (lhas mdzad pa'i lugs)

I.3. The [School of Texts] Composed by Sages (drang srong gis mdzad pa):

I.3.I-8. The eight sages who taught the Eightfold [Compendium of] Caraka (tsa ra ka sde brgyad).

I.4. The Noble School ('phags pa'i lugs):

I.4.I. Nāgārjuna

I.4.2. Sadāprarudita

to identify the species of this herb, but its properties are described in Dbang 'dus, Gso rig pa'i tshig mdzod g.yu thog dgongs rgyan (Beijing: Mi rigs dpe skrun khang, 1982), 629.

${ }^{656}$ As far as I know there are at least two copies of this work: one in the Giuseppe Tucci collection in Rome and the other in the collection of Professor Wangdü (dbang 'dus) in Lhasa. Yang $\mathrm{Ga}$ is said to have received a photocopy of the latter, portions of which he has summarized in his dissertation, but unfortunately this copy was later lost and he has been unable to replace it. Yang Ga, personal communication, December 26, 2015. Yang Ga (Sources for the Writing, 75-80) has written of another title attributed to Cherjé, the Clarification of Meaning: A Commentary on the Introduction to the Compendium of the Essence lof the Eight Branches] (snying po bsdus pa la 'jug pa'i ți ka don khrigs gsal byed, I225?), but the contents of this work are identical to that which Martin studied. Regarding the manuscript in the Tucci collection, I have been unable to gain access to the work, but fortunately Dan Martin has comprehensively analyzed the Blazing Peak in not one, but two articles, which form the basis of the present discussion. Dan Martin, "An Early Tibetan History of Indian Medicine," in Soundings in Tibetan Medicine. Anthropological and Historical Perspectives. Proceedings of the Ioth Seminar of the International Association of Tibetan Studies, ed. Mona Schrempf (Leiden: Brill, 2007), 307-25; and Dan Martin, "Greek and Islamic Medicines' Historical Contact with Tibet," Islam and Tibet: Interactions along the Musk Routes (Burlington, VT: Ashgate Publishing Company, 20II), II7-44. 
I.5. The Schools of the Scholarly Class (mkhas ldan mnga' rigs gi lugs), or the Scholars of the Five Sciences (lnga rig pa’i mkhas pa):

I.5.I-IO. [See below]

I.6. The School of the [Chinese] Heshang (ha shong gi lugs):

I.6.I. Heshang Mahāyāna (ha shong ma ha yan)

I.6.2. Liga Zinta (li ga zin ta)

I.7. The School of Worthy Tibet[ans] (rigs ldan bod kyi lugs):

I.7.I. Yiong Lekpé Gyen (yid 'ong legs pa’i rgyan)

I.7.2. Zhang Zijibar (zhang gzi brjid 'bar)

I.7.3. Gyongmen Penné (gyong sman phan ne)

I.7.4. "Myself” (Cherjé) $)^{657}$

As D. Martin explicitly expresses, with the exception of the "School of Worthy Tibet[ans]," this list must be understood as an historical representation of foreign medical traditions, and not a list of physicians that came to visit Tibet. ${ }^{658}$ Drangti also includes a similar list of seven schools in his classification of treatises (rigs rnam par dbye ba) in the Expanded Elucidation of Knowledge. He effectively reproduces the categories listed in the writings of Cherje and recreated above, except he replaces the "School of the [Chinese] Heshang" with a list of treatises "Composed by Non-Buddhist Extremists" (mu stegs byed kyis mdzad pa). ${ }^{659}$ In this alteration, Drangti may be following the list of treatises found in the Flight of the Khyung, which is also explicit in differentiating the medical teachings of Buddhist traditions from those of the non-Buddhist extremists. ${ }^{660}$ In the Flight, for example, Paktön lists six nonBuddhist extremist tantras, including the Great Ísvara Belt Tantra and the Collection of Caraka. ${ }^{661}$ Drangti acts as the mediator, for he retrieves the Caraka from the extremists and lists it among the treatises composed by sages, while still relegating Saiva medical traditions to the non-Buddhist category. The popularity of and paranoia regarding Saiva medical traditions at the Sakya Medical House, are evinced by several works found in the Gold Measure

${ }^{657}$ Reproduced with modification from Martin, "Greek and Islamic Medicines' Historical Contact with Tibet," I40. Tibetan equivalents have been provided wherever they are available. ${ }^{658}$ Martin, "Greek and Islamic Medicines' Historical Contact with Tibet," I23.

${ }^{659}$ Gsang ba man ngag gis [sic] rgyud kyi spyi don shes bya rab gsal rgyas pa (Beijing), 24a: byang chub sems dpas mdzad pa/_’phags pas mdzad pal_lhas mdzad pa/_drang srong gis mdzad pal_mu stegs byed kyis mdzad pa/_rigs so so'i lugs dang /_bod kyis mdzad pa dang bdun no/.

${ }^{660}$ Khyung chen lding ba, in Cha lag bco brgyad, I4: "After all of the [above treatises] were collected and summarized in the four great tantras, five tantras and five discourses [derived] from the Buddhist [retinue]" (de rnams thams cad hril te dril nas rgyud sde chen po bzhi ru bsdus pa las/_nang pa sangs rgyas pa las rgyud lnga dang /_mdo lnga yod de/). Following this statement are lists of the Buddhist tantras and discourses.

${ }^{661}$ Khyung chen lding ba, in Cha lag bco brgyad, I4-I5: mu stegs la rgyud drug ste/_skra shad 'dzing pa'i rgyud/_me ltar 'bar ba'i rgyud/_rdo rje kha smra'i rgyud/_ri bo brtsegs pa'i rgyud/_dbang phyug chen po ske rags kyi rgyud/_tsa ra ka 'bum sde'i rgyud dang drug go/. 
collection, perhaps explains the expressly anti-Śaiva stance taken by Drangti. ${ }^{662}$ As this brief discussion conveys, Drangti's conception of treatises and their related schools derives from both the outline of Cherjé, as well as the religious distinctions of Paktön, resulting in a nuanced conception of both Buddhist Insider (nang pa) and non-Buddhist Outsider (phyi pa) or extremist ( $m u$ stegs pa) cosmopolitan medicine.

Drangti's list of foreign physicians in the "Schools of Each Classification" (rigs so so'i lugs) approximately corresponds to those found in Cherjé's "Schools of the Scholarly Class" (mkhas ldan mnga' rigs gi lugs), ${ }^{663}$ with some minor modifications. Like Cherjé, Drangti also lists representatives from Kashmir (kha che), for example, but describes both a Western Kashmiri School (kha che nub phyogs kyi lugs) that includes the Essence of the Eight Branches by Vāgbhața (Tib. slob dpon dpa' bo = Skt. ācārya śūra), as well as an Eastern Kashmiri School (kha che nub shar phyogs kyi lugs) that includes the Stainless Radiance (dri med gzi brjid) by Tenpé Lodrö (Tib. brtan pa'i blo gros = Skt. sthiramati). ${ }^{64}$ By differentiating the Eastern Kashmiri School from the Western, Drangti is able to effectively incorporate the formative text of the Blazing Peak-that is, the Essence of the Eight Branches by Vāgbhața-as a commentary in his own Expanded Elucidation of Knowledge. Drangti also describes the Three Transformations of Place (gnas 'gyur gsum) by Śrī Ananta (shrī a nan ta) as belonging to the Nepalese School (bal po'i lugs), not the Magadha School (dbus 'gyur'chang), the latter of which has no place in the Expanded Elucidation of Knowledge. Finally, the earliest edition of the Expanded Elucidation replaces the Tangut School (mi nyag gi lugs) with the Chinese School (rgya nag gi lugs) - the latter of which is an entirely different category in the writings of Cherjé summarized above-but later editions of the Expanded Elucidation not only restore the Tangut School, but also add Turkish (gru gu'i lugs) and Mongolian Schools (sog po'i lugs). ${ }^{665}$ Simply put, despite the general consistency exhibited by the accounts of the medical cosmopolis found in both the Blazing Peak and the Expanded Elucidation, the shift of emphasis away from South Asia (by excluding Magadha, for example) and toward East Asia (by including China), also represents a shift of Tibet away from the periphery and toward the center.

${ }^{662}$ See, for example, Dbang phyug chen po'i dug dbang and Dbang phyug chen po'i dug 'joms 'khor lo in the Gser bre chen mo, 89-III.

${ }^{663}$ For a thorough discussion of these figures, see Martin, "Greek and Islamic Medicines' Historical Contact with Tibet," I23-32, and I40-42 (Appendix D).

${ }^{664}$ Gsang ba man ngag gis [sic] rgyud kyi spyi don shes bya rab gsal rgyas pa (Beijing), 26a: slob dpon dpa bos mdzad pa'i yan lag brgyad pa'i snying po bsdus pa la sogs pa kha che nub phyogs kyi lugs/_bstan pa blo gros kyis mdzad pa’i dri med gzi brjid la sogs pa kha che shar phyogs kyi lugs/.

${ }^{665}$ Compare Gsang ba man ngag gis [sic] rgyud kyi spyi don shes bya rab gsal rgyas pa (Beijing Ms), 26b; with Shes bya rab gsal rgyas pa (Delhi), 7I: rgyud gsum gyi mdo byang che chung la sogs pa gru gu'i lugs/_dus pa rin po che'i srog 'khor la sogs pa sog po'i lugs/_brtson 'grus snying pos mdzad pa'i gsum khungs la sogs pa mi nyag gi lugs/. Note that the details of the restored Tangut School are nearly identical to those of the Cherjé list, but the Turkish and Mongolian Schools appear to have been later additions. 
Important to note is that in both the Blazing Peak and the Expanded Elucidation, each of the figures listed in the Seven Schools is associated with a unique text title. Nearly all of the texts listed are no longer extant-representing mythological cycles of texts that were probably never available on earth-but there are a few important exceptions to this trend. As D. Martin has also observed, Cherjé's list takes on a descending character in which the teachings of bodhisattvas and gods are gradually redacted and transmitted down to a specific locality. ${ }^{666}$ Drangti transitions from the utopian lineages of the bodhisattvas, nobles, gods, and sages by contrasting the awareness or knowledge (rig pa) of extraordinary beings with that of ordinary beings:

Whatever knowledge was sublimely held by the buddhas, as well as specific sages and nobles—such as Brahmā, Atriputra, and so forth-common beings have no actual access to such knowledge. Thus, adhering to the textual traditions of medicine, even representative fragments [of their knowledge] must suffice. ${ }^{667}$

Thus, within the seven schools the foreign traditions act as a bridge between the teachings of the trans-local divine lineages and the local traditions found in Tibet. Unlike the mythological works that Drangti attributes to the gods, bodhisattvas, and foreign physicians, the works attributed to Tibetan authors are generally extant:

Although there are many commentarial treatises by scholars of earlier generations, here are some specific [titles]: ${ }^{668}$

Ambrosia in eight chapters by Yiong Lekpé Gyen; ${ }^{669}$

The Illuminating Lamp: Thirty Instructions by Zhang Zijibar; ${ }^{670}$

The Commentary on the Topic of the Thoracic Cavity by Drangti Gyelnyé Kharpukpa; ${ }^{67 \mathrm{I}}$

\begin{tabular}{l}
\hline${ }^{666}$ Martin, “Greek and Islamic Medicines' Historical Contact with Tibet,” I22. \\
${ }^{667}$ Gsang ba man ngag gis [sic] rgyud kyi spyi don shes bya rab gsal rgyas pa (Beijing), 24b: sangs \\
rgyas la phun sum tshogs par mnga' la/_khyad par can gyi drang srong 'phags pa rnams dang \\
/_tshangs pa dang rgyun shes kyi bu la sogs pa rnams la'ang /_ci rig par yod cing /_so so skye bo rnams \\
de dag dngos su med cing gso dpyad kyi gzhung lugs la brten nas cha mtshungs su yod par rung ngo /. \\
${ }_{668}$ Gsang ba man ngag gis [sic] rgyud kyi spyi don shes bya rab gsal rgyas pa (Beijing Ms), 26b: snga \\
rab mkhas pa'i gzhung 'brel [='grel?] bstan bcos mang du yod na'ang/_khyad par [...]. \\
${ }_{669}$ Gsang ba man ngag gis [sic] rgyud kyi spyi don shes bya rab gsal rgyas pa (Beijing Ms), 26b: yid \\
'ong legs pa'i rgyan gyi mdzad pa'i bdud rtsi le'u brgyad/. This author appears in the Blazing Peak, \\
but his work is otherwise unattested. \\
670 Gsang ba man ngag gis [sic] rgyud kyi spyi don shes bya rab gsal rgyas pa (Beijing Ms), 26b: \\
zhang gzi brjid 'bar gyis mdzad pa'i sgron gsal gdams pa sum cu pa/. This author appears in the \\
Blazing Peak, and after a long absence from public availability, this work is now available in \\
one hundred and fifty-six folios (!). See Ga las pa sum cu pa, in Krung go’i bod lugs gso rig rtsa che'i \\
dpe rnying kun btus, vol. I, text I2, pp. 66-I64 (ff. Ia-I56a). \\
671 Gsang ba man ngag gis [sic] rgyud kyi spyi don shes bya rab gsal rgyas pa (Beijing Ms), 26b: brang \\
ti rgyal mnyes mkhar phug pas mdzad pa'i byang khog don tig. Although the title listed here is
\end{tabular} 


\author{
Stainless Radiance by Gyongmen Penné; ${ }^{672}$ \\ The Medicine of the Royal Treasury by the Great Jetsün [Drakpa Gyentsen]; ${ }^{673}$ \\ [The Sunbeams of the Little Eight (Branches) by Zhö Pelchen Öpo;] ${ }^{674}$ \\ The Summary of the Eight Branches by Sakya Penchen; ${ }^{675}$ \\ The Ornamental Flower of Healing Science by Chomden Rikrel; ${ }^{676}$ \\ The Profound Liberation by Minyak Dorjé Bum; ${ }^{677}$ \\ The Practical Manual by Yutok Gönpo; ${ }^{678}$
}

somewhat distinct, this must refer to the Byang khog dmar byang gsal ba'i sgron me, Bod kyi gso ba rig pa'i gna' dpe phyogs bsgrigs dpe tshogs vol. IOI (Beijing: Mi rigs dpe skrun khang, 20I4).

${ }^{672}$ Gsang ba man ngag gis [sic] rgyud kyi spyi don shes bya rab gsal rgyas pa (Beijing Ms), 26b: gyong sman 'phen nas mdzad pa'i dri med gzi brjid/. This author appears in the Blazing Peak, and the Stainless Radiance is now extant, but attributed to Zhangtön Zijibar. See Gzhung dri med gzi brjid kyi 'grel ba nyi ma'i 'od zer, Bod kyi gso ba rig pa'i gna' dpe phyogs bsgrigs dpe tshogs, vol. IOI (Beijing: Mi rigs dpe skrun khang, 20I4). Although the title indicates that this work is a commentary, the actual work does not conform to the scholastic conventions of textual commentary.

${ }^{673}$ Gsang ba man ngag gis [sic] rgyud kyi spyi don shes bya rab gsal rgyas pa (Beijing Ms), 26b: rje btsun chen pos mdzad pa'i gso spyad rgyal po'i skor [=dkor] mdzod/. This work can be found in the many editions of the Book of Sakya (sa skya bka' 'bum), such as Dpal brtsegs bod yig dpe rnying zhib 'jug khang, ed., Sa skya gong ma rnam lnga'i gsung 'bum dpe bsdur ma las grags pa rgyal mtshan gyi gsung pod lnga pa (Beijing: Krung go'i bod rig pa dpe skrun khang, 2007), vol. I2, 372533. See also Sman dpyad rgyal po'i dkor mdzod bzhugs so/ gso dpyad bdud rtsi thigs pa/, in Krung go'i bod lugs gso rig rtsa che'i dpe rnying kun btus, vol. I, text I5, pp. 2I7-72 (ff. Ia-84b).

${ }^{674}$ This particular entry cannot be found in Gsang ba man ngag gis [sic] rgyud kyi spyi don shes bya rab gsal rgyas pa (Beijing Ms), 26b; but does appear in Shes bya rab gsal rgyas pa (Delhi), 72: zhod dpal chen 'od pos mdzad pa'i brgyad chung nyi 'od zer/. I have been able to identify neither this author nor this work.

${ }^{675}$ Gsang ba man ngag gis [sic] rgyud kyi spyi don shes bya rab gsal rgyas pa (Beijing Ms), 26b: sa skya pan chen gyis mdzad pa'i yan lag brgyad pa’i don bsdus/. This work can be found in the later additions to the Book of Sakya. For a modern book reproduction, see Yan lag brgyad pa'i snying po, Bod kyi gso ba rig pa'i gna' dpe phyogs bsgrigs dpe tshogs, vol. 85 (Beijing: Mi rigs dpe skrun khang, 2008).

${ }^{676}$ Gsang ba man ngag gis [sic] rgyud kyi spyi don shes bya rab gsal rgyas pa (Beijing Ms), 26b: bcom ldan rig ral gyis mdzad pa'i gso spyad gyan gyis me tog. This work can be found in manuscript form in the Gso ba rig pa rgyan gyi me tog, in Krung go'i bod lugs gso rig rtsa che'i dpe rnying kun btus, vol. 3, no. 40, pp. 472-9I (ff. Ia-38a). A modern book edition can be found in Gso ba rig pa rgyan gyi me tog, Bod kyi gso ba rig pa'i gna' dpe phyogs bsgrigs dpe tshogs vol. 8o (Beijing: Mi rigs dpe skrun khang, 2008).

${ }_{777}^{6}$ Gsang ba man ngag gis [sic] rgyud kyi spyi don shes bya rab gsal rgyas pa (Beijing Ms), 26b: $m i$ nyag rdo rje 'bum gyi mdzad pa'i zab grol/. I have been able to definitively identify neither this author nor this work.

${ }^{678}$ Gsang ba man ngag gis [sic] rgyud kyi spyi don shes bya rab gsal rgyas pa (Beijing Ms), 26b: g.yu thog mgon pos mdzad pa'i lag len pu ti/. This title refers, of course, to the Small Practical Manual (lag len spod chung) discussed in Chapter Three. This work is no longer extant, but a commentary attributed to Drangti Jampel Zangpo can be found in Lag len spod chung gyi 'brel 
The Subsequent Compendium of All Essences by Nyemo Jozung; ${ }^{679}$ and

The Drop of Ambrosia by Zhangtön Zhikpo. ${ }^{680}$

This is a brief presentation of texts that were indisputably composed by those that authentically hail from the Land of Snow. ${ }^{68 \mathrm{I}}$

Not unlike the descent of perfect religious teachings from otherworldly beings to imperfect human understanding, here Drangti builds upon Cherjé to imply that the available and extant medical teachings of Tibet are merely representative pieces (cha mtshungs su yod pa) of a much larger, unattainable cosmopolis of medical literature. By listing dozens and dozens of unattested texts - text that probably were never even were available to him-Drangti demonstrates the extent of knowledge that came to be represented in the Four Tantras and other works that were available in fourteenth-century Tibet. Complimenting the descending transmission conveyed by these seven schools, however, is the notion that these differentiated cosmopolitan teachings ultimately derive from the emanations of the same enlightened teacher. Instead of representing the essence of fundamentally disparate teachings coming together into one, the Four Tantras presents itself as the source of all foreign medical lineages. Indeed, like a single moon reflecting in many individual ladles of water, "although there is one teaching, there are many individual understandings."

The nine foreign physicians listed by Drangti Penden Tsojé as coming to Tibet during the reign of Tri Songdetsen correspond approximately to the foreign physicians listed in the "Schools of Each Classification" (rigs so so'i lugs) found in the Expanded Elucidation of Knowledge,

[sic] pa, in Krung go’i bod lugs gso rig rtsa che’i dpe rnying kun btus, vol. 3, text 2, pp. 230-56 (ff. Ia40a); and Rgyud rgyal bdud rtsi snying po las lag len dmar khrid sde tshan lnga'i 'grel pa, in Krung go'i bod lugs gso rig rtsa che’i dpe rnying kun btus, vol. 8, text 6, pp. 307-25 (ff. Ia-38a). For a modern print edition, see Rgyud rgyal bdud rtsi snying po las lag len dmar khrid sde tshan lnga'i 'grel pa, in Phyi ma rgyud kyi 'grel ba phyogs bsgrigs, Bod kyi gso ba rig pa'i gna' dpe phyogs bsgrigs dpe tshogs vol. 89 (Beijing: Mi rigs dpe skrun khang, 2008), 265-325. Importantly, later editions of the Expanded Elucidation list the Familial Practices (lag len bu don) of Yutok Gönpo instead. See Shes bya rab gsal rgyas pa (Delhi), 72.

${ }^{679}$ Gsang ba man ngag gis [sic] rgyud kyi spyi don shes bya rab gsal rgyas pa (Beijing Ms), 26b: snye mo jo bzungs kyis mdzad pa’i snying po kun la btus pa’i phyi ma/. I have been able to definitively identify neither this author nor this work.

${ }^{680}$ Gsang ba man ngag gis [sic] rgyud kyi spyi don shes bya rab gsal rgyas pa (Beijing Ms), 26b: zhang ston zhig pos mdzad pa'i bdud rtsi'i thigs pa rnams ni/. This, of course, refers to the author of the Blazing Peak, Cherjé Zhangtön Zhikpo. I have been unable to locate any works of this title attributed to Cherjé, but there are several sets of medical instructions that are called the Drop of Ambrosia. See, for example, the manuscript edition of the Royal Treasury that also includes the title Drop of Ambrosia: Sman dpyad rgyal po'i dkor mdzod bzhugs so/ gso dpyad bdud rtsi thigs pa/, in Krung go'i bod lugs gso rig rtsa che'i dpe rnying kun btus, vol. I, text I5, pp. 217-72 (ff. Ia-84b).

${ }^{681}$ Gsang ba man ngag gis [sic] rgyud kyi spyi don shes bya rab gsal rgyas pa (Beijing Ms), 26b: gangs can du tshad mar gyur pa'i skyes bu rnams kyis rtsod med kyi gzhungs ji ltar mdzad pa'i rnam dbye mdo tsam mo/.

${ }^{682}$ Dpal ldan rgyud bzhi dpe bsdur ma, vol. 3, 288: gcig tu gsungs kyang so sos du mar go//. 
as well as those listed in the "Schools of the Scholarly Class" (mkhas ldan mnga' rigs gi lugs) found in Cherjé's Blazing Peak. ${ }^{683}$ As we saw above, however, there are discrepancies between the list of schools found in the Expanded Elucidation and that found in the Blazing Peak, and even among the different editions of the Expanded Elucidation. Comparing these lists with the nine physicians that are said to have come to teach in Tibet during the reign Tri Songdetsen, we find further omissions in which the eastern and western Kashmiri traditions are represented by only one figure, and several other traditions are not mentioned, such as those of Orgyen, Khotan, Byzantium, the Uyghurs, and the Tangut. Considering the general trajectory of foreign physicians listed in the seven schools of Cherjé's Blazing Peak and Drangti's Expanded Elucidation, as well as the narrative of nine physicians that came to Tibet during the reign of Tri Songdetsen, there is a shift from mere lists to historiographical narrative, from placing Tibet at the periphery of the medical world to its center, and even a shift from reverence to criticism. By shifting the narrative focus of cosmopolitan lists found in previous works of Tibetan medical historiography, Drangti effectively brings the temporally and spatially removed characters of foreign medical traditions alive in local space and relatable time. In doing so, not unlike parallel tales in Lama Dampa's Mirror Illuminating the Royal Genealogies, Drangti reflects the imagined past into the subjunctive future with the mirror of creative historiography.

\section{The Establishment of Professional Ethics in the Tibetan Medical Tradition}

The narratives of foreign physicians coming to Tibet during the reigns of Songtsen Gampo, Tri Songdetsen, and so forth that were first articulated by Drangti Penden Tsojé continued to echo in subsequent traditions of Tibetan historiography, both medical and religious. Writing about one hundred and fifty years after the composition of the Expanded Elucidation of Knowledge, for example, the antiquarian and scholar, Pawo II Tsuklak Trengwa (dpa' bo gtsug lag phreng $b a$, I504-1566), transmitted and transformed the narratives formulated by Drangti, but with a few important modifications. Pawo further transmitted Drangti's notion that physicians from East, South, and Central Asia came to Tibet and helped translate medical teachings, but he changed the identities of these figures from the more obscure characters with precedents in Tibetan medical histories to the more recognizable founding physicians of Indian, Chinese, and Greco-Arab traditions. This inclusion of a recognizably Greek physician - that is, Galen of Pergamon-has sparked suppositions of Greek roots in the establishment of medical instructions and professional ethics in Tibet. While the ethical pronouncements framed within the narratives of the Tibetan empire may indeed have been

${ }^{683}$ Again, see Martin, "Greek and Islamic Medicines' Historical Contact with Tibet," I23-32, and $140-42$ (Appendix D). As we saw above, early editions of the Expanded Elucidation include ten physicians from nine distinct traditions in the "Schools of Each Classification" sectionworks from east and west Kashmir, Orgyen, Nepal, Persia, Dölpo, the Uighurs, Khotan, Byzantium, and China-to which later editions add works from Turkish, Mongolian, and Tangut traditions. 
related to an Arab iteration of the Hippocratic Oath, as we have seen throughout this chapter, the narration of these royal ordinances must be understood not as a faithful narration of eighth-century events, but as a reflection of fourteenth-century historiographical developments at Sakya.

\section{Galen in Tibet}

Pawo II Tsuklak Trengwa is one of the first Buddhist scholars that was not himself a physician to treat the subject of medicine by citing the works of Tibetan physician themselves. Previous scholars certainly did of course treat the five sciences, including medicine, but would often do so without citing Tibetan-authored medical literature. Chomden Rikpé Reldri, for example, wrote about medicine, but did not acknowledge the contributions of Tibetan authors themselves. In the medical sections of his consummate history and discussion of Tibet intellectual traditions, the Feast for Scholars (mkhas pa'i dga' ston), Pawo II Tsuklak Trengwa explicitly cites the khokbuk curriculum of Drangti Penden Tsojé before reiterating the legends of medical activity during the Tibetan empire found in the Expanded Elucidation of Knowledge. ${ }^{64}$ Taking Drangti's account of Songtsen Gampo's contributions to medicine as the basis for his own, Pawo describes the arrival of neither Dhanarāja from India, Heshang Mahākyindha from China, nor Prince Tsen Pashilahā from Byzantium; but of Bharadhvāja from India, Xuanyuan Huangdi 軒轅黃帝 from China, and Galen from Byzantium in Persia. ${ }^{65}$ He lists several other physicians as well, ultimately conforming to the motif of nine foreign physicians coming to Tibet during the imperial period.

This reference to Galen of Pergamon, the celebrated physician of the second-century Roman world-not to mention Bharadhvāja, the requestor of the Compendium of Caraka, and the Yellow Emperor, one of the interlocutors featured in the Inner Classic of the Yellow Emperor (huangdi neijing 黃帝內經)—was noted and explored by C. I. Beckwith as early as I979, sparking a series of subsequent articles assessing the implications of this and other similar legends. ${ }^{686}$ In light of the fact that Bharadhvāja, the Yellow Emperor, and Galen appear nowhere in Drangti's Expanded Elucidation of Knowledge or any other work of the fourteenth or fifteenth century, the question still remains regarding how, exactly, the figure of Galen was introduced to Tibetan medical and historiographical traditions. Tsen Pashilahā also plays a

${ }^{684}$ Chos 'byung mkhas pa'i dga' ston (Beijing: Mi rigs dpe skrun khang, 1986), vol. 2, I5I8: brang ti dpal ldan 'tsho byed kyi khog dbub legs snang sgron mer/.

${ }^{685}$ Chos 'byung mkhas pa'i dga' ston (Beijing: Mi rigs dpe skrun khang, 1986), vol. 2, I5I8: de'i tshe rgya gar nas badzra dhwa dzal_rgya nag nas hen weng hang de/_stag gzig gi khrom nas ga le nos ste sman pa gsum spyan drangs/.

${ }^{686}$ Christopher I. Beckwith, "The Introduction of Greek Medicine into Tibet in the Seventh and Eighth Centuries," Journal of the American Oriental Society 99, no. 2 (I979): 297-3I3. See also the aforementioned articles by Beckwith's student, D. Martin: "Greek and Islamic Medicines' Historical Contact with Tibet"; and "An Early Tibetan History of Indian Medicine"; as well as Garrett, "Critical Methods in Tibetan Medical Histories"; and Ronit Yoeli-Tlalim, "Re-visiting 'Galen in Tibet," Medical History 56, no. 3 (2012): 355-65. 
prominent role in the Feast for Scholars, just under the new title of Biji Tsen Pashilahā. Pawo appears to have conflated two characters featured separately in Drangti's Expanded Elucidation-Prince Tsen Pashilahā who was active during the reign of Songtsen Gampo, and Doctor Biji who was active during the reign of Tri Detsukden-leading to a new character named Biji Tsen Pashilahā from Byzantium. ${ }^{687}$ Like the reappellation of Tsen Pashilahā, however the introduction of Galen to Tibet may have occurred exactly, it appears to have been the consequence of developments during the fifteenth and/or sixteenth centuries, as opposed to those of the seven, eighth, and/or ninth. ${ }^{688}$

\section{Professional Ethics in the Tibetan Medical Tradition}

While much ink has been spilled regarding the identity of Galen and the potential transmission of Greek medicine to Tibet since the work of C. Beckwith in 1979, less attention has been paid to the second part of his groundbreaking article regarding the transmission of the Hippocratic Oath to Tibet. ${ }^{69}$ As prophesied by Beckwith ${ }^{690}$ the increased availability of early manuscripts like Drangti's Expanded Elucidation of Knowledge have allowed scholars to better assess the question of whether or not it was the Hippocratic Oath that formed the basis for the ethical proclamations found in the Feast for Scholars. Indeed, six of the thirteen ordinances regarding the treatment of physicians found in the Expanded Elucidation are repeated in the Feast for Scholars, with some additions and substitutions for the more redundant and controversial prescriptions:

\begin{tabular}{|l|l|l|}
\hline $\begin{array}{l}\text { Drangti's Expanded Elucidation of } \\
\text { Knowledge (ca. 1372) }\end{array}$ & Pawo's Feast for Scholars (ca. 1564) \\
\hline $\begin{array}{l}\text { Ministers and subjects of Tibet, please } \\
\text { listen to my words without distraction. } \\
\text { These healers and physicians deserve the }\end{array}$ & & \\
\hline
\end{tabular}

${ }^{687}$ Chos 'byung mkhas pa'i dga' ston (Beijing: Mi rigs dpe skrun khang, 1986), vol. 2, 1519: dei tshe khrom nas bi ci tsan pa shi la ha bya ba spyan drangs/.

${ }^{688}$ For similar conclusions, see Garrett, "Critical Methods in Tibetan Medical Histories"; and Yoeli-Tlalim, "Re-visiting 'Galen in Tibet."

${ }^{689}$ Beckwith, "The Introduction of Greek Medicine into Tibet in the Seventh and Eighth Centuries," 304: "The second [text cited], however, appears to be close enough to the basic tenets of the Hippocratic oath to be called a version of it. A comparison with another Greek version of the famous Oath shows that the Tibetan one, while just as brief, is actually closer to the traditionally accepted one." None of the above cited articles address this claim.

${ }^{690}$ Beckwith, "The Introduction of Greek Medicine into Tibet in the Seventh and Eighth Centuries," 312, n. 70: "If or when original Tibetan materials stored up in the great libraries of Europe and India become more easily available to researchers, no doubt the translation and interpretation of this and of other texts dealt with here (particularly those quoted from the Mkhaspa'i dgāston) will have to be revised." Little did he know that it would be the great libraries of Beijing and Lhasa that would become more easily available. 


\begin{tabular}{|c|c|c|}
\hline $\begin{array}{l}\text { offerings of all the Tibetan people. How so? } \\
\text { Because they are masters of healing, I, the } \\
\text { emperor, lord of all the black-headed } \\
\text { people, }\end{array}$ & & \\
\hline $\begin{array}{l}\text { [I.] bestow upon each of them the title of } \\
\text { "Divine Lord," }\end{array}$ & $=$ & $\begin{array}{l}\text { [I.] Saying, "He is the lord of the king," } \\
\text { bestow upon [each physicians] the title of } \\
\text { Divine Lord. }\end{array}$ \\
\hline $\begin{array}{l}\text { [2.] designating each as the father of beings } \\
\text { and the center of society. }{ }^{691}\end{array}$ & $=$ & $\begin{array}{l}\text { [2.] Designate them as the masters of all and } \\
\text { the center of society. }\end{array}$ \\
\hline $\begin{array}{l}\text { We should [3.] give them silken seats of } \\
\text { badger hides and so forth, }\end{array}$ & $=$ & [3.] Set out excellent cushions [for them]; \\
\hline $\begin{array}{l}\text { [4.] serve them food, tea, and beer in silver } \\
\text { cups, }\end{array}$ & $=$ & $\begin{array}{l}\text { [4.] feed them the best food and drink as } \\
\text { presents; }\end{array}$ \\
\hline [5.] welcome them with horses, & $=$ & $\begin{array}{l}\text { [5.] provide horses for them for coming and } \\
\text { going; }\end{array}$ \\
\hline [6.] offer them payment in gold, and & $=$ & [6.] pay their fees in gold; \\
\hline $\begin{array}{l}\text { [7.] offer racks of meat and the blood of the } \\
\text { channels pulled from carcasses. }{ }^{692}\end{array}$ & $\neq$ & [7.] be grateful for their work and so on. ${ }^{693}$ \\
\hline $\begin{array}{l}\text { [8.] Measure each of them, and give them } \\
\text { fine silken robes and turbans to wear, }\end{array}$ & $\neq$ & $\begin{array}{l}\text { [8.] Even if the physician calls from nearby, } \\
\text { [one should provide him] his transportation } \\
\text { and fees; }\end{array}$ \\
\hline $\begin{array}{l}\text { [9.] have them sit higher than everyone } \\
\text { except the royal family, }\end{array}$ & $\neq$ & $\begin{array}{l}\text { [9.] even if he is a relative, [one should } \\
\text { provide] clean food and presents; }\end{array}$ \\
\hline $\begin{array}{l}\text { [Io.] bring all the beautiful maidens before } \\
\text { the eyes of the Divine Lords, }\end{array}$ & $\neq$ & $\begin{array}{l}\text { [Io.] even if he is a servant, [one should] } \\
\text { honor and respect him; }\end{array}$ \\
\hline
\end{tabular}

${ }^{691}$ Gsang ba man ngag gis [sic] rgyud kyi spyi don shes bya rab gsal rgyas pa (Beijing), 30a-3ob: bod kyi zhang blon 'bangs su bcas pa rnams//_nga yi tshig la ma yang [=g.yengs?] gus pas nyon//_tsho mdzad sman par gyur pa 'di rnams la//_bod 'bangs kun gyi mchod pa'i 'os yin pas//_ci'i phyir'di rnams srog 'tsho'i slob dpon yin//_mgo nag yongs kyi rje ni btsan po ste//_nga yis bkur bas mtshan yang lha rjer thogs//'gro ba'i pha yin gral gyi dbus su bzhog/.

${ }^{692}$ Gsang ba man ngag gis [sic] rgyud kyi spyi don shes bya rab gsal rgyas pa (Beijing), 3ob: grum ze la sogs dar zab gdan yang thongs//_zhal zas ja chang dngul skyogs nang du grongs [=drongs]//_skyel bsu rtas kyis zhabs gla gser du phul//_za tshud sha khog drangs la rtsa'i kha dmar zhus//.

${ }^{693}$ Chos 'byung mkhas pa'i dga' ston (Beijing: Mi rigs dpe skrun khang, I986), vol. 2, I5I9: rgyal po'i rje yin zhes lha rjer btags te thams cad kyis blar bkur ba gral gyi dgung la 'jog pa stan bzang du 'ding pa zas skom spyan gzigs kyi mchog stob pa skyel bsu rtas byed pa yon gser du 'bul ba pa drin du gzo ba sogs kyi bkar btags/. 


\begin{tabular}{|l|l|l|}
\hline $\begin{array}{l}\text { [II.] and even if they eat one hundred } \\
\text { portions in one day, do not consider them } \\
\text { greedy. } \text {.94 }^{-}\end{array}$ & $\neq$ & $\begin{array}{l}\text { [II.] even if he does not meet [with patients] } \\
\text { on time, one should wish him joy and be } \\
\text { respectful; }\end{array}$ \\
\hline $\begin{array}{l}\text { [I2.] In cases of malpractice-even if [a } \\
\text { physician] takes a human life-do not seek } \\
\text { blood money, and }\end{array}$ & $\neq$ & $\begin{array}{l}\text { [I2.] even if he is an enemy, [one should] be } \\
\text { confident out of faith; and }\end{array}$ \\
\hline $\begin{array}{l}\text { [I3.] whatever medicine is prescribed, pay } \\
\text { for it in gold. }\end{array}$ & $\neq$ & $\begin{array}{l}\text { [I3.] even if he is greedy for food and } \\
\text { money, [one should] not mistreat him; }\end{array}$ \\
\hline $\begin{array}{l}\text { [I4.] [even] when they are sick people crying } \\
\text { out, petitioning to be cure, [one should] give } \\
\text { thanks [to the physicians]; }\end{array}$ \\
\hline $\begin{array}{l}\text { Whoever transgresses these thirteen } \\
\text { ordinances that I have given, shall } \\
\text { henceforth be punished. }\end{array}$
\end{tabular}

Table 5.I. A Comparison of Popular Medical Ethics in the Expanded Elucidation of Knowledge and the Feast for Scholars

As can be seen in the Expanded Elucidation of Knowledge edition, this list is a set of ordinances that are said to have been pronounced by Tri Songdetsen before the aristocrats and subjects of Tibet. Following these thirteen commandments, Drangti informs us that "during the reign of Tri Songdetsen, respecting his influence, the professional status [of physicians] was made equal with that of religious teachers [lit. "virtuous friends']". ${ }^{697}$ It is perhaps this closing

${ }^{694}$ Gsang ba man ngag gis [sic] rgyud kyi spyi don shes bya rab gsal rgyas pa (Beijing), 3ob: re 'bri dar zab ber bkon dbu la dar thod chings [=bcing] //_rgyal sras ma gtogs kun gyi zhengs phul//_bu mo mdzes ma kun gyi lha rje'i spyan yang khrid//_nyin cig zan brgya zos kyang dro po [=grod pa?] cher ma 'dogs//.

${ }^{695}$ Chos 'byung mkhas pa'i dga' ston (Beijing: Mi rigs dpe skrun khang, 1986), vol. 2, I5I9: sman pa rnams kyis kyang khyim mtshes nas bos kyang skyel bsu dang zhabs gla/_gnyen tshan yin yang lag dkar dang zhu rten/_bran kho yin yang bkur sti dang gus pa/_dus min du phrad kyang mdongs gsol dang bsnyen bkur/_dgra bo yin yang dad gus kyis blo gtod pa/_zas nor la 'dod sred byas rung skur ba mi 'debs/_nad pa gso ba la zhu 'bul/_dran nas gtang rag_rting bskul sgye'u skyel sogs bco lnga gtsigs su bzung/.

${ }^{696}$ Gsang ba man ngag gis [sic] rgyud kyi spyi don shes bya rab gsal rgyas pa (Beijing), 3ob: bcos nor mi srog bcad kyang stong ma len//_sman du ci 'dra btang yang sman rin gser du phul//_nga'i gnang ba'i bka' tshigs bcu gsum 'di//_gang gis 'das na de la chad pas gcod//.

${ }^{697}$ Gsang ba man ngag gis [sic] rgyud kyi spyi don shes bya rab gsal rgyas pa (Beijing), 3ob: khri srong lde btsan gyi ring la mnga' thang bstod de/_dge ba'i bshes gnyen dang gral mnyam por byas so/. 
comment that most explicitly describes what these commandments, placed in the voice of Tri Songdetsen, serve to accomplish: from the fourteenth century onward, all physicians are to be treated with equal veneration and generosity that is usually afforded to the clergy.

This set of ordinances could not have been inspired by the prescriptions of the Hippocratic Oath, of course, because they do not form a set of professional ethics, but a description of the ideal treatment of physicians that is to be provided by patients and other members of society. Although the origins of each ordinance may be obscure, the narrative motif of transmitting ethical prescriptions by means of royal ordinance is by no means unique to the medical tradition. ${ }^{698}$ As told in the Mirror Illuminating the Royal Genealogies, following the return of Tönmi Sambhota from India and his invention of the Tibetan script, hundreds of ministers gathered for the pronouncement of the (approximately) twenty laws of Tibet (bod khrims nyi shu). ${ }^{699}$ One layer of this legal pronouncement appears to be intended for the common people, for they are instructed to "refrain from quarreling with upper-class people and noblemen, and to yield to them," to "pay debts on time," to "refrain from conducting fraud in weighting and measuring," and so forth. ${ }^{700}$ A distinct textual layer provides a set of ethical prescriptions the landed aristocracy themselves, however, for it describes the division of lands, emphasizes that "the high should be restricted by laws," that "writing should be taught to men," that "variable fines should be imposed upon murderers," and so forth. ${ }^{\text {7or }}$ Following the articulation of these ethical and legal codes, Lama Dampa celebrates their success with a narrative description of the harmonious society to which they led: "as the laws had been made based upon religious teachings, the subjects paid heed, and the entire kingdom was happy with the acts of the Divine Ruler of Man."702 Thus, despite some

${ }^{698}$ For genealogies of these legal prescriptions, see Rolf A. Stein, "Tibetica Antiqua IV: The Tradition Relative to the Debut of Buddhism in Tibet," in Rolf Stein's Tibetica Antiqua, trans. Arthur P. McKeown (Leiden: Brill, 20IO), 2I5-20; originally published "Tibetica Antiqua IV: La tradition relative au début du Bouddhisme au Tibet," Bulletin de l'Ecole française d'ExtrêmeOrient 75 (1986): I69-96.

${ }^{699}$ Sørensen, Tibetan Buddhist Historiography, I8I-86; Rgyal rabs gsal ba’i me long, vol. I, 74-75. Sørensen arranges this pronouncement according to the "ten virtues" (dge ba bcu), the "sixteen pure popular rules of conduct" (mi chos gtsang ma bcu drug), and the "twenty laws of Tibet" (bad khrims nyi shu), based on intertextuality with other sources (see Sørensen, Tibetan Buddhist Historiography, I83, n. 526). Lama Dampa seems to indicate that these laws are based on the famed ten virtues (dge ba bcu la dpe byas nas), however, and total in approximately twenty laws. ${ }^{700}$ Translated in consultation with Sørensen, Tibetan Buddhist Historiography, I83; Rgyal rabs gsal ba’i me long, vol. I, 75: mi ya rabs dang rigs btsun pa la mi rgol cing dang du len pa/ ... bu lon dus su ’jal cing /_bre srang la g.yo zol mi bya bal.

${ }^{701}$ Translated in consultation with Sørensen, Tibetan Buddhist Historiography, I82; Rgyal rabs gsal ba'i me long, vol. I, 74-75: mtho ba khrims kyis gnon/ ... mi la yi ge bslabs/... sad pa la che chung gi stong byed pa/.

${ }^{702}$ Translated in consultation with Sørensen, Tibetan Buddhist Historiography, I84; Rgyal rabs gsal ba'i me long, vol. I, 75: chos kyi bka' khrims mdzad pas 'bangs rnams bka' la nyan//_mi rje lha yis mdzad pas rgyal khams thams cad skyid//. 
ambiguity in its organization, Lama Dampa's account is composed of moral and legal instructions for both the gentry and the commoners, as well as a description of their success.

Not unlike the parallel stories of Minister Gar's escape and Tri Songdetsen's examination physicians, the medical prescriptions found in the Expanded Elucidation of Knowledge parallel the set of legal and ethical prescriptions found in the Mirror Illuminating the Royal Genealogies. As we can see above, the thirteen ordinances issued by Tri Songdetsen cocern the behavior of the patients of the Tibetan empire, and not the physicians themselves. Comparing the two codes, while the respectful titles and timely payments of the Expanded Elucidation are not unreasonable, the inexhaustible offerings of clothing, food, and even women seems excessive compared to the modest prescriptions found in the Mirror. Despite this fact, the Mirror's subsequent description of the Tibetan empire acting under such laws is similarly hyperbolic, with Lama Dampa describing a perfectly joyous and harmonious society in imperial Tibet. Drangti's description continues this trend, emphasizing the thirteen prescriptions found above and describing an ideal form of the medical practice under Tri Songdetsen:

In accordance with the royal ordinances, the physicians were invited in by their neighbors and paid wages. They were called "Brother Doctor," and were given gifts and presents. Whenever they prescribed medicine they would be paid and thanked. Helping people and valuing their lives, they would be welcomed when coming and escorted when going. ${ }^{703}$

[Even if they came at a bad time, they would be treated as guests. Even if a physician killed a patient through malpractice, there would not be any suit or litigation. The people would listen to whatever the physician said. And even if they desired livestock (as payment), there would be no dispute. $]^{704}$

Even if side effects arose due to negligence, the physician would not be held as a fallible. Even if medicines and instruments were cast aside, they would not be sued for damages. During the time when these physicians flourished, [patients] sought after them and upheld the thirteen ordinances. ${ }^{705}$

${ }^{703}$ Gsang ba man ngag gis [sic] rgyud kyi spyi don shes bya rab gsal rgyas pa (Beijing), 3ob: de’i sman pa rnams la rgyal po'i bka' tshigs ltar/_khyim tshes [=mtshes] nas gdan 'dren yang zhabs gla/_sman pa gnyen lags kyang phyag dkar dang zhu rten/_sman du ci btang yang sman rin dang gtang rag_mi gces la srog rin/_tshur'ong la bsu ma/_phar'gro la skyel ma/.

${ }^{704}$ Gsang ba man ngag gis [sic] rgyud kyi spyi don shes bya rab gsal rgyas pa (Beijing), 3ob: dus min 'ongs kyang mgron/_sman pas nad pa lag nyes la shi yang gyod dang 'khris med pa/_sman pa'i ngag ci zer la nyan pa/_nor la'dod pa byas kyang cis mi gdags pa/. This passage is missing from Shes bya rab gsal rgyas pa (Delhi), 83.

${ }^{705}$ Gsang ba man ngag gis [sic] rgyud kyi spyi don shes bya rab gsal rgyas pa (Beijing), 30b-3Ia: bag g.yeng 'gal ba byung yang skyon mi bzung ba/_sman dang lag cha bor yang god du mi stong pa/_sman pa’i bya ba la dus su snyeg pa dang /_rtsigs bcu gsum bzung ngo /. 
This ideal form of the medical practice is, of course, presented from the physician's perspective. As these elaborations indicate, for example, the twelfth of the thirteen ordinances listed above- "in cases of malpractice, even if [a physician] takes a human life, do not seek blood money" - was an important, and probably contested one. Indeed, contradicting the legal prescriptions for "blood money" (mi stong) delineated in the Mirror, Drangti tells us that "Even if a physician killed a patient through malpractice, there would not be any suit or litigation." As has been described elsewhere, this notion of blood money has a long history in the Tibetan legal tradition and is supported by early legal documents found at Dunhuang. ${ }^{706}$ The unconditional exemption of physicians from this fine appears to have been high on Drangti's agenda, for he overturns the application of blood money compensation to physicians in both the prescriptions and descriptions attributed to the imperial age of Tri Songdetsen. As can be seen in Table 5.I, however, Pawo elided these prescriptions from his own set of fifteen medical prescriptions, replacing them with more vague prescriptions for hospitality, honor, and respect.

Just as Lama Dampa provides two separate legal codes for the gentry or the masses that together contribute to his vision of a harmonious society, Drangti Penden Tsojé and Pawo II Tsuklak Trengwa also provide separate moral precepts for both the common patient and the physician. Under these codes, just as the patients are expected to trust and respect the physician, the physician is instructed to care for his patients:

\begin{tabular}{|l|l|l|}
\hline $\begin{array}{l}\text { Drangti's Expanded Elucidation of } \\
\text { Knowledge (ca. I372) }\end{array}$ & Pawo's Feast for Scholars (ca. I564) \\
\hline $\begin{array}{l}\text { [I.] Because the physician is the father, } \\
\text { one should aspire to help [patients]. }\end{array}$ & $=\begin{array}{l}\text { [I.] Because the lama physician is the father, } \\
\text { one should generate love [for patients]. }\end{array}$ \\
\hline $\begin{array}{l}\text { [2.] Because the patient is the son, one } \\
\text { should not deceive them. }\end{array}$ & $=\begin{array}{l}\text { [2.] Because the patient is the son, one should } \\
\text { not deceive them. }\end{array}$ \\
\hline $\begin{array}{l}\text { [3.] Because it will tarnish one's } \\
\text { intelligence and modesty, one should } \\
\text { not misbehave. }\end{array}$ & $=\begin{array}{l}\text { [3.] Because it will tarnish one's intelligence } \\
\text { and modesty, one should not misbehave with } \\
\text { patients. }\end{array}$ \\
\hline $\begin{array}{l}\text { [4.] Because it will ruin one's aristocratic } \\
\text { standing, one should not misbehave }\end{array}$ & $=\begin{array}{l}\text { [4.] Because it will ruin one's aristocratic } \\
\text { standing, one should not misbehave while }\end{array}$ \\
\hline
\end{tabular}

${ }^{706}$ See, for example, the description and references in Stein, “Tibetica Antiqua IV," 2I9, n. 43. For the so-called "blood-price" in Dunhuang documents, see Brandon Dotson, "Trial for Homicide," in Sources of Tibetan Tradition, ed. Kurtis R. Schaeffer, Matthew T. Kapstein, Gray Tuttle (New York, NY: Columbia University Press, 20I3), 87-88. See also Brandon Dotson, "Introducing Early Tibetan Law: Codes and Cases," in Secular Law and Order in the Tibetan Highland, ed. Dieter Schuh (Andiast: International Institute for Tibetan and Buddhist Studies $\mathrm{GmbH}, 20 \mathrm{I6}), 273$. 


\begin{tabular}{|l|l|l|}
\hline while eating. & & eating. \\
\hline $\begin{array}{l}\text { [5.] Because it will lead to malpractice, } \\
\text { one should not crave alcohol. }\end{array}$ & $=\begin{array}{l}\text { [5.] Because it will lead to malpractice, one } \\
\text { should not crave alcohol. }\end{array}$ \\
\hline $\begin{array}{l}\text { [6.] Because one will lose the reason for } \\
\text { healing when time passes, one should } \\
\text { not be lazy. }\end{array}$ & $\approx \begin{array}{l}\text { [6.] Because the management of pain is special } \\
\text { and consequential, one should be neither too } \\
\text { lax nor too ambitious. }\end{array}$ \\
\hline $\begin{array}{l}\text { [7.] So that one's profits will not lead to } \\
\text { afflictive emotions, one should cultivate } \\
\text { the mind of enlightenment. }\end{array}$ & $\neq$ & $\begin{array}{l}\text { [7.] Because one will not strike the target in } \\
\text { surgery, one should be neither too nervous } \\
\text { nor too arrogant with patients. }\end{array}$ \\
\hline
\end{tabular}

Table 5.2. A Comparison of Professional Medical Ethics in the Expanded Elucidation of Knowledge and the Feast for Scholars

This list of seven ethical prescriptions, said to have been spoken by Tri Songdetsen to the foreign physicians at Chimpu, compliments the previous list of ethical prescriptions designed for the common patients of Tibet. Just as the patient is expected to welcome and respect physicians, physicians are to maintain this projected status by behaving with honesty, manners, and diligence. Perhaps recognizing the fact that these prescriptions lay outside the realm of religious doctrine, Drangti states in his final instruction that one should cultivate the altruistic mind of enlightenment, presumably through the practice of the six perfections (phar phyin drug) that are delineated toward the end of the Expanded Elucidation. ${ }^{709}$ With the exception of this final item, Pawo's list of professional ethics is nearly identical to that of Drangti, potentially indicating a sharper distinction between bodhisattva ethics and medical ethics in the Kagyü Zur school than in the Sakya Medical House.

Although a consummate study of the transmission of these ethical codes is beyond the purview of the present study, it is worth noting that they were transmitted and transformed by prominent figures in subsequent centuries_such as Kawa Shākya Wangchuk Künga Gyentsen Pelzangpo (ska ba shākya dbang phyug kun dga' rgyal mtshan dpal bzang po, b. late I5th

${ }^{707}$ Gsang ba man ngag gis [sic] rgyud kyi spyi don shes bya rab gsal rgyas pa (Beijing), 3Ia: sman pa pha yin phan pa'i blo bskyed//_nad pa bu yin [pas] mtshang mi brjod//_mdzangs kyis khrel 'chor bas ngan ma byed//_ya rabs kyi gral 'chor bas zas la ma ngan//_dpyad la [=lag?] nyes 'ong bas chang la ma sred//_dus 'das na gzo rgyu 'chor bas le lo ma byed//_bras bu nyon mongs su mi 'gyur gyis byang chub tu sems bskyed//.

${ }^{708}$ Chos 'byung mkhas pa'i dga' ston (Beijing: Mi rigs dpe skrun khang, 1986), vol. 2, I5I9: mnga' bdag gis sman pa bla ma dang pha yin pas byams pa bskyed/_nad pa bu dang slob ma yin pas mtshang ngan phyir ma brjod/_mdzangs kyi khrel'chor bas khyim nas lag ngan ma byed/_ya rabs kyi tshul la gnod pas zas la ma ngan/_sman dpyad la lag nyes yong pas chang la ma dga'_zug gcog pa la khyad yod cing thal nyen yod pas le lo dang tshod'chos ma byed/_sman dpyad gnad du mi phog pas nad pa la ngo tsha dang tshul 'chos ma byed/_ces zhal ta bdun mdzad/.

${ }^{709}$ See Gsang ba man ngag gis [sic] rgyud kyi spyi don shes bya rab gsal rgyas pa (Beijing), 45b-47b. 
c.?), ${ }^{710}$ Zurkhar Lodrö Gyelpo, ${ }^{711}$ and the Desi Sanggyé Gyatso. ${ }^{712}$ Each iteration of the popular and/or professional ethics included in these fifteenth-, sixteenth-, and seventeenth-century khokbuk curricula appears to have been transformed by its author, although important trends emerge from their comparison. Like Pawo, Kawa Shākya Wangchuk and Zurkhar Lodrö Gyelpo of the Zur tradition remove the exemption of physicians from the blood money laws, while the Desi Sanggye Gyatso-known for his affinities to the Jang (byang) tradition of Tibetan medicine-reiterates the exemption in a fashion similar to the ethical prescriptions of Drangti. In light of the fact that a thorough comparison of the Zur and Jang schools during the fifteenth, sixteenth, and seventeenth centuries remains a desideratum in the study of the Tibetan medical tradition, perhaps the transformations of these codes of medical ethics over time-particularly in the context of the institutional relationship between medicine and religion-might be a good place to begin such an assessment. Regardless of the details, the transmission of social codes for popular and professional ethics in the Tibetan medical tradition involved transformation with each and every iteration, reflecting the values of the era in which each edition was published and recommending behavioral prescriptions for future generations of physicians and patients.

\section{Precedents and Interpretations of Professional Ethics in the Tibetan Medical Tradition}

Although it was Drangti Penden Tsojé that first articulated these medical prescriptions in the fourteenth century, they were not without precedent. As we have already seen, the Pillar Testament, the Mirror Illuminating the Royal Genealogies, and so forth all contain similar sets of legal and ethical prescriptions that were presented as royal ordinances. Just like the transformation of Minister Gar's escape from China into a test for physicians, here too we witness the gradual transformation of legal codes to moral prescriptions and finally to a set of professional ethics. Just as the laws and ethics described in the Mirror were depicted as the foundations for a peaceful and harmonious society in which the gentry and the common subjects mutually benefit, here too Drangti provides an outline for the ideal manner in which both physician and patient might act to ensure reciprocal satisfaction. Just as these ordinances were adapted for the changing circumstances of the fourteenth century, so they continued to be adapted in subsequent writings.

${ }^{710}$ The work of Kawa Shākya Wangchuk Künga Gyentsen Pelzangpo is not currently extant, but see Jampa Trinlé citing his work in Byams pa 'phrin las, Byams pa'phrin las kyi gsung rtsom phyogs bsgrigs (Beijing: Krung go'i bod kyi shes rig dpe skrun khang, 1996), 47I-72.

${ }_{7 I I}$ See Sman pa rnams kyis mi shes su mi rung ba'i shes bya spyïi khog dbubs (Chengdu: Si khron mi rigs dpe skrun khang, 200I), 259-60.

${ }^{712}$ Sde srid sman gyi khog 'bubs, Bod kyi gso ba rig pa'i gna' dpe phyogs bsgrigs dpe tshogs vol. 8 (Beijing: Mi rigs dpe skrun khang, 2005), I23. For a translation, see Gavin Kilty, trans., Mirror of Beryl: A Historical Introduction to Tibetan Medicine (Boston, MA: Wisdom Publications, 2009), I65-66. 
If we can confidently trace the inspiration for this narrative framing of medical ethics to the same narrative framing of social ethics found in the Pillar Testament, Mirror Illuminating the Royal Genealogies, and so forth, as argued above, how should we explain the stark difference in ethical prescriptions? As described above, for example, the legal codes found in the Mirror expressly prescribe the payment of a fee following the murder of another person. ${ }^{713}$ This, of course, refers to the "blood money" from which Drangti's twelfth prescription for patients and narrative description so adamantly protects practicing physicians. This stipulation must not have been popular in subsequent centuries, for it appears in none of the subsequent ordinances for patient prescriptions cited above. Seeing that this first articulation of medical ethics as royal ordinance effectively contradicts-or, at the very least, complicates-the social ethics outlined in the Mirror, it is hard to posit the ultimate source for these popular prescriptions in the Mirror itself, beyond the notion of royal ordinance as narrative frame.

Comparing the fourteenth- and sixteenth-century iterations of popular and professional ethics in Tables 5.I and 5.2, it becomes apparent that the latter is a more stable tradition of transmission. Five out of seven of the prescriptions found in the Feast for Scholars are effectively identical to those found in the Expanded Elucidation, with the exception of the prescription for the development of bodhisattva ethics. If Drangti's advice for physicians to cultivate the mind of enlightenment clearly derive from the Buddhist ethical tradition, whence do the other six codes for professional ethics derive? From the Hippocratic Oath, as suggested by Beckwith nearly four decades ago? As proposed by L. Edelstein, the Hippocratic Oath was not initially a "message of timeless validity," but, rather, the product of a specific school of physicians acting within a specific historical and intellectual context. ${ }^{714}$ By the fourteenth century, with the translation and transmission of Greek medical works in the Arabic medical tradition, ${ }^{715}$ as well as the transmission of professional codes for medical ethics based on the Hippocratic Oath throughout Eurasia for nearly two millennia, ${ }^{716}$ the likelihood that members of the Sakya Medical House might have encountered the Hippocratic Oath

713 Sørensen, Tibetan Buddhist Historiography, I82: "Variable fines to be introduced on murderers"; Rgyal rabs gsal ba'i me long, vol. I, 75: sad pa la che chung gi stong byed pa/.

${ }^{714}$ See Ludwig Edelstein, "The Hippocratic Oath: Text, Translation and Interpretation," Ancient Medicine: Selected Papers of Ludwig Edelstein, ed. Owsei Temkin and C. Lilian Temkin (Baltimore, MD: The Johns Hopkins Press, I967 [repr. 1943]), 3-63. The notion that the Oath primarily derives from a Pythagorean school of medicine has been challenged by $\mathrm{L}$. Edelstein's student, O. Temkin in Owsei Temkin, "On Second Thought," in "On Second Thought" and Other Essays in the History of Medicine and Science (Baltimore, MD: The Johns Hopkins University Press, 2002), I-20.

${ }_{715}$ The Hippocratic Oath appears to have been largely neglected as a basis of medical ethics during the Early Middle Ages, but this changed with new translations from Greek and Arabic in later periods. See Carlos R. Galvão-Sobrinho, "Hippocratic Ideals, Medical Ethics, and the Practice of Medicine in the Early Middle Ages: The Legacy of the Hippocratic Oath," The Journal of the History of Medicine and Allied Sciences 5I (I996): 438-55.

${ }^{716}$ See, for example, S. S. Kottek, J. O. Leibowitz, and B. Richler, "A Hebrew Paraphrase of the Hippocratic Oath (from a Fifteenth-century Manuscript)," Medical History 22 (1978): 438-445. 
through Central Asian physicians that were active during the Yuan dynasty is relatively high. ${ }^{717}$ Despite this possible encounter, however, few traces of the Hippocratic Oath remain in the seven-point set of professional ethics expounded by Drangti.

A careful comparison of the Hippocratic Oath with Tibetan professional ethics yields some parallels. The opening presentation of physician as father and patient as son in the first two points of Drangti's list is intriguing, for example, in light of the presentation of the teacher as the father and the equation of sons and pupils in the Oath. ${ }^{718}$ If there were any historical connection between these parallel comparisons, however, they would have been fundamentally altered over the course of the transmission of the Oath. The general emphasis on comportment in the third, fourth, and fifth points of Drangti's list also find parallels in the Oath, although with different emphases on types of misbehavior.$^{79}$ Thus, while points six and seven find no parallel in the Oath, the general appeal to familial relations in points one and two of Drangti's list, as well as the emphasis on professional chastity in terms of behavior and eating in points three, four, and five, may indicate a distant Hippocratic ancestor. Further studies into the imbrications of Chinese and Central Asian medical traditions during the Yuan dynasty may indeed reveal the circumstances under which the tenets of the Greek medical tradition may have been (re-)introduced to Tibet.

\section{Summary and Conclusions: A Tradition of Historiographical Creativity at the Sakya Medical House}

In writing his magnum opus, the Expanded Elucidation of Knowledge, Drangti Penden Tsojé undoubtedly was working within the creative confines of tradition. In writing his biography of Sākyamuni Buddha, for example, Drangti cites copious canonical translations from Chinese sources, all of which can be found in the Religious History written by Butön Rinchen Drup at the Sakya monastery of Zhalu (zhwa lu) a generation before Drangti and his Expanded Elucidation. In line with his Sakya predecessor's emphasis on orthodoxy and accuracy, Drangti is sure not to contract the canonical scriptures in telling the life story of Sākyamuni Buddha.

${ }^{717}$ On the fourteenth-century collection of West and Central Asian medical instructions written in Chinese一the Huihui Formulary (huihui yaofang 回回藥方)—see Shinno, The Politics of Chinese Medicine under Mongol Rule, I38-40; and Angela Schottenhammer, "Huihui Medicine and Medicinal Drugs in Yuan China," in Eurasian Influences on Yuan China, ed. Morris Rossabi (Singapore: Institute of Southeast Asian Studies, 2013), 75-IO2.

718 For a translation, see Edelstein, "The Hippocratic Oath: Text, Translation and Interpretation," 6: "To hold him who has taught me this art as equal to my parents ... to give a share of precepts and oral instruction and all the other learning to my sons and the sons of him who has instructed me ...."

${ }^{719}$ Edelstein, "The Hippocratic Oath: Text, Translation and Interpretation," 6: "Whatever houses I may visit, I will come for the benefit of the sick, remaining free of all intentional injustice, of all mischief and in particular of sexual relations with both female and male persons, be they free or slaves." 
Even here, however, Drangti demonstrates his propensity for creativity, for he does not merely summarize the writings of Butön and Lama Dampa Sönam Gyentsen, instead opting to include an historical account of the revelation of the Nyingma tantras. Thus, Drangti explicitly positions himself as the disciple of Lama Dampa and faithfully includes the Sakya narrative traditions of his teacher, but is also not hesitant to include the Nyingma tantras of his own familial lineage.

Following the synthesis of imperial narratives by Lama Dampa at fourteenth-century Sakya, Drangti Penden Tsoje also centrally features narratives of the Tibetan empire in his Expanded Elucidation. In Drangti's narration of medical developments in Tibet again we find his penchant for preserving tradition while still transforming its contexts and connotations. The entertaining tale of Minister Gar's deception of royal physicians and escape from China-a story that already had a long and complex history of transmission by the fourteenth century-was transformed into a tale of Tri Songdetsen testing the nine foreign physicians that had famously come to Tibet following reports of an ill emperor. Instead of illustrating the cleverness of Minister Gar in his escape, the tale came to demonstrate the skill of foreign physicians that translated their teaching into the Tibetan language, thereby demonstrating their mastery of medicine and the reliability of their medical instructions. This narrative transformation appears to have been the contribution of Drangti Penden Tsojé himself, demonstrating the hermeneutic importance of reading fourteenth-century tellings of the eighth century as just that-fourteenth-century narratives that may or may not relate to the eighth century at all.

By the time Drangti was depicting Tibet as the center of the medical cultural world, the geographic shift of Tibet from the periphery of the Indian cosmopolis to the center of the Buddhist world had already been under way for centuries. Even in the medical tradition, the thirteenth-century instructions of the Gold Measure collection were already depicting Tibetan instructions as the essence of the teachings of neighboring traditions. The penultimate chapter of the Subsequent Tantra epitomizes this mentality, for it demonstrates that the Four Tantras itself is indeed the ultimate source of all neighboring traditions, like a moon reflected in many different ladles of water. This geographic elaboration must have been a later addition to the text, however, for earlier layers of the work consistently present itself as the primordial teaching of emanated sages that presumably existed beyond the confines of Tibetan space. In light of the contradicting notions of space and time presented in the Four Tantras, the conflicting ethical values presented in the work should also come as no surprise.

Perhaps in response to the generally deceptive ethical prescriptions found in the early layers of Explanatory Tantra, Drangti Penden Tsojé mimicked Lama Dampa's establishment of legal codes in fourteenth-century Tibet through the ordinances of the Tibetan emperors. Like Lama Dampa's explicit delineation of rules for both the governors and the governed, Drangti did not only prescribe ethics for physicians, but also for patients. Commanding the common people to hold medical authorities as the equals of spiritual authorities with threats of punishment, Drangti effectively sought to create an ideal environment for the practice of 
medicine, beyond the possibility of complaints, threats, and/or lawsuits from patients and their families. In order to ensure cooperation, Drangti also provided a set of professional ethics that encourages a physician to develop a rapport with his patients, behave with comportment and chastity, and develop the altruistic mind of enlightenment. Indeed, by relating these ethical prescriptions through the ordinances of Tri Songdetsen, Drangti effectively delineates an ethical code for the bodhisattva physician-a figure that would continue dominate the Tibetan medical tradition, particularly under the Ganden Podrang. Even as early as the Explanatory Tantra, amidst instructions for the deception of patients, we are told that "By abstaining from deceit, desire, and so forth, while engaging in healing patients, the ultimate result is proceeding to the ground of an unexcelled buddha." ${ }^{720}$ By imagining a past in which physicians would genuinely care for patients, and patients would revere and trust physicians, while simultaneously providing specific ethical codes for the actualization of this vision, Drangti Penden Tsoje subjunctively recreated the social and institutional world of the Tibetan physician, in the fourteenth century and beyond.

${ }^{720}$ Dpal ldan rgyud bzhi dpe bsdur ma, vol. I, 274-75: mthar thug 'bras bu g.yo sgyu 'dod pa rnams//_spang nas nad pa gso ba la 'jug pal/_bla med sangs rgyas sa la bgrod zhes//_thos mdzad sman pa'i rgyal bos bshad pa yin//. 


\section{Conclusions: Diagnosis and Prescription, History and Prophesy}

The rhetorical trajectory of the Tibetan medical tradition is a movement from diversity to unity, from difference to sameness. This movement was so complete that, by the end of the fourteenth century, even moments of difference and periods of development are difficult to discern in the retroactively unified voice of the Buddha, Master of Medicine, and the royal physicians of imperial Tibet. Even if these histories of origins and transmissions render the theories and practices of the Tibetan medical tradition timeless and unchanging, eternally given, the origins and transmissions of such histories elicit the opposite effect. Such has been the task of the present dissertation-to discern controversy, competition, and change, even within a unified Tibetan medical tradition, and to retrieve voices that have long fallen silent. To achieve these goals, we have had to revive unresolved dialogues in composite works of instruction, commentary, and narrative, while simultaneously entertaining the perspectives of both history and tradition, all of which would occasionally fall into conflict. The end result, I hope, has not been a definitive perspective on this early and formative period in Tibetan medical history, but instead a colloquium of prescriptive and prophetic voices that came to shape subsequent understandings of the Tibetan medical tradition.

As should be the case for all good medical investigations, we began by observing the expressions of the body and considering their many therapeutic implications. Despite observing the same haptic phenomenon, the distinct training and dissonant etiologies of different healers resulted in different prescriptions for therapy. As these modes of observing, interpreting, and healing came into competition, the conceptual flexibility of channel examination allowed it to subsume nearly all other modes of diagnosis, resulting in a composite diagnostic repertoire of demons, humors, and other related theories of balance and disease. Even if channel examination and urinalysis did come to replace divinatory modes of diagnosis in the Tibetan medical tradition, the divinatory interpretations regarding pathogenic demons, mundane fortunes, and the time of death were never elided from the physician's hermeneutic repertoire. By exhuming the earliest available representations of such unresolved controversies between the diviner and the physician, the practical and theoretical foundations of the Tibetan medical tradition also begin to come to light.

Just as when the same body was examined, the diviner would hear demon while the physician would feel humors, when the same teachings of the Four Tantras were taught, the physician would hear the Buddha, Master of Medicine, while the literatus would merely hear some Tibetan imposter. Not unlike the early scholars active during the Tibetan assimilation of Buddhism, Tibetan physicians of the eleventh and twelfth centuries were continually translating, summarizing, and expanding upon both received and extant theories and instructions, such that by the turn of the thirteenth century the corpus of Tibetan medical literature was unmanageable. During this time Tibetan literati, self-styled masters of the five Indian fields of knowledge, came to distinguish the Indian from the Tibetan, the cosmopolitan 
from the vernacular, rendering the most legible and locally practical instructions as outside canonical medicine and, therefore, outside the Buddhist monastic institution. Physicianscholars and representatives of such practical traditions responded by creatively framing their own instructions as the teachings of buddhas, bodhisattvas, and Buddhist sages, as well as even the teachings of cosmopolitan figures like Vāgbhața and Candranandana. Even if vernacular medical instructions were never included in the Translated Treatises of the Tibetan Buddhist canon, it was the Buddhist framing and superior efficacy of these local traditions that ultimately led to their institutionalization in the late fourteenth century.

Indeed, how could a Tibetan representative of Buddhist scholasticism promote the medical teachings of Brahmā in good faith? One could render medicine as a field of knowledge and practice outside of Buddhist soteriology, for example, or deemphasize the originary role of Brahmā and highlight its transmission among Buddhist sages, or even creatively overturn the very notion that Brahmā first remembered medicine with creative hermeneutics and storytelling. Indeed, it was the latter technique that would ultimately gain prominence in the Tibetan medical tradition, for if Brahmā remembered medical teachings, he would have had to hear medical teachings, which could have potentially been taught by a buddha. Reconciling distinct narratives that had long been established in Indian tradition such that Brahmā became the student of a buddha proved challenging, but not impossible. By evoking Kanakamuni Buddha instead of Śākyamuni Buddha, all while promoting a neoconservative and orthodox telling of the latter's life story, Drangti Penden Tsojé was able to integrate both the Brāhmanic and the Buddhist, the Indian and the Tibetan, all while subsuming the former within the narrative frame of the latter.

The narrative creativity of Penden Tsojé extends beyond his reconciliation of the literatus and physician approaches to medical mythology, for he also effectively united the frayed practical lineages of Yutok, Sumtön, Jang, Biji, and potentially others, all within the framework of the Sakya Medical House. Integrating the Yutok and Drangti familial lineages proved to be the most problematic, for he appears to have invented scions of the Yutok clan, and potentially even an entire Yutok school of medicine at Gozhi Retang, before narratively absorbing these figures and their teachings into the scions of the Drangti family. While unifying the many familial lineages and schools of the Tibetan medical tradition, Penden Tsojé also worked to standardize the contents of the Four Tantras, separating it from the previously amorphous corpus of exegetical and narrative literature found in the Eighteen Partial Branches. He then arranged the contents of these two corpuses-root text and commentaries-within his khokbuk curriculum for the Sakya Medical House, effectively standardizing the lineage history and instructional materials for a unified Tibetan medical tradition, institutionalized at the Buddhist monastery.

If the teachings of the Sakya Medical House were originally taught by the Buddha and then transmitted in South Asia among Buddhist sages, how, then, did such a Buddhist medical tradition come to be transmitted to Tibet? Elaborating upon the legends of the Tibetan empire that had been transmitted outside of the Buddhist monastery for centuries and finally 
integrated along with orthodox Indian narratives at fourteenth-century Sakya, Penden Tsojé also provides a vision for the political centralization of pan-Asian medical traditions in Tibet during the imperial period (ca. 600-850). Promoting the Four Tantras as the essence of all medical teachings-both Buddhist and non-Buddhist—and the Tibetan tradition as the essence of all medical traditions-including South, East, and Central Asian-Penden Tsojé presents an inspiring vision for the study and practice of Tibetan medicine. These legends take on a prophetic tone for, following the translation and transmission of cosmopolitan medical theories and practices to Tibet, Penden Tsojé also prescribes a code of professional medical ethics for physicians and prophesies the promotion of bodhisattva-physicians to the social status of the clergy through legal codes pronounced by emperor Tri Songdetsen himself. With this final narrative piece in place, the teachings of the Tibetan medical tradition would paradoxically continue to be both Buddhist and cosmopolitan in origin, both Indian and Tibetan in transmission, and finally both mundane and transcendent in practice.

As we have seen, the Tibetan medical tradition has grown and changed over the centuries-progressed, even-but, importantly, very few theories and practices have been discarded, only changed and reinterpreted. As described in the Upanișads, and as evoked by T. S. Eliot at the end of "The Waste Land," when Prajāpati thunderously exclaimed DA DA DA to the gods, demigods, and humans, the gods, given to pleasure, heard "control" (damyatā), the demigods, given to cruelty, heard "be compassionate" (dayādhvam), and the humans, given to greed, heard "give to others" (dattâ). ${ }^{721}$ Similarly, in performing our archeology of knowledge, we have found that the twelfth-century diviner, given to exorcism, may have heard the voices of demons in the channels at the exclusion of humors and thermal imbalances; the thirteenthcentury literatus, given to Indocentrism, may have heard the voices of Tibetan authors in the Four Tantras at the expense of buddhas and emanated sages; and the fourteenth-century physician, given to Buddhocentrism and even Tibetocentrism, may have heard the voices of enlightened emanations in Tri Songdetsen and Yutok Gönpo at the expense of Tibetan individuals. With the unification of such diverse perspectives in the standard narratives of the Sakya Medical House, the Tibetan medical tradition became a palimpsest of unresolved controversies-a continued colloquium of medically prescriptive and historically prophetic voices with which the student of tradition might engage. Indeed, it was this accretion of diverse theories and practices that allowed for the continued success of a unified Tibetan medical tradition in the diverse social and political contexts of subsequent Tibetan history. From the fourteenth century onward, the primary institutional center of Tibetan medical scholasticism has been the monastery, the prescribed ethics of the Tibetan medical tradition have been altruistic, and the origins of the Tibetan medical teachings have been Buddhist.

${ }^{721}$ See Chapter Five of the Bṛhadāranyaka Upaniṣad in Patrick Olivelle, trans., Upanișads (Oxford: Oxford University Press, 1996), 73. See also T. S. Eliot, The Waste Land and Other Poems (Buffalo, NY: Broadview Press, 20II), 8I-82; and, for an analysis of this parable in relation to context and different ways of thinking, see A. K. Ramanujan, "Is There an Indian Way of Thinking? An Informal Essay," Contributions to Indian Sociology 23, no. I (I989): 4I-58. 


\section{Bibliography}

\section{Tibetan- and Chinese-language Works}

Bka' chems ka khol ma. Lanzhou: Kan su'u mi rigs dpe skrun khang, I99I.

Bod ljongs bod lugs gso rig slob grwa chen mo, ed. Krung go’i bod lugs gso rig rtsa che’i dpe rnying kun btus: Pho brang po ta la'i gsung rab gter mdzod las btus [Zhongguo yiyao yingyin guji zhenben 中国藏医药影印古籍珍本; China's Traditional Tibetan Medical Texts: A Treasury of Scriptures from the Potala Palace]. Lha sa: Bod ljongs mi dmangs dpe skrun khang, 20I4. 30 vols.

Bad kan smug po'i stong thun, vol. I4, text 5.

Bdud rtsi snying po bsang [sic] ba yan lag brgyad pa phyi ma 'phrin las kyi rgyud las/_jug don yongs su dpyad [sic] pa, vol. 4, text 6, pp. 523-30 (ff. Ia-I6a).

Bdud rtsi snying po gsang ba man ngag gi rgyud, vol. 4 , text 5.

Bdud rtsi snying po kha che zla dga' yis mdzad pa, vol. II, text I.

Ga las pa sum cu pa, vol. I, text I2.

Grang ba'i stong thun, vol. 3, text 9.

Grang ba'i stong thun, vol. I4, text 4.

Gser khri [=bre] rgyas pa zhes bya ba bzhugs so, vol. I8, text I3.

Gso ba rig pa rgyan gyi me tog, vol. 3, text 40.

Gso dpyad yan lag brgyad pa'i snying po bsdus pa las phyi ma’i gnas bzhugs so, vol. 2, text 6.

Gso spyad [=dpyad] yan lag brgyad pa'i snying po bsdus pa, vol. 2, text I.

Khog dbubs shes bya rab gsal rgyas pa, vol. 20, text 2I.

Lag len spod chung gyi 'brel [sic] pa, vol. 3, text 2.

Med thabs med pa'i mchong [sic] gsum, vol. 3, text 3.

Sman dpyad rgyal po'i dkor mdzod bzhugs so/ gso dpyad bdud rtsi thigs pa, vol. I, text I5, pp. 2I772 (ff. Ia-84b).

Reg pa rtsa'i spra sgrub klu sgrub gyis mdzad pa bzhugs s.ho, vol. I, text Io.

Rgyud bzhi' 'jug don gyis dbu', vol. 4, text 6, pp. 512-22 (ff. Ia-I6b).

Rgyud bzhii mjug don yongs gtad, vol. 8, text 8, pp. 332-37 (ff. Ia-IIb).

Rgyud rgyal bdud rtsi snying po las lag len dmar khrid sde tshan lnga'i 'grel pa, vol. 8, text 6.

Rtsa chu'i stong thun g.yu thog gi bzhed pa, vol. 3, text 7 .

Rtsa mdo'i 'grel pa nyi ma'i 'od zer, vol. I, text I4.

Skor tshoms stong thun bcu gcig las dang po rtsa'i stong thun, vol. 3, text 5.

Skor tshoms stong thun bcu gcig, vol. I4, text 4.

Sman dpyad zla ba'i rgyal po, vol. 5, text I.

Sman dpyad zla ba'i rgyal po, vol. 5, text 2.

Be’u bum nag po. Bod kyi gso ba rig pa'i gna' dpe phyogs bsgrigs dpe tshogs, vol. 34. Beijing: Mi rigs dpe skrun khang, 2005. 
Brang ti lha rje'i rim brgyud kyi man ngag gser bre chen mo. Lhasa: Bod ljongs mi dmangs dpe skrun khang, 2005.

Byams pa 'phrin las. Byams pa 'phrin las kyi gsung rtsom phyogs bsgrigs. Beijing: Krung go'i bod kyi shes rig dpe skrun khang, 1996.

Byang khog dmar byang gsal ba’i sgron me. Bod kyi gso ba rig pa'i gna' dpe phyogs bsgrigs dpe tshogs, vol. IoI. Beijing: Mi rigs dpe skrun khang, 2014.

Cha lag bco brgyad. Bod kyi gso ba rig pa'i gna' dpe phyogs bsgrigs dpe tshogs, vol. 25. Beijing: Mi rigs dpe skrun khang, 2005.

Brgyud pa'i rnam thar med thabs med pa, text I2, pp. 487-97.

'Grel pa 'bum chung gsal sgron nor bu'i 'phreng mdzes, text 5, pp. III-223.

Gso dpyad mu tig 'phreng ba, text I7, pp. 745-70.

Kha 'thor rin chen phung po, text IO, pp. 44I-54.

Khog dbug khyung chen lding ba, text I, pp. I-24.

Khyad par zab pa rnam gsum, text I4, pp. 522-30.

Lag len dmar khrid yig chung, text II, pp. 455-86.

Lag len rin chen gter spungs, text 9, pp. 396-440.

Mkhas khyad ngo mtshar bzhi sprugs, text 15, pp. 53I-33.

Ming don brda sprod rnam lnga, text 8, pp. 387-95.

Phan bya sngags 'bum dkar po, text I8, pp. 77I-87.

Rgyud chung bdud rtsi snying po, text I6, pp. 534-744.

Rtsod bzlog gegs sel 'khor lo, text 6, pp. 224-42.

Sa dpyad stag mos rngam thabs, text 3, pp. 53-84.

Skor tshoms stong thun bcu gcig, text 7, pp. 243-386.

Stong thun mdzes pa'i 'ja' ris, text 2, pp. 25-52.

Tikka mun sel sgron me, text 4 , pp. 85-IIO.

Yang sbas gab pa bco brgyad, text I3, pp. 498-52I.

Chos 'byung me tog snying po sbrang rtsi’i bcud. Lhasa: Bod ljongs mi dmangs dpe skrun khang, 1988.

Chos 'byung mkhas pa'i dga' ston. Beijing: Mi rigs dpe skrun khang, I986. 2 vols.

Da Yuan shengzheng guochao dianzhang 大元聖政國朝典章. Taibei: Guoli Gugong bowu yuan, I976.

Dbang 'dus. Gso rig pa'i tshig mdzod g.yu thog dgongs rgyan. Beijing: Mi rigs dpe skrun khang, 1982.

Dpal brtsegs bod yig dpe rnying zhib 'jug khang, ed. Sa skya gong ma rnam lnga'i gsung 'bum dpe bsdur ma las grags pa rgyal mtshan gyi gsung pod lnga pa. Beijing: Krung go’i bod rig pa dpe skrun khang, 2007.

Gsang ba man ngag gis [sic] rgyud kyi spyi don shes bya rab gsal rgyas pa. Unpublished manuscript held at the Nationalities Cultural Palace Museum (Minzu wenhua gong 民族文化宫) in Beijing.

Gser mchan rnam bkra gan mdzod. Beijing: Mi rigs dpe skrun khang, 2006.

W. A. McGrath | Buddhism and Medicine in Tibet | 229 
Gso ba rig pa rgyan gyi me tog. Bod kyi gso ba rig pa'i gna' dpe phyogs bsgrigs dpe tshogs, vol. 8o. Beijing: Mi rigs dpe skrun khang, 2008.

Gso rig 'bum bzhi. Bod kyi gso ba rig pa'i gna' dpe phyogs bsgrigs dpe tshogs, vol. 36. Beijing: Mi rigs dpe skrun khang, 2006.

Gso rig sman gyi khog 'bugs. Bod kyi gso ba rig pa'i gna' dpe phyogs bsgrigs dpe tshogs, vol. 6. Beijing: Mi rigs dpe skrun khang, 2005.

Gtsang stod zin thig dang yang thig. Bod kyi gso ba rig pa'i gna' dpe phyogs bsgrigs dpe tshogs, vol. 42. Beijing: Mi rigs dpe skrun khang, 2006.

G.yu thog snying thig. Bod kyi gso ba rig pa'i gna' dpe phyogs bsgrigs dpe tshogs vol. 43. Beijing: Mi rigs dpe skrun khang, 2007.

Gzhung dri med gzi brjid kyi 'grel ba nyi ma’i 'od zer. Bod kyi gso ba rig pa'i gna' dpe phyogs bsgrigs dpe tshogs, vol. IoI. Beijing: Mi rigs dpe skrun khang, 2014.

Krung go'i bod rig pa zhib 'jug ste gnas kyi bka' bstan dpe sdur khang, ed. Bka' 'gyur dpe bsdur ma. Beijing: Krung go'i bod rig pa dpe skrun khang, 2006-2009.

'Phags pa dpung bzang gis zhus pa zhes bya ba'i rgyud. Text 0835, vol. 96 (wa), pp. 434-508.

'Phags pa gser'od dam pa mchog tu rnam par rgyal ba'i mdo sde'i rgyal po theg pa chen po'i mdo. Text 0583, vol. 89 (pa), pp. pp. 80-459.

'Phags pa gser 'od dam pa mdo sde'i dbang po'i rgyal po zhes bya ba theg pa chen po'i mdo. Text 0584, vol. 89 (pa), pp. 460-798.

'Phags pa gser 'od dam pa mdo sde'i dbang po'i rgyal po zhes bya ba theg pa chen po'i mdo. Text 0585, vol. 90 (pha), pp. 3-I75.

'Phags pa lag bzangs kyis zhus pa zhes bya ba theg pa chen po'i mdo. Text oo87, vol. 43 (ca), pp. 433-5IO.

Krung go'i bod rig pa zhib 'jug ste gnas kyi bka' bstan dpe sdur khang, ed. Bstan 'gyur dpe bsdur ma. Beijing: Krung go'i bod rig pa dpe skrun khang, 2006-2009.

Dpung bzangs kyis zhus pa’i rgyud kyi bsdus pa’i don. Text I578, vol. 36 (thu [7I]), pp. I02-49.

'Phags pa dpung bzangs kyis zhus pa'i rgyud kyi bsdus pa'i don dgrol ba'i brjed byang. Text I580, vol. 36 (thu [7I]), pp. 274-3I9.

'Phags pa dpung bzangs kyis zhus pa'i rgyud kyi tshig gi don bshad pa'i brjed byang. Text I579, vol. 36 (thu [7I]), pp. 150-273.

Rnam par bshad pa’i rigs pa. Text 3290, vol. 77 (shi [15I]).

Sbyor ba brgya ba. Text 3543, vol. III (he [213]), pp. 3-22.

Sman dpyad yan lag brgyad pa'i sying po'i 'grel pa. Text 3546, vol. III (he [213]), pp. 39-I42.

Sman 'tsho ba'i mdo. Text 3544, vol. III (he [213]), pp. 23-33.

Theg pa chen po mdo sde’i rgyan zhes bya ba'i tshig le'ur byas pa bzhugs so. Text 3252, vol. 70 (phi [138]).

Theg pa chen po rgyud bla ma'i bstan bcos. Text 3256, vol. 70 (phi [138]).

Yan lag brgyad pa'i snying po zhes bya ba’i sman dpyad kyi bshad pa. Text 3548, vols. III-I2 (he$e$ [2I3-I4]).

Yan lag brgyad pa’i snying po’i bsdus pa. Text 3547, vol. III (he [213]), pp. I43-944. 
Yan lag brgyad pa'i snying po'i rnam par 'grel pa tshig gi don gyi zla zer. Text 3549, vol. II3 (kokho [215-I6]), pp. 3-I716; vol. II4 (go [217]), pp. 3-840.

Lam 'bras Tshogs bśad: The Sa-skya-pa Teachings of the Path and the Fruit, According to the Nor-pa Transmission. Dehra Dun: Sakya Centre, 1985.

Lobsang Tenzin and Losang Norbu Shastri, trans. Drang srong chen po me bzhin 'jug gis mdzad pa'i tsa ra ka'i bsdu ba [Caraka-saṃhitā of Maharși Agniveśa]. Varanasi: Central Institute of Higher Tibetan Studies, 2006.

Luo Bingfen 罗秉芬, Huang Bufan 黄布凡, and Byams pa 'phrin las. Tun hong nas thon pa'i bod kyi gso rig yig cha bdams bsgrigs [Dunhuang ben Tubo yixue wenxian xuanbian 敦煌本吐蕃医学文献选编; An Anthology of Tibetan Medical Texts from Dunhuang]. Beijing: Mi rigs dpe skrun khang, 1983.

Luo Bingfen 罗秉芬, Huang Fukai 黄福开, and Byams pa 'phrin las. Tun hong nas thon pai bod kyi gso rig yig cha gces bsdus [Dunhuang ben Tubo yixue wenxian jingyao 敦煌本吐蕃医学文献精要; A Selection of Tibetan Medical Texts from Dunhuang]. Beijing: Mi rigs dpe skrun khang, 2002.

Ma ṇi bka' 'bum. Lhasa: Ser gtsug nang bstan dpe rnying 'tshol bsdu phyogs sgrig khang, 2008. 2 vols.

Man ngag gser bre ma dang dngul bre ma. Bod kyi gso ba rig pa'i gna' dpe phyogs bsgrigs dpe tshogs, vol. 6. Beijing: Mi rigs dpe skrun khang, 2004.

Miaobi pusa suowen jing 妙臂菩薩所問經 (Ti8no896).

Rba bzhed phyogs bsgrigs. Beijing: Mi rigs dpe skrun khang, 2009.

Rin chen rgyal. Sman dpyad zla ba'i rgyal po'i gzhung don la dpyad pa [An Analysis of Text and Meaning in the Medicine of the Moon King], Bod kyi 'bum rams pa'i dpyad rtsom dpe tshogs [Tibetan Doctoral Dissertation Publication Series]. Xining: Mtsho sngon mi rigs dpe skrun khang, 20II.

Rgyal rabs gsal bai me long. Beijing: Mi rigs dpe skrun khang, 2002. 2 vols.

Rgyud bzhi bka' dang bstan bco rnam par dbye ba mun sel sgron me zhes bya ba bzhugs so. In Bod kyi sman rtsis ched rtsom phyogs bsdus, ed. Bod rang skyong ljongs sman rtsis khang, 64-7I. Lhasa: Bod ljongs mi dmangs dpe skrun khang, 1986.

Rgyud bzhi'i 'grel pa mes poï zhal lung. Bod kyi gso rig pa'i gna' dpe phyogs bsgrigs dpe tshogs, vol. 19. Beijing: Mi rigs dpe skrun khang, 2005. 2 vols.

Rgyud bzhii spyi don shes bya rab gsal rgyas pa. Delhi: TY Tashigang, 2005.

Rgyud rgyal bdud rtsi snying po las lag len dmar khrid sde tshan lnga'i 'grel pa. In Phyi ma rgyud kyi 'grel ba phyogs bsgrigs. Bod kyi gso ba rig pa'i gna' dpe phyogs bsgrigs dpe tshogs vol. 89, 265-325. Beijing: Mi rigs dpe skrun khang, 2008.

Rje bstan 'dzin don grub, ed. Dpal ldan rgyud bzhi dpe bsdur ma. Chengdu: Si khron dpe skrun khang, 20I0. 4 vols.

Sa skya sman grong pa’i man ngag dngul bre ma. Lhasa: Bod ljongs mi dmangs dpe skrun khang, 2005. 
Sde srid sman gyi khog 'bubs. Bod kyi gso ba rig pa'i gna' dpe phyogs bsgrigs dpe tshogs, vol. 8. Beijing: Mi rigs dpe skrun khang, 2005.

Sgrol dkar skyabs. "Zla rgyal dang rgyud bzhi'i rtsa brtag thad la cung tsam bsdur te dpyad pa" [Comparative Studies on Pulsology in the Texts: King of Moon and rGyu-Zhi (sic)]. Krung go'i bod kyi gso rig [Tibetan Medicine in China] 7, no. 3 (2008): I03-IIO.

Sgrolkar, et al., eds. A Collection of Historical Archives of Tibet [Xizang lishi dang'an huicui 西藏历史档案荟萃]. Lhasa: Wenwu chubanshe, 1995.

Slob dpon klu sgrub kyi sman yig gces btus. Bod kyi gso ba rig pa'i gna' dpe phyogs bsgrigs dpe tshogs, vol. 73. Beijing: Mi rigs dpe skrun khang, 2008.

Slob dpon pad 'byung gi sman yig gces btus. Bod kyi gso ba rig pa'i gna' dpe phyogs bsgrigs dpe tshogs, vol. 24. Beijing: Mi rigs dpe skrun khang, 2006.

Sman pa rnams kyis mi shes su mi rung ba’i shes bya spyi’ khog dbubs. Chengdu: Si khron mi rigs dpe skrun khang, 200I.

Sipohu tongzi qingwen jing 蘇婆呼童子請問經 (TI8no895).

Sman dpyad bdud rtsii bum pa. Bod kyi gso ba rig pa'i gna' dpe phyogs bsgrigs dpe tshogs, vol. 97. Beijing: Mi rigs dpe skrun khang, 2013.

Sman dpyad zla ba’i rgyal po. Bod kyi gso rig pa'i gna' dpe phyogs bsgrigs dpe tshogs, vol. 33. Beijing: Mi rigs dpe skrun khang, 2005.

Sman dpyad zla ba’i rgyal po: The Somaräjabhaisajyasādhanā, an Indian medical work by Nägärjuna, in its Tibetan translation, by Hashang Mahayana and Vairocana: Reproduced from a set of prints from the Sde-dge blocks from Library of Tashigang. Smanrtsis shesrig spendzod, vol. I35. Leh: T. Y. Tashigang, 1989.

Si tu chos kyi rgya mtsho. Dbus gtsang gnas yig. Chengdu: Si khron mi rigs dpe skrun khang, 2001 .

Yan lag brgyad pa’i snying po. Bod kyi gso ba rig pa'i gna' dpe phyogs bsgrigs dpe tshogs, vol. 85. Beijing: Mi rigs dpe skrun khang, 2008.

Yang thig rdo rje pha lam. Bod kyi gso ba rig pa'i gna' dpe phyogs bsgrigs dpe tshogs, vol. 98. Beijing: Mi rigs dpe skrun khang, 2013.

Yaoshi rulai guanxing yigui fa 藥師如來觀行儀軌法 (Ti9no923).

Zhang ston gyi lo rgyus 'bri 'phro. Unpublished manuscript scanned in New Delhi for TBRC, WiCZI873.

Zin thig bsam 'phel nor bu. Bod kyi gso ba rig pa'i gna' dpe phyogs bsgrigs dpe tshogs, vol. 98. Beijing: Mi rigs dpe skrun khang, 2013.

\section{European-language Works}

Amundsen, Darrel W. Medicine, Society, and Faith in the Ancient and Medieval Worlds. Baltimore, MD: Johns Hopkins University Press, 1996. 
Atwood, Christopher P. Encyclopedia of Mongolia and the Mongol Empire. New York, NY: Facts on File, Inc., 2004.

Baily, Cameron. "The Demon Seer: Rāhula and the Inverted Mythology of Indo-Tibetan Buddhism." Journal of the International Association of Buddhist Studies 38 (2015): 33-72.

Barrett, Timothy. "History." In Critical Terms for the Study of Buddhism, edited by Donald Lopez. Chicago, IL: University of Chicago Press, 2005.

Bauer, Kenneth. High Frontiers: Dolpo and the Changing World of Himalayan Pastoralists. New York, NY: Columbia University Press, 2004.

Beckwith, Christopher I. "The Introduction of Greek Medicine into Tibet in the Seventh and Eighth Centuries." Journal of the American Oriental Society 99, no. 2 (1979): 297-313.

___ "The Tibetans in the Ordos and North China: Considerations on the Role of the Tibetan Empire in World History." In Silver on Lapis: Tibetan Literary Culture and History, edited by Christopher I. Beckwith. Bloomington, IN: Tibet Society, 1987.

- - Warriors of the Cloisters: The Central Asian Origins of Science in the Medieval World. Princeton, NJ: Princeton University Press, 20I2.'

Bell, Catherine. Ritual Theory, Ritual Practice. Oxford: Oxford University Press, 1992.

Birnbaum, Raoul. The Healing Buddha. Boulder, CO: Shambhala, 1979.

Blezer, Henk, et al. "Brief Outlook: Desiderata in the Study of the History of Tibetan Medicine." In Soundings in Tibetan Medicine: Anthropological and Historical Perspectives. Proceedings of the Ioth Seminar of the International Association of Tibetan Studies, edited by Mona Schrempf, 427-38. Leiden: Brill, 2007.

Bloch, Maurice. "Symbols, Song, Dance and Features of Articulation." European Journal of Sociology I5, no. I (1974): 55-8I.

Bourdieu, Pierre. Outline of a Theory of Practice, translated by Richard Nice. Cambridge: Cambridge University Press, 1977.

Bradburn, Leslie, ed. Masters of the Nyingma Lineage. Berkeley, CA: Dharma Publications, 1995.

Cabezón, José. Buddhism and Language: A Study of Indo-Tibetan Scholasticism. Albany, NY: State University of New York Press, I994.

- - - A Dose of Emptiness: An Annotated Translation of the sTong thun chen mo of mKhas grub dGe legs dpal bzang. Albany, NY: State University of New York Press, 1992.

-__ Scholasticism in Cross-Cultural and Comparative Perspectives. Albany, NY: State University of New York Press, 1998.

Campany, Robert F. Making Transcendents: Ascetics and Social Memory in Early Medieval China. Honolulu, HI: University of Hawai'i Press, 2009.

Cantwell, Cathy. "The Medicinal Accomplishment (sman sgrub) Practice in the Dudjom Meteoric Iron Razor (gnam lcags spu gri) Tradition: Reflections on the Ritual and Meditative Practice at a Monastery in Southern Bhutan." Journal of the Oxford Centre for Buddhist Studies 8 (2015): 49-95.

Cantwell, Cathy, and Robert Mayer. Early Tibetan Documents on Phur pa from Dunhuang. Wien: Verlag der Österreichischen Akademie der Wissenchaften, 2008. 
Clark, Barry, trans. The Quintessence Tantras of Tibetan Medicine. Ithaca, NY: Snow Lion, 1995.

Cornu, Philippe. Tibetan Astrology. Boston, MA: Shambhala, 2002.

Craig, Sienna. Healing Elements: Efficacy and the Social Ecologies of Tibetan Medicine. Berkeley, CA: University of California Press, 2012.

Cuevas, Bryan J. “The 'Calf's Nipple' (Be'u bum) of Ju Mipam ('Ju Mi pham): A Handbook of Tibetan Ritual Magic.” In Tibetan Ritual, edited by José I. Cabezón, I65-86. Oxford: Oxford University Press, 2010.

___ " "Some Reflections on the Periodization of Tibetan History." In the Tibetan History Reader, edited by Gray Tuttle and Kurtis R. Schaeffer. New York, NY: Columbia University Press, 2013.

Czaja, Olaf. "The Making of the Blue Beryl: Some Remarks on the Textual Sources of the Famous Commentary of Sangye Gyatsho (I653-1705)." In Soundings in Tibetan Medicine: Anthropological and Historical Perspectives. Proceedings of the Ioth Seminar of the International Association of Tibetan Studies, edited by Mona Schrempf, 345-71. Leiden: Brill, 2007.

___ "Zurkharwa Lodro Gyalpo (I509-1579) on the Controversy of the Indian Origin of the rGyud bzhi." The Tibet Journal 30, no. 4; and 3I, no. I (2005-2006): I3I-52.

D’Amato, Mario. The Mahāyānasūtrālaṃkāra: A Terminological Analysis. Chicago, IL: University of Chicago Doctoral Dissertation, 2000.

Dalton, Jacob P. The Uses of the Dgongs pa 'dus pa'i mdo in the Development of the Rnying-ma School of Tibetan Buddhism. Ann Arbor, MI: Doctoral Dissertation at the University of Michigan, 2002.

Dalton, Jacob P., and Sam van Schaik, eds. Tibetan Tantric Manuscripts from Dunhuang: A Descriptive Catalogue of the Stein Collection at the British Library. Leiden: Brill, 2006.

Dash, Bhagwan. Illustrated Materia Medica of Indo-Tibetan Medicine. Delhi: Classics India Publication, 1987.

___ "Sbyor-ba brgya-pa, vis-à-vis Yogaśataka: A Very Critical Study." In Tibetan Medicine: Theory and Practice, 69-250. Dharamsala: Library of Tibetan Works and Archives, 1976.

Davidson, Ronald M. "Gsar ma Apocrypha: The Creation of Orthodoxy, Gray Texts, and the New Revelation." In The Many Canons of Tibetan Buddhism, edited by Helmut Eimer and David Germano, 203-24. Leiden: Brill, 2002.

___ Indian Esoteric Buddhism: A Social History of the Tantric Movement. New York, NY: Columbia University Press, 2002.

___ Tibetan Renaissance: Tantric Buddhism in the Rebirth of Tibetan Culture. New York, NY: Columbia University Press, 2005.

Demiéville, Paul. Buddhism and Healing: Demiéville’s Article "Byō" from Hōbōgirin, translated by Mark Tatz. Lanham, MD: University Press of America, I985 [1937].

Dharmachakra Translation Committee, trans. Play in Full: Lalitavistara. New York, NY: 8400o, 20I3. Accessed I8 March 20I5. <http://read.84000.co/\#UT22084-046-00I/>.

Diemberger, Hildegard. "Female Oracles in Modern Tibet." In Women in Tibet, edited by Janet Gyatso and Hanna Havnevik (New York, NY: Columbia University Press, 2005). 
Doniger, Wendy. The Hindus: An Alternative History. New York, NY: The Penguin Press, 2009.

- - The Origins of Evil in Hindu Mythology. Berkeley, CA: University of California Press, 1976.

Dotson, Brandon. "Introducing Early Tibetan Law: Codes and Cases." In Secular Law and Order in the Tibetan Highland, ed. Dieter Schuh. Andiast: International Institute for Tibetan and Buddhist Studies GmbH, 2016.

—__ " "Trial for Homicide." In Sources of Tibetan Tradition, edited by Kurtis R. Schaeffer, Matthew T. Kapstein, Gray Tuttle, 87-88. New York, NY: Columbia University Press, 2013.

Dreyfus, Georges. The Sound of Two Hands Clapping: The Education of a Tibetan Buddhist Monk. Berkeley, CA: The University of California Press, 2003.

Edelstein, Ludwig. “The Hippocratic Oath: Text, Translation and Interpretation.” In Ancient Medicine: Selected Papers of Ludwig Edelstein, edited by Owsei Temkin and C. Lilian Temkin, 3-63. Baltimore, MD: The Johns Hopkins Press, I967 (repr. 1943).

___ _Hippocratic Prognosis." In Ancient Medicine: Selected Papers of Ludwig Edelstein, edited by Owsei Temkin and C. Lilian Temkin, 65-86. Baltimore, MD: Johns Hopkins University Press, 1967.

Eliot, T. S. The Waste Land and Other Poems. Buffalo, NY: Broadview Press, $201 \mathrm{I}$.

Emmerick, Ronald E. "Sources of the rGyud-bzhi." In Zeitschrift der Deutschen Morgenländischen Gesellschaft, ed. Wolfgang Voigt, supplement 3.2, II35-42. Wiesbaden: Franz Steriner, I977.

Filliozat, Jean. Yogaśataka; texte médical attribué à Nāgārjuna. Pondicherry: Institut Français d'Indologie, I979.

Galvão-Sobrinho, Carlos R. "Hippocratic Ideals, Medical Ethics, and the Practice of Medicine in the Early Middle Ages: The Legacy of the Hippocratic Oath." The Journal of the History of Medicine and Allied Sciences 5I (I996): 438-55.

Garrett, Frances. "Buddhism and the Historicising of Medicine in Thirteenth-century Tibet." Asian Medicine 2, no. 2 (2006): 204-24.

___ "Critical Methods in Tibetan Medical Histories." Journal of Asian Studies 66, no. 2 (2007): 363-87.

Gerke, Barbara. "The Art of Tibetan Medical Practice." In Bodies in Balance: The Art of Tibetan Medicine, edited by Theresia Hofer and Barbara Gerke. New York, NY: Rubin Museum of Art, 20I4.

___ " "The Authorship of the Tibetan Medical Treatise Cha lag bco brgyad (Twelfth Century AD) and a Description of its Historical Background." Traditional South Asian Medicine 6 (200I): 27-50.

Germano, David F. Poetic Thought, the Intelligent Universe, and the Mystery of Self: The Tantric Synthesis of rDzogs Chen in Fourteenth-century Tibet. Madison, WI: The University of Wisconsin Doctoral Dissertation, 1992.

Gold, Jonathan C. The Dharma's Gatekeepers: Sakya Pandita on Buddhist Scholarship in Tibet. Albany, NY: State University of New York Press, 2007. 
Gummer, Natalie. Articulating Potency: A Study of the Suvarna(pra)bhāsottamasūtra. Cambridge, MA: Harvard University Doctoral Dissertation, 2000.

Gray, David B. "On the Very Idea of a Tantric Canon: Myth, Poilitics, and the Formation of the Bka' 'gyur." Journal of the International Association of Tibetan Studies 5 (2009): I-37. $<$ www.thlib.org?tid=T5690 $>$.

Gyatso, Janet. "The Authority of Empiricism and the Empiricism of Authority: Medicine and Buddhism in Tibet on the Eve of Modernity." Comparative Studies of South Asia, Africa and the Middle East 24, no. 2 (2004): 83-96.

-_- Being Human in a Buddhist World: An Intellectual History of Medicine in Early Modern Tibet. New York, NY: Columbia University Press, 2015.

- - . "Experience, Empiricism and the Fortunes of Authority: Tibetan Medicine and Buddhism on the Eve of Modernity." In the Tibetan History Reader, edited by Gray Tuttle and Kurtis R. Schaeffer, 363-85. New York, NY: Columbia University Press, 2013.

__ _. "The Logic of Legitimation in the Tibetan Treasure Tradition." History of Religions 33, no. 2 (1993): 97-I34.

- - ed. Mirror of Memory: Reflections on Mindfulness and Remembrance in Indian and Tibetan Buddhism. Albany, NY: State University of New York Press, 1992.

Gyurme Dorje, trans. Tibetan Elemental Divination Paintings: Illuminated Manuscript from the White Beryl of Sangs-rgyas rGya-mtsho with the Moonbeams Treatise of Lo-chen Dharmaśri. London: John Eskenazi and Sam Fogg, 20oI.

Halbertal, Moshe. People of the Book: Canon, Meaning, and Authority. Cambridge, MA: Harvard University Press, 1997.

Hatchell, Christopher. Naked Seeing: The Great Perfection, the Wheel of Time, and Visionary Buddhism in Renaissance Tibet. Oxford: Oxford University Press, 2014.

Heller, Amy. "The Paintings of Gra thang: History and Iconography of an IIth century Tibetan Temple." The Tibet Journal 27, nos. I-2 (2002): 37-70.

Herrmann-Pfandt, Adelheid, ed. Die Lhan Kar Ma: Ein früher Katalog der in Tibetische übersetzten buddhistischen Texte. Wien: Verlag der Österreichischen Akademie der Wissenschaften, 2008.

Hirshberg, Daniel A. Remembering the Lotus-born: Padmasambhava in the History of Tibet's Golden Age.Boston, MA: Wisdom Publications, 2016.

Hodge, Stephen. The Maha-Vairocana-Abhisambodhi Tantra: With Buddhaguhya's Commentary. New York, NY: Routledge, 2003.

Hofer, Theresia. "Illustrated Materia Medica Prints, Manuscripts, and Modern Books." In Bodies in Balance: The Art of Tibetan Medicine, edited by Theresia Hofer and Barbara Gerke, 226-45. New York, NY: Rubin Museum of Art, 2014.

Hoog, Constance. "Lama Pakpa's Elucidation of the Knowable." In Sources of Tibetan Tradition, edited by Kurtis R. Schaeffer, Matthew T. Kapstein, and Gray Tuttle, 328-37. New York, NY: Columbia University Press, 2013. 
___ Prince Jin-gim's Textbook of Tibetan Buddhism: The Shes bya rab gsal by 'Phags-pa Blo-gros rgyal-mtshan dPal-bzan்-po of the Sa-skya-pa. Leiden: Brill, I983.

Hsu, Elisabeth. "A Hybrid Body Technique: Does the Pulse Diagnostic cun guan chi Method Have Chinese-Tibetan Origins?" Gesnerus 65, nos. I-2 (2008): 5-29

_- _- "Le diagnostic du pouls dans la chine mediévale d'apres les manuscrits de Dunhuang (with notes on P2115, P3106, P3287, P3477, P348I, P3655, P4093, S79, Si8I, S202, S56I4, S6245, S8289, plus index." In Médecine, religion et société dans la Chine médiévale : Étude de manuscrits chinois de Dunhuang et de Turfan, edited by C. Despeux, vol. I, pp. I07-84. Paris: College de France, Institut des Haute Etudes Chinoises, 2010.

Imaeda, Yoshiro. "The History of the Cycle of Birth and Death: A Tibetan Narrative from Dunhuang." In Contributions to the Cultural History of Early Tibet, edited by Matthew T. Kapstein and Brandon Dotson, I05-8I. Leiden: Brill, 2007.

Kapstein, Matthew T. "The Amnesic Monarch and the Five Mnemic Men: 'Memory' in Great Perfection (Rdzogs-chen) Thought." In the Mirror of Memory: Reflections on Mindfulness and Remembrance in Indian and Tibetan Buddhism, edited by Janet Gytaso, 239-69. Albany, NY: State University of New York Press, 1992.

___ "What is 'Tibetan Scholasticism'? Three Ways of Thought," in The Tibetan Assimilation of Buddhism: Conversion, Contestation, and Memory, 85-I20. Oxford: Oxford University Press, 2000.

Karmay, Samten G. "The Four Tibetan Medical Treatises and Their Critics." In The Arrow and the Spindle, 228-37. Kathmandu: Mandala Publications, 1998 [reprint of "Vairocana and the Rgyud-bzhi." Tibetan Medicine I3 (1990): I9-3I].

Kilty, Gavin, trans. Mirror of Beryl: A Historical Introduction to Tibetan Medicine. Boston, MA: Wisdom Publications, 2009.

Kottek, S. S., J. O. Leibowitz, and B. Richler. "A Hebrew Paraphrase of the Hippocratic Oath (from a Fifteenth-century Manuscript)." Medical History 22 (1978): 438-45.

Kovacs, Jürgen, and Paul U. Unschuld. Essential Subtleties on the Silver Sea: The Yin-hai jing-wei, a Chinese Classic on Ophthalmology. Berkeley, CA: University of California Press, 1998.

Kuhn, Thomas. The Structure of Scientific Revolutions. Chicago, IL: University of Chicago Press, 1962.

Lloyd, G. E. R., ed. Hippocratic Writings. London: Penguin Books, 1978.

Ludvik, Catherine. Sarasvatī, Riverine Goddess of Knowledge: From the Manuscript-carrying Vīnāplayer to the Weapon-wielding Defender of the Dharma. Leiden: Brill, 2007.

MacIntyre, Alasdair. Whose Justice? Whose Rationality? Notre Dame, IN: University of Notre Dame Press, 1988.

Makdisi, George. The Rise of Colleges: Institutions of Learning in Islam and the West. Edinburgh: Edinburgh University Press, I98I.

___ “_The Scholastic Method in Medieval Education." Speculum 49 (1974): 640-6I. 
Martin, Dan. "An Early Tibetan History of Indian Medicine." In Soundings in Tibetan Medicine: Anthropological and Historical Perspectives. Proceedings of the Ioth Seminar of the International Association of Tibetan Studies, edited by Mona Schrempf, 307-25. Leiden: Brill, 2007.

___ . "Greek and Islamic Medicines' Historical Contact with Tibet." Islam and Tibet: Interactions along the Musk Routes, edited by Anna Akasoy, Charles S. F. Burnett, and Ronit Yoeli-Tlalim, II7-44. Burlington, VT: Ashgate Publishing Company, $20 I I$.

- - "Tibet at the Center: A Historical Study of Some Tibetan Geographical Conceptions Based on Two Types of Country-lists Found in Bon Histories." In Tibetan Studies: Proceedings of the 6th Seminar of the International Association for Tibetan Studies, Fagernes 1992, edited by Per Kværne, vol. I, 517-32. Oslo: The Institute for Comparative Research in Human Culture, 1994.

McVaugh, Michael R. Medicine Before the Plague: Practitioners and Their Patients in the Crown of Aragon I285-I345. Cambridge: Cambridge University Press, 1993.

Meinert, Carmen. "The Conjunction of Chinese Chan and Tibetan Rdzogs chen Thought: Reflections on the Tibetan Dunhuang Manuscripts IOL Tib J 689-I and PT 699." In Contributions to the Cultural History of Early Tibet, edited by Matthew T. Kapstein and Brandon Dotson, 275-77. Leiden: Brill, 2007.

Meserve, Ruth. "The Science and Archaeology of Injury and Disease in Central Eurasia." In Archivum Eurasiae Medii Aevi I8 (201I): 225-69.

Meulenbeld, G. Jan. A History of Indian Medical Literature. Groningen: Egbert Forsten, 19992002. 5 vols.

Momigliano, Arnaldo. "The Herodotean and Thucydidean Tradition." In The Classical Foundations of Modern Historiography, 29-53. Berkeley, CA: University of California Press, I990.

Mumford, Stan Royal. Himalayan Dialogue: Tibetan Lamas and Gurung Shamans in Nepal. Madison, WI: The University of Wisconsin Press, 1989.

Murthy, K. R. Srikantha. Vägbhața's Aștāanga Hṛdayam: Text, English Translation, Notes, Appendix and Indices. Varanasi: Krishnadas Academy, 1991-1992. 2 vols.

Nance, Richard F. Speaking for Buddhas: Scriptural Commentary in Indian Buddhism. New York, NY: Columbia University Press, 2012.

Nanjio, Bunyiu. A Catalogue of the Chinese Translation of the Buddhist Tripitaka: The Sacred Canon of the Buddhists in China and Japan. Oxford: Clarendon Press, I883.

de Nebesky-Wojkowitz, René. Oracles and Demons of Tibet: The Cult and Iconography of the Tibetan Protective Deities. The Hague: Mouton, 1956.

Newman, John R. "A Brief History of the Kalachakra." In The Wheel of Time: The Kalachakra in Context, edited by Beth Simon, 5I-90. Madison, WI: Deer Park Books, 1985.

Obermiller, E., trans. History of Buddhism (Chos ḩbyung) by Bu ston. Heidelberg: H. Winter Verlag, I93I-I932. 2 vols. 
Oetke, Claus. Die aus dem Chinesischen übersetzten tibetischen Versionen des Suvarṇaprabhāsasūtra: philologische und linguistische Beiträge zur klassifizierenden Charakterisierung übersetzter Texte. Wiesbaden: Franz Steiner Verlag GmbH., I977.

Olivelle, Patrick, trans. Upaniṣads. Oxford: Oxford University Press, 1996.

Orofinao, Giacomella. "Divination with Mirrors: Observations on a Simile Found in the Kālacakra Literature." In Tibetan Studies: Proceedings of the 6th Seminar of the International Association for Tibetan Studies, Fagernes 1992, edited by Per Kvaerne, 612-28. Oslo: Institute for Comparative Research in Human Culture, 1994.

Orzech, Charles D. "The 'Great Teaching of Yoga' the Chinese Appropriation of the Tantras, and the Question of Esoteric Buddhism." Journal of Chinese Religions 34 (2006): 29-78.

___ "Translation of Tantras and Other Esoteric Buddhist Scriptures." In Esoteric Buddhism and the Tantras in East Asia, edited by Charles D. Orzech, Henrik H. Sørensen, and Richard K. Payne, 439-50. Leiden: Brill, 201 .

Parfionovitch, Yuri, Fernand Meyer, and Gyurme Dorje, eds. Tibetan Medical Paintings: Illustrations to the Blue Beryl Treatise of Sangye Gyamtso (I653-I705). New York, NY: Harry N. Abrams, 1992.

Pasang Wangdu, and Hildegard Diemberger, trans. Dba' bzhed: The Royal Narrative Concerning the Brining of the Buddha's Doctrine to Tibet. Wien: Österreichischen Akademie der Wissenschaften, 2000.

Pasang Yontan Arya. "External Therapies in Tibetan Medicine: The Four Tantras, Contemporary Practice, and a Preliminary History of Surgery." In Bodies in Balance: The Art of Tibetan Medicine, edited by Theresia Hofer and Barbara Gerke, 64-89. New York, NY: Rubin Museum of Art, 20I4.

Pema Kunsang, Erik. Wellsprings of the Great Perfection: The Lives and Insights of the Early Masters. Kathmandu: Rangjung Yeshe Publications, 2012.

Petech, Luciano. Central Tibet and the Mongols: The Yüan-Sa-skya Period of Tibetan History. Rome: Instituto Italiano per il Medio ed Estermo Oriente, I990.

Pollock, Sheldon. “The Cosmopolitan Vernacular." The Journal of Asian Studies 57, no. I (I998): 6-37.

—__ _Philology in Three Dimensions." Postmedieval: A Journal of Medieval Cultural Studies 5, no. 4 (20I4): 398-4I3.

___ "The Revelation of Tradition: śruti, smrti, and the Sanskrit Discourse of Power." In Boundaries, Dynamics and Construction of Traditions in South Asia, edited by Federico Squarcini. New York, NY: Anthem Press, 20II [originally published in 1997]).

Popper, Karl R. Conjectures and Refutations: The Growth of Scientific Knowledge. New York, NY: Basic Books, I963.

Ramanujan, A. K. "Is There an Indian Way of Thinking? An Informal Essay." Contributions to Indian Sociology 23, no. I (I989): 4I-58. 
Ruegg, David Seyfort. The Life of Bu ston Rin po che: With the Tibetan Text of the Bu ston rnam thar. Serie Orientale Roma, vol. 34. Roma: Istituto Italiano Per il Medio ed Estremo Oriente, 1966.

-. Ordre Spirituel et Ordre Temporel dans La Pensée Bouddhique de l'Inde et du Tibet. Paris: Collège de France, Institut de Civilisation Indienne, 1995.

Salguero, C. Pierce, ed. Buddhism and Medicine: An Anthology. New York, NY: Columbia University Press, 2017.

- _ . "The Buddhist Medicine King in Literary Context: Reconsidering an Early Medieval Example of Indian Influence on Chinese Medicine and Surgery" History of Religions 48, no. 3 (2009): 183-210.

- _ . "On Eliminating Disease': Translations of the Medical Chapter from the Chinese Versions of the Sutra of Golden Light." eJournal of Indian Medicine 6 (2013): 2I-43.

Schaeffer, Kurtis R. "Death, Diagnosis, and the Physician's Reputation in Tibet." In Heroes and Saints: The Moment of Death in Cross-cultural Perspectives, edited by Phyllis Granoff and Koichi Shinohara, 159-72 (Newcastle: Cambridge Scholars Publishing, 2007).

_- - "Textual Scholarship, Medical Tradition, and Mahāyāna Buddhist Ideals in Tibet." Journal of Indian Philosophy 3I (2003): 62I-4I.

Schaeffer, Kurtis R., and Leondard W. J. van der Kuijp. An Early Tibetan Survey of Tibetan Buddhist Literature: The Bstan pa rgyas pa rgyan gyi nyi 'od of Bcom ldan ral gri. Harvard Oriental Series, vol. 64. Cambridge, MA: Harvard Oriental Series, 2009.

Schottenhammer, Angela. "Huihui Medicine and Medicinal Drugs in Yuan China." In Eurasian Influences on Yuan China, edited by Morris Rossabi, 75-IO2. Singapore: Institute of Southeast Asian Studies, 20I3.

Schweiger, Peter. "History as Myth: On the Appropriation of the Past in Tibetan Culture." In the Tibetan History Reader, edited by Gray Tuttle and Kurtis R. Schaeffer. New York, NY: Columbia University Press, 2013.

Seligman, Adam B., Robert P. Weller, Michael J. Puett, and Bennet Simon. Ritual and Its Consequences: An Essay on the Limits of Sincerity. Oxford: Oxford University Press, 2008.

Sen, Tansen. "The Revival and Failure of Buddhist Translations During the Song Dynasty." T'oung Pao 88 (2002): 27-80.

Sharma, P. V. Caraka Saṃhitā. Varanasi: Chaukhambha Orientalia, I98I-1994. 4 vols.

Shinno, Reiko. The Politics of Chinese Medicine under Mongol Rule. New York, NY: Routledge, 2016.

Sivin, Nathan. "On the Word 'Taoist' as a Source of Perplexity: With Special Reference to the Relations of Science and Religion in Traditional China." History of Religions 17 (1978): 30330.

Slouber, Michael. Early Tantric Medicine: Snakebite, Mantras, and Healing in the Gāruḍa Tantras. Oxford: Oxford University Press, 2016.

Smith, Frederick M. The Self Possessed: Deity and Spirit Possession in South Asian Literature and Civilization. New York, NY: Columbia University Press, 2006. 
Sontag, Susan. Illness as Metaphor. New York, NY: Farrar, Straus and Giroux, 1977.

Sørensen, Per. "Preface." In Dba' bzhed: The Royal Narrative Concerning the Brining of the Buddha's Doctrine to Tibet, translated by Pasang Wangdu and Hildegard Diemberger, $i x-x v$. Wien: Österreichischen Akademie der Wissenschaften, 2000.

- - Tibetan Buddhist Historiography: The Mirror Illuminating the Royal Genealogies, an Annotated Translation of the XIVth Century Tibetan Chronicle: rGyal-rabs gsal-bai me-long. Wiesbaden: Harrassowitz Verlag, 1994.

Staal, Frits. Discovering the Vedas: Origins, Mantras, Rituals, Insights. New York, NY: Penguin, 2008.

Stearns, Cyrus. The Buddha from Dölpo: A Study of the Life and Thought of the Tibetan Master Dölpopa Sherab Gyaltsen. Ithaca, NY: Snow Lion, 20I0 (repr. 1999).

- _ - Luminous Lives: The Story of the Early Masters of the Lam 'bras Tradition in Tibet. Boston, MA: Wisdom Publications, 200I.

Stein, Lisa, and Ngawang Zangpo, trans. Butön's History of Buddhism in India and Its Spread in Tibet: A Treasury of Priceless Scripture. Ithaca, NY: Snow Lion Publications, 2013.

Stein, Rolf A. "Tibetica Antiqua IV: The Tradition Relative to the Debut of Buddhism in Tibet." In Rolf Stein's Tibetica Antiqua, translated by Arthur P. McKeown. Leiden: Brill, 2010. Originally published as "Tibetica Antiqua IV: La tradition relative au début du Bouddhisme au Tibet." Bulletin de l'Ecole française d'Extrême-Orient 75 (1986): I69-96.

Strickmann, Michel. Chinese Magical Medicine. Edited by Bernard Faure. Stanford, CA: Stanford University Press, 2002.

Tarthang Tulku et al., eds. The Nyingma Edition of the sDe-dge bKa'-'gyur/bsTan-'gyur: Research Catalogue and Bibliography. Oakland, CA: Dharma Press, 1977-1983. 8 vols.

Temkin, Owsei. "On Second Thought." In "On Second Thought" and Other Essays in the History of Medicine and Science, I-20. Baltimore, MD: The Johns Hopkins University Press, 2002.

Thurman, Robert, trans. The Universal Vehicle Discourse Literature (Mahāyānasūtrālaṃkāra) by Maitreyanätha/Āryāsañga, Together with Its Commentary (Bhāṣa) by Vasubandhu. New York, NY: American Institute of Buddhist Studies at Columbia University, 2004.

Tuttle, Gray. "Challenging Central Tibet's Dominance of History: The Oceanic Book, a Igthcentury Politico-religious Geographic History." In Mapping the Modern in Tibet. Andiast: International Institute for Tibetan and Buddhist Studies GmbH, 20II.

Uray, Géza. "A Chronological Problem in the Old Tibetan Chronicle." Acta Orientalia Academiae Scientiarum Hungaricae II (1968): 258-69.

van der Kuijp, Leonard W. J. "Bayši' and Bayši-s in Tibetan Historical, Biographical and Lexicographical Texts." Central Asiatic Journal 39, no. 2 (1995): 280-86.

- _ . "Fourteenth-century Tibetan Culture III: The Oeuvre of Bla ma dam pa Bsod nams rgyal mtshan (1312-I375)." Berliner Indologische Studien 7 (1993): I09-I47.

- _ - "The Lives of Bu ston Rin chen grub and the Date and Sources of His Chos 'byung, a Chronicle of Buddhism in India and Tibet." Revue d'Etudes Tibétaines 35 (2016): 203-308. 
__ _. "Some Remarks on the Textual Transmission and Text of Bu ston Rin chen grub's Chos 'byung, a Chronicle of Buddhism in India and Tibet." Revue d'Etudes Tibétaines 25 (2013): II5-93.

_- _ "Za hor and Its Contribution to Tibetan Medicine, Part One: Some Names, Places, and Texts." Bod rig pa'i dus deb [Zangxue xuekan 藏学学刊; Journal of Tibetology] 6 (2010): 2I50.

___ . "Za hor and Its Contribution to Tibetan Medicine, Part Two: Sources of the Tibetan Medical Tradition.” Bod rig pa'i dus deb [Zangxue xuekan 藏学学刊; Journal of Tibetology] I2 (2016): 63-108.

van Schaik, Sam. "A Tibetan Book of Spells." Early Tibet. I9 February 2009. <earlytibet.com/2009/02/19/a-tibetan-book-of-spells/>.

van Schaik Sam, and Imre Galambos. Manuscripts and Travellers: The Sino-Tibetan Documents of a Tenth-Century Buddhist Pilgrim. Berlin: Walter de Gruyter GmbH \& Co. KG, 2012.

van Schaik, Sam, and Kazushi Iwao. "Fragments of the Testament of $B a$ from Dunhuang." Journal of the American Oriental Society 128, no. 3 (2008): 477-87.

Vitali, Roberto. Early Temples of Central Tibet. London: Serindia Publications, 1990.

Vogel, Claus. Vägbhața's Aștāñgahridayasaṃhitā: The First Five Chapters of Its Tibetan Version. Wiesbaden: Franz Steiner Verlag GMBH, 1965.

Walser, Joseph. Nägārjuna in Context: Mahāyāna Buddhism and Early Indian Culture. New York, NY: Columbia University Press, 2005.

Willemen, Charles, Bart Dessein, and Collett Cox. Sarvāstivāda Buddhist Scholasticism. Brill: Leiden, 1998.

Yang Ga, Sources for the Writing of the Rgyud bzhi, Tibetan Medical Classic. Cambridge, MA: Doctoral Dissertation at Harvard University, 2010.

Yoeli-Tlalim, Ronit. "Between Medicine and Ritual: Tibetan 'Medical Rituals' from Dunhuang." In Tibetan and Himalayan Healing: An Anthology for Anthony Aris, edited by Charles Ramble and Ulrike Roesler, 749-55. Kathmandu: Vajra Books, 2015.

_- _. "Central Asian Mélange: Early Tibetan Medicine from Dunhunag." In Scribes, Texts, and Rituals in Early Tibet and Dunhuang, edited by Brandon Dotson, Kazushi Iwao, and Tsuguhito Takeuchi, 53-60. Wiesbaden: Reichert-Verlag, 2013.

___. "On Urine Analysis and Tibetan Medicine's Connections with the West." In Studies of Medical Pluralism in Tibetan History and Society, edited by Sienna Craig, Mingji Cuomu, Frances Garrett, and Mona Schrempf, 195-2II. Halle: International Institute for Tibetan and Buddhist Studies GmbH, 2010.

——_. "Re-visiting 'Galen in Tibet." Medical History 56, no. 3 (2012): 355-65.

Zhen Yan. "rTsa in the Tibetan Manuscripts from Dunhuang." Translated by Vivienne Lo. Asian Medicine 3 (2007): 296-307.

Zhen Yan and Cai Jingfeng. "Tibetan and Chinese Pulse Diagnostics: A Comparison-With Special Reference to Locations for Pulse Taking." In Soundings in Tibetan Medicine: 
Anthropological and Historical Perspectives. Proceedings of the Ioth Seminar of the International Association of Tibetan Studies, edited by Mona Schrempf, 327-43. Leiden: Brill, 2007.

Zysk, Kenneth G. Asceticism and Healing in Ancient India: Medicine in the Buddhist Monastery. Delhi: Motilal Banarsidass, 2000 (repr. 199I).

_- - Medicine in the Veda: Religious Healing in the Veda. Delhi: Motilal Banarsidass, 1996 (repr. 1985).

_- - "Mythology and the Brāhmaṇization of Indian Medicine: Transforming Heterodoxy into Orthodoxy." In Categorisation and Interpretation: Indological and Comparative Studies from an International Indological Meeting at the Department of Comparative Philology, Göteborg University, edited by Folke Josephson, I25-45. Göteborg: Novum Grafiska AB, 1999. 


\section{Appendix: Approximate Chronology and Annotated Bibliography of Early Literature in the Tibetan Medical Tradition}

Multiple sources and series have been used in research for the present dissertation. Because the temporal scope of the project is primarily concerned with the intellectual history of the Tibetan medical tradition from the $\mathrm{II}^{\text {th }}-\mathrm{I} 4^{\text {th }}$ century, the majority of the works described below derive from this same period or earlier. Wherever possible, I have attempted to provide information regarding the provenance of the texts, such as the dates of and agents involved in the composition, redaction, and transmission of the works. Due to the general lack of information regarding the provenance of most texts from this period, the dates below reflect their proposed century of redaction - that is, the approximate period in which a text was compiled-such that we might begin to understand the relative chronology of these scriptures, treatises, and other collections. This bibliography is by no means exhaustive and only represents the works studied in the course of the present project.

\section{Pre-eleventh Century}

Canonical Translations of Medical Scriptures ( $b k a$ 'gyur)

The Gatang Bumpa Manuscripts (dga' thang 'bum pa)

London: Tibetan-language Medical Manuscripts in the Stein Collection

Paris: Medical Manuscripts in the Pelliot Tibétain Collection

\section{The Eleventh and Twelfth Centuries}

The Book of Sakya (sa skya bka' 'bum), Medical Works

Canonical Translations of Medical Treatises (bstan 'gyur)

The Eleven Thousand-session Tutorials (skor tshoms stong thun bcu gcig)

The Essence of Ambrosia [in Eight Branches] (bdud rtsi snying po [yan lag brgyad pa])

Kyebu Melha (skyes bu me lha), Medical Works

The Medicine of the Moon King (sman dpyad zla ba'i rgyal po, so ma rā dza)

Nāgārjuna (klu sgrub), Non-canonical Medical Works

Padmasambhava (padma 'byung gnas), Medical Works

The Three Indispensable Rituals (med thabs med pa'i 'phyong gsum)

Zhangtön Zijibar (zhang ston gzi brjid 'bar), Medical Works

\section{The Thirteenth Century}

The Commentary on the Small Practical Manual (lag len spod chung gi 'grel pa)

The Complete Entrustment (yongs su gtad pa)

The Lamp that Illuminates the Red Register (dmar byang gsal ba'i sgron me)

The Ornamental Flower of Healing Science (gso ba rig pa rgyan gyi me tog)

The Secret Essence of Ambrosia (bdud rtsi snying po gsang ba man ngag gi rgyud)

The Secret Essence of Ambrosia in Eight Branches: An Instructional Tantra (bdud rtsi snying po yan lag brgyad pa gsang ba man ngag gi rgyud), aka the Four Tantras (rgyud bzhi) 


\section{The Fourteenth Century}

Drangti Penden Tsojé (brang ti dpal ldan 'tsho byed), Medical Works

The Eighteen Partial Branches (cha lag bco brgyad) Collection

The Gold Measure (gser bre) and Silver Measure (dngul bre) Collections

\section{Pre-eleventh Century}

Despite the fact that many later anthologies and scriptural collections contain medical instructions based on earlier materials that may very well have been transmitted from this early period, relatively few collections and individual works of medical instructions can be confidently considered to have been redacted prior to the translation of the Essence of the Eight Branches (yan lag brgyad pai snying po"i bsdus pa) in the early eleventh century. ${ }^{722}$ Exceptions include the Tibetan-language medical works found at archeological sites, which will be the subject of Ronit Yoeli-Tlalim's forthcoming work, Central Asian Mélange, and have not been discussed above to any significant degree. Despite their lack of explicit association with the Tibetan-language instructional texts found at Dunhuang, the medical theories and instructions found in the translated works of the eighth and potentially even seventh centuries are also worth considering.

\section{Canonical Translations of Medical Scriptures (bka' 'gyur)}

As discussed in the Introduction abvove, one of the most important sutras including instructions for the practice of medicine is the Sutra of Golden Light (Skt. suvarna[pra]bhāsottama-sūtra). Other early canonical works can be found in the Discipline ('dul $b a=$ Skt. vinaya $)$ and Discourse ( $m d o=$ Skt. sütra) sections of the Buddhist canons, among others. ${ }^{723}$

'Phags pa gser'od dam pa mchog tu rnam par rgyal bäi mdo sde'i rgyal po theg pa chen po'i mdo. Text 0583, vol. 89 (pa), pp. pp. 80-459.

'Phags pa gser 'od dam pa mdo sde'i dbang po'i rgyal po zhes bya ba theg pa chen po'i mdo. Text 0584, vol. 89 (pa), pp. 460-798.

'Phags pa gser'od dam pa mdo sde'i dbang po'i rgyal po zhes bya ba theg pa chen po'i mdo. Text 0585 , vol. 90 (pha), pp. 3-175.

\section{The Gatang Bumpa Manuscripts (dga' thang 'bum pa)}

A collection of early manuscripts found in the Gatang Bumpa stupa in Lhokha Prefecture (tho kha khul), Tsomé County (mtsho smad rdzong), Tamshül Village (gtam shul), in the summer of

${ }^{722}$ On the translation of the Essence of the Eight Branches as a seminal moment in the history of the Tibetan medical tradition, see Yang Ga, Sources for the Writing of the Rgyud bzhi.

${ }^{723}$ For examples from the Chinese Buddhist canon, see Paul Demiéville, Buddhism and Healing: Demiéville’s Article "Byō" from Hōbōgirin, trans. Mark Tatz (Lanham, MD: University Press of America, I985 [1937]). For more diverse examples and translations, see C. Pierce Salguero, ed., Buddhism and Medicine: An Anthology (New York, NY: Columbia University Press, 20I7). 
2006. The three out of four works concern instructions for "bönpo" rituals, while one out of the four is a damaged and incomplete medical work (sman dpyad), primarily detailing the prescriptin of materia medica. The dates for these four works are unclear, but they do contain early orthography and probably date from the tenth or eleventh century.

Pa tshab sangs dbang 'dus and Glang ru nor bu tshe ring, eds. Gtam shul dga' thang 'bum pa che nas gsar rnyed byung ba'i bon gyi gna' dpe bdams bsgrigs [Dangxu gatang bangba qita bengu benjiao wenshu huibian]. Lhasa: Bod ljongs bod yig dpe rnying dpe skrun khang, 2007.

\section{London: Tibetan-language Medical Manuscripts in the Stein Collection (II)}

IOL Tib J 755: digitization currently unavailable on IDP; ${ }^{724}$ fragmented segment from a scroll (I94 X $25 \mathrm{~cm}$ ). The front side contains IO4 columns of Chinese (the Dharmaguptaka-bhikșuñikarman) and the back contains 124 lines of Tibetan script, but not Tibetan language. Said to be a Zhang Zhung medical text. ${ }^{725}$

IOL Tib J 756: digitization currently unavailable on IDP; ${ }^{726}$ a single segment from a scroll (4IO $\mathrm{x}$ I7 cm) that was composed of several separate pages that were then detached and mounted at the British Library. ${ }^{727}$ The sum of the verso side contains 455 lines of Tibetan that begin as a headed official script and end as a headless script. ${ }^{728}$

IOL Tib J 757: digitization currently unavailable on IDP; ${ }^{729}$ a damaged segment from a scroll (I7 $\mathrm{x} 7 \mathrm{~cm})$. "Fragment of a medical text."

IOL Tib J 758: digitization currently unavailable on IDP; ${ }^{730}$ a damaged segment from a scroll (3I x 3I cm). "A medical text, divided into paragraphs."

IOL Tib J 759: digitization available on IDP; ${ }^{731}$ a damaged single folio $(5 \times 24 \mathrm{~cm})$. "On bodily ills."

IOL Tib J 760: digitization currently unavailable on IDP; ${ }^{732}$ a damaged segment from a scroll $(38 \times 32 \mathrm{~cm})$. "Fragment of a veterinary work, on horses: divided into paragraphs."

IOL Tib J 76I: digitization currently unavailable on IDP; ${ }^{733}$ a damaged segment from a scroll $(88 \times 25 \mathrm{~cm})$. "Fragment of a veterinary work, on horses."

\footnotetext{
${ }^{724}$ de la Vallée Poussin, Catalogue of the Tibetan Manuscripts from Tun-huang, 755.

${ }^{725}$ Reproduced in Luo Bingfen et al., Tun hong nas thon pa'i bod kyi gso rig yig cha gces bsdus, 2425 I.

${ }^{726}$ de la Vallée Poussin, Catalogue of the Tibetan Manuscripts from Tun-huang, 756.

${ }^{727}$ I would like to thank Sam van Schaik for sending me unofficial scans of a portion of this document.

${ }^{728}$ Reproduced in Luo Bingfen et al., Tun hong nas thon pa'i bod kyi gso rig yig cha gces bsdus, I3I57.

${ }^{729}$ de la Vallée Poussin, Catalogue of the Tibetan Manuscripts from Tun-huang, 757.

${ }^{730}$ de la Vallée Poussin, Catalogue of the Tibetan Manuscripts from Tun-huang, 758.

${ }^{731}$ de la Vallée Poussin, Catalogue of the Tibetan Manuscripts from Tun-huang, 759.

${ }^{732}$ de la Vallée Poussin, Catalogue of the Tibetan Manuscripts from Tun-huang, 760.

${ }^{733}$ de la Vallée Poussin, Catalogue of the Tibetan Manuscripts from Tun-huang, 76I.
} 
IOL Tib J 762: digitization currently unavailable on IDP; ${ }^{734}$ a damaged segment from a scroll ( 5 x 13 cm). "Recto: veterinary. Verso: omens."

IOL Tib J 763: digitization available on IDP; ${ }^{735}$ a damaged and largely illegible segment from a scroll $(25$ x $22 \mathrm{~cm})$. "Veterinary."

IOL Tib J I246: digitization currently unavailable on IDP, ${ }^{736}$ medical text containing 42 lines of Tibetan; called "I.O. 56" and "I.O. 57 " elsewhere. ${ }^{737}$

IOL Tib J I278: digitization currently unavailable on IDP; 738 "Fragment of a medical text."

\section{Paris: Medical Manuscripts in the Pelliot Tibétain Collection (I2)}

PT 127: digitization available on the International Dunhuang Project; ${ }^{739}$ a single complete scroll $(300 \times 29.5 \mathrm{~cm})$ that appears to be composed of eight separate pages that were glued together. ${ }^{740}$ Each page contains a different number of lines of Tibetan writing, but full pages each contain 28 lines per page (e.g. pages $5 \mathrm{r}-7 \mathrm{r}$ ). Despite lacking any official content or seals, the scripts appear to alternate between a headless and a headed official style. ${ }^{74}$ At least five separate but related works can be discerned on this scroll:

PT I27.I: Untitled divination text (pp. Ir-4r, 1l. I-77).

\footnotetext{
${ }^{734}$ de la Vallée Poussin, Catalogue of the Tibetan Manuscripts from Tun-huang, 762.

${ }^{735}$ de la Vallée Poussin, Catalogue of the Tibetan Manuscripts from Tun-huang, 763.

${ }^{736}$ de la Vallée Poussin, Catalogue of the Tibetan Manuscripts from Tun-huang, I246.

${ }^{737}$ Reproduced in Luo Bingfen et al., Tun hong nas thon pa'i bod kyi gso rig yig cha gces bsdus, 203206.

${ }^{738}$ Yamaguchi Zuihō et al., eds., Sutain shūshū Chibettogo bunken kaidai mokuroku, I38-70-3 (005).

${ }^{739}$ Lalou, Inventaire des manuscrits tibétains, vol. I, I27: "Recueil contenant 2 textes dont un bilingue et 17 l. de ouïgour... I rouleau $(29.5 \times 3 \mathrm{~m})$. Complet. Les paragraphes sont séparés par des petits lotus. Les syllabes transcrites du bilingue (3) sont séparées par des traits verticaux tandis que les syllabes tibétaines sont séparées par le point normal"; Section One: "Présages?"; Section Two: "Début d'un autre texte, ou d'un paragraphe"; Section Three: "Formules pour animer la terre, l'or, etc." Lalou's "bilingual Uighur text" refers to PT I27.3c, which shall be analyzed further below. His assessment of PT I27.3d is also problematic.

${ }^{740}$ From visual inspection of the digital reproductions alone, the paper seems to be similar to that which is described in Agnieszka Helman-Ważny, The Archaeology of Tibetan Books (Leiden: Brill, 20I4), 238: “\#30. IOL Tib J I404...Raw material: Rag paper: Boehmeria nivea sp. (Ramie) and Cannabis sativa sp. (Hemp). Type of paper: Laid paper: $\mathbf{I} 2$ laid lines in $3 \mathrm{~cm}$. Find site: Dunhuang Cave 17. Dating: 9th-Ioth c. Format: Scroll fragment (vertical). Size $(\mathrm{h} \times \mathrm{w}): 6 \mathrm{I} \times 3 \mathrm{I}$ $\mathrm{cm}$. Language/script: Tibetan (official style) and Chinese. Page layout: 29 lines on fragment, no margins or guidelines. Content: Recto: Tibetan transliteration of Chinese Sukhāvatīvyūha sūtra. Verso: various memoranda concerning provisions."

${ }^{74 I}$ On the "official style" script in Tibetan Dunhuang documents, see Sam van Schaik, "Towards a Tibetan Palaeography: Developing a Typology of Writing Styles in Early Tibet" in Manuscript Cultures: Mapping the Field, ed. Jörg B. Quenzer, Dmitry Bondarev, and Jan-Ulrich Sobisch (Berlin: Walter de Gruyter GmbH, 20I4), 3I2-I4.
} 
PT 127.2: Untitled cauterization text (pp. 4r-8r, 11. 78-I84). ${ }^{742}$

PT I27.3: A series of divination works related to PT I27.I as well (p. 5v-7v, ll. I-77 [pp. IV-4v and $8 \mathrm{v}$ are blank])

PT I27.3a: Untitled sexagenary cycle (p. 5v, 1l. I-9 [pp. IV-4V are blank]). ${ }^{73}$

PT I27.3b: "Incompatible Birth Years" (srog my-i mthun ba) and "Compatible Birth Years" (srog mthun ba; p. 5v, ll. IO-I4).

PT 127.3c: An "Account Relating the Nine Clans of Men and the Pentatonic Scale" (my-i” rus pa dgu ay-im gang la gtogs pa'-i mdo; ; pp. 5v-6v, 1l. 15-28). ${ }^{744}$

PT I27.3d: The "Fine Lace Parasol" (na bza' dra ba'-i gdugs; pp. 6v-7v, 1l. 29-77).

PT I044: digitization available on IDP; ${ }^{745}$ a single scroll (I35 $\times 25.5 \mathrm{~cm}$ ) that appears to be composed of three separate pages that were glued together. Because the Tibetan appears to have been written on the back of a Chinese-language Lotus Sutra (saddharmapundarika) fragment, we shall count the pages from right to left (with the first page of the Chinese writing being damaged). The first damaged page (Ir) contains I8 columns of Chinese writing, while the two undamaged pages of Chinese $(2 \mathrm{r}-3 \mathrm{r})$ each contain 28 columns. The first page of Tibetan writing (3v) contains 36 lines of Tibetan, while the second page (2v) contains 23 lines (with large spaces), and the third page (Iv) contains Io lines. Headless official script style. Excluding the Chinese-language Lotus Sutra fragment (pp. Ir-3r), two works can be discerned:

${ }^{742}$ Reproduced in Luo Bingfen et al., Tun hong nas thon pa'i bod kyi gso rig yig cha gces bsdus, 2I5223. For English-language translations selected from this work, see Kurtis R. Schaeffer, Matthew Kapstein, Gray Tuttle, eds., Sources of Tibetan Tradition (New York, NY: Columbia University Press, 2013), II6-I7.

${ }^{743}$ For a study of this cycle see Géza Uray, "The Earliest Evidence of the Use of the Chinese Sexagenary Cycle in Tibetan," in Tibetan and Buddhist Studies Commemorating the 2ooth Anniversary of the Birth of Alexander Csoma de Körös, ed. Louis Ligeti (Budapest: Akadémiai Kiadó, 1984), vol. 2, 34I-60; especially 345-47.

${ }^{744}$ For a short English description of this work, see Takata Tokio, "Multilingualism in Tunhuang," Acta Asiatica 78 (2000): 554. See also Takata Tokio 高田时雄, “Gosei wo toku Tonkō shiryō” 五姓を說く敦煌資料 [Material from Dunhuang Concerning the Five-surname Theory], Kokuritsu Minzokugaku Hakubutsukan Kenkyū Hōkoku 國立民族學博物館研究報告 I4 (I99I): 249-68; and Chen Yuzhu 陈于柱, “Dunhuang wenshu PT I27 'Renxing guishu wuyin jing' yu guiyijun shiqi Dunhuang Tubo yimin shehui yanjiu” 敦煌文书P.T. I27《人姓归属五音经》与归义军时期敦煌吐蕃移民社会研究 [Five Surnames and the Social History of the Tibetan Immigrants in Dunhuang Areas in the Gui yijun Period (sic)], Minzu yanjiu 民族研究 [Ethnic National Studies (sic)] 5 (201I): 76-84.

${ }^{745}$ Lalou, Inventaire des manuscrits tibétains, vol. II, I044: "Écrit au dos d'un texte chinois: fragment du Saddharmapuṇ̣arīka, comparaison de la maison en flammes... I rouleau (25.5 $\mathrm{x}$ Im 35). Le début manque." 
PT I044.I: Untitled cauterization text fragment that is missing its opening section (pp. $3 \mathrm{~V}-$ 2v, 11. I-59). ${ }^{746}$

PT I044.2: Short and badly damaged medical text fragment (p. Iv, 11. 6o-69).

PT I057: digitization available on IDP; $;^{74}$ a single complete scroll $(450 \times 26.3 \mathrm{~cm})$ that appears to be composed of twelve separate pages that were glued together. PT IO57 was also written on the back of a witness of the Lotus Sutra, so we shall count the pages from right to left, but this time the first page of Chinese corresponds to the first page of Tibetan. The first page of Chinese is badly damaged (Ir) and contains nine columns of Chinese. Pages $2 \mathrm{r}-\mathrm{IIr}$ each contain 22 columns of Chinese, while page I2r contains 8.5 columns (and appears to have been cut). The first page of Tibetan writing (Iv) is also badly damaged, containing 4 lines of writing. Pages 2V-IIV contain an average of 20 lines each $(23,19,18,20,20,20,19,22$, I9, 20) and I2v contains 4 lines. Mostly headless official script style, but not without examples of headed official script (e.g. 9v). Excluding the Chinese-language Lotus Sutra fragment (pp. Ir-I2r), there appears to only be one untitled Tibetan-language medical text (pp. IV-I2v, ll. I-208). ${ }^{748}$

PT I058: digitization available on IDP; ${ }^{749}$ a single fragmentary segment of a scroll $(37 \times 30 \mathrm{~cm})$. On the front (Ir) are two anatomical drawings with about twelve labeled points on one figure and six on the other. Fragmented labels indicate that there probably were other illustrations as well. The back (IV) contains 26 lines of Tibetan writing that does not appear to relate to the drawings. The writing on the front (Ir) appears to be a headless official script, while the writing on the back (Iv) appears to be a headed official script.

PT I058.I: Anatomical drawings for cauterization therapy (Ir) ${ }^{750}$

PT I058.2: An untitled text on impermanence, behavior, and governance (Iv, 1l. I-26).

PT 1059: digitization currently unavailable on IDP; ${ }^{751}$ damaged fragments of a scroll $(3 \mathrm{I} \mathrm{cm}$ wide), at least one of which includes medical prescriptions.

${ }^{746}$ Reproduced in Luo Bingfen et al., Tun hong nas thon pa'i bod kyi gso rig yig cha gces bsdus, 234-38. For English-language translations selected from this work, see Schaeffer et al., Sources of Tibetan Tradition, II6-I7.

${ }^{747}$ Lalou, Inventaire des manuscrits tibétains, vol. II, I057: “Texte médical, sans titre ni colophon; 'écrit corrigé, donc sans erreur'... Écrit au dos d'un texte chinois: Saddharmapuṇ̣arīka, traduction de Kumārajīva, fin du chap. I2, chap. I3 complet, début du chap. I4... I rouleau (26.3 x 4m50). Complet."

${ }^{748}$ Reproduced in Luo Bingfen et al., Tun hong nas thon pa'i bod kyi gso rig yig cha gces bsdus, I7888. For English-language translations selected from this work, see Schaeffer et al., Sources of Tibetan Tradition, II5-I6.

${ }^{749}$ Lalou, Inventaire des manuscrits tibétains, vol. II, I058: "Deux dessins provenant d'un traité d'anatomie, ou peut-être d'acupuncture. Les points du corps sont indiqués par des légendes. Reproduction dans Journal Asiatique, Janv.-Juin, 1940.

Au dos, fragment d'un texte qui ne paraît avoir aucun rapports avec les dessins médicaux (recueil de sentences?).

I morceau de rouleau (30 x 37)."

${ }^{750}$ Reproduced in Luo Bingfen et al., Tun hong nas thon pa'i bod kyi gso rig yig cha gces bsdus, 35. 
PT 1060: ${ }^{752}$ digitization available on IDP; ${ }^{753}$ a single damaged scroll $(\mathrm{I} 3 \mathrm{I} \times 30.5 \mathrm{~cm})$ that appears to have been repaired and is composed of three separate pages that have been glued together. The first page (Ir) is damaged at the top and appears to contain a total of 37 lines of writing, the second page (2r) contains 34, and the third page (3r) contains 29. With the exception of some faint scribbling on the back of the first page (IV), all verso sides are blank. The script style is mostly headless official but, as Lalou notes, can also oscillate between headed and headless. There appear to be four separate works on divination in relation to horses. ${ }^{754}$

PT I06I: digitization available on IDP; a single scroll $(490 \times 25.5 \mathrm{~cm})$ of a Chinese-language Vimalakìrtinirdeśasūtra, with a short and slightly damaged fragment written in Tibetan. The first page of Tibetan writing (Iv) has seven lines of headed official script about veterinary medicine. ${ }^{755}$

${ }^{751}$ Lalou, Inventaire des manuscrits tibétains, vol. II, IO59: "Fragments en très mauvais état; sur l'un d'eux on parvient à lire des presciptions médicales (ou médico-magiques). Au dos, quelques caractères chinois isolés et traces de sceau rose. Morceaux provenant d'un rouleau qui devait mesurer 3I cent. de large. Écriture dont les lignes ondulent et parfois se confondent."

${ }^{752}$ Note, this work is not listed in Luo Bingfen and Liu Yinghua, "Dunhuangben Tubo yixue wenxian jieti mulu."

753 Lalou, Inventaire des manuscrits tibétains, vol. II, I060: "Présages en relation avec les chevaux... La fin est d'une autre main.

I rouleau (30.5 X Im3I) dont le début manque. Marges grises (non observées à la fin de la ligne qui est terminée par un trait vertical). Très abîmé; a été réparé."

${ }^{754}$ For a French-language study of PT 1060-I066, see Anne-Marie Blondeau, Matériaux pour l'étude de l'hippologie et de l'hippiatrie tibétaines: à partir des manuscrits de Touen-houang (Genève: Librairie Droz, 1972). This is also a study of other hippological works of Indian and Tibetan provenance-such as Sālihotra's Hippology (Skt. aśvāyurvedasaminhita = Tib. rta’i tshe’i rig byed sha li ho tras bsdus pa) included in the Tengyur (Dpe bsdur ma, sna tshogs, vol. 2I8 [ngo], text II4, pp. I496-I825). For an English-language selection on hippiatry, see Schaeffer et al., Sources of Tibetan Tradition, II8. For further studies on Tibetan hippology, see the work of Petra Maurer: Handschriften zur tibetischen Hippiatrie und Hipplogie (Bonn: Beiträge zur Zentralasienforschung, Band 8, 200I) [her dissertation]; as well as Petra Maurer, "The Horse Book of the Prince of Jharkot," Kailash I7 (1995): I47-56; Petra Maurer, "A First Survey of Tibetan Hippology and Hippiatry," in Tibetan Studies, Proceedings of the 7th Seminar of the International Association for Tibetan Studies, Graz 1995, ed. Helmut Krasser et al. (Wien: Österreichische Akademie der Wissen-schaf-ten, I997), vol. 2, 6I3-I8; Petra Maurer, "Tibetan Veterinary Medicine: Written and Oral Traditions," Zentralasiatische Studien 35 (2006): 247-72; and so forth.

${ }^{755}$ Lalou, Inventaire des manuscrits tibétains, vol. II, I06I: "Fragment (7 lignes) d'art vétérinaire. Le début est brûlé." 
PT 1062: digitization available on IDP; ${ }^{756}$ a single scroll (I80 $\times 28 \mathrm{~cm}$ ) composed of three separate pages that have been glued together, but also appears to have been ripped and then repaired (2r). The first page (Ir) appears to have been ripped, so not including partial letters from a previous section, Ir contains 40 lines, $2 r$ contains 45 lines, and $3 r$ contains 24 lines of headed official script writing. Lalou has identified fourteen sections and calls this an important work on veterinary medicine.

PT I063: digitization available on IDP, ${ }^{757}$ a single segment of a scroll $(63 \times 27.5 \mathrm{~cm})$ composed of two separate and fragmentary pages that have been glued together. The first page (Ir) appears to have been ripped at the top and contains 30 lines, while the second page (2r) is ripped at the bottom and contains 3I lines of headed official script. The back side (2v) has 8 lines of faint headless official script that appears to be from a text fragment used to repair the larger page. Lalou has identified eight sections for this work on veterinary medicine.

PT 1064: digitization available on IDP; $;^{758}$ thirteen folios $(9 \times 30.7 \mathrm{~cm})$ each with either six or seven lines written in a headed Buddhist manuscript style with thick horizontal strokes. ${ }^{759}$ The work lacks page numbers, and Lalou notes that it is on veterinary medicine, but does not consider it to be very coherent.

PT I065: ${ }^{760}$ digitization available on IDP; ${ }^{76 \mathrm{I}}$ a single segment of a scroll $(63 \times 27.5 \mathrm{~cm})$ composed of three separate pages that have been glued together. The first page (Ir) appears to have been ripped at top right corner and contains I 8 lines, the second page (2r) contains 55 lines, and the third page (3r) contains 32 lines. The scroll includes four separate sections that each have titles written in red ink (the last of which is only a title). The first two sections were written in headless official script, while the latter two section were written in headed official script. Verso scans are not available on IDP. A work on riding and caring for horses.

${ }^{756}$ Lalou, Inventaire des manuscrits tibétains, vol. II, I062: "Important fragment, sans début ni fin, d'un texte d'art vétérinaire: soins à donner aux chevaux... I rouleau ( $28 \mathrm{x} \mathrm{Im80)}$ dont le début et la fin manquent. Très usé; mutilé partiellement en largeur."

${ }^{757}$ Lalou, Inventaire des manuscrits tibétains, vol. II, I063: "Soins à donner aux chevaux blessés ou malades... I morceau de rouleau (27.5 x 63). Le début est déchiqueté et la fin manque. Consolidé d'origine. A été réparé."

${ }^{758}$ Lalou, Inventaire des manuscrits tibétains, vol. II, I064: "Un texte d'art vétérinaire: soins à donner aux chevaux, juments, poulains."

759 For the headed Buddhist manuscript style, see van Schaik, "Towards a Tibetan Palaeography," 319-20.

${ }^{760}$ Note, this work is not listed in Luo Bingfen and Liu Yinghua, "Dunhuangben Tubo yixue wenxian jieti mulu."

${ }^{761}$ Lalou, Inventaire des manuscrits tibétains, vol. II, I065: "Sur l'équitation et les soins à donner aux chevaux. Recueil dont le début paraît être tronqué et qui n'est pas terminé. Les titres sont donnés en rouge... I rouleau ( 32 x 95) sans règl. ni marges, éléments en rouge. Légèrement mutilé au coin droit." 
PT I066: digitization available on IDP ${ }^{762}$ a single fragmentary page $(19.8 \times 46 \mathrm{~cm})$ containing II lines of headed official style script. A scan of the verso side is not available on IDP. On the examination of horses.

\section{The Eleventh and Twelfth Centuries}

Following the translation of the Essence of the Eight Branches in the early eleventh century, a proliferation of Tibetan-language medical texts ensued, particularly summaries of and commentaries on the Eight Branches. Medical scriptures and instructional collections of familial lineages of physicians also came to be redacted during this time, many of which contain instructions deriving from even earlier periods.

\section{The Book of Sakya (sa skya bka' 'bum), Medical Works}

There are two texts that might be considered medical works in the Book of Sakya: one which is a collection of miscellaneous instructional texts traditionally attributed to Jetsün Drakpa Gyentsen (rje btsun grags pa rgyal mtshan, II47-I216), ${ }^{763}$ and one which is a summary of the Essence of the Eight Branches traditionally attributed to Sakya Pandita Künga Gyentsen (sa skya pandita kun dga' rgyal mtshan, II82-I25I). The latter was a later addition to the Book of Sakya, as attested by its inclusion in the Selections of Recently Found Materials (gsar rnyed phyogs bsgrigs).

Sman dpyad rgyal poi dkor mdzod bzhugs so/ gso dpyad bdud rtsi thigs pa. In Krung go'i bod lugs gso rig rtsa cheï dpe rnying kun btus, vol. I, text 15.

Gso dpyad rgyal po'i dkor mdzod. In Sa skya gong ma rnam lnga'i gsung 'bum dpe bsdur ma las grags pa rgyal mtshan gyi gsung pod lnga pa, vol. 5, pp. 372-533.

Yan lag brgyad pa'i snying po. Bod kyi gso ba rig pa'i gna' dpe phyogs bsgrigs dpe tshogs, vol. 85. Beijing: Mi rigs dpe skrun khang, 2008.

Yan lag brgyad pa'i snying po. In Sa skya bka' 'bum ma phyi gsar rnyed phyogs bsgrigs (Lhasa: TBRC computer input, I990s), vol.3 (tsha), pp. 2II-6I (ff. Ia-26a).

\section{Canonical Translations of Medical Treatises (bstan 'gyur)}

In addition to the early Buddhist medical sources that were presumably translated during the Tibetan imperial period, nearly a dozen miscellaneous treatises and commentaries on medical theory and practice were translated in the eleventh and twelfth centuries. These treatises can be found in the Medicine (gso ba rig pa) and Miscellaneous (sna tshogs) sections of the Translated Treatises (bstan 'gyur) canon. The Essence of the Eight Branches and its Moonbeams

${ }^{762}$ Lalou, Inventaire des manuscrits tibétains, vol. II, I066: "Fragment sur les qualités des chevaux... I morceau de rouleau (I9.8 x 46), écrit sans lés dans le sens de la longueur; Io 1. Mutilé à gauche."

${ }^{763}$ For a critique of this attribution, see Olaf Czaja, "The Making of the Blue Beryl: Some Remarks on the Textual Sources of the Famous Commentary of Sangye Gyatsho (I653-I705)," in Soundings in Tibetan Medicine: Anthropological and Historical Perspectives. Proceedings of the Ioth 
commentary were purportedly translated by Rinchen Zangpo at the beginning of the eleventh century (see Chapter Two). In addition to these translations, several other works attributed to Nāgārjuna were translated from Sanskrit around this period and included in the medicine section (gso rig) in the Canon of Translated Treatises (bstan 'gyur).

Sbyor ba brgya ba (= Skt. yogaśataka). ${ }^{764}$ In Bstan 'gyur dpe bsdur ma, text 3543, vol. III (he [2I3]),

pp. 3-22.

Gso ba rig pa'i man ngag sbyor ba brgya pa bzhugs so. In Krung go’i bod lugs gso rig rtsa che’i dpe rnying kun btus, vol. I, text 9.

Sman dpyad sbyor ba brgya pa zhes bya ba legs pa bzhugs so. In Krung go'i bod lugs gso rig rtsa che'i dpe rnying kun btus, vol. I, text 7 .

Slob dpon klu sgrub kyis bshad pa sman a ba’i cho ga (= Skt. *ācāryanāgärjunabhāṣitaavabheșajakalpa). ${ }^{765}$ In Bstan 'gyur dpe bsdur ma, text 3545, vol. III (he [2I3]), pp. 34-38.

Sman dpyad gces pa grub pa zhes bya ba le'u sum cu rtsa gcig pa (= Skt. siddhasāra). ${ }^{766}$ In Bstan 'gyur dpe bsdur ma, text 3683, vol. I20 (no [226]), pp. 464-695.

Sman dpyad yan lag brgyad pa'i sying po'i 'grel pa (= Skt. *vaidyāștāngahrdayavrtti). ${ }^{767}$ In Bstan 'gyur dpe bsdur ma, text 3546, vol. III (he [213]), pp. 39-I42.

Sman 'tsho ba'i mdo (= Skt. jīvasūtra). ${ }^{768}$ In Bstan 'gyur dpe bsdur ma, text 3544, vol. III (he [2I3]), pp. 23-33.

Sman 'tsho ba'i mdo. In Krung go'i bod lugs gso rig rtsa che’i dpe rnying kun btus, vol. I, text 8.

Yan lag brgyad pa'i snying po zhes bya ba'i sman dpyad kyi bshad pa (= Skt. aștāñgahṛdayanāmavaiḍūryakabhāṣya) ${ }^{769}$ In Bstan 'gyur dpe bsdur ma, text 3548, vols. III-I2 (he-e [213-I4]).

Yan lag brgyad pa'i snying po’i bsdus pa (= Skt. așțāngahṛdayasaṃhita). ${ }^{770}$ In Bstan 'gyur dpe bsdur ma, text 3547, vol. III (he [213]), pp. I43-944.

Seminar of the International Association of Tibetan Studies, edited by Mona Schrempf (Leiden: Brill, 2007), 367, n. 74 .

${ }^{764}$ For further citations and information on this work, see Tarthang Tulku et al., eds., The Nyingma Edition of the sDe-dge bKa'-gyur/bsTan-'gyur: Research Catalogue and Bibliography (Oakland, CA: Dharma Press, 1977-1983), vol. 7, text 4306, pp. 50-5I; Meulenbeld, A History of Indian Medical Literature, vol. 2a, pp. 139-4I.

${ }^{765}$ Tarthang Tulku et al., eds., The Nyingma Edition of the sDe-dge bKa'-'gyur/bsTan-'gyur, vol. 7, text 4308, p. 52.

${ }^{766}$ Tarthang Tulku et al., eds., The Nyingma Edition of the sDe-dge bKa'-'gyur/bsTan-'gyur, vol. 7, text 4434, pp. I53-54; Meulenbeld, A History of Indian Medical Literature, vol. Ia, pp. I46-48.

${ }^{767}$ Tarthang Tulku et al., eds., The Nyingma Edition of the sDe-dge bKa'-'gyur/bsTan-'gyur, vol. 7, text 4309, p. 53; Meulenbeld, A History of Indian Medical Literature, vol. Ia, p. 666.

${ }^{768}$ Tarthang Tulku et al., eds., The Nyingma Edition of the sDe-dge bKa'-'gyur/bsTan-'gyur, vol. 7 , text 4307, p. 52; Meulenbeld, A History of Indian Medical Literature, vol. 2a, pp. 135-36.

${ }^{769}$ Tarthang Tulku et al., eds., The Nyingma Edition of the sDe-dge bKa'-'gyur/bsTan-'gyur, vol. 7, text 43II, pp. 59-6o; Meulenbeld, A History of Indian Medical Literature, vol. Ia, p. 666. 
Gso dpyad yan lag brgyad paii snying po bsdus pa bzhugs so. In Krung go’i bod lugs gso rig rtsa chëi dpe rnying kun btus, vol. 2, texts I-6.

Yan lag brgyad pa'i snying po bsdus pa zhes bya ba bzhugs so. In Krung go’i bod lugs gso rig rtsa chei dpe rnying kun btus, vol. Io, text I.

Yan lag brgyad pa'i snying po 'dus pa bzhugs so. In Krung go'i bod lugs gso rig rtsa che'i dpe rnying kun btus, vol. 5, text 3 .

Yan lag brgyad pai snying po’i rnam par 'grel pa tshig gi don gyi zla zer (= Skt. padārthacandrikāprabhāsanāma-aștāingahṛdayavivruti). ${ }^{771}$ In Bstan 'gyur dpe bsdur ma, text 3549, vol. II3 (ko-kho [215-I6]), pp. 3-I7I6; vol. II4 (go [217]), pp. 3-840.

\section{The Eleven Thousand-session Tutorials (skor tshoms stong thun bcu gcig)}

These thousand-session tutorials (stong thun) represent some of the earliest practical instructions that were transmitted within the Yutok school (beginning in the $\mathrm{I}^{\mathrm{th}} \mathrm{c}$.). According to the Indispensable Account of Transmission these practical instructions may have been arranged based on the teachings of Yutok Yönten Gönpo himself. The group of eleven represent the teachings of Lharjé Sanggye Pelrin, ${ }^{772}$ which was then included in the Eighteen Partial Branches around the turn of the fourteenth century.

Skor tshoms stong thun bcu gcig. In Cha lag bco brgyad, text 7, pp. 243-386.

Skor tshoms stong thun bcu gcig las dang po rtsa'i stong thun. In Krung go'i bod lugs gso rig rtsa che'i dpe rnying kun btus, vol. 3 , text 5 .

Skor tshoms stong thun bcu gcig. In Krung göi bod lugs gso rig rtsa cheï dpe rnying kun btus, vol. I4, text 4 .

Grang baï stong thun. In Krung göi bod lugs gso rig rtsa cheï dpe rnying kun btus, vol. 3, text 9. Grang bai stong thun. In Krung go'i bod lugs gso rig rtsa che'i dpe rnying kun btus, vol. I4, text 4 . Bad kan smug po’i stong thun. In Krung go’i bod lugs gso rig rtsa cheii dpe rnying kun btus, vol. I4, text 5.

Rtsa chu'i stong thun g.yu thog gi bzhed pa. In Krung göi bod lugs gso rig rtsa che’i dpe rnying kun btus, vol. 3, text 7 .

The Essence of Ambrosia [in Eight Branches] (bdud rtsi snying po [yan lag brgyad pa])

The set of instructions described by Sumtön Yeshé Zung (sum ston ye shes gzungs, fl. late $12^{\text {th }} \mathrm{c}$. and early $\mathrm{I}^{\text {th }} \mathrm{c}$.) in his Indispensable Account of Transmission (brgyud pa'i rnam thar med thabs med $p a$, II74?). Although we might infer that this work approximately corresponds to the

${ }^{770}$ Tarthang Tulku et al., eds., The Nyingma Edition of the sDe-dge bKa'-'gyur/bsTan-'gyur, vol. 7 , text 4310, pp. 53-58; Meulenbeld, A History of Indian Medical Literature, vol. Ia, pp. 392-473.

${ }^{771}$ Tarthang Tulku et al., eds., The Nyingma Edition of the sDe-dge bKa'-'gyur/bsTan-'gyur, vol. 7 , text 4312, pp. 6o-6I; Meulenbeld, A History of Indian Medical Literature, vol. ra, p. 665.

${ }^{772}$ Skor tshoms stong thun bcu gcig, in Krung go'i bod lugs gso rig rtsa che'i dpe rnying kun btus, vol. I4, text 4, p. 40 (f. 35b): mkhas pa g.yu thog mgon po'i lugs so//_lha rje sangs rgyas dpal rin gyis [sic] khyad nor yin//. On this figure, see Chapter Four above. 
Explanatory Tantra (bshad rgyud) and parts of the Instructional Tantra (man ngag rgyud) of the Four Tantras (rgyud bzhi), it is no longer extant and represents a missing developmental stage in the history of the Four Tantras. This work is cited as a source in the Secret Essence of Ambrosia.

Kyebu Melha (skyes bu me lha), Medical Works

Kyebu Melha, also sometimes called "Handless Bharo" (bharo phyag rdum), is an eleventhcentury figure of some renown in renaissance Tibet. He is said to have been the son of Jinamitra, a pandit from Oḍdiyāna, with a long and illustrious career in South Asia. Once, when treating a queen in South Asia, he is said to have committed an infraction, resulting in his hand being severed (phyag rdum) as a punishment. He is traditionally said to have come to Tibet in the eleventh century during the reign of Lord Tsedé (mnga' bdag rtse lde), but further research would be necessary to historically verify any of these claims. Regardless, a series of works that are traditionally said to derive from the medical traditions of Oḍdiyāna can be attributed to him, including the Collection of the Fist ('bum khu tshur), the Fist Collection (khu tshur 'bum), and the Black Calf's Nipple (be'u bum nag po). ${ }^{773}$ Another title cited as a source in the Secret Essence of Ambrosia is the Pebble Cycle (rde'u skor), which probably refers to the Black Calf's Nipple, in light of the fact that the titles White Pebble (rde'u dkar) cycle, the Black Pebble (rde'u nag) cycle, and the Mother and Son Pebble Cycles (rde skor ma bu) appear there (see Be'u bum nag po, 570).

'Bum khu tshur, Khu tshur 'bum, and Be'u bum nag po. Bod kyi gso ba rig pa'i gna' dpe phyogs bsgrigs dpe tshogs, vol. 34 .

\section{The Medicine of the Moon King (sman dpyad zla ba'i rgyal po, so ma rā dza)}

The Moon King is one of the earliest and most important scriptural collections of theories and instructions in the Tibetan medical tradition. The Moon King, also called the Somaradza or

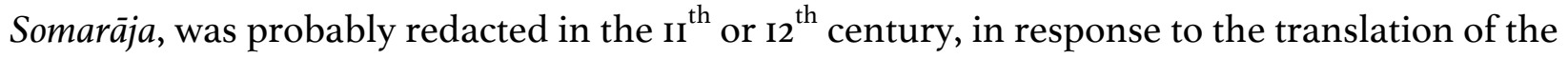
Essence of the Eight Branches. The narrative frame of the work attributes its own origins to the teachings of Mañjuśrī and the redaction of Nāgārjuna (see Chapter Three), and is composed of instructions related to South, East, and Central Asian traditions. Perhaps due to the status of Nāgārjuna as a sagacious practitioner of medicine established here an elsewhere, a small body of instructions related to the Moon King also came to be transmitted during this time period. Despite its early importance, the work was ultimately eclipsed by the Four Tantras and was not

${ }^{773}$ For a description of the "calf's nipple" (be'u bum) genre, see Bryan Cuevas, "The 'Calf's Nipple' (Be'u bum) of Ju Mipam ('Ju Mi pham): A Handbook of Tibetan Ritual Magic," in Tibetan Ritual, ed. José I. Cabezón (Oxford: Oxford University Press, 20I0), 165-86. His mention of related oral instructions entitled lde'u may help explain the somewhat idiosyncratic appellation of the Pebble Cycle (rde'u skor). 
published in a xylographic edition until the efforts of Situ Paṇchen Chökyi Jungné (si tu paṇ chen chos kyi 'byung gnas, $1700-1774) .{ }^{774}$

Sman dpyad zla ba'i rgyal po. Bod kyi gso rig pa'i gna' dpe phyogs bsgrigs dpe tshogs, vol. 33. Beijing: Mi rigs dpe skrun khang, 2005.

Sman dpyad zla baï rgyal po: The Somarājabhaisajyasādhanā, an Indian medical work by Nägärjuna, in its Tibetan translation, by Hashang Mahayana and Vairocana: Reproduced from a set of prints from the Sde-dge blocks from Library of Tashigang. Smanrtsis shesrig spendzod, vol. 135. Leh: T. Y. Tashigang, 1989.

Sman dpyad zla ba’i rgyal po. In Krung göi bod lugs gso rig rtsa che’i dpe rnying kun btus, vol. 5, text I.

Sman dpyad zla ba’i rgyal po. In Krung göi bod lugs gso rig rtsa che’i dpe rnying kun btus, vol. 5, text 2.

Sman dpyad zla bai rgyal po: The Somaräjabhaisajyasādhanā, an Indian Medical Work by Nägārjuna in its Tibetan Translation by Hashang Mayayana and Vairocana. Smanrtsis Shesrig Spendzod. vol. 135. Leh: D. L. Tashigang, 1989. Sde dge print.

\section{Nāgārjuna (klu sgrub), Non-canonical Medical Works}

Related to the identification of Nāgārjuna as the redactor of the Medicine of the Moon King, a series of other works including early descriptions of channel examination have also been attributed to Nāgārjuna. Perhaps the most famous work that fits this description would be the Lamp of the Secret Nucleus (gsang tig sgron ma), which is listed among the sources for the Secret Essence of Ambrosia. Another important work detailed instructions for channel examination that presumably predate the Subsequent Tantra is the Lamp of Sunbeams: A Channel Manual (rtsa yig nyi zer sgron me, see Chapter One), also included in the collection below.

Slob dpon klu sgrub kyi sman yig gces btus. Bod kyi gso ba rig pa'i gna' dpe phyogs bsgrigs dpe tshogs, vol. 73.

Gsang tig sgron ma. In Slob dpon klu sgrub kyi sman yig gces btus, 180-308.

Rtsa yig nyi zer sgron me. In Slob dpon klu sgrub kyi sman yig gces btus, 360-77.

\section{Padmasambhava (padma 'byung gnas), Medical Works}

Like the diverse traditions of the early Great Perfection, cycles of medical instructions also ultimately come to be attributed to the illustrious teachings of Padmasambhava. The most famous text would most probably be the Instructions for the Vase of Deathless Ambrosia Tantra ('chi med bdud rtsi bum pa'i rgyud man ngag), as well as other related miscellaneous works included in the work listed below. I have done very little work on this collection, whose analysis remains an important desideratum in the field of Tibetan medical studies.

${ }^{774}$ Again, see Leonard W. J. van der Kuijp, "Za hor and Its Contribution to Tibetan Medicine, Part Two: Sources of the Tibetan Medical Tradition," Bod rig pa'i dus deb [Zangxue xuekan 藏学学刊; Journal of Tibetology] I2 (2016): 83 et passim. 
Bdud rtsi sman gyi bslangs la skul ba'i cho ga bzhugs so. In Krung go’i bod lugs gso rig rtsa che’i dpe rnying kun btus, vol. I, text 3.

Bdud rtsi sman gyi gsang bsgrub bzhugs so. In Krung go’i bod lugs gso rig rtsa chei dpe rnying kun btus, vol. I, text I.

Bdud rtsi sman gyi spra khrid lag len gyi yig chung bzhugs so. In Krung go’i bod lugs gso rig rtsa che’i dpe rnying kun btus, vol. 9, text 65.

Bdud rtsi sman gyi yig chung zhes bya ba bzhugs so. In Krung go'i bod lugs gso rig rtsa che'i dpe rnying kun btus, vol. I, text 2.

'Chi med bdud rtsi'i bum pa'i rgyud bzhugs so. In Krung go'i bod lugs gso rig rtsa che'i dpe rnying kun btus, vol. I8, text 12.

Nag chung gsang ba’i khro yig ces bya ba bzhugs so. In Krung go’i bod lugs gso rig rtsa che’i dpe rnying kun btus, vol. 9, text 66.

Slob dpon pad 'byung gi sman yig gces btus. Bod kyi gso ba rig pa'i gna' dpe phyogs bsgrigs dpe tshogs, vol. 24.

'Chi med bdud rtsi bum pa'i rgyud man ngag zhes bya ba sems can thams cad kyi sdug bsngal sel byed. In Slob dpon pad 'byung gi sman yig gces btus, I-I92.

\section{The Three Indispensable Rituals (med thabs med pa'i 'phyong gsum)}

A collection of four distinct works: [I.] the Indispensable Account of Transmission (brgyud pa'i rnam thar med thabs med pa, II74?) attributed to Sumtön Yeshé Zung (sum ston ye shes gzungs, fl. late $12^{\text {th }}$ c. and early I3 ${ }^{\text {th }}$ c.); [2.] the Channel Prasenā Rituals (rtsa'i pra sgrub med thabs med pa)including both [2.I.] the Channel Divination of the Three Goddess Sisters of Medicine (sman gyi lha mo spun gsum gyi rtsa'i pra sgrub) and [2.2.] the Channel Evocation of the Black-lipped Brahminess (bram ze mchu nag ma'i rtsa'i sgrub thabs) —which purportedly derive from Chinese traditions, were translated by Vairocana, and are associated with Drapa Ngönshé (gra pa mngon shes, I0I2-I090); and [3.] the Instructions for Pediatrics (sri'u gso ba med thabs med pa). This collection probably represents eleventh-century instructions that preceded the redaction of the Essence of Ambrosia in Eight Branches (bdud rtsi snying po yan lag brgyad pa), but then came to be transmitted together within the Yutok school (see Chapter One). This collection was ultimately included in the Eighteen Partial Branches around the turn of the fourteenth century.

Brgyud pa'i rnam thar med thabs med pa. In Cha lag bco brgyad, text I2, pp. 487-97.

Brgyud pa'i rnam thar med thabs med pa bzhugs so. In Krung go'i bod lugs gso rig rtsa che'i dpe rnying kun btus, vol. Io, text 4 .

Med thabs med pa'i mchong [sic] gsum. In Krung go'i bod lugs gso rig rtsa che'i dpe rnying kun btus, vol. 3, text 3 .

Rtsa'i spra sgrub med thabs med pa bzhugs so. In Krung go'i bod lugs gso rig rtsa che'i dpe rnying kun btus, vol. Io, text 5 .

\section{Zhangtön Zijibar (zhang ston gzi brjid 'bar), Medical Works}


Zhangtön Zijibar and his brother Zhangtön Chömbar (zhang ston chos 'bar, I053-II35) were both involved in the early transmission of the Sakya Path and Fruit (sa skya lam 'bras) literature, remembered for their role in teaching Sachen Künga Nyingpo (sa chen kun dga' snying po, I092-II58) of the Khön clan (see Chapter Two). Zhangtön Zijibar also played an essential role in the assimilation and practice of the Essence of the Eight Branches, for he helped summarize the work and provide practical instructions in his Illuminating Lamp: Thirty Instructions (sgron gsal gdams pa sum cu pa) and Rays of Sunlight (nyi ma'i 'od zer). These works have only been recently republished (2014) and their study remains a major desideratum in writing the early history of the Tibetan medical tradition.

Gzhung dri med gzi brjid kyi 'grel ba nyi ma’i 'od zer. Bod kyi gso ba rig pa'i gna' dpe phyogs bsgrigs dpe tshogs, vol. IOI.

Ga las pa sum cu pa [Thirty Oral Instructions]. In Krung go’i bod lugs gso rig rtsa che’i dpe rnying kun btus, vol. I, text $\mathbf{2}$.

\section{The Thirteenth Century}

Following the development of scholastic commentaries and practical summaries based on the Essence of the Eight Branches and its related works, by the end of the twelfth century a sizable corpus of practical literature based on both cosmopolitan and vernacular traditions began to emerge. One of the most important collections to emerge in this period was the Secret Essence of Ambrosia - an anthology of primarily vernacular instructions that were not included in the Essence of the Eight Branches or its derivatives in the Essence of Ambrosia in Eight Branches. By the end of the thirteenth century, the essence of this Secret Essence, among other works, was appended to the Essence of Ambrosia in Eight Branches as a Subsequent Tantra, resulting in the Four Tantras as we approximately know it today.

The Commentary on the Small Practical Manual (lag len spod chung gi 'grel pa)

The commentary on the Small Practical Manual is an important late thirteenth-century work outlining the practical repertoire of Drangti Jampel Zangpo (brang ti jam dpal bzang po; ca. I276-I335) on the basis of a non-extant practical manual attributed to Yutok Gönpo. The work can be approximately divided into three parts: [I.] an account of transmission that appears to be a later addition to the work, [2.] a section on diagnostics that appears to be a short treatise composed by Jampel Zangpo, and [3.] a commentary on Yutok's Small Practical Manual, outlining the five (or eight) classifications (sde tshan) of medicine. Like the Secret Essence of Ambrosia, the Small Practical Manual summarizes and expands the instructions of several earlier, more terse works, and probably influenced the composition of the Subsequent Tantra. This proposed scenario may help explain the disappearance of the Small Practical Manual root text, which has only been transmitted in the context of Jampel Zangpo's commentary.

Lag len spod chung gyi 'brel [sic] pa. In Krung go'i bod lugs gso rig rtsa che'i dpe rnying kun btus, vol. 3, text 2. 
Rgyud rgyal bdud rtsi snying po las lag len dmar khrid sde tshan lnga'i 'grel pa. In Krung göi bod lugs gso rig rtsa che’i dpe rnying kun btus, vol. 8, text 6.

Rgyud rgyal bdud rtsi snying po las lag len dmar khrid sde tshan lnga'i 'grel pa. In Phyi ma rgyud kyi 'grel ba phyogs bsgrigs. Bod kyi gso ba rig pa'i gna' dpe phyogs bsgrigs dpe tshogs vol. 89, 265-325. Beijing: Mi rigs dpe skrun khang, 2008.

\section{The Complete Entrustment (yongs su gtad pa)}

If the Secret Essence of Ambrosia represents a draft of the Subsequent Tantra, which it very well may be, the "Summary" (don bsdus pa) and "Complete Entrustment" (yongs su gtad pa) chapters of the back section represent the final additions to the Four Tantras. As demonstrated by the plethora of manuscripts below, this summary and short story of transmission were disseminated independently at one point, perhaps acting as an abbreviated form of the work as a whole. These chapters also contain the geographic references to the medical teachings of Tibet as being separate from those of India, China, and Dölpo, perhaps representing a geographical consciousness of the late thirteenth- or even fourteenth-century Yuan dynasty (see Chapter Five).

Bdud rtsi snying po bsang [sic] ba yan lag brgyad pa phyi ma 'phrin las kyi rgyud las/_jug don yongs su dpyad [sic] pa. In Krung go'i bod lugs gso rig rtsa che’i dpe rnying kun btus, vol. 4, text 7, pp. 523-30 (ff. Ia-I6a).

Rgyud bzhi' 'jug don gyis dbu'. In Krung go'i bod lugs gso rig rtsa che'i dpe rnying kun btus, vol. 4, text 6, pp. 5I2-22 (ff. Ia-I6b).

Rgyud bzhiłi mjug don yongs gtad. In Krung goii bod lugs gso rig rtsa che’i dpe rnying kun btus, vol. 8, text 8, pp. 332-37 (ff. Ia-IIb).

\section{The Lamp that Illuminates the Red Register (dmar byang gsal ba'i sgron me)}

The Red Register begins with a legend describing its own origins: Drangti Gyelnyé Kharbu (brang ti rgyal mnyes mkhar bu), the imperial ancestor of the Drangti lineage, is depicted working as a minister for Tri Detsuktsen (khri lde gtsug btsan, 704-755), when he requests a medical text that can be understood without the instructions of a teacher. The emperor agrees to give it to him on the condition that he continue to work as a minister for a short time longer, and the ultimate reward is the Red Register. With this, Gyelnyé Kharbu is also appointed as the royal physician of Tri Detsuktsen, establishing a long line of Drangti physicians that is said to have extended down to the fourteenth century and beyond. Although this opening legend was probably added in the thirteenth or even fourteenth century when the work was redacted, the instructions found in the work appear to have a much older provenance. ${ }^{775}$

Byang khog dmar byang gsal ba'i sgron me. Bod kyi gso ba rig pa'i gna' dpe phyogs bsgrigs dpe tshogs, vol. IoI. Beijing: Mi rigs dpe skrun khang, 2014.

\footnotetext{
${ }^{775}$ For a thorough analysis of this work in comparison to the Four Tantras, see Yang Ga, Sources for the Writing of the Rgyud bzhi, 44-54 et passim.
} 


\section{The Ornamental Flower of Healing Science (gso ba rig pa rgyan gyi me tog)}

Seemingly in response to the proliferation of vernacular medical texts, Chomden Rikpé Reldri (bcom ldan rig pa'i ral gri, 1227-1305) composed a short work of medical instructions in the late thirteenth century. In the first chapter of this work he provides his account of the origins of Tibetan medical tradition-which, he says, derives from Indian, Chinese, and Oḍdiyānan traditions-and emphasizes the importance of the Essence of the Eight Branches. He also derides the Four Tantras as a Tibetan treatise that purports to be the teachings of the Buddha. In the subsequent chapters he provides an overview of the basic tenets of medical theory and practice. This work represents and early example of a Tibetan literatus and scholar of the five sceicnes writing about medicine without necessarily practicing it.

Gso ba rig pa rgyan gyi me tog. In Krung go’i bod lugs gso rig rtsa che’i dpe rnying kun btus, vol. 3, text 40.

Gso ba rig pa rgyan gyi me tog. Bod kyi gso ba rig pa'i gna' dpe phyogs bsgrigs dpe tshogs, vol. 8o. Beijing: Mi rigs dpe skrun khang, 2008.

\section{The Secret Essence of Ambrosia (bdud rtsi snying po gsang ba man ngag gi rgyud)}

The Secret Essence of Ambrosia: An Instructional Tantra can now be found in the Eighteen Partial Branches (cha lag bco brgyad). Since its redaction in this collection in the fourteenth century, it has usually been called the Little Tantra or the Lesser Tantra (rgyud chung), as opposed to the Victorious Tantra or the King of Tantras (rgyud rgyal), the latter of which generally refers to the Four Tantras. The work has at least two different framing narratives: both the Eighteen Partial Branches edition and one manuscript witness depict the work as [I.] a treatise composed by the Kashmiri pandit, Candranandana, and translated by Rinchen Zangpo; and one manuscript depicts the work as [2.] a treatise composed by the Tibetan sage, Yutok Gönpo, based on several explicitly stated sources. It is the latter statement of sources that can only be found in one manuscript witness (see manuscript vol. 4, text 5) that provides some of the most important bibliographic information regarding the early development of the Four Tantras (see Chapter Two). If the Secret Essence of Ambrosia was composed based on Essence of Ambrosia in Eight Branches, the Essence of the Eight Branches, the Yogaśataka [?], the Somaräja, Lamp of the Secret Nucleus, the Pebble Cycle, and the Illuminating Lamp[: Thirty Instructions], ${ }^{776}$ then we know that [I.] a work called the Essence of Ambrosia in Eight Branches, probably an early version of the Explanatory and Instructional Tantras, predates and compliments the Secret Essence of Ambrosia, and [2.] the Secret Essence of Ambrosia represents the summary and combination of instructions deriving from the Essence of the Eight Branches as well as more vernacular traditions. This information, combined with the descriptions of standardizing the Four Tantras in both the Flight of the Great Khyung and the Expanded Elucidation of Knowledge present a picture of the 
Four Tantras in general and the Subsequent Tantra in particular as an evolving work that represents the developments of the Tibetan medical tradition in both the twelfth and thirteenth centuries. ${ }^{777}$

Bdud rtsi snying po gsang ba man ngag gi rgyud. In Krung go’i bod lugs gso rig rtsa che’i dpe rnying kun btus, vol. 4, text 5.

Bdud rtsi snying po kha che zla dga' yis mdzad pa. In Krung go’i bod lugs gso rig rtsa che’i dpe rnying kun btus, vol. II, text I.

Rgyud chung bdud rtsi snying po. In Cha lag bco brgyad, text I6, pp. 534-744.

The Secret Essence of Ambrosia in Eight Branches: An Instructional Tantra (bdud rtsi snying po yan lag brgyad pa gsang ba man ngag gi rgyud), also known as the Four Tantras (rgyud bzhi)

A major claim made by the present dissertation is that, while many of the theories and instructions found in the Explanatory and Instructional Tantras may derive from the twelfthcentury teachings of Yutok Gönpo and his students, the work also remained an open document through the thirteenth and even fourteenth centuries, until the "essence" of these instructions was finally complimented by the Subsequent Tantra in the thirteenth century and canonized as the Four Tantras by Drangti Penden Tsojé in the fourteenth. Comparing the contents of the Four Tantras described in the Flight of the Great Khyung and the Expanded Elucidation of Knowledge, for example, reveals discrepancies in the number of parts (gnas) and descriptions of adding the Subsequent Tantra for the sake of "completing lacunae" (ma tshang ba kha bskang; see Chapter Three). The end result is that, from the fourteenth century onward, the Four Tantras came to represent the twelfth-century summary of the Essence of Ambrosia and other cosmopolitan works of medical theories and practices, as well as the thirteenth- and fourteenth-century developments in diagnosis, external therapy, and medical concoctions, thereby representing the essence of the Tibetan medical tradition.

Rje bstan 'dzin don grub, ed. Dpal ldan rgyud bzhi dpe bsdur ma. Chengdu: Si khron dpe skrun khang, 20I0. 4 vols.

Bdud rtsi snying po yan lag brgyad pa gsang ba man ngag gi rgyud. Lhasa: Bod ljongs mi dmangs dpe skrun khang, 1982.

Bdud rtsi snying po yan lag brgyad pa gsang ba man ngag gi rgyud. Delhi: Bod kyi lcags po ri'i drang rten slob gnyer khang, 1993.

${ }^{776}$ Bdud rtsi snying po gsang ba man ngag gi rgyud, in Krung go’i bod lugs gso rig rtsa che’i dpe rnying kun btus, vol. 4, text 5, p. 56 (f. 2b). See my translation and discussion in Chapter Two of the present dissertation.

777 For a demonstration of the fact that the Secret Essence of Ambrosia has smalle degree of intertextuality with the Explanatory Tantra (3/3I chapters), but a great degree of influence seen in the expanded explanations of the Subsequent Tantra, see Yang Ga, Sources for the Writing of the Rgyud bzhi, I80-8I, and 264. Yang Ga interprets the Secret Essence of Ambrosia (there called Rgyud chung) as a "draft" for the Four Tantras, whereas I see the Secret Essence of Ambrosia as a summary of the Instructional Tantra (among other sources) and a source used in turn for the final edition of the Subsequent Tantra. 
Bdud rtsi snying po yan lag brgyad pa gsang ba man ngag gi rgyud bzhugs so. In Krung gơi bod lugs gso rig rtsa che’i dpe rnying kun btus, vol. 4 , text 2.

Bshad päi rgyud le’u sum cu gcig pa bar snang nyi zla lta bu bzhugs s.ho. In Krung göi bod lugs gso rig rtsa che'i dpe rnying kun btus, vol. 4 , text 3 .

Bshad pa'i rgyud bar snang gi nyi zla 'dra ba'i mdo. In Krung go'i bod lugs gso rig rtsa che'i dpe rnying kun btus, vol. 4 , text 4 .

Rgyud Bźi: A Reproduction of a Set of Prints from the 1988 Lha-sa Lcags-po-ri Blocks. Leh: T. S. Tashigangpa, 1978.

Rgyud bzi: A Reproduction of a Set of Prints from the $1{ }^{\text {th }}$ Century Zun-cu Ze Blocks from the Collections of Raghu Vira. Smanrtsis Shesrig Spendzod, vol. 68. Leh: S. W. Tashigangpa.

\section{The Fourteenth Century}

If the thirteenth century should be understood as a time marked by the proliferation of vernacular medical instructions and their dialogue with established cosmopolitan theories and instructions, the fourteenth century was a time of standardization, redaction, and centralization. With the establishment of the Sakya Medical House at the turn of the fourteenth century, the Drangti family of physicians worked to standardize a canon of educational materials for the study and practice of medicine in Tibet, centering around the Four Tantras. Despite promoting the Four Tantras and its corpus of related commentarial literature-that is, the Eighteen Partial Branches-collections of other ritual and clinical practices that were being transmitted in the Drangti family also came to be redacted by the end of the century. Thus, the fourteenth century marks the establishment of both a standardized Four Tantras and Eighteen Partial Branches, as well as the miscellaneous instructions found within the Drangti lineage.

\section{Drangti Penden Tsojé (brang ti dpal ldan 'tsho byed), Medical Works}

Drangti Penden Tsojé (ca. I3IO-I380)—monk, scholar, physician, and member of the Sakya Medical House-is the single most important historical figure in the present dissertation. Around the year 1372 he composed a curriculum for the Sakya Medical House, the Expanded Elucidation of Knowledge (shes bya rab gsal), modeling it on the Flight of the Great Khyung, but also the Buddhist educational curriculum that had been established at Sakya. He also worked to standardize and redact the teachings of the Yutok school of medicine-including the Four Tantras and the Eighteen Partial Branches-establishing the core educational materials for much of the subsequent Tibetan medical tradition. Finally, he also composed several commentaries on the Four Tantras, two of which are still extant.

Rtsa mdo'i 'grel pa nyi maï 'od zer. In Krung göi bod lugs gso rig rtsa chei dpe rnying kun btus, vol. I, text I4. A commentary on the channel examination section of the Subsequent Tantra.

Rtsa rgyud gyi 'grel pa rgyud don rab gsal. In Krung go'i bod lugs gso rig rtsa chei dpe rnying kun btus, vol. I, text I3. A commentary on the Root Tantra. 
Khog dbubs shes bya rab gsal rgyas pa. In Krung go'i bod lugs gso rig rtsa che'i dpe rnying kun btus, vol. 20, text 2I. Incomplete.

Bstan pa snga phyi bar gsum gyi gso dpyad dar tshul shes bya rab gsal nas btus pa. In Krung goi bod lugs gso rig rtsa che'i dpe rnying kun btus, vol. 20, text 23. Incomplete.

Gsang ba man ngag gis [sic] rgyud kyi spyi don shes bya rab gsal rgyas pa. Unpublished manuscript held at the Nationalities Cultural Palace Museum (Minzu wenhua gong 民族文化宫) in Beijing. Incomplete.

Rgyud bzhii spyi don shes bya rab gsal rgyas pa. Delhi: TY Tashigang, 2005. Complete.

\section{The Eighteen Partial Branches (cha lag bco brgyad) Collection}

The Eighteen Partial Branches is a highly diverse collection of eighteen texts and subcollections, all attributed to early physicians and scholars of the Yutok lineage. The contents of the Eighteen Partial Branches were first listed in the Expanded Elucidation of Knowledge by Drangti Penden Tsojé (see Chapter Four) around the year 1372, finally standardizing this corpus of instructions from the Yutok school of Tibetan medicine. Some works attributed to Yutok Gönpo and his students were not included in this collection, however, indicating a degree of selectivity in deciding this corpus of supplemental summaries, commentaries, and outlines related to the teachings of the Four Tantras. Even during the fourteenth century these early commentaries were beginning to be replaced by newer ones composed by the prominent physicians of the era, which is a trend that would continue throughout the history of the Tibetan medical tradition. Regardless, this collection of supplemental instructions was still transmitted along with the Four Tantras down to the present day.

Cha lag bco brgyad. Bod kyi gso ba rig pa'i gna' dpe phyogs bsgrigs dpe tshogs, vol. 25. Beijing: Mi rigs dpe skrun khang, 2005.

G.yu thog cha lag bco brgyad: A Corpus of Tibetan Medical Teachings Attributed to G'yu-thog the Physician. Delhi: Tibetan Bonpo Monastic Centre, 1976. Reproduced from a set prints from Lhasa Zhol blocks. 2 vols.

\section{The Gold Measure (gser bre) and Silver Measure (dngul bre) Collections}

Attributed to the editorial efforts of Drangti Penden Gyentsen (brang ti dpal ldan rgyal mtshan, fl. late $14^{\text {th }}$ c.), nephew of Drangti Penden Tsojé, the Gold and Silver Measure collections represent a corpus of instructions that were transmitted within the Drangti lineage, but not included in the commentarial writings of Jampel Zangpo and Penden Tsojé. The Gold Measure collection probably represents earlier and more diverse materials-including instructions for divination, alchemy, and other miscellaneous ritual activities-while the Silver Measure focuses on instructions for the healing of specific diseases. Like other collections of this kind, the materials undoubtedly derive from earlier periods, but were not redacted together until the late fourteenth century and beyond.

Brang ti lha rjei rim brgyud kyi man ngag gser bre chen mo. Lhasa: Bod ljongs mi dmangs dpe skrun khang, 2005. 
Gser khri [=bre] rgyas pa zhes bya ba bzhugs so. In Krung göi bod lugs gso rig rtsa che’i dpe rnying kun btus, vol. 18 , text 13 .

Reg pa rtsa'i spra sgrub klu sgrub gyis mdzad pa bzhugs s.ho. In Krung go’i bod lugs gso rig rtsa che’i dpe rnying kun btus, vol. I, text Io.

Man ngag gser bre ma dang dngul bre ma. Bod kyi gso ba rig pa'i gna' dpe phyogs bsgrigs dpe tshogs, vol. 6. Beijing: Mi rigs dpe skrun khang, 2004.

Sa skya sman grong pai man ngag dngul bre ma. Lhasa: Bod ljongs mi dmangs dpe skrun khang, 2005.

Gser bre chen mo: A Collection of Medical Formulae and Incantations of the Brantit. Leh: T. Paljor Emchi, 1975. 